PEDRO PAULO DE SIQUEIRA VARGAS

\title{
O CONTRATO DE DOAÇÃO COMO INSTRUMENTO DE PLANEJAMENTO SUCESSÓRIO NO DIREITO CIVIL BRASILEIRO
}

Dissertação de mestrado

Professor Orientador Alessandro Hirata

Faculdade de Direito da Universidade de São Paulo

São Paulo

2014 
PEDRO PAULO DE SIQUEIRA VARGAS

N. USP: 5157835

O CONTRATO DE DOAÇÃO COMO INSTRUMENTO DE PLANEJAMENTO SUCESSÓRIO NO DIREITO CIVIL BRASILEIRO

Dissertação de Mestrado apresentada na Faculdade de Direito da Universidade de São Paulo.

ORIENTADOR: Professor Doutor Alessandro Hirata

São Paulo

2014 


\section{RESUMO}

O presente trabalho tem por objetivo mostrar que no sistema pátrio brasileiro é possível usar a doação como método de implementação de um planejamento sucessório e quais os ditames legais, doutrinários e jurisprudenciais o intérprete deve ter em conta para a tal proceder. Assim, se fará uma explanação dos elementos gerais do regime jurídico da doação e após se estudará os casos específicos de doação que afetam diretamente a sucessão do doador. 


\begin{abstract}
This paper intends to demonstrate that in the Brazilian's system it is possible to use the gift as a means to succession planning implementation and which are the legal rules, doctrines and jurisprudences that the person should take into consideration in the process. A thorough explanation of the gift legal regime general elements will be followed by the study of specific donation cases that have affected directly the succession of the donator.
\end{abstract}




\section{SUMÁRIO}

INTRODUÇÃO . .6

CAPÍTULO I - A DOAÇÃO NO CÓDIGO CIVIL BRASILEIRO DE 2002. . .9

1) Conceito e natureza jurídica . .9

2) Elementos da doação..........................................................................................................31

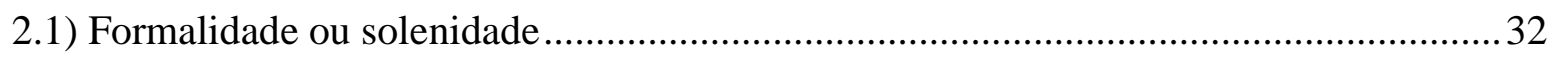

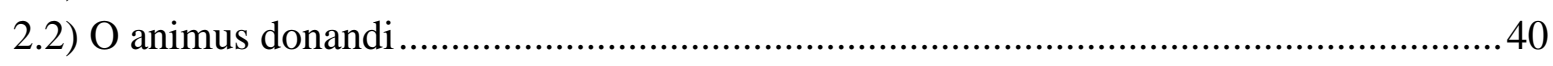

2.3) Transferência patrimonial ou gratuidade ..................................................................... 44

3) A doação e os demais atos jurídicos..................................................................................47

4) Do Aceite e suas consequências ......................................................................................................56

5) Espécies ou tipos de doação ....................................................................................................77

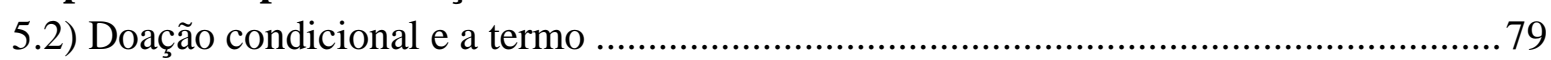



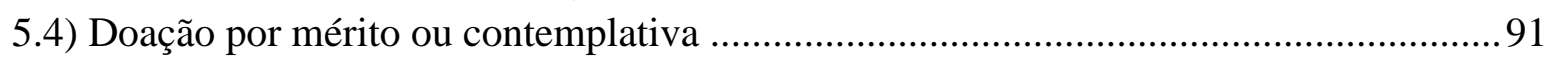

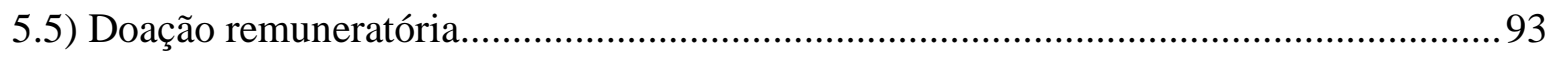

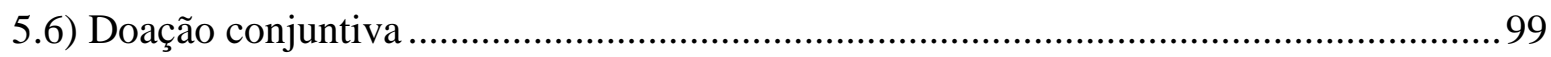

5.7) Doação em contemplação a casamento futuro e sua prole ...........................................102

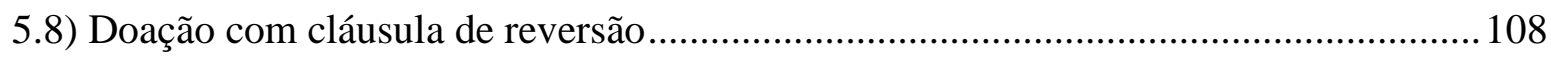

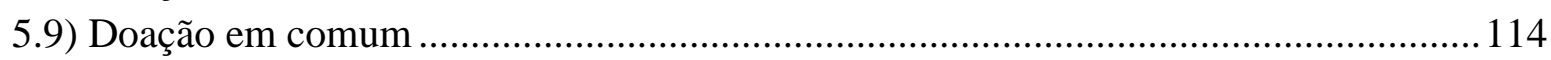

5.10) Doação em forma de subvenção periódica ................................................................... 114

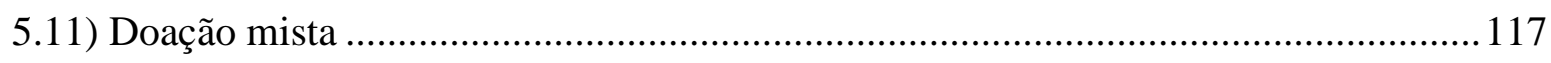

5.12) Doação indireta, simulada e disfarçada .................................................................... 119

6) Promessa de doação ...........................................................................................................................121

7) Revogação da doação ..................................................................................................126

7.1) Revogação por inexecução do encargo ................................................................. 135

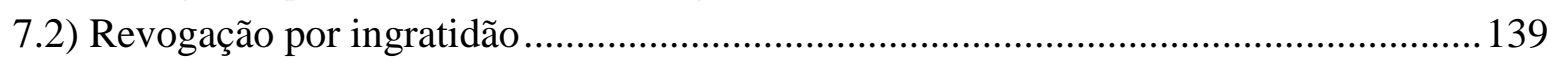

7.2.1) se o donatário atentou contra a vida do doador ou cometeu crime de homicídio

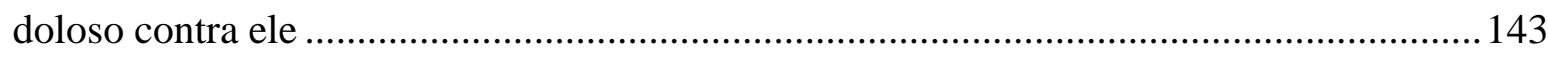

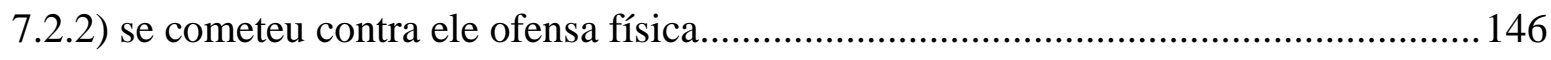

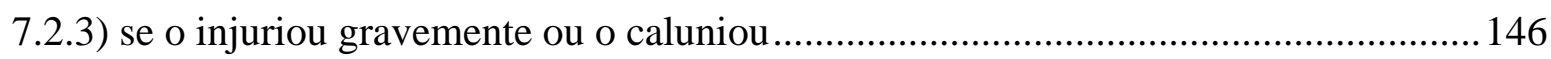

7.2.4) se, podendo ministrá-los, recusou ao doador os alimentos de que este necessitava. 148

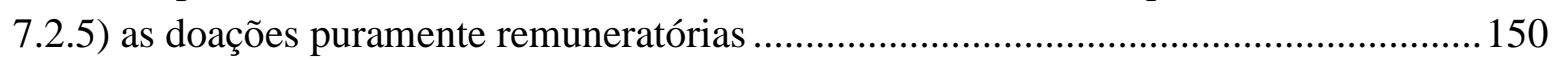

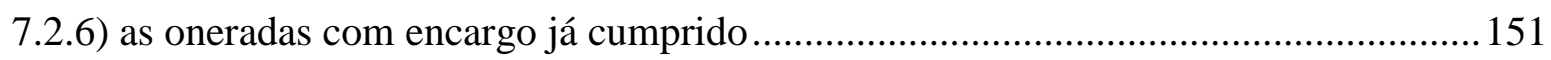

7.2.7) as que se fizerem em cumprimento de obrigação natural......................................... 152

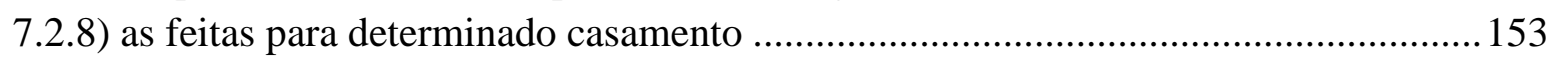


CAPÍTULO II - CASOS DE DOAÇÃO AFETAS À SUCESSÃo NO CÓDIGO CIVIL BRASILEIRO DE 2002 ................................................................................................155

1) Doação causa mortis ........................................................................................................155

2) Doação universal .............................................................................................................................158

3) Doação entre cônjuges ......................................................................................................................163

4) Doação do cônjuge adúltero ao seu cúmplice .........................................................................172

5) Doação de ascendente para descendente ...................................................................................185

6) Doação inoficiosa .............................................................................................................................194

7) Partilha em vida .............................................................................................................................209

CONCLUSÃO

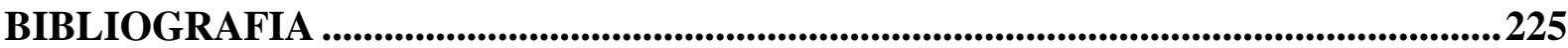




\section{INTRODUÇÃO}

O presente trabalho tem por objetivo demonstrar que a doação pode ser utilizada como um meio de implementação de um planejamento sucessório, descortinando o modo correto de manejá-la para se atingir o fim almejado.

É um dado sociológico o fato de as pessoas se sentirem urgidas, por diversos motivos, a cuidarem, ainda em vida, do destino do seu patrimônio para quando de sua morte.

Por exemplo, segundo informa o "Family Business Institute", em seu sítio eletrônico ${ }^{1}$, aproximadamente $70 \%$ das empresas familiares se extinguem quando sua administração passa da primeira para a segunda geração, sendo que esse número aumenta para cerca de $88 \%$ quando passa da segunda para terceira geração, e gira em torno de $97 \%$ na sucessão da terceira para a quarta geração.

Desse modo, planejar a sucessão numa empresa familiar é uma questão de sobrevivência da sociedade empresária, até para que ela adeque suas atividades empresariais às demandas do mercado ${ }^{2}$. E, para tanto, de extrema importância que se realize ainda em vida do fundador ou do presidente, que deverá impulsionar e arbitrar as negociações necessárias entre os herdeiros ${ }^{3}$. Por conta disso, pode a doação ser um instrumento jurídico valiosíssimo no cumprimento deste desiderato, hábil para a concretização do entendimento a que se chegou entre as partes envolvidas ${ }^{4}$.

Mas pode ainda a doação vir ao encontro daqueles que querem solver problemas até mesmo de ordem pessoal. É famosa, na tradição cristã, a história dramática do pai que adianta em vida a legítima de seu filho a pedido do próprio donatário e à revelia do outro irmão herdeiro necessário, para significar a outorga de irrestrita liberdade e a extinção de qualquer vínculo de poder entre o pai e seu filho caçula ${ }^{5}$. MIGUEL DE CERVANTES narra

\footnotetext{
${ }^{1}$ Disponível em: http://www.familybusinessinstitute.com/index.php/Succession-Planning/. Acesso em: 17 de setembro de 2014.

${ }^{2}$ EDUARDO RICCA, Sucessão na empresa familiar, São Paulo, CLA, 2007, 11-15.

3 JOSÉ FERREIRA DE MACEDO, Sucessão na Empresa Familiar, São Paulo, Nobel, 2009, pp. 119-135; RENATO BERNHOEFT, Como Criar, Manter e Sair de uma Sociedade Familiar (sem brigar), 4ª ed., São Paulo, Senac, 2005, p. 51.

${ }^{4}$ LESLIE AMENDOLARA, A Sucessão na Empresa Familiar, 2a ed., Série Apimec, São Paulo, Lazuli, 2005, pp. 38-40; ROBERTA NIOAC PRADO, KARIME COSTALUNGA e DEBORAH KIRSCHBAUM, Sucessão e Planejamento Societário II, in ROBERTA NIOAC PRADO, DANIEL MONTEIRO PEIXOTO e EURICO MARCOS DINIZ DE SANTI (Coords.), Estratégias Societárias, Planejamento Tributário e Sucessório, $2^{\mathrm{a}}$ ed., Série GVLaw, São Paulo, Saraiva, 2011, pp. 263-290.

5 cf.: Lc. $15,11-24$.
} 
ainda, na sua obra-prima ${ }^{6}$, a história de um pai de 3 filhos que, sabendo-se pródigo, fiou-se em ao menos garantir-lhes algum futuro, motivo pelo qual dividiu seu patrimônio em 4 quinhões iguais e deu um para cada herdeiro, reservando o quarto para sua velhice, impondolhes ainda o encargo de seguirem profissões pré-pactuadas entre eles.

Certo é que a primeira referência é uma parábola, ao passo que a segunda citação é uma obra épica, porém a linguagem literária se mostra método científico eficaz para se extrair o verdadeiro problema social ${ }^{7}$, que no mundo jurídico acaba por desaguar, muitas vezes, nos Tribunais ${ }^{8}$. Desse modo, pode-se dizer que a doação surge como ferramenta jurídica de relevo para os pais que queiram planejar a sua sucessão articulando a vontade dos filhos e as particularidades de cada qual, a fim de evitar a dissenção familiar e a dissipação patrimonial que as contendas trazem consigo.

Mas além dos problemas sociais que se apresentam, do ponto de vista da dogmática jurídica o presente trabalho se justifica na medida em que busca formar um compêndio atualizado do tratamento legal, doutrinário e jurisprudencial da doação vista sob o prisma sucessório, verificando a possibilidade de ela figurar no instrumental de quem queira por em prática um planejamento sucessório e quais requisitos deverão ser cumpridos para a validade do negócio jurídico.

Tendo em vista esse escopo, a pesquisa se desenvolve em dois capítulos.

No primeiro, será lançada as bases de uma teoria geral da doação, investigando-se o modo como ela se insere na disciplina contratual e suas implicações, passando-se após ao estudo dos seus elementos intrínsecos, isto é, à forma jurídica que deve ser empregada, a vontade que deve animar o ato e a transferência patrimonial gratuita, passando-se, em seguida, à averiguação de diversos atos jurídicos para que se afira na prática o que realmente seja uma doação. Será analisada ainda a manifestação de vontade do donatário, haja vista sua importância no aperfeiçoamento do negócio jurídico.

\footnotetext{
${ }^{6}$ El ingenioso hidalgo don Quijote de la Mancha, trad. port. de Sérgio Molina, O Engenhoso Fidalgo D. Quixote De La Mancha, Livro Primeiro, 6a ed., São Paulo, Editora 34, 2011, pp. 557-559.

7 cf., a esse respeito, as consideração feitas por GILBERTO DE MELLO KUJAWSKI ao método de pesquisa do sociólogo Gilberto Freire (Idéia do Brasil: a arquitetura imperfeita, São Paulo, Senac, 2001, pp. 108-109).

${ }^{8}$ Vale recordar, ainda, que CLÓVIS BEVILAQUA antepunha-se frontalmente à presença de previsão legal da partilha em vida no projeto do Código Civil e um dos argumentos por ele brandido perante a Câmara dos Deputados é o problema familiar estampado no romance La Terre, de ÉMILE ZOLA (cf.: ASTOLPHO DE REZENDE, Do Inventário e da Partilha, in PAULO DE LACERDA, Manual do Código Civil Brasileiro, vol. XX, Rio de Janeiro, Jacintho Ribeiro dos Santos Editor, 1930, pp. 289-290). Como se verá adiante, sua posição veio a soçobrar, tendo sido o Código Civil de 1916 aprovado com a redação do seu art. 1.776.
} 
Ainda na mesma parte, serão analisados diversos casos ou espécies de doação, pois o intérprete deve ter bem presente as diversas realidades a que ela está apta a abarcar. Após isso, será analisado um caso especial, que é a promessa de doação, a qual pode ter considerável relevo neste trabalho, haja vista ser largamente empregada na solução de conflitos familiares. Por fim, encerrando o capítulo, se dissertará sobre os modos pelos quais as doações são revogadas.

Uma vez que se empreendeu esse estudo, abre-se o capítulo segundo, que consiste apenas em casos especiais de doação com o condão de afetar diretamente a sucessão do doador. Diante disso, serão estudadas as seguintes formas de doações: a causa mortis; a de todos os bens do doador ou universal; a realizada entre cônjuges; aquela feita em favor de cúmplice de adultério; e, a que se dá de ascendente para descendente. Depois, será feita a análise da doação inoficiosa, dado o liame direto entre essa categoria e o direito sucessório, e, por fim, se encerrará o capítulo com o estudo da utilização da doação como meio de se fazer partilha em vida.

Com todas as balizas teóricas adquiridas ao longo de todo esse estudo, à guisa de conclusão, será demonstrado que a doação, nos seus diversos aspectos e na sua função multifacetária, pode sim ser um meio eficaz de implantação de estratégia sucessória, desde que se saiba ultrapassar as barreiras legais, a fim de não se ensejar a confecção de negócio jurídico inválido e futura demanda judicial. 


\section{CAPÍTULO I - A DOAÇÃO NO CÓDIGO CIVIL BRASILEIRO DE 2002}

\section{1) Conceito e natureza jurídica}

A doação, no sistema civil brasileiro atual, tem definição legal. Essa é a redação do art. 538 do Código Civil de 2002: "Considera-se doação o contrato em que uma pessoa, por liberalidade, transfere do seu patrimônio bens ou vantagens para o de outra".

Como se verifica na redação transcrita do dispositivo legal, o legislador começa por definir a doação como uma espécie contratual, o que é reafirmado pela localização topográfica da figura no Código, cujo regramento está previsto no Capítulo IV (“Da Doação”) do Título VI ("Das Várias Espécies de Contratos”), do Livro I (“Do Direito das Obrigações”), da Parte Especial.

Por conta disso, também a maior parte da doutrina parece não se separar do entendimento de que a doação é um contrato. Muitos estudiosos ${ }^{9}$ do tema afirmam explicitamente em sua obra que a natureza contratual da doação.

Esse posicionamento havia sido vincado pela legislação anterior. No âmbito do revogado Código Civil de 1916, a doação foi disciplinada no Capítulo III ("Da Doação”), do Título V ("Das Várias Espécies de Contratos”), do Livro III ("Do Direito das Obrigações”), da Parte Especial, a partir do art. 1.165, que tinha a seguinte redação: “Considera-se doação o

\footnotetext{
${ }^{9}$ ARNALDO RIZZARDO, Contratos, $10^{\mathrm{a}}$ ed., Rio de Janeiro, Forense, 2010, p. 439; ARNOLDO WALD, Direito Civil, vol. III, $18^{\mathrm{a}}$ ed., São Paulo, Saraiva, 2009, p. 58; CARLOS ROBERTO GONÇALVES, Direito Civil Brasileiro, vol. III, $4^{\mathrm{a}}$ ed., São Paulo, Saraiva, 2007, pp. 254-255; CÉSAR FIUZA, Direito Civil, $11^{\mathrm{a}}$ ed., Belo Horizonte, Del Rey, 2008, p. 499; CHRISTIANO CASSETARI, Elementos de Direito Civil, São Paulo, Saraiva, 2011, p. 212; FÁBIO ULHOA COELHO, Curso de Direito Civil, vol. III, $6^{a}$ ed., São Paulo, Saraiva, 2013, p. 238; FRANCISCO GLAUBER PESSOA ALVES, Das Várias Espécies de Contrato - Arts. 533 a 578, in ARRUDA ALVIM e THEREZA ALVIM (Coords.), Comentários ao Código Civil Brasileiro, vol. V, Rio de Janeiro, Forense, 2007, pp. 875-878; LUIZ GUILHERME LOUREIRO, Curso Completo de Direito Civil, $2^{\mathrm{a}}$ ed., São Paulo, Método, 2009, pp. 504-505; MARIA HELENA DINIZ, Tratado Téricico e Prático dos Contratos, vol. II, $7^{\text {a }}$ ed., São Paulo, Saraiva, 2013, p. 72; PABLO STOLZE GAGLIANO, $O$ Contrato de Doação, $3^{\mathrm{a}}$ ed., São Paulo, Saraiva, 2010, p. 34; PAULO DE TARSO VIEIRA SANSEVERINO, Contratos Nominados II, São Paulo, Revista dos Tribunais, 2005, pp. 59 e 62; PAULO GERALDO DE OLIVEIRA MEDINA, A Doação, in DOMINGOS FRANCIULLI NETTO, GILMAR FERREIRA MENDES e IVES GANDRA DA SILVA MARTINS FILHO (Coords.), O Novo Código Civil, São Paulo, LTR, 2003, p. 461; PAULO NADER, Curso de Direito Civil, vol. III, $4^{\text {a }}$ ed., Rio de Janeiro, Forense, 2009, p. 225; RODRIGO SENISE LISBOA, Manual de Direito Civil, v. III, $7^{\mathrm{a}}$ ed., São Paulo, Saraiva, 2013, p. 257; SAMUEL LUIZ ARAÚJO, O Princípio da Igualdade e sua Projeção no Contrato de Doação, Porto Alegre, Núria Fabris, 2009, p. 73; SÍLVIO DE SALVO VENOSA, Direito Civil, vol. III, $5^{\text {a }}$ ed., São Paulo, Atlas, 2005, pp. 124-125; SILVIO RODRIGUES, Direito Civil, vol. III, 30ª ed., São Paulo, Saraiva, 2004. pp. 199200; SYLVIO CAPANEMA DE SOUZA, Das Várias Espécies de Contratos - Da Troca ou Permuta - Do Contrato Estimatório - Da Doação - Da Locação de Coisas, in SÁLVIO DE FIGUEIREDO TEIXEIRA (Coord.), Comentários ao Novo Código Civil, vol. VIII, Forense, Rio de Janeiro, 2008, pp. 83-86; WASHINGTON DE BARROS MONTEIRO e CARLOS ALBERTO DABUS MALUF, Curso de Direito Civil, vol. V, $38^{\text {a }}$ ed., São Paulo, Saraiva, 2011, p. 163.
} 
contrato em que uma pessoa, por liberalidade, transfere do seu patrimônio bens ou vantagens para o de outra, que os aceita".

Assim, também muito dos autores ${ }^{10}$ que escreveram na vigência daquela legislação são concordes com a visão de que a doação é um contrato. Comentando o supracitado dispositivo legal, CLÓVIS BEVILAQUA ${ }^{11}$ aplaude a opção legislativa e reafirma que a doação não passa de uma espécie do gênero contrato, estando bem localizada a seguir às regras do contrato de compra e venda, segundo seu parecer, pois enquanto o segundo expressa a onerosidade contratual, aquela é paradigma das liberalidades ${ }^{12}$.

Insta salientar que os doutrinadores ${ }^{13}$ que afirmam ser a doação um contrato assim o fazem não apenas com fundamento na disposição legal vigente ao tempo de sua obra, mas

${ }^{10}$ AGOSTINHO ALVIM, Da Doação, $3^{\text {a }}$ ed., São Paulo, Saraiva, 1980, p. 7; ANTÔNIO CHAVES, Lições de Direito Civil - Obrigações III, São Paulo, Revista dos Tribunais, 1976, p. 233; ARNALDO MARMITT, Doação, Rio de Janeiro, Aide Editora, 1994, p. 09; CARLOS ALBERTO BITTAR, Contratos Civis, $2^{\mathrm{a}}$ ed., Rio de Janeiro, Forense Universitária, 1991, p. 41; EDUARDO ESPINOLA, Dos Contratos Nominados no Direito Civil Brasileiro, $2^{\mathrm{a}}$ ed., Rio de Janeiro, Conquista, 1956, p. 154; JOÃO LUIZ ALVES, Código Civil da República dos Estados Unidos do Brasil, vol. II, $2^{\mathrm{a}}$ ed., São Paulo, Saraiva, 1935, p. 241; LIMONGI FRANÇA, Manual de Direito Civil, vol. IV, tomo II, São Paulo, Revista dos Tribunais, 1969, p. 96; ORLANDO GOMES, Contratos, $12^{a}$ ed., Rio de Janeiro, Forense, 1993, pp. 233-234; OZÉIAS J. SANTOS, Da Doação, Campinas, Agá Juris, 1998, p. 11; PONTES DE MIRANDA, Tratado de Direito Privado, tomo XLVI, $3^{\text {a }}$ ed., Rio de Janeiro, Borsoi, 1972, p. 198; SERPA LOPES, Curso de Direito Civil, vol. III, $6^{\text {a }}$ ed., Rio de Janeiro, Freitas Bastos, 1996, pp. 385-386; VICENTE SABINO JÚNIOR, Contrato de doação, São Paulo, Brasilivros, 1979, p. 14.

${ }^{11}$ Código Civil dos Estados Unidos do Brasil, vol. IV, 10ª ed., Rio de Janeiro, Ed. Paulo de Azevedo, 1955, p. 270.

${ }^{12} \mathrm{Na}$ Consolidação das Leis Civis, de TEIXEIRA DE FREITAS, ocorre o inverso. A doação é tratada no Capítulo I ("Da doação"), do Título II ("Dos contractos em particular"), da Secção II ("Dos Direitos Pessoaes nas Relações Civis"), do Livro I ("Dos Direitos Pessoaes"), da Parte Especial, ao passo que a compra e venda só aparece no Capítulo V, depois de se regulamentar, respectivamente, o depósito, o mandato e o empréstimo, de modo que na mencionada obra regula-se em primeiro lugar os contratos a título gratuito e só após se passa aos onerosos. De qualquer forma, como se vê, o mencionado autor considerava a doação um contrato, o que afirma expressamente em sua obra (vol. I, ed. fac-sim., Brasília, Senado Federal, 2003, p. 284). Tal ordem também era empregada por CARVALHO DE MENDONÇA, que também via na doação um contrato (Contratos no Direito Civil Brasileiro, Tomo I, $4^{\text {a }}$ ed., Rio de Janeiro, Forense, 1957, pp. 31-32).

${ }^{13}$ Neste sentido: ARNALDO RIZZARDO, Contratos, cit., pp. 439-440; ARNOLDO WALD, Direito (...), cit., pp. 58-59; CAIO MÁRIO DA SILVA PEREIRA, Instituições de Direito Civil, vol. III, 13a ed., Rio de Janeiro, Forense, 2009, pp. 209 e 211; CARLOS ALBERTO BITTAR, Contratos (...), cit., p. 42; CARLOS ROBERTO GONÇALVES, Direito (...), cit., pp. 254-255; CARVALHO DE MENDONÇA, Contratos (...), cit., pp. 38-39; EDUARDO ESPINOLA, Dos Contratos (...), cit. pp. 156-157; FÁBIO ULHOA COELHO, Curso (...), cit., pp. 238-239; FRANCISCO GLAUBER PESSOA ALVES, Das Várias (...), cit., pp. 876-877; LIMONGI FRANÇA, Manual (...), cit., p. 97; MARIA HELENA DINIZ, Tratado (...), cit., p. 72; NELSON ROSENVALD, Contratos (em espécie) - Arts. 481 a 652, in CEZAR PELUSO (Coord.), Código Civil Comentado, $4^{\text {a }}$ ed., Barueri, Manole, 2010, p. 538; ORLANDO GOMES, Contratos, cit., pp. 234-235; OZÉIAS J. SANTOS, Da Doação, cit., p. 13; PABLO STOLZE GAGLIANO, O Contrato (...), cit., pp. 2627; PAULO GERALDO DE OLIVEIRA MEDINA, A Doação, cit., p. 461; PAUlO LÔBO, Das Várias Espécies de Contratos, in ANTÔNIO JUNQUEIRA DE AZEVEDO (Coord.), Comentários ao Código Civil, vol. VI, São Paulo, Saraiva, 2003, p. 282; PONTES DE MIRANDA, Tratado (...), cit., p. 198; ROGÉRIO MARRONE DE CASTRO SAMPAIO, Direito Civil, $5^{a}$ ed., São Paulo, Atlas, 2004, p. 122; SÍLVIO DE SALVO VENOSA, Direito (...), cit., p. 124; SILVIO RODRIGUES, Direito (...), cit., p. 199; TEIXEIRA DE FREITAS, Consolidação (...), cit., p. 284; VICENTE SABINO JÚNIOR, Contrato (...), cit., pp. 13-14; 
também em vista do fato de o aperfeiçoamento do ato depender do aceite do donatário, formando-se, assim, o sinalagma contratual, o que afastaria a hipótese de ato unilateral de vontade, mesmo no âmbito do Código atual, que tirou do seu art. 538 a parte final do revogado art. 1.165, como se verifica nas transcrições acima.

Não obstante, o entendimento de que a doação seja um contrato não é unânime na ciência jurídica e nem em outros sistemas jurídicos.

No Código Napoleônico, por exemplo, a doação é prevista dentre os modos de aquisição da propriedade e está disciplinada ao lado do testamento, ao passo que os contratos são regrados em local diferente no diploma. Assim, no Livro III dessa legislação, que versa sobre os modos de aquisição da propriedade (no original: "Des différentes manières dont on acquiert la propriétê"), há diversos títulos nos quais ele se desdobra, sendo que o primeiro trata da sucessão (no original: "Des successions"), o segundo das liberalidades (no original: "Des libéralités"), o terceiro da teoria geral das obrigações e dos contratos (no original: "Des contrats ou des obligations conventionnelles en général"), e assim por diante. Mas é no capítulo quarto do mencionado título segundo que se regula a doação (no original: "Des donations entre vifs"), em precedência ao capítulo quinto, o qual versa sobre o testamento (no original: "Des dispositions testamentaires"), ou seja, baseando-se na localização a doação é diferente de contrato para a Lei civil gálica.

Ademais, inaugurando o título que versa sobre as liberalidades, o art. $893^{14}$ do diploma civil francês enquadra a doação e o testamento nesse gênero (de modo que a primeira não consta topograficamente na parte do código que versa sobre contratos, e o segundo está arredado da sucessão, que, como visto, está tratada no título anterior) e embraça a ambos com o termo 'ato', fornecendo a característica principal de consistirem em uma transferência a título gratuito para benefício de outrem. Em seguida a esse dispositivo, no seu art. $894^{15}$, o Code Civil define doação iniciando a redação do artigo com o termo 'ato', ao invés de 'contrato', ressaltando a necessidade da atualidade da transferência e da irregocabilidade do bem doado, bem como do aceite.

\footnotetext{
WASHINGTON DE BARROS MONTEIRO-DABUS MALUF, Curso (...), cit., p. 164.

${ }^{14}$ Art. 893. "La libéralité est l'acte par lequel une personne dispose à titre gratuit de tout ou partie de ses biens ou de ses droits au profit d'une autre personne. Il ne peut être fait de libéralité que par donation entre vifs ou par testament".

15 Art. 894. "La donation entre vifs est un acte par lequel le donateur se dépouille actuellement et irrévocablement de la chose donnée en faveur du donataire qui l'accepte".
} 
A esse respeito, porém, NESTOR DIÓGENES ${ }^{16}$ afirma que no Código Civil francês apenas em termos de localização a doação é tratada ao lado dos testamentos, mas que, na realidade, o conceito que se extrai do diploma é o de contrato.

Respaldando a ilação acima carreada, HUGUETTE MÉAU-LAUTOUR ${ }^{17}$ considera que a redação emprestada ao mencionado art. 894 do Código Civil da França encontra sua justificativa no dispositivo legal anterior, que, por sua vez, teria o escopo de expurgar a doação causa mortis do sistema, o que significa dizer que a definição de doação engendrada pela lei quer traçar o marco divisor entre a figura definida e o testamento.

Assim, conclui a autora ${ }^{18}$ que é inegável a adoção, pelo Código Napoleônico, do molde contratual para qualificar a doação, justamente porque o testamento é marcadamente ato unilateral, de modo a evitar a mistura de ambos, o que também se realiza com a imposição da atualidade da diminuição patrimonial do doador e da irrevogabilidade dos bens, pois esses elementos não ocorrem na deixa testamentária, que se perfaz post mortem e é revogável. No que toca à transferência ou empobrecimento (“dépouillement"), entende que serve de marco divisório para inserir a doação nos atos gratuitos.

No mesmo sentido, PAUL DELNOY ${ }^{19}$ também entende que doação é contrato, explicando que se trata de negócio jurídico bilateral quanto à sua formação, pois por imposição do mencionado art. 894 depende de acordo de vontade, ao passo que, pelo seus efeitos, é unilateral, haja vista que acarreta dever jurídico apenas ao doador.

JEAN RAY ${ }^{20}$ também afirma que a doação, do modo como tratada no Código Napoleônico, é contrato, fato este indubitável e de acordo com a tradição da doutrina francesa, segundo ele, e fundamenta sua opinião explicando que o contrato causa a ascensão de uma obrigação pelo encontro de duas vontades, o que se dá no caso, haja vista a necessidade do aceite, por imposição do art. 894, já mencionado, e do art. $932^{21}$.

\footnotetext{
${ }^{16}$ Doação não é contrato, Recife, 1947, p. 63.

${ }_{17}^{17}$ La Donation Déguisée en Droit Civil, Paris, Librairie Générale de Droit et de Jurisprudence, 1985, pp. 39-40.

${ }^{18}$ La Donation (...), cit, p. 40.

${ }^{19}$ Le Libéralités Et Les Successions, Liège, Ed. Collection Scientifique de la Faculté de Droit de Liège, 1991, p. 25.

${ }^{20}$ De La Notion de Donation, Paris, Recueil Sirey, 1912, pp. 51-52.

${ }^{21}$ Art. 932. "1. La donation entre vifs n'engagera le donateur, et ne produira aucun effet, que du jour qu'elle aura été acceptée en termes exprès. 2. "L'acceptation pourra être faite du vivant du donateur par un acte postérieur et authentique, dont il restera minute; mais alors la donation n'aura d'effet, à l'égard du donateur, que du jour où l'acte qui constatera cette acceptation lui aura été notifié".
} 
A disparidade entre a lei civil francesa e os pareceres doutrinários apresentados se deve à formação histórica dos dispositivos legais. PLANIOL ${ }^{22}$ relata que no projeto original do Código, o termo utilizado não era 'ato', mas sim 'contrato', porém o próprio Napoleão teria requisitado a mudança, pois para ele contrato ocorre apenas quando há bilateralidade nas obrigações originadas, o que não convém pensar na doação, tendo então os demais conselheiros, por fraqueza, acedido a tal pedido. Mas o autor rechaça tal opinião do Primeiro Cônsul externada no Conselho de Estado, que seria fruto da sua ignorância do Direito, pois é evidente, segundo sua opinião, que a doação é um contrato, haja vista que depende do acordo de duas partes para sua realização, porém é unilateral no que toca à obrigação que dela nasce.

TROPLONG ${ }^{23}$, em comentário ao art. 893 do Código Napoleônico, também não hesita em tratar a doação como um contrato que se realiza a título gratuito e explica que sua única peculiaridade em relação aos demais contratos graciosos está no imediato empobrecimento do doador em favor do donatário.

Em outro passo de sua obra ${ }^{24}$, pondera que a doutrina produziu intenso debate sobre a matéria, mas que é evidente ser a doação um contrato, haja vista ser fonte de obrigação, pois do entendimento entre doador e donatário surge a obrigação daquele de se despojar do objeto doado em favor desse, só podendo ser causa desse liame obrigacional uma convenção ou contrato. A fim de apoiar sua tese, argumenta ainda que o projeto do Code Civil definia a doação como contrato, e reconta a supramencionada intervenção de Napoleão e a fraqueza dos demais conselheiros em admitir substituir o termo 'contrato' por 'ato', apontando que o Primeiro Cônsul cometeu equívoco em vista até da própria lei civil, pois ela não compartilha da visão de que o contrato só pode ser bilateral, como se vê nos seus arts. $1.102^{25}$ e $1.103^{26}$, admitindo-o também com efeito unilateral.

Outrossim, a fim de demonstrar um ponto fraco na argumentação feita por Napoleão, aponta TROPLONG ${ }^{27}$ como exemplo o empréstimo, que ninguém duvida ser um

\footnotetext{
${ }^{22}$ Traité Élémentaire de Droit Civil, tomo III, $10^{\mathrm{a}}$ ed., Paris, Librairie Générale de Droit \& de Jurisprudence, 1927, p. 641.

${ }^{23}$ Des Donations Entre-Vifs et des Testaments, in Commentaire du Titre II du Livre III du Code Napoléon, tomo I, $3^{\mathrm{a}}$ ed., Paris, Henri Plon, 1872, pp. 8-9.

${ }^{24}$ Des Donation (...), cit., pp. 75-77.

${ }^{25}$ Art. 1.102. "Le contrat est synallagmatique ou bilatéral lorsque les contractants s'obligent réciproquement les uns envers les autres".

${ }^{26}$ Art. 1.103. "Il est unilatéral lorsqu'une ou plusieurs personnes sont obligées envers une ou plusieurs autres, sans que de la part de ces dernières il y ait d'engagement".

${ }^{27}$ Des Donation (...), cit., pp. 77-80.
} 
contrato e tal natureza jurídica é afirmada pelo Código Civil de França. Nesse negócio, observa-se que o comodante entrega o objeto ao comodatário, surgindo assim, para o último, a obrigação de devolvê-lo nos termos pactuados, sendo que a tradição do bem pelo comodante não é uma obrigação do negócio jurídico, mas sim fato que o traz a existência, pois, sem essa ocorrência, não nasce a única obrigação que tem o contrato celebrado pelas partes como causa, isto é, o dever de devolução do objeto pelo comodatário. Assim, não há reciprocidade nesse negócio, mas nem por isso deixa ele de ser contrato, pelo que a falta de bilateralidade na doação não é argumento suficiente para afastar sua natureza contratual, podendo-se dizer, no máximo, que se trata de um contrato diferente dos outros, pois sua causa é o espírito de liberalidade, de modo que é um contrato sui generis, com consequências especiais.

Assim, como se verificou, no ordenamento jurídico francês apenas aparentemente a doação não é um contrato. Da análise do Código Napoleônico e da doutrina a ele pertinente, verifica-se que também na França a doação um contrato.

Da mesma maneira que na experiência jurídica gálica, no Código Civil espanhol os artigos de lei que regem a doação estão agrupados no Título II (no original: "De la donación") do livro que versa sobre os modos de aquisição da propriedade (no original: “Libro III - De los diferentes modos de adquirir la propiedad"), ao lado da ocupação e da sucessão, ao passo que os contratos são regrados em livro diverso (no original: "Livro IV - De las obligaciones y contratos"). Ademais, assim como acontece no Código Civil Napoleônico, a lei civil espanhola, em seu art. $618^{28}$, não define a doação como um contrato, mas sim como um 'ato'.

Todavia, a doutrina e a jurisprudência daquele país não questionam a natureza contratual da doação, seja por interpretação sistemática do próprio Código Civil ${ }^{29}$, que só topograficamente arreda a doação dos contratos, seja pela simples razão de que também no sistema espanhol é necessária a anuência por parte do donatário para aperfeiçoamento do

\footnotetext{
${ }^{28}$ Art. 618. "La donación es un acto de liberalidad por el cual una persona dispone gratuitamente de una cosa en favor de otra, que la acepta".

${ }^{29}$ v.g.: Art. 621. "Las donaciones que hayan de producir sus efectos entre vivos se regirán por las disposiciones generales de los contratos y obligaciones en todo lo que no se halle determinado en este título"; Art. 628. "Las donaciones hechas a personas inhábiles son nulas, aunque lo hayan sido simuladamente, bajo apariencia de otro contrato, por persona interpuesta".
} 
negócio jurídico, de modo que não é um ato unilateral, mas sim contrato com dever imputado a apenas uma das partes, ou seja, um contrato unilateral ${ }^{30}$.

O Código Civil português vigente, por seu turno, da mesma forma que o brasileiro, insere a doação na disciplina dos contratos, logo após tratar da compra e venda, compondo ambos, em seus respectivos capítulos, o Título II ("Dos contratos em especial”) do Livro II ("Direito das Obrigações”). O Código luso também se dedica a lançar uma definição de doação e, coerentemente, começa-o por classificá-la dentre os contratos, em seu art. $940^{31}$. Chama a atenção que se tenha criado um parágrafo para se definir negativamente, isto é, desenhou-se, por força de lei, as fronteiras da doação em relação a outros negócios jurídicos.

Comentando a contratualidade da doação no sistema civil português, MANUEL BAPTISTA LOPES ${ }^{32}$ afirma que é corolário do mencionado dispositivo legal a necessidade precípua de haver aceitação da benesse pelo donatário, mesmo no caso do donatário absolutamente incapaz, porque nessa hipótese não há dispensa, mas sim presunção da ocorrência do ato.

A lei civil portuguesa anterior, de 1867, também tratava a doação como contrato, regulando-a no Capítulo V ("Das Doações”), do Título II (“Dos contratos em particular"), do Livro II ("Dos direitos que se adquirem por facto e vontade própria e de outrem conjunctamente"), da Parte II ("Da aquisição dos direitos"), daquele Código, e a conceitua no seu art. $1.452^{33}$.

Em comentário a esse dispositivo legal, CUNHA GONÇALVES ${ }^{34}$ pondera que é admissível equiparar-se a doação ao testamento enquanto ambos são atos a título gratuito, pontuando a diferença entre uma e outra figura, mas entende que nenhuma delas podem ser enquadradas nos modos de aquisição da propriedade, porque são antes um benefício feito por alguém e podem significar a assunção de obrigações, sendo que o testamento não

\footnotetext{
30 MANUEl AlBADALEJO GARCíA e SILVIA DIAZ ALABART, La Donación, Madrid, Colegio de Registradores de la Propiedad y Mercantiles de España, 2006, pp. 29-35.

${ }^{31}$ Art. $940 .^{\circ}$ (Noção) "1. Doação é o contrato pelo qual uma pessoa, por espírito de liberalidade e à custa do seu património, dispõe gratuitamente de uma coisa ou de um direito, ou assume uma obrigação, em benefício do outro contraente. 2. Não há doação na renúncia a direitos e no repúdio de herança ou legado, nem tão pouco nos donativos conformes aos usos sociais".

${ }^{32}$ Das Doações, Coimbra, Almedina, 1970, pp. 09-10.

${ }^{33}$ Art. 1.452. "Doação é um contracto, por que qualquer pessoa transfere a outrem gratuitamente uma parte, ou a totalidade dos seus bens presentes".

${ }^{34}$ Tratado de Direito Civil, $2^{\mathrm{a}}$ ed., vol. VIII, tomo I, São Paulo, Max Limonad, 1956, pp. 78-79.
} 
necessariamente versa sobre transferência patrimonial, de modo que entende acertada a opção legislativa de tratar a doação como uma modalidade contratual.

Num outro passo ${ }^{35}$, explica que a doação não é ato unilateral justamente porque se faz necessária a aceitação do donatário, de modo que há encontro de duas vontades autônomas, excetuando-se as hipóteses em que a lei presume o aceite.

D'ABRANCHES FERRÃO ${ }^{36}$, por seu turno, começa por pontuar que a doação é essencialmente diferente do testamento, pois a sua relação com o direito das sucessões é meramente eventual, ao passo que o segundo está contido nessa seara do direito civil, e, enquanto negócio jurídico, é bilateral, ao passo que o testador pratica ato unilateral, de modo que o Código Civil de Portugal de 1867 bem fez em se afastar da opção legislativa francesa, segundo seu parecer.

No entanto, o autor ${ }^{37}$ reconhece a dificuldade de se definir a doação, pois entende que dificilmente uma formulação lógica da figura será capaz de abarcar toda a realidade na qual ela se desdobra, o que se verifica até pelos diversos pareceres doutrinários divergentes e pelas diferenças existentes nas experiências jurídicas dos povos, de maneira que, segundo sua opinião, o indigitado art. 1.452 apenas teria melhorado a definição da figura em realação ao Código Napoleônico e ao sistema civil italiano de 1865, mas que não seria ainda perfeito.

Mas quanto à contratualidade da doação, entende ${ }^{38}$ que tal característica é indubitável tanto na dogmática, como no regime jurídico do Código Civil português de 1867, pois a existência do negócio depende da concorrência tanto da vontade do doador como do donatário, ainda que de modo tácito quanto ao último, e sem isso pode até haver um negócio unilateral, mas seus efeitos terão como causa a prática do ato em si, mas não o contrato de doação. E frisa, ainda, que uma coisa é a formação do negócio e outra é seu efeito, de modo que na doação observa-se que a bilateralidade está na origem, porém o contrato formado é unilateral.

Por fim, no que toca ao pensamento lusitano a respeito da doação, cumpre destacar que já COELHO DA ROCHA ${ }^{39}$, que escreveu antes ainda do Código de 1867 do seu

\footnotetext{
${ }^{35}$ Tratado (...), cit., p. 81 .

${ }^{36}$ Das Doações, tomo I, Coimbra, F. França Amado, 1911, p. 4.

${ }^{37}$ Das Doações, cit., pp. 5-8.

${ }^{38}$ Das Doações, cit., pp. 38-43.

39 Instituições de Direito Civil, Tomo II, in ALCIDES TOMASETTI JR. (Coord.), Clássicos do Direito
} 
país, entendia que ela é um contrato, tendo dela tratado dentre os contratos gratuitos, ao lado do empréstimo, do depósito e do mandato. Entendia ele que as Ordenações tratavam a doação de maneira imerecidamente fragmentária, pois era apenas casuística e sem uma elaboração sistemática, mas, de todo modo, sublinha que é possível aproximá-la do testamento enquanto ambos são liberalidades, porém a grande diferença está em que para haver doação é preciso ocorrer o aceite pelo donatário.

No sistema civil italiano, topograficamente a doação vem tratada no Título V (no original: "Delle Donazioni”) do Livro II (no original: "Delle Successioni”) do Código Civil italiano de 1942, ao passo que os contratos são regulados nos Títulos II (no original: "Dei Contratti in Generale") e III (no original: "Dei Singoli Contratti”) do Livro IV (no original: “Delle Obbligazioni”). Ou seja, a colocação do regime jurídico da doação no referido diploma está separado dos contratos. No entanto, o art. $769^{40}$ da mencionada legislação afirma explicitamente que a doção é um contrato, sem deixar qualquer margem para dúvidas a esse respeito.

GUIDO ALPA ${ }^{41}$ afirma que é indiscutível o fato de a doação ser um contrato, afastando explicitamente a hipótese de ato unilateral de vontade, e que o posicionamento topográfico especial no Código se deve à sua pertença à classe das liberalidades, que despertam a desconfiança do legislador, de modo ter preferido tratá-la em apartado, da mesma forma e ao lado do testamento, pressupondo-se as afinidades entre ambas figuras, permitindo assim dispensar-lhe um regime mais rígido em comparação com os outros contratos.

Com efeito, LYCIA GARDANI CONTURSI LISI ${ }^{42}$ afirma ter a novidade trazida pelo mencionado art. 769, que impôs o tratamento contratual à doação, gerado a necessidade de se buscar a causa de tal contrato, de modo a diferenciá-lo dos outros da sua espécie, tendo a doutrina e a jurisprudência coetâneas à autora concluído que ela está na liberalidade, consistente no ânimo de beneficiar o donatário, que deve aceitar a disposição, de modo que a doação é um contrato que tem base de sustentação no conceito de liberalidade.

\footnotetext{
Brasileiro, São Paulo, Saraiva, 1984, pp. 426-427.

${ }^{40}$ Art. 769 ("Definizione"). "La donazione è il contrato col quale, per spirito di liberalità, uma parte arricchisce l'altra, disponendo a favore di questa di um suo diritto o assumen-do verso la stessa un'obbligazione".

${ }^{41}$ Manuale de Diritto Privato, 6a ed., Pádova, CEDAM, 2009, pp. 1225-1226.

${ }^{42}$ Le Donazioni, in WALTER BIGIAVI (Dir.), Giurisprudenza Sistematica Civile e Commerciale, Torino, UTET, 1967, pp. 4-5.
} 
Já GIANFRANCO AMENTA ${ }^{43}$, também versando sobre a localização da doação no Código Civil italiano de 1942, opina que tal escolha legislativa obnubila o significado completo de se tratar a figura como contrato, justamente por representar um retrocesso em relação ao Código Civil de 1865, que já havia se esforçado em afastar a doação da influência francesa, ao tratá-la nos modos de aquisição da propriedade, mas em título apartado, em meio às aquisições mortis causa e às obrigações, pelo que estava separada da sucessão.

Buscando as fontes que justificam a posição da doação no Código Civil italiano atual, o mesmo autor ${ }^{44}$ noticia que, em geral, afirma-se que na elaboração da lei o livro das sucessões foi redigido antes do que o das obrigações, tendo sido a doação já regrada nele, de modo que, por conveniência e evitando-se atrasos, não se procedeu a mais nenhuma alteração. No entanto, explica que, na verdade, tanto no projeto preliminar como no definitivo da lei civil, a doação era definida como 'ato', mas que o relator era da opinião de que deveria se empregar o termo 'contrato', o qual, porém, guardava muita semelhança com o testamento, vindo seu parecer a triunfar, de modo que o Código cristalizou tal entendimento, colocando a doação em uma posição que seria anômala, segundo ele.

Ademais, GIANFRANCO AMENTA ${ }^{45}$ compreende que há um segundo motivo para o legislador assim se conduzir, o qual é parecido com o quanto afirmado por GUIDO ALPA, e é que, sendo inescapável o enquadramento da doação como contrato, preferiu-se então sujeitá-la ao regime sucessório, como se, junto com o testamento, fosse uma espécie do gênero liberalidade, retomando-se o esquema francês, justamente como forma de mitigar a plena aplicação do regime contratual, dada a particularidade do negócio jurídico.

ANDREA TORRENTE ${ }^{46}$, por seu turno, aponta que no âmbito do Código Civil italiano há uma anteposição entre liberalidade e doação, sendo, em verdade, ambas espécies dos negócios a título gratuito, que é gênero, de maneira que a principal finalidade de se conceituar a doação é justamente distingui-la da categoria geral a que pertence, o que se dá pela identificação da sua causa, mas não de sua estrutura.

\footnotetext{
${ }^{43}$ La Donazione e la Sua Struttura Contrattuale, Torino, G. Giappichelli, 2002, p. 93.

${ }^{44}$ La Donazione (...), cit., pp. 93-95.

${ }^{45}$ La Donazione (...), cit., pp. 95-96.

${ }^{46}$ La Donazione, in ANTONIO CICU e FRANCESCO MESSINEO (Dirs.), Trattato di Diritto Civile e Commerciale, vol. XXII, Milano, Giuffrè, 1956, pp. 10-12 e 142-143.
} 
De todo modo, o autor ${ }^{47}$ explica que o Código de 1942 começou por reformar a teoria contratual, em comparação com o de 1865, eliminando a diferença entre contrato bilateral e contrato unilateral que havia nesse último, colocando a figura em termos de que há contratos com prestações correspectivas e há outros em que apenas uma das partes contrai obrigação, perfazendo ambas a mesma realidade, a permitir a definição envidada pelo art. 769 do atual diploma, pois o aceite passa a ser uma declaração de vontade qualificada, que não importa no donatário contrair obrigação, mas na constituição do vínculo contratual de per si, o que também elimina a hipótese de ato unilateral, haja vista que a aceitação não é mera expressão de um sentimento.

Assim, como a estrutura do ato não determina as consequências, mas sim a sua causa, como já dito, para ANDREA TORRENTE ${ }^{48}$ a consequência lógica da adoção pelo Código Civil italiano de 1942 do sistema contratual para regular a doação é a de que a ela se aplica, naquilo que não houver expressa derrogação, a teoria geral dos contratos ${ }^{49}$.

Ainda no âmbito do direito italiano, BIONDO BIONDI ${ }^{50}$ entende que a definição de doação não é uma questão a ser resolvida pela dogmática jurídica, haja vista a diversidade de entendimentos externados pelo debate acadêmico e legislações de experiências diversas, mas sim pelo direito positivo, pois é impossível alcançar-se um conceito universal nesse campo, segundo ele. Afirma que a ciência pode até construir a teoria dos atos de liberalidade ou dos negócios a título gratuito, mas nenhuma delas poderão abarcar todas as situações em que a doação se apresenta, de maneira que o estudo do tema só faz sentido diante da incipiente e ambígua legislação anterior. Tendo, porém, a lei se manifestado sobre a figura, a ela é que cabe dizer quais atos de liberalidade são doação, integrando a lacuna existente por conta do limite científico.

Dessa maneira, faz ${ }^{51}$ uma primeira análise do art. 769 do Código Civil da Itália em comparação com o revogado sistema civil de 1865, o qual teria se inspirado no Código

\footnotetext{
${ }^{47}$ La Donazione, cit., pp. 141-142.

${ }^{48}$ La Donazione, cit., pp. 143-144.

${ }^{49}$ No mesmo sentindo se manifesta TANIA CASSANDRO, que reconhece a afinidade existente entre a doação e o testamento, porque em ambos se ressalta a unilateralidade, sendo que a doação é mormente utilizada com efeitos sucessórios, mas ainda assim não nega a natureza contratual da primeira e a consequente aplicação da teoria geral dos contratos à figura (in ANTONIO CATAUDELLA (Coord.), La Donazione, Milano, Giuffrè, 1996, pp. 9-10).

${ }^{50}$ Le Donazioni, in FILIPPO VASSALI (Dir.), Trattato di Diritto Civile Italiano, vol. XII, tomo IV, Torino, UTET, 1961, pp. 67-70.

${ }^{51}$ Le Donazioni, cit., pp. 89-90.
} 
Napoleônico, mas o autor critica o posicionamento dos dois últimos, pois a submissão da doação aos modos de transferência de propriedade seria muito estreita para ela, que importa também em outras realidades, pelo que não faz sentido exigir-se o imediato despojamento do objeto doado, da mesma forma que nada define se destacar a irrevogabilidade do ato, pois se for perfeitamente acabado qualquer ato é irrevogável, ao menos unilateralmente, pelo que afirma merecer encômios a opção legislativa do Código de 1942, que baniu tais caracteres da sua definição.

Após, apontando para as mudanças sofridas nos projetos do atual Código Civil e considerando que é inútil discutir melhorias legais a não ser em sede de reforma legislativa, BIONDI $^{52}$ afirma que andou bem o Código de 1942 ao regulamentar dois regimes de doação, pois há uma que é dispositiva (por ser contrato), e outra que é obrigatória em seus efeitos ${ }^{53}$, e também por destacar, no seu já transcrito art. 769, dois elementos essenciais para se identificar a figura: um objetivo, consistente no enriquecimento, e outro subjetivo, que importa no espírito de liberalidade.

Explicando essa dualidade de tratamento para as liberalidades, GIOVANNI $\mathrm{BALBI}^{54}$ pondera que, em verdade, a noção comum de doação é diferente da jurídica, sendo mais larga que esta e podendo se realizar de diversas maneiras, não necessariamente na forma de transferência patrimonial, daí a previsão do art. 809, mas justifica a criação de uma espécie jurídica para que se proteja o doador de ir à ruína graças a um impulso benfeitor, ou a terceiros, mormente familiares, de serem lesados em seus direitos em prol do donatário, de modo que é necessária a criação de um regime jurídico próprio para o negócio, como faz o Código Civil italiano de 1942, nos arts. 769 em diante ${ }^{55}$.

\footnotetext{
${ }^{52}$ Le Donazioni, cit., pp. 90-91.

${ }^{53}$ Art. 809 ("Norme sulle donazioni applicabili ad altri atti di liberalità"). "1. Le liberalità, anche se risultano da atti diversi da quelli previsti dall'articolo 769, sono soggette alle stesse norme che regolano la revocazione delle donazioni per causa d'ingratitudine e per sopravvenienza di figli nonché a quelle sulla riduzione delle donazioni per integrare la quota dovuta ai legittimari. 2. Questa disposizione non si applica alle liberalità previste dal secondo comma dell'articolo 770 e a quelle che a norma dell'articolo 742 non sono soggette a collazione”.

54 Saggio Sulla Donazione, in R. UNIVERSITÀ DI TORINO, Memorie Dell'Istituto Giuridico, Série II, Memoria L, Torino, L'Istituto Giuridico della R. Università, 1942, p. 7.

55 Sintetizando o enquadramento dogmático da doação, TANIA CASSANDRO explica que no Código Civil italiano os negócios a título gratuito são gênero, do qual as liberalidades são espécie, e a mais relevante das liberalidades é a doação (La Donazione, cit., pp. 7-9).
} 
Ademais, o autor ${ }^{56}$ defende a contratualidade da doação justamente porque o aceite é elemento essencial desta, o que resguarda o sinalagma, não sendo mero sentimento de gratidão, pois a lei visa tutelar a faculdade de recusa do donum pelo beneficiário. Além disso, fosse a doação negócio unilateral, seria irrevogável desde a ciência do donatário, mas, ao invés, enquanto não houver aceite o donante pode revogar o ato, o que até diferencia essa liberalidade do legado.

Como se verifica, também no direito italiano a doação é um contrato, mas a ela se dispensa um tratamento especial para abarcar algumas realidades que a contratualidade, ao que parece, não consegue regulamentar. Assim, a figura é aproximada topograficamente pela lei do testamento, em vista de ambas serem uma liberalidade. Outrossim, a fim de se abarcar o máximo possível da realidade, sujeita-se à quase totalidade das liberalidades os mesmos efeitos revogatórios da doação e de proteção da legítima, como se verifica na redação do mencionado art. 809 da lei ${ }^{57}$.

No direito americano, a doação é tratada sob o nome de gift, apesar de este ser o mesmo termo usado para designar o objeto do ato, ao lado de present, de maneira que mais propriamente seria adequado empregar a locução gift giving, mas não é esse o padrão adotado pelos estudiosos, sendo que a falta de um termo para expressar o que se entende por doação demonstra que na tradição jurídica anglo-saxã preocupa-se menos com o ato em si, acentuando-se mais as doações passíveis de discussão judicial ${ }^{58}$.

\footnotetext{
${ }^{56}$ BALBI, Saggio (...), cit., pp. 13-19.
}

${ }^{57}$ Escrevendo no âmbito da legislação civil italiana de 1865, que assim definia a doação, em seu art. 1.050: " $L a$ donazione è um atto di spontanea liberalità, col quale il donante si spoglia attualmente ed irrevocabilmente della cosa donata in favore del donatario che l'accetta", ALFREDO ASCOLI (Trattato delle Donazioni, $2^{\mathrm{a}}$ ed., Milano, Società Editrice Libraria, pp. 8-9) já criticava tal definição, dizendo que conceitua deficientemente a doação, utilizando termos vagos, o que não permiti sua identificação concreta e sua finalidade. Também o autor impugna o uso do termo 'ato', ao invés de se utilizar do molde contratual, que, segundo seu parecer, era o posicionamento quase unânime na doutrina, e entende que se superou o Código Napoleônico apenas pelo fato de se ter relacionado a doação com liberalidade, mas não com negócios a título gratuito. Por esse motivo, formula uma definição própria em que trata a doação como contrato e fornece os elementos que entende característicos da sua contratualidade (gratuito, com o escopo de exercer liberalidade, tendo por objeto bem não acessório e não passível de ser revogado ao arbítrio do autor), mostrando assim que a simples leitura da lei pode induzir o estudioso em erro, haja vista que, apesar da disposição legal, o tratadista já entendia que a doação é contrato, inclusive na esteira da doutrina francesa. No mesmo sentido, VALERIO ADOLFO COTTINO criticava a posição adotada pelo Código Civil italiano de 1865 por ter adotado o sistema francês de regulamentar a doação, pois no sistema de seu país o testamento era regido de modo diverso do gálico, pelo que conclui que a doação deveria ser regulamentada em meio aos contratos a título gratuito e, por ser consensual, logo em seguida à compra e venda (Le Donazioni, Torino, UTET, 1913, pp. 10-11 e 17), o que antecipou a posição adotada pelo Código Civil de 1916 e de 2002 brasileiros.

${ }^{58}$ RICHARD HYLAND, Gifts - A Study in Comparative Law, New York, Oxford University Press, 2009, Kindle Edition, item 211 
Na tradição da commom law, ao contrário do sistema pátrio e de tantos outros, não há um artigo de lei que defina a doação. ROBERT LUDLOW FOWLER ${ }^{59}$ reporta que no direito antigo inglês o gift, que ele identifica expressamente com a donatio, apenas servia para a instituição do estate tail, instituto esse semelhante ao fideicomisso do sistema romanogermânico, mas que na era moderna a doação teve seu sentido alargado, sendo que os precedentes judiciais do estado de Nova Iorque apontavam que ela consiste num ato voluntário de transferência de um direito real sobre bem móvel ou imóvel de uma pessoa para outra, sem a presença do consideration, elemento este essencial para a formação de um contrato no âmbito da commom law ${ }^{60}$. Isto é, para esse doutrinador a doação não é um contrato.

RICHARD HYLAND ${ }^{61}$ também tem o mesmo parecer, porque entende que o enquadramento da doação no molde contratual é causa de distorções, pois, ao menos no sistema civil americano, os contratos estão necessariamente ligados a transações comerciais, suas obrigações têm força de lei entre as partes, pelo que passível de cumprimento forçado, e têm como causa uma barganha (consideration), sendo que nenhum desses elementos se fazem presentes na doação.

Ademais, crê que a visão contratualista é insuficiente para possibilitar ao aplicador do direito identificar os atos passíveis de serem emoldurados como doação, a fim de deles tirarem as devidas consequências, pois estas nada têm que ver com a realidade do contrato (v.g.: capacidade de doar e receber doação, necessidade de levar à colação, casos de revogação, etc.).

Outrossim, continua o mesmo autor ${ }^{62}$ a ponderar que uma definição legal que vise equiparar a doação com a categoria contratual, nela entrevendo proposta, aceitação e adimplemento, é defeituosa. Explica que na elaboração de um contrato qualquer, mesmo que as partes não tenham cumprido os requisitos legais, ainda assim permanecem livres para manter o pacto, ao passo que na doação a não observância de ao menos um requisito fulmina de nulidade todo o ato e importa inclusive na revocação do objeto já transferido, concluindo

\footnotetext{
${ }^{59}$ The Law Of Charitable Uses, 1896, ed. fac-sim., New Delhi, Isha Books, 2013, pp. 3 e 84-85.

${ }^{60}$ Sobre o consideration, consultar: OLIVER WENDELL HOLMES, The Common Law, Boston, Little Brown and Company, 1951, pp. 289-297; ROLAND SÉROUSSI, Introdution aux droits anglais et américain, 1999 , trad. port. de Renata Maria Parreira Cordeiro, Introdução ao Direito Inglês e Norte-Americano, São Paulo, Landy Editora, 2006, pp. 118-119.

${ }^{61}$ Gifts (...), cit., item 212.

${ }^{62}$ Gifts (...), cit., item 213.
} 
então que a lei assume um risco maior em definir doação, o que não ocorre num contrato puro.

Desse modo, assumindo que faltam elementos universais na doação, que às vezes nem sequer importa em transferência, ou nem em ceder um bem tangível, ou nem ainda no enriquecimento do donatário em detrimento do doador, RICHARD HYLAND ${ }^{63}$ conclui que uma definição de doação, para ser útil, deve estar adequada ao objeto de estudo do pesquisador. Como quer fazer uma pesquisa comparativa, o autor adota como critério de verificação a combinação de quatro elementos: a gratuidade (entendida como a ausência de desejo de lucro), o desiderato de fazer a doação (o que se entende por animus donandi), o fato de se tratar de uma transação inter vivo e o objeto a ser doado.

Da mesma forma, em obra voltada à exposição da figura da doação para estudantes e operadores do direito norte-americano, os seus autores ${ }^{64}$ preferiram abordar o gift de acordo com o modo de transferência de direito, de maneira que: sendo o objeto doado um real property, bastaria haver intenção de doar, entrega de documento escrito de acordo com os requisitos do Statute of Frauds $(1676)^{65}$ e aceitação pelo donatário, e destacam que não precisa haver consideration; e, em se tratando de personal property, porém, o problema reside apenas na aceitação do ato como doação pelos Tribunais, que acatam a noção comum tripartite do negócio jurídico, consistente no intento de doar, na tradição da coisa e na aceitação pelo donatário, podendo, porém, a tradição ser substituída pela entrega de um instrumento particular ${ }^{66}$.

Afirmam $^{67}$, ainda, que o desenvolvimento histórico e conceitual da doação e dos contratos, no âmbito da commom law, são distintos, mas que nada impede, por razões funcionais apenas, que o doador se utilize da formatação de um contrato para fazer doação, como no caso da estipulação benéfica em favor de terceiro.

\footnotetext{
${ }^{63}$ Gifts (...), cit., itens 223-224.

${ }^{64}$ ELIAS CLARK et al., Cases and Materials on Gratuitous Transfers, $5^{\mathrm{a}}$ ed., Saint Paul, Thomson West, pp. 419-420 e 429-432.

${ }^{65}$ A jurisprudência americana, no entanto, admite qualquer documento escrito com a assinatura das partes como suficiente para tal fim, bem como a exceção do part performance, que consiste na admissão de doação de imóvel sem instrumento escrito baseado apenas no comportamento do doador. Outra exceção à regra é a defesa do adquirente de boa-fé [nesse sentido: ELIAS CLARK et al., Cases (...), cit., pp. 423-425].

${ }^{66}$ Sobre o conceito de real property e personal property, consultar: RENÉ DAVID, Le Droit Anglais, 1987, trad. port. de Eduardo Brandão, O Direito Inglês, $2^{\mathrm{a}}$ ed., São Paulo, Martins Fontes, 2006, pp. 91-99.

${ }^{67}$ ELIAS CLARK et al., Cases (...), cit., p. 452
} 
Como se verifica, no direito norte-americano a doação não é um contrato e a aproximação dogmática que se faz sobre ela tem por escopo responder mais a questões de ordem prática do que a criação de um sistema teórico, de modo que sobressaem como elementos constitutivos o intento das partes e a verificação de enriquecimento de uma delas em detrimento da outra.

Mas não foi apenas no ambiente do direito estadunidense que aflorou a doutrina que não vê na doação um contrato, havendo estudiosos de outras nacionalidade preferindo também destacar alguns elementos caracterizadores da figura. Nesse sentido, FRIEDRICH CARL VON SAVIGNY ${ }^{68}$ começa apontando que no Direito Romano pós-clássico a doação era tratada sob a categoria de modo de aquisição de propriedade, mas critica tal abordagem, pois a causa da doação, nessa ótica, é igual à da compra e venda e de diversos outros contratos, segundo seu parecer, pelo que, por coerência, deveriam então todos esses negócios jurídicos serem abordados do ponto de vista da propriedade, o que não ocorre, e, além disso, o fato é que a propriedade é insuficiente para abarcar todos eles, inclusive a doação, pois pode ser objeto desta não apenas o direito de propriedade.

Por conta disso, aduz o autor ${ }^{69}$, os juristas modernos optaram por usar o molde contratual para regular a doação, na sua modalidade unilateral, mas também se insurge contra esse posicionamento, classificando-a, assim como a anterior, de infundada e insatisfatória, porque parte do pressuposto de que a doação seja um negócio jurídico único, o que seria falso, segundo ele, pois, em verdade, consistiria a doação em uma figura geral presente nos diversos negócios jurídicos e explica que esse é o motivo pelo qual, em sua obra, trata dela como uma categoria geral ao lado dos contratos.

Dessa maneira, SAVIGNY ${ }^{70}$ acaba por destacar que será doação qualquer negócio jurídico realizado por ato inter vivos em que estão presentes o empobrecimento do sujeito ativo e o enriquecimento do recebedor, tendo como motor a vontade do doador de que tal efeito se realize, explicando que, de fato, tal negócio exige a presença de duas partes, sendo o autor o doador, mas que não é genuíno falar-se em 'donatário', tanto é assim a locução

\footnotetext{
${ }^{68}$ System des heutigen römischen Rechts, trad. it. de Vittorio Scialoja, Sistema del Diritto Romano Attuale, vol. IV, Torino, UTET, 1889, pp. 1-2.

${ }^{69}$ Sistema (...), cit., pp. 2-3.

${ }^{70}$ Sistema (...), cit., pp. 3-4.
} 
utilizada pelos romanos para se referir a essa parte do negócio significa mais recebedor da benesse $^{71}$, sendo mais próprio falar-se em 'aceitante', segundo sua lição.

Não deixa o mencionado autor ${ }^{72}$ de considerar uma certa arbitrariedade na sua conceituação, mas afirma que os elementos elencados não têm o objetivo de criar um instituto jurídico e lançar as bases de seu sistema, e assim se conduziram os diversos ordenamentos jurídicos apenas para resguardar a observância de algumas regras na doação, que de início eram a sua forma, a vedação de doação entre cônjuges e a revogabilidade do ato em algumas hipóteses, o que são necessidades práticas, de modo que para se afirmar o que não seria doação se fez necessária uma definição marcada por exatidão, mas que tal sutileza é desnecessária se busca-se o lado positivo da definição.

Com isso, justifica ${ }^{73}$ sua visão explicando que do lado do doador a essência do ato está na benemerência que quer executar em favor do beneficiário, ao passo que do lado desse o fulcro reside em receber algo sem precisar se esforçar para recebê-lo, o que classicamente se chama de lucrativa causa, diferenciando-se tal dinâmica das demais relações jurídicas por conta da presença da vontade de doar do autor do ato, ressalvando que, em verdade, a conceituação da doação vai depender da regra positiva, que dará a utilidade da criação de tal desiderato, de modo que em seu estudo, por exemplo, afirma que não perde de vista as três proibições acima elencadas.

Também no âmbito de estudos do tema na doutrina brasileira não há unanimidade no que toca ao fato de a doação ter ou não natureza jurídica contratual, apesar da disposição legislativa e da ampla gama de juristas que a ela se associam, como foi acima colacionado.

LUCIANO DE CAMARGO PENTEADO ${ }^{74}$ afirma haver muita ambiguidade no delineamento da natureza jurídica da doação, em que pese a clareza do Código Civil de 2002, que o submete explicitamente ao regime dos contratos, pois, segundo esse autor, ela poderia ser vista não só sob o prisma contratual, mas também como ato unilateral de vontade, modo de aquisição da propriedade, ato atípico, etc.. Desse modo, chega a aplaudir a tendência de se

\footnotetext{
${ }^{71}$ Por exemplo: "is cui donatum est".

${ }^{72}$ Sistema (...), cit., pp. 4-9.

${ }^{73}$ Sistema (...), cit., pp. 9-23.

${ }^{74}$ Doação com Encargo e Causa Contratual, Campinas, Millennium, 2004, pp. 206-207.
} 
relativizar a forma de celebração do contrato de doação, e assim o faz adotando a tese de que a teoria contratual não é suficiente para enquadrar a figura ${ }^{75}$.

Em outro passo, o mesmo autor ${ }^{76}$ afirma, em relação aos negócios unilaterais, que sua característica principal é o fato de ser idealizado exclusivamente pelo proponente, cabendo à outra parte aceder ou não ao que lhe é proposto, e, após, constata que na doação não há propriamente negociação, mas sim o fato de que o doador tem a vontade de doar e ao donatário cabe aceitar tal ato volitivo ou não, e se quiser proceder a tratativas da benesse, deverá fazê-lo em ato apartado, ou seja, a doação tem os caracteres necessários para configurar ato unilateral de vontade, mas o autor ressalva que tentativas de sistematização não são capazes de abarcar toda a realidade da figura.

Por esses motivos, acaba por sugerir ${ }^{77}$ uma nova natureza jurídica para a doação, e opina que seja tratada não como um instituto, mas sim como uma "figura", e fundamenta sua tese no fato de que a doação é multifacetária, adotando uma determinada característica de acordo com a realidade que abarca, e aponta as diversas espécies de doação possíveis de se realizarem, as quais possuem uma valência própria, de acordo com o desiderato almejado pelo doador e/ou o donatário. Assim, entende que é melhor relegar ao fato concreto a real qualificação da doação, podendo ora revestir-se de natureza contratual, consensual ou real, ora ato unilateral de vontade, ora modo de aquisição da propriedade, etc..

NESTOR DIÓGENES ${ }^{78}$, por sua vez, afirma expressamente entender que a doação não é um contrato, devendo, antes, ser vista como um ato de transferência patrimonial específico, que importa em ser gratuito e ter uma única manifestação de vontade, a do doador, comparável ao testamento. Em outra passagem, se manifesta ${ }^{79}$ no sentido de que o próprio termo contrato evoca a imposição de uma obrigação ou a sua constituição, ao passo que doação, vista de maneira natural, remete à transferência de um bem do patrimônio de uma pessoa a outra, sem que haja uma contraprestação ou cumprimento de uma obrigação.

Os motivos que o levaram a crer que a doação não é contrato podem ser resumidos nas seguintes ideias: inexiste comutatividade e a obrigação se perfaz com a mera manifestação de vontade do doador, sendo o aceite do donatário mera formalidade vazia, pois

\footnotetext{
${ }^{75}$ Doação com Encargo (...), cit., p. 136.

${ }^{76}$ Doação com Encargo (...), cit., p. 213.

${ }^{77}$ Doação com Encargo (...), cit., pp. 220-224.

${ }^{78}$ Doação não (...), cit., p. 56.

${ }^{79}$ Doação não (...), cit., p. 138.
} 
o dom já foi realizado, podendo-se citar, como exemplo, a aceitação de herança ou legado, em que a transferência ocorre com ou sem aceite, e tanto vale essa afirmação para a doação que existem hipóteses legais em que o aceite é ficto ou presumido. Assim, procura o estudioso definir a doação combinando o fato de ser sempre uma transferência com a realização de uma liberalidade, cujo motor próprio é a exclusiva vontade do doador ${ }^{80}$.

Deste modo, para NESTOR DIÓGENES ${ }^{81}$ a natureza jurídica da doação não é a contratual, pelo que aduz um leque de possíveis qualificações dela, não se restringindo a apenas uma. Ao tratar da formalidade imposta às doações, por exemplo, critica mais uma vez a roupagem de contrato e formalismo que lhe é dispensada, pois faz com que receba tratamento dogmático despregado da realidade, e conclui ser dispensável maiores formalidades, cabendo ao donatário recusar se estiver descontente, mas que seria de maior "bom senso" admitir-se que a doação melhor se adéqua ao testamento.

No entanto, em outra passagem de sua obra, reafirmando seu entendimento de que a doação, na forma pura, não é contrato, não deixa de negar que se trata de um negócio jurídico $^{82}$. De outro lado, pondera que na doação modal vislumbra-se o elemento contratual, o mesmo não ocorrendo com a pura, de modo que para ele a figura encontra-se numa posição intermediária, e, após trazer à baila a cessão de crédito, que tem no Código tratamento próprio dentro do livro das obrigações, isto é, fora dos contratos, explica que nessa figura o objeto do negócio pode ser transferido tanto onerosamente, como por um ato de liberalidade, ou até por sucessão, justamente como ocorre na doação. Assim, pergunta-se por que não se dá à doação também um tratamento sui generis, como se fez com a cessão de crédito, e ele mesmo responde que tal não se dá por "preconceito dogmático" 83 .

Como visto, não se deve afirmar sem detida análise que a doação é um contrato, pois até os autores que se filiam à visão contratualista da doação titubeiam, como ARNALDO MARMITT $^{84}$, que entende não fazer mais sentido discutir-se a natureza contratual da doação, haja vista a unanimidade que se formou nesse tema, segundo ele, porém admite que às vezes ela ganha feição de negócio unilateral, especialmente quando a vontade do donatário não se

\footnotetext{
${ }^{80}$ Doação não (...), cit., pp. 141-142.

${ }^{81}$ Doação não (...), cit., p. 133.

${ }^{82}$ Doação não (...), cit., p. 54.

${ }^{83}$ Doação não (...), cit., pp. 25-26.

${ }^{84}$ Doação, Rio de Janeiro, Aide Editora, 1994, pp. 10-11.
} 
faz necessária para sua formação, de modo que, por ser rara exceção, prevalece a tese dominante ${ }^{85}$.

Desse modo, esse mesmo autor ${ }^{86}$ afirma que a doação é um "contrato sui generis", e fundamenta sua asserção no fato de estar revestida de uma maior proteção pela lei, seja para refrear o doador, seja para protegê-lo de dolo de terceiros, ao mesmo tempo que é alargada quanto à capacidade do donatário, e, por fim, tem o condão de transferir a propriedade. Verifica-se, assim, que mesmo para esse doutrinador a figura do contrato é uma roupa justa que se veste com dificuldades na doação, mas criar uma nova categoria, como pretende, não parece ser a solução, não apenas porque desvirtuaria a teoria contratual a base de enxertos desnecessários, mas também não responderia às necessidades práticas das partes.

Admitindo-se, porém, que a doação seja um contrato, há divergência na doutrina, havendo os que entendem ser real, ou então consensual, ou ainda unilateral.

Para os que acham que a doação é um contrato real ${ }^{87}$, invocam a favor de seu parecer que em alguns casos é necessária a tradição da coisa, podendo-se falar ainda que o aceite é mero elemento formador da consensualidade contratual, não servindo como critério distintivo do ato, o que somente se verifica quando há a transferência patrimonial ${ }^{88}$. PAULO LÔBO $^{89}$, sem negar a unilateralidade do contrato, afirma que a doação importa necessariamente na entrega imediata da coisa doada e sem isso nem sequer existe, mesmo no caso de imóveis, sendo até exceção à regra de inscrição do título no registro de imóveis, pois o próprio contrato já atribui domínio de per $\mathrm{si}^{90}$.

\footnotetext{
${ }^{85}$ No mesmo sentido: ORLANDO GOMES, Contratos, cit., p. 234.

${ }^{86}$ Doação, cit., p. 10.

${ }^{87}$ Nesse sentido: VICENTE SABINO JÚNIOR, Contrato de doação, cit., pp. 61-62 (não obstante, o mesmo autor, ao tratar da revogação da doação (p. 133), faz notar que, no sistema do Código Civil de 1916, o termo revogação somente se aplica aos atos unilaterais, tais como o mandato ou testamento, donde conclui que a doação é um "contrato unilateral", porém afirma expressamente que somente o doador é quem contrata, sendo que o donatário apenas dá ou não seu aceite).

${ }^{88}$ LUCIANO DE CAMARGO PENTEADO, Doação com Encargo (...), cit., p. 183.

${ }^{89}$ Direito Civil - Contratos, São Paulo, Saraiva, 2011, pp. 281-282.

${ }^{90}$ Sem falar explicitamente que a doação é contrato real, CAIO MÁRIO DA SILVA PEREIRA externa a opinião de que não há doação sem transferência patrimonial, não bastando, para sua formação, o simples consenso [Instituições (...), cit., p. 209]. Também se filiando a esse entendimento, JOÃO BAPTISTA VILLELA manifesta a opinião de que a entrega do objeto doado é da própria gênese do negócio jurídico, por conseguinte não é ato de execução do pacto, ao contrário do que ocorre na compra e venda, até por imposição do art. 538 do Código Civil de 2002, segundo sua ótica, que não admitiria a simples consensualidade na formação do contrato [Contrato de Doação: Pouca Luz e Muita Sombra, in ANTONIO JORGE PEREIRA JÚNIOR e GILBERTO HADDAD JABUR (Coords.), Direito dos Contratos, São Paulo, Quartier Latin, 2006, pp. 261-264].
} 
Para outros autores ${ }^{91}$, porém, a doação é contrato consensual, porque não se faz necessária a tradição do bem doado para seu aperfeiçoamento, bastando, para tanto, o simples consenso das partes. A visão da doação como contrato consensual tem seu maior respaldo legal no art. $545^{92}$ do Código Civil de 2002, que trata da doação por subvenção periódica, pois nessa hipótese a relação surge antes da tradição do bem, e esta não é aperfeiçoamento do contrato, mas sim adimplemento da obrigação contraída pelo doador, como leciona LUCIANO DE CAMARGO PENTEADO ${ }^{93}$, ressalvando que essa espécie poderia ser melhor abordada sob a qualificação de "promessa de doações periódicas", de modo que vindo a falecer o donatário extingue-se o dever de entregar a coisa, não o contrato de doação, que se manteria real, mesmo na hipótese ${ }^{94}$.

No entanto, a contrariar tudo o que se afirmou até então, AGOSTINHO ALVIM ${ }^{95}$ entende que a doção não é nem contrato consensual, nem contrato real. Com fundamento na disposição do art. 1.168, caput, e parágrafo único ${ }^{96}$, do Código Civil de 1916, afirma que o contrato de doação não é consensual justamente porque o simples consenso não lhe dá plena formação, fazendo-se necessária a confecção de um instrumento ou a tradição da coisa de pequeno valor. Explica, em outro passo de sua obra, que não conceitua consensual em anteposição ao real, mas sim com base no fato de que o mero consenso é o suficiente para a formação do contrato, como a compra e venda de bem móvel, sem demais formalidades. Como assim não de dá na doação, ela não é consensual, o que, aliás, até a diferencia em um aspecto dos demais contratos ${ }^{97}$.

${ }^{91}$ ARNALDO MARMITT, Doação, cit., p. 10; ARNOLDO WALD, Direito (...), cit., p. 59; CARLOS ROBERTO GONÇALVES, Direito (...), cit., p. 257; CARVALHO DE MENDONÇA, Contratos (...), cit., p. 39; CÉSAR FIUZA, Direito (...), cit., p. 501; FLÁVIO TARTUCE, Direito Civil, vol. III, $3^{a}$ ed., São Paulo, Método, 2008, p. 313; FRANCISCO GLAUBER PESSOA ALVES, Das Várias (...), cit., p. 882; NELSON ROSENVALD, Contratos (...), cit., p. 585; OZÉIAS J. SANTOS, Da Doação, cit., p. 11; PAULO GERALDO DE OLIVEIRA MEDINA, A Doação, cit., p. 462; PAULO NADER, Curso (...), cit., p. 227; RODRIGO SENISE LISBOA, Manual (...), cit., p. 258.

${ }^{92}$ Art. 545: "A doação em forma de subvenção periódica ao beneficiado extingue-se morrendo o doador, salvo se este outra coisa dispuser, mas não poderá ultrapassar a vida do donatário".

${ }^{93}$ Doação com Encargo (...), cit., pp. 217-218. No mesmo sentido: PAULO LÔBO, Direito (...), cit., p. 282.

${ }^{94}$ Há ainda quem afirme que a doação é contrato consensual na sua formação, mas unilateral nos efeitos. Nesse sentido: CARLOS ALBERTO BITTAR, Contratos (...), cit., p. 42; LUIZ GUILHERME LOUREIRO, Curso (...), cit., pp. 504-505; ORLANDO GOMES, Contratos, cit., pp. 233-234; SYLVIO CAPANEMA DE SOUZA, Das Várias (...), cit., p. 88.

${ }^{95}$ Da Doação, cit., pp. 7 e 55.

${ }^{96}$ Art. 1.168. "A doação far-se-á por escritura pública, ou instrumento particular (art. 134). Parágrafo único. A doação verbal será válida, se, versando sobre bens móveis e de pequeno valor, se lhe seguir incontinenti a tradição".

${ }^{97}$ Da Doação, cit., pp. 75-76. 
Outrossim, entende ${ }^{98}$ que o contrato de doação, assim como o contrato de compra e venda, por si só, não transmite a propriedade, que somente se perfaz com a transcrição do título para os bens imóveis e com a tradição para os móveis, de maneira que consiste apenas numa promessa de transferência ${ }^{99 / 100}$. Ademais, em outro passo de sua obra ${ }^{101}$, explica que, ao contrário dos contratos reais, a doação não se perfaz somente com a tradição, mas sim com a celebração do contrato na forma escrita, inclusive no caso de doação de bens de pequeno valor, em que é possível o instrumento substituir a entrega, de modo que a tradição não é essencial para a celebração do ato.

Por isso, muitos autores ${ }^{102}$ entendem que a doação é, antes de mais nada, um contrato unilateral, por meio do qual o doador exerce uma liberalidade e o donatário tem seu patrimônio aumentado, sem contrair qualquer obrigação, nem mesmo a de receber a coisa doada, isto é, trata-se de negocio jurídico sem correspectivo por parte do beneficiário ${ }^{103}$. PONTES DE MIRANDA ${ }^{104}$ esmiúça essa realidade explicando que o negócio jurídico em si considerado consistente em uma doação é bilateral, mas o contrato é unilateral, pois não há

${ }^{98}$ Da Doação, cit., pp. 64-68.

${ }^{99}$ Não obstante, entende que a transferência do bem doado abrange também o direito de ingressar com ação possessória ao donatário, caso a coisa doada se encontre na posse de terceiros.

100 No mesmo sentido: AMANDA ZOE MORRIS, Doação, in GISELDA M. F. NOVAES HIRONAKA (Orient.), AMANDA ZOE MORRIS (Coord.), e LUCAS ABREU BARROSO (Coord.), Direito Civil Direito Dos Contratos, vol. III, São Paulo, Revista dos Tribunais, 2008, p. 277; ARNALDO RIZZARDO, Contratos, cit., p. 440; CAIO MÁRIO DA SILVA PEREIRA, Instituições (...), cit., p. 218; CARLOS ALBERTO BITTAR, Contratos (...), cit., p. 42; JONES FIGUEIRÊDO ALVES, Arts. 421 a 729, in REGINA BEATRIZ TAVARES DA SILVA (Coord.), Código Civil Comentado, $7^{\mathrm{a}}$ ed., São Paulo, Saraiva, 2010, p. 444; LUIZ GUILHERME LOUREIRO, Curso (...), cit., pp. 504-505; MARIA HELENA DINIZ, Tratado (...), cit., p. 72; ORLANDO GOMES, Contratos, cit., p. 235; PAULO DE TARSO VIEIRA SANSEVERINO, Contratos (...), cit., pp. 73-74; SÍlVIO DE SALVO VENOSA, Direito (...), cit., p. 124; SILVIO RODRIGUES, Direito (...), cit., p. 200.

${ }^{101}$ Da Doação, cit., pp. 78-79. A favor da realização de doação manual por meio de instrumento: ARNOLDO MEDEIROS DA FONSECA, Doação Indireta, in GUSTAVO TEPEDINO e LUIZ EDSON FACHIN (Orgs.), Doutrinas Essenciais - Obrigações e Contratos, vol. V, São Paulo, Revista dos Tribunais, 2011, p. 297.

${ }^{102}$ AGOSTINHO ALVIM, Da Doação, cit., pp. 7-8; ANTÔNIO CHAVES, Liç̃̃es (...), cit., p. 233; ARNALDO RIZZARDO, Contratos, cit., p. 440; CARLOS ROBERTO GONÇALVES, Direito (...), cit., p. 257; EDUARDO ESPINOLA, Dos Contratos (...), cit. p. 157; FLÁVIO AUGUSTO MONTEIRO DE BARROS, Manual de Direito Civil, vol. II, São Paulo, Método, 2005, p. 345; MARIA HELENA DINIZ, Curso de Direito Civil Brasileiro, vol. III, 29ª ed., São Paulo, Saraiva, 2013, p. 253; PAULO DE TARSO VIEIRA SANSEVERINO, Contratos (...), cit., p. 69; SAMUEL LUIZ ARAÚJO, O Princípio (...), cit., p. 73; SERPA LOPES, Curso (...), cit., p. 386; SÍLVIO DE SALVO VENOSA, Direito (...), cit., p. 125; SILVIO LUÍS FERREIRA DA ROCHA, Curso Avançado de Direito Civil, vol. III, São Paulo, Revista dos Tribunais, 2002, p. 170; SYLVIO CAPANEMA DE SOUZA, Das Várias (...), cit., p. 86.

103 Também no sistema civil espanhol a doação, por si, como todos os outros contratos, não importa em transferência, sendo antes promessa de transferência, pelo que é classificada por obligatoria ou obligacional, em anteposição a transmisiva, dispositiva ou real (neste sentido: MANUEL ALBADALEJO GARCÍA e SILVIA DIAZ ALABART, La Donación, cit., pp. 35-51). De outro lado, como já visto, no Código Napoleônico a doação é modo de aquisição da propriedade, sendo que a simples celebração do contrato já importa na transmissão do objeto doado para o patrimônio do donatário, isto é, no "dépouille actuellement" exigido pelo art. 894 do diploma legal.

${ }^{104}$ Tratado (...), cit., p. 198. 
proposta e contraproposta, como na compra e venda, mas sim proposta do doador e aceitação (ou não) por parte do donatário.

Diante de tudo o que até aqui se expôs, verifica-se que, como sói acontecer nas ciências humanas, os teóricos não são concordes quanto à conceituação da doação, ou, se o são, apenas em alguns aspectos, mas não em todos eles, a demonstrar a riqueza do debate. No entanto, dada a finalidade da presente pesquisa, adotar-se-á a definição entregue pelo art. 538 do Código Civil de 2002.

Assim, a fim de descortinar a possibilidade e os modos de utilização da doação como instrumento de planejamento sucessório no sistema civil pátrio, ela será tomada por contrato, de acordo com o regime disciplinador próprio do sistema; a causa necessária para sua ocorrência será a liberalidade de que fala a lei; e, consistirá em o doador fazer uma promessa de que irá proceder à transferência de um bem do seu patrimônio para o do donatário, que a aceitará, tudo isso de acordo com o quanto gizado no sobredito art. 538, de modo a se possibilitar a realização de negócio jurídico perfeito.

Não obstante, dada a robustez dos argumentos amealhados, não se desprezará a possibilidade de a lei não ser capaz de esgotar o caso concreto e, se tal vier a ocorrer, não se titubeará de lançar mão às demais soluções que já se empregam em sistemas e pensamentos diversos.

\section{2) Elementos da doação}

Como se viu acima, a pesquisa da definição da doação não se esgota apenas em verificar sua contratualidade, sendo bastante profícuo se destacar os elementos que a caracterizam, de acordo com uma determinada finalidade.

Assim, dificilmente se poderá encontrar unanimidade na lista de características que compõem a doação, justamente porque diversos são os fins almejados pelos pesquisadores do tema. De todo modo, para os efeitos do presente estudo, elenca-se aqui os três principais: formalidade ou solenidade; o animus donandi; e, a transferência patrimonial ou gratuidade.

Pode ocorrer de no magistério de um autor apontar-se uma característica aqui omitida ou então omitir-se uma característica aqui estampada, o que seria natural, haja vista o quanto discutido em relação ao conceito e à natureza jurídica da figura da doação. Tenta-se 
aqui abarcar os elementos gizados pelo art. 538 do Código Civil de 2002 e pelo sistema de normas que regem a figura, a fim de garantir que se alcance doação que sirva de instrumento inconteste de planejamento sucessório.

\section{1) Formalidade ou solenidade}

Muitos dos que escreveram ${ }^{105}$ sobre a doação afirmam expressamente que ela é um contrato formal ou solene. Assim, afirma-se ${ }^{106}$ que, no caso da doação, a forma compõe sua substância e sua ausência não pode nem sequer ser suprida pela confissão do doador, levando à inexistência do ato, ensinando ainda PAUL DELNOY ${ }^{107}$ que nela está o marco divisório entre a liberalidade e os atos onerosos, pois enquanto esses se formam com o consenso, aquela depende de uma forma específica.

Desse modo, a solenidade imposta à doação pela própria lei constitui a causa contratual do negócio jurídico ${ }^{108}$. No entanto, outros doutrinadores ${ }^{109}$ ensinam que a substância do ato está na intenção liberal, não na forma.

${ }^{105}$ AMANDA ZOE MORRIS, Doação, cit., p. 278; CAIO MÁRIO DA SILVA PEREIRA, Instituições (...), cit., p. 208; FLÁVIO AUGUSTO MONTEIRO DE BARROS, Manual (...), cit., p. 345; JONES FIGUEIRÊDO ALVES, Código (...), cit., p. 444; MARIA HELENA DINIZ, Tratado (...), cit., pp. 72-73; NELSON ROSENVALD, Contratos (...), cit., p. 586; PAULO GERALDO DE OLIVEIRA MEDINA, A Doação, cit., pp. 461 e 462; PAULO NADER, Curso (...), cit., p. 227; PLANIOL, Traité (...), cit., p. 646; ROGÉRIO MARRONE DE CASTRO SAMPAIO, Direito (...), cit., p. 123; SAMUEL LUIZ ARAÚJO, O Princípio (...), cit., p. 74; SÍLVIO DE SALVO VENOSA, Direito (...), cit., pp. 124-125; SILVIO RODRIGUES, Direito (...), cit., p. 200.

${ }^{106}$ CARLOS ROBERTO GONÇALVES, Direito (...), cit., pp. 257-258; JEAN RAY, De La Notion (...), cit., pp. 71-72 (o autor afirma que é preciso a solenidade ou entrega real do objeto para haver doação passível de qualificação jurídica); LUCIANO DE CAMARGO PENTEADO, Doação (...), cit., p. 100; MANUEL ALBADALEJO GARCÍA e SILVIA DIAZ ALABART, La Donación, cit., pp. 52-53 e 183-185; NELSON ROSENVALD, Contratos (...), cit., p. 586; PAULO DE TARSO VIEIRA SANSEVERINO, Contratos (...), cit., p. 70; PLANIOL, Traité (...), cit., p. 651e 653-654; TORRENTE, La Donazione, cit., p. 426.

Há precedentes judiciais, porém, que declaram o ato como sendo de mútuo, pelo que necessária a devolução do bem pela parte que o recebeu (nesse sentido: STJ, $3^{\mathrm{a}}$ T., R. Esp. 1.225.861/RS, rel. NANCY ANDRIGHI, j. 22-04-14; TJSP, $7^{\mathrm{a}}$ Câm. de Dir. Priv., Apel. 0072751-22.2009.8.26.0114, rel. LUIZ ANTONIO COSTA, j. 04-07-12). Não obstante, ao contrário, há julgado que declarou existente contrato de doação por falta de prova do empréstimo, deduzindo o animus donandi dos elementos dos autos, o que não se mostra de acordo com a disposição legal da forma da doação (TJSP, $4^{\mathrm{a}}$ Câm. de Dir. Priv., Apel. 0132115-64.2009.8.26.0003, rel. TEIXEIRA LEITE, j. 04-04-13).

${ }^{107}$ PAUL DELNOY, Le Libéralités (...), cit., pp. 24 e 32. No sistema civil francês a formalidade ganha relevo porque a doação é também modo de aquisição da propriedade [nesse sentido: JEAN RAY, De La Notion (...), cit., pp. 38-39]. De qualquer forma, justamente por faltar à doação a consensualidade que há nos atos onerosos, trata-se de negócio jurídico que levantaria suspeitas do legislador, segundo JEAN RAY, daí a necessidade de se lhe emprestar uma forma [De La Notion (...), cit., pp. 64-68].

${ }^{108}$ GIANFRANCO AMENTA, La Donazione (...), cit., pp. 114-122.

${ }^{109}$ PABLO STOLZE GAGLIANO, $O$ Contrato (...), cit., p. 38 (o autor, porém, na p. 39 da sua obra, não deixa de reconhecer que, à luz da redação do art. 541 do Código Civil de 2002, o contrato de doação é "negócio jurídico formal ou solene"); PAULO GERALDO DE OLIVEIRA MEDINA, A Doação, cit., p. 463 (o autor assume que a doação é contrato formal, porém ensina que a formalidade apenas dá eficácia ao ato, mas não existência ou validade); VICENTE SABINO JÚNIOR, Contrato de (...), cit., p. 45 (para esse autor, a não 
Várias são as explicações do fundamento para a imposição de formalidade à doação pelo legislador.

Para alguns ${ }^{110}$, reside no fato de o oficial registrador poder também funcionar como conselheiro do doador e como expressão da importância da prática de tal ato. Nessa linha, NESTOR DIÓGENES ${ }^{111}$ explica o formalismo da doação como modo de emprestar notoriedade ao ato e de dificultá-lo, assim o doador não só poderá melhor refletir, como também será protegido de manipulações externas. Isto é, há uma desconfiança do legislador a respeito das liberalidades, por representar perigo ao doador, à sua família, aos seus credores e à sociedade, daí a necessidade de maior controle ${ }^{112}$.

AGOSTINHO ALVIM ${ }^{113}$, esmiuçando tais ideias do ponto de vista do autor do negócio jurídico, entende que o ato de doação é o extremo oposto do egoísmo vigente no ser humano, pelo que o legislador impõe uma forma a fim de o doador poder ter todas as chances de praticar um ato bem refletido e ponderado. Explica ${ }^{114}$ também que não significa que o codificador nutra aversão para com os atos liberais, antes pelo contrário, é de se ter consciência que no mais das vezes se trata de um ato moralmente bom, haja vista consistir numa negação do egoísmo, mas impõe uma forma rígida a fim de proteger o doador, pois esse

observância da forma do contrato de doação, quando muito, representará hipótese de anulabilidade).

Há um julgado do Tribunal de Justiça do Estado do Mato Grosso do Sul, porém, que parece não acolher esse entendimento, pois concluiu que a não observância da forma se sobrepuja à vontade do donatário. Com efeito, em sede de julgamento de recurso de apelação, a mencionada Corte entendeu que uma doação de imóvel rural atendeu à vontade da doadora, apesar de ter omitido a transferência gratuita de um outro bem, não discutida nos autos, mas ainda assim a turma julgadora decretou a nulidade da liberalidade, porque ficou provado que as testemunhas não estavam presentes no instante da lavratura da escritura pelo tabelião (Apel. n. 2004.012981-4/0000-00, rel. Vladimir Abreu da Silva, j. 12-03-09).

Esse entendimento é especialmente válido no âmbito da commom law [RICHARD HYLAND, Gifts (...), cit., item 288].

Uma possível conciliação deste antagonismo estaria em assumir que a forma não distingue a liberalidade, mas sim a doação no sistema civil brasileiro [a respeito da insuficiência da forma para se conceituar liberalidade e sua importância para a doação: PAUL DELNOY, Le Libéralités (...), cit., pp. 27-28 e 32]. Vale consultar a esse respeito, ainda, a obra de MÉAU-LAUTOUR, que explica o avanço da autonomia da vontade sobre a doação e a posterior retomada do formalismo a serviço da real expressão do desejo do doador, pois surge justamente para sua proteção [La Donation (...), cit., pp. 257-269. No mesmo sentido: GARDANI CONTURSI LISI, Le Donazioni, cit., pp. 165-166].

${ }^{110}$ LUCIANO DE CAMARGO PENTEADO, Doação com Encargo (...), cit., p. 129; PLANIOL, Traité (...), cit., p. 652 .

111 Doação não (...), cit., p. 48. No mesmo sentido: PLANIOL, Traité (...), cit., p. 652; TORRENTE, La Donazione, cit., pp. 421-422 (o autor explica que o legislador contrabalanceia tal ideia com a necessidade de não se sufocar o impulso generoso do doador); SYLVIO CAPANEMA DE SOUZA, Das Várias (...), cit., p. 127.

112 PAUL DELNOY, Le Libéralités (...), cit., pp. 42-44.

${ }^{113}$ Da Doação, cit., pp. 55-56. No mesmo sentido: LIMONGI FRANÇA, Manual (...), cit., pp. 97-98; PAULO LÔBO, Direito (...), cit., p. 294.

${ }^{114}$ Da Doação, cit., pp. 76-77. Também entendo que se trata de medida protetiva do donante: FÁBIO ULHOA COELHO, Curso (...), cit., p. 240. 
poderá praticar um ato antieconômico enredado em falsas seduções ou induzido por artimanhas, pelo que a lei leva o sujeito a externar refletidamente sua liberalidade, não tomado por impulso.

\section{VASSANTA POROBO TAMBÁ ${ }^{115}$ acrescenta, ainda, que o formalismo na} doação, além de proteger o doador, o que se refere à substância do ato, também tem a finalidade de regrar a prova do mesmo, pois a prova testemunhal se mostra insegura para atestar a existência de um contrato de doação. Com isso, resguarda-se também o direito de terceiros $^{116}$.

A adoção desses fundamentos tem implicação prática de relevo, pois se a solenidade da doação tem essa função de proporcionar ao doador ocasião para refletir, então ela se aplica à formação do contrato, não à entrega do bem, de maneira que se desde o nascedouro há nulidade, todo o ato está eivado de vício, não obrigando o autor a entregar o donum $^{117}$.

De todo o modo, como sintetizou OZÉIAS J. SANTOS ${ }^{118}$, a forma do contrato de doação varia de acordo com a função e com o objeto a ser doado ${ }^{119}$, o que é regulamentado no sistema pátrio por meio do art. $541^{120}$ do Código Civil de $2002^{121}$.

${ }^{115}$ Doação Verbal de Móveis - a Tradição, Coimbra, Almedina, 1970, pp. 20-21.

${ }^{116}$ PAULO LÔBO, Das Várias (...), cit., p. 299.

${ }^{117}$ MANUEL ALBADALEJO GARCÍA e SILVIA DIAZ ALABART, La Donación, cit., pp. 188-189.

${ }^{118}$ Da Doação, cit., p. 9. No mesmo sentido: ARNALDO RIZZARDO, Contratos, cit., p. 449.

119 Por esse motivo, RICHARD HYLAND, ao invés de enfocar a forma da doação, prefere apontar como elemento o objeto transferido, pois é ele que ditará a solenidade a ser utilizada, e explica que assim se conduz porque no âmbito da common law não há o mesmo grau de desconfiança para com a doação como ocorre nas legislações inspiradas no sistema romano-germânico, e esclarece que a preocupação da jurisprudência do mencionado sistema tem sido a de resguardar a vontade do doador e defender a propriedade individual de falsas alegações de transferência patrimonial por doação. Com isso, a forma da doação é relativizada, pois o foco está no cumprimento de outros requisitos [Gifts (...), cit., itens 317, 854-855 e 992].

De qualquer forma, há um julgado do Superior Tribunal de Justiça em que se negou a uma viúva supérstite doar sua meação aos outros filhos herdeiros em sede de arrolamento dos bens deixados pelo pai da família, justamente porque a alienação gratuita de meação é ato inter vivos, a exigir a lavratura de escritura pública, nos termos dos arts. 108 e 541 do Código Civil de 2002, e assim se concluiu mesmo diante da alegação da cônjuge sobrevivente de que não tinha capacidade econômica para suportar os emolumentos cartorários $\left(3^{\mathrm{a}}\right.$ T., R. Esp. n. 1.196.992/MS, rel. NANCY ANDRIGHI, j. 06-08-13). Com isso, verifica-se que na determinação da forma a ser adotada para a prática da doação deve-se analisar o verdadeiro ato a ser praticado e se observar a prescrição legal.

${ }^{120}$ Art. 541. "A doação far-se-á por escritura pública ou instrumento particular. Parágrafo único. A doação verbal será válida, se, versando sobre bens móveis e de pequeno valor, se lhe seguir incontinenti a tradição".

${ }^{121}$ No direito francês, a doação deve se realizar por escritura pública, conforme determina o art. 931 do seu Código Civil: "Tous actes portant donation entre vifs seront passés devant notaires dans la forme ordinaire des contrats; et il en restera minute, sous peine de nullité". Deve ainda se realizar na presença de dois notários ou um notário e duas testemunhas [cf.: PAUL DELNOY, Le Libéralités (...), cit., p. 33]. A necessidade de a parte guardar uma cópia da minuta está na necessidade de se resguardar a irrevogabilidade 
Assim, com fundamento nesse dispositivo e no art. $108^{122}$ do Código Civil de 2002, pode-se afirmar que se o bem doado for imóvel cujo valor é superior a 30 salários mínimos deverá a benesse se consubstanciar numa escritura pública, sob pena de o ato ser inquinado de nulidade absoluta ${ }^{123}$.

do ato [nesse sentido: PLANIOL, Traité (...), cit., p. 652]. Sobre as hipóteses excepcionais à norma: PLANIOL, Traité (...), cit., pp. 654-655.

No âmbito do Código Civil italiano, a regra geral é que a doação se dê por escritura pública, de acordo com o primeiro parágrafo do art. 782 ("Forma della donazione") desse diploma legal: "1. La donazione deve essere fatta per atto pubblico, sotto pena di nullità. Se ha per oggetto cose mobili, essa non è valida che per quelle specificate con indicazione del loro valore nell'atto medesimo della donazione, ovvero in una nota a parte sottoscritta dal donante, dal donatario e dal notaio. 2. L'accettazione può essere fatta nell'atto stesso o con atto pubblico posteriore. In questo caso la donazione non è perfetta se non dal momento in cui l'atto di accettazione è notificato al donante. 3. Prima che la donazione sia perfetta, tanto il donante quanto il donatario possono revocare la loro dichiarazione". TORRENTE comenta que por força desse dispositivo o emprego da escritura pública não está ligado ao objeto da doação, mas sim ao dever legal, valendo inclusive para as doações indiretas [consultar: La Donazione, cit., pp. 422-427]. BIONDI ressalta, porém, que ato público não é apenas notarial, pelo que pode haver doações por meio de instrumentos públicos diversos [Le Donazioni, cit., pp. 443-448]. Além do instrumento público, porém, se faz necessária a presença de testemunha [nesse sentido: CELESTE IACOVINO, in ANTONIO CATAUDELLA (Coord.), La Donazione, cit., p. 28; GARDANI CONTURSI LISI, Le Donazioni, cit., pp. 341-343]. Para uma justificativa da opção legislativa pelo ato público como regra, consultar: BIONDI, Le Donazioni, cit., pp. 435-439.

O Código Civil português, porém, no art. 947 ("Forma da doação"), impôs a escritura pública para os imóveis apenas e a tradição para os móveis, podendo essa ser suprida por instrumento particular: "1. Sem prejuízo do disposto em lei especial, a doação de coisas imóveis só é válida se for celebrada por escritura pública ou por documento particular autenticado. 2. A doação de coisas móveis não depende de formalidade alguma externa, quando acompanhada de tradição da coisa doada; não sendo acompanhada de tradição da coisa, só pode ser feita por escrito". Consultar a respeito: MANUEL BAPTISTA LOPES, Das Doações, cit., pp. 41-45.

Na obra de TEIXEIRA DE FREITAS, além da escritura, previa-se na forma da doação a insinuação (art. 411), que consistia num procedimento perante o juiz, cujo papel era inquirir o autor da benesse e seus vizinhos, para verificar a higidez da manifestação de vontade (art. 415), e sendo essa constatada, o magistrado confirmava o ato (art. 416) e ordenava a sua transcrição em livro próprio (art. 414) e, nestes casos, a escritura pública era da substância do ato (art. 413) [Consolidações (...), cit., pp. 284-289]. Tais disposições seguiram os moldes das Ordenações, em cujo regramento a imposição de escritura pública valia apenas para as liberalidades necessitadas de insinuação, podendo as demais serem realizadas e provadas por quaisquer outros meios [COELHO DA ROCHA, Instituições (...), cit., 429].

${ }^{122}$ Art. 108. "Não dispondo a lei em contrário, a escritura pública é essencial à validade dos negócios jurídicos que visem à constituição, transferência, modificação ou renúncia de direitos reais sobre imóveis de valor superior a trinta vezes o maior salário mínimo vigente no País".

${ }^{123}$ FÁBIO ULHOA COELHO, Curso (...), cit., p. 239; JONES FIGUEIRÊDO ALVES, Código (...), cit., p. 446; LUIZ GUILHERME LOUREIRO, Curso (...), cit., pp. 514-515; NELSON ROSENVALD, Contratos (...), cit., p. 587; ORLANDO GOMES, Contratos, cit., p. 238; PABLO STOLZE GAGLIANO, O Contrato (...), cit., p. 41; PAULO DE TARSO VIEIRA SANSEVERINO, Contratos (...), cit., pp. 70-71; PAULO NADER, Curso (...), cit., pp. 227-228; SÍLVIO DE SALVO VENOSA, Direito (...), cit., p. 131; SYLVIO CAPANEMA DE SOUZA, Das Várias (...), cit., p. 89.

Há um julgado da Suprema Corte do estado norte-americano da Carolina do Norte em que se reconheceu a existência de doação verbal de bem imóvel. Alegava o filho mais novo de seis irmãos que seus pais, ainda em vida, lhe teria doado oralmente a fazenda de propriedade de ambos, porém os outros irmãos impugnaram sua pretensão amparando seu ataque na falta de instrumento escrito da doação. No entanto, ficou demonstrado nos autos que: o reivindicante exerceu a posse sobre a fazenda e nela trabalhou sozinho por quase 35 anos; pagou nesse período todos os tributos; nunca pagou aluguel; contratou seguro sobre a propriedade em nome próprio; colhia para si todos os frutos do bem; realizou na fazenda diversas benfeitorias de relevo; apenas com a morte do pai e a descoberta da ausência de instrumento os demais irmãos disputaram a propriedade do bem; por 5 anos seguidos, na declaração de bens do pai feita por uma das herdeiras à assistência de saúde do genitor, ela fez constar que o pai não é dono da fazenda e nada recebe por ela; e, a mesma informação o 
No mesmo sentido, em vista dos arts. $134^{124}$ e $1168^{125}$ do Código Civil de 1916, os autores ${ }^{126}$ que escreveram à época dessa legislação ensinam que se o bem doado for imóvel de valor superior a dez cruzeiros, a escritura pública é da própria substância do ato, e assim também o é o instrumento particular para disposição de bem de valor inferior ao quanto apontado, de modo que a forma escrita é essencial para a doação de bem imóvel, não passível de ser suprida pela confissão das partes ${ }^{127}$.

Quanto à doação de bens móveis, também deverá, a princípio, se realizar por meio de instrumento escrito, não bastando o simples consenso das partes, sob pena de o ato ser inválido $^{128}$. MANUEL ALBADALEJO GARCÍA e SILVIA DIAZ ALABART ${ }^{129}$ aventam

próprio pai da família fez constar na sua declaração anual à Administração de Seguridade Social de seu país. Diante destes fatos, o mencionado Sodalício houve por bem confirmar a decisão já tomada em instância inferior e reconheceu a existência e validade da transferência de bem imóvel por meio de doação verbal [Mertz v. Arendt, 564 N. W.2d 294 (1997) in ELIAS CLARK et al., Cases (...), cit., pp. 420-423]. Tal aresto padeceria de ilegalidade no sistema pátrio, como se demonstrou (sobre a invalidade da doação verbal de imóvel, consultar: TJSP, $14^{a}$ Câm. de Dir. Priv., Apel. n. 9074115-29.2006.8.26.0000, rel. LIGIA ARAÚJO BISOGNI, j. 24-08-11), mas os fatos carreados no decisório sem dúvida convidam o intérprete à reflexão e até desperta um laivo de admiração para com o modus operandi das Cortes de commom law. Ainda assim, à mesma conclusão poderia se ter chegado num Tribunal brasileiro com fundamento na usucapião extraordinária, o que certamente geraria um acalorado debate. De qualquer forma, mostra-se aí que no direito norte-americano a doação pode até não seguir uma determinada formalidade, podendo o magistrado revolver as circunstâncias do ato para delas extrair o animus donandi [RICHARD HYLAND, Gifts (...), cit., item 855].

${ }^{124}$ Art. 134. "É, outrossim, da substância do ato a escritura pública: [...]. II - nos contratos constitutivos ou translativos de direitos reais sobre imóveis de valor superior a $\operatorname{Cr} \$ 50.000,00$ (cinqüenta mil cruzeiros), excetuado o penhor agrícola. (Redação dada pela Lei no 7.104 , de 20.6.1983)".

${ }^{125}$ Art. 1168. "A doação far-se-á por escritura pública, ou instrumento particular (art. 134). Parágrafo único. A doação verbal será válida, se, versando sobre bens móveis e de pequeno valor, se lhe seguir incontinenti a tradição".

126 AGOSTINHO ALVIM, Da Doação, cit., pp. 70-71; ANTÔNIO CHAVES, Lições (...), cit., p. 239; ARNALDO MARMITT, Doação, cit., p. 16; CLÓVIS BEVILAQUA, Código (...), cit., p. 274; SERPA LOPES, Curso (...), cit., p. 401.

${ }^{127}$ Essa também essa é a solução do Código Civil espanhol, que no seu art. 633 ("Para que sea válida la donación de cosa inmueble, ha de hacerse en escritura pública, expresándose en ella individualmente los bienes donados y el valor de las cargas que deba satisfacer el donatario. La aceptación podrá hacerse en la misma escritura de donación o en otra separada; pero no surtirá efecto si no se hiciese en vida del donante. Hecha en escritura separada, deberá notificarse la aceptación en forma auténtica al donante, y se anotará esta diligencia en ambas escrituras") impõe a escritura pública como meio de confecção da doação de bens imóveis, constituindo formalidade substancial do ato, sob pena de nulidade (nesse sentido: MANUEL ALBADALEJO GARCÍA e SILVIA DIAZ ALABART, La Donación, cit., p. 206).

No âmbito da commom law, em que pese os fundamentos noticiados em nota acima, o já mencionado Statue of Fraud impõe a confecção de instrumento escrito para a transferência de real property, impondo que se descreva o direito real que se está transferindo e a assinatura das partes, instrumento este que recebe o nome de deed, devendo-se seguir depois a tradição do bem, conforme as circunstâncias [RICHARD HYLAND, Gifts (...), cit., itens 859-860]. Como se verá, porém, a jurisprudência norte-americana desenvolveu alguns mecanismos para afastar tal exigência.

${ }^{128}$ FÁBIO ULHOA COELHO, Curso (...), cit., p. 239; JONES FIGUEIRÊDO ALVES, Código (...), cit., p. 446; LUIZ GUILHERME LOUREIRO, Curso (...), cit., p. 507; MARIA HELENA DINIZ, Tratado (...), cit., p. 87; NELSON ROSENVALD, Contratos (...), cit., p. 587; PAULO DE TARSO VIEIRA SANSEVERINO, Contratos (...), cit., p. 71; PAULO LÔBO, Das Várias (...), cit., p. 300; PAULO NADER, Curso (...), cit., p. 228; SÍLVIO DE SALVO VENOSA, Direito (...), cit., p. 131.

${ }^{129}$ La Donación, cit., pp. 202-203. 
hipótese de instrumento escrito indireto admissível para a doação de bens móveis, aludindo à confecção de uma ata na qual se relatasse o negócio realizado pelas partes e, após, fosse subscrita por doador e donatário. Em princípio, tal forma não encontra impedimento legal, tendo sido atendida a forma escrita.

Além disso, os mesmo autores entendem ${ }^{130}$ que uma vez feito o contrato escrito, a forma já foi atendida, pelo que se o instrumento vier a se extraviar, ainda assim seria admissível a existência da doação porque houve cumprimento da solenidade exigida. Mas tal entendimento esbarra no caput do art. $212^{131}$ do Código Civil de 2002, pois não é possível às partes fazerem prova no caso, com o inconveniente de se admitir alegação fraudulenta ${ }^{132}$.

Ademais, conforme dispõe o parágrafo único do art. 541 do Código Civil de 2002, se forem de pequeno valor os bens doados ${ }^{133}$, então não se faz necessária a forma escrita, bastando a simples tradição, o que não transforma a doação em contrato real, para alguns autores $^{134}$, pois tão somente o sinalagma faz surgir o contrato, sendo que o mesmo se passava no revogado Código Civil de $1916^{135}$.

A ausência de instrumento na doação manual, porém, não é exceção à formalidade da doação, pois a entrega da coisa doada se dá ad solemnitatem, isto é, substitui a escritura e compõe a substância do ato ${ }^{136 / 137}$.

${ }^{130}$ La Donación, cit., p. 205.

${ }^{131}$ Art. 212. "Salvo o negócio a que se impõe forma especial, o fato jurídico pode ser provado mediante: [...]".

${ }^{132}$ No Código Civil da França há ainda uma outra formalidade para a doação de bens móveis, que é a anexação ao contrato de uma declaração do valor do bem [PAUL DELNOY, Le Libéralités (...), cit., p. 33], conforme ordena o art. 948 do mencionado diploma legal: "Tout acte de donation d'effets mobiliers ne sera valable que pour les effets dont un état estimatif, signé du donateur et du donataire, ou de ceux qui acceptent pour lui, aura été annexé à la minute de la donation". Tal exigência vem a resguardar a irrevogabilidade do ato e, além disso, em caso de desfazimento, garante que o donatário entregue aquilo que recebeu ou valor equivalente em caso de bem fungível, sendo que a ausência desse instrumento induz à nulidade absoluta do negócio [PLANIOL, Traité (...), cit., pp. 669-670].

A mesma formalidade consta do primeiro parágrafo do art. 782 do Código Civil italiano, como acima transcrito [confrontar a respeito: BIONDI, Le Donazioni, cit., pp. 448-465; CELESTE IACOVINO, La Donazione, cit., pp. 29-30; GARDANI CONTURSI LISI, Le Donazioni, cit., pp. 356-359; TORRENTE, La Donazione, cit., pp. 428-432].

${ }^{133}$ A exigência do pequeno valor tem origem antiga, de acordo com o brocardo "De minimis non curat praetor". Mas no Código Napoleônico, porém, afastou-se tal critério para se aferir a possibilidade de se realizar doação manual [JEAN RAY, De La Notion (...), cit., pp. 29-31].

${ }^{134}$ PABLO STOLZE GAGLIANO, O Contrato (...), pp. 39-41; TORRENTE, La Donazione, cit., pp. 148-150. Em sentido contrário: NELSON ROSENVALD, Contratos (...), cit., p. 587; VINCENZO TAVASSI, in ANTONIO CATAUDELLA (Coord.), La Donazione, cit., p. 39.

${ }^{135}$ ARNALDO MARMITT, Doação, cit., p. 16; CLÓVIS BEVILAQUA, Código (...), cit., p. 274.

${ }^{136}$ MANUEL ALBADALEJO GARCÍA e SILVIA DIAZ ALABART, La Donación, cit., pp. 190-191; MÉAULAUTOUR, La Donation (...), cit., p. 390; TORRENTE, La Donazione, cit., pp. 144-148 (o autor explica que o fundamento não está na posse do bem móvel, mas sim na tradição, que por força de lei tem o condão de transmitir a propriedade, sem necessariamente ser uma "condicio iuris"). Manifestando opinião contrária: 
Para se aferir se a doação é de pequeno valor, há ${ }^{138}$ quem sugira empregar-se o salário mínimo como diapasão. Outros autores ${ }^{139}$, porém, adotam por critério o patrimônio do doador, por ser expressão objetiva do valor do bem transmitido, pois o mesmo objeto pode ser considerado de alto valor para alguns, ao mesmo tempo que para outros será inexpressivo.

Já AGOSTINHO ALVIM ${ }^{140}$ emite a opinião de que se deve, no sistema pátrio, deixar ao juiz verificar, no caso concreto, a correta qualificação da liberalidade, adotando por balizamento a situação financeira do doador (não interessa, segundo o autor, para esse fim, a

VINCENZO TAVASSI, La Donazione, cit., p. 39 (o autor explica que a entrega do bem é simples meio idôneo de manifestação do negócio, mas não uma forma propriamente dita).

${ }^{137}$ No Código Napoleônico não há previsão de tal modalidade de doação, por isso PLANIOL ensina que a característica dessa hipótese está na tradição de bens móveis, independente de seu valor, e afirma ser ausente qualquer formalidade [no mesmo sentido: JEAN RAY, De La Notion (...), cit., pp. 31-32; PAUL DELNOY, Le Libéralités (...), cit., pp. 33-34]. Opinando pela validade do ato, o autor chega afirmar que nesse caso a doação não é nem um contrato e nem uma promessa, mas sim um modo de transferência da propriedade constituído pela vontade das partes de dar e receber doação, respectivamente, e a entrega da coisa, que não importa em execução de contrato, mas sim na constituição da própria liberalidade, e conclui que a doação manual é menos ato jurídico do que um fenômeno econômico [Traité (...), cit., pp. 655-657. Confrontar ainda: MÉAU-LAUTOUR, La Donation (...), cit., pp. 390-394]. Por esses motivos, JEAN RAY chega a afirmar a importância de se distinguir a doação inter-vivos, que é ato jurídico, da doação fenômeno econômico [De La Notion (...), cit., pp. 33-34]. Sobre a possibilidade de se poder realizar essa espécie de doação por meio de procurador, mandatário e locação de cofre: MÉAU-LAUTOUR, La Donation (...), cit., pp. 382-385.

Já no âmbito da common law, os bens móveis podem ser tangíveis (chattels) ou intangíveis (choses in action) e é a natureza do objeto doado que determinará a forma, mas em regra basta a tradição, podendo ainda se dar por instrumento escrito, ou a ausência das duas formas em alguns casos [consultar, a respeito: RICHARD HYLAND, Gifts (...), cit., itens 863-951]. Por esse motivo, a doação de bens móveis no sistema americano se aproxima da doação manual pátria [RICHARD HYLAND, Gifts (...), cit., item 984].

${ }^{138}$ PABLO STOLZE GAGLIANO, O Contrato (...), cit., p. 41 (mas reconhece que é melhor deixar à analise do caso concreto a aferição do justo critério).

${ }^{139}$ ARNALDO MARMITT, Doação, cit., p. 16; CAIO MÁRIO DA SILVA PEREIRA, Instituições (...), cit., p. 213; CARLOS ROBERTO GONÇALVES, Direito (...), cit., p. 272; CÉSAR FIUZA, Direito (...), cit., p. 504; EDUARDO ESPINOLA, Dos Contratos (...), cit. p. 172; FÁBIO ULHOA COELHO, Curso (...), cit., pp. 239-240; FLÁVIO TARTUCE, Direito (...), cit., p. 313; ROGÉRIO MARRONE DE CASTRO SAMPAIO, Direito (...), cit., p. 124; SERPA LOPES, Curso (...), cit., p. 402; SYLVIO CAPANEMA DE SOUZA, Das Várias (...), cit., pp. 131-133; WASHINGTON DE BARROS MONTEIRO-DABUS MALUF, Curso (...), cit., p. 169. PAULO LÔBO compartilha essa opinião, mas impondo o limite do décuplo do salário mínimo, previsto no art. 227 do Código Civil de 2002, quando se tratar de doação feita apenas com testemunhos [Direito (...), cit., p. 295].

140 Da Doação, cit., pp. 79-81. No mesmo sentido: CARVALHO SANTOS, Código (...), cit., pp. 348-352; FRANCISCO GLAUBER PESSOA ALVES, Das Várias (...), cit., p. 893; LUIZ GUILHERME LOUREIRO, Curso (...), cit., p. 506; MARIA HELENA DINIZ, Curso (...), cit., p. 266; NELSON ROSENVALD, Contratos (...), cit., p. 587; PAULO DE TARSO VIEIRA SANSEVERINO, Contratos (...), cit., pp. 98-99; PONTES DE MIRANDA, Tratado (...), cit., p. 241.

No sistema civil da Itália, em vista da redação do art. 783 ("Donazioni di modico valore") de seu Código Civil, que assim dispõe: "1. La donazione di modico valore che ha per oggetto beni mobili è valida anche se manca l'atto pubblico, purché vi sia stata la tradizione. 2. La modicità deve essere valutata anche in rapporto alle condizioni economiche del donante", a jurisprudência da mencionada nacionalidade também se desenvolveu no sentido de se levar em conta o patrimônio do doador, segundo lição de GARDANI CONTURSI LISI [no mesmo sentido: TORRENTE, La Donazione, cit., p. 455; VINCENZO TAVASSI, La Donazione, cit., p. 44], mas explica também que em vista da exigência de tradição ou ao menos de pacto translativo por doação, torna-se necessário revolver-se os elementos do negócio jurídico [Le Donazioni, cit., pp. 361-365]. 
do donatário) e seu grau de consentimento, mas sem fugir à objetividade, que se encontra na prudência do homem médio.

No que toca à tradição "incontinente" exigida pela lei, é possível fazer sua interpretação da mesma forma que MANUEL ALBADALEJO GARCÍA e SILVIA DIAZ ALABART ${ }^{141}$ realizam na exegese da locução "entrega simultánea" do art. $632^{142}$ do Código Civil espanhol, considerando que compreende o momento da formação da vontade das partes e o aceite final do donatário, de modo que mesmo que os contratantes façam acordo em um momento, mas a entrega só ocorre posteriormente, houve apenas um ato e até o aceite é possível ser tido por simultâneo ${ }^{143}$.

Diante do que se afirmou sobre a doação de bens móveis, é de se perguntar se a forma escrita na doação dessa espécie de objetos é da substância do ato (ad substantiam) ou se sua exigência se dá meramente para fins probatórios (ad probationem), de modo a ser suprível pela confissão do doador.

Para AGOSTINHO ALVIM ${ }^{144}$, a forma escrita para doação de bem móvel de alto valor é da substância do ato, mas admite que a confissão importará na ocorrência de um ato de doação com efeito ex nunc. Salienta ainda que, em se tratando de bem móvel de baixo valor, se há confissão sem tradição, o ato é nulo, ao passo que, se o bem for de alto valor e há confissão sem tradição, pode o donatário exigir a entrega da coisa. Não obstante, afirma ${ }^{145}$ que $\mathrm{o}$ ato escrito pode suprir a tradição na doação de pequeno valor ${ }^{146}$.

Assim, considerando que na maior parte das vezes um patrimônio cuja sucessão se deseja planejar ainda em vida será composto de bens imóveis e outros móveis de alto valor, e, independentemente disso, levando-se em conta que se quer atingir situação tal livre de questionamentos futuros, é de se concluir que no uso da doação para a implementação da

${ }^{141}$ La Donación, cit., pp. 194-195. No mesmo sentido: VASSANTA POROBO TAMBÁ, Doação (...), cit., p. 23.

${ }^{142}$ Art. 632. "La donación de cosa mueble podrá hacerse verbalmente o por escrito. La verbal requiere la entrega simultánea de la cosa donada. Faltando este requisito, no surtirá efecto si no se hace por escrito y consta en la misma forma la aceptación".

143 SYLVIO CAPANEMA DE SOUZA, por seu turno, entende que o critério é o doador proceder à tradição na primeira oportunidade, mormente simultaneamente à manifestação de sua vontade [Das Várias (...), cit., p. 127].

144 Da Doação, cit., pp. 71-75. No mesmo sentido: MANUEL ALBADALEJO GARCÍA e SILVIA DIAZ ALABART, La Donación, cit., p. 201.

145 Da Doação, cit., p. 78. No mesmo sentido: CARVALHO SANTOS, Código (...), cit., p. 356. Sobre a prova da doação manual, confrontar: PLANIOL, Traité (...), cit., pp. 658-661; TORRENTE, La Donazione, cit., p. 454 (o autor afirma que a doação manual não deixa de ser contrato, pelo que admite até a prova testemunhal).

146 SAVIGNY defende ainda que é necessário se computar os frutos do objeto doado a serem percebidos para determinação da forma [Sistema (...), cit., pp. 51-59]. 
vontade do doador que quer cristalizar a sucessão de seus bens segundo sua estratégia, devese utilizar a escritura pública.

Com isso, ficará demonstrada a boa-fé do doador, atestada a livre manifestação de sua vontade pelo tabelião, que goza de fé pública, e garantida a improcedência de qualquer alegação de nulidade quanto à forma.

Igualmente, apesar de a Lei 10.406/2002 nada falar a respeito, é de se levar em conta a exigência constante nos arts. 948 do Código Napoleônico e 782 do Código Civil italiano de declaração de valor dos bens móveis, pois isso também evita intervenções futuras.

Tal medida mostra-se salutar, devendo-se fazer constar da escritura o valor atribuído a cada bem doado e a expressa concordância dos donatários a esse respeito, porque evitará que posteriormente venha-se a exigir reavaliação dos bens e eventual desfazimento da partilha, além de contribuir com a higidez do recolhimento do tributo devido.

Com efeito, seguindo lição dos antigos juristas, pode-se assumir que quanto mais às claras for praticado o ato, menos espaço haverá para interpretações.

\section{2) O animus donandi}

A vontade de doar ou animus donandi pode ser entendido como ato volitivo do doador de ver diminuído seu patrimônio para enriquecer o donatário ${ }^{147}$. LUCIANO DE CAMARGO PENTEADO ${ }^{148}$ explica que se trata de um ato de vontade especial, pela qual alguém quer ceder algo sem ter nada em troca, sendo que o beneficiário também tem a vontade de receber, que chama de animus donum accipiendi. Em vista disso, se afirma que o animus donandi é a causa da doação, por consistir na fusão destas duas vontades, a de prestar a liberalidade e a de recebê-la ${ }^{149}$.

\footnotetext{
${ }^{147}$ ARNALDO MARMITT, Doação, cit., p. 09; CARVALHO DE MENDONÇA, Contratos (...), cit., p. 34; EDUARDO ESPINOLA, Dos Contratos (...), cit. p. 169; MANUEL BAPTISTA LOPES, Das Doações, cit., p. 12; MÉAU-LAUTOUR, La Donation (...), cit., pp. 58-59; PAULO DE TARSO VIEIRA SANSEVERINO, Contratos (...), cit., p. 64; PAULO NADER, Curso (...), cit., p. 225.

${ }^{148}$ Doação com Encargo (...), cit., p. 115. No mesmo sentido: CARLOS ROBERTO GONÇALVES, Direito (...), cit., p. 255. Não assim na commom law, onde não se vê a doação como contrato, de maneira que é dispensável a concordância do beneficiário [RICHARD HYLAND, Gifts (...), cit., item 287].

${ }^{149}$ CÉSAR FIUZA, Direito (...), cit., p. 502; MANUEL ALBADALEJO GARCÍA e SILVIA DIAZ ALABART, La Donación, cit., p. 54; PONTES DE MIRANDA, Tratado (...), cit., p. 231.
} 
CLÓVIS BEVILAQUA ${ }^{150}$ ressalta que nem sempre a intenção do doador é a de enriquecer o donatário, e por este fundamento explica que, em verdade, o animus donandi é o escopo de exercer uma liberalidade, por quaisquer que sejam os motivos ou intenções. Por isso, afirma-se ${ }^{151}$ que o animus donandi consiste no espírito liberal do doador.

O contrato de doação não tem uma causa natural, isto é, a disposição gratuita do bem não vem seguida de uma contraprestação, o que dificulta seu enquadramento nos contratos, de modo que o animus donandi veio a suprir essa lacuna, dando uma causa à celebração do contrato ${ }^{152}$. VICENTE SABINO JÚNIOR ${ }^{153}$ também vê no animus donandi a causa da doação, e afirma que a simples transferência patrimonial é insuficiente para explicála, pois ela somente ganha existência quando existe vontade do doador de realizar o ato, ainda que levado por motivos não altruísticos.

Por conta disso, alguns autores ${ }^{154}$ veem no animus donandi a essência da doação, discutindo-se porém no que consistiria essa vontade especial de exercer doação.

Há ${ }^{155}$ quem identifique o animus donandi com os motivos subjetivos que levaram o doador a praticar a doação, de modo que deverá ser um agraciamento ou uma benfeitoria,

${ }^{150}$ Código (...), cit., p. 270. No mesmo sentido: CARVAlHO SANTOS, Código (...), cit., p. 321; PAULO LÔBO, Das Várias (...), cit., p. 276; PONTES DE MIRANDA, Tratado (...), cit., p. 193; SERPA LOPES, Curso (...), cit., p. 387. SAVIGNY ressalta, porém, que é de extrema importância que o doador tenha intenção de enriquecer o donatário, sob pena de não haver doação. À guisa de exemplo, afirma que não há doação: compra acima ou venda abaixo do preço por alguma necessidade; renúncia feita em sede de transação; etc. [Sistema (...), cit., pp. 94-102].

${ }^{151}$ PAULO DE TARSO VIEIRA SANSEVERINO, Contratos (...), cit., p. 64. O Código Civil italiano empregou o termo "spirito di liberalită" no seu art. 769, mas na verdade equivale ao termo "animus donandi", largamente empregado na tradição romana [BIONDI, Le Donazioni, cit., p. 94 (o autor prefere utilizar a versão romana no seu estudo)]. Sobre o desenvolvimento na doutrina italiana do que seja o "spirito di liberalitá", consultar: CELESTE IACOVINO, La Donazione, cit., pp. 24-26.

152 D'ABRANCHES FERRÃO, Das Doações, cit., p. 27; LUCIANO DE CAMARGO PENTEADO, Doação com Encargo (...), cit., p. 124; PAUL DELNOY, Le Libéralités (...), cit., p. 29; RICHARD HYLAND, Gifts (...), cit., item 253. Confrontar ainda: BIONDI, Le Donazioni, cit., pp. 98-101; GARDANI CONTURSI LISI, Le Donazioni, cit., pp. 203-205.

${ }^{153}$ Contrato (...), cit., p. 23.

${ }^{154}$ Nesse sentido: AMANDA ZOE MORRIS, Doação, cit., p. 278; ARNALDO MARMITT, Doação, cit., p. 09 (o autor afirma, na p. 19 da sua obra, que o ânimo de doar não pode nem sequer ser suprida judicialmente); BIONDI, Le Donazioni, cit., p. 94 (interpretando o Código Civil italiano, o autor afirma que o animus donandi tem o condão de qualificar a doação dentre os atos de liberalidade); CAIO MÁRIO DA SILVA PEREIRA, Instituições (...), cit., p. 209; CARLOS ROBERTO GONÇALVES, Direito (...), cit., p. 255; CARVALHO SANTOS, Código (...), cit., p. 321; ELIAS CLARK et al., Cases (...), cit., p. 438 (também no direito norte-americano o desiderato de transferir o objeto da liberalidade é fundamental); MANUEL BAPTISTA LOPES, Das Doações, cit., pp. 15-16; ORLANDO GOMES, Contratos, cit., p. 236; OZÉIAS J. SANTOS, Da Doação, cit., p. 15 (afirma que a doação "É um contrato realizado animus donandi, pois sem essa intenção de dar não se constitui a liberalidade"); PAULO GERALDO DE OLIVEIRA MEDINA, $A$ Doação, cit., p. 462; SAMUEL LUIZ ARAÚJO, O Princípio (...), cit., p. 75; SAVIGNY, Sistema (...), cit., p. 93 (o autor combina o ânimo de doar com outros elementos, porém afirma que eles podem ocorrer sem que haja doação, o que não se passa com o animus donandi); WASHINGTON DE BARROS MONTEIRODABUS MALUF, Curso (...), cit., p. 164. 
mas, se forem imorais os motivos, a vontade de doar também estará contaminada por tal imoralidade, de modo que nulo é o negócio, até porque não houve real ânimo de doar.

Para outros estudiosos ${ }^{156}$, porém, o ato de vontade do doador deve ser juridicamente compreendido, de modo que não importa sua qualificação moral, em que pese sua subjetividade, isto é, não se confunde o ânimo de doar com os motivos do doador. Também não se trata de um "consentimento". Desse modo, consiste o desiderato do doador unicamente em aumentar o patrimônio de outrem.

${ }^{155}$ ARNALDO MARMITT, Doação, cit., p. 09; JEAN RAY, De La Notion (...), cit., pp. 88-102 (o autor, após expor os elementos que formaram a teoria da causa da doação na França, conclui que é necessário ao juiz investigar os motivos que deram origem ao ato nas demandas que lhe são submetidas, sendo insuficiente operar com ideias abstratas nos casos concretos, pelo que é importante averiguar-se os motivos enquanto causa determinante do atos); MANUEL BAPTISTA LOPES, Das Doações, cit., pp. 14-15 (o autor entende ser da maior importância considerar nula a doação quando há erro de motivo ou intento fraudador); MÉAULAUTOUR, La Donation (...), cit., pp. 335-339.

Sobre a consideração dos motivos na constituição do animus donandi na jurisprudência francesa, consultar: PAUL DELNOY, Le Libéralités (...), cit., pp. 29 (o autor explica que abstratamente o animus donandi é a escolha do doador de se empobrecer para enriquecer o donatário, mas a causa determinante e impulsiva do ato são os motivos de quem executa a liberalidade, que estão já num plano concreto); PLANIOL, Traité (...), cit., pp. 645-646.

No que toca ao direito norte-americano, RICHARD HYLAND compreende a dificuldade de se analisar os motivos do doador no caso concreto, mas afirma que a tendência dos Tribunais é de anular a liberalidade, caso não se envide sequer identificá-los, por induzir à ausência de animus donandi, mas que, por outro lado, se se constar que a doação se deu em fraude a lei ou a direito de terceiros, ainda assim será tido por presente o ânimo de doar [Gifts (...), cit., itens 255 e 288].

Já no Código Civil italiano, o art. 787, encabeçado pelos dizeres "Errore sul motivo della donazione", assim dispõe: "La donazione può essere impugnata per errore sul motivo, sia esso di fato o di diritto, quando il motivo risulta dall'atto ed è il solo che ha determinato il donante a compiere la liberalità", e o dispositivo de lei seguinte, o 788 (título: "Motivo illecito"), reza que: "Il motivo illecito rende nulla la donazione quando risulta dall'atto ed è il solo che ha determinato il donante alla liberalità". CELESTE IACOVINO explica que a regra geral é não dar relevo aos motivos das partes contratantes, pela sua subjetividade, mas abre-se uma exceção no caso da doação [La Donazione, cit., pp. 26-27], o que, segundo BALBI, se justifica jurídica e socialmente pelo fato de, nesse negócio jurídico, a vontade do doador ser prevalente, restando ao donatário, a princípio, aceitá-la, sem que com isso se transforme num contrato de adesão [Saggio (...), cit., pp. 19-20]. Para GIANFRANCO AMENTA, a possibilidade de se analisar o motivo na doação é compatível apenas se não se adotar o animus donandi como causa do contrato de doação [La Donazione (...), cit., pp. 109-111. Confrontar também: BIONDI, Le Donazioni, cit., pp. 96-98; GARDANI CONTURSI LISI, Le Donazioni, cit., pp. 205-217 (a autora mostra que a jurisprudência italiana, até o momento de sua pesquisa, via no animus donandi a causa da doação, de modo a afastar a investigação dos motivos)].

156 AMANDA ZOE MORRIS, Doação, cit., p. 278; ANTÔNIO CHAVES, Lições (...), cit., p. 234; D’ABRANCHES FERRÃO, Das Doações, cit., p. 27; ELIAS CLARK et al., Cases (...), cit., p. 438; FRANCISCO GLAUBER PESSOA ALVES, Das Várias (...), cit., p. 881; LUCIANO DE CAMARGO PENTEADO, Doação com Encargo (...), cit., p. 115; MANUEL ALBADALEJO GARCÍA e SILVIA DIAZ ALABART, La Donación, cit., p. 54; MARIA HELENA DINIZ, Curso (...), cit., p. 254; NELSON ROSENVALD, Contratos (...), cit., p. 584; PAULO DE TARSO VIEIRA SANSEVERINO, Contratos (...), cit., p. 65; PAULO GERALDO DE OLIVEIRA MEDINA, A Doação, cit., p. 462; PAULO NADER, Curso (...), cit., p. 223; PONTES DE MIRANDA, Tratado (...), cit., p. 197; SAVIGNY, Sistema (...), cit., pp. 103104; SÍlVIO DE SALVO VENOSA, Direito (...), cit., pp. 125-126; WASHINGTON DE BARROS MONTEIRO-DABUS MALUF, Curso (...), cit., p. 165. 
Nesse sentido, PABLO STOLZE GAGLIANO ${ }^{157}$ pontua a diferença entre causa e motivo, sendo que a liberalidade, segundo o autor, se enquadra no âmbito da causa, suficiente para caracterizar o contrato de doação, ao passo que o motivo não interessa para tal fim, pois as razões internas do donante não servem de espeque para a caracterização da liberalidade, que se sobressai apenas com o critério objetivo da gratuidade.

Por esse fundamento, há ${ }^{158}$ quem afirme que o animus donandi não constitui a centralidade da figura, pois necessita da complementação fática e real de disposição do bem pelo doador em favor do donatário, pois somente nesse momento é que o âmbito de atuação do direito atingirá sua abrangência e haverá uma realidade objetiva, como aplicado em experiências jurídicas de outros países.

A resumir o que se disse até aqui, AGOSTINHO ALVIM ${ }^{159}$ ensina que o animus donandi integra a doação, mas que a liberalidade, para sua caracterização, não consiste nos motivos internos do doador, mas sim na externalidade da diminuição de seu patrimônio e acréscimo da fazenda do doador, ou seja, traduz-se por meio da gratuidade, que será tratada a seguir, bastando isso para sua caracterização.

ARNALDO MARMITT ${ }^{160}$ sustenta que casos há, porém, que se mostra inafastável a importância de se sondar a real intenção do doador, mormente quando falecido,

${ }^{157}$ O Contrato (...), cit., pp. 30-33.

${ }^{158}$ LUCIANO DE CAMARGO PENTEADO, Doação com Encargo (...), cit., p. 127 e 245-246. VICENTE SABINO JÚNIOR afirma explicitamente que se ao ato de vontade não se seguir a diminuição patrimonial do doador em favor do donatário, então não há doação, pois essa carece de elemento objetivo. Não obstante, o mesmo autor traça a diferença entre liberalidade e gratuidade, pontuando que enquanto a segunda se mede por um critério econômico, a primeira se traduz em um conceito "subjetivo e moral", e aduz que o animus donandi é justamente a tradução da vontade liberal do disponente, de modo que uma doação feita por motivos imorais ou ilegais é nula, donde conclui que a verificação da causa da doação se presta a aferir sua validade ou nulidade, haja vista que se verifica sua adequação à lei e aos bons costumes. Ou seja, também não diferencia a vontade de doar dos motivos do disponente [Contrato (...), cit., pp. 16-17].

GIANFRANCO AMENTA, por seu turno, ensina que o animus donandi não pode ser a causa da doação e nem a sua essência, pois essa tem caráter objetivo, isto é, diminuição do patrimônio do doador e aumento respectivo dos bens do donatário, enquanto aquela é notadamente subjetiva. Ademais, expõe o autor que o animus donandi pode ser elemento caracterizador das liberalidades, não só da doação, de maneira que não serve como essência Por fim, conclui que seria incoerente com o sistema do Código Civil italiano jungir-se o animus donandi ao status de causa contratual, porque tendeu-se nos demais contratos a desvalorizar o âmbito subjetivo, com fundamento na teoria da confiança, de modo que é importante também a vontade da outra parte [La Donazione (...), cit., pp. 103-106]. Também é desse parecer TORRENTE, que afirma ser a gratuidade a causa da doação, mas não o animus donandi, que é manifestação subjetiva desta, [ La Donazione, cit., pp. 171-183]. Quanto à necessidade de se integrar a transferência patrimonial e o animus donandi para caracterizar-se a doação, confrontar: MÉAU-LAUTOUR, La Donation (...), cit., pp. 55-58; RICHARD HYLAND, Gifts (...), cit., item 256.

${ }^{159}$ Da Doação, cit., pp. 8-10.

${ }^{160}$ Doação, cit., p. 19 (o autor opina pela prevalência da intenção do autor). Sobre a necessidade de se investigar os motivos do ato para diferenciar a doação de adimplemento, bem como a possibilidade de se anular doação por motivo errôneo ou ilícito, consultar: GARDANI CONTURSI LISI, Le Donazioni, cit., pp. 217-226. 
como, por exemplo, na hipótese de o objeto da benesse serem cotas de sociedade empresária, mas, em data posterior à liberalidade, o doador procedeu a alteração contratual com cláusula que contraria a doação. Prevalece a doação ou o último fato objetivo, que denota a intenção do autor?

A tal problema, porém, poderá se antepor a objetividade da doação e a sua formalidade, bem como o fato de se tratar de uma promessa de transferência, mas não um contrato real, de modo que ao donatário caberá a ação de anulação do ato ou perdas e danos, já que não poderá requerer a execução específica do contrato, nos termos do art. $475^{161}$ do Código Civil de 2002.

Desse modo, tendo em vista os fins da presente pesquisa, cumpre ponderar que deve o doador fazer constar da escritura pública de doação expressamente que determinado bem doado sairá de seu patrimônio para ingressar no do donatário, de modo a afastar qualquer dúvida de que o ato é praticado sob o ânimo de doar.

No entanto, não é necessário declinar-se no instrumento todos os motivos psicológicos que o levaram a tanto, pois esse elemento lhe é de foro íntimo e deve ser considerado pelo donatário no ato do aceite que, como visto, compõe o animus donandi.

Quanto ao mais, é evidente que o Direito já fornece a eventual lesado meios de desfazer o ato na hipótese de dano por má-fé, haja vista que à doação, por ser contrato, aplicase o art. $422^{162}$ da Lei $10.406 / 2002$, afora a proteção já existente contra simulação e fraude contra credores.

De todo modo, para afastar dúvidas, pode ser de bom aviso fazer constar da minuta que a doação se realiza com o objetivo de beneficiar o donatário e até, se o caso, como partilha em vida.

\section{3) Transferência patrimonial ou gratuidade}

A gratuidade da doação consiste no fato de haver uma diminuição no patrimônio do doador e o correspectivo acréscimo no patrimônio do donatário ${ }^{163}$. Como se verifica, trata-

\footnotetext{
${ }^{161}$ Art. 475. "A parte lesada pelo inadimplemento pode pedir a resolução do contrato, se não preferir exigir-lhe o cumprimento, cabendo, em qualquer dos casos, indenização por perdas e danos".

162 Art. 422. "Os contratantes são obrigados a guardar, assim na conclusão do contrato, como em sua execução, os princípios de probidade e boa-fé".

163 ARNALDO MARMITT, Doação, cit., pp. 14-15; BIONDI, Le Donazioni, cit., pp. 92-93; PLANIOL, Traité (...), cit., p. 642 (o autor emprega o termo appauvrissement - empobrecimento - e frisa que deve ele ser
} 
se de dado objetivo, no qual se enfoca a transferência patrimonial e o empobrecimento do doador concomitante ao enriquecimento do donatário ${ }^{164}$.

OZÉIAS J. SANTOS ${ }^{165}$ entende que a gratuidade é o título no qual se celebra o contrato de doação, porque nele não há contraprestação, sendo um elemento do contrato. De fato, para alguns autores ${ }^{166}$, a gratuidade é essencial à doação.

Outros estudiosos ${ }^{167}$ da matéria, porém, afirmam que aqueles que veem na gratuidade a centralidade da doação exageram na objetividade, pois desconsideram o papel do animus donandi na caracterização do instituto.

\section{A esse respeito, MANUEL ALBADALEJO GARCÍA e SILVIA DÍAZ} $\mathrm{ALABART}^{168}$ compreendem que a gratuidade não é essencial à doação justamente porque pode haver doação com encargo cuja expressão econômica é maior do que a benesse, de maneira que o essencial é haver uma prestação sem correspectivo dever jurídico por parte do recebedor. Igualmente, PAUL DELNOY ${ }^{169}$ afirma que pode haver ato jurídico com gratuidade (renúncia abdicativa, por exemplo) sem ânimo de doar, o que o desqualifica como

gratuito); SYLVIO CAPANEMA DE SOUZA, Das Várias (...), cit., pp. 114-115; VICENTE SABINO JÚNIOR, Contrato (...), cit., p. 16. GIANFRANCO AMENTA, por seu turno, explica que deve se levar em conta, nessa definição, o intento das partes, pois não se pode reduzir a gratuidade a simples critério econômico [La Donazione (...), cit., pp. 124-126]. Também entendendo que a gratuidade deve ser interpretada em conjunto com o animus donandi: CELESTE IACOVINO, La Donazione, cit., p. 22.

${ }^{164}$ CARLOS ROBERTO GONÇALVES, Direito (...), cit., p. 256; CÉSAR FIUZA, Direito (...), cit., p. 502; PAULO DE TARSO VIEIRA SANSEVERINO, Contratos (...), cit., pp. 63; SAVIGNY, Sistema (...), cit., pp. 28-29 e 63-64; SYLVIO CAPANEMA DE SOUZA, Das Várias (...), cit., p. 116. Pode haver doação, porém, de objetos inestimáveis ou inúteis ao donatário [nesse sentido: PONTES DE MIRANDA, Tratado (...), cit., pp. 196-197]. Sobre a diferença entre gratuidade e onerosidade, bem como sua relação com o conceito de liberalidade, consultar: BIONDI, Le Donazioni, cit., pp. 74-77. Outrossim, sobre a atualidade da gratuidade, verificar: CELESTE IACOVINO, La Donazione, cit., pp. 23-24.

${ }^{165}$ Da Doação, cit., p. 13 e 15.

166 ARNALDO MARMITT, Doação, cit., pp. 14-15; ARNALDO RIZZARDO, Contratos, cit., p. 440; ARNOLDO WALD, Direito (...), cit., p. 64; CAIO MÁRIO DA SILVA PEREIRA, Instituições (...), cit., p. 209; CARVALHO DE MENDONÇA, Contratos (...), cit., p. 33; MARIA HELENA DINIZ, Curso (...), cit., p. 254; ORLANDO GOMES, Contratos, cit., p. 236; PAULO LÔBO, Das Várias (...), cit., pp. 277-278; PONTES DE MIRANDA, Tratado (...), cit., p. 194; SYLVIO CAPANEMA DE SOUZA, Das Várias (...), cit., p. 115; VICENTE SABINO JÚNIOR, Contrato (...), cit., p. 16.

Também na commom law a gratuidade se mostra essencial, pois naquele regramento se considera a gratuidade em contraponto ao consideration, pois estando presente este último há um contrato, afastando hipótese de doação [RICHARD HYLAND, Gifts (...), cit., item 231].

Em comentário ao já citado art. 1452 do Código Civil de Portugal de 1867, D’ABRANCHES FERRÃO afirma que o mencionado dispositivo legal expurgou o animus donandi, integrando-o na alienação realizada em gratuidade [Das Doações, cit., pp. 24-25].

${ }^{167}$ CÉSAR FIUZA, Direito (...), cit., p. 502; LUCIANO DE CAMARGO PENTEADO, Doação com Encargo (...), cit., p. 123.

${ }^{168}$ La Donación, cit., pp. 54-55.

${ }^{169}$ PAUL DELNOY, Le Libéralités (...), cit., p. 31. 
doação, ao passo que pode haver liberalidade com desejo de doar sem gratuidade, como na doação com encargo em favor do doador ou na doação mútua.

Há quem afirme ${ }^{170}$ que a gratuidade está presente apenas na doação na sua forma pura, enquanto que não se verifica na modalidade onerosa, havendo, no entanto, opinião contrária a esse respeito $^{171}$, o que é de se esperar, haja vista que, mesmo havendo encargo, esse será economicamente menos expressivo que a coisa doada, ao menos a princípio, pelo que o quesito objetivo de diminuição do patrimônio do donante e aumento do patrimônio do donatário continua a ser contemplado. Se o encargo for de valor igual ou maior que a própria doação, é da própria dicção do Código Civil de 2002, em seu art. $540^{172}$, que se o merecimento, o serviço remunerado ou o encargo imposto ultrapassarem o valor do objeto doado, o ato continua a consistir em uma liberalidade.

No entanto, a importância de se verificar a presença da gratuidade no negócio jurídico se constata em ponderação aduzida por AGOSTINHO ALVIM ${ }^{173}$, que entende ser a doação essencialmente benéfica, na medida em que representar a diminuição do patrimônio do doador e o acréscimo dos bens do donatário, de modo que chega a duas rápidas conclusões: não é doação, em regra, serviço prestado gratuitamente, e a benesse realizada pelo doador deve ser de interpretação restrita, nos moldes do quanto preconizado pelo art. $1090^{174}$ do Código Civil de 1916, que foi transplantado no atual Código na teoria geral dos negócios jurídicos, como se verifica na redação do art. $114^{175}$ do Código Civil de $2002^{176}$.

De qualquer forma, com o intuito de afastar todas as dúvidas que porventura venham a surgir no uso da doação como meio de realização de estratégia sucessória, importa declarar-se na escritura pública a vontade de transferir os bens doados por doação, levando-a,

${ }^{170}$ PABLO STOLZE GAGLIANO, O Contrato (...), cit., pp. 43-44 (ressalva o autor que, apesar da exceção que menciona, mesmo assim fez constar a gratuidade no rol das características do instituto estudado porque a doação pura se verifica em maior quantidade, de modo que ficaria assim ressalvada a cientificidade, segundo seu entender).

${ }^{171}$ ARNALDO MARMITT, Doação, cit., pp. 14-15.

${ }^{172}$ Art. 540. “A doação feita em contemplação do merecimento do donatário não perde o caráter de liberalidade, como não o perde a doação remuneratória, ou a gravada, no excedente ao valor dos serviços remunerados ou ao encargo imposto".

${ }^{173}$ Da Doação, cit., p. 08. Com efeito, a gratuidade do ato tem o condão de diferenciar a doação de diversos outros negócios jurídicos [nesse sentido: RICHARD HYLAND, Gifts (...), cit., item 228].

${ }^{174}$ Art. 1090. "Os contratos benéficos interpretar-se-ão estritamente". Esse dispositivo tem correspondência com o art. 114 do Código Civil de 2002: “Os negócios jurídicos benéficos e a renúncia interpretam-se estritamente".

175 Art. 114. "Os negócios jurídicos benéficos e a renúncia interpretam-se estritamente".

${ }^{176}$ PAULO LÔBO, Das Várias (...), cit., p. 275. 
após, para registro, nas repartições competentes, procedendo-se ainda à tradição dos móveis, para não possibilitar-se que se questione a ausência de transferência patrimonial ${ }^{177}$.

Além disso, deve-se ter o cuidado de computar eventuais encargos ou ônus decorrentes (como os tributos) da benesse, a fim de garantir que o donatário esteja efetivamente se enriquecendo com o ato, inclusive do ponto de vista econômico.

\section{3) A doação e os demais atos jurídicos}

Em que pese as dificuldades de encontrar o conceito e a natureza jurídica da doação, é possível traçar algumas diferenças entre ela e diversos outros atos jurídicos, o que se revela muito útil ao intérprete, não apenas para intentar definições negativas, mas também para desbastar algumas dificuldades que porventura surjam no caso concreto, trazendo assim mais a lume o que realmente é constitutivo de uma doação no sistema brasileiro atual ${ }^{178}$.

Autores há que diferenciam a doação da cessão de crédito, uns ${ }^{179}$ por acharem que a primeira tem por objeto bens corpóreos alienáveis, sendo que direitos, por serem incorpóreos, são pertinentes à cessão de crédito, de modo que direitos hereditários ou quotas sociais são passíveis de cessão, mas não de compra e venda ou doação, ao passo que VICENTE SABINO JÚNIOR ${ }^{180}$ traça tal diferença pelo fato de a cessão expressar um interesse econômico das partes, o que se afina melhor ao art. 538 do Código Civil de 2002, que admite a doação de "vantagens"181 e impõe a presença de liberalidade.

Por esse motivo, afirma-se ${ }^{182}$ que a cessão de direitos gratuita é doação ${ }^{183}$, havendo autores ${ }^{184}$, porém, que ensinam a não aplicação deste entendimento à cessão de direitos hereditários, por falta de gratuidade.

${ }^{177}$ Há um julgado do Superior Tribunal de Justiça que não reformou acórdão do Tribunal de Justiça do Rio de Janeiro, mantendo a negativa de efeitos a escritura pública de doação de ações de sociedade anônima, pois não se procedeu à escrituração da alienação em livro próprio, de modo que não houve transferência das ações, apesar de a liberalidade ter sido aprovada em Assembleia Geral Extraordinária ( $3^{a}$ T., R. Esp. 1.196.634/RJ, rel. PAULO DE TARSO SANSEVERINO, j. 05-11-13). Outro precedente, do Tribunal de Justiça de Minas Gerais, confirmou sentença de improcedência tirada em sede de embargos de terceiro, mantendo a penhora que recaiu sobre o imóvel penhorado, mesmo que ele já tivesse sido doado por meio de escritura pública, e declarou que o donatário foi desidioso em não levá-la a registro, pelo que não houve transferência de propriedade (10ª Câm. Cív., Apel. n. 4493180-81.2007.8.13.0024, rel. GUTEMBERG DA MOTA E SILVA, j. 24-08-2010).

${ }^{178}$ Sobre a utilidade de se realizar tal pesquisa: SAVIGNY, Sistema (...), cit., pp. 125-126.

179 ANTÔNIO CHAVES, Lições (...), cit., p. 238; FÁBIO ULHOA COELHO, Curso (...), cit., p. 239; PABLO STOLZE GAGLIANO, O Contrato (...), cit., p. 30; SÍLVIO DE SALVO VENOSA, Direito (...), cit., p. 124.

${ }^{180}$ Contrato de (...), cit., p. 17.

${ }^{181}$ Sobre a abrangência do termo, consultar: PAULO LÔBO, Das Várias (...), cit., p. 277.

182 AGOSTINHO ALVIM, Da Doação, cit., p. 17; MANUEL ALBADALEJO GARCÍA e SILVIA DIAZ 
Ao tratar do contrato de doação, o Código Civil de 2002 também não incluiu nele a hipótese de assunção de uma obrigação, pois tal figura se enquadra melhor na disciplina da assunção de dívida ou novação ${ }^{185}$. Também não lhe atribuiu como causa a vontade de pagar uma dívida (animus solvendi), mas sim de fazer uma liberalidade (animus donandi), o que diferencia a doação da dação em pagamento ${ }^{186}$.

Também se pode diferenciar doação de depósito ou mandato, na medida em que esses contratos, apesar de poderem ser celebrados a título gratuito e com obrigação unilateral, não têm como causa a liberalidade típica da doação (animus donandi) ${ }^{187}$, e nem estão dotados de gratuidade, isto é, a efetiva diminuição do patrimônio do autor do ato jurídico e acréscimo do recebedor ${ }^{188}$. Com efeito, tal asserção é possível de se fazer porque o potencial empobrecimento do mandante ou do depositante não caracteriza gratuidade, sendo que o mesmo se aplica às garantias reais ou fidejussórias ${ }^{189}$.

Nesse mesmo sentido, o trabalho prestado a título gratuito, em regra, não caracteriza doação, por não importar na diminuição do patrimônio do doador, ou seja, falta gratuidade $^{190}$, mas há ${ }^{191}$ quem delineie na hipótese uma doação quando se verifica que ao

ALABART, La Donación, cit., p. 57; TORRENTE, La Donazione, cit., pp. 208-209.

${ }^{183}$ Em precedente já mencionado, o Superior Tribunal de Justiça declarou no voto condutor do acórdão que a cessão gratuita de meação é uma doação (3 ${ }^{\mathrm{a}}$ T., R. Esp. n. 1.196.992/MS, rel. NANCY ANDRIGHI, j. 06-0813).

${ }^{184}$ CARlos ALBERTO BITTAR, Contratos (...), cit., p. 43; MARIA HELENA DINIZ Curso (...), cit., p. 252.

185 PABLO STOLZE GAGLIANO, O Contrato de (...), p. 28. No entanto, segundo PONTES DE MIRANDA, pode haver doação se a assunção se realiza por terceiro [Tratado (...), cit., p. 197].

${ }^{186}$ PABLO STOLZE GAGLIANO, O Contrato de (...), p. 43.

187 ARNALDO MARMITT, Doação, cit., p. 11; SERPA LOPES, Curso (...), cit., p. 386; SÍLVIO DE SALVO VENOSA, Direito (...), cit., p. 125; TANIA CASSANDRO, Le Donazione, cit. p. 9.

${ }^{188}$ ARNOLDO WALD, Direito (...), cit., p. 64; EDUARDO ESPINOLA, Dos Contratos (...), cit. p. 154; MARIA HELENA DINIZ, Curso (...), cit., p. 254; PLANIOL, Traité (...), cit., p. 642 (o autor fala apenas do depósito); SAVIGNY, Sistema (...), cit., pp. 34 (o autor ressalta que nos presentes casos não há nem sequer alienação) e 149 (mas ressalva que pode haver doação quando o depositante determina que o depositário devolva o bem a outrem, que passa a ser donatário); VICENTE SABINO JÚNIOR, Contrato (...), cit., p. 89.

189 AGOSTINHO ALVIM, Da Doação, cit., p. 16; ARNALDO MARMITT, Doação, cit., p. 11; ARNALDO RIZZARDO, Contratos, cit., p. 440; ARNOLDO WALD, Direito (...), cit., p. 64; CARLOS ROBERTO GONÇALVES, Direito (...), cit., p. 256; CLÓVIS BEVILAQUA, Código (...), cit., p. 271; FÁBIO ULHOA COELHO, Curso (...), cit., p. 235; MARIA HELENA DINIZ, Curso (...), cit., p. 255; PAULO LÔBO, Direito (...), cit., p. 284; PONTES DE MIRANDA, Tratado (...), cit., p. 195; SAMUEL LUIZ ARAÚJO, O Princípio (...), cit., p. 73; SAVIGNY, Sistema (...), cit., p. 141 (nesse passo o autor fala apenas do penhor).

TORRENTE, por seu turno, também entende que a concessão de garantia não é doação, mas discorda que a falta de gratuidade seja o diferencial, afirmando antes que a causa desses negócios é que os diferencia da doação [La Donazione, cit., pp. 220-221].

${ }^{190}$ AGOSTINHO ALVIM, Da Doação, cit., pp. 16-17; CARLOS ALBERTO BITTAR, Contratos (...), cit., p. 43; CLÓVIS BEVILAQUA, Código (...), cit., p. 271; FÁBIO ULHOA COELHO, Curso (...), cit., p. 239; MARIA HELENA DINIZ, Curso (...), cit., p. 254; MÉAU-LAUTOUR, La Donation (...), cit., p. 71 (a autora entende que a definição de liberalidade é importante justamente para distinguir a doação do serviço gratuito); PAULO NADER, Curso (...), cit., p. 226; PLANIOL, Traité (...), cit., p. 642 (o autor exclui a hipótese porque afirma que a doação somente pode ter por objeto uma promessa ou obrigação de dar, mas não de fazer, ainda 
executar o serviço o que o fez deixou de auferir ganhos, ou então afastou as despesas que seriam cobertas por oferecimento do beneficiário ${ }^{192}$, ou ainda no dinheiro que o beneficiário economizou $^{193 / 194}$.

Também por falta de gratuidade, não há doação no mútuo ou no comodato gratuito $^{195}$, porém se ao fazer o empréstimo o autor do ato estiver deixando de perceber algum fruto que adviria da coisa, então se pode dizer que há doação, pois passa a haver gratuidade ${ }^{196}$.

Dentro da especificidade da doação com cláusula de reversão, não se deve confundi-la com a retrovenda, pois o doador nada repõe em favor do donatário. Além disso, não há preempção ou preferência do donatário para com o doador, caso aliene o objeto da benesse $^{197}$.

A diferença entre doação e promessa de recompensa reside no fato de que a primeira pode ocorrer em premiação por uma atividade ou virtude do donatário, ao passo que a segunda consiste antes em um ato unilateral de vontade anterior que promete remunerar quem praticar determinado ato, pelo que falta animus donandi ao ofertante ${ }^{198}$. PONTES DE

que de execução imediata); PONTES DE MIRANDA, Tratado (...), cit., p. 199; RICHARD HYLAND, Gifts (...), cit., item 353 (o autor explica que no direito norte-americano a tradição ('delivery') é elemento essencial na doação, de modo a excluir o serviço gratuito); SÍLVIO DE SALVO VENOSA, Direito (...), cit., p. 125; SYLVIO CAPANEMA DE SOUZA, Das Várias (...), cit., p. 115.

${ }^{191}$ AGOSTINHO ALVIM, Da Doação, cit., p.17.

${ }^{192}$ PONTES DE MIRANDA, Tratado (...), cit., p. 195.

${ }^{193}$ SAVIGNY, Sistema (...), cit., p. 131.

${ }^{194}$ BIONDI enquadra o problema da prestação de serviço no problema de a doutrina se negar a ver doação em obrigação de fazer. Compreende o doutrinador, assim, que a prestação de serviço gratuito é uma liberalidade de uso, o que exclui a presença de doação. Não obstante, compreende que há hipóteses de prestação de serviço gratuito em que não se pode dar outra qualificação jurídica, a não ser a de doação [Le Donazioni, cit., pp. 389-393].

195 ARNOLDO WALD, Direito (...), cit., p. 64; CARLOS ALBERTO BITTAR, Contratos (...), cit., p. 43; EDUARDO ESPINOLA, Dos Contratos (...), cit. p. 154; FÁBIO ULHOA COELHO, Curso (...), cit., p. 235; MARIA HELENA DINIZ, Curso (...), cit., p. 254; PAULO LÔBO, Direito (...), cit., p. 284; PLANIOL, Traité (...), cit., p. 642; SAVIGNY, Sistema (...), cit., p. 34; SERPA LOPES, Curso (...), cit., p. 387; SÍLVIO DE SALVO VENOSA, Direito (...), cit., p. 125. Há quem veja nas hipóteses, assim como no mandato, a presença de enriquecimento de uma parte em detrimento de outra, mas só não é doação por não haver a causa própria desse negócio (nesse sentido: BIONDI, Le Donazioni, cit., p. 388; TANIA CASSANDRO, Le Donazione, cit. p. 9).

${ }^{196}$ AGOSTINHO ALVIM, Da Doação, cit., pp. 19-20. Também afirmando que a renúncia de juros futuros importa em doação: PONTES DE MIRANDA, Tratado (...), cit., p. 193. Confrontar ainda: SAVIGNY, Sistema (...), cit., pp. 40-51 e 148-149 (nesse último passo, o autor entende que há doação quando se empresta dinheiro próprio em nome de outrem, ou se dispõe a devolução do objeto emprestado a outrem).

${ }^{197}$ VICENTE SABINO JÚNIOR, Contrato (...), cit., p. 17.

${ }^{198}$ AGOSTINHO ALVIM, Da Doação, cit., p. 48; PAUL DELNOY, Le Libéralités (...), cit., p. 30; PAULO DE TARSO VIEIRA SANSEVERINO, Contratos (...), cit., p. 75; TORRENTE, La Donazione, cit., pp. 167-170. 
MIRANDA $^{199}$ acentua, nesse sentido, que a doação é negócio jurídico bilateral, ao passo que a promessa de recompensa é unilateral desde a sua formação.

É possível ver na concessão dos direitos de usufruto, uso e habitação a título gratuito contrato de doação, sendo a coisa doada não o direito de propriedade, mas sim as faculdades de uso e gozo ${ }^{200}$.

Também é possível diferenciar a doação do testamento, podendo-se apontar que a primeira é transmissão de bem por ato inter vivos, ao passo que o segundo é mortis causa, sendo que a doação só se revoga em determinadas hipóteses, enquanto o testamento pode ser revogado a qualquer tempo da vida do testador, sem necessidade de fundamentação ${ }^{201}$. Além disso, segundo o sistema civil vigente, a doação é contrato, ao passo que o testamento é ato unilateral $^{202 / 203}$.

Tal diferenciação traz, como efeito prático, o fato de que, se o testador deserdar um seu filho que também seja donatário, o ato não atingirá o recebedor da benesse, mesmo que deduza como fundamento as mesmas hipóteses necessárias para a revogação de doação por ingratidão ${ }^{204}$.

A doação também não é legado, porque este é um ato unilateral mortis causa, que não depende do aceite do beneficiário para se aperfeiçoar, e quando condicional só tem

${ }^{199}$ Tratado (...), cit., p. 197.

200 AGOSTINHO ALVIM, Da Doação, cit., p. 22; EDUARDO ESPINOLA, Dos Contratos (...), cit. p. 167; SAVIGNY, Sistema (...), cit., pp. 131 (o autor explica que a doação estaria no dinheiro poupado pelo beneficiário) e pp. 139-141 (e na própria concessão).

${ }^{201}$ ORLANDO GOMES, Contratos, cit., pp. 235-236; SÍlVIO DE SALVO VENOSA, Direito (...), cit., p. 124; VICENTE SABINO JÚNIOR, Contrato (...), cit., p. 66.

${ }^{202}$ MARIA HELENA DINIZ, Curso (...), cit., p. 252.

${ }^{203}$ Para envidar a diferença entre doação e testamento, o direito norte-americano tem como um possível critério prático o momento em que o ato passa a gerar efeitos. Um julgado da Divisão de Apelação da Suprema Corte de Nova Iorque confirmou decisão de instância inferior que anulou um ato de renúncia ("quitclaim deed") feita por esposa a favor de seu marido, porque entendeu que ela deveria ter realizado um testamento, mas não o mencionado negócio jurídico, o qual não cumpri os requisitos formais necessários para se formalizar as disposições de última vontade. A fundamentar sua conclusão, o aresto afirma que era evidente o fato de os bens continuarem sob o controle da virago, que sua transmissão somente se daria com a morte dela e que havia ainda cláusula de reversão, sendo forçoso concluir-se, então, que apenas com o advento da morte dela é que se deflagraria os efeitos do ato jurídico praticado, o que é uma típica transmissão mortis causa. Afirma-se ainda pela possibilidade de se ter recebido o ato como um gift, pelos elementos externos, mas impossível convolá-lo em testamento justamente pela forma adotada [Butler v. Sherwood, 196 A.D. 603, 188 N.Y.S. 242, aff'd mem., 233 N.Y. 655, 135 N.E. 957 (1922) in ELIAS CLARK et al., Cases (...), cit., pp. 458-460].

${ }^{204}$ VICENTE SABINO JÚNIOR, Contrato (...), cit., pp. 67-69. 
eficácia após o cumprimento do modus, ao passo que a doação é contrato inter vivos e a modal tem efeitos desde a celebração do ato ${ }^{205}$.

A renúncia a direitos ou recusa de herança ou legado não é doação, por faltar a gratuidade, isto é, atribuição ou transferência patrimonial ${ }^{206}$. AGOSTINHO ALVIM $^{207}$ manifesta opinião contrária, pois entende que a renúncia tem todos os elementos da doação, como quando, por exemplo, um titular de direito real sobre coisa alheia renuncia visando beneficiar o proprietário, ou mesmo em se tratando de renúncia de herança, na qual reconhece que o bem doado nem sequer ingressou no patrimônio do doador, pois presentes a unilateralidade, o animus donandi e a gratuidade.

${ }^{205}$ ARNOLDO WALD, Direito (...), cit., p. 64; EDUARDO ESPINOLA, Dos Contratos (...), cit. p. 154; MÉAULAUTOUR, La Donation (...), cit., p. 90 (a autora explica que ambos são liberalidades, mas a diferença está na causa: a vida ou a morte); RODRIGO SENISE LISBOA, Manual (...), cit., p. 258; VICENTE SABINO JÚNIOR, Contrato (...), cit., p. 17.

${ }^{206}$ ARNALDO RIZZARDO, Contratos, cit., pp. 440-441; ARNOLDO WALD, Direito (...), cit., p. 64; CAIO MÁRIO DA SILVA PEREIRA, Instituições (...), cit., p. 209; CARLOS ALBERTO BITTAR, Contratos (...), cit., p. 43; CARVALHO DE MENDONÇA, Contratos (...), cit., pp. 33-34; EDUARDO ESPINOLA, Dos Contratos (...), cit. p. 154; MARIA HELENA DINIZ, Curso (...), cit., p. 255; NELSON ROSENVALD, Contratos (...), cit., p. 584; PABLO STOLZE GAGLIANO, O Contrato (...), p. 42; PAUL DELNOY, Le Libéralités (...), cit., p. 31; PAULO DE TARSO VIEIRA SANSEVERINO, Contratos (...), cit., p. 63; PAULO LÔBO, Direito (...), cit., p. 284; PONTES DE MIRANDA, Tratado (...), cit., pp. 193-194 e 230; SAVIGNY, Sistema (...), cit., p. 37 (explica o autor que a inação daquele que é titular de uma expectativa de direito não significa diminuição de seu patrimônio); SÍLVIO DE SALVO VENOSA, Direito (...), cit., p. 126; SYLVIO CAPANEMA DE SOUZA, Das Várias (...), cit., p. 115; TORRENTE, La Donazione, cit., pp. 207210; VICENTE SABINO JÚNIOR, Contrato de (...), p. 17. Para SERPA LOPES, a diferença da doação e os demais atos a título gratuito está em que a primeira tem como causa a vontade do autor de realizar a benesse, de modo que só não é renúncia por faltar animus donandi [Curso (...), cit., p. 385]. Se posicionam nesse mesmo sentido: AMANDA ZOE MORRIS, Doação, cit., p. 278; MARIA HELENA DINIZ, Curso (...), cit., p. 253; SAMUEL LUIZ ARAÚJO, O Princípio (...), cit., p. 74.

Como já foi mencionado, o art. 940 do Código Civil de Portugal, no seu segundo parágrafo, excluiu expressamente a renúncia dos quadros da doação. MANUEL BAPTISTA LOPES ensina, porém, que apenas a renúncia abdicativa não é doação, podendo o ser a traslativa, pois nessa hipótese há bilateralidade [Das Doações, cit., pp. 17-19].

GARDANI CONTURSI LISI, expondo a evolução da doutrina italiana na matéria, demonstra que a renúncia, abdicativa ou até translativa para alguns, não é doação por lhe faltar contratualidade, sem que com isso, eventualmente, não seja um ato de liberalidade. No entanto, a jurisprudência tem acolhido renúncia traslativa em matéria de transferência de direitos hereditários, impondo, inclusive, que se lavre escritura pública [Le Donazioni, cit., pp. 217-226 e 88-89]. BALBI também compreende que a renúncia não pode ser doação por consistir em ato unilateral [Saggio (...), cit., pp. 20-29]. TORRENTE, por seu turno, entende que a renúncia abdicativa a herança não é doação, mas poderá o ser caso seja traslativa [La Donazione, cit., pp. 208-210]. BIONDI aceita que a doação se perfaça por meio de renúncia traslativa, mas aponta que há atos de renúncia não passíveis de transmissão por ato inter vivos, daí a impossibilidade de ser objeto de doação [Le Donazioni, cit., pp. 323-325].

${ }^{207}$ Da Doação, $3^{\mathrm{a}}$ ed., São Paulo, Saraiva, 1980, p. 14. CARVALHO SANTOS também manifesta opinião de poder se ver doação na renúncia se houver liberalidade [Código (...), cit., p. 325]. No direito norte-americano qualquer espécie de renúncia feita com intenção liberal é doação [RICHARD HYLAND, Gifts (...), cit., item $355]$. 
Quanto ao fato de a renúncia não ser contrato, ao contrário da doação, alega ainda o autor ${ }^{208}$ que por isso mesmo entende que a definição do art. 1165 do Código Civil de 1916 nem sempre conseguirá acobertar as situações fáticas. Porém ressalva que, para a renúncia se caracterizar como doação, não poderá ser o fim último do ato, posição essa própria da liberalidade ${ }^{209}$.

De todo modo, a tese de que a renúncia, mesmo de direito hereditário, não é doação, foi acolhida também pela jurisprudência, tendo já decidido nesse sentido o Superior Tribunal de Justiça, que não deu guarida à pretensão do Fisco Estadual de cobrar o imposto de transmissão de bens imóveis de renunciantes à herança a favor do monte-mor ${ }^{210}$, assim como declarou que a renúncia de três filhos à herança dos bens deixados pelo pai deles cuja consequência foi tornar a mãe viúva e herdeira universal, não é doação, pelo que não se configurou hipótese de incidência do imposto de transmissão inter vivos e doação ${ }^{211}$.

Em continuidade à comparação entre a doação e as demais figuras jurídicas, verifica-se que MANUEL ALBADALEJO GARCÍA e SILVIA DIAZ ALABART ${ }^{212}$ afirmam ser possível haver doação de um direito que o doador tem em face do próprio donatário, o que chamam de doação liberatória, desde que haja contrato específico para tal desiderato ${ }^{213}$, o que teria o mesmo efeito que a renúncia, mas tem-se na hipótese uma causa diferente, podendo haver então repercussões diferentes, podendo-se citar, à guisa de exemplo, a incidência de tributos específicos para cada qual.

${ }^{208}$ Da Doação, cit., p. 15.

209 Nesse sentido, há quem admita ser doação a renúncia classificada como translativa, cujo contrário é a abdicativa, por meio da qual o renunciante nomeia o beneficiado do ato, pois nesse caso houve ingresso do direito no patrimônio do autor do ato [ARNALDO RIZZARDO, Contratos, cit., p. 441; CAIO MÁRIO DA SILVA PEREIRA, Instituições (...), cit., p. 209; PAULO DE TARSO VIEIRA SANSEVERINO, Contratos (...), cit., p. 63]. Há, porém, quem veja doação até mesmo na renúncia abdicativa, desde que a causa de fundo seja o animus donandi [nesse sentido: JEAN RAY, De La Notion (...), cit., pp. 44-45; PLANIOL, Traité (...), cit., pp. 662-663 (o autor chama essa espécie de 'donations indirectes')].

${ }^{210} 1^{\text {a }}$ T., R. Esp. n. 36.076/MG, rel. GARCIA VIEIRA, j. 03-12-98.

211 a T., R. Esp. 20.183/RJ, rel. HUMBERTO GOMES DE BARROS, j. 01-12-93.

${ }^{212}$ MANUEL ALBADALEJO GARCÍA e SILVIA DIAZ ALABART, La Donación, cit., pp. 52-53. Essa também é a definição de BIONDI, que da mesma forma diferencia a espécie da obrigatória, pois essa última consiste no ato de o doador se comprometer a não exercer seu direito de crédito em face do donatário [Le Donazioni, cit., pp. 399-400].

${ }^{213}$ EDUARDO ESPINOLA entende que a liberação de uma obrigação pelo credor sem contrato não é doação [Dos Contratos (...), cit. p. 154]. TORRENTE afirma que o direito italiano não admite a hipótese como doação [La Donazione, cit., pp. 214-219], mas essa não é a opinião de BIONDI, que ensina ser a espécie perfeitamente congruente com a definição de doação do art. 769 do Código Civil da Itália, e o autor demonstra ainda as diferenças entre a doação liberatória e a renúncia de direito [Le Donazioni, cit., pp. 396399]. 
Há ${ }^{214}$ ainda quem entenda que a satisfação de um dever social, ou de um dever moral, ou de uma obrigação natural (dívida prescrita ou a não alegação de prescrição quando esta ocorreu), não é doação, justamente por ser adimplemento, mas há quem ${ }^{215}$ não descarte a possibilidade de se mudar tal visão, à luz do art. 1187, III $^{216}$, do Código Civil de 1916, visão esta perfeitamente aplicável ao sistema atual, haja vista a redação do inciso III do art. $564^{217}$, da Codificação Civil atual ${ }^{218}$.

De todo modo, aquele que deixa correr prazo prescricional aquisitivo ou extintivo não doa, por falta de animus donandi ${ }^{219}$, mas se houve expressa remissão de dívida ou

${ }^{214}$ ARNALDO MARMITT, Doação, cit., p. 11; BIONDI, Le Donazioni, cit., pp. 77-78 e 81-87; CARVALHO DE MENDONÇA, Contratos (...), cit., p. 34; CARVALHO SANTOS, Código (...), cit., p. 324; FRANCISCO GARDANI CONTURSI LISI, Le Donazioni, cit., pp. 17-24 e 33-35 (a autora descreve o trabalho jurisprudencial de distinção da causa donandi e adimplemento e, ao tratar da especificidade da obrigação natural, a separação do que seja doação remuneratória e adimplemento); GLAUBER PESSOA ALVES, Das Várias (...), cit., p. 882; JOÃO BAPTISTA VILLELA, Contrato (...), cit., pp. 258-259; MARIA HELENA DINIZ, Curso (...), cit., p. 253; PAULO LÔBO, Direito (...), cit., p. 285; PONTES DE MIRANDA, Tratado (...), cit., p. 195; SAVIGNY, Sistema (...), cit., pp. 64-70 (o autor dá como exemplos: devedor que paga sua dívida por meio vantajoso; possuidor que devolve a posse ao proprietário sem necessidade de demanda; aceitação de garantia; dar penhor para crédito próprio; e, declaração judicial de pagamento de dívida quitada. São hipóteses em que não há alteração no patrimônio do doador); TANIA CASSANDRO, La Donazione, cit., pp. 105-106; TORRENTE, La Donazione, cit., pp. 184-191.

${ }^{215}$ AGOSTINHO ALVIM, Da Doação, cit., p. 12; ARNOLDO WALD, Direito (...), cit., p. 69.

Sobre o desenvolvimento da matéria na jurisprudência francesa, consultar: JEAN RAY, De La Notion (...), cit., pp. 109-115.

${ }^{216}$ Art. 1187. "Não se revogam por ingratidão: [...] III - as [doações] que se fizerem em cumprimento de obrigação natural".

${ }^{217}$ Art. 564. "Não se revogam por ingratidão: [...] III - as [doações] que se fizerem em cumprimento de obrigação natural; [...]".

${ }^{218}$ PONTES DE MIRANDA crítica tal posicionamento, por entender que no mencionado dispositivo legal há erro terminológico, de modo que o devedor de dívida natural não doa, mas sim adimple a obrigação [Tratado (...), cit., pp. 229-230].

Essa distinção pode se mostrar relevante para o objeto da presente pesquisa, como demonstra um julgado do Tribunal de Justiça de São Paulo: ficou assentado que um casal procedeu à partilha em vida de seus bens entre os filhos, porém uma filha ficou prejudicada posteriormente, porque após à transferência parte da fazenda que recebeu em doação sofreu desapropriação e o pai redigiu documento particular em que reconhece o desequilíbrio e o desejo de que a equanimidade fosse restabelecida, o que teve a concordância dos outros irmãos, que não cumpriram, porém, a avença. Brandindo tal instrumento, a mencionada donatária ingressou em juízo requerendo o equilíbrio da partilha, mas entendeu-se, porém, que se tratava de mera manifestação de intenção, sem efeito vinculativo e revogável, de maneira que havia no caso mera obrigação natural, mas não dever de doar (9 $9^{\mathrm{a}}$ Câm. de Dir. Priv., Apel. 9161180-57.2009.8.26.0000, rel. JOSÉ LUIZ GAVIÃO DE ALMEIDA, j. 13-03-12).

Na mesma linha, há precedentes judiciais não conferindo eficácia a promessa de doação sob o fundamento de que se trata de obrigação natural. Assim, em uma ação condenatória promovida por ex-esposa e os dois filhos de um varão, que lhe cobrava o pagamento de pecúnia por ter descumprido acordo extrajudicial de dissolução de sociedade, alienação de imóvel e posterior doação à prole, consubstanciado em instrumento particular, o Tribunal de Justiça de São Paulo manteve sentença de improcedência, sob o fundamento de que o acordo realizado era mera liberalidade e obrigação natural, mas não uma promessa validade e eficaz ( $7^{\mathrm{a}} \mathrm{Câm}$. de Dir. Priv., Apel. 0099505-23.2007.8.26.0000, rel. MENDES PEREIRA, j. 08-08-12).

Como se verifica, em matéria de doação a observância da forma legal na formação do negócio traz segurança jurídica de relevo, pois evita questionamentos sobre a natureza das obrigações das partes.

${ }^{219}$ AGOSTINHO ALVIM, Da Doação, cit., pp. 11-12; ARNALDO MARMITT, Doação, cit., p. 11; BIONDI, Le Donazioni, cit., p. 324 (para esse autor, falta, em verdade, gratuidade na hipótese); CARLOS ALBERTO 
deliberado silêncio do proprietário em ação de usucapião promovida por filho deste, então seria possível vislumbrar a hipótese de doação ${ }^{220}$.

Para alguns autores ${ }^{221}$, certas ações típicas da vida social não são uma doação, tais como presentes, atos filantrópicos ou concessão de bolsa de estudos, pois o motivo por trás do ato é o de "presentear", mas não "doar", e isto não porque costumam ser de baixo valor, mas sim porque não são ato jurídico, mas sim fato jurídico, e assim se afirma porque o fim imediato do disponente não é o de criar ou modificar um direito, mas sim a de fazer uma gentileza ou cumprir um rito social.

MANUEL ALBADALEJO GARCÍA e SILVIA DIAZ ALABART ${ }^{222}$ concordam com tal posicionamento, mas qualificam tais atos no gênero "liberalidade de uso", referindose aos usos sociais, e concordam não ser tal situação uma doação por faltar animus donandi ${ }^{223}$.

Assim também as gorjetas ou gratificações não são doação, haja vista serem meras gentilezas que não criam ou modificam direitos, e também não o é a esmola, mesmo a

BITTAR, Contratos (...), cit., p. 43; CARLOS ROBERTO GONÇALVES, Direito (...), cit., p. 256; JOÃO BAPTISTA VILLELA, Contrato (...), cit., p. 258; MARIA HELENA DINIZ, Curso (...), cit., p. 253; PAULO LÔBO, Direito (...), cit., p. 284; SAMUEL LUIZ ARAÚJO, O Princípio (...), cit., p. 74; SAVIGNY, Sistema (...), cit., pp. 94 e 130-131 (nesse último excerto, o autor afirma que a derrelicção de um bem em favor de outro não é negócio jurídico, logo deixar correr o prazo da usucapião não é doar); SERPA LOPES, Curso (...), cit., p. 387; SÍLVIO DE SALVO VENOSA, Direito (...), cit., p. 126.

${ }^{220}$ AGOSTINHO ALVIM, Da Doação, cit., p. 12. Quanto à remissão de dívida, há quem entenda não ser doação por falta de transferência patrimonial [ARNALDO RIZZARDO, Contratos, cit., p. 441; NELSON ROSENVALD, Contratos (...), cit., p. 584], mas SAVIGNY, por seu turno, explica que só deixa de haver alienação quando a dívida pode ser fulminada por conta de alguma exceção, ao passo que, se assim não for, há verdadeira doação [Sistema (...), cit., pp. 156-157]. Ver ainda os comentários feitos sobre a doação indireta.

221 AMANDA ZOE MORRIS, Doação, cit., p. 278; ARNALDO MARMITT, Da Doação, cit., pp. 17-19; CARLOS ROBERTO GONÇALVES, Direito (...), ob. cit., p. 256; MÉAU-LAUTOUR, La Donation (...), cit., pp. 83-85 (a autora sugere o critério de autonomia para enquadramento teórico desdes atos); NELSON ROSENVALD, Contratos (...), cit., p. 584 (fala apenas na hipótese dos presentes); PAUL DELNOY, Le Libéralités (...), ob. cit., p. 30; SÍLVIO DE SALVO VENOSA, Direito (...), cit., p. 126; SYLVIO CAPANEMA DE SOUZA, Das Várias (...), cit., p. 115; VICENTE SABINO JÚNIOR, Contrato (...), cit., p. 17.

${ }^{222}$ La Donación, cit., pp. 396-397.

${ }^{223}$ O Código Civil italiano é expresso na exclusão das liberalidades de uso das doações, conforme se verifica na redação do segundo parágrafo do art. 770 ("Donazione rimuneratoria"): "1. Ė donazione anche la liberalità fatta per riconoscenza o in considerazione dei meriti del donatario o per speciale rimunerazione. 2. Non costituisce donazione la liberalità che si suole fare in occasione di servizi resi o comunque in conformità agli usi". TANIA CASSANDRO explica que a expressa menção à remuneração de serviços, aplicável às gorjetas e gratificações, são, em verdade, destaque de caso especial de uma liberalidade de uso (La Donazione, cit., p. 95). Confrontar ainda: BIONDI, Le Donazioni, cit., p. 77 
que se dá em grande vulto, aos hospitais, por exemplo, nem a espórtula que se dá a uma instituição religiosa ${ }^{224}$.

Na lição de AGOSTINHO ALVIM ${ }^{225}$ também se encontra a afirmação de que a esmola não é doação, por falta de animus donandi, e respalda tal posicionamento em vista do fato de que o autor da esmola não olha a quem está dando, mas o faz de modo genérico. Não obstante, reconhece não ser fácil a diferenciação entre uma e outra, trazendo à baila um exemplo concreto, a fim de traçar a diferença, aventando a hipótese de alguém que resolve cuidar de um órfão: se o faz por caridade, é esmola; mas se o faz em vista de ser filho de um amigo ou parente, então é doação. Entende que a esmola é ato jurídico, não facilmente distinguível da doação, mas traçada a diferença o ato não se submete ao regime próprio desta.

A venda feita abaixo do preço normal ou a compra por preço maior por ignorância também está despida de animus donandi, estando melhor qualificada pela má negociação, pelo que não é doação ${ }^{226}$, porém pode se vislumbrar a hipótese de doação quando as partes são próximas por vínculos de parentesco ou amizade, estipulando preço simbólico, pelo que se tem aí um negotium mixtum cum donatione ${ }^{227}$.

${ }^{224}$ AMANDA ZOE MORRIS, Doação, cit., p. 278; ARNALDO MARMITT, Doação, cit., p. 76; ARNALDO RIZZARDO, Contratos, cit., p. 441; CAIO MÁRIO DA SILVA PEREIRA, Instituições (...), cit., p. 209; FRANCISCO GLAUBER PESSOA ALVES, Das Várias (...), cit., p. 885; PAULO LỔBO, Direito (...), cit., p. 284; RICHARD HYLAND, Gifts (...), cit., item 356 (o autor se refere apenas à gorjeta, explicando que no direito norte-americano não é doação); SAMUEL LUIZ ARAÚJO, O Princípio (...), cit., p. 74; SÍLVIO DE SALVO VENOSA, Direito (...), cit., p. 126; SYLVIO CAPANEMA DE SOUZA, Das Várias (...), cit., p. 115. Não obstante, PONTES DE MIRANDA admite o que intitula de "doação de cartaz", que se realiza com o intento do doador de ocupar determinada posição ou gozar de certo título [Tratado (...), cit., p. 193]. A respeito do espectro de atos que há entre a doação pura e o mero cumprimento de dever social, consultar: JEAN RAY, De La Notion (...), cit., pp. 120-124.

No âmbito do Código Civil português, no já transcrito § $2^{\circ}$ do art. 940, tais hipóteses são expressamente declaradas como não sendo doação, mas MANUEL BAPTISTA LOPES ensina, a esse respeito, que assim se considera pelo baixo valor patrimonial desses atos, mas que se o objeto da liberalidade representar alto valor, então ela deve ser considerada uma doação [Das Doações, cit., pp. 20 e 21].

${ }^{225}$ Da Doação, cit., pp. 20-22.

${ }^{226}$ ARNALDO RIZZARDO, Contratos, cit., p. 441; CARLOS ALBERTO BITTAR, Contratos (...), cit., p. 43; D'ABRANCHES FERRÃO, Das Doações, cit., p. 29; MARIA HELENA DINIZ, Tratado (...), cit., p. 73 (a autora destaca, para qualificar a hipótese, a venda feita a preço menor do mercado para atrair clientela); RODRIGO SENISE LISBOA, Manual (...), cit., p. 259; SAVIGNY, Sistema (...), cit., p. 94; TORRENTE, La Donazione, cit., p. 181 (o autor aplica a mesma conclusão na hipótese de o motivo ser a necessidade do vendedor ou comprador).

${ }^{227}$ AGOSTINHO ALVIM, Da Doação, cit., p. 13; CARLOS ROBERTO GONÇALVES, Direito (...), cit., p. 256. MANUEL ALBADALEJO GARCÍA e SILVIA DIAZ ALABART, em sua obra, citam precedente em que as partes celebraram compra e venda com preço bem abaixo do mercado e o Tribunal recusou qualificar o ato como doação, justamente por falta de animus donandi, mas os autores entendem que se houver estima entre as partes, então haveria doação dissimulada (La Donación, cit., p. 54). 
AGOSTINHO ALVIM ${ }^{228}$ emite opinião de que a "doação de sangue" é doação, pois algumas partes do corpo, quando destacadas deste, tornam-se do comércio, como o cabelo, passível de ser vendido para fabricação de perucas, o mesmo ocorrendo com o sangue, que, quando extraído, pode ser vendido aos bancos de sangue, de modo que fica satisfeito a necessidade de transferência de patrimônio do Código. No entanto, tal opinião não possui validade legal atualmente, pois esbarraria no art. $13^{229}$ do Código Civil de 2002, e, além do mais, não se trata de hipótese de contrato de doação propriamente dita, mas sim uma cessão $^{230}$.

Diante do que se expôs, verifica-se que vários são os critérios determinantes utilizados pelos autores para constatar se determinado evento se enquadraria no que o Código chama de contrato de doação, como, por exemplo, especialmente se estão presentes a forma, o animus donandi e a gratuidade.

Assim, cumpre salientar que o presente trabalho não pretenderá verificar modos indiretos, ou tortuosos, ou ainda acidentais, de se utilizar a doação para a implementação de um planejamento sucessório. Neste tópico procurou-se mostrar exatamente como há diversas situações limites que trazem dificuldade interpretativa e dão ensejo a futuras discussões judiciais, o que não se busca aqui.

Com efeito, o objeto da presente pesquisa pressupõe um sujeito de direito que, no exercício da autonomia da sua vontade, planejou a sua sucessão e quer fazê-lo ainda em vida, de maneira que será considerada apenas a doação realizada nos ditames do regime jurídico contratual. Certamente que a vida prática apresentará outros problemas que escaparão à estratégia arquitetada pelo doador, o que apenas virá a confirmar a importância do quanto apresentado no presente tópico.

\section{4) Do Aceite e suas consequências}

Ao se debruçar sobre a Seção I ("Disposições Gerais"), do capítulo do Código Civil de 2002 que versa sobre as doações, o leitor verifica que há razoável número de artigos que dispõem especialmente sobre a forma de aceitação da doação por parte do donatário,

\footnotetext{
${ }^{228}$ Da Doação, cit., pp. 22-23.

229 Art. 13. "Salvo por exigência médica, é defeso o ato de disposição do próprio corpo, quando importar diminuição permanente da integridade física, ou contrariar os bons costumes".

230 PAULO LÔBO, Direito (...), cit., p. 285 (o autor fala em "dação"). Sobre o tema, confrontar: MARIA HELENA DINIZ, Curso (...), cit., p. 262; RICHARD HYLAND, Gifts (...), cit., itens 396 e 993-1033; RODRIGO SENISE LISBOA, Manual (...), cit., p. 257.
} 
donde se afere a importância do tema, pelo que se destacou um item para versar a esse respeito.

Com efeito, a necessidade de se regulamentar a externalização do animus donum accipiendi do donatário reside no fato de que, para se sustentar a tese contratualista da doação encampada pelo Código Civil de 2002, o aceite é fundamental, pois graças a ele é que se tem a bilateralidade necessária ao aperfeiçoamento da doação ${ }^{231}$. Por isso, enquanto não se dá o aceite, o ato do doador é mera proposta e pode ser revogado ${ }^{232}$, mas, de outro lado, tem o condão de tornar a doação irrevogável quando da sua ocorrência ${ }^{233}$.

Tal entendimento goza de sedimentado apoio na dogmática civil pátria. TEIXEIRA DE FREITAS ${ }^{234}$ afirmava que a doação era ato unilateral enquanto não houvesse aceitação, equiparando-se ao testamento, e só ganhava caráter contratual apenas com a ocorrência do aceite pelo donatário ${ }^{235}$. Da mesma forma, ressaltando a contratualidade, bem

${ }^{231}$ Neste sentido: AGOSTINHO ALVIM, Da Doação, cit., p. 40; AMANDA ZOE MORRIS, Doação, cit., p. 279; ARNALDO MARMITT, Doação, cit., p. 53; ARNALDO RIZZARDO, Contratos, cit., p. 442; BIONDI, Le Donazioni, cit., pp. 131 e 151-155; CARLOS ROBERTO GONÇALVES, Direito (...), cit., p. 256; CARVALHO DE MENDONÇA, Contratos (...), cit., p. 39; CARVALHO SANTOS, Código (...), cit., p. 326; EDUARDO ESPINOLA, Dos Contratos (...), cit. p. 169; FÁBIO ULHOA COELHO, Curso (...), cit., p. 247; JONES FIGUEIRÊDO ALVES, Código (...), cit., p. 445; LIMONGI FRANÇA, Manual (...), cit., p. 97; MANUEL ALBADALEJO GARCÍA e SILVIA DIAZ ALABART, La Donación, cit., p. 137; MARIA HELENA DINIZ, Curso (...), cit., p. 255; OZÉIAS J. SANTOS, Da Doação, cit., p. 27; PABLO STOLZE GAGLIANO, $O$ Contrato (...), cit., p. 48; PAULO GERALDO DE OLIVEIRA MEDINA, A Doação, cit., p. 463; PAULO LÔBO, Das Várias (...), cit., pp. 279-282 (o autor entende que nos casos em que não há aceite aplica-se a teoria da conduta social típica, a fim de se resguardar a bilateralidade volitiva); PAULO NADER, Curso (...), cit., p. 226; PLANIOL, Traité (...), cit., p. 671; RODRIGO SENISE LISBOA, Manual (...), cit., p. 259; SILVIO LUÍS FERREIRA DA ROCHA, Curso (...), cit., p. 174; SYLVIO CAPANEMA DE SOUZA, Das Várias (...), cit., p. 92 e 117; TORRENTE, La Donazione, cit., p. 438; VICENTE SABINO JÚNIOR, Contrato (...), cit., p. 14-15 (para esse último autor, a renúncia de um herdeiro à herança somente não será doação se não aceita pelos outros herdeiros, o que demonstra ser para ele o aceite ínsito à doação); WASHINGTON DE BARROS MONTEIRO-DABUS MALUF, Curso (...), cit., p. 164.

No direito norte-americano, em que pese a doação não ser tida por contrato, também é necessário o aceite do donatário para o aperfeiçoamento do gift [nesse sentido: ELIAS CLARK et al., Cases (...), cit., p. 443]. Com efeito, SAVIGNY aponta que é possível distinguir diversos atos que constituem doação que não são contrato, mas que, enquanto tal, o aceite se faz necessário [Sistema (...), cit., pp. 182-187].

Sobre a prevalência da vontade do doador na formação do contrato: BIONDI, Le Donazioni, cit., pp. 132135 .

${ }^{232}$ ANTÔNIO CHAVES, Lições (...), cit., p. 241; SAVIGNY, Sistema (...), cit., pp. 187-188; SERPA LOPES, Curso (...), cit., p. 392; VICENTE SABINO JÚNIOR, Contrato (...), cit., p. 31.

${ }^{233}$ ARNALDO MARMITT, Doação, cit., p. 54; CARVALHO DE MENDONÇA, Contratos (...), cit., p. 39. Ao contrário, a recusa pelo donatário induz ao desfazimento do oferecimento. Há um acórdão que deixou de executar promessa de doação realizada em sede de partilha em separação judicial homologada em juízo, porque os filhos-donatários recusaram-se expressamente receber a benesse, tendo-se determinado então a partilha do imóvel prometido entre os separandos, de acordo com o regime de bens então vigente (TJSP, $10^{\mathrm{a}}$ Câm. de Dir. Priv., Apel. 9176545-54.2009.8.26.0000, rel. ELCIO TRUJILLO, j. 23-04-2013).

${ }^{234}$ Consolidação (...), cit., p. 284. No mesmo sentido: CARVALHO DE MENDONÇA, Contratos (...), cit., p. 38.

${ }^{235}$ SERPA LOPES afirma, de outro lado, que a disposição do art. 1173 do Código Civil de 1916 ("A doação feita em contemplação de casamento futuro com certa e determinada pessoa, quer pelos nubentes entre si, quer por terceiro a um deles, a ambos, ou aos filhos que, de futuro, houverem um do outro, não pode ser impugnada 
como a unilateralidade da doação, CARVALHO DE MENDONÇA ${ }^{236}$ ensina que uma vez formado o contrato, isto é, policitação do doador e aceite pelo donatário, este poderá, ainda que não tenha havido imediata tradição do bem doado, aliená-lo, pactuando que a tradição do objeto vendido ao comprador seja realizada pelo doador ${ }^{237}$.

Explicando esse conjunto de ideias, BIONDI ${ }^{238}$ leciona que as declarações do doador e do donatário, realizadas de acordo com a forma imposta por lei, é que trazem a doação à existência, do ponto de vista jurídico, justamente por ser um contrato, pelo que são esses elementos que a tornam perfeita, ainda que haja uma nulidade ${ }^{239}$.

por falta de aceitação, e só ficará sem efeito se o casamento não se realizar"), ao não permitir a impugnação fundada em falta de aceite de liberalidade realizada em vista de casamento futuro, que foi mantido pela lei civil de 2002, no seu art. 546 ("A doação feita em contemplação de casamento futuro com certa e determinada pessoa, quer pelos nubentes entre si, quer por terceiro a um deles, a ambos, ou aos filhos que, de futuro, houverem um do outro, não pode ser impugnada por falta de aceitação, e só ficará sem efeito se o casamento não se realizar"), seria contrária ao entendimento esposado de que só há contrato com a aceitação [Curso (...), cit., p. 386]. Não obstante, como se verá, o próprio matrimônio, de per si, pode ser tido por aceite tácito, haja vista a falta de negativa do donatário.

${ }^{236}$ Contratos (...), cit., pp. 36-37.

${ }^{237}$ O Código Civil espanhol, quanto ao aceite, acompanha o brasileiro, e expressamente afirma, em seu art. 629: "La donación no obliga al donante, ni produce efecto, sino desde la aceptación", de modo que o aceite do donatário é que faz a doação gerar efeitos, porém seu aperfeiçoamento somente se dá com a ciência do aceite pelo doador, conforme dispõe o art. 623 do mencionado diploma legal: "La donación se perfecciona desde que el donante conoce la aceptación del donatario". Tais disposições geram debate na doutrina e na jurisprudência desse país, havendo quem veja aí um conflito de normas e interpretam um artigo em detrimento de outro, ou quem busque compaginá-los afirmando que a aplicação dos dispositivos se dá em âmbitos distintos, ou ainda quem explique que o aceite já aperfeiçoa a doação, ao passo que somente com a ciência do ato pelo doador é que ela passa a ser irrevogável [MANUEL ALBADALEJO GARCÍA e SILVIA DIAZ ALABART, La Donación, cit., pp. 75-96].

Da mesma forma, no sistema civil italiano, no segundo parágrafo do já citado art. 782, há expressa menção de que a doação somente se aperfeiçoa com a ciência do doador quanto ao aceite posterior ("ex intervalo") do donatário. TORRENTE se opõe expressamente a qualquer interpretação que vise afastar essa formalidade e a tem por fundamental, por força de lei (La Donazione, cit., pp. 440-443). No mesmo sentido: BIONDI, Le Donazioni, cit., pp. 472-476. Confrontar ainda: GARDANI CONTURSI LISI, Le Donazioni, cit., pp. 6-12.

O Código Civil português também regulamenta o aceite, no seu art. 945. (“Aceitação da doação"), nos seguintes termos: "1. A proposta de doação caduca, se não for aceita em vida do doador. 2. A tradição para o donatário, em qualquer momento, da coisa móvel doada, ou do seu título representativo, é havida como aceitação. 3. Se a proposta não for aceita no próprio acto ou não se verificar a tradição nos termos do número anterior, a aceitação deve obedecer à forma prescrita no artigo 947. ${ }^{\circ}$ e ser declarada ao doador, sob pena de não produzir os seus efeitos”. MANUEL BAPTISTA LOPES ensina que, na hipótese de aceite ex intervalo, se não houver o cumprimento da mesma formalidade da doação, e a notificação do doador, o ato não gera efeitos (Das Doações, cit., p. 34).

${ }^{238}$ BIONDI, Le Donazioni, cit., pp. 468-469. No mesmo sentido: CELESTE IACOVINO, La Donazione, cit., pp. 30 e 33-34.

${ }^{239}$ Com efeito, ainda que o instrumento de doação não tenha sido levado aos devidos registros para transferência da propriedade do bem doado, com o aperfeiçoamento da liberalidade, nos termos mencionados, poderá ela gerar efeitos. Nesse sentido, há um aresto que declarou réu em ação de cobrança de taxa condominial parte ilegítima, porque o credor tinha ciência que o imóvel foi doado a outra pessoa, em que pese o título não constar da matrícula do imóvel (TJSP, 36ª Câm. de Dir. Priv., Apel. 0205658- 37.2008.8.26.0100, rel. ARANTES THEODORO, j. 28-06-2012). 
NESTOR DIÓGENES ${ }^{240}$, por seu turno, entende que o aceite, por si só, não justifica afirmar que haja bilateralidade na doação, e para argumentar aduz que o fato de o legatário aceitar receber um legado em herança não torna o testamento um contrato. Em outro passo $^{241}$, reforça dizendo que é desnecessária a exigência do aceite na formalidade da doação e afirma pensar que tal regra é apego a formas arcaicas, mormente à luz do art. $1170^{242}$ do Código Civil de 1916, que permite aos incapazes dar seu aceite às doações puras, donde conclui que se trata de uma "excrescência"243.

Também leciona o autor ${ }^{244}$ que o doador pode assinar prazo ao donatário, a fim de este manifestar o aceite e se não o fizer e se é o caso de doação ser pura, então a benesse é tida por aceita. Se for com encargo, porém, desfaz-se o ato ${ }^{245}$. Com esses dados, conclui que o aceite não é ato essencial para caracterizar a doação e que a doação pura, por isto, pode ser vista como um ato unilateral de vontade.

Como se verifica, a existência do aceite é fundamental para se sustentar o tratamento contratual dispensado à doação pelo Código Civil de $2002^{246}$, e a tentativa de fulminá-lo parte justamente dos autores que não querem ver a figura comentada sendo regrada pela teoria contratual ${ }^{247}$.

Quanto às formas do aceite, o Código Civil de 2002 prevê o aceite expresso, o tácito, o presumido, o ficto e o manual ${ }^{248}$. Da mesma maneira que o Código Civil anterior,

${ }^{240}$ Doação (...), cit., p. 15.

${ }^{241}$ Doação (...), cit., p. 39.

${ }^{242}$ Art. 1170. "Às pessoas que não puderem contratar é facultado, não obstante, aceitar doações puras". Como se verá, esse artigo tem correspondência no Código Civil vigente.

${ }^{243}$ Doação (...), cit., p. 42. Também TORRENTE, refletindo sobre esse fato, aduz que ele aproxima a doação do ato unilateral (La Donazione, cit., p. 150).

${ }^{244}$ Doação (...), cit., pp. 16-17.

${ }^{245}$ FRANCISCO GLAUBER PESSOA ALVES explica, porém, que no caso se tem uma forma expressa de manifestação, por meio do silêncio, por força de lei [Das Várias (...), cit., p. 889].

${ }^{246}$ Da mesma forma, o Código Civil de 1916 não admitia a existência de doação sem aceite [CARVALHO SANTOS, Código (...), cit., p. 338; CLÓVIS BEVILAQUA, Código (...), cit., p. 270].

${ }^{247}$ Há, porém, quem entenda não ser o aceite essencial à doação, sem, porém, chegar à conclusão de que ela não é contrato: FLÁVIO TARTUCE, Direito (...), cit., p. 310.

${ }^{248}$ CARLOS ROBERTO GONÇALVES, Direito (...), cit., p. 256; OZÉIAS J. SANTOS, Da Doação, cit., p. 27; PABLO STOLZE GAGLIANO, $O$ Contrato (...), cit., p. 50; VICENTE SABINO JÚNIOR, Contrato (...), cit., p. 15. Alguns autores não tratam estas formas de aceite como foram sistematizadas neste trabalho, onde se buscou o tratamento geral da doutrina. ARNALDO MARMITT afirma em um passo de sua obra que o aceite do incapaz é presumido, mas fala também no ficto (Doação, cit., p. 55); SILVIO RODRIGUES, por seu turno, abrange sob a denominação de presumido o aceite por silêncio, para o incapaz e em vista de casamento futuro [Direito (...), cit., p. 201]; VICENTE SABINO JÚNIOR absorve na definição de aceite tácito o que aqui se tratou sob o nome de aceite presumido [Contrato (...), cit., p. 15. No mesmo sentido: CARVALHO SANTOS, Código (...), cit., p. 338; JONES FIGUEIRÊDO ALVES, Código (...), cit., p. 445; SERPA LOPES, Curso (...), cit., p. 391].

Quanto a esse tema no direito francês, há apenas a previsão do aceite expresso, seja no momento do contrato, 
não se reconheceu o aceite dado pelo tabelião, mas ao contrário daquele o atual sistema restaurou o aceite presumido ${ }^{249}$.

$\mathrm{O}$ aceite expresso consiste na declaração do donatário de que aceita a benesse a ele oferecida ${ }^{250}$, sendo inexistente uma forma sacramentada de tal expressão de $\operatorname{vontade}^{251} \mathrm{e}$, como se verifica da redação do art. $539^{252}$ do Código Civil de 2002, pode ser aposto tanto no ato da celebração do contrato, como posteriormente ${ }^{253}$, dentro do prazo dado pelo autor da benesse.

A doação com encargo é a única modalidade em que o aceite expresso é obrigatório, porque o beneficiário tem o direito de refletir sobre o ônus que assumirá, haja vista que poderá ser maior que a própria benesse ${ }^{254}$, ou manifestar ciência da existência do modus, a fim de não ocorrer de perder a dádiva por ignorar o encargo ${ }^{255}$.

Se a aceitação for posterior à oferta de doação, deverá ser observada a mesma solenidade exigida pela coisa doada, isto é, ocorrerá por instrumento público ou particular, conforme o caso ${ }^{256}$. TORRENTE ${ }^{257}$ ensina que o fundamento dessa exigência está em que o animus donum accipiendi é elemento constitutivo do contrato, daí ter de acompanhá-lo também na sua forma, e, além disso, deflagra uma série de consequências jurídicas, sendo então necessário que o doador e terceiros possam tomar conhecimento da alienação gratuita envidada $^{258}$.

seja posteriormente [PAUL DELNOY, Le Libéralités (...), cit., p. 33; PLANIOL, Traité (...), cit., p. 671], o que se depreende do já citado art. 932 do Código Napoleônico, que exige manifestação em 'termos expressos', na sua redação.

${ }^{249}$ CLÓVIS BEVILAQUA, Código (...), cit., p. 270.

${ }^{250}$ AMANDA ZOE MORRIS, Doação, cit., p. 279; ARNALDO MARMITT, Doação, cit., p. 53; ARNALDO RIZZARDO, Contratos, cit., p. 442; CARLOS ROBERTO GONÇALVES, Direito (...), cit., p. 256; FÁBIO ULHOA COELHO, Curso (...), cit., p. 248; FRANCISCO GLAUBER PESSOA ALVES, Das Várias (...), cit., p. 889; MARIA HELENA DINIZ, Curso (...), cit., p. 257; PAULO DE TARSO VIEIRA SANSEVERINO, Contratos (...), cit., p. 66.

${ }^{251}$ BIONDI, Le Donazioni, cit., pp. 158 (o autor ressalva, porém, que deve haver clareza na manifestação de aceite); TORRENTE, La Donazione, cit., p. 439.

${ }^{252}$ Art. 539. "O doador pode fixar prazo ao donatário para declarar se aceita ou não a liberalidade. Desde que o donatário, ciente do prazo, não faça, dentro dele, a declaração, entender-se-á que aceitou, se a doação não for sujeita a encargo".

${ }^{253}$ CARLOS ROBERTO GONÇALVES, Direito (...), cit., p. 256; PAULO LÔBO, Das Várias (...), cit., p. 291. O já citado art. 932 do Código Napoleônico traz previsão semelhante [v.: PLANIOL, Traité (...), cit., p. 671].

${ }^{254}$ ARNALDO MARMITT, Doação, cit., p. 53; PAULO LÔBO, Das Várias (...), cit., p. 290.

${ }^{255}$ VICENTE SABINO JÚNIOR, Contrato (...), cit., p. 16.

${ }^{256}$ MANUEL ALBADALEJO GARCÍA e SILVIA DIAZ ALABART, La Donación, cit., p. 192.

${ }^{257}$ La Donazione, cit., pp. 438-439. Por esse motivo, o autor ensina que não pode haver aceitação na forma tácita (no mesmo sentido: BIONDI, Le Donazioni, cit., pp. 157-158).

${ }^{258}$ Além da formalidade legal, pode haver alguma outra solenidade imposta pelo próprio contrato, o que dificulta a interpretação dos fatos. Um julgado do Tribunal de Justiça do Mato Grosso do Sul, por exemplo, debruçou- 
No que concerne ao prazo referido no dispositivo de lei acima citado, não há limites para seu estabelecimento, ficando a livre disposição do doador ${ }^{259}$, mas é necessário haver alguma razoabilidade na sua fixação, em homenagem aos princípios da segurança e estabilidade contratual ${ }^{260}$. De todo modo, caso o doador não tenha fixado nenhum prazo ao donatário para manifestar seu aceite, então este poderá externar sua vontade quando bem entender, mas poderá o autor da benesse, a qualquer tempo, se não o tiver feito inicialmente, consignar prazo ao donatário para o fazê- $10^{261}$.

Enquanto, porém, não houver a manifestação de aceite pelo donatário, não se formou ainda o contrato de doação, havendo mera proposta ${ }^{262}$.

Assim, pode o doador se arrepender neste interregno, não lhe vinculando a proposta, havendo quem justifique tal fato por ainda não ter havido o aperfeiçoamento do negócio de modo a ser revogável ${ }^{263}$, ao passo que outros entendem que tal faculdade decorre

se sobre termo de doação de rede de energia elétrica, no qual ficou constando que a doação feita por usuário de imóvel rural em favor da prestadora de serviço de fornecimento de energia elétrica deveria ser aceita pela sua diretoria. O julgado concluiu pela existência de aceitação expressa posterior, pois um representante legal da pessoa jurídica apôs sua firma no instrumento, acompanhado de uma testemunha, afora que o aceite foi confessado em sede de contestação, bem como ser evidente que houve a prática de atos pela pessoa jurídica a induzirem que ela se reputava dona do objeto doado ( $3^{\mathrm{a}}$ T. Cív., Apel. n. 004.001352-3/0000-00, j. 14-102004). Como se verifica, o acórdão precisou recorrer a elementos indiciários para declarar a existência do aceite, haja vista que no seu voto condutor não há afirmação de que foi demonstrada diretamente a aceitação da doação pela diretoria. De qualquer forma, é preciso se atentar para esses fatos na elaboração de eventuais formalidades ou então no cuidado de sua prova, pois pode acontecer de elementos extrínsecos não virem em socorro das partes.

${ }^{259}$ PABLO STOLZE GAGLIANO, O Contrato (...), cit., p. 48.

${ }^{260}$ SYLVIO CAPANEMA DE SOUZA, Das Várias (...), cit., p. 120.

${ }^{261}$ AGOSTINHO ALVIM, Da Doação, cit., p. 40-41; SILVIO LUÍS FERREIRA DA ROCHA, Curso (...), cit., p. 174; SYLVIO CAPANEMA DE SOUZA, Das Várias (...), cit., p. 120. Há quem opine em contrário, entendo que na ausência de prazo assinado pelo doador, então o aceite deverá ser imediato [neste sentido: FRANCISCO GLAUBER PESSOA ALVES, Das Várias (...), cit., p. 890].

262 AGOSTINHO ALVIM, Da Doação, cit., p. 40; FÁBIO ULHOA COELHO, Curso (...), cit., p. 248-249; MANUEL ALBADALEJO GARCÍA e SILVIA DIAZ ALABART, La Donación, cit., pp. 138-139; PONTES DE MIRANDA, Tratado (...), cit., p. 235.

Cumpre salientar a lição de BIONDI, para quem não há oferta na doação, mas sim "declaração" do doador (Le Donazioni, cit., pp. 131-132), e, em outro passo de sua obra, explica que enquanto não for aceita a doação, o ato guarda forte semelhança, sem o sê-lo, com a condição suspensiva (p. 470).

${ }^{263}$ BIONDI, Le Donazioni, cit., pp. 470-472 (explica o autor que a irrevogabilidade é da doação, mas não do ato unilateral); CARLOS ALBERTO BITTAR, Contratos (...), cit., p. 45; CARVALHO DE MENDONÇA, Contratos (...), cit., p. 41; MARIA HELENA DINIZ, Curso (...), cit., p. 258; NELSON ROSENVALD, Contratos (...), cit., p. 585; PAULO DE TARSO VIEIRA SANSEVERINO, Contratos (...), cit., p. 90; PLANIOL, Traité (...), cit., p. 672 (para o autor, não se pode aceitar uma oferta retirada); SÍLVIO DE SALVO VENOSA, Direito (...), cit., p. 128; TORRENTE, La Donazione, cit., p. 443 (o autor entende que a revogação não precisa seguir a mesma forma do ato de disposição); WASHINGTON DE BARROS MONTEIRO-DABUS MALUF, Curso (...), cit., p. 167. 
de importar na necessidade de o animus donandi ser atual à completa formação do contrato $^{264 / 265}$.

Da mesma forma, se o doador vier a falecer, sua proposta não se transmite aos herdeiros, de modo que vem a se extinguir e se estes quiserem doar, tratar-se-á de um novo negócio $^{266}$. Por fim, se o doador se reduzir a uma incapacidade civil, a proposta se resolverá, por falta de capacidade para o exercício atual do animus donandi ${ }^{267}$.

${ }^{264}$ AGOSTINHO ALVIM, Da Doação, cit., pp. 42-43 (para o autor, o doador, ainda assim, deverá indenizar o donatário por eventuais perdas); FLÁVIO AUGUSTO MONTEIRO DE BARROS, Manual (...), cit., p. 346; SILVIO LUÍS FERREIRA DA ROCHA, Curso (...), cit., p. 174.

No direito norte-americano também é necessário que o animus donandi seja atual ao aperfeiçoamento do ato. Há um julgado da Suprema Corte do Estado de Wyoming que se debruçou sobre os seguintes fatos: um octogenário, a fim de aplainar sua sucessão, celebrou um documento particular ("warranty deed") no qual declarou que a propriedade sua casa deveria ser transferida para sua única filha quando morresse, depositou o documento num cofre e logo em seguida deu ciência da sua intenção para a beneficiária, entregando-lhe ainda um cartão de acesso ao depósito. Tendo ocorrido um acidente com o genitor, esse, do hospital, pediu à filha que fosse até o cofre resgatar alguns créditos e, após a alta, foi até o depósito averiguar o seu conteúdo e deu pela falta do documento, tendo constatado posteriormente que sua filha subtraiu o instrumento, levando-o a registro. Assim, promoveu demanda para cancelar tal ato e a tese de defesa foi justamente de que o warranty deed deveria ser acolhido como doação, pois o suposto doador teria entregue o documento à alegada donatária afirmando explicitamente que estava the transferindo gratuitamente o bem, o que satisfaz os requisitos da doação. Não obstante, o mencionado Tribunal afastou tais alegações fáticas e sufragou a tese de que a tradição da coisa ou a entrega de documento, para que tenha efeitos de transferência de propriedade, deve estar acompanhada da intenção da parte de fazer a doação, pelo que confirmou a decisão tomada em grau inferior, mantendo a sentença que declarou inválido o registro da transferência do bem imóvel, justamente porque, no caso, o animus donandi não era atual à plena formação do ato [Lenhart v. Desmond, 705 P.2d 338 (1985) in ELIAS CLARK et al., Cases (...), cit., pp. 425-427].

${ }^{265}$ Há quem pense que só pode haver revogação da oferta até a ciência pelo donatário, ao passo que a partir desse evento o doador está vinculado [nesse sentido: PAULO LÔBO, Direito (...), cit., p. 285]. Pelo art. 932 do Código Civil francês, porém, tal efeito se perfaz até a ciência do doador de que houve o aceite do donatário [cf.: PLANIOL, Traité (...), cit., pp. 671-672].

Em consonância com o sistema pátrio, o art. 969. ("Revogação da proposta de doação") do Código Civil português, desde o seu título, trata o oferecimento do doador como proposta, e assim dispõe: "1. Enquanto não for aceita a doação, o doador pode livremente revogar a sua declaração negocial, desde que observe as formalidades desta. 2. A proposta de doação não caduca pelo decurso dos prazos fixados no n. ${ }^{\circ} 1$ do artigo 228."”. Consultar: MANUEL BAPTISTA LOPES, Das Doações, cit., p. 32.

${ }^{266}$ AGOSTINHO ALVIM, Da Doação, cit., pp. 43-44; CARLOS ALBERTO BITTAR, Contratos (...), cit., p. 45; CARVALHO SANTOS, Código (...), cit., p. 329; FLÁVIO AUGUSTO MONTEIRO DE BARROS, Manual (...), cit., p. 346; MARIA HELENA DINIZ, Curso (...), cit., p. 258; MANUEL BAPTISTA LOPES, Das Doações, cit., p. 32-33; PAULO GERALDO DE OLIVEIRA MEDINA, A Doação, cit., p. 463; RODRIGO SENISE LISBOA, Manual (...), cit., p. 259; SAVIGNY, Sistema (...), cit., p. 188; SILVIO LUÍS FERREIRA DA ROCHA, Curso (...), cit., p. 174; SYLVIO CAPANEMA DE SOUZA, Das Várias (...), cit., p. 121; TORRENTE, La Donazione, cit., pp. 446-447; WASHINGTON DE BARROS MONTEIRO-DABUS MALUF, Curso (...), cit., p. 168. A este respeito, CLÓVIS BEVILAQUA concorda com dois fundamentos dogmáticos para a extinção do negócio: a resolução do contrato ou a sua caducidade [Código (...), cit., p. 270], e no último fundamento é acompanhado por CARVALHO DE MENDONÇA [Contratos (...), cit., p. 40] e SERPA LOPES [Curso (...), cit., p. 392]. Em sentido contrário, opinando pela não revogação da oferta: ARNALDO MARMITT, Doação, cit., p. 55; ARNALDO RIZZARDO, Contratos, cit., p. 443; ARNOLDO WALD, Direito (...), cit., p. 65; CAIO MÁRIO DA SILVA PEREIRA, Instituições (...), cit., p. 211; CÉSAR FIUZA, Direito (...), cit., p. 503; NELSON ROSENVALD, Contratos (...), cit., p. 585; PAULO DE TARSO VIEIRA SANSEVERINO, Contratos (...), cit., p. 90; PONTES DE MIRANDA, Tratado (...), cit., pp. 235236 (o autor concorda com a revogação da oferta apenas se o doador não tiver estipulado prazo para a aceitação do donatário). 
Quanto ao donatário, se vier a falecer antes de manifestar seu aceite, a promessa se resolve, pois o direito não se transmite aos seus herdeiros ${ }^{268}$. Se o donatário se tornar incapaz, nada impede que seu representante aceite a benesse, mas não poderá se dar na modalidade presumida, de maneira que se não houver curador ou se este não se manifestar, extingue-se a promessa ${ }^{269}$.

O fundamento dogmático para que a morte de qualquer das partes ou a redução à incapacidade leve à extinção da liberalidade caso não haja o aceite do donatário, reside no fato de que somente com esse ato jurídico é que o contrato ganha substantividade e, até então, não tem independência em relação aos seus autores ${ }^{270}$.

Cumpre considerar, ainda, que na hipótese de revogação por livre vontade de qualquer das partes, $\mathrm{BIONDI}^{271}$ ensina que não se faz necessária qualquer formalidade, ficando a cargo do donatário tomar ciência da vontade atual do doador. Ou então dar-lhe a conhecer que aceitou a benesse.

Sobre esse tema, há um julgado do Superior Tribunal de Justiça deveras interessante, pois nele se declarou como doação uma escritura pública de renúncia de doação, porém como a doadora originária e beneficiária de dita renúncia não manifestou qualquer indício de aceite de tal ato antes da morte do doador, declarou-se a caducidade da liberalidade (4ª T., R. Esp. 444/RJ, rel. ATHOS CARNEIRO, j. 07-08-1990).

${ }^{267}$ AGOSTINHO ALVIM, Da Doação, cit., p. 44; CELESTE IACOVINO, La Donazione, cit., p. 35; MANUEL ALBADALEJO GARCÍA e SILVIA DIAZ ALABART, La Donación, cit., p. 105; PLANIOL, Traité (...), cit., p. 672; SAVIGNY, Sistema (...), cit., p. 188; TORRENTE, La Donazione, cit., pp. 447-448. CARVALHO SANTOS, porém, entende que a capacidade civil deve existir apenas no momento da oferta, mas não no interregno entre esta e o aceite [Código (...), cit., p. 319].

${ }^{268}$ AGOSTINHO ALVIM, Da Doação, cit., p. 45; ARNALDO RIZZARDO, Contratos, cit., p. 443; BIONDI, Le Donazioni, cit., p. 157; CARVALHO DE MENDONÇA, Contratos (...), cit., pp. 40-41; CARVALHO SANTOS, Código (...), cit., pp. 330 e 339; CAIO MÁRIO DA SILVA PEREIRA, Instituições (...), cit., pp. 211-212; CELESTE IACOVINO, La Donazione, cit., p. 35; CÉSAR FIUZA, Direito (...), cit., p. 503; FLÁVIO AUGUSTO MONTEIRO DE BARROS, Manual (...), cit., p. 347; MARIA HELENA DINIZ, Tratado (...), cit., p. 77; PAULO GERALDO DE OLIVEIRA MEDINA, A Doação, cit., p. 463; SERPA LOPES, Curso (...), cit., p. 392. Em sentido contrário: ARNOLDO WALD, Direito (...), cit., p. 65; PAULO DE TARSO VIEIRA SANSEVERINO, Contratos (...), cit., pp. 91-92; SILVIO LUÍS FERREIRA DA ROCHA, Curso (...), cit., p. 174; SYLVIO CAPANEMA DE SOUZA, Das Várias (...), cit., pp. 120-121 (afirma o autor que tal efeito não se alcança se o contrato prevê a mantença da oferta aos herdeiros do beneficiário).

${ }^{269}$ AGOSTINHO ALVIM, Da Doação, cit., p. 45; CELESTE IACOVINO, La Donazione, cit., p. 35; FLÁVIO AUGUSTO MONTEIRO DE BARROS, Manual (...), cit., p. 347. Admitindo também o aceite presumido: CARVALHO SANTOS, Código (...), cit., p. 339. Em sentido contrário: ARNALDO MARMITT, Doação, cit., pp. 85-86.

270 MANUEL ALBADALEJO GARCÍA e SILVIA DIAZ ALABART, La Donación, cit., pp. 218-219. Não obstante, TORRENTE admite a possibilidade de o doador emprestar irrevogabilidade temporária à oferta de doação, fazendo constar cláusula expressa para tanto (La Donazione, cit., pp. 448-449). Confrontar ainda as opiniões contrárias de: BIONDI (Le Donazioni, cit., pp. 488-494) e CELESTE IACOVINO (La Donazione, cit., pp. 36-37) (a autora afirma que a espécie é incompatível com a espontaneidade da doação, mas se rende à maioria da doutrina e da jurisprudência).

271 Le Donazioni, cit., pp. 476-479. Consultar ainda: CELESTE IACOVINO, La Donazione, cit., pp. 34-35; GARDANI CONTURSI LISI, Le Donazioni, cit., pp. 244-248 (a autora explana também a posição pretoriana da revogação tácita da declaração de doação). 
Se, porém, a doação for pura, e o donatário nada manifestar, então presume-se que aceitou a benesse, pelo que a doutrina chama a esse fenômeno de aceitação presumida ${ }^{272}$, havendo quem destaque $\mathrm{e}^{273} \mathrm{o}$ fato de o dispositivo legal emprestar à doação na forma pura a possibilidade de dar origem a uma hipótese de aquisição de direito pelo silêncio. O silêncio também leva à presunção de recusa se a doação for onerosa ${ }^{274}$.

Tácito é o aceite que importa no silêncio do donatário, mas observável por meio de seu comportamento, como no caso da doação em vista de casamento futuro, em que o donatário se casa, mas não aceita expressamente, ou o que, sem apor o aceite, leva o título para transcrição na matrícula do imóvel e recolhe os tributos devidos, todos estes comportamentos que levam a crer que o donatário aceitou a benesse e são incompatíveis com a recusa $^{275}$

Ou seja, diferencia-se sensivelmente do aceite presumido, na medida em que não é um non facere, mas sim uma série de atitudes adotadas pelo donatário que de modo indiciário levam à conclusão de que ele aceitou a benesse ${ }^{276}$.

${ }^{272}$ AGOSTINHO ALVIM, Da Doação, cit., p. 41; AMANDA ZOE MORRIS, Doação, cit., p. 279; ARNALDO MARMITT, Doação, cit., p. 55; ARNALDO RIZZARDO, Contratos, cit., pp. 442-443; ARNOLDO WALD, Direito (...), cit., p. 65; CAIO MÁRIO DA SILVA PEREIRA, Instituições (...), cit., p. 211; CARLOS ROBERTO GONÇALVES, Direito (...), cit., pp. 256-257; ELIAS CLARK et al., Cases (...), cit., p. 443 (o direito norte-americano também aceita essa presunção de aceite); FÁBIO ULHOA COELHO, Curso (...), cit., p. 248; FLÁVIO TARTUCE, Direito (...), cit., p. 310; NELSON ROSENVALD, Contratos (...), cit., p. 585; PAULO DE TARSO VIEIRA SANSEVERINO, Contratos (...), cit., p. 67; ROGÉRIO MARRONE DE CASTRO SAMPAIO, Direito (...), cit., p. 122; SÍlVIO DE SALVO VENOSA, Direito (...), cit., p. 128. Há quem afirme tratar-se de presunção iuris tantum [PAULO LÔBO, Direito (...), cit., p. 287]. Ademais, há quem admita a aceitação presumida na hipótese de haver reserva de usufruto, pois a hipótese não se confunde com a modal [SYLVIO CAPANEMA DE SOUZA, Das Várias (...), cit., pp. 121-122].

${ }^{273}$ PABLO STOLZE GAGLIANO, O Contrato (...), cit., p. 48; Síl. VIO DE SALVO VENOSA, Direito (...), cit., p. 128; SYLVIO CAPANEMA DE SOUZA, Das Várias (...), cit., pp. 118-119.

${ }^{274}$ ARNALDO MARMITT, Doação, cit., p. 55; ARNALDO RIZZARDO, Contratos, cit., p. 443; CAIO MÁRIO DA SILVA PEREIRA, Instituições (...), cit., p. 211; CÉSAR FIUZA, Direito (...), cit., p. 503; EDUARDO ESPINOLA, Dos Contratos (...), cit. p. 169; LIMONGI FRANÇA, Manual (...), cit., p. 97; NELSON ROSENVALD, Contratos (...), cit., p. 585.

${ }^{275}$ AMANDA ZOE MORRIS, Doação, cit., p. 279; ARNALDO MARMITT, Doação, cit., p. 54; CAIO MÁRIO DA SILVA PEREIRA, Instituições (...), cit., p. 211; CARLOS ALBERTO BITTAR, Contratos (...), cit., p. 43; CÉSAR FIUZA, Direito (...), cit., p. 503; FÁBIO UlHOA COELHO, Curso (...), cit., p. 248; FLÁVIO AUGUSTO MONTEIRO DE BARROS, Manual (...), cit., p. 345; FLÁVIO TARTUCE, Direito (...), cit., p. 311; FRANCISCO GLAUBER PESSOA ALVES, Das Várias (...), cit., p. 889; PAULO DE TARSO VIEIRA SANSEVERINO, Contratos (...), cit., p. 67; ROGÉRIO MARRONE DE CASTRO SAMPAIO, Direito (...), cit., p. 122; SÍLVIO DE SALVO VENOSA, Direito (...), cit., p. 128; SILVIO RODRIGUES, Direito (...), cit., p. 201; SYLVIO CAPANEMA DE SOUZA, Das Várias (...), cit., p. 118. No caso da doação em vista de casamento futuro, há dispensa de aceite expresso, pois se configura com a realização das núpcias, segundo certa doutrina [CLÓVIS BEVILAQUA, Código (...), cit., p. 277], pelo que há quem afirme ser aceite presumido [CARLOS ROBERTO GONÇALVES, Direito (...), cit., p. 257; ROGÉRIO MARRONE DE CASTRO SAMPAIO, Direito (...), cit., p. 122].

${ }^{276}$ AGOSTINHO ALVIM, Da Doação, cit., p. 12; NESTOR DIÓGENES, Doação (...), cit., p. 15; PABLO STOLZE GAGLIANO, $O$ Contrato (...), cit., p. 49. 
Há quem entenda incabível a aceitação tácita na doação com encargo ${ }^{277}$, por aplicação da parte final do art. 539 do Código Civil de 2002. AGOSTINHO ALVIM ${ }^{278}$ sustenta opinião em contrário, haja vista que há demonstração positiva da vontade do donatário $^{279}$.

Quanto ao aceite ficto, ocorre na aceitação da benesse pelo incapaz, pois, a princípio, esse nem sequer pode manifestar vontade, mas, na hipótese de doação pura, a lei não só admite sua declaração, como, fictamente, a toma por válida, com fundamento no fato de que só lhe trará benefícios ${ }^{280}$.

Com efeito, o art. $1.170^{281}$ do Código Civil de 1916, referindo-se às "pessoas que não puderem contratar", admitia a aceitação de doação por incapazes, trazendo grande celeuma na doutrina, instaurando o seguinte debate: o absolutamente incapaz estava contemplado pelo Código Civil ou o artigo previa apenas tal faculdade ao relativamente incapaz?

Comentando esse dispositivo, AGOSTINHO ALVIM ${ }^{282}$ pondera, em primeiro lugar, que diferente a capacidade de doar e a capacidade de aceitar, sendo que a segunda pressupõe a primeira. Ademais, comparando experiências jurídicas de outros países e a doutrina que se formou na matéria ${ }^{283}$, manifesta opinião de que apenas o relativamente

A esse respeito, há um acórdão do Tribunal de Justiça de São Paulo, tirado de ação de embargos de terceiro, no qual o embargante tentou desconstituir ato de penhora, sob a alegação de que a doação feita ao executado não se aperfeiçoou por falta de aceite, pelo que os embargantes-doadores seriam os verdadeiros proprietários do bem. A Turma Julgadora afastou a argumentação declinada, considerando que houve aceite tácito, uma vez que por duas vezes o donatário agiu como se proprietário fosse do bem (praticou ato pregresso de adjudicação e outro de alienação), de modo que a doação aperfeiçoou-se, reputando-se então hígida a constrição (23 ${ }^{a}$ Câm. de Dir. Priv., Apel. 0000721-03.2009.8.26.0562, rel. SÉRGIO SHIMURA, j. 19-092012).

${ }^{277}$ ARNALDO MARMITT, Doação, cit., pp. 54-55; CLÓVIS BEVILAQUA, Código (...), cit., p. 272; FLÁVIO TARTUCE, Direito (...), cit., p. 311.

${ }^{278}$ AGOSTINHO ALVIM, Da Doação, cit., p. 46.

${ }^{279}$ O Superior Tribunal de Justiça já declarou que não é possível admitir aceitação tácita de doação com encargo quando a União é donatária, por ser ente público, haja vista que, enquanto tal, necessita cumprir os requisitos legais para assumir obrigação contratual (3 $3^{\mathrm{a}}$ T., R. Esp. 00012462-0/MT, rel. EDUARDO RIBEIRO, j. 11-101993).

${ }^{280}$ AMANDA ZOE MORRIS, Doação, cit., p. 279; ARNALDO MARMITT, Doação, cit., p. 56; ARNALDO RIZZARDO, Contratos, cit., p. 443; CAIO MÁRIO DA SILVA PEREIRA, Instituições (...), cit., p. 212; CARLOS ROBERTO GONÇALVES, Direito (...), cit., p. 257; FRANCISCO GLAUBER PESSOA ALVES, Das Várias (...), cit., p. 896. CLÓVIS BEVILAQUA explica que, nessa hipótese, a lei entende por bem levantar a incapacidade do donatário, inclusive do nascituro [Código (...), cit., p. 270], mas em outro passo de sua obra chama a espécie de tácita, louvando a opção legislativa (p. 275).

281 Art. 1.170. "Às pessoas que não puderem contratar é facultado, não obstante, aceitar doações puras".

${ }^{282}$ Da Doação, cit., pp. 87-98.

283 A esse respeito, consultar: BIONDI, Le Donazioni, cit., pp. 160-162; GARDANI CONTURSI LISI, Le Donazioni, cit., pp. 286-288; VINCENZO TAVASSI, La Donazione, cit., pp. 156-157 (o autor traz à colação precedente da Corte de Cassação, na qual se reconhece aceite aposto pelo menor, por a doação ser pura). 
incapaz está autorizado a dar o seu aceite, pois sendo a doação um contrato, se faz necessária a manifestação de vontade do donatário, de modo que não se pode admitir um louco ou uma criança apondo seu aceite a um contrato de doação, o mesmo não se dando com o relativamente incapaz, sendo então razoável a interpretação restritiva do dispositivo.

No entanto, o mencionado doutrinador ${ }^{284}$ continua seu raciocínio afirmando que o mencionado art. 1.170 contradiz o disposto no art. 427, III $^{285}$, do Código Civil de 1916, que exige a manifestação do aceite também pelo responsável legal do incapaz, mas entende que é o caso de afastar esse dispositivo no caso da doação, pois admitir o contrário seria tornar o indigitado art. 1.170 do mesmo diploma legal em letra morta ${ }^{286}$.

Todavia, diante do que está estabelecido no art. $543^{287}$ do Código Civil de 2002, tal debate está superado, pois a lei admite expressamente a plena eficácia da doação ao absolutamente incapaz, não por meio de um aceite ficticiamente expresso, mas sim dispensando-lhe da prática desse ato ${ }^{288}$, o que não deixa de ser uma ficção ${ }^{289}$.

${ }^{284}$ Da Doação, cit., pp. 98-103.

${ }^{285}$ Art. 427. "Compete-lhe [ao tutor], também, com autorização do juiz: [...]. III - aceitar por ele heranças, legados, ou doações, com ou sem encargos".

286 Também opinando pela dispensa de aceitação expressa pelo absolutamente incapaz: CARVALHO SANTOS, Código (...), cit., p. 365. Confrontar ainda: PONTES DE MIRANDA, Tratado (...), cit., pp. 225-228; SERPA LOPES, Curso (...), cit., p. 395. Havia autores, porém, que opinavam pela aplicação do aceite ficto aos absolutamente incapazes: CARVALHO SANTOS, Código (...), cit., p. 364; NATAL NADER, Questões Relativas à Doação (II), in GUSTAVO TEPEDINO (Org.) e LUIZ EDSON FACHIN (Org.), Doutrinas Essenciais - Obrigações e Contratos, vol. V, São Paulo, Revista dos Tribunais, 2011, p. 458.

${ }^{287}$ Art. 543. "Se o donatário for absolutamente incapaz, dispensa-se a aceitação, desde que se trate de doação pura".

Sobre o regramento dessa hipótese no Direito Civil italiano, consultar: TORRENTE, La Donazione, cit., pp. 371-375.

Nada impede, porém, que a doação, mesmo sendo pura, seja aceita expressamente pelo representante legal. O Tribunal de Justiça de São Paulo, encampando sentença de primeiro grau, manteve a força de doação pura realizada em favor de menor e aceita pelo seu pai. Com efeito, o donatário ajuizou demanda visando desconstituir doação de cotas sociais feita em seu favor por sua genitora e aceita por seu genitor, mas o decisum houve por bem afastar o pleito, pois com o aceite o ato de doação se formou plenamente e por isso impassível de desconstituição, de maneira que o desejo do donatário de se retirar da sociedade deveria ser deduzido sob fundamento diverso e pelas vias próprias ( $3^{\mathrm{a}}$ Câm. de Dir. Priv., Apel. n. 907128209.2004.8.26.0000, rel. JOÃO PAZINE NETO, j. 30-08-2011).

${ }^{288}$ CÉSAR FIUZA, Direito (...), cit., p. 503; FLÁVIO TARTUCE, Direito (...), cit., p. 310; FRANCISCO GLAUBER PESSOA ALVES, Das Várias (...), cit., pp. 895-896; LUIZ GUILHERME LOUREIRO, Curso (...), cit., p. 504; MARIA HELENA DINIZ, Curso (...), cit., p. 256; NELSON ROSENVALD, Contratos (...), cit., pp. 587-588; PAULO DE TARSO VIEIRA SANSEVERINO, Contratos (...), cit., pp. 67-68; PAULO GERALDO DE OLIVEIRA MEDINA, A Doação, cit., p. 465; PAULO LÔBO, Direito (...), cit., pp. 288-289; SÍlVIO DE SALVO VENOSA, Direito (...), cit., p. 127; SYLVIO CAPANEMA DE SOUZA, Das Várias (...), cit., p. 91. Sobre a aplicação da norma para os absolutamente incapazes sob tutela ou curatela, confrontar: EDUARDO ESPINOLA, Dos Contratos (...), cit. p. 164; FLÁVIO AUGUSTO MONTEIRO DE BARROS, Manual (...), cit., p. 351; MARIA HELENA DINIZ, Tratado (...), cit., pp. 75-76; SERPA LOPES, Curso (...), cit., p. 395; SILVIO LUÍS FERREIRA DA ROCHA, Curso (...), cit., p. 173.

Acatando a disposição legal, há um julgado que afasta alegação do apelante de não realização de doação por falta de aceite, tendo o acórdão considerado que o donatário era menor de idade à época da doação, de modo 
Se, porém, a doação for onerosa, então deverá ser aceita por meio de representante $\operatorname{legal}^{290}$. Quanto ao relativamente incapaz, ele próprio dará seu aceite, assistido por seu representante ${ }^{291}$.

Poderá ainda a doação ser realizada em favor do nascituro, sendo que, nessa hipótese, deverá haver aceitação expressa do seu representante legal, conforme dispõe o art. $542^{292}$ do Código Civil de $2002^{293}$. Tal aceitação é condicional, pois sua eficácia dependerá do nascimento com vida do donatário ${ }^{294}$, sob pena de caducidade ${ }^{295}$, e, para que a condição se

que, como se tratava de liberalidade pura, estava ele dispensado de manifestar sua concordância (TJSP, $10^{\mathrm{a}}$ Câm. de Dir. Priv., Apel. 0000928-90.2011.8.26.0025, rel. ROBERTO MAIA, j. 02-10-2012).

289 Apoiando tal asserção, CARLOS ROBERTO GONÇALVES afirma que o atual Código Civil reparou a omissão do diploma legal revogado admitindo nova hipótese de aceite ficto [Direito (...), cit., p. 257]. No mesmo sentido: MARIA HELENA DINIZ, Curso (...), cit., p. 256. Sobre o dispositivo, pode-se ainda confrontar as críticas de JOÃO BAPTISTA VILLELA [Contrato (...), cit., pp. 273-276]. Quanto à necessidade de o representante legal requerer autorização judicial para aceitar ou recusar doação: MANUEL BAPTISTA LOPES, Das Doações, cit., pp. 66-68.

${ }^{290}$ CÉSAR FIUZA, Direito (...), cit., p. 504; CLÓVIS BEVILAQUA, Código (...), cit., p. 275; EDUARDO ESPINOLA, Dos Contratos (...), cit. p. 164; NELSON ROSENVALD, Contratos (...), cit., p. 588.

O Código Civil português tem regime semelhante ao pátrio quanto ao aceite do menor, como se verifica no seu art. 951. (“Aceitação por parte de incapazes"): "1. As pessoas que não têm capacidade para contratar não podem aceitar doações com encargos senão por intermédio dos seus representantes legais. 2. Porém, as doações puras feitas a tais pessoas produzem efeitos independentemente de aceitação em tudo o que aproveite aos donatários". MANUEL BAPTISTA LOPES ensina que tal dispositivo pode abarcar inclusive as doações remuneratórias, quando não representar onerosidade ao donatário (Das Doações, cit., p. 63).

291 FLÁVIO AUGUSTO MONTEIRO DE BARROS, Manual (...), cit., p. 346; LUIZ GUILHERME LOUREIRO, Curso (...), cit., p. 512; SYLVIO CAPANEMA DE SOUZA, Das Várias (...), cit., p. 148. Há quem entenda que a melhor interpretação do mencionado dispositivo legal é a dispensa também do relativamente incapaz de manifestar o aceite, em vista da finalidade da lei, pois se ao absolutamente incapaz é concedida tal benesse, não haveria sentido em negá-la ao relativamente incapaz [nesse sentido: ROGÉRIO MARRONE DE CASTRO SAMPAIO, Direito (...), cit., p. 123]. Ocorre que no sistema civil a manifestação de vontade do relativamente incapaz é juridicamente considerada, exigindo-se apenas assistência por quem de direito, ao passo que o desiderato do absolutamente incapaz não é um fato jurídico para fins negociais, pois somente atua por meio de seu representante, de modo que aí reside a verdadeira novidade do art. 543 da Lei 10.406/2002.

${ }^{292}$ Art. 542. "A doação feita ao nascituro valerá, sendo aceita pelo seu representante legal”.

${ }^{293}$ No sistema civil italiano, a aceitação da doação ao nascituro deverá se realizar pelos genitores, por aplicação do primeiro parágrafo do art. 320 ("Rappresentanza e amministrazione") do Código Civil desse país: "I genitori congiuntamente, o quello di essi che esercita in via esclusiva la potestà, rappresentano i figli nati e nascituri in tutti gli atti civili e ne amministrano $i$ beni. Gli atti di ordinaria amministrazione, esclusi $i$ contratti con i quali si concedono o si acquistano diritti personali di godimento, possono essere compiuti disgiuntamente da ciascun genitore". Mas, na ausência dos pais, pode ser nomeado curador, como prevê o art. 321 ("Nomina di un curatore speciale") do mencionado diploma legal: "In tutti $i$ casi in cui $i$ genitori congiuntamente, o quello di essi che esercita in via esclusiva la potestà, non possono o non vogliono compiere uno o più atti di interesse del figlio, eccedenti l'ordinaria amministrazione, il giudice, su richiesta del figlio stesso, del pubblico ministero o di uno dei parenti che vi abbia interesse, e sentiti i genitori, può nominare al figlio un curatore speciale autorizzandolo al compimento di tali atti". Consultar a respeito: BIONDI, Le Donazioni, cit., pp. 250-253; VINCENZO TAVASSI, La Donazione, cit., pp. 149-156.

${ }^{294}$ CHRISTIANO CASSETARI, Elementos (...), cit., p. 215; FÁBIO ULHOA COELHO, Curso (...), cit., pp. 242-243; FLÁVIO TARTUCE, Direito (...), cit., p. 316; JONES FIGUEIRÊDO ALVES, Código (...), cit., p. 447; LUIZ GUILHERME LOUREIRO, Curso (...), cit., p. 513; PAULO DE TARSO VIEIRA SANSEVERINO, Contratos (...), cit., p. 102; RODRIGO SENISE LISBOA, Manual (...), cit., p. 263; TORRENTE, La Donazione, cit., pp. 151 (o autor explica que o nascimento não pode ser elemento de existência ou validade do negócio porque seria negar a contratualidade da doação); SÍLVIO DE SALVO 
realize, é necessário apenas um breve momento de vida ${ }^{296}$, posição essa que se coaduna com o art. $2^{\text {o297 }}$ do Código Civil de $2002^{298}$.

VENOSA, Direito (...), cit., p. 128. BIONDI discorda que se trate de hipótese de condição, porque com o aceite o contrato formou-se perfeitamente, sendo o nascimento antes um fator de eficácia, pelo que aponta a dificuldade de se abordar dogmaticamente a hipótese, que só encontra paralelo na ciência jurídica com o testamento (Le Donazioni, cit., pp. 253-254). Também entendendo que o não nascimento do donatário importa na ineficácia do ato, mas não sua nulidade [NELSON ROSENVALD, Contratos (...), cit., p. 587; SYLVIO CAPANEMA DE SOUZA, Das Várias (...), cit., pp. 146-147].

295 CARVAlHO SANTOS, Código (...), cit., p. 363; FLÁVIO TARTUCE, Direito (...), cit., p. 316; MARIA HELENA DINIZ, Curso (...), cit., pp. 255-256; PAULO GERALDO DE OLIVEIRA MEDINA, A Doação, cit., p. 465; ROGÉRIO MARRONE DE CASTRO SAMPAIO, Direito (...), cit., p. 123; WASHINGTON DE BARROS MONTEIRO-DABUS MALUF, Curso (...), cit., p. 167.

BIONDI, por entender que o nascimento do donatário não é uma condição, afirma que a lei italiana se preocupa apenas em regrar a administração do objeto da doação, pois no entrevero da liberalidade e da eficácia da transferência patrimonial não há um proprietário (Le Donazioni, cit., pp. 256-258).

296 ARNALDO RIZZARDO, Contratos, cit., p. 447; CARLOS ROBERTO GONÇALVES, Direito (...), cit., p. 265; ClÓVIS BEVILAQUA, Código (...), cit., p. 274; FLÁVIO TARTUCE, Direito (...), cit., p. 316; MANUEL ALBADALEJO GARCÍA e SILVIA DIAZ ALABART, La Donación, cit., p. 157; MARIA HELENA DINIZ, Curso (...), cit., p. 256; PAULO GERALDO DE OLIVEIRA MEDINA, A Doação, cit., p. 465 (o autor fala em "um segundo apenas"); SYLVIO CAPANEMA DE SOUZA, Das Várias (...), cit., pp. 140 (já esse doutrinador fala apenas em um respirar para se adquirir o direito); WASHINGTON DE BARROS MONTEIRO-DABUS MALUF, Curso (...), cit., p. 168. O efeito prático dessa posição é que o donatário adquire a propriedade com um simples respirar, ainda que seja tido por "inviável” [nesse sentido: JONES FIGUEIRÊDO ALVES, Código (...), cit., p. 447].

297 Art. $2^{\circ}$. "A personalidade civil da pessoa começa do nascimento com vida; mas a lei põe a salvo, desde a concepção, os direitos do nascituro".

298 Há quem afirme ser necessário o nascituro-donatário ter sido concebido (ARNALDO RIZZARDO, Contratos, cit., p. 447; NELSON ROSENVALD, Contratos (...), cit., p. 587; SYLVIO CAPANEMA DE SOUZA, Das Várias (...), cit., pp. 141-145), e, como corolário desse entendimento, se afirma que a constatação de que o donatário tenha sido concebido em data posterior à da liberalidade leva à nulidade do negócio, pela impossibilidade do objeto [PAULO LÔBO, Direito (...), cit., p. 288]. Outrossim, para ser considerado nascituro, não importa que a concepção tenha se dado pelas vias artificiais [neste sentido: PAULO LÔBO, Das Várias (...), cit., pp. 305-306].

Sobre esse tema, há três pronunciamentos do Tribunal de Justiça de Minas Gerais, sob uma base fática que guarda grande similitude: liberalidade avoenga que quer beneficiar seus netos e aponta como donatários todos os filhos que vierem a nascer de um casal em que um dos cônjuges é filho do doador. Assim, em um primeiro julgado do mencionado Sodalício, concluiu-se que, apesar de duas netas não terem sido sequer concebidas na data da liberalidade, o benefício era válido, por interpretação da real intenção das partes contratantes, especialmente a dos doadores (17 Câm. Cív., Apel. n. 1.0527.06.000441-5/001, rel. IRMAR FERREIRA CAMPOS, j. 14-06-2007); em outro aresto, porém, nem sequer se adentrou no problema da concepção, afirmando-se que bastaria o neto comprovar o parentesco para receber a doação (4ª Câm. Cív., Apel. n. 1.0699.06.058999-0/001, rel. AUDEBERT DELAGE, j. 04-09-2008); por derradeiro, pouco depois, foi prolatado outro acórdão em outro recurso, no qual se declarou que os netos concebidos em data posterior à liberalidade não faziam jus à mesma, por serem inexistentes (15ª Câm. Cív., Apel. n. 1.0355.05.0061488/001, rel. JOSÉ AFFONSO DA COSTA CÔRTES, j. 24-09-2008).

O Código Civil de França também exige a concepção do nascituro para validade da doação, no seu art. 906: "1. Pour être capable de recevoir entre vifs, il suffit d'être conçu au moment de la donation. 2. Pour être capable de recevoir par testament, il suffit d'être conçu à l'époque du décès du testateur. 3. Néanmoins, la donation ou le testament n'auront leur effet qu'autant que l'enfant sera né viable".

Já o Código Civil italiano, por sua vez, no seu art. 784 ("Donazione a nascituri”), prevê a doação não apenas ao nascituro, mas também ao não concebido: "1. La donazione può essere fatta anche a favore di chi ̀̀ soltanto concepito, ovvero a favore dei figli di una determinata persona vivente al tempo della donazione, benché non ancora concepiti. 2. L'accettazione della donazione a favore di nascituri, benché non concepiti, è regolata dalle disposizioni degli articoli 320 e 321. 3. Salvo diversa disposizione del donante, l'amministrazione dei beni donati spetta al donante o ai suoi eredi, i quali possono essere obbligati a prestare idonea garanzia. I frutti maturati prima della nascita sono riservati al donatario se la donazione è 
A nova redação dada pela lei 10.406/2002 a esse tema veio a encerrar debate que se formava quanto ao art. $1.169^{299}$ do Código Civil de 1916 ao substituir o termo "pais" por representante legal. Com efeito, AGOSTINHO ALVIM ${ }^{300}$ lecionava, a esse respeito, que basta apenas o aceite do pai e, na ausência deste, o da mãe, para a aceitação gerar efeitos, ou então o do curador, que deverá ter autorização judicial expressa para o fim, ou até mesmo pelo próprio nascituro, quando este vier a nascer e depois que atingir sua capacidade, sendo que, neste caso, entende que deve se considerar o prazo de 300 dias para considerar que ele já existia $^{301}$.

No atual sistema, tais conclusões perderam seu motivo de ser e, além disso, o aceite pode ser dado não apenas pelos pais, mas também por outro representante de direito ${ }^{302}$.

Como o Código impõe a retroação dos direitos do nascituro desde que nasça ele com vida, pode-se afirmar que, mesmo que o doador venha a falecer antes do nascimento do donatário, não caduca a liberalidade, pois desde a data da benesse será eficaz ${ }^{303}$. Tanto é assim que, enquanto a doação não ganha plena eficácia, a administração do objeto da doação cabe ao doador ou aos seus herdeiros ${ }^{304}$.

Outrossim, o Código Civil de 2002 também prevê a doação a entidades futuras, como se verifica na redação do art. $554^{305}$ do Código Civil de 2002 , que a regulamenta ${ }^{306}$.

fatta a favore di un nascituro già concepito. Se è fatta a favore di un non concepito, i frutti sono riservati al donante sino al momento della nascita del donatario". Sobre a estrutura dessa espécie, mormente no que se refere à doação ao não-existente, consultar: TORRENTE, La Donazione, cit., pp. 150-155. Tratando a respeito da história da possibilidade de se doar ao nascituro, bem como da problemática de se adequar a espécie com a contratualidade da doação, mormente no que toca ao donatário não existente: BIONDI, $L e$ Donazioni, cit., pp. 237-244.

Da mesma forma que o italiano, o Código Civil português, no seu art. 952. ("Doações a nascituro"), também prevê a doação ao fillho não concebido: "1. Os nascituros concebidos ou não concebidos podem adquirir por doação, sendo filhos de pessoa determinada, viva ao tempo da declaração de vontade do doador. 2. Na doação feita a nascituro presume-se que o doador reserva para si o usufruto dos bens doados até ao nascimento do donatário". Comentando esse dispositivo: MANUEL BAPTISTA LOPES, Das Doações, cit., pp. $72-75$.

${ }^{299}$ Art. 1.169. "A doação feita ao nascituro valerá, sendo aceita pelos pais".

${ }^{300}$ Da Doação, cit., pp. 84-86. Confrontar: PONTES DE MIRANDA, Tratado (...), cit., pp. 228-229.

${ }^{301}$ VICENTE SABINO JÚNIOR também entende que na doação para nascituro o aceite deve ser dado pelo pai e, na ausência deste, pela mãe [Contrato (...), cit., pp. 42-43].

302 FLÁVIO TARTUCE, Direito (...), cit., p. 310; FRANCISCO GLAUBER PESSOA ALVES, Das Várias (...), cit., p. 894; MARIA HELENA DINIZ, Tratado (...), cit., p. 75; PAULO DE TARSO VIEIRA SANSEVERINO, Contratos (...), cit., p. 101; SÍlVIO DE SALVO VENOSA, Direito (...), cit., pp. 127-128; SYLVIO CAPANEMA DE SOUZA, Das Várias (...), cit., pp. 145-146.

${ }^{303}$ MANUEL ALBADALEJO GARCÍA e SILVIA DIAZ ALABART, La Donación, cit., p. 158.

${ }^{304}$ BIONDI, Le Donazioni, cit., pp. 254-256.

305 Art. 554. "A doação a entidade futura caducará se, em dois anos, esta não estiver constituída regularmente".

${ }^{306}$ Trata-se de novidade introduzida pela Lei $10.406 / 2002$, porém já a doutrina que se desenvolveu em época pregressa ao diploma legal, em homenagem à autonomia da vontade, admitia a doação para pessoa jurídica ainda não constituída oficialmente, até porque o aceite posterior convalida o ato [neste sentido: CARVALHO 
Trata-se de hipótese de aceite presumido, que ocorre com a criação da entidade ${ }^{307}$, fato esse caracterizador de uma condição suspensiva ${ }^{308}$, podendo ela ser entendida como qualquer das modalidades de pessoa jurídicas previstas no Código ${ }^{309}$. Não se formando o ente moral, caduca a doação ${ }^{310}$, nada impedindo que haja a prorrogação do prazo de maneira expressa ou presumida, caso o doador permaneça inerte ${ }^{311}$.

Por derradeiro, o aceite manual é aquele previsto no parágrafo único do já citado art. 541 do Código Civil de 2002, que regulamenta a doação de bens móveis de pequeno valor, perfazendo-se com a mera tradição da coisa no ato da realização da benesse, de modo que ao se apossar do bem o donatário está a aceitar a benesse ${ }^{312}$. Há quem afirme tratar-se de doação de natureza real ${ }^{313}$.

Também, cumpre considerar que é possível admitir, na hipótese, a tradição brevi manu, que ocorre quando a coisa dada já se encontrava na posse do donatário, assim como se

DE MENDONÇA, Contratos (...), cit., p. 33].

No Direito Civil português admite-se a doação a associação não reconhecida, cujo prazo de caducidade para sua constituição regular é de 1 ano (MANUEL BAPTISTA LOPES, Das Doações, cit., pp. 71-72).

O Código Civil italiano também tratava do assunto no seu no art. 786 "Donazione a ente non riconosciuto", que assim dizia: "1. La donazione a favore di un ente non riconosciuto non ha efficacia, se entro un anno non è notificata al donante l'istanza per ottenere il riconoscimento. La notificazione produce gli effetti indicati dall'ultimo comma dell'articolo 782. 2. Salvo diversa disposizione del donante, i frutti maturati prima del riconoscimento sono riservati al donatario". No entanto, o dispositivo foi revogado por lei de 15 de maio de 1997, n. 127. Sobre o tema, consultar: BIONDI, Le Donazioni, cit., pp. 260-268; GARDANI CONTURSI LISI, Le Donazioni, cit., pp. 261-264; VINCENZO TAVASSI, La Donazione, cit., pp. 168-170.

${ }^{307}$ CARLOS ROBERTO GONÇALVES, Direito (...), cit., p. 273.

308 ARNALDO RIZZARDO, Contratos, cit., p. 463; FLÁVIO TARTUCE, Direito (...), cit., p. 328; NELSON ROSENVALD, Contratos (...), cit., p. 596; PAULO DE TARSO VIEIRA SANSEVERINO, Contratos (...), cit., p. 151; ROGÉRIO MARRONE DE CASTRO SAMPAIO, Direito (...), cit., p. 123; WASHINGTON DE BARROS MONTEIRO-DABUS MALUF, Curso (...), cit., p. 177.

${ }^{309}$ CARLOS ROBERTO GONÇALVES, Direito (...), cit., p. 273; FRANCISCO GLAUBER PESSOA ALVES, Das Várias (...), cit., pp. 916-917 (o autor admite, além disso, a inclusão na espécie das entidades condominiais e das sociedades despersonalizadas); NELSON ROSENVALD, Contratos (...), cit., p. 596 (também inclui no termo 'entidade' os entes despersonalizados).

310 ARNOLDO WALD, Direito (...), cit., p. 66; CÉSAR FIUZA, Direito (...), cit., p. 503; NELSON ROSENVALD, Contratos (...), cit., p. 596; RODRIGO SENISE LISBOA, Manual (...), cit., p. 259; SYLVIO CAPANEMA DE SOUZA, Das Várias (...), cit., p. 91; WASHINGTON DE BARROS MONTEIRO-DABUS MALUF, Curso (...), cit., p. 176.

${ }^{311}$ ARNALDO RIZZARDO, Contratos, cit., p. 463.

312 CAIO MÁRIO DA SILVA PEREIRA, Instituições (...), cit., p. 213; FLÁVIO TARTUCE, Direito (...), cit., p. 323; PAUlO LÔBO, Direito (...), cit., p. 295; VASSANTA POROBO TAMBÁ, Doação (...), cit., p. 26; VICENTE SABINO JÚNIOR, Contrato (...), cit., p. 45. Assim, caso haja tradição do bem móvel de pequeno valor antes mesmo de que haja o aceite formal do donatário, é possível entrever aceitação manual na hipótese (neste sentido: MANUEL BAPTISTA LOPES, Das Doações, cit., pp. 34-35).

313 ANTÔNIO CHAVES, Lições (...), cit., p. 239; CARLOS ROBERTO GONÇALVES, Direito (...), cit., p. 257; FLÁVIO AUGUSTO MONTEIRO DE BARROS, Manual (...), cit., p. 345; MANUEL ALBADALEJO GARCÍA e SILVIA DIAZ ALABART, La Donación, cit., p. 193; NELSON ROSENVALD, Contratos (...), cit., p. 587. 
deve aceitar que a tradição seja realizada por terceiros em nome do donatário, bem como aceita por terceiros, isto é, não precisa ocorrer necessariamente entre as partes contratantes ${ }^{314}$.

Do estudo que até aqui se definiu, pode-se afirmar, quanto à capacidade das partes que figuram no contrato de doação, que o doador, à luz do art. 104, $\mathrm{I}^{315}$, do Código Civil de 2002, deverá ser plenamente capaz para realizar a disposição gratuita de seu patrimônio tangível $^{316}$, ao passo que o donatário poderá ser incapaz, de modo que o aceite deverá ser dado por seu representante legal, podendo, porém, ser ficto na doação pura ${ }^{317}$, sendo que, em se tratando de nascituro que morre ao nascer, o bem retorna ao patrimônio do doador ${ }^{318 / 319}$.

${ }^{314}$ CARVALHO SANTOS, Código (...), cit., pp. 353-356; MANUEL ALBADALEJO GARCÍA e SILVIA DIAZ ALABART, La Donación, cit., pp. 197-198; PONTES DE MIRANDA, Tratado (...), cit., p. 243; SYLVIO CAPANEMA DE SOUZA, Das Várias (...), cit., pp. 133-136; VINCENZO TAVASSI, La Donazione, cit., pp. 39-44 (o autor fala da tradição simbólica do bem doado). Se, porém, o doador falecer antes da tradição do bem pelo mandatário, não é admissível a doação, pois o mandato perdeu sua força (MANUEL BAPTISTA LOPES, Das Doações, cit., p. 83).

${ }^{315}$ Art. 104. "A validade do negócio jurídico requer: I - agente capaz [...]".

${ }^{316}$ CAIO MÁRIO DA SILVA PEREIRA, Instituições (...), cit., p. 210; CARLOS ROBERTO GONÇALVES, Direito (...), cit., p. 255; CARVALHO DE MENDONÇA, Contratos (...), cit., pp. 42-45; CÉSAR FIUZA, Direito (...), cit., p. 502; JOÃO BAPTISTA VILLELA, Contrato (...), cit., p. 272; LUIZ GUILHERME LOUREIRO, Curso (...), cit., p. 505; PABLO STOLZE GAGLIANO, O Contrato (...), cit., p. 50; PAULO DE TARSO VIEIRA SANSEVERINO, Contratos (...), cit., p. 81; SYLVIO CAPANEMA DE SOUZA, Das Várias (...), cit., p. 89; VICENTE SABINO JÚNIOR, Contrato (...), cit., p. 30. Há uma exceção à essa regra, que é a hipótese de doação feita em vista de casamento futuro por nubentes entre si menores, que está condicionada à autorização do representante legal e à realização do matrimônio [CARVALHO SANTOS, Código (...), cit., pp. 318-319; EDUARDO ESPINOLA, Dos Contratos (...), cit. p. 159], o que está encampado pelo art. 1.654 do Código Civil de 2002. Sobre a realização de doação por incapaz por meio de seus representantes legais, confrontar: ANTÔNIO CHAVES, Lições (...), cit., pp. 237-238; ARNALDO RIZZARDO, Contratos, cit., p. 445; CARVALHO SANTOS, Código (...), cit., p. 318; EDUARDO ESPINOLA, Dos Contratos (...), cit. p. 160; MARIA HELENA DINIZ, Tratado (...), cit., pp. 79-80; SÍLVIO DE SALVO VENOSA, Direito (...), cit., pp. 128-129; SYLVIO CAPANEMA DE SOUZA, Das Várias (...), cit., pp. 90-91. Sobre a diferença entre incapacidade e indisponibilidade de doar, verificar: CARVALHO SANTOS, Código (...), cit., p. 318. Opinando pela vedação de tutores e curadores doarem aos seus representados: MANUEL BAPTISTA LOPES, Das Doações, cit., pp. 68-69; ORLANDO GOMES, Contratos, cit., p. 237.

A respeito da capacidade do doador, há um precedente judicial que declarou nula doação de imóvel a companheira, realizada por doador com 85 anos, analfabeto, com considerável grau de surdez e com sinais de depressão, tendo havido ainda perícia posterior que atestou sua incapacidade desde data pregressa (TJSP, $3^{\mathrm{a}}$ Câm. de Dir. Priv., Apel. n. 0025137-10.2002.8.26.0003, rel. JESUS LOFRANO, j. 27-09-2011). Outro aresto, ao arrepio de declaração do Tabelião de que o disponente estava no uso das suas faculdades mentais, declarou a nulidade de escritura pública de doação de imóvel, porque havia nos autos atestado médico de que o doador apresentava senilidade mental e câncer, cujo tratamento pode levar à perda do controle mental, $o$ que veio a ser confirmado em juízo pelo médico do próprio doador (TJMG,, 11 a Câm. Cív., Apel. n. 1.0378.04.013520-4/001, rel. MARCELO RODRIGUES, j. 22-07-2009).

No Código de Napoleão, o art. 901 traz a seguinte redação: "Pour faire une libéralité, il faut être sain d'esprit. La libéralité est nulle lorsque le consentement a été vicié par l'erreur, le dol ou la violence". Por conta desse dispositivo, PAUL DELNOY leciona que o consentimento do doador é qualificado, devendo ele ser reforçado ou consolidado ("consentement renforcé"), de modo que qualquer abalo na sua formação ou externalização é o suficiente para se anular o ato, o que coloca as liberalidades em posição mais frágil que os atos onerosos [Le Libéralités (...), cit., pp. 45-46].

${ }^{317}$ BIONDI, Le Donazioni, cit., p. 233; CARLOS ROBERTO GONÇALVES, Direito (...), cit., p. 255; CÉSAR FIUZA, Direito (...), cit., p. 503; LUIZ GUILHERME LOUREIRO, Curso (...), cit., p. 505; MARIA HELENA DINIZ, Curso (...), cit., pp. 261-262; PAULO DE TARSO VIEIRA SANSEVERINO, Contratos 
Vale ressaltar, porém, que uma coisa é a capacidade de aceitar a doação e outra a de recebê-la. Pode acontecer de haver uma pessoa civilmente capaz impossibilitado pela lei de receber um bem em doação, de modo que, por decorrência lógica, tal sujeito é também incapaz de aceitá-la ${ }^{320}$, ao passo que o civilmente incapaz é socorrido pelo instituto da representação ${ }^{321}$.

De todo modo, no caso da incapacidade civil, com a cessação da causa o sujeito retoma a capacidade, como, por exemplo, o donatário que havia perdido a sanidade à época da oferta, mas depois a recobrou, sem que tenha havido retratação pelo doador do oferecimento feito, pode aceitar a benesse ${ }^{322}$. Claro que tal hipótese não se aplica às doações puras ou no caso de aceite pelo representante legal.

Além do mais, uma vez que o donatário aceita a benesse, surgem os efeitos do art. $552^{323}$ do Código Civil de 2002, de modo que o doador não responde por juros de mora, pela

(...), cit., p. 81; VICENTE SABINO JÚNIOR, Contrato (...), cit., p. 30. Sobre a designação de donatário por mandatário do doador, consultar: ARNALDO RIZZARDO, Contratos, cit., p. 445; EDUARDO ESPINOLA, Dos Contratos (...), cit. p. 162; SERPA LOPES, Curso (...), cit., p. 396; SÍlVIO DE SALVO VENOSA, Direito (...), cit., p. 129. Sobre a atuação de um terceiro por escolha do doador, consultar: BIONDI, Le Donazioni, cit., pp. 135-145; MANUEL BAPTISTA LOPES, Das Doações, cit., pp. 81-83.

${ }^{318}$ PABLO STOLZE GAGLIANO, O Contrato (...), cit., p. 50-51.

${ }^{319}$ Sobre a possibilidade de se doar a tutor ou curador, confrontar: ORLANDO GOMES, Contratos, cit., p. 237; SERPA LOPES, Curso (...), cit., p. 395.

No Código Civil italiano, porém, há expressa vedação do ato, conforme se verifica em seu art. 779 ("Donazione a favore del tutore o protutore"): "1. È nulla la donazione a favore di chi è stato tutore o protutore del donante, se fatta prima che sia stato approvato il conto o sia estinta l'azione per il rendimento del conto medesimo. 2.Si applicano le disposizioni dell'articolo 599". Consultar a respeito: BIONDI, Le Donazioni, cit., pp. 150-151; TORRENTE, La Donazione, cit., pp. 381-383; VINCENZO TAVASSI, La Donazione, cit., pp. 174-176.

${ }^{320}$ MANUEL ALBADALEJO GARCÍA e SILVIA DIAZ ALABART, La Donación, cit., pp. 123 e 130-131.

O Código Civil português estabelece o momento no qual se verifica a capacidade de receber doação, no seu art. 950. ("Capacidade passiva"): "1. Podem receber doações todos os que não estão especialmente inibidos de as aceitar por disposição da lei. 2. A capacidade do donatário é fixada no momento da aceitação". Consultar: MANUEL BAPTISTA LOPES, Das Doações, cit., p. 62.

${ }^{321}$ BIONDI, Le Donazioni, cit., p. 159. Sobre a atuação de terceiros na manifestação do aceite, consultar, na mesma obra: pp. 162-164.

${ }^{322}$ CARVALHO DE MENDONÇA, Contratos (...), cit., p. 45.

${ }^{323}$ Art. 552. "O doador não é obrigado a pagar juros moratórios, nem é sujeito às conseqüências da evicção ou do vício redibitório. Nas doações para casamento com certa e determinada pessoa, o doador ficará sujeito à evicção, salvo convenção em contrário".

No Código Civil de Portugal, a matéria vem assim tratada no art. 957. ("Ónus ou vícios do direito ou da coisa doada"): "1. O doador não responde pelos ónus ou limitações do direito transmitido, nem pelos vícios da coisa, excepto quando se tiver expressamente responsabilizado ou tiver procedido com dolo. 2. A doação é, porém, anulável em qualquer caso, a requerimento do donatário de boa fé". Consultar: MANUEL BAPTISTA LOPES, Das Doações, cit., p. 93.

O Código Civil italiano, quanto à responsabilidade do doador pela evicção, traz normativa semelhante à brasileira, como se verifica na redação do art. 797 ("Garanzia per evizione"): "Il donante è tenuto a garanzia verso il donatario, per l'evizione che questi può soffrire delle cose donate, nei casi seguenti: 1) se ha espressamente promesso la garanzia; 2) se l'evizione dipende dal dolo o dal fatto personale di lui; 3) se si tratta di donazione che impone oneri al donatario, o di donazione rimuneratoria, nei quali casi la garanzia è 
evicção do bem ou por vício redibitório, sendo que na doação feita em vista de casamento futuro responde por evicção, podendo as partes convencionarem o contrário ${ }^{324}$.

A redação do indigitado dispositivo legal é mais abrangente que a do Código Civil anterior, que regulava a matéria no art. $1.179^{325}$, pois essa abarcava apenas a evicção e os juros moratórios, sem falar em vício redibitório, mas tal omissão já era integrada pela doutrina $^{326}$, e, além disso, até pela própria lei, por aplicação sistemática do art. 1.101, parágrafo único $^{327}$, do mencionado diploma legal ${ }^{328}$.

As doações marcadas pela onerosidade, tais como as modais $\mathrm{e}$ as remuneratórias $^{329}$, têm expressa previsão legal de salvaguarda do donatário quanto aos vícios redibitórios, por imposição do parágrafo único do art. $441^{330}$ do Código Civil de 2002.

$\mathrm{O}$ benefício do mencionado art. 552 tem seu fundamento na natureza do contrato, que é benéfico, pelo que goza de tratamento especial do legislador, que atende os executores do ato de liberalidade de modo mais parcimonioso $^{331}$. Considera o legislador o fato de que o

dovuta fino alla concorrenza dell'ammontare degli oneri o dell'entità delle prestazioni ricevute dal donante". Sobre a disciplina de garantia da evicção ao doador no contexto desse dispositivo, consultar: TORRENTE, La Donazione, cit., pp. 505-508. BIONDI afirma que as exceções dos parágrafos, porém, não são da doação, mas sim da teoria geral do direito civil, sendo, respectivamente: princípio da autonomia da vontade e responsabilidade civil. Assim, conclui que a exceção se abre no regime jurídico das evicções (Le Donazioni, cit., p. 549).

Da mesma forma, assim regula o mencionado Código a disciplina dos vícios do objeto doado, no seu art. 798 ("Responsabilità per vizi della cosa"): "Salvo patto speciale, la garanzia del donante non si estende ai vizi della cosa, a meno che il donante sia stato in dolo". Consultar: BIONDI, Le Donazioni, cit., pp. 565-566; CELESTE IACOVINO, La Donazione, cit., pp. 274-276; TORRENTE, La Donazione, cit., pp. 513-515. BIONDI afirma que de fato não é necessário a lei afirmar explicitamente que o doador não responde pelos vícios redibitórios, pois é evidente que ele quer transferir a coisa como ela realmente é, e rememora velho ditado que em italiano está assim citado: "a caval donato non si guarda in bocca" (Le Donazioni, cit., pp. 562-563).

${ }^{324}$ CARLOS ROBERTO GONÇALVES, Direito (...), cit., p. 259; FRANCISCO GLAUBER PESSOA ALVES, Das Várias (...), cit., p. 913; LIMONGI FRANÇA, Manual (...), cit., p. 101; NELSON ROSENVALD, Contratos (...), cit., p. 595.

${ }^{325}$ Art. 1.179. "O doador não é obrigado a pagar juros moratórios, nem é sujeito à evicção, exceto no caso do art. 285 ".

${ }^{326}$ EDUARDO ESPINOLA, Dos Contratos (...), cit. p. 178; OZÉIAS J. SANTOS, Da Doação, cit., p. 22; PONTES DE MIRANDA, Tratado (...), cit., p. 260.

327 Art. 1.101. "A coisa recebida em virtude de contrato comutativo pode ser enjeitada por vícios ou defeitos ocultos, que a tornem imprópria ao uso a que é destinada ou lhe diminuam o valor. Parágrafo único. É aplicável a disposição deste artigo às doações gravadas de encargo".

${ }^{328}$ CLÓVIS BEVILAQUA, Código (...), cit., p. 282.

329 ARNALDO RIZZARDO, Contratos, cit., p. 467; FRANCISCO GLAUBER PESSOA ALVES, Das Várias (...), cit., p. 913; RODRIGO SENISE LISBOA, Manual (...), cit., p. 258; ROGÉRIO MARRONE DE CASTRO SAMPAIO, Direito (...), cit., pp. 126-127; SÍlVIO DE SALVO VENOSA, Direito (...), cit., p. 132.

330 Art. 441. "A coisa recebida em virtude de contrato comutativo pode ser enjeitada por vícios ou defeitos ocultos, que a tornem imprópria ao uso a que é destinada, ou lhe diminuam o valor. Parágrafo único. É aplicável a disposição deste artigo às doações onerosas".

331 AGOSTINHO ALVIM, Da Doação, cit., pp. 216-217; AMANDA ZOE MORRIS, Doação, cit., p. 277; BIONDI, Le Donazioni, cit., pp. 547-549 (o autor fala apenas da evicção, afirmando que a irresponsabilidade 
donatário nada perderá na eventualidade de ter de pagar alguma coisa ou até o todo do valor recebido, caso tenha de arcar com evicção ou reparação de vício redibitório, ao passo que o doador almejou apenas dar o objeto, mas não eventual indenização, sendo injusto presumir-se o contrário ${ }^{332}$.

No entanto, em caso de dolo, responde o doador, e por simples culpa o donatário, haja vista que a doação é contrato unilateral, pelo que aplicável ao caso o art. $1.057^{333}$ do Código Civil de $1916^{334}$, substituído depois pelo art. $392^{335}$ do Código Civil de $2002^{336}$. Mesmo que não houvesse a disposição legal, porém, é possível recorrer-se à culpa aquiliana $^{337}$. Ademais, há ${ }^{338}$ quem afirme que no caso da doação modal, vindo o donatário a cumprir o encargo, o doador passa a responder pela evicção e vícios redibitórios. Porém, como se verá, o encargo não torna a doação um contrato bilateral.

Não obstante, por não haver disposição legal em contrário, é possível que as partes pactuem que o doador responda pela evicção e por vícios redibitórios, o que não contraria o espírito liberal do ato, antes o faz aumentar, e podem pactuá-lo de maneira limitada ou ampla, seja no ato da celebração do donum, seja posteriormente ${ }^{339}$. Mas tal pacto

do doador pela mesma é um "naturale negotii” da doação); CAIO MÁRIO DA SILVA PEREIRA, Instituições (...), cit., p. 220; CARLOS ALBERTO BITTAR, Contratos (...), cit., p. 44; CARLOS ROBERTO GONÇALVES, Direito (...), cit., p. 259; CLÓVIS BEVILAQUA, Código (...), cit., p. 282; FÁBIO ULHOA COELHO, Curso (...), cit., p. 240; FRANCISCO GLAUBER PESSOA ALVES, Das Várias (...), cit., p. 912913; MARIA HELENA DINIZ, Tratado (...), cit., p. 86; NELSON ROSENVALD, Contratos (...), cit., p. 594; PAULO LÔBO, Direito (...), cit., p. 283. Há quem compreenda, porém, que esse benefício não é decorrência lógica da liberalidade, mas sim um mero favor legislativo: CELESTE IACOVINO, La Donazione, cit., pp. 269-270; TORRENTE, La Donazione, cit., p. 505.

${ }^{332}$ MANUEL ALBADALEJO GARCÍA e SILVIA DIAZ ALABART, La Donación, cit., pp. 338-339.

${ }^{333}$ Art. 1.057. "Nos contratos unilaterais, responde por simples culpa o contraente, a quem o contrato aproveite, e só por dolo, aquele a quem não favoreça. Nos contratos bilaterais, responde cada uma das partes por culpa".

${ }^{334}$ CLÓVIS BEVILAQUA, Código (...), cit., p. 282; PONTES DE MIRANDA, Tratado (...), cit., pp. $259-260$.

335 Art. 392. "Nos contratos benéficos, responde por simples culpa o contratante, a quem o contrato aproveite, e por dolo aquele a quem não favoreça. Nos contratos onerosos, responde cada uma das partes por culpa, salvo as exceções previstas em lei".

${ }^{336}$ PAULO LÔBO, Direito (...), cit., p. 283. Em sentido contrário, há quem entenda que aplica-se ao caso o princípio do res perit debitori na hipótese de o objeto doado vir a perecer na posse do doador, que responde por culpa [RODRIGO SENISE LISBOA, Manual (...), cit., p. 257], mas esse posicionamento é contra legem. No direito civil italiano, porém, o doador responde também por culpa grave, consistente na omissão de diligência que deveria ser tomada, mas o ônus da prova do dolo ou da culpa grave é do donatário (TORRENTE, La Donazione, cit., pp. 503-504). Confrontar ainda: BIONDI, Le Donazioni, cit., pp. 534-536; CELESTE IACOVINO, La Donazione, cit., pp. 283-285.

${ }^{337}$ Neste sentido: MANUEL ALBADALEJO GARCÍA e SILVIA DIAZ ALABART, La Donación, cit., pp. 340343. No entanto, ainda assim a responsabilidade limitada do doador absorve a culpa aquiliana, de modo que mesmo sob esse fundamento não responde por culpa leve (BIONDI, Le Donazioni, cit., p. 537).

${ }^{338}$ CÉSAR FIUZA, Direito (...), cit., p. 509.

339 MANUEL ALBADALEJO GARCÍA e SILVIA DIAZ ALABART, La Donación, cit., pp. 343-345. Cf. também: CARVALHO SANTOS, Código (...), cit., p. 427. Não obstante, a cláusula que garante a proteção pelo doador por eventual evicção não pressupõe a cobertura por vício redibitório (TORRENTE, $L a$ Donazione, cit., p. 514), podendo-se afirmar que o contrário também é verdadeiro. 
não pode ser declaração unilateral, mas sim aceito pelo donatário, pelo que deverá ser expresso $^{340}$. Todavia, é nula a cláusula que afasta a responsabilidade do doador por dolo ${ }^{341}$.

Para AGOSTINHO ALVIM ${ }^{342}$, quando a lei fala em "juros", está a dizer muito mais do que isso, pois também se pode afirmar que o doador não incorre em perdas e danos, na reposição de frutos e rendimentos ${ }^{343}$, assim como não responde pela deterioração do bem, o que é perfeitamente aplicável ao sistema civilístico atual ${ }^{344}$.

A partir do momento, porém, que o donatário proceda à interpelação do doador para que este proceda à entrega da coisa doada e aceita, a posse dela passa a ser dolosa pelo disponente, de modo que responde pelos juros moratórios, exceto na hipótese de força maior, o que o desobriga do cumprimento da obrigação ${ }^{345}$.

Quanto à evicção, há uma inovação na redação do art. 552 do Código Civil de 2002 em relação ao diploma civil de 1916. Com efeito, a exceção que se mencionava na parte final do art. 1.179 do revogado Código Civil tinha a finalidade de complementar os efeitos previstos no art. $285^{346}$ do mesmo diploma legal, de maneira que se um terceiro, isto é, exceto os pais, alienasse um bem por meio de dote, receberia o mesmo tratamento geral do doador quanto à evicção, ou seja, não responderia pela mesma ${ }^{347}$.

Como já se viu no transcrito art. 797 do Código Civil italiano, o primeiro parágrafo desse dispositivo legal permite o mencionado pacto para a assunção da obrigação por evicção ao doador, não impondo nenhuma sacramentalidade, mas exigindo termos expressos, de modo que não se pode admitir tal cláusula por dedução tácita ou por presunção. Se posterior à doação, deverá observar a mesma forma dessa. De todo modo, trata-se de um só contrato (BIONDI, Le Donazioni, cit., pp. 549-551). Ver também: CELESTE IACOVINO, La Donazione, cit., pp. 270-271.

${ }^{340}$ BIONDI, Le Donazioni, cit., pp. 561-562.

${ }^{341}$ BIONDI, Le Donazioni, cit., p. 537; CELESTE IACOVINO, La Donazione, cit., p. 285.

${ }^{342}$ Da Doação, cit., pp. 219.

343 ANTÔNIO CHAVES entende, porém, que a mora do doador deve fazê-lo responder pelos frutos da coisa [Lições (...), cit., p. 252].

344 BIONDI, no entanto, afirma que, no silêncio da lei italiana, incorrendo o doador em dolo ou culpa grave, deverá indenizar todas as perdas e danos (Le Donazioni, cit., pp. 537-538).

345 AGOSTINHO ALVIM, Da Doação, cit., pp. 219-222; CARVALHO DE MENDONÇA, Contratos (...), cit., pp. 83-84; NELSON ROSENVALD, Contratos (...), cit., pp. 594-595; PAULO DE TARSO VIEIRA SANSEVERINO, Contratos (...), cit., p. 85; PONTES DE MIRANDA, Tratado (...), cit., pp. 260-261; SÍLVIO DE SALVO VENOSA, Direito (...), cit., p. 132. AMANDA ZOE MORRIS, pelo contrário, entende que, dada a natureza de liberalidade do ato, mesmo que haja atraso na entrega do bem pelo doador, não responde ele por juros [Doação (...), cit., p. 277]. Para os que entendem que a doação seja contrato real, não faz sentido falar-se em pagamento de juros de mora pelo doador, pois enquanto não houver a entrega da coisa o pacto não se aperfeiçoou [nesse sentido: PAULO LÔBO, Direito (...), cit., p. 283]. MANUEL BAPTISTA LOPES, por seu turno, afirma que, por o aceite aperfeiçoar a doação, é o termo a quo para assunção do dever do doador de entregar o objeto dado ao donatário (Das Doações, cit., pp. 86-88).

${ }^{346}$ Art. 285. "Quando o dote for constituído por qualquer outra pessoa, esta só responderá pela evicção se houver procedido de má-fé, ou se a responsabilidade tiver sido estipulada".

347 AGOSTINHO ALVIM, Da Doação, cit., pp. 225-226. 
O art. 552 do Código Civil de 2002, ao contrário, impôs que qualquer pessoa que doasse em vista de casamento futuro, em regra, responderia pela evicção, a não ser que o contrato tenha previsão em contrário ${ }^{348}$.

Além disso, a proteção da evicção não se aplica aos doadores que fizerem doações com encargo e remuneratórias ${ }^{349}$, mas como tal norma decorre da excepcional onerosidade presente nessas espécies, trata-se de regra dispositiva ${ }^{350}$.

Diante de todos os elementos carreados no presente item da pesquisa, pode-se afirmar que no uso da doação como instrumento de planejamento sucessório, deve-se atentar especialmente para o aceite de todos os donatários que o doador pretende agraciar, a fim de não haver dúvidas quanto ao aperfeiçoamento do negócio.

Convém, por primeiro, buscar um acordo com todos os beneficiados e procurar que estejam pessoalmente presentes no ato da lavratura da escritura de doação, evitando-se ao máximo terceiros intervenientes, exceto os representantes legais e assistentes dos incapazes, dado a doutrina afirmar que a oferta de doação e seu aceite são atos pessoais. Outrossim, essa medida permitirá o aceite expresso unânime, afastando quaisquer dúvidas a respeito e permitindo o aperfeiçoamento imediato da liberalidade.

Sem embargo, não sendo possível a reunião de todos os donatários, pode ainda o doador recorrer ao aceite ex intervalo, fixando um prazo razoável ao beneficiário ausente para manifestar seu aceite, e diligenciando para que esse tome ciência da benesse, bem como cuidando para que o aceite posterior chegue ao seu conhecimento, evitando os questionamentos que a doutrina estrangeira apresenta, que podem ser aplicadas no sistema pátrio, em vista de seus efeitos práticos de relevo.

No que toca aos incapazes, tanto os relativamente quanto os absolutamente, assim como os nascituros, convém obter o aceite expresso de seus representantes legais se se quer

\footnotetext{
${ }^{348}$ Há quem entenda descabida a norma, por imputar indevida onerosidade à hipótese e por o regime dotal ter sido banido do sistema [neste sentido: ARNALDO RIZZARDO, Contratos, cit., p. 467; PAULO DE TARSO VIEIRA SANSEVERINO, Contratos (...), cit., p. 143].

349 ARNALDO RIZZARDO, Contratos, cit., p. 467; BIONDI, Le Donazioni, cit., pp. 555-557; CARLOS ROBERTO GONÇALVES, Direito (...), cit., p. 259; CARVALHO DE MENDONÇA, Contratos (...), cit., p. 84; CLÓVIS BEVILAQUA, Código (...), cit., p. 282; LIMONGI FRANÇA, Manual (...), cit., p. 101; MANUEL ALBADALEJO GARCÍA e SILVIA DIAZ ALABART, La Donación, cit., pp. 346-351; MARIA HELENA DINIZ, Tratado (...), cit., p. 86; PAULO DE TARSO VIEIRA SANSEVERINO, Contratos (...), cit., p. 143; PAULO GERALDO DE OLIVEIRA MEDINA, A Doação, cit., p. 472 (o autor destaca que se trata de hipótese legal excepcional de proteção pela evicção sem dolo do alienante). Em sentindo contrário, por entender que não pode haver doação modal onerosa: PAULO LÔBO, Das Várias (...), cit., p. 347.

${ }^{350}$ TORRENTE, La Donazione, cit., pp. 511-512.
} 
beneficiar-lhes, evitando-se principalmente de lhes fazer doação onerosa, a fim de não ensejar questionamentos futuros. Se por algum motivo for necessário fazer-lhes um dom oneroso, convém que seus representantes legais obtenham autorização judicial.

Em relação à capacidade das partes, sendo o doador de idade avançada, é conveniente que obtenha de profissional médico algum atestado de sua sanidade mental, a fim de evitar que alguém possa, futuramente, vir a questioná-la em juízo, anexando o documento na escritura pública, ficando arquivada no tabelionato. Outrossim, conhecendo o doador a quem quer beneficiar, e tendo ciência de sua incapacidade mental, convém antes nomear um curador.

Por fim, uma vez celebrado o contrato de doação, importa levá-lo a registro nos órgãos que competir não apenas em vista da gratuidade, mas também para que não venha a responder pela mora, procedendo-se assim à imediata tradição dos bens doados, ainda que simbólica, afastando-se, dessa forma, eventual pretensão por perdas e danos.

Outrossim, a fim de evitar desequilíbrio entre os herdeiros, convém que o doador se responsabilize pelos vícios redibitórios e pela evicção, reservando inclusive patrimônio para qualquer eventualidade, de modo que ficará garantida a isonomia entre os beneficiados, mesmo que sobrevenha algum revés.

\section{5) Espécies ou tipos de doação}

Um rol de espécies ou tipos de doação, possivelmente, não envidará ser exaustivo, pois as tentativas de classificação são, em verdade, cristalizações da realidade, que, no presente caso, como visto acima, guarda uma riqueza quase insondável.

De qualquer forma, declina-se abaixo algumas hipóteses, separando-se para o capítulo seguinte aquelas que estão mais intimamente ligadas ao objeto da presente pesquisa $^{351}$.

\section{1) Doação pura}

A doação pura é aquela em que, por um ato de vontade do doador, isto é, por uma liberalidade e com a aceitação do beneficiário, o patrimônio do primeiro é reduzido em prol

\footnotetext{
${ }^{351}$ PONTES DE MIRANDA ensina que só há duas espécies de doação: real ou consensual. Para o autor, os tipos ora declinados são "casos especiais de doação" [Tratado (...), cit., p. 202].
} 
do aceitante, que não assume nenhum encargo ou qualquer outro dever jurídico ${ }^{352}$. Justamente por isso, pela total gratuidade do ato e pela falta de retribuição ou restrição, há quem afirme ser a doação por excelência ${ }^{353}$.

Para alguns autores ${ }^{354}$, a doação, para ser considerada como pura, além de não trazer nenhum modo, também não poderá estar clausulada com condição ou ter sido realizada para remunerar o donatário ${ }^{355}$. Outros doutrinadores ${ }^{356}$, além disso, ensinam que a imposição das cláusulas de inalienabilidade, de impenhorabilidade ou de incomunicabilidade não tira da disposição liberal o caráter de pura, por não serem encargos. A reserva de usufruto também não desfigura a doação pura ${ }^{357}$.

TEIXEIRA DE FREITAS ${ }^{358}$, no art. $419^{359}$ das suas Consolidações das Leis Civis, traçou algumas linhas da doação pura, dela destacando qualquer condição ou causa, isto é, as liberalidades que tenham outra causa além do animus donandi, sejam as que se referem

352 PABLO STOLZE GAGLIANO, O Contrato (...), cit., p. 116; ROGÉRIO MARRONE DE CASTRO SAMPAIO, Direito (...), cit., pp. 124-125; SÍLVIO DE SALVO VENOSA, Direito (...), cit., p. 132.

353 ARNALDO MARMITT, Doação, cit., p. 27; FÁBIO ULHOA COELHO, Curso (...), cit., p. 241; FRANCISCO GLAUBER PESSOA ALVES, Das Várias (...), cit., p. 883; MARIA HELENA DINIZ, Curso (...), cit., p. 267; ROGÉRIO MARRONE DE CASTRO SAMPAIO, Direito (...), cit., p. 125; SILVIO LUÍS FERREIRA DA ROCHA, Curso (...), cit., p. 175.

${ }^{354}$ CARLOS ROBERTO GONÇALVES, Direito (...), cit., p. 262; CARVAlHO SANTOS, Código (...), cit., p. 330; CHRISTIANO CASSETARI, Elementos (...), cit., p. 212; CLÓVIS BEVILAQUA, Código (...), cit., p. 272; FLÁVIO TARTUCE, Direito (...), cit., p. 14; FRANCISCO GLAUBER PESSOA ALVES, Das Várias (...), cit., p. 883; MARIA HELENA DINIZ, Curso (...), cit., p. 267; PAULO NADER, Curso (...), cit., p. 230; RODRIGO SENISE LISBOA, Manual (...), cit., p. 260; VICENTE SABINO JÚNIOR, Contrato (...), cit., p. 38.

${ }^{355}$ Há quem afirme que a doação contemplativa não é pura [nesse sentido: LUIZ GUILHERME LOUREIRO, Curso (...), cit., p. 507; ORLANDO GOMES, Contratos, cit., p. 239; PAULO LÔBO, Das Várias (...), cit., p. 294 e SILVIO LUÍS FERREIRA DA ROCHA, Curso (...), cit., p. 175], porém há opiniões em sentido contrário [assim: FLÁVIO AUGUSTO MONTEIRO DE BARROS, Manual (...), cit., p. 347; MARIA HELENA DINIZ Tratado (...), cit., p. 88; SAMUEL LUIZ ARAÚJO, O Princípio (...), cit., p. 76; SILVIO RODRIGUES, Direito (...), cit., pp. 203-204]. A favor de que a doação seja pura mesmo que haja condição: MANUEL ALBADALEJO GARCÍA e SILVIA DIAZ ALABART, La Donación, cit., p. 152.

356 ARNALDO MARMITT, Doação, cit., p. 27; ARNALDO RIZZARDO, Contratos, cit., p. 454; LUIZ GUILHERME LOUREIRO, Curso (...), cit., p. 507; SÍlVIO DE SALVO VENOSA, Direito (...), cit., p. 133.

${ }^{357}$ LUIZ GUILHERME LOUREIRO, Curso (...), cit., p. 507; MARIA HELENA DINIZ, Curso (...), cit., p. 268; RODRIGO SENISE LISBOA, Manual (...), cit., p. 260; WASHINGTON DE BARROS MONTEIRODABUS MALUF, Curso (...), cit., p. 170. O efeito prático desse entendimento é que pode ocorrer a aceitação presumida na hipótese [nesse sentido: PONTES DE MIRANDA, Tratado (...), cit., p. 236]. Sobre a solução teórica dos problemas que advenham quanto à tradição do bem, consultar: SAVIGNY, Sistema (...), cit., pp. 127-128.

${ }^{358}$ Consolidação (...), cit., pp. 296-297.

${ }^{359}$ Art. 419. "A doação pura e simples, sem condição ou causa, desde que é aceita pelo donatario, ou em seu nome pelo Tabelião, ou por pessôa competente; não póde sêr revogada em tempo algum, salvo por ingratidão do donatário". 
ao passado e ao presente (v.g.: remuneratória), como as ligadas com o futuro (doação modal $)^{360}$.

Dessa forma, querendo o doador, ao implementar sua estratégia sucessória, alcançar a aceitação presumida do bem, deve se atentar para não impor qualquer condição, termo ou encargo, bem como não dispor em contemplação ou remuneração, afastando assim qualquer dúvida. Caso não seja possível ou faça parte de seu desiderato impor algum ônus ao beneficiário, é de bom alvitre obter o aceite expresso dele.

No entanto, caso imponha cláusula limitativa ou usufruto, poderá contar com o aceite presumido, se o caso, haja vista que a natureza da doação continuará a ser pura.

\section{2) Doação condicional e a termo}

Poderá também o contrato de doação conter cláusulas de condição ${ }^{361}$ ou termo ${ }^{362}$.

No que toca à condição, PABLO STOLZE GAGLIANO ${ }^{363}$ afirma que no contrato de doação ela será necessariamente suspensiva, e, por estar marcada pela incerteza, há mera expectativa de direito, ocorrendo sua aquisição, apenas e tão somente, com a ocorrência da condição. Para VICENTE SABINO JÚNIOR ${ }^{364}$, a condição resolutiva na doação deverá ser tida por não escrita.

\footnotetext{
${ }^{360}$ Versando sobre a gratuidade da doação, MÉAU-LAUTOUR explica que a jurisprudência francesa do final do séc. XIX, ao interpretar o art. 1.105 do Código Napoleônico (Art. 1.105: "Le contrat de bienfaisance est celui dans lequel l'une des parties procure à l'autre un avantage purement gratuit"), entendia que para haver liberalidade não poderia o doador ter qualquer interesse nela, nem sequer moral, pois do contrário tratar-se-ia de um ato oneroso, pois a satisfação desse desejo já seria contraprestação. A autora explica que posteriormente criticou-se esse posicionamento, pois se fosse assim seria impossível praticar-se qualquer liberalidade, afora a subjetividade do critério adotado [La Donation (...), cit., pp. 45-46].

Outrossim, no sistema jurídico pátrio, há um certo entendimento pretoriano que nega executividade a promessa de doação pura em sede de partilha em separação judicial, sob o fundamento de que a liberalidade não pode ser coativa (STJ, $4^{\text {a }}$ T., R. Esp. n. 730626/SP, rel. JORGE SCARTEZZINI, j. 17-10-2006), ao passo que outros precedentes consideram haver nessa hipótese onerosidade, pelo que perfeitamente passível de execução (STJ, $3^{\text {a }}$ T., R. Esp. n. 742048/RS, rel. SIDNEI BENETI, J. 14-04-2009).

361 Art. 121 do Código Civil de 2002: "Considera-se condição a cláusula que, derivando exclusivamente da vontade das partes, subordina o efeito do negócio jurídico a evento futuro e incerto".

${ }^{362}$ Interpretando a contrario sensu o artigo citado na nota acima, tem-se que o termo é a subordinação do ato a um evento futuro e certo.

${ }^{363}$ O Contrato (...), cit., p. $117-118$

${ }^{364}$ Contrato (...), p. 107.
} 
A maior parte da doutrina ${ }^{365}$, porém, pensa ser possível haver tanto condição suspensiva, como resolutiva na doação, desde que não se trate de direito potestativo de qualquer das partes ${ }^{366}$.

Há condição suspensiva na doação quando o aperfeiçoamento dela se liga à ocorrência de um evento futuro e incerto, podendo-se citar, à guisa de exemplo, a doação em contemplação de casamento futuro $^{367}$, não podendo ser "potestativa pura", nem depender de uma ilegalidade, nem representar limite à liberdade do donatário e nem afrontar as ordens jurídica e pública ${ }^{368}$. Essa é a regra do art. $122^{369}$ do Código Civil de 2002, aplicável também à resolutiva.

365 AMANDA ZOE MORRIS, Doação, cit., p. 282; ARNALDO MARMITT, Doação, cit., p. 38; ARNOLDO WALD, Direito (...), cit., p. 67; CAIO MÁRIO DA SILVA PEREIRA, Instituições (...), cit., p. 215; CARVAlHO SANTOS, Código (...), cit., p. 330; CÉSAR FIUZA, Direito (...), cit., p. 505; LUIZ GUILHERME LOUREIRO, Curso (...), cit., p. 507; OZÉIAS J. SANTOS, Da Doação, cit., p. 18; PAULO NADER, Curso (...), cit., p. 231; PLANIOL, Traité (...), cit., p. 688; SAMUEL LUIZ ARAÚJO, O Princípio (...), cit., pp. 78-79; SERPA LOPES, Curso (...), cit., p. 388; SÍlVIO DE SALVO VENOSA, Direito (...), cit., p. 135; SILVIO LUÍS FERREIRA DA ROCHA, Curso (...), cit., p. 175; SYLVIO CAPANEMA DE SOUZA, Das Várias (...), cit., pp. 94-95.

${ }^{366}$ CARVALHO DE MENDONÇA, Contratos (...), cit., pp. 76-77; RODRIGO SENISE LISBOA, Manual (...), cit., p. 260; SERPA LOPES, Curso (...), cit., pp. 411-412; SÍLVIO DE SALVO VENOSA, Direito (...), cit., p. 135. A esse respeito, EDUARDO ESPINOLA pontua que deve se distinguir as condições puramente potestativas daquelas que são simplesmente potestativas, consistindo as primeiras num ato arbitrário de vontade do autor do ato, ao passo que as segundas consistem numa ação que o autor deverá praticar ou num evento cuja ocorrência depende dele, segundo sua lição, e afirma que o sistema civil brasileiro admite a segunda para as doações, pois nada impediria de o doador reservar para o futuro a análise das circunstâncias do momento posterior e avaliar a conveniência da transferência, pois não se trata de mero capricho [Dos Contratos (...), cit. pp. 183-184. Confrontar ainda: PAUL DELNOY, Le Libéralités (...), cit., pp. 53-54 (interpretando o art. 944 do Código Civil francês, o autor conclui que são nulas as condições puramente e simplesmente potestativas); PLANIOL, Traité (...), cit., p. 685 (o autor fala ainda em condições potestativas mistas, as quais dependem da vontade do doador e de um terceiro, como no caso da doação em vista de casamento futuro)].

Ou seja, a questão está em que a condição resolutiva não pode representar burla à irrevogabilidade típica da doação [CARVALHO SANTOS, Código (...), cit., p. 331]. Com efeito, há precedente do Superior Tribunal de Justiça reputando nula condição estipulada em sede de doação feita por ocasião da separação judicial de casal que transmitiu gratuitamente os bens aos filhos, consistindo ela em que os pais poderiam, a qualquer tempo, retomar a propriedade do bem. Na sentença homologatória, o magistrado declarou a nulidade da cláusula por ser potestativa pura, o que foi confirmado pelo Tribunal estadual e pelo STJ ( $4^{\mathrm{a}}$ T., R. Esp. n. 220608/SP, rel. RUY ROSADO DE AGUIAR, j. 04-12-2001).

Sobre a possibilidade de o doador alegar exceção de necessidade (beneficium competentiae), consultar: PONTES DE MIRANDA, Tratado (...), cit., pp. 247-248; SAVIGNY, Sistema (...), cit., pp. 144-145. BIONDI ensina, a respeito do beneficium competentiae, que ele contraria o princípio da força vinculativa dos contratos, pelo que afirma ser o instituto inadmissível no sistema positivo do Direito Civil italiano (Le Donazioni, cit., pp. 538-539). A respeito do instituto, consultar: AGOSTINHO ALVIM, Da Doação, cit. pp. 301-303.

367 ARNALDO MARMITT, Doação, cit., p. 39; CLÓVIS BEVILAQUA, Código (...), cit., p. 277; MARIA HELENA DINIZ, Curso (...), cit., p. 258.

${ }^{368}$ ARNALDO MARMITT, Doação, cit., p. 39; CAIO MÁRIO DA SILVA PEREIRA, Instituições (...), cit., p. 215; OZÉIAS J. SANTOS, Da Doação, cit., p. 18; PAULO NADER, Curso (...), cit., p. 231.

369 Art. 122. "São lícitas, em geral, todas as condições não contrárias à lei, à ordem pública ou aos bons costumes; entre as condições defesas se incluem as que privarem de todo efeito o negócio jurídico, ou o sujeitarem ao puro arbítrio de uma das partes". 
Quanto à doação com condição resolutiva, é aquela que se dissolve com a ocorrência de evento futuro e incerto e, como exemplo, tem-se a doação com cláusula de reversão e a modal, pois tanto a morte do donatário antes do doador e o descumprimento do encargo são eventos futuros e incertos ${ }^{370}$.

Outrossim, no âmbito do Código Civil de 1916, conforme se verifica na redação do seu art. $116^{371}$, apenas a impossibilidade jurídica da condição induzia à invalidade do ato, ao passo que a impossibilidade física levava ao desprezo da cláusula.

Desse modo, VICENTE SABINO JÚNIOR ${ }^{372}$ manifesta a opinião de que, se a condição imposta for impossível, a doação é nula, desde que a cláusula seja a causa da liberalidade, de modo que se a condição não for ínsita ao contrato, então para o autor o negócio jurídico se mantém, mas como não distingue o tipo de impossibilidade, pode-se pressupor que ele fale da física, o que é plenamente compatível com a lei de então.

Como, porém, ao emitir tal opinião, VICENTE SABINO JÚNIOR tinha em mente apenas a condição suspensiva, é de se perguntar se a tese por ele sufragada é compatível com o quanto posto no art. $123, \mathrm{I}^{373}$, do Código Civil de 2002, que fulmina de nulidade os negócios subordinados a condições tanto jurídica, como fisicamente impossíveis.

Por primeiro, verifica-se que a lei não deixa margens a exceções. Ademais, como visto, a causa da doação é o animus donandi, mas não os motivos do doador, que se dão no âmbito da cogitatio, pelo que difíceis de serem juridicamente enquadrados, donde se constata que é preciso aferir tal possibilidade de se distinguir na doação uma causa principal e outra acessória. Como o indigitado autor não o faz, é de se concluir que sua asserção não é compatível com o atual sistema civil ${ }^{374}$.

No tocante ao termo, a possibilidade de sua aposição a uma doação não é questionada na doutrina. Por o termo ser um evento futuro e certo, o donatário adquire o

${ }^{370}$ AMANDA ZOE MORRIS, Doação, cit., p. 282; ARNALDO MARMITT, Doação, cit., p. 39; CLÓVIS BEVILAQUA, Código (...), cit., p. 279.

${ }^{371}$ Art. 116. "As condições fisicamente impossíveis, bem como as de não fazer coisa impossível, tem-se por inexistentes. As juridicamente impossíveis invalidam os atos a elas subordinados".

${ }^{372}$ Contrato (...), cit., p. 106.

${ }^{373}$ Art. 123. "Invalidam os negócios jurídicos que lhes são subordinados: I - as condições física ou juridicamente impossíveis, quando suspensivas; [...]".

${ }^{374}$ No Código Napoleônico, porém, a impossibilidade física ou jurídica da condição faz com que ela seja tida por não escrita, como se vê no art. 900 desse diploma legal: "Dans toute disposition entre vifs ou testamentaire, les conditions impossibles, celles qui sont contraires aux lois ou aux moeurs, seront réputées non écrites" [confrontar ainda: MÉAU-LAUTOUR, La Donation (...), cit., pp. 295-296; PAUL DELNOY, Le Libéralités (...), cit., p. 50-51]. 
direito sobre o bem doado, não tendo, porém, capacidade de exercê-lo, o que só se cessará quando da concretização do termo ${ }^{375}$, de acordo com os arts. $126^{376}$ e $135^{377}$ do Código Civil de 2002. Ademais, o termo pode ser tanto inicial como final ${ }^{378}$, pelo que é possível cogitar-se em termo suspensivo ${ }^{379}$.

O estudo dessas duas espécies de doação também ganha relevo na questão de doação de bens que só futuramente ingressarão no patrimônio do doador, seja o fato certo ou não.

Muito autores ${ }^{380}$ admitem esta espécie de doação condicional ou a termo, e entendem que se não ocorrer a condição, não haverá a doação, até porque se o objeto doado vier a ser adquirido pelo doador, a liberalidade é convalidada, nos termos do $\$ 1^{\circ}$ do art. $1.268^{381}$ do Código Civil de 2002. Outros pesquisadores ${ }^{382}$ do tema, porém, negam tal possibilidade, por entenderem que a doação deve representar um benefício imediato e concreto ao donatário, por expressa disposição da lei ${ }^{383}$.

\footnotetext{
${ }^{375}$ PABLO STOLZE GAGLIANO, O Contrato (...), cit., p. 118.

${ }^{376}$ Art. 126. "Se alguém dispuser de uma coisa sob condição suspensiva, e, pendente esta, fizer quanto àquela novas disposições, estas não terão valor, realizada a condição, se com ela forem incompatíveis".

${ }^{377}$ Art. 135. "Ao termo inicial e final aplicam-se, no que couber, as disposições relativas à condição suspensiva e resolutiva".

378 AMANDA ZOE MORRIS, Doação, cit., p. 282; MARIA HELENA DINIZ, Curso (...), cit., p. 269; RODRIGO SENISE LISBOA, Manual (...), cit., p. 261; SAMUEL LUIZ ARAÚJO, O Princípio (...), cit., p. 79; SERPA LOPES, Curso (...), cit., p. 411; SYLVIO CAPANEMA DE SOUZA, Das Várias (...), cit., p. 95.

${ }^{379}$ CARVAlHO SANTOS, Código (...), cit., p. 333 (para o autor, pode-se até adotar por termo a morte do doador, que ainda assim não se tratará de doação causa mortis).

${ }^{380}$ AGOSTINHO ALVIM, Da Doação, cit., p. 11; ARNALDO MARMITT, Doação, cit., p. 63; CAIO MÁRIO DA SILVA PEREIRA, Instituições (...), cit., p. 212; CARLOS ROBERTO GONÇALVES, Direito (...), cit., p. 260; CARVALHO SANTOS, Código (...), cit., pp. 325-326; CÉSAR FIUZA, Direito (...), cit., p. 504; EDUARDO ESPINOLA, Dos Contratos (...), cit. pp. 167-168 (o autor excetua, porém, os que vierem a representar pacta corvina); FÁBIO ULHOA COELHO, Curso (...), cit., pp. 239 e 243; PAULO DE TARSO VIEIRA SANSEVERINO, Contratos (...), cit., p. 81; PAULO NADER, Curso (...), cit., pp. 226-227;
} SYLVIO CAPANEMA DE SOUZA, Das Várias (...), cit., p. 99.

${ }^{381}$ Art. 1.268. "Feita por quem não seja proprietário, a tradição não aliena a propriedade, exceto se a coisa, oferecida ao público, em leilão ou estabelecimento comercial, for transferida em circunstâncias tais que, ao adquirente de boa-fé, como a qualquer pessoa, o alienante se afigurar dono. $\S 1^{\circ} \mathrm{Se}$ o adquirente estiver de boa-fé e o alienante adquirir depois a propriedade, considera-se realizada a transferência desde o momento em que ocorreu a tradição [...]".

${ }^{382}$ ANTÔNIO CHAVES, Lições (...), cit., pp. 238-239; CARLOS ALBERTO BITTAR, Contratos (...), cit., p. 42; LUIZ GUILHERME LOUREIRO, Curso (...), cit., p. 506; ORLANDO GOMES, Contratos, cit., pp. 237238; PAULO LÔBO, Direito (...), cit., p. 283; VICENTE SABINO JÚNIOR, Contrato (...), cit., pp. 24-25.

${ }^{383} \mathrm{O}$ art. 943 do Código Civil francês é expresso na matéria: "La donation entre vifs ne pourra comprendre que les biens présents du donateur; si elle comprend des biens à venir, elle sera nulle à cet égard" [cf.: PAUL DELNOY, Le Libéralités (...), cit., p. 53 (o autor entende que tal vedação decorre da irrevogabilidade da doação); PLANIOL, Traité (...), cit., pp. 682-684].

Da mesma forma, diz o art. 771 do Código Civil italiano ("Donazione di beni futuri"): "1. La donazione non può comprendere che i beni presenti del donante. Se comprende beni futuri, è nulla rispetto a questi, salvo che si tratti di frutti non ancora separati. 2. Qualora oggetto della donazione sia una universalità di cose e il donante ne conservi il godimento trattenendola presso di sé, si considerano comprese nella donazione anche 
Interpretando o art. $624^{384}$ do Código Civil espanhol, MANUEL ALBADALEJO GARCÍA e SILVIA DÍAZ ALABART ${ }^{385}$ entendem que o limite de capacidade da lei referese apenas a algumas classes de bens, como, por exemplo, a legítima dos herdeiros, mas não exige a disponibilidade plena, de maneira que seria possível doar não apenas os bens futuros, mas também os alheios. Considerando que a doação não é transferência patrimonial, mas promessa, e que nada impede tal condição suspensiva, é possível compatibilizar tal visão com o sistema pátrio ${ }^{386}$.

le cose che vi si aggiungono successivamente, salvo che dall'atto risulti una diversa volontà" [consultar: GARDANI CONTURSI LISI, Le Donazioni, cit., p. 359; GIANFRANCO AMENTA, La Donazione (...), cit., p. 124].

Também na commom law não se usa a doação para promessa de transferência de bens futuros, mas essa regra pode ser mitigada em alguns casos que são acolhidos como doação de juros futuros ('future interests') ou de direitos a termos [RICHARD HYLAND, Gifts (...), cit., itens 347, 372 e 374-375].

O art. 942. ("Objecto da doação") do Código Civil Português também é expresso em vedar a doação de bem futuro, o que fulmina de nulidade eventual liberalidade que tenha esse objeto, mas abre uma exceção à regra: "1. A doação não pode abranger bens futuros. 2. Incidindo, porém, a doação sobre uma universalidade de facto que continue no uso e fruição do doador, consideram-se doadas, salvo declaração em contrário, as coisas singulares que venham de futuro a integrar a universalidade". Consultar a respeito: MANUEL BAPTISTA LOPES, Das Doações, cit., pp. 23-27.

${ }^{384}$ Art. 624. "Podrán hacer donación todos los que puedan contratar y disponer de sus bienes".

${ }^{385}$ La Donación, cit., pp. 102-103.

${ }^{386}$ Nesse sentido, há um precedente judicial que declarou válida a doação de coisa alheia, pois os doadores adquiriram posteriormente o imóvel doado, pelo que ratificaram a liberalidade anteriormente realizada (TJMS, $3^{a}$ T. Cív., Apel. n. 2008.023815-3/0000-00, rel. OSWALDO RODRIGUES DE MELO, j. 29-062009).

SAVIGNY entende que se houver concordância do proprietário original, esteja ele com a intenção de doar ao doador então secundário ou de lhe vender o bem, nada impede que ocorra a doação de coisa alheia. No entanto, se não houver tal consentimento, não há doação, mas sim o surgimento da hipótese de usucapião pro donato [Sistema (...), cit., pp. 133-139].

$\mathrm{Na}$ doutrina pátria, há quem entenda, porém, que não se pode doar bens alheios [CARLOS ALBERTO BITTAR, Contratos (...), cit., p. 42; LUIZ GUILHERME LOUREIRO, Curso (...), cit., p. 506; ORLANDO GOMES, Contratos, cit., pp. 237-238], mas o doador poderá ratificar o ato caso adquira o bem, como já se disse [AMANDA ZOE MORRIS, Doação, cit., p. 277; ARNALDO RIZZARDO, Contratos, cit., p. 463; MARIA HELENA DINIZ, Curso (...), cit., p. 265; RODRIGO SENISE LISBOA, Manual (...), cit., p. 264; SERPA LOPES, Curso (...), cit., p. 400].

No sistema da common law também não se admite a doação de bens alheios [RICHARD HYLAND, Gifts (...), cit., itens 383-385].

Já no direito civil italiano é possível aplicar-se às doações o quanto disposto no art. 651 ("Legato di cosa dell'onerato o di un terzo") do Código Civil do mencionado país, que assim dispõe: "1. Il legato di cosa dell'onerato o di un terzo è nullo, salvo che dal testamento o da altra dichiarazione scritta dal testatore risulti che questi sapeva che la cosa legata apparteneva all'onerato o al terzo. In questo ultimo caso l'onerato è obbligato ad acquistare la proprietà della cosa dal terzo e a trasferirla al legatario, ma è in sua facoltà di pagarne al legatario il giusto prezzo. 2. Se però la cosa legata, pur appartenendo ad altri al tempo del testamento, si trova in proprietà del testatore al momento della sua morte, il legato è valido", pelo que tal liberalidade é passível de convalidação [nesse sentido: GIANFRANCO AMENTA, La Donazione (...), cit., pp. 123-124].

No sistema civil português, a doação de coisa alheia está regrada no art. 956. ("Doação de bens alheios") do Código Civil do dito país, que assim dispõe: "1. É nula a doação de bens alheios; mas o doador não pode opor a nulidade ao donatário de boa fé. 2 . O doador só responde pelo prejuízo causado ao donatário quando este esteja de boa fé e se verifique algum dos seguintes factos: a) Ter o doador assumido expressamente a obrigação de indemnizar o prejuízo; b) Ter o doador agido com dolo; c) Ter a doação carácter remuneratório; d) Ser a doação onerosa ou modal, ficando a responsabilidade do doador limitada, neste caso, ao valor dos 
Do quanto aqui foi exposto, pode-se afirmar que o doador, caso não se importe em abrir mão de utilizar doação pura, tem a faculdade de apor condição ou termo, devendo se atentar apenas para o fato de que tais elementos não se tornem atos potestativos puros, que podem acarretar na nulidade de toda a doação, ou sejam impossíveis de se alcançar pelo donatário, por barreira física, jurídica ou moral.

No que toca à doação de bens futuros ou alheios, convém evitá-los para fins de planejamento sucessório, dada a margem de discussão que criam, sendo preferível aguardar sua aquisição e posteriormente aliená-lo gratuitamente a quem houver por bem.

\section{3) Doação modal ou com encargo}

Essa espécie de doação consiste na aposição de um encargo ou um dever a ser cumprido pelo donatário, em vista da liberalidade recebida, sob pena de ser revogada ${ }^{387}$.

O encargo é um dever jurídico ${ }^{388}$, o que se reforça à luz do art. 553, caput $^{389}$, do Código Civil de 2002 e pela não aplicação do art. $563^{390}$ do mesmo diploma legal à hipótese ${ }^{391}$. Em termos analíticos, pode-se afirmar que consiste na imposição de uma obrigação, positiva ou negativa, ao donatário, obrigação esta que poderá ou não guardar relação com a coisa doada, desde que imposta no ato da doação, pois se for posterior trata-se de um novo negócio ${ }^{392}$.

Já que o encargo é uma obrigação, lhe é aplicável o regime próprio destas e se apresentará nas modalidades previstas no Código Civil de 2002, isto é, consistirá ou num dare, ou num facere, ou ainda num non facere $^{393}$. De modo específico, o Código Civil

encargos. 3. É imputável no prejuízo do donatário o valor da coisa ou do direito doado, mas não os benefícios que ele deixou de obter em consequência da nulidade. 4. Não havendo lugar a indemnização, o donatário fica sub-rogado nos direitos que possam competir ao doador relativamente à coisa ou direito doado". Sobre a interpretação desse dispositivo e a possibilidade de convalidação, consultar: MANUEL BAPTISTA LOPES, Das Doações, cit., pp. 88-92.

${ }^{387}$ ARNALDO MARMITT, Doação, cit., p. 28; VICENTE SABINO JÚNIOR, Contrato (...), cit., p. 43.

388 ARNALDO MARMITT, Doação, cit., p. 251; CAIO MÁRIO DA SILVA PEREIRA, Instituições (...), cit., p. 214.

${ }^{389}$ Art. 553. "O donatário é obrigado a cumprir os encargos da doação, caso forem a benefício do doador, de terceiro, ou do interesse geral".

390 Art. 563. "A revogação por ingratidão não prejudica os direitos adquiridos por terceiros, nem obriga o donatário a restituir os frutos percebidos antes da citação válida; mas sujeita-o a pagar os posteriores, e, quando não possa restituir em espécie as coisas doadas, a indenizá-la pelo meio termo do seu valor".

${ }^{391}$ LUCIANO DE CAMARGO PENTEADO, Doação (...), cit., p. 231.

392 AGOSTINHO ALVIM, Da Doação, cit., pp. 232-234. Afirmando que o modus não necessariamente guarda relação com o objeto doado: PONTES DE MIRANDA, Tratado (...), cit., pp. 205-206.

393 MANUEL ALBADALEJO GARCÍA e SILVIA DIAZ ALABART, La Donación, cit., p. 477; NELSON ROSENVALD, Contratos (...), cit., p. 595; ROBERTO WAGNER MARQUESI, A Doação Modal no Código 
português, em seu art. $964 .{ }^{0394}$, e o espanhol, nos arts. $642^{395}$ e $643^{396}$, regulam a imposição de encargo em que se estipula ao donatário solver as dívidas do doador ${ }^{397 / 398}$, o que pode se aplicar no sistema civil pátrio, como obrigação de fazer $^{399}$.

Ademais, trata-se o encargo de uma obrigação assumida pelo donatário quando aceita a doação, afirmando alguns ser ínsito ao contrato, tanto que, quando for viciado, também a doação é inquinada de nulidade, desde que não sejam independentes um do outro $^{400}$, nada impedindo, porém, que o doador modifique o modus e até exonere o donatário de cumpri-1o ${ }^{401}$. Há, porém, quem ensine ser o encargo acessório ao negócio principal, pelo que sua nulidade em nada o afeta ${ }^{402}$.

Vale ressaltar que o encargo não é uma contraprestação, pois sua ocorrência não depende da postura do doador, estando antes no mesmo plano ${ }^{403}$. Também é diferente de

Reale, in GUSTAVO TEPEDINO (Org.) e LUIZ EDSON FACHIN (Org.), Doutrinas Essenciais Obrigações e Contratos, vol. V, São Paulo, Revista dos Tribunais, 2011, p. 490; TANIA CASSANDRO, Le Donazione, cit. p. 80 (a autora defende, porém, que a obrigação deve ter valor econômico).

${ }^{394}$ Artigo 964. ("Pagamento de dívidas"): "1. Se a doação for feita com o encargo de pagamento das dívidas do doador, entender-se-á a cláusula, na falta de outra declaração, como obrigando ao pagamento das que existirem ao tempo da doação. 2. Só é legal o encargo do pagamento de dívidas futuras do doador desde que se determine o seu montante no acto da doação". Consultar a respeito: MANUEL BAPTISTA LOPES, Das Doações, cit., pp. 115-118.

395 Art. 642. "Si la donación se hubiere hecho imponiendo al donatario la obligación de pagar las deudas del donante, como la cláusula no contenga otra declaración, sólo se entenderá aquél obligado a pagar las que apareciesen contraídas antes".

396 Art. 643, "No mediando estipulación respecto al pago de deudas, sólo responderá de ellas el donatario cuando la donación se haya hecho en fraude de los acreedores. Se presumirá siempre hecha la donación en fraude de los acreedores cuando al hacerla no se haya reservado el donante bienes bastantes para pagar las deudas anteriores a ella".

397 A esse respeito: MANUEL ALBADALEJO GARCÍA e SILVIA DIAZ ALABART, La Donación, cit., pp. 497-514.

398 Tal hipótese aparece como condição no Código Napoleônico, conforme a redação do art. 945: "Elle sera pareillement nulle si elle a été faite sous la condition d'acquitter d'autres dettes ou charges que celles qui existaient à l'époque de la donation ou qui seraient exprimées soit dans l'acte de donation, soit dans l'état qui devrait y être annexé".

399 O monografista português MANUEL BAPTISTA LOPES explica que o essencial é o modo representar um interesse do doador passível de proteção jurídica (Das Doações, cit., pp. 113-114).

${ }^{400}$ AMANDA ZOE MORRIS, Doação, cit., p. 282; ARNALDO MARMITT, Doação, cit., p. 29; CAIO MÁRIO DA SILVA PEREIRA, Instituições (...), cit., p. 214; NELSON ROSENVALD, Contratos (...), cit., p. 586. Há quem entenda que na doação modal com mais de um donatário, se o encargo de um deles for nulo, todos os demais estarão eivados de vício [MARIA HELENA DINIZ, Curso (...), cit., p. 268; WASHINGTON DE BARROS MONTEIRO-DABUS MALUF, Curso (...), cit., p. 170]. Outrossim, SÍlVIO DE SALVO VENOSA entende que, apesar de o modus ser ínsito ao contrato, podem as partes pactuar que sua nulidade ou descumprimento não fulminam o principal [Direito (...), cit., p. 133].

${ }^{401}$ ARNALDO MARMITT, Doação, cit., p. 251.

${ }^{402}$ CLÓVIS BEVIlAQUA, Código (...), cit., p. 279; JONES FIGUEIRÊDO ALVES, Código (...), cit., p. 446; MANUEL ALBADALEJO GARCÍA e SILVIA DIAZ ALABART, La Donación, cit., p. 477; ROBERTO WAGNER MARQUESI, A Doação (...), cit., pp. 484-485; VICENTE SABINO JÚNIOR, Contrato (...), cit., p. 40.

403 CAIO MÁRIO DA SILVA PEREIRA, Instituições (...), cit., p. 214; CÉSAR FIUZA, Direito (...), cit., p. 506; MANUEL ALBADALEJO GARCÍA e SILVIA DIAZ ALABART, La Donación, cit., p. 475; NELSON 
ônus, porque o descumprimento daquele não faz o donatário perder uma vantagem, mas sim dá a possibilidade de o doador ou o beneficiário de revogar a benesse ${ }^{404}$. Ademais, não se pode confundir o encargo com prestação sem causa ${ }^{405}$.

Também não é condição, porque essa condiciona a eficácia ou existência do ato a um evento futuro e incerto, ao passo que na doação com encargo os efeitos decorrem do ato mesmo, não dependendo do clausulado ${ }^{406}$, mas é possível admitir que o encargo possa ser atrelado a uma doação como se condição fosse ${ }^{407}$. Além disso, o encargo importa num dever, ao passo que a condição consiste num evento que aperfeiçoa ou cessa o direito ${ }^{408}$. Por fim, no caso de condição suspensiva apenas, essa precede a execução da doação, ao passo que o encargo é superveniente ${ }^{409}$, sendo que a benesse é desde logo adquirida ${ }^{410}$.

As cláusulas de inalienabilidade, incomunicabilidade e impenhorabilidade não são encargo, pois não trazem benefício a ninguém, de modo que as doações assim clausuladas permanecem puras. Pode acontecer de a imposição de uma dessas cláusulas vir a beneficiar a alguém ou a um grupo, mas, mesmo assim, como o objetivo principal do doador não era tal benefício, são mera consequência, de modo que mesmo assim não são um encargo ${ }^{411}$.

ROSENVALD, Contratos (...), cit., p. 595; PAULO NADER, Curso (...), cit., p. 230. Há, porém, quem defina o encargo como contraprestação [nesse sentido: SILVIO RODRIGUES, Direito (...), cit., p. 204]. ROGÉRIO MARRONE DE CASTRO SAMPAIO entende que é possível o encargo ganhar natureza de contraprestação e apagar o caráter liberal do ato e cita como exemplo a doação de um terreno com o encargo de nele construir uma creche [Direito (...), cit., pp. 125], mas tal parecer não se coaduna com a redação do art. 540 do Código Civil de 2002.

${ }^{404}$ LUCIANO DE CAMARGO PENTEADO, Doação (...), cit., p. 230. Em sentido contrário: SERPA LOPES, Curso (...), cit., p. 388; SYLVIO CAPANEMA DE SOUZA, Das Várias (...), cit., p. 95.

405 LUCIANO DE CAMARGO PENTEADO, Doação (...), cit., p. 241; PABLO STOLZE GAGLIANO, $O$ Contrato (...), cit., p. 119. Sobre a diferença entre doação e prestação sem causa, consultar: PONTES DE MIRANDA, Tratado (...), cit., p. 200.

406 ARNALDO MARMITT, Doação, cit., pp. 28-29; LUCIANO DE CAMARGO PENTEADO, Doação (...), cit., p. 232; MANUEL ALBADALEJO GARCÍA e SILVIA DIAZ ALABART, La Donación, cit., p. 475; NELSON ROSENVALD, Contratos (...), cit., p. 586; ; ORLANDO GOMES, Contratos, cit., p. 239; PAULO DE TARSO VIEIRA SANSEVERINO, Contratos (...), cit., p. 95. JEAN RAY, por seu turno, entende que, diante da possibilidade de se dissolver a doação pelo descumprimento do encargo, tal diferença se fragiliza [De La Notion (...), cit., p. 130].

${ }^{407}$ EDUARDO ESPINOLA, Dos Contratos (...), cit. p. 189; LUCIANO DE CAMARGO PENTEADO, Doação (...), cit., p. 232; ROBERTO WAGNER MARQUESI, A Doação (...), cit., p. 485; SILVIO LUÍS FERREIRA DA ROCHA, Curso (...), cit., p. 177

${ }^{408}$ FÁBIO ULHOA COELHO, Curso (...), cit., p. 242; ; ORLANDO GOMES, Contratos, cit., p. 239.

409 ARNALDO MARMITT, Doação, cit., p. 40; ARNOLDO WALD, Direito (...), cit., p. 68; MANUEL ALBADALEJO GARCÍA e SILVIA DIAZ ALABART, La Donación, cit., p. 476.

${ }^{410}$ ARNOLDO WALD, Direito (...), cit., p. 68; CARLOS ROBERTO GONÇALVES, Direito (...), cit., p. 262; LUIZ GUILHERME LOUREIRO, Curso (...), cit., p. 508; OZÉIAS J. SANTOS, Da Doação, cit., p. 19.

${ }^{411}$ AGOSTINHO ALVIM, Da Doação, cit., pp. 249-250; ROBERTO WAGNER MARQUESI, A Doação (...), cit., p. 485. 
O fato de o doador impor um encargo ao donatário não afasta a unilateralidade do contrato $^{412}$, por ausência de sinalagma ${ }^{413}$. Para CLÓVIS BEVILAQUA ${ }^{414}$, porém, o encargo acaba por, em certo sentido, transformar a doação em contrato bilateral, mas afirma que o modus não é um correspectivo da liberalidade realizada.

Outrossim, a imposição de encargo não retira a liberalidade da doação, pois o encargo é mera limitação da benesse e não um ganho para o doador, e mesmo que o beneficie, deverá ser em valor menor que a própria coisa doada, segundo parte da doutrina ${ }^{415}$. MANUEL ALBADALEJO GARCÍA e SILVIA DIAZ ALABART ${ }^{416}$ lecionam que mesmo que haja imposição de encargo, continua a haver liberalidade e negócio gratuito, pois o modus apenas diminui o quanto recebido pelo donatário, e isso vale para todo o ato, não podendo haver divisão quanto à sua natureza, mas sim em relação aos seus efeitos.

Com fundamento no art. $1.167^{417}$ do Código Civil de 1916, AGOSTINHO $\mathrm{ALVIM}^{418}$ entende que a doação modal, até a parte que corresponde ao valor do encargo, é alienação onerosa, e será doação pura a parte excedente, sendo que um ato não é absorvido pelo outro, devendo cada qual seguir seu regime. Tal entendimento guarda compatibilidade

${ }^{412}$ FLÁVIO TARTUCE, Direito (...), cit., p. 314; LUIZ GUILHERME LOUREIRO, Curso (...), cit., p. 508; PABLO STOLZE GAGLIANO, O Contrato (...), cit., p. 119; TANIA CASSANDRO, Le Donazione, cit. pp. 76-79. Há, porém, quem afirme ser a hipótese de contrato bilateral: CÉSAR FIUZA, Direito (...), cit., pp. 506-507; FÁBIO ULHOA COELHO, Curso (...), cit., pp. 241-242.

${ }^{413}$ FRANCISCO GLAUBER PESSOA ALVES, Das Várias (...), cit., p. 882; ORLANDO GOMES, Contratos, cit., p. 234; OZÉIAS J. SANTOS, Da Doação, cit., p. 12; PAULO LÔBO, Direito (...), cit., p. 281; SYLVIO CAPANEMA DE SOUZA, Das Várias (...), cit., p. 87.

${ }^{414}$ Código (...), cit., p. 283. No mesmo sentido: PAUL DELNOY, Le Libéralités (...), cit., p. 25 (o autor afirma que a doação com encargo se torna contrato unilateral imperfeito); ROBERTO WAGNER MARQUESI, $A$ Doação (...), cit., pp. 487-488. A distinção se faz importante para traçar a diferença da doação modal e da mista [neste sentido: PONTES DE MIRANDA, Tratado (...), cit., p. 208].

${ }^{415}$ CLÓVIS BEVILAQUA, Código (...), cit., p. 279; FÁBIO ULHOA COELHO, Curso (...), cit., pp. 237-238; MARIA HELENA DINIZ, Tratado (...), cit., pp. 88-89; NELSON ROSENVALD, Contratos (...), cit., p. 586; PAULO DE TARSO VIEIRA SANSEVERINO, Contratos (...), cit., p. 64; PAULO LÔBO, Direito (...), cit., p. 293; ROBERTO WAGNER MARQUESI, A Doação (...), cit., p. 485; VICENTE SABINO JÚNIOR, Contrato (...), cit., p. 139. Negando a onerosidade da doação modal, PONTES DE MIRANDA afirma que o modus até pode ser sem valor econômico [Tratado (...), cit., p. 206. No mesmo sentido: PAULO LÔBO, Das Várias (...), cit., p. 296]. Sobre o desenvolvimento desse tema na dogmática civil lusitana e a retirada do Código Civil daquele país do termo "doação onerosa", consultar: MANUEL BAPTISTA LOPES, Das Doações, cit., pp. 109-113.

${ }^{416}$ La Donación, cit., pp. 474-475. Em sentido contrario: FÁBIO ULHOA COELHO, Curso (...), cit., p. 242.

${ }^{417}$ Art. 1.167. "A doação feita em contemplação do merecimento do donatário não perde o caráter de liberalidade, como o não perde a doação remuneratória ou gravada, no excedente ao valor dos serviços remunerados, ou ao encargo imposto".

${ }^{418}$ Da Doação, cit., pp. 52-53. No mesmo sentido: CARVALHO SANTOS, Código (...), cit., pp. 344-345; FÁBIO UlHOA COELHO, Curso (...), cit., p. 242; FLÁVIO TARTUCE, Direito (...), cit., pp. 314-315; LIMONGI FRANÇA, Manual (...), cit., p. 98; PAULO GERALDO DE OLIVEIRA MEDINA, A Doação, cit., p. 461; SERPA LOPES, Curso (...), cit., p. 412; SILVIO RODRIGUES, Direito (...), cit., p. 204. Há, porém, quem rejeite tal divisão e conclui pela inexistência de doação na hipótese [PONTES DE MIRANDA, Tratado (...), cit., p. 207]. 
com o art. $540^{419}$ do Código Civil de 2002, mas como se verá ao se tratar da doação remuneratória, tal interpretação é questionável ${ }^{420}$.

Não obstante, o mesmo autor ${ }^{421}$ explica, em outro passo, que o encargo, apesar de ser passível de figurar nos contratos sinalagmáticos, tem seu âmbito próprio nos contratos que contém liberalidade, pelo que, apesar de tornar a doação onerosa, não a leva a todos os efeitos dos atos desta natureza, como no caso da ocorrência de força maior, que não só afasta a indenização, como o desfazimento do próprio contrato. De outro lado, na hipótese de descumprimento do encargo, revoga-se não só a parte onerosa, mas também aquela que é doação pura.

Segundo lição de ARNALDO MARMITT ${ }^{422}$, em caso de imposição de encargo ilícito ou impossível, a cláusula é tida por não escrita e a doação torna-se pura, ao passo que, para AGOSTINHO ALVIM ${ }^{423}$, se o encargo for impossível, deve ser aplicada a disposição do art. $116^{424}$ do Código Civil de 1916, de modo que, se a impossibilidade for física, então apenas o encargo é nulo, mas se for caso de impossibilidade jurídica, então todo o ato é nulo, sendo que, se o doador já tiver cumprido sua parte na avença, à luz do art. $971^{425}$ daquele diploma, terá direito à repetição apenas se o encargo não resultar em ato imoral, como o erro de direito. Tais entendimentos só guardarão compatibilidade com a redação do art. $137^{426}$ do Código Civil de 2002 a depender dos motivos do doador, pois se o encargo for intrinsecamente relacionado com esses, então todo o negócio é inválido, da mesma forma se for ilícito ${ }^{427}$.

${ }^{419}$ Art. 540. "A doação feita em contemplação do merecimento do donatário não perde o caráter de liberalidade, como não o perde a doação remuneratória, ou a gravada, no excedente ao valor dos serviços remunerados ou ao encargo imposto".

${ }^{420}$ PONTES DE MIRANDA, por exemplo, entende que o encargo poderá superar a doação quando for beneficiário um terceiro [Tratado (...), cit., p. 206].

${ }^{421}$ Da Doação, cit., pp. 234-236. No mesmo sentido: MANUEL ALBADALEJO GARCÍA e SILVIA DIAZ ALABART, La Donación, cit., pp. 469-471.

${ }^{422}$ Doação, cit., p. 30 (tal posicionamento é incoerente com a visão desse autor de que o encargo é ínsito ao contrato). No mesmo sentido: MANUEL ALBADALEJO GARCÍA e SILVIA DIAZ ALABART, La Donación, cit., p. 477; MARIA HELENA DINIZ, Curso (...), cit., p. 268; PAULO LÔBO, Direito (...), cit., p. 293; ; ORLANDO GOMES, Contratos, cit., p. 239.

${ }^{423}$ Da Doação, cit., pp. 245-246. No mesmo sentido: SILVIO LUíS FERREIRA DA ROCHA, Curso (...), cit., p. 178.

${ }^{424}$ Ver nota $6 \mathrm{~b}$.

${ }^{425}$ Art. 971 . "Não terá direito à repetição aquele que deu alguma coisa para obter fim ilícito, imoral, ou proibido por lei".

${ }^{426}$ Art. 137. "Considera-se não escrito o encargo ilícito ou impossível, salvo se constituir o motivo determinante da liberalidade, caso em que se invalida o negócio jurídico".

427 CARLOS ROBERTO GONÇALVES, Direito (...), cit., p. 263; PAULO DE TARSO VIEIRA SANSEVERINO, Contratos (...), cit., p. 95; ROBERTO WAGNER MARQUESI, A Doação (...), cit., p. 486; 
Na hipótese de o encargo ser de valor igual ao bem doado, então o donatário será mero executor da vontade do donante, segundo alguns ${ }^{428}$, ou permuta, segundo outros ${ }^{429}$, e se for de valor maior, há então, em verdade, inversão de polos ${ }^{430}$ e se está diante de um outro contrato, como a compra e venda ou a locação ${ }^{431}$, o que já foi dito acima quando se falou da gratuidade $^{432}$. Não obstante, há quem afirme que o fato de o encargo absorver todo o valor doado não desnatura o ato como doação, se as partes assim o quiseram ${ }^{433}$, o que está de acordo com o art. 540 do Código Civil de 2002.

Pode acontecer de o encargo se tornar maior que o bem doado por causas supervenientes à benesse, o que faz que subsista a doação ${ }^{434}$, não podendo o donatário distratar unilateralmente, pois é da natureza contratual do ato assumir os riscos do negócio ${ }^{435}$.

ARNALDO MARMITT ${ }^{436}$, porém, pensa que se o encargo ultrapassar o bem doado em valor então é possível o donatário pleitear a revogação do próprio modus e teria até o direito de descumpri-1o ${ }^{437}$.

Tal debate, porém, encontra sua solução no regime da onerosidade excessiva e na disposição do art. $480^{438}$ do Código Civil de 2002, de modo que o donatário deverá pleitear a

SYLVIO CAPANEMA DE SOUZA, Das Várias (...), cit., p. 96. Entende alguns que somente a ilicitude acarreta a nulidade de todo o ato, ao passo que a impossibilidade física ou jurídica apenas deverão ser tidas por não escritas [nesse sentido: EDUARDO ESPINOLA, Dos Contratos (...), cit. p. 191; Curso (...), cit., p. 507; LUIZ GUILHERME LOUREIRO; PAULO LÔBO, Das Várias (...), cit., p. 298].

${ }^{428}$ AGOSTINHO ALVIM, Da Doação, cit., p. 238. JEAN RAY cogita ainda a hipótese de liberalidade que tem por objeto um imóvel, na qual o doador impõe ao donatário que preste alimentos a um terceiro e afirma que se trata de aquisição onerosa por meio de contrato aleatório, pois a sobrevida do terceiro pode levar o encargo a igualar a benesse, de modo que o verdadeiro donatário é o terceiro. Se, no entanto, as rendas do imóvel forem suficientes para cumprir o encargo, então há verdadeira doação [De La Notion (...), cit., p. 140].

${ }^{429}$ LUIZ GUILHERME LOUREIRO, Curso (...), cit., p. 508; ROBERTO WAGNER MARQUESI, A Doação (...), cit., p. 488.

${ }^{430}$ AGOSTINHO ALVIM, Da Doação, cit., pp. 237-238; LUIZ GUILHERME LOUREIRO, Curso (...), cit., p. 508; ROBERTO WAGNER MARQUESI, A Doação (...), cit., p. 485.

431 ARNALDO MARMITT, Doação, cit., p. 30; ARNOLDO WALD, Direito (...), cit., p. 68; PAULO DE TARSO VIEIRA SANSEVERINO, Contratos (...), cit., p. 95.

432 Também entendendo que o encargo não pode igualar ou superar o valor da doação, sob pena de desnaturá-la: FÁBIO ULHOA COELHO, Curso (...), cit., p. 237; MANUEL BAPTISTA LOPES, Das Doações, cit., p. 115; PAULO DE TARSO VIEIRA SANSEVERINO, Contratos (...), cit., p. 64; PAULO LÔBO, Direito (...), cit., p. 293; SYLVIO CAPANEMA DE SOUZA, Das Várias (...), cit., p. 87.

${ }^{433}$ MANUEL ALBADALEJO GARCÍA e SILVIA DIAZ ALABART, La Donación, cit., pp. 481-483.

${ }^{434}$ AGOSTINHO ALVIM, Da Doação, cit., p. 237.

${ }^{435}$ AGOSTINHO ALVIM, Da Doação, cit., pp. 245-246.

${ }^{436}$ Doação, cit., p. 247.

437 O art. 963. " (Cláusulas modais") do Código Civil lusitano dispensa expressamente o donatário de dar cumprimento a encargo maior que o valor recebido: "1. As doações podem ser oneradas com encargos. 2. O donatário não é obrigado a cumprir os encargos senão dentro dos limites do valor da coisa ou do direito doado". Conferir: MANUEL BAPTISTA LOPES, Das Doações, cit., pp. 108-109.

438 Art. 480. "Se no contrato as obrigações couberem a apenas uma das partes, poderá ela pleitear que a sua prestação seja reduzida, ou alterado o modo de executá-la, a fim de evitar a onerosidade excessiva”. 
redução do encargo ou alterar seu cumprimento, nada impedindo, ademais, que o doador desobrigue-o do dever assumido ${ }^{439}$. Aliás, eis aqui uma consequência de se admitir a natureza contratual da doação ${ }^{440}$.

Se o encargo aposto à doação tiver por beneficiário o próprio donatário, então se trata de mera recomendação, pelo que não é dever ${ }^{441}$, mas tal não se dá quanto às doações cujo modus também ou somente beneficie terceiros ou o interesse geral, pois nessa hipótese há obrigação, podendo-se exigir sua execução específica ou a revogação do contrato ${ }^{442}$.

Outro aspecto especial da doação com encargo é que o seu descumprimento terá efeito ex tunc, de modo que se o bem for alienado a terceiros e o donatário não cumprir o encargo, eles deverão retornar ao patrimônio do doador, mesmo à luz do regime da propriedade resolúvel, pois não há regra especial para a hipótese, ao contrário do que ocorre na revogação por ingratidão, e, além disso, o adquirente poderá dar cumprimento ao encargo, se não se tratar de obrigação personalíssima e também poderá embutir o risco no preço de aquisição do bem ${ }^{443}$.

Para se exigir o cumprimento específico do encargo, tem legitimidade o doador e o beneficiado quando houver cláusula estipulada em seu favor, sendo que, na hipótese de doação em interesse geral, enquanto vivo o doador, terá ele legitimidade exclusiva para exigi-

${ }^{439}$ PAULO LÔBO entende que a onerosidade excessiva, assim como alguns outros aspectos contratuais, não se aplica à doação, por o donatário não ter nenhum dever jurídico, o que não guarda relação com a hipótese comentada [Direito (...), cit., p. 283]. De qualquer forma, PONTES DE MIRANDA preconizava a possibilidade de o donatário exigir o complemento da doação pelo doador, quando havia vício de direito ou de objeto, consubstanciado em encargo maior que o bem doado, pelo que poderia o beneficiário se defender com exceção suspensiva ou exigir indenização quando já tivesse adimplido sua obrigação [Tratado (...), cit., pp. 210-211].

${ }^{440}$ EDUARDO ESPINOLA é do parecer de que o encargo jamais deverá ultrapassar o valor do bem doado e, se isso vier a acontecer, então o donatário deverá ser indenizado pelo doador, pelos gastos excedentes advindos [Dos Contratos (...), cit. p. 192].

O Código Civil Francês, por seu turno, no art. 900-2, prevê expressamente a possibilidade de revisão judicial do encargo por alteração das circunstâncias: "Tout gratifié peut demander que soient révisées en justice les conditions et charges grevant les donations ou legs qu'il a reçus, lorsque, par suite d'un changement de circonstances, l'exécution en est devenue pour lui soit extrêmement difficile, soit sérieusement dommageable".

${ }^{441}$ CARLOS ROBERTO GONÇALVES, Direito (...), cit., pp. 262-263; CLÓVIS BEVILAQUA, Código (...), cit., p. 283; EDUARDO ESPINOLA, Dos Contratos (...), cit. p. 189; MARIA HELENA DINIZ, Tratado (...), cit., p. 90; PAULO GERALDO DE OLIVEIRA MEDINA, A Doação, cit., pp. 472-473; PONTES DE MIRANDA, Tratado (...), cit., p. 206; SERPA LOPES, Curso (...), cit., p. 412; SÍlVIO DE SALVO VENOSA, Direito (...), cit., p. 133. Sobre a diferença entre recomendação e encargo, confrontar: EDUARDO ESPINOLA, Dos Contratos (...), cit. p. 187; SILVIO LUÍS FERREIRA DA ROCHA, Curso (...), cit., p. 176; TANIA CASSANDRO, Le Donazione, cit. p. 80. Chegando à essa mesma conclusão, JEAN RAY tira por consequência que é possível haver doação de dinheiro a pródigo com encargo de investir apenas em imóvel [De La Notion (...), cit., p. 132].

${ }^{442}$ CLÓVIS BEVILAQUA, Código (...), cit., p. 283; LUIZ GUILHERME LOUREIRO, Curso (...), cit., p. 508.

${ }^{443}$ AGOSTINHO ALVIM, Da Doação, cit., pp. 238-240. 
lo e, somente após o seu decesso, é que o Ministério Público terá legitimidade ou então a instituição beneficiada $^{444}$.

Assim, em vista do objeto da presente pesquisa, cumpre considerar que, se for do desejo do doador, poderá ele impor algum encargo ao donatário, que consista numa obrigação jurídica e mensurável economicamente, para que não venha a ser desqualificado posteriormente. A consequência prática dessa opção é a necessidade de aceite expresso pelo donatário.

Deve estar o disponente atento para que o valor do encargo não venha a ultrapassar o valor do bem alienado, pois, como visto, poderá haver sérios questionamentos futuros e até a anulação de todo o ato, a depender do posicionamento adotado. Havendo possibilidade de o encargo se tornar vultoso, importa fazer reserva patrimonial para acobertálo ou apor cláusula em que o donatário assume os riscos que dele advenham.

Em vista da dúvida quanto a relação entre o negócio principal e o modo, deve-se atentar também para que ela não seja ilícita, ou jurídica ou fisicamente impossível de se cumprir, pois se assim o for pode acarretar o desmoronamento de todo o ato de disposição.

Por fim, deve o doador ter consciência de que quando o beneficiado pelo encargo for exclusivamente o donatário, não poderá exigir-lhe o cumprimento específico da doação, mas apenas buscar a revogação da doação, o que pode ser um inconveniente, a depender da estratégia arquitetada.

\section{4) Doação por mérito ou contemplativa}

Doação por mérito ou contemplativa é aquela em que o doador procede à entrega benemérita do bem doado fundado na admiração que tem da vida ou boa conduta do recebedor da benesse ${ }^{445}$, e pode se dar tanto por serviços prestados ou feitos realizados pelo donatário, como por alguma virtude que ele tenha ${ }^{446}$.

\footnotetext{
${ }^{444}$ AGOSTINHO ALVIM, Da Doação, cit., pp. 248-249; CAIO MÁRIO DA SILVA PEREIRA, Instituições (...), cit., p. 220; CARLOS ROBERTO GONÇALVES, Direito (...), cit., p. 263; CÉSAR FIUZA, Direito (...), cit., p. 505; CLÓVIS BEVILAQUA, Código (...), cit., pp. 283-284; EDUARDO ESPINOLA, Dos Contratos (...), cit. p. 190; FLÁVIO TARTUCE, Direito (...), cit., p. 312; NELSON ROSENVALD, Contratos (...), cit., pp. 595-596; ROGÉRIO MARRONE DE CASTRO SAMPAIO, Direito (...), cit., pp. 125. Também têm legitimidade os herdeiros do doador: SÍLVIO DE SALVO VENOSA, Direito (...), cit., p. 133.

445 ARNALDO MARMITT, Doação, cit., p. 43; EDUARDO ESPINOLA, Dos Contratos (...), cit. p. 179; PAULO DE TARSO VIEIRA SANSEVERINO, Contratos (...), cit., p. 75.

${ }^{446}$ ARNALDO MARMITT, Doação, cit., p. 44; CARLOS ROBERTO GONÇALVES, Direito (...), cit., p. 264;
} 
A exposição dos motivos, para PABLO STOLZE GAGLIANO ${ }^{447}$, não é requisito necessário para sua validade, mas se o doador não envidar provar que se trata de doação contemplativa, tratar-se-á de uma doação pura. Por outro lado, CLÓVIS BEVILAQUA ${ }^{448}$ ressalta, quanto à espécie, que deve haver expressa manifestação da causa do ato por parte do disponente, só que essa em nada afeta a causa da doação, que continua a ser o animus donandi, e tal se dá, segundo o autor, porque aquilo que se deseja contemplar é mera externalização de um afeto interno.

De qualquer forma, a necessidade de se saber a causa da liberalidade tem efeito prático de relevo, pois se provada a inexistência do mérito que deu causa ao contrato, poderá então o doador obter a nulidade do ato, por inexistência de causa ${ }^{449}$. Além disso, se se tratar de causa ilícita, a doação será nula ${ }^{450}$.

Para alguns autores ${ }^{451}$, somente se dá na forma pura, porém não há impeditivo legal de se apor à benesse um encargo, pelo que seria mais correto afirmar que prevalece na forma pura, mas não é contrário à sua natureza lhe apor um encargo, ou, até, prever o mérito como condição ${ }^{452}$. Há ${ }^{453}$ quem lecione, porém, que se trata de doação onerosa, dado o interesse de premiação.

O atual Código Civil de 2002 não define o que seja a espécie comentada, porém faz questão de arredá-la dos negócios jurídicos onerosos e incluí-la dentre as liberalidades, como se verifica na redação do seu art. $540^{454}$, de modo que se pode afirmar ser regrada pelo regime das doações e dos contratos ${ }^{455}$.

PAULO LÔBO, Direito (...), cit., pp. 291-292; ROGÉRIO MARRONE DE CASTRO SAMPAIO, Direito (...), cit., pp. 125.

${ }^{447}$ O Contrato (...), cit., p. 120.

448 Código (...), cit., p. 272. No mesmo sentido, há quem explique que a doação contemplativa tem por característica a exteriorização dos motivos do doador [NELSON ROSENVALD, Contratos (...), cit., p. 586].

${ }^{449}$ MANUEL ALBADALEJO GARCÍA e SILVIA DIAZ ALABART, La Donación, cit., pp. 383-386 (para os autores, ainda que na doação contemplativa deva haver expressa manifestação do doador quanto aos motivos, sob pena de ser tido por pura, admitem, no mesmo passo, que mesmo na ausência da causa é possível perquirir das razões do ato para alegação de erro de pessoa). Há quem entenda que a hipótese de inexistência da causa é de anulabilidade [LUIZ GUILHERME LOUREIRO, Curso (...), cit., p. 511], ou então de redução a forma de doação pura [FLÁVIO TARTUCE, Direito (...), cit., p. 316], pois o que se quer contemplar é mero motivo da doação, não tendo força de causa [neste sentido: ANTÔNIO CHAVES, Lições (...), cit., pp. 243244]..

${ }^{450}$ LUIZ GUILHERME LOUREIRO, Curso (...), cit., p. 511.

${ }^{451}$ ARNALDO MARMITT, Doação, cit., p. 43; PABLO STOLZE GAGLIANO, $O$ Contrato (...), cit., p. 120; SÍLVIO DE SALVO VENOSA, Direito (...), cit., p. 133.

${ }^{452}$ MANUEL ALBADALEJO GARCÍA e SILVIA DIAZ ALABART, La Donación, cit., p. 386.

${ }^{453}$ LUIZ GUILHERME LOUREIRO, Curso (...), cit., p. 510-511; PAULO LÔBO, Das Várias (...), cit., p. 295.

${ }^{454}$ Art. 540. "A doação feita em contemplação do merecimento do donatário não perde o caráter de liberalidade, 
Para ARNALDO MARMITT ${ }^{456}$, se o bem doado for de valor superior ao serviço prestado pelo donatário contemplado, a parte excedente não será disposição gratuita, sendo hipótese de doação mista, de modo que a parte sobressalente responderá por evicção e não é passível de revogação por ingratidão. CLÓVIS BEVILAQUA ${ }^{457}$ entende que tais efeitos decorrem da lei, pelo que inquestionáveis, mas critica a opção legislativa, por contrariar a natureza da doação.

De qualquer forma, como assegura o art. 540 do atual sistema civil, ainda que ultrapasse o quanto contemplado, não perde o ato o caráter de liberalidade, o que será mais detidamente analisado no próximo item ${ }^{458}$.

Do exposto, deve o autor atentar-se ao expressar sua admiração pelo donatário, pois ao assim fazer seu ato poderá ser tido por oneroso, de modo que é de bom alvitre exigir o aceite expresso. De outro lado, ao assim se conduzir, está a garantir que a benemerência alcance a quem deseja deveras premiar e seja tolhida caso se apresente alguma falsidade ou erro.

Outrossim, para evitar qualquer dúvida, caso o objeto doado ultrapasse em valor a ação que se quer premiar (apesar de algumas delas serem impossíveis de se mensurar economicamente, pois como se avaliará alguém que é contemplado por ser corajoso?), é bom fazer constar expressamente no instrumento o caráter liberal da alienação.

\section{5) Doação remuneratória}

Doação remuneratória é aquela que tem nítido caráter de "recompensa", isto é, dádiva feita pelo doador ao donatário por algum serviço que esse fez, mas que não pode ser pago, ou que não há obrigação de pagar $^{459}$.

como não o perde a doação remuneratória, ou a gravada, no excedente ao valor dos serviços remunerados ou ao encargo imposto".

455 FÁBIO ULHOA COELHO, Curso (...), cit., p. 243; MANUEL ALBADALEJO GARCÍA e SILVIA DIAZ ALABART, La Donación, cit., pp. 359-360.

${ }^{456}$ Doação, cit., p. 44.

${ }^{457}$ Código (...), cit., p. 272.

${ }^{458}$ CARVALHO SANTOS, Código (...), cit., p. 343 (para o autor, não faz sentido em cogitar-se da onerosidade do ato, pois o doador não tinha nenhuma obrigação de premiar o donatário).

${ }^{459}$ ARNALDO RIZZARDO, Contratos, cit., p. 455; CAIO MÁRIO DA SILVA PEREIRA, Instituições (...), cit., p. 214; OZÉIAS J. SANTOS, Da Doação, cit., p. 18; PAULO LÔBO, Direito (...), cit., pp. 281-282; SAVIGNY, Sistema (...), cit., pp. 105-106 (o autor nega explicitamente a tese de que não há doação na hipótese). Há quem entenda, porém, que só há doação remuneratória para débitos exigíveis [FLÁVIO TARTUCE, Direito (...), cit., p. 315].

O art. 947. ("Doação remuneratória") do Código Civil de Portugal é expresso em prever a inexigibilidade da 
VICENTE SABINO JÚNIOR ${ }^{460}$ entende que a doação remuneratória pode se realizar não apenas em atenção a um serviço já prestado, mas também que esteja em execução ou que ainda se realizará, mas tal situação, segundo sua opinião, é bastante teórica e não faz sentido prático, pois se o serviço não ocorrer a doação deve ser anulada, de modo que será de eficácia simultânea à ocorrência do quanto remunerado ${ }^{461}$. Deverá ser verificado, ainda, se não se trata de legado de crédito, aplicável apenas ao testamento ${ }^{462}$.

MANUEL ALBADALEJO GARCÍA e SILVIA DIAZ ALABART ${ }^{463}$ entendem que o desiderato do doador de recompensar o donatário por um serviço prestado não é simples motivo, mas sim causa da doação, que se acresce ao desejo de enriquecer o donatário (causa da doação em geral), de tal modo que se não houver o serviço que se quer compensar, há doação sem causa, logo nula. Admitem, porém, a tese de que se tem no caso um "motivo causalizado", mas assumem que o efeito prático é o mesmo ${ }^{464}$.

Assim, a doação remuneratória tem por característica o fato de o doador querer compensar o donatário por algum serviço que este prestou, passível de ser medido economicamente, mas que não originou um dever jurídico de pagar ${ }^{465}$. Por outro lado, não há vedação no direito pátrio de se considerar remuneratória a liberalidade feita em vista de serviço prestado que seja inestimável ${ }^{466}$, de modo ser possível sua admissibilidade, mas os efeitos práticos não são relevantes, a não ser em matéria de forma, pois, em todo o resto, é forçoso admitir que a regulação será a da doação pura ${ }^{467}$.

dívida: "É considerada doação a liberalidade remuneratória de serviços recebidos pelo doador, que não tenham a natureza de dívida exigível". Consultar a respeito: MANUEL BAPTISTA LOPES, Das Doações, cit., pp. 20-21.

460 Contrato (...), cit., p. 44. No mesmo sentido: MANUEL ALBADALEJO GARCÍA e SILVIA DIAZ ALABART, La Donación, cit., pp. 402-406.

${ }^{461}$ Entendendo que só há doação remuneratória para fato pretérito: ARNALDO RIZZARDO, Contratos, cit., p. 455; FRANCISCO GLAUBER PESSOA ALVES, Das Várias (...), cit., p. 886; MANUEL BAPTISTA LOPES, Das Doações, cit., p. 21; SAMUEL LUIZ ARAÚJO, O Princípio (...), cit., p. 78; SÍLVIO DE SALVO VENOSA, Direito (...), cit., p. 133; SYLVIO CAPANEMA DE SOUZA, Das Várias (...), cit., p. 96.

${ }^{462}$ PABLO STOLZE GAGLIANO, O Contrato (...), cit., p. 121.

${ }^{463}$ La Donación, cit., pp. 392-393.

${ }^{464}$ Entendendo que o motivo do doador de remunerar qualifica a causa: TANIA CASSANDRO, Le Donazione, cit. pp. 64-65. Há, porém, quem compreenda ser o desejo de remunerar mero motivo: PAULO LÔBO, Direito (...), cit., p. 282.

465 ARNALDO MARMITT, Doação, cit., p. 41; ARNALDO RIZZARDO, Contratos, cit., p. 455; CARLOS ROBERTO GONÇALVES, Direito (...), cit., p. 264; CARVALHO DE MENDONÇA, Contratos (...), cit., p. 80; CLÓVIS BEVILAQUA, Código (...), cit., p. 272; SÍlVIO DE SALVO VENOSA, Direito (...), cit., p. 133; SYLVIO CAPANEMA DE SOUZA, Das Várias (...), cit., p. 96.

${ }^{466}$ Mormente diante dos comentários que se faz ao art. 540 do Código Civil de 2002 abaixo declinados.

${ }^{467}$ MANUEL ALBADALEJO GARCÍA e SILVIA DIAZ ALABART, La Donación, cit., pp. 399-402; NELSON ROSENVALD, Contratos (...), cit., p. 586 (admite o autor que se pode doar em remuneração a conselhos particulares dados pelo donatário). Em sentido contrário: TANIA CASSANDRO, Le Donazione, cit. p. 65. 
A doação remuneratória diferencia-se da dação em pagamento ou da contraprestação porque permanece o intuito de se fazer uma liberalidade, e é independente quanto ao valor do objeto doado, que pode ser até maior que o serviço prestado ${ }^{468}$. Com efeito, tanto o serviço prestado como a remuneração que a ele se faz por doação são atos autônomos, e carecem do intuito de cumprir um dever jurídico bilateral, sendo antes duas liberalidades independentes, todavia, dada a causa do ato jurídico, é que parte da doutrina entende ser necessário reconhecer um elemento de onerosidade presente no caso ${ }^{469}$. Tal conjunto de ideias também tem o condão de afastar a opinião de quem vê na espécie mera aparência de liberalidade, afirmando ser antes uma troca ${ }^{470}$.

Há autores ${ }^{471}$ que manifestam a opinião de que as doações remuneratórias só podem abranger dívidas inexigíveis não segundo a natureza do próprio débito, como as dívidas naturais, mas sim por manifestação direta ou tácita do titular, sendo que, se assim não for, trata-se então de dação em pagamento, e a diferença entre um e outro só pode ser traçada pelas circunstâncias ensejadoras do ato. Assim, admite-se ser doação remuneratória a hipótese em que se fez em vista de serviço originariamente oneroso, mas posteriormente tornado gratuito por declaração do credor ${ }^{472}$. Mas há ${ }^{473}$ os que entendem ser possível haver doação em remuneração a simples obrigação natural.

Interessa anotar nesse passo a lição de PLANIOL ${ }^{474}$, que enuncia a semelhança da espécie com o adimplemento de obrigação, mas afirma que a liberalidade está sim presente no ato jurídico. Leciona ainda que o caráter de doação somente sede lugar a pagamento quando o serviço prestado é mensurável economicamente e o desejo de quem transfere o bem não é o de expressar um afeto de reconhecimento, mas sim livrar-se do débito.

${ }^{468}$ ARNALDO MARMITT, Doação, cit., p. 42; ARNOLDO WALD, Direito (...), cit., p. 68; CAIO MÁRIO DA SILVA PEREIRA, Instituições (...), cit., p. 214; PAULO LÔBO, Direito (...), cit., p. 292. Mesmo SERPA LOPES, que classifica as doações remuneratórias como "impróprias", porque o motivo da liberalidade seria um dever moral de adimplemento, concorda em não defini-las por pagamento ou permuta [Curso (...), cit., p. 407]. No entanto, há quem manifeste a opinião de que a doação remuneratória tem efeito de pagamento, de maneira que o donatário não poderá mais reclamar sua remuneração [SÍLVIO DE SALVO VENOSA, Direito (...), cit., p. 134]. JEAN RAY, por seu turno, ensina que a doação remuneratória pode ser dação em pagamento, a depender da comparação entre o valor do serviço prestado e do objeto transferido [De La Notion (...), cit., pp. 106-107].

${ }^{469}$ ARNALDO RIZZARDO, Contratos, cit., pp. 455-456; FÁBIO ULHOA COELHO, Curso (...), cit., p. 243; MANUEL ALBADALEJO GARCÍA e SILVIA DIAZ ALABART, La Donación, cit., pp. 391-392.

${ }^{470}$ LIMONGI FRANÇA, Manual (...), cit., pp. 98-99; PONTES DE MIRANDA, Tratado (...), cit., p. 203.

${ }^{471}$ AGOSTINHO ALVIM, Da Doação, cit., pp. 49-51; CARLOS ROBERTO GONÇALVES, Direito (...), cit., p. 263.

${ }^{472}$ MANUEL ALBADALEJO GARCÍA e SILVIA DIAZ ALABART, La Donación, cit., p. 398.

${ }^{473}$ FLÁVIO AUGUSTO MONTEIRO DE BARROS, Manual (...), cit., p. 348; NELSON ROSENVALD, Contratos (...), cit., p. 586; PAULO LÔBO, Direito (...), cit., p. 292.

${ }^{474}$ Traité (...), cit., p. 643. 
No que toca à pessoa do doador, é possível haver a prática de doação remuneratória por quem não foi objeto do serviço recompensado, e o fato que fundamentaria tal admissibilidade está no dever natural de cooperação entre os familiares, pelo que ascendentes, descendentes ou cônjuges podem fazer doação em remuneração a serviço prestados a um dos seus, ou até mesmo por um terceiro interessado, mas não caberá nas duas hipóteses as regras especiais da doação remuneratória. Da mesma forma, é possível admitir, em tese, doação remuneratória em favor de quem está ligado ao prestador de serviço ${ }^{475}$.

Em relação à forma, importa salientar que, para fins de prova, devem as partes consignar a natureza remuneratória do ato e os exatos serviços remunerados, a fim de evitar a confusão com a doação pura e permitir a comprovação do serviço e a mensuração de seu valor, quando necessário, mas nada impede que assim se faça à margem do ato ou em instrumento apartado ${ }^{476}$.

Outrossim, quanto a eventual excesso entre a doação e o serviço prestado, com fundamento no art. 1.167 do Código Civil de 1916, o qual guarda correspondência com o art. 540 do Código Civil de 2002, há ${ }^{477}$ quem afirme que a doação remuneratória não é doação até a parte que remunera o serviço prestado, pois não há liberalidade, ao passo que é doação pura na parte excedente. Dentro desta mesma linha, ensina-se que não se aplica ao caso a teoria da absorção, de modo que se deve cindir os dois atos e cada um terá o seu regime próprio, devendo-se então proceder à avaliação do serviço, para se detectar o excedente, sendo que tal avaliação será imprescindível mesmo no caso de ser serviço moral ${ }^{478}$.

No entanto, ao comentar o citado art. 540 do Código Civil de 2002, LUCIANO DE CAMARGO PENTEADO ${ }^{479}$ explica que não há nesse caso uma divisão em duas partes do negócio, mas sim uma delimitação jurídica de um fato, pois o legislador demonstra saber

\footnotetext{
${ }^{475}$ MANUEL ALBADALEJO GARCÍA e SILVIA DIAZ ALABART, La Donación, cit., pp. 406-410.

476 MANUEL ALBADALEJO GARCÍA e SILVIA DIAZ ALABART, La Donación, cit., pp. 395-396. Admitindo, porém, que haja doação remuneratória sem manifestação expressa e apreendida de elementos externos ao negócio: TANIA CASSANDRO, Le Donazione, cit. pp. 75-76.

${ }^{477}$ AGOSTINHO ALVIM, Da Doação, cit., pp. 48-49; CARLOS ROBERTO GONÇALVES, Direito (...), cit., p. 263; FÁBiO ULHOA COELHO, Curso (...), cit., p. 243; FLÁVIO TARTUÇ, Direito (...), cit., p. 315; LIMONGI FRANÇA, Manual (...), cit., p. 99; MARIA HELENA DINIZ, Curso (...), cit., p. 268; PAULO GERALDO DE OLIVEIRA MEDINA, A Doação, cit., p. 461; PAULO NADER, Curso (...), cit., p. 230; TANIA CASSANDRO, Le Donazione, cit. pp. 72-74; WASHINGTON DE BARROS MONTEIRO-DABUS MALUF, Curso (...), cit., p. 170.

${ }^{478}$ AGOSTINHO ALVIM, Da Doação, cit., pp. 51-52; CARVALHO SANTOS, Código (...), cit., p. 344; SILVIO RODRIGUES, Direito (...), cit., p. 204.

${ }^{479}$ Doação (...), cit., pp. 176-177.
} 
que a doação só ocorreu para "remunerar" o donatário, mas que no plano jurídico tal relação não terá efeito, por não ter se tratado de dação em pagamento.

Assim, é estranha a interpretação que tenta explicar a regra pela exceção, sendo mais coerente admitir que o legislador, no art. 540 do Código Civil de 2002, quis regular o mais para abranger o menos, isto é, se é doação o ato cujo merecimento premiado, serviço remunerado ou encargo pactuado é superado pela liberalidade, quanto mais aquela onde não ocorre tal excesso, ressalvados eventuais particularidades previstas em leis, haja vista que cada um desses atos têm causas diferentes.

Com efeito, a certa carga de onerosidade que há nas hipóteses, especialmente nas doações modais e remuneratórias, levaram o legislador a lhes dar tratamento diferenciado, como se verifica na redação do parágrafo único do art. 441 do Código Civil de 2002, que fala expressamente em doações onerosas ${ }^{480}$, ou na ausência de proteção pela evicção do doador, ou na dispensa de se levar à colação (no caso das liberalidades remuneratórias), ou ainda na vedação de revogação por ingratidão.

No entanto, a medição de interesses econômicos ou de equivalências financeiras não serve de regra universal científica para detecção da liberalidade, pois apresenta muitas fragilidades (por exemplo, não é capaz de abarcar serviços ou encargos inestimáveis) ${ }^{481}$, assim como aquelas hipóteses de doação em que as partes estão cientes de o encargo ser maior que o objeto doado.

Com efeito, o fato de ser excedente ou não o modus ou o quanto remunerado não serve de critério para qualificação jurídica do ato, que continuará a ser doação estando presente seus elementos caracterizadores, e por consequência uma liberalidade ${ }^{482}$, de modo que se submete ao seu regime jurídico, mas não a um duplo regramento, como querem $\operatorname{alguns}^{483}$.

\footnotetext{
${ }^{480}$ PONTES DE MIRANDA critica o emprego dessa locução pela lei, pois, segundo ele, confunde o fato de a liberalidade estar onerada com um encargo ou causa pretérita com os negócios onerosos, cuja natureza é diferente da doação [Tratado (...), cit., pp. 208-209]. A favor da expressão: PLANIOL, Traité (...), cit., p. 643.

${ }^{481}$ MÉAU-LAUTOUR, La Donation (...), cit., pp. 46-50.

${ }^{482}$ PAULO LÔBO, Das Várias (...), cit., pp. 294-295 (o autor, porém, afirma que o encargo não pode superar o valor doado).

${ }^{483}$ Sobre os questionamentos trazidos na matéria, confrontar: EDUARDO ESPINOLA, Dos Contratos (...), cit. p. 180; JEAN RAY, De La Notion (...), cit., pp. 134-138 (o autor mostra como os critérios financeiros e psicológicos precisam ser alinhavados para se identificar a doação, dada a incerteza fronteiriça que há entre os atos onerosos e gratuitos); JOÃO BAPTISTA VILLELA, Contrato (...), cit., pp. 259-261.
} 
De toda maneira, em relação às demais espécies de liberalidades, há autores ${ }^{484}$ que tratam conjuntamente a doação por merecimento do donatário e a remuneratória por guardarem semelhança entre $\mathrm{si}^{485}$, e até mesmo a modal ${ }^{486}$, sendo que, nas duas primeiras, pode-se afirmar que estão fundadas em uma causa pretérita, que, neste caso, não tem o condão de desnaturar a doação, pois não a torna um negócio jurídico sinalagmático, haja vista não se tratar de uma contraprestação ${ }^{487}$, isto é, não perdem a natureza jurídica de liberalidade $^{488}$.

De outro lado, a doação contemplativa, ao contrário da remuneratória, não pode ser uma recompensa ${ }^{489}$, por isso não se deve confundir uma e outra ou alocá-las como se fossem espécies de um único gênero, pois, como já se afirmou, enquanto na doação remuneratória o motivo está em compensar de alguma maneira um serviço prestado pelo donatário, na que é realizada por merecimento do beneficiário visa-se apenas premiá-lo por algum fundamento adotado pelo doador.

Além disso, o art. 540 do Código Civil de 2002, ao elencar as duas espécies junto com a doação modal, quer apenas ressaltar o caráter liberal das três modalidades e seu regime jurídico, mas não agrupá-las ontologicamente ${ }^{490}$. Por fim, dada a natureza diferente entre ambas, pois enquanto a doação por mérito é gratuita a remuneratória tem sua carga de onerosidade, o regime delas tem efeitos diferentes ${ }^{491}$.

Por fim, se a doação remuneratória ultrapassar a legítima, deverá sofrer redução $^{492}$, e se a causa remunerada for ilícita, a liberalidade é nula ${ }^{493}$.

Do que aqui se expôs, deve-se considerar que pode o doador, ao usar a doação no desiderato de aplainar sua sucessão, consignar no instrumento de doação a remuneração almejada, atentando-se à necessidade de aceite expresso para as liberalidade não-puras.

A vantagem de fazer constar o quanto se remunera está em permitir, da mesma forma que a contemplativa, que o donatário seja devidamente recompensado e torne possível

\footnotetext{
${ }^{484}$ LUCIANO DE CAMARGO PENTEADO, Doação (...), cit., p. 100; PAULO NADER, Curso (...), cit., p. 230.

${ }^{485}$ O já citado art. 770 do Código Civil italiano também se conduz nesse sentido, o que leva a doutrina italiana a distinguir três subespécies de doação remuneratória: por reconhecimento, contemplativa e por remuneração especial. Conferir: TANIA CASSANDRO, Le Donazione, cit. pp. 65-74.

${ }^{486}$ VICENTE SABINO JÚNIOR, Contrato (...), cit., p. 40.

${ }^{487}$ LUCIANO DE CAMARGO PENTEADO, Doação (...), cit., p. 176.

${ }^{488}$ VICENTE SABINO JÚNIOR, Contrato (...), cit., p. 40.

${ }^{489}$ CARLOS ROBERTO GONÇALVES, Direito (...), cit., p. 264.

${ }^{490}$ MANUEL ALBADALEJO GARCÍA e SILVIA DIAZ ALABART, La Donación, cit., pp. 360-362.

${ }^{491}$ MANUEL ALBADALEJO GARCÍA e SILVIA DIAZ ALABART, La Donación, cit., pp. 381-383.

${ }^{492}$ PABLO STOLZE GAGLIANO, O Contrato (...), cit., p. 121.

${ }^{493}$ LUIZ GUILHERME LOUREIRO, Curso (...), cit., p. 515.
} 
desfazer-se o ato por erro de pessoa, ou então alegar pagamento caso esse último opte por cobrar o débito em juízo.

Outrossim, pode acontecer de o doador querer dar privilégio especial ao donatário remunerado (que seja um seu descendente) na partilha de bens, sendo necessário, por isso, fazer constar a natureza remuneratória da liberalidade, permitindo, assim, que o beneficiário da alienação goze do quanto posto no art. $2.011^{494}$ do Código Civil de 2002.

Deve-se chamar atenção, ainda, para o quanto se afirmou em relação à doação contemplativa e à modal, a fim de se curar para que não haja dúvidas quanto à liberalidade, seja calculando as diferenças econômicas, seja apondo cláusula em que as partes concordam com valor da doação a maior.

\section{6) Doação conjuntiva}

A doação conjuntiva é aquela prevista no art. $551^{495}$, caput, do Código Civil de 2002, que consiste na doação feita de um bem a mais de uma pessoa, sendo que, se não houver expressa manifestação do doador, presume-se ter sido feita em quotas iguais ${ }^{496}$.

Com efeito, a previsão legal de divisão equânime na doação conjuntiva goza de presunção, sendo que a prova em contrário deverá ser feita por meio do instrumento de doação, mas se omisso o instrumento, admissíveis outros meios probantes, porém o fato objeto da prova será a declaração do doador, não sua intenção, o mesmo valendo para as doações manuais $^{497}$.

\section{MANUEL ALBADALEJO GARCÍA e SILVIA DIAZ ALABART ${ }^{498}$ explicam} esse posicionamento utilizando-se da natureza contratual da doação, de modo a ser admissível a prova da vontade do contratante, mas não basta a declaração do doador, sendo necessária também provar a aceitação dos donatários em relação à vontade do beneficiário, pois se trata

\footnotetext{
494 Art. 2.011. "As doações remuneratórias de serviços feitos ao ascendente também não estão sujeitas a colação".

${ }^{495}$ Art. 551. "Salvo declaração em contrário, a doação em comum a mais de uma pessoa entende-se distribuída entre elas por igual".

496 ARNALDO MARMITT, Doação, cit., p. 45; LIMONGI FRANÇA, Manual (...), cit., p. 100; NELSON ROSENVALD, Contratos (...), cit., p. 594; ROGÉRIO MARRONE DE CASTRO SAMPAIO, Direito (...), cit., p. 127.

497 AGOSTINHO ALVIM, Da Doação, cit., pp. 210-211. Admitindo que se extraia do contexto do negócio jurídico o afastamento da presunção legal: ORLANDO GOMES, Contratos, cit., p. 240.

498 La Donación, cit., p. 167-168.
} 
de um sinalagma e, se os donatários não forem concordes com a declaração do doador, então o negócio é nulo por falta de aceite ${ }^{499}$.

Caso o bem doado a mais de uma pessoa seja indivisível, por conta da regra do mencionado dispositivo legal, os donatários se tornarão condôminos ${ }^{500}$. Se o objeto doado for uma universalidade de bens e não houver destinação específica de proprietários, então cada donatário participará sobre a cota ideal de cada unidade ${ }^{501}$.

Outrossim, o parágrafo único desse mesmo dispositivo legal estabelece que se os donatários forem cônjuges, na morte de um deles, o bem passa a pertencer totalmente ao outro $^{502}$. Há autores ${ }^{503}$ que opinam pela extensão da regra aos companheiros de uma união estável, mas como se trata de inovação no tratamento legal ao regime de bens, sua aplicação é restritiva, pelo que descabida na hipótese a interpretação extensiva da lei ${ }^{504}$.

É de se ponderar, além disso, que tal norma representa uma exceção ao regime legal da sucessão, colocando o cônjuge sobrevivente em uma situação de privilégio em relação aos demais herdeiros necessários ${ }^{505}$. CLÓVIS BEVILAQUA ${ }^{506}$ explica que tal benesse se justifica pela situação especial dos cônjuges, especialmente os casados no regime da comunhão universal, pois o benefício que um recebe é de ambos. Todavia, para que haja tal efeito, é preciso haver doação conjuntiva, pelo que se o donatário for apenas um dos nubentes, então não há a incidência do parágrafo único do art. 551 do Código Civil de $2002^{507}$.

499 Não admitindo o afastamento da presunção legal por elemento exterior ao instrumento: ARNALDO RIZZARDO, Contratos, cit., p. 463; FLÁVIO AUGUSTO MONTEIRO DE BARROS, Manual (...), cit., p. 349; PAULO DE TARSO VIEIRA SANSEVERINO, Contratos (...), cit., p. 139; PAULO GERALDO DE OLIVEIRA MEDINA, A Doação, cit., pp. 470-471.

${ }^{500}$ FRANCISCO GLAUBER PESSOA ALVES, Das Várias (...), cit., p. 909; MARIA HELENA DINIZ, Curso (...), cit., p. 264; PAULO LÔBO, Das Várias (...), cit., p. 345; PAULO NADER, Curso (...), cit., p. 236.

${ }^{501}$ PAULO LÔBO, Das Várias (...), cit., p. 345.

${ }^{502}$ Art. 551, Parágrafo único. "Se os donatários, em tal caso, forem marido e mulher, subsistirá na totalidade a doação para o cônjuge sobrevivo".

${ }^{503}$ ARNALDO RIZZARDO, Contratos, cit., p. 464 (por outro lado, o autor restringe a aplicação do benefício até na doação em vista de casamento futuro); PABLO STOLZE GAGLIANO, $O$ Contrato (...), cit., pp. 122-123; PAULO DE TARSO VIEIRA SANSEVERINO, Contratos (...), cit., p. 75.

${ }^{504}$ No mesmo sentido: FLÁVIO TARTUCE, Direito (...), cit., p. 323. Por conta desse fundamento, há também os que entendem pela não aplicação da regra aos cônjuges unidos sob o regime da separação voluntária ou obrigatória de bens [NATAL NADER, Questões Relativas à Doação (II), cit., p. 470].

${ }^{505}$ PABLO STOLZE GAGLIANO, $O$ Contrato (...), cit., p. 122; VICENTE SABINO JÚNIOR, Contrato (...), cit., p. 38. Há quem se posicione contrariamente a esse entendimento: PAULO LÔBO, Das Várias (...), cit., p. 345 .

${ }^{506}$ Código (...), cit., p. 282.

${ }^{507}$ CARLOS ROBERTO GONÇALVES, Direito (...), cit., p. 267; PAULO NADER, Curso (...), cit., p. 236. Esse é também o entendimento perfilado pelo Superior Tribunal de Justiça: $3^{a}$ T., R. Esp. n. 324.593/SP, rel. 
O fato de o cônjuge donatário supérstite se tornar proprietário de toda a coisa não guarda nenhuma relação com o direito de acrescer, que é típico do direito sucessório ${ }^{508}$, e nem com o fideicomisso, mas se trata de regra sui generi ${ }^{509}$. Por não ser norma de ordem pública, é passível de disposição pelo doador ${ }^{510}$. Vale ponderar, ainda, não ser aplicável as regras da doação conjuntiva às doações antenupciais, bem como não ser o mandamento do art. 551 do Código civil atrelada ao regime de bens ${ }^{511}$.

No direito civil espanhol é possível que as partes de um contrato de doação estipulem que haja o mesmo efeito do parágrafo único do art. 551 do Código Civil de 2002 entre quaisquer donatários não-cônjuges ${ }^{512}$, mas não é possível haver tal aplicação no sistema pátrio, dada a excepcionalidade do direito de acrescer inter vivos e a barreira do parágrafo único do art. $547^{513}$ do Código Civil de $2002^{514}$.

NANCY ANDRIGHI, j. 16-09-2003.

${ }^{508}$ CLÓVIS BEVILAQUA afirma que a regra da doação conjuntiva é a confirmação de que o direito de acrescer não é presumido nos atos inter vivos [Código (...), cit., p. 282].

${ }^{509}$ AGOSTINHO ALVIM, Da Doação, cit., p. 212. Há, porém, quem entenda não ser descabido falar em direito de acrescer [neste sentido: CARVALHO SANTOS, Código (...), cit., p. 423; PAULO DE TARSO VIEIRA SANSEVERINO, Contratos (...), cit., p. 140].

${ }^{510}$ AGOSTINHO ALVIM, Da Doação, cit., p. 213; FLÁVIO AUGUSTO MONTEIRO DE BARROS, Manual (...), cit., p. 349; NATAL NADER, Questões Relativas à Doação (II), cit., p. 470; PAULO DE TARSO VIEIRA SANSEVERINO, Contratos (...), cit., p. 141; PAULO NADER, Curso (...), cit., p. 236. Com isso, fica superada a questão da compatibilidade entre a doação conjuntiva e a cláusula de reversão, que segundo certa doutrina acarreta a anulação da primeira e que deve prevalecer o acréscimo em favor do cônjuge [neste sentido: FRANCISCO GLAUBER PESSOA ALVES, Das Várias (...), cit., pp. 909-911]. De outra banda, há quem afirme haver perfeita compatibilização entre ambas (PAULO GERALDO DE OLIVEIRA MEDINA, $A$ Doação, cit., p. 471).

511 AGOSTINHO ALVIM, Da Doação, cit., p. 213. MANUEL ALBADALEJO GARCÍA e SILVIA DIAZ ALABART entendem ser esse entendimento perfeito, mas acrescentam que interpretando a lei civil espanhola é possível estender o direito de acrescer à doação feita em vista de casamento futuro ( $L a$ Donación, cit., pp. 174-176).

${ }^{512}$ MANUEL ALBADALEJO GARCÍA e SILVIA DIAZ ALABART, La Donación, cit., p. 169.

O art. 944. ("Doação conjunta") do Código Civil português também permite ao doador estipular que o objeto doado acresça ao patrimônio dos outros codonatários com a morte ou renúncia de um deles: "1. A doação feita a várias pessoas conjuntamente considera-se feita por partes iguais, sem que haja direito de acrescer entre os donatários, salvo se o doador houver declarado o contrário. 2. O disposto no número anterior não prejudica o direito de acrescer entre usufrutuários, quando o usufruto tenha sido constituído por doação". Consultar a respeito: MANUEL BAPTISTA LOPES, Das Doações, cit., pp. 29-31.

Também o direito norte-americano prevê a possibilidade de se instaurar uma espécie de condomínio (não é exata a comparação porque a property não corresponde ao direito de propriedade do sistema civil pátrio, logo as partes não são condôminos), no qual se prevê a transferência automática de uma parte a outra caso um deles venha a falecer, em detrimento dos herdeiros, ato esse que recebe o nome de joint-and-survivor arrangements [ELIAS CLARK et al., Cases (...), cit., pp. 455-456].

${ }^{513}$ Art. 547. "O doador pode estipular que os bens doados voltem ao seu patrimônio, se sobreviver ao donatário. Parágrafo único. Não prevalece cláusula de reversão em favor de terceiro".

514 FLÁVIO AUGUSTO MONTEIRO DE BARROS, Manual (...), cit., pp. 349-350; PAULO DE TARSO VIEIRA SANSEVERINO, Contratos (...), cit., p. 141. Há, porém, quem entenda pela possibilidade de o doador dispor que o bem doado ao codonatário acresça ao outro quando do seu falecimento [JONES FIGUEIRÊDO ALVES, Código (...), cit., p. 455; MARIA HELENA DINIZ, Curso (...), cit., p. 264; NATAL NADER, Questões Relativas à Doação (II), cit., p. 470; NELSON ROSENVALD, Contratos (...), cit., p. 594; 
O presente tipo de doação tem extrema relevância no manejo da doação para preparação sucessória, pois em muitos casos haverá um conjunto de donatários, devendo-se, por isso, atentar-se ao regime do art. 551 do Código Civil de 2002, que integra a vontade do alienante quando ele não indica a correspondente participação de cada donatário.

Assim, deverá o doador ter claramente em conta a medida de participação de cada beneficiário, bem como as consequências de transformá-los em condôminos, se o caso.

Outrossim, caso almeje que o objeto doado não passe totalmente ao cônjuge do donatário sem que seja antes partilhado entre os descendentes do casal, deverá evitar doar a ambos o mesmo objeto ${ }^{515}$.

\section{7) Doação em contemplação a casamento futuro e sua prole}

A doação em contemplação a casamento futuro está regulamentada no art. $546^{516}$ do Código Civil de 2002, que prevê sua possibilidade, impede sua impugnação por falta de aceite e estabelece sua ineficácia apenas na hipótese de não realização do matrimônio ${ }^{517}$.

Há quem sustente que para a doação se enquadrar na espécie, nos moldes do supracitado dispositivo legal, não se trata de matrimônio provável ou possível, nem de amparo a possível casamento, e nem de condição cujo evento futuro e incerto seja o matrimônio, mas sim a perspectiva de casamento com pessoa certa e determinada, o que se dá no noivado, aferível faticamente ${ }^{518}$.

SÍlVIO DE SALVO VENOSA, Direito (...), cit., p. 135; WASHINGTON DE BARROS MONTEIRODABUS MALUF, Curso (...), cit., pp. 175-176].

515 Cumpre considerar ainda, a esse respeito, um precedente do Superior Tribunal de Justiça, no qual se considerou que, se o donatário for casado no regime da comunhão parcial de bens, e não houver menção no contrato de doação, então o bem doado não se comunica com o outro cônjuge ( $3^{\mathrm{a}}$ T., R. Esp. n. 1.318.599/SP, rel. NANCY ANDRIGHI, j. 23-04-2013.

${ }^{516}$ Art. 546. "A doação feita em contemplação de casamento futuro com certa e determinada pessoa, quer pelos nubentes entre si, quer por terceiro a um deles, a ambos, ou aos filhos que, de futuro, houverem um do outro, não pode ser impugnada por falta de aceitação, e só ficará sem efeito se o casamento não se realizar".

$517 \mathrm{O}$ art. 785 ("Donazione in riguardo di matrimonio") do Código Civil italiano se expressa em termos semelhantes, ao mesmo tempo em que dá providências específicas: "1. La donazione fatta in riguardo di un determinato futuro matrimonio, sai dagli sposi tra loro, sia da altri a favore di uno o di entrambi gli sposi o dei figli nascituri da questi, si perfeziona senza bisogno che sia accettata, ma non produce effetto finché non segua il matrimonio. 2. L'annullamento del matrimonio importa la nullità della donazione. Restano tuttavia salvi i diritti acquistati dai terzi di buona fede tra il giorno del matrimonio e il passaggio in giudicato della sentenza che dichiara la nullità del matrimonio. Il coniuge di buona fede non è tenuto a restituire i frutti percepiti anteriormente alla domanda di annullamento del matrimonio. 3. La donazione in favore di figli nascituri rimane efficace per i figli rispetto ai quali si verificano gli effetti del matrimonio putativo". Consultar: VINCENZO TAVASSI, La Donazione, cit., pp. 44-46.

518 AGOSTINHO ALVIM, Da Doação, cit., pp. 116-117. No mesmo sentido: NELSON ROSENVALD, Contratos (...), cit., p. 590; PAULO GERALDO DE OLIVEIRA MEDINA, A Doação, cit., p. 467 (o autor 
Para alguns autores, a não realização do matrimônio não é hipótese de nulidade, pois não se trata deste plano ${ }^{519}$. Assim, a inexistência do matrimônio induz à inexistência do contrato de doação ${ }^{520}$. Há ${ }^{521}$, porém, quem sustente ser o futuro casamento um fator de eficácia $^{522}$.

De outro lado, há ${ }^{523}$ quem afirme que, se não houver prazo para a celebração do casamento, os efeitos da benesse perdurarão até a morte do donatário, pois, até então, em tese, poderá contrair núpcias com determinada pessoa, mas nada impede que haja renúncia explícita do matrimônio por ambos ${ }^{524}$.

As doações feitas em vista de casamento futuro abrangem as doações antenupciais, como o dote ou joias esponsalícias ${ }^{525}$, sendo que a doação feita pelos nubentes entre si terá a mesma natureza de pacto antenupcial ${ }^{526}$, pelo que deverão se realizar por meio de escritura pública, nos termos do art. $1.653^{527}$ do Código Civil de $2002^{528}$, mas terá a mesma

não fala na específica condição de noivo, porém ensina ser a iminência do matrimônio um pré-requisito); PAULO LÔBO, Das Várias (...), cit., p. 320. Também não se aplica à união estável [FLÁVIO TARTUCE, Direito (...), cit., p. 319]. Em sentindo contrário, entendendo que o casamento futuro se trata de simples condição, de modo que não precisa haver noivado: ARNALDO RIZZARDO, Contratos, cit., p. 465.

${ }^{519}$ PABLO STOLZE GAGLIANO, O Contrato (...), cit., p. 124. Em sentindo contrário, opinando que a não realização do matrimônio induz à invalidade da doação: JONES FIGUEIRÊDO ALVES, Código (...), cit., p. 449.

${ }^{520}$ ARNALDO MARMITT, Doação, cit., p. 28; PAULO LÔBO, Direito (...), cit., p. 300; VICENTE SABINO JÚNIOR, Contrato (...), cit., p. 116.

${ }^{521}$ ARNALDO RIZZARDO, Contratos, cit., p. 465; EDUARDO ESPINOLA, Dos Contratos (...), cit. p. 170; FRANCISCO GLAUBER PESSOA ALVES, Das Várias (...), cit., p. 901; LUIZ GUILHERME LOUREIRO, Curso (...), cit., p. 514; MARIA HELENA DINIZ, Curso (...), cit., p. 25; PAULO DE TARSO VIEIRA SANSEVERINO, Contratos (...), cit., p. 115; SYLVIO CAPANEMA DE SOUZA, Das Várias (...), cit., p. 169; VINCENZO TAVASSI, La Donazione, cit., p. 46.

${ }^{522} \mathrm{Na}$ específica hipótese de doação entre os nubentes, o direito norte-americano leva em conta o comportamento das partes, de maneira que se o desfazimento do noivado se der por mútuo consentimento, a doação se desfaz, assim como se a dissolução tiver se dado por culpa do donatário, mantém-se válida a liberalidade se o culpado pelo rompimento for a pessoa do doador [ELIAS CLARK et al., Cases (...), cit., pp. 450-451 (os autores apontam também a dificuldade de tal posicionamento em face das diversas decisões que afastam a culpa em matéria matrimonial)].

Já no âmbito do Código Napoleônico, a não realização do matrimônio leva à caducidade da liberalidade, conforme enuncia o art. 1.088 desse diploma legal: "Toute donation faite en faveur du mariage sera caduque si le mariage ne s'ensuit pas" [cf. também: PAUL DELNOY, Le Libéralités (...), cit., p. 62].

${ }_{523}^{523}$ ARNALDO MARMITT, Doação, cit., p. 35; CARVALHO SANTOS, Código (...), cit., pp. 378-379.

${ }^{524}$ De outro lado, FRANCISCO GLAUBER PESSOA ALVES entende que o doador deve estipular um prazo já na formação do contrato [Das Várias (...), cit., p. 901].

${ }_{525}^{525}$ LUCIANO DE CAMARGO PENTEADO, Doação (...), cit., p. 180.

${ }^{526}$ AGOSTINHO ALVIM, Da Doação, cit., pp. 142-143; SÍLVIO DE SALVO VENOSA, Direito (...), cit., p. 135.

${ }^{527}$ Art. 1.653. "É nulo o pacto antenupcial se não for feito por escritura pública, e ineficaz se não lhe seguir o casamento".

528 AGOSTINHO ALVIM, Da Doação, cit., pp. 119-120; ARNALDO MARMITT, Doação, cit., p. 34; ARNALDO RIZZARDO, Contratos, cit., pp. 465-466; NELSON ROSENVALD, Contratos (...), cit., p. 590; SÍlVIO DE SALVO VENOSA, Direito (...), cit., p. 135; SYLVIO CAPANEMA DE SOUZA, Das Várias (...), cit., p. 99. Há quem entenda que se não se realizar por escritura pública, então deverá ser regida pelas 
exigência de forma da doação em geral quando realizada por terceiro ${ }^{529}$. De qualquer modo, deverá haver expressa menção no instrumento ${ }^{530}$.

Apesar de a doação em vista de casamento futuro ser uma doação com condição suspensiva (isto é, o casamento), nada impede que haja a tradição do bem doado ou a transcrição da escritura no cartório do registro de imóveis, porém a efetiva transferência da propriedade sobre a coisa somente se dará com a consumação do evento futuro e incerto ${ }^{531}$. Assim, na doação em vista de casamento futuro o bem não se transmite enquanto não se verificar o matrimônio, pois só a partir daí é que terá plena eficácia ${ }^{532}$. Não havendo o casamento, então o bem doado deverá ser devolvido ${ }^{533}$.

Quanto ao aceite, há autores que entendem que uma das peculiaridades dessa espécie de doação é justamente o fato de que ele é dispensado ${ }^{534}$. Outros, porém, esposam a tese de que a hipótese não é de dispensa da aceitação da benesse, pois o casamento, por si,

normas de uma doação comum, sem os privilégios da hipótese comentada [CARVALHO SANTOS, Código (...), cit., p. 378].

PAUL DELNOY explica que a doação em vista de casamento futuro, no sistema civil francês, não precisa necessariamente se realizar sob a forma de um pacto antenupcial (“contrat de mariage”) [Le Libéralités (...), cit., p. 62].

${ }^{529}$ PAULO DE TARSO VIEIRA SANSEVERINO, Contratos (...), cit., p. 115; SERPA LOPES, Curso (...), cit., p. 413. PAULO LÔBO entende que a possibilidade de a doação em vista de casamento futuro ser feita por terceiro, que guardaria aparência com o extinto regime dotal, é inconstitucional e de ética duvidosa, por representar ingerência externa na escolha a ser feita pelos nubentes, haja vista que a oferta liberal do doador induziria a opção pelo casamento com certa pessoa, ferindo o livre planejamento familiar [Direito (...), cit., p. 300. Esposando mesmo parecer: NELSON ROSENVALD, Contratos (...), cit., p. 590], mas tal posição parece carecer de fundamento, pois ao donatário é permitido recusar o dom e, ao mesmo tempo, indução não é o mesmo que coação ou quaisquer outras hipóteses de defeitos do negócio jurídico, de modo que inexiste conflito com a Constituição Federal. Concernente à questão ética, apenas a pessoa patológica ou moralmente fraca se veria compelida a se casar na hipótese. À primeira, o direito já assegura a via das nulidades, ao passo que à segunda nada pode ser feito, pois sua fraqueza é fruto das suas escolhas, sem prejuízo de se poder discutir sua ação dolosa. Outrossim, o Estado atual viabiliza a ambos a hipótese do divórcio [sobre o tema, confrontar: EDUARDO ESPINOLA, Dos Contratos (...), cit., pp. 183-186. Opinando pela ausência de imoralidade na hipótese: SYLVIO CAPANEMA DE SOUZA, Das Várias (...), cit., p. 169]. De qualquer forma, a hipótese presente somente ocorre "em contemplação de casamento futuro com certa e determinada pessoa", conforme reza o mencionado art. 546 do Código Civil de 2002, de modo que os nubentes já se escolheram mutuamente (SÍLVIO DE SALVO VENOSA comenta que já deve haver promessa de casamento entre os nubentes [Direito (...), cit., p. 135]), independentemente da liberalidade [sobre a diferença entre o regime do dispositivo legal ora comentado e do extinto dote: SYLVIO CAPANEMA DE SOUZA, Das Várias (...), cit., p. 171; sobre a relação do dote, da dotação e da doação no sistema do Código Civil de 1916 , consultar: PONTES DE MIRANDA, Tratado (...), cit., pp. 200-201].

${ }^{530}$ PAULO GERALDO DE OLIVEIRA MEDINA, A Doação, cit., p. 467.

531 AGOSTINHO ALVIM, Da Doação, cit., pp. 120-122. No mesmo sentido: PAULO LÔBO, Das Várias (...), cit., p. 322; PAULO NADER, Curso (...), cit., p. 234.

532 ARNALDO MARMITT, Doação, cit., p. 33; PAULO DE TARSO VIEIRA SANSEVERINO, Contratos (...), cit., p. 76.

${ }^{533}$ PAULO LÔBO, Direito (...), cit., p. 301.

534 ANTÔNIO CHAVES, Lições (...), cit., p. 246; ARNALDO MARMITT, Doação, cit., p. 34; CLÓVIS BEVILAQUA, Código (...), cit., p. 277; LUIZ GUILHERME LOUREIRO, Curso (...), cit., p. 504; MARIA HELENA DINIZ, Tratado (...), cit., p. 77; SYLVIO CAPANEMA DE SOUZA, Das Várias (...), cit., pp. 169170; WASHINGTON DE BARROS MONTEIRO-DABUS MALUF, Curso (...), cit., p. 168. 
aperfeiçoa o ato, isto é, já é aceite, de modo que, no caso, o silêncio é aceitação, mas pode o donatário rejeitar a liberalidade, pelo que o doador deverá tratar de dar plena ciência ao beneficiário da benesse que lhe é endereçada ${ }^{535}$. Com efeito, PABLO STOLZE GAGLIANO $^{536}$ afirma que o donatário pode rejeitar a doação, sendo que a vedação de impugnação tem por destinatário o doador ${ }^{537}$.

Com fundamento na regra do art. $314^{538}$ do Código Civil de 1916, AGOSTINHO $\mathrm{ALVIM}^{539}$ via na doação em vista de casamento futuro uma hipótese de doação causa mortis, pois a lei permitia que o donatário estabelecesse a transferência do bem para depois de sua morte $^{540}$. Se um dos filhos falecerem antes do donatário, seus herdeiros têm direito à doação por conta da representação. Explica o autor que esse dispositivo foi inspirado no Código de Napoleão, pelo que o interpreta com inspiração na doutrina e jurisprudência francesa, donde conclui que a doação somente se aperfeiçoa com a morte do donatário, que até então fica no uso e gozo da coisa, e que o ato se rege não pelo regime sucessório, mas sim no âmbito do contrato de doação. No entanto, o autor se afasta da fonte gálica ao afirmar que o doador não poderá mais alienar o bem doado a qualquer título, mesmo que a propriedade só venha a se transferir com sua morte. Tal discussão, porém, perdeu o seu contexto com o advento do Código Civil de 2002, que não incorporou tal artigo ao seu corpo.

No que toca à doação feita pelos nubentes entre si, há o problema da existência de eventual direito de retenção na hipótese de injusto rompimento por um dos noivos. A esse respeito, AGOSTINHO $\mathrm{ALVIM}^{541}$ ensina que não existe tal direito, devendo-se resolver eventuais danos em indenização, com fundamento em culpa extracontratual, ponderando, porém, ser difícil a aferição de culpa na hipótese, por se tratar de questões delicadas. De

\footnotetext{
535 AGOSTINHO ALVIM, Da Doação, cit., pp. 119-120; CARVALHO SANTOS, Código (...), cit., pp. 329 e 378; CLÓVIS BEVILAQUA, Código (...), cit., p. 270; JONES FIGUEIRÊDO ALVES, Código (...), cit., p. 449; PAULO NADER, Curso (...), cit., p. 234; SERPA LOPES, Curso (...), cit., p. 413; SÍlVIO DE SALVO VENOSA, Direito (...), cit., p. 128 (o autor afirma que a realização do casamento é aceitação tácita).

${ }^{536}$ O Contrato (...), cit., pp. 124-125.

537 Também o Código Napoleônico afasta a necessidade de aceite expresso na hipótese, no seu art. 1.087: "Les donations faites par contrat de mariage ne pourront être attaquées ni déclarées nulles sous prétexte de défaut d'acceptation", que, segundo PAUL DELNOY, trata-se de dispensa de formalidade [Le Libéralités (...), cit., p. 63].

538 Art. 314. "As doações estipuladas nos contratos antenupciais, para depois da morte do doador, aproveitarão aos filhos do donatário, ainda que este faleça antes daquele".

${ }^{539}$ Da Doação, cit., pp. 126-132. No mesmo sentido: ANTÔNIO CHAVES, Lições (...), cit., p. 246; CLÓVIS BEVILAQUA, Código (...), cit., p. 277.

${ }^{540}$ CARVALHO DE MENDONÇA, Contratos (...), cit., p. 93.

${ }^{541}$ Da Doação, cit., pp. 135-142.
} 
qualquer modo, a separação, divórcio ou estado de viuvez não importa na extinção da doação ${ }^{542}$.

Outrossim, no âmbito do Código Civil de 1916, a doação feita entre os nubentes não podia exceder a parte legítima ${ }^{543}$, por expressa disposição do art. $312^{544}$ daquele diploma legal. Tal dispositivo não foi retomado na atual codificação, o que seria desnecessário, pois tal vedação se aplica a todas as doações ${ }^{545}$.

Ainda no campo da doação dos nubentes entre si, há quem entenda, interpretando o art. 263, VIII ${ }^{546}$, do Código Civil de 1916, que os bens assim doados serão incomunicáveis se o matrimônio se realizar no regime da comunhão universal de bens, com a cláusula de incomunicabilidade. Se não houver tal cláusula, a doação se consome pelo regime de bens ${ }^{547}$. Tal interpretação é perfeitamente aplicável no sistema civil atual, à luz do art. $1.668, \mathrm{IV}^{548}$, do Código Civil de 2002.

No caso de a doação ser feita em favor da prole eventual do casal, a propriedade da coisa doada é dos filhos que advirão, o que afasta a hipótese de fideicomisso, pois não se trata de propriedade sucedida em um segundo ato, mas transferência direta de patrimônio. No entanto, os pais têm o uso e o gozo sobre a coisa, o que aproxima tal doação do usufruto, e assim o é mesmo quando o bem for fungível, devendo os genitores entregarem aos donatários o equivalente quando deixarem de ser representantes legais deles ${ }^{549}$.

${ }^{542}$ CARLOS ROBERTO GONÇALVES, Direito (...), cit., p. 266.

${ }^{543}$ CLÓVIS BEVILAQUA, Código (...), cit., p. 277; SERPA LOPES, Curso (...), cit., p. 413.

${ }^{544}$ Art. 312. "Salvo o caso de separação obrigatória de bens (art. 258, parágrafo único), é livre aos contraentes estipular, na escritura antenupcial, doações recíprocas, ou de um ao outro, contanto que não excedam à metade dos bens do doador (arts. 263, VIII, e 232, II)".

${ }^{545}$ A lei espanhola tem disposição idêntica ao art. 312 do revogado Código Civil para tratar da doação de bens futuros entre os noivos: Art. 1.341. "1. Por razón de matrimonio los futuros esposos podrán donarse bienes presentes. 2. Igualmente podrán donarse antes del matrimonio en capitulaciones bienes futuros, sólo para el caso de muerte, y en la medida marcada por las disposiciones referentes a la sucesión testada", que é também aplicável às doações de bens presentes (a respeito: MANUEL ALBADALEJO GARCÍA e SILVIA DIAZ ALABART, La Donación, cit., pp. 591-592).

${ }^{546}$ Art. 263. "São excluídos da comunhão: (Redação dada pela Lei no 4.121, de 27.8.1962) [...]; VIII - as doações antenupciais feitas por um dos cônjuges ao outro com a cláusula de incomunicabilidade (art. 312); (Redação dada pela Lei $\mathrm{n}^{\circ}$ 4.121, de 27.8.1962)".

${ }^{547}$ AGOSTINHO ALVIM, Da Doação, cit., pp. 143-145.

${ }^{548}$ Art. 1.668. "São excluídos da comunhão: [...] IV - as doações antenupciais feitas por um dos cônjuges ao outro com a cláusula de incomunicabilidade".

${ }^{549}$ AGOSTINHO ALVIM, Da Doação, cit., pp. 123-124. Da mesma forma, se não tiverem filhos, entregarão ao doador: PAULO LÔBO, Direito (...), cit., p. 301. 
Mas a peculiaridade presente nesse caso é que o donatário é inexistente ${ }^{550}$, o que em si não acarreta problema, pois é indiscutível ser admissível a doação com condição, e se coaduna perfeitamente com a doação em favor de nascituro ou entidade futura. Além do mais, fica resguardada a contratualidade da doação na hipótese, haja vista que a lei dispensa o aceite $^{551}$.

De qualquer forma, por conta desta condição, AGOSTINHO ALVIM ${ }^{552}$ entende que a propriedade do objeto da benesse somente se vem a transferir não com o casamento, mas sim com o nascimento do primeiro filho, sendo que se sobrevierem outros filhos, tornarse-ão condôminos do primeiro, motivo pelo qual deverão os pais manterem-se na posse dos bens, até que se torne impossível haverem outros filhos daquele matrimônio, o que só ocorre com a morte de um dos cônjuges, sendo que, se for o marido, deve-se esperar dez meses. Outrossim, considera-se cumprida a condição suspensiva de prole eventual do casal quando adotam um filho ${ }^{553}$.

Ainda que o doador faleça antes do nascimento da prole eventual, seus herdeiros deverão cumprir a liberalidade realizada quando do nascimento do beneficiário ${ }^{554}$.

Por fim, como já foi dito, a doação de joias esponsalícias também se enquadram na doação em vista de casamento futuro. O art. 263, IX ${ }^{555}$, do Código Civil de 1916, dispunha que eram incomunicáveis, consistindo nos adornos dados pelo esposo, sendo que o emprego do termo "esposo" no dispositivo se dá no sentido do que hoje comumente se entende por noivo. Como o Código Civil de 1916 emprega somente "esposo", as doações feitas pela

550 ANTÔNIO CHAVES, Lições (...), cit., p. 246; ARNALDO MARMITT, Doação, cit., p. 34; CLÓVIS BEVILAQUA, Código (...), cit., p. 277; PAULO DE TARSO VIEIRA SANSEVERINO, Contratos (...), cit., p. 115; PAULO LÔBO, Direito (...), cit., p. 301; SERPA LOPES, Curso (...), cit., p. 413; SYLVIO CAPANEMA DE SOUZA, Das Várias (...), cit., pp. 91 e 170. Sobre o problema da capacidade civil da pessoa inexistente, na hipótese, consultar: TORRENTE, La Donazione, cit., pp. 362-364.

${ }_{551}^{552}$ BIONDI, Le Donazioni, cit., p. 251.

${ }^{552}$ Da Doação, cit., pp. 125. No mesmo sentido: CARLOS ROBERTO GONÇALVES, Direito (...), cit., p. 266; PAULO DE TARSO VIEIRA SANSEVERINO, Contratos (...), cit., p. 116. Há quem pense que o limite final deve ser a fertilidade da mulher: PAULO LÔBO, Direito (...), cit., p. 301.

${ }^{553}$ PAULO DE TARSO VIEIRA SANSEVERINO, Contratos (...), cit., pp. 116-117. Há quem entenda que tal efeito somente se alcança quando o doador o faça constar expressamente no instrumento [neste sentido: NELSON ROSENVALD, Contratos (...), cit., p. 590; SÍlVIO DE SALVO VENOSA, Direito (...), cit., p. 135]. Ao contrário, TORRENTE ensina que, se a lei enuncia apenas o termo "fillho", a presunção é de que não há aí quaisquer distinções, pelo que o silêncio do doador induz à presunção de que também são contemplados os filhos adotivos (La Donazione, cit., pp. 364-365).

${ }_{555}^{554}$ PAULO LÔBO, Das Várias (...), cit., p. 321.

${ }^{555}$ Art. 263. "“...] IX - as roupas de uso pessoal, as joias esponsalícias dadas antes do casamento pelo esposo, os livros e instrumentos de profissão e os retratos da família; (Redação dada pela Lei n ${ }^{\circ} 4.121$, de 27.8.1962)". 
esposa ingressam na comunhão ${ }^{556}$, entendimento esse que não teria guarida no atual sistema, não apenas por falta de amparo legal, mas também pela igualdade entre homem e mulher resguardada pela Constituição.

Nesse sentido, LUCIANO DE CAMARGO PENTEADO ${ }^{557}$ aduz que a doação de joias esponsalícias, por quaisquer dos cônjuges, tornam-na incomunicável, desde que se realize por escritura pública. Com efeito, justamente por ser forma de doação antenupcial, vigora o entendimento de que, para ser válida, deverá a doação de joia esponsalícia ser feita por escritura pública, sob pena de nulidade ${ }^{558}$.

Não obstante, mesmo entendendo que a doação de joias esponsalícias também se enquadra nas doações antenupciais, pelo que deverá se realizar por meio de escritura pública, e a não observância dessa formalidade inquina o ato de nulidade, AGOSTINHO ALVIM ${ }^{559}$ afirma que, como assim não se faz na realidade, o resultado prático desse entendimento contraria frontalmente os costumes, pelo que encampa a tese de que a doação manual feita pelo noivo também ingressaria na comunhão.

O estudo da presente espécie não apresenta relação direta com o objeto da presente pesquisa, mas elucida o doador, caso almeje, na estrutura sucessória planejada, doar a noivos, a fim de apoiá-los em sua vida matrimonial.

A externalização do negócio por meio de escritura pública já é um pressuposto, devendo-se cuidar apenas da identificação dos donatários, nomeando os noivos e afirmando expressamente que estão incluídos sua futura prole, caso assim o deseje, dispondo ainda sobre os filhos eventualmente reconhecidos e adotados.

Importa ainda, no caso de doação a prole futura, dispor sobre a administração dos bens, assim como o limite de tempo que se deverá aguardar para vinda de toda a prole, para que os bens doados não passem aos filhos tardiamente.

\section{8) Doação com cláusula de reversão}

\footnotetext{
${ }^{556}$ AGOSTINHO ALVIM, Da Doação, cit., pp. 145-148.

${ }^{557}$ Doação (...), cit., p. 180.

${ }^{558}$ ARNALDO MARMITT, Doação, cit., p. 78.

${ }^{559}$ Da Doação, cit., pp. 148-150.
} 
O contrato de doação pode ter também cláusula de reversão, o que vem regulamentado no art. 547, caput $^{560}$, do Código Civil de 2002, no qual fica estipulado que, se o donatário falecer antes do doador, o bem doado volta a integrar o patrimônio deste ${ }^{561}$. VICENTE SABINO JÚNIOR ${ }^{562}$ leciona que se trata de uma cláusula facultativa, mas acha que deveria constar expressamente do contrato, podendo ser revogada a qualquer tempo, havendo quem ${ }^{563}$ admita que se revista da natureza de um direito potestativo uma vez que foi pactuada pelas partes.

OZÉIAS J. SANTOS ${ }^{564}$ entende até que, na hipótese de haver descumprimento do encargo, deverá constar do instrumento a cláusula de reversão para que haja o efeito de o bem doado retornar ao patrimônio do doador, o que não é necessário, pois tal efeito decorre da lei. De todo modo, no caso específico da doação modal, há ${ }^{565}$ quem entenda poder haver cláusula de reversão na espécie, mas essa somente alcançará a parte gratuita, a não ser que haja expressa manifestação de vontade das partes em contrário, mas tal posicionamento carece de base legal no sistema pátrio.

Pode-se afirmar que a morte é termo, mas a morte do donatário antes do doador é evento futuro e incerto, pelo que a reversão é condição resolutiva ${ }^{566}$, cujo efeito prático é o fato de o donatário ser titular de todos os poderes inerentes ao direito de propriedade, a qual, porém, será resolúvel, de modo que, sobrevindo a condição, resolvem-se os direitos reais e pessoais que realizou no bem, havendo, se necessário, ação judicial ao doador para reaver a

\footnotetext{
${ }^{560}$ Art. 547. "O doador pode estipular que os bens doados voltem ao seu patrimônio, se sobreviver ao donatário".

${ }^{561}$ O Código Civil português, no art. 960. ("Cláusula de reversão"), permite que a reversão se opere após a morte dos herdeiros do donatário: "1. O doador pode estipular a reversão da coisa doada. 2. A reversão dá-se no caso de o doador sobreviver ao donatário, ou a este e a todos os seus descendentes; não havendo estipulação em contrário, entende-se que a reversão só se verifica neste último caso. 3 . A cláusula de reversão que respeite a coisas imóveis, ou a coisas móveis sujeitas a registo, carece de ser registada". Consultar a respeito: MANUEL BAPTISTA LOPES, Das Doações, cit., pp. 99-103.

562 Contrato (...), cit., p. 54. Sobre a cláusula ser facultativa, confrontar: CARVALHO SANTOS, Código (...), cit., p. 380.

563 MANUEL ALBADALEJO GARCíA e SILVIA DIAZ ALABART, La Donación, cit., p. 528; PABLO STOLZE GAGLIANO, $O$ Contrato (...), cit., p. 126.

${ }^{564}$ Da Doação, cit., p. 12.

${ }^{565}$ MANUEL ALBADALEJO GARCÍA e SILVIA DIAZ ALABART, La Donación, cit., pp. 494-495.

${ }^{566}$ AGOSTINHO ALVIM, Da Doação, cit., p. 154; ARNALDO MARMITT, Doação, cit., p. 36; CARLOS ROBERTO GONÇALVES, Direito (...), cit., p. 271; ClÓVIS BEVILAQUA, Código (...), cit., p. 277; FLÁVIO AUGUSTO MONTEIRO DE BARROS, Manual (...), cit., pp. 348-349; LUIZ GUILHERME LOUREIRO, Curso (...), cit., p. 509; MANUEL ALBADALEJO GARCÍA e SILVIA DIAZ ALABART, $L a$ Donación, cit., p. 532; MARIA HELENA DINIZ, Curso (...), cit., p. 265; NATAL NADER, Questões Relativas à Doação (II), cit., p. 468; OZÉIAS J. SANTOS, Da Doação, cit., p. 18; PAULO DE TARSO VIEIRA SANSEVERINO, Contratos (...), cit., pp. 76-77 e 118; PAULO LÔBO, Das Várias (...), cit., p. 322; PLANIOL, Traité (...), cit., pp. 688-689; ROGÉRIO MARRONE DE CASTRO SAMPAIO, Direito (...), cit., p. 126.
} 
coisa, e, ademais, tal perspectiva impede que o donatário venha a consumir a substância da $\operatorname{coisa}^{567}$.

De outro lado, morrendo o doador, o direito de propriedade do donatário torna-se completo $^{568}$, tendo o mesmo efeito a hipótese de comoriência entre doador e donatário, pois se presume que o primeiro não terá sobrevivido ao segundo ${ }^{569}$. Há ${ }^{570}$ quem entenda, porém, que a interpretação da cláusula de reversão deve ser restritiva, de modo que no silêncio das partes presume-se que a vontade do disponente era que seus herdeiros recebessem o bem, ou então de que nessa hipótese a cláusula caduca ${ }^{571}$.

Ademais, considerando o aspecto acima declinado, há quem afirme ser a doação com cláusula de reversão intuitu personae, pois ficaria nítida a intenção do doador de não desejar que o bem doado passe para os herdeiros do donatário, mas apenas para o próprio beneficiário $^{572}$.

A cláusula de reversão deverá constar expressamente no instrumento ${ }^{573}$, pelo que não se adéqua bem às doações manuais, mas pode ocorrer mesmo nestas, por não ser, em si,

${ }^{567}$ AGOSTINHO ALVIM, Da Doação, cit., pp. 154-155; ARNALDO MARMITT, Doação, cit., p. 36; CARLOS ROBERTO GONÇALVES, Direito (...), cit., p. 271; CLÓVIS BEVILAQUA, Código (...), cit., p. 278; CHRISTIANO CASSETARI, Elementos (...), cit., p. 214; MANUEL ALBADALEJO GARCÍA e SILVIA DIAZ ALABART, La Donación, cit., p. 529 (por o ordenamento civil espanhol admitir o fideicomisso por ato inter vivos, os autores afirmam que a situação do negócio jurídico, na hipótese, é igual à do fideicomissário); PABLO STOLZE GAGLIANO, O Contrato (...), cit., p. 126; PAULO DE TARSO VIEIRA SANSEVERINO, Contratos (...), cit., p. 119. Não obstante, há quem entenda que o terceiro adquirente de boa-fé não tem dever de repetição do bem adquirido, e o estipulado fica sem efeito por perda de objeto [PAULO LÔBO, Direito (...), cit., p. 302].

Há julgado que afasta as penhoras que recaíram sobre bem recebido em doação com cláusula de reversão, considerando que o donatário tem mera propriedade resolúvel e, no caso, tendo se operado a reversão, afastam-se os ônus que recaíram sobre o bem (TJSP, 4a Câm. de Dir. Priv., Apel. n. 000848161.2011.8.26.0132 rel. MILTON CARVALHO, j. 31-01-2013).

${ }^{568}$ CARLOS ROBERTO GONÇALVES, Direito (...), cit., p. 271; CARVAlHO SANTOS, Código (...), cit., p. 380; CLÓVIS BeVILAQUA, Código (...), cit., p. 278; FLÁVIO TARTUCE, Direito (...), cit., p. 321; FRANCISCO GLAUBER PESSOA ALVES, Das Várias (...), cit., p. 901; LUIZ GUILHERME LOUREIRO, Curso (...), cit., p. 509; NATAL NADER, Questões Relativas à Doação (II), cit., p. 468; SYLVIO CAPANEMA DE SOUZA, Das Várias (...), cit., p. 97; WASHINGTON DE BARROS MONTEIRO-DABUS MALUF, Curso (...), cit., p. 171.

${ }^{569}$ CARLOS ROBERTO GONÇALVES, Direito (...), cit., p. 272; MARIA HELENA DINIZ, Curso (...), cit., p. 265; NELSON ROSENVALD, Contratos (...), cit., p. 591; PAULO LÔBO, Das Várias (...), cit., p. 323; RODRIGO SENISE LISBOA, Manual (...), cit., p. 262.

${ }^{570}$ MANUEL ALBADALEJO GARCÍA e SILVIA DIAZ ALABART, La Donación, cit., pp. 528.

${ }^{571}$ CHRISTIANO CASSETARI, Elementos (...), cit., p. 214.

572 CARLOS ROBERTO GONÇALVES, Direito (...), cit., p. 271; FLÁVIO AUGUSTO MONTEIRO DE BARROS, Manual (...), cit., p. 348; FLÁVIO TARTUCE, Direito (...), cit., p. 321; MARIA HELENA DINIZ, Curso (...), cit., p. 265; NELSON ROSENVALD, Contratos (...), cit., p. 590; PAULO LÔBO, Direito (...), cit., p. 302; ROGÉRIO MARRONE DE CASTRO SAMPAIO, Direito (...), cit., p. 126; SILVIO RODRIGUES, Direito (...), cit., p. 205.

573 AGOSTINHO ALVIM, Da Doação, cit., p. 154; ARNALDO RIZZARDO, Contratos, cit., p. 466; CAIO MÁRIO DA SILVA PEREIRA, Instituições (...), cit., p. 219; CLÓVIS BEVILAQUA, Código (...), cit., p. 
uma liberalidade, de modo que é passível de prova testemunhal, desde que o valor do negócio não exija forma escrita ${ }^{574}$. De qualquer forma, deverá existir desde o início do contrato e se for aposta posteriormente, há, em verdade, uma nova doação do donatário para o anterior doador $^{575}$. Pode o doador, porém, mesmo posteriormente à ocorrência da resolução, renunciar à reversão ${ }^{576}$.

Para alguns autores ${ }^{577}$, a reversão do bem doado terá efeito ex tunc, mas, para outros $^{578}$, tal não se dá, sendo antes atual a aquisição da propriedade do bem pelo doador, com efeitos ex nunc, quando da ocorrência da reversão, sem prejuízo de receber a coisa no estado em que a entregou, de modo a se desfazer as alienações e ônus que sobrevieram à liberalidade ${ }^{579}$.

278; MARIA HELENA DINIZ, Curso (...), cit., p. 265; NATAL NADER, Questões Relativas à Doação (II), cit., p. 468; PAULO NADER, Curso (...), cit., p. 231; PAULO LÔBO, Direito (...), cit., p. 302; SYLVIO CAPANEMA DE SOUZA, Das Várias (...), cit., p. 179; VICENTE SABINO JÚNIOR, Doação, cit., p. 36; WASHINGTON DE BARROS MONTEIRO-DABUS MALUF, Curso (...), cit., p. 171.

${ }^{574}$ ARNALDO MARMITT, Da Doação, cit., p. 154. PLANIOL ensina que a jurisprudência francesa aponta para a mesma conclusão [Traité (...), cit., p. 658].

${ }^{575}$ MANUEL ALBADALEJO GARCÍA e SILVIA DIAZ ALABART, La Donación, cit., pp. 522-523.

${ }^{576}$ CARVALHO SANTOS, Código (...), cit., pp. 385-386; SÍLVIO DE SALVO VENOSA, Direito (...), cit., p. 137; SYLVIO CAPANEMA DE SOUZA, Das Várias (...), cit., p. 179.

577 ARNOLDO WALD, Direito (...), cit., pp. 68-69; CARVALHO DE MENDONÇA, Contratos (...), cit., p. 81; CARVALHO SANTOS, Código (...), cit., pp. 382-383; JONES FIGUEIRÊDO ALVES, Código (...), cit., p. 450; MARIA HELENA DINIZ, Curso (...), cit., p. 269; SÍLVIO DE SALVO VENOSA, Direito (...), cit., p. 137; SYLVIO CAPANEMA DE SOUZA, Das Várias (...), cit., p. 182; VICENTE SABINO JÚNIOR, Doação, cit., p. 40.

578 ANTÔNIO CHAVES, Lições (...), cit., p. 249; ARNALDO RIZZARDO, Contratos, cit., p. 466; CAIO MÁRIO DA SILVA PEREIRA, Instituições (...), cit., p. 219; MANUEL ALBADALEJO GARCÍA e SILVIA DIAZ ALABART, La Donación, cit., pp. 531-532; NELSON ROSENVALD, Contratos (...), cit., p. 590.

579 O efeito prático de ambas posições é que se permite ao donatário alienar o objeto doado, sabendo o comprador da cláusula resolutiva, sem prejuízo de poder haver também cláusula de inalienabilidade [CARVALHO SANTOS, Código (...), cit., pp. 381-382; SÍlVIO DE SALVO VENOSA, Direito (...), cit., p. 137; SYLVIO CAPANEMA DE SOUZA, Das Várias (...), cit., p. 181]. No entanto, há quem compreenda que, na hipótese de alienação, por o sistema civil proteger o adquirente de boa-fé, a cláusula de reversão fica sem efeito por perda de objeto, mas o doador pode perseguir outro bem se demonstrar sub-rogação. A mesma solução se aplica caso o objeto doado pereça [neste sentido: PAULO LÔBO, Das Várias (...), cit., pp. 323324]. Tal posicionamento, além de minoritário, parece ferir o disposto no art. 1.359 do Código Civil de 2002. Outrossim, há quem entenda que o doador só terá direito a receber o bem doado no estado em que se encontra [SERPA LOPES, Curso (...), cit., p. 411].

No que concerne ao desfazimento de alienações e ônus reais, o Código Napoleônico é expresso: Art. 952. "L'effet du droit de retour est de résoudre toutes les aliénations des biens et des droits donnés, et de faire revenir ces biens et droits au donateur, libres de toutes charges et hypothèques, exceptée l'hypothèque légale des époux si les autres biens de l'époux donataire ne suffisent pas à l'accomplissement de ce retour et que la donation lui a été faite par le contrat de mariage dont résultent ces charges et hypothèques" [confrontar: PLANIOL, Traité (...), cit., pp. 692-693]; assim como o Código Civil Italiano: Art. 792. "\$1 ${ }^{\circ}$ : Il patto di riversibilità produce l'effetto di risolvere tutte le alienazioni dei beni donati e di farli ritornare al donante liberi da ogni peso o ipoteca, ad eccezione dell'ipoteca iscritta a garanzia della dote o di altre convenzioni matrimoniali, quando gli altri beni del coniuge donatario non sono sufficienti, e nel caso soltanto in cui la donazione è stata fatta con lo stesso contratto matrimoniale da cui l'ipoteca risulta. $\$ 2^{\circ}$ : È valido il patto per cui la riversione non deve pregiudicare la quota di riserva spettante al coniuge superstite sul patrimonio del donatario, compresi in esso i beni donati". 
Ademais disso, mesmo tendo sido o contrato de doação revertido por morte do donatário, os frutos percebidos até então serão do beneficiário da liberalidade ${ }^{580}$, o que alguns ${ }^{581}$ sustentam com fundamento no art. $1.214^{582}$ do Código Civil de 2002. Outrossim, afirma-se ${ }^{583}$ que o donatário tem direito a ser indenizado no caso do bem doado revertido ter recebido acessão física ou intelectual.

Quanto ao parágrafo único do art. $547^{584}$ do Código Civil de 2002, traz expressa vedação à estipulação da reversão em favor de terceiro ${ }^{585}$. Segundo PABLO STOLZE GAGLIANO $^{586}$, tal proibição reside nos escopos de se evitar hipótese de fideicomisso inter vivos, de possibilitar a circulação da riqueza e de emprestar maior segurança nas relações jurídicas. Com efeito, tal vedação não constava do art. $1.174^{587}$ do Código Civil de 1916, a demonstrar a vontade de eliminar hipótese nova de substituição fideicomissária pelo atual Código $\mathrm{Civil}^{588}$. Mas vale ressaltar, porém, que já no âmbito da legislação civil anterior, a doutrina $^{589}$ não admitia a reversão em favor de terceiro, justamente porque a substituição fideicomissária somente poderia ser estabelecida por testamento.

${ }^{580}$ ARNALDO MARMITT, Doação, cit., p. 36; CAIO MÁRIO DA SILVA PEREIRA, Instituições (...), cit., pp. 219-220; CARVALHO SANTOS, Código (...), cit., pp. 383-385; JONES FIGUEIRÊDO ALVES, Código (...), cit., p. 450; MANUEL ALBADALEJO GARCÍA e SILVIA DIAZ ALABART, La Donación, cit., p. 530; MARIA HELENA DINIZ, Curso (...), cit., p. 265; NATAL NADER, Questões Relativas à Doação (II), cit., p. 468; SERPA LOPES, Curso (...), cit., p. 411. Em sentido contrário: WASHINGTON DE BARROS MONTEIRO-DABUS MALUF, Curso (...), cit., p. 172.

581 CARLOS ROBERTO GONÇALVES, Direito (...), cit., p. 271; SYlVIO CAPANEMA DE SOUZA, Das Várias (...), cit., p. 184.

${ }_{583}^{582}$ Art. 1.214. "O possuidor de boa-fé tem direito, enquanto ela durar, aos frutos percebidos".

${ }^{583}$ ARNALDO MARMITT, Doação, cit., p. 38.

${ }_{584}^{584}$ Art. 547, parágrafo único. "Não prevalece cláusula de reversão em favor de terceiro".

${ }^{585}$ Não assim no direito norte-americano, que permite ao doador transferir a posse do bem a terceiro com a imposição de esse aliená-lo em doação ao beneficiário final, diante da ocorrência de uma condição resolutiva, como a sua morte, por exemplo, negócio esse que recebe o nome de escrow [nesse sentido: ELIAS CLARK et al., Cases (...), cit., p. 428].

Já no Código Napoleônico, há a mesma vedação do sistema civil pátrio, como se verifica na redação do art. 951 do diploma legal francês: "1. Le donateur pourra stipuler le droit de retour des objets donnés soit pour le cas du prédécès du donataire seul, soit pour le cas du prédécès du donataire et de ses descendants. 2. Ce droit ne pourra être stipulé qu'au profit du donateur seul'. Sobre o tema, consultar: PLANIOL, Traité (...), cit., pp. 689-691.

586 O Contrato (...), cit., p. 126. No mesmo sentido: CARLOS ROBERTO GONÇALVES, Direito (...), cit., p. 272.

587 Art. 1.174. "O doador pode estipular que os bens doados voltem ao seu patrimônio, se sobreviver ao donatário".

588 Neste sentido: FLÁVIO AUGUSTO MONTEIRO DE BARROS, Manual (...), cit., p. 349; FRANCISCO GLAUBER PESSOA ALVES, Das Várias (...), cit., p. 902; PAULO DE TARSO VIEIRA SANSEVERINO, Contratos (...), cit., p. 120; PAULO GERALDO DE OLIVEIRA MEDINA, A Doação, cit., p. 468; ROGÉRIO MARRONE DE CASTRO SAMPAIO, Direito (...), cit., p. 126; SYLVIO CAPANEMA DE SOUZA, Das Várias (...), cit., p. 177.

${ }^{589}$ CLÓVIS BEVILAQUA, Código (...), cit., p. 278; EDUARDO ESPINOLA, Dos Contratos (...), cit. p. 176; NATAL NADER, Questões Relativas à Doação (II), cit., p. 468. 
No mesmo sentido, VICENTE SABINO JÚNIOR ${ }^{590}$ explica que não poderia figurar como beneficiário da reversão um terceiro, pois importaria em substituição fideicomissária, o que só pode se constituir por meio de testamento, mas, no entanto, entende que nada impede que haja a imposição de encargo ao donatário de conservar o bem e transferi-lo a terceiro após a morte do donante.

Tais considerações se aplicariam ao sistema atual, pois o fideicomisso somente pode ser constituído pelo testador, como se verifica nos arts. 1.951 e seguintes do Código Civil de 2002, não adiantando arquitetar uma doação mortis causa.

Em que pese tais ponderações, no âmbito do Código Civil revogado era possível a estipulação da reversão em favor de terceiro, justamente porque o diploma admitia a substituição fideicomissária, segundo certa doutrina ${ }^{591}$.

AGOSTINHO ALVIM ${ }^{592}$ ensinava que nada impede de a cláusula de reversão beneficiar terceiro, mesmo que tenha natureza fideicomissária, e apresentava, como argumentos para fundamentar sua ilação: há muito que o fideicomisso perdeu o caractere "confiança" no sistema civil; nada impede que haja reversão ainda em vida do donatário, não prejudicando ao doador o destino do bem doado; e, por fim, por o sistema do Código de 1916 admitir o fideicomisso até o segundo grau, nada impede que o mesmo haja nas doações ${ }^{593}$.

De qualquer forma, no sistema atual, se as partes aporem cláusula de reversão em favor de terceiro no contrato de doação, ela será tida por não escrita ${ }^{594}$.

Assim, o quanto se encontra disciplinado a respeito da cláusula de reversão, interessa para a presente pesquisa caso o doador não tenha interesse em que os bens doados se transfiram para os herdeiros do donatário, pelo que deverá fazer constar no instrumento a

\footnotetext{
${ }^{590}$ Contrato (...), cit., p. 55.

591 ARNALDO MARMITT, Doação, cit., 1994, p. 37; PONTES DE MIRANDA, Tratado (...), cit., pp. 237-238; SERPA LOPES, Curso (...), cit., p. 411; VIEIRA FERREIRA, Fideicommisso em Doação, in GUSTAVO TEPEDINO (Org.) e LUIZ EDSON FACHIN (Org.), Doutrinas Essenciais - Obrigações e Contratos, vol. V, São Paulo, Revista dos Tribunais, 2011, pp. 497-500. CARVALHO SANTOS afirmava expressamente que a reversão não poderia se dar em favor de terceiro, porém admitia que houvesse aposição de fideicomisso, dispondo a passagem do bem para terceiro quando da morte do donatário. [Código (...), cit., pp. 380-381].

${ }^{592}$ Da Doação, cit., pp. 155-161. No mesmo sentido: ORLANDO GOMES, Contratos, cit., p. 240.

593 Tal posicionamento, porém, soçobraria diante do entendimento de que a reversão em favor de terceiros importaria em pacta corvina, o que é vedado pelo art. 426 do Código Civil de 2002 (Art. 426. "Não pode ser objeto de contrato a herança de pessoa viva") [neste sentido: CHRISTIANO CASSETARI, Elementos (...), cit., p. 214; FLÁVIO TARTUCE, Direito (...), cit., p. 322].

594 CÉSAR FIUZA, Direito (...), cit., p. 509. Não obstante, há quem admita a aposição de cláusula de fideicomisso em sede de doação [v.: SYLVIO CAPANEMA DE SOUZA, Das Várias (...), cit., pp. 97-98].
} 
cláusula de reversão, estipulando um termo para ela, podendo ser até momento anterior ao falecimento do donatário.

Outrossim, importa adotar-se a diligência de se levar a registro, no órgão competente, a transferência com a mencionada cláusula, a fim de evitar-se eventual alienação em boa-fé e afastar-se eventuais ônus.

\section{9) Doação em comum}

A doação mútua ou em comum é aquela em que as partes, num mesmo ato, doam bens um ao outro, reciprocamente ${ }^{595}$, diferenciando-se da troca, segundo PABLO STOLZE GAGLIANO $^{596}$, pelo fato de a causa dos negócios jurídicos ser a liberalidade que um almeja fazer ao outro, ao passo que PLANIOL ${ }^{597}$ leciona que haverá troca se as partes desejarem a dependência de uma liberalidade em relação à outra ${ }^{598}$.

Caso haja alguma nulidade em algumas das declarações, todo o ato é reputado nulo, mas em caso de descumprimento de encargo ou cometimento de ingratidão, apenas o ato em favor do que deu causa a tais eventos será revogado ${ }^{599}$.

Diante disso, não é interessante usar esse tipo de doação na implementação de planejamento sucessório, pois importa que o negócio jurídico seja autônomo, dada as diversas barreiras legais já existentes para uma só doação.

Caso, porém, as partes queiram lançar mão desse tipo de liberalidade, devem se atentar para que fique claro o ânimo de doar de cada qual.

\subsection{0) Doação em forma de subvenção periódica}

A doação em forma de subvenção periódica é regulamentada pelo art. $545^{600}$ do Código Civil de 2002, e nela o doador estabelece que doará ao beneficiário uma renda ou

\footnotetext{
${ }^{595}$ ARNOLDO WALD, Direito (...), cit., p. 69; SILVIO LUÍS FERREIRA DA ROCHA, Curso (...), cit., p. 179.

${ }^{596}$ O Contrato (...), cit., p. 128.

${ }^{597}$ Traité (...), cit., pp. 643-644.

598 Sobre o tema, EDUARDO ESPINOLA ressalta que o emprego de um mesmo instrumento e do vocábulo mútuo não são suficientes para caracterizar a espécie, sendo imprescindível investigar-se a causa do ato, justamente para se distinguir eventual contrato de troca [Dos Contratos (...), cit. p. 194]. PONTES DE MIRANDA, por seu turno, afirma que a hipótese presente não é de doação, mas sim permuta [Tratado (...), cit., p. 203], ao passo que JEAN RAY afirma ser um ato intermediário, não completamente oneroso, mas também não inteiramente conforme aos atos gratuitos [De La Notion (...), cit., p. 129].

${ }^{599}$ CARVALHO DE MENDONÇA, Contratos (...), cit., p. 82; EDUARDO ESPINOLA, Dos Contratos (...), cit. p. 194; SILVIO LUÍS FERREIRA DA ROCHA, Curso (...), cit., p. 179. Há, porém, quem entenda que, por haver diversidade de causa, a resolução de um dos contratos, por quaisquer motivos, não induz à do outro [nesse sentido: PLANIOL, Traité (...), cit., p. 644].
} 
estipêndio periodicamente, sendo que a lei impõe o limite temporal da morte do donatário. Há quem a compare a uma pensão ${ }^{601}$ ou a uma concessão de renda ${ }^{602}$. Trata-se de uma obrigação de trato sucessivo, de modo que não consiste em várias doações seguidas, mas sim em uma só liberalidade de execução continuada, o que tem como consequência o fato de a incapacidade posterior à doação não lhe afetar ${ }^{603}$.

Tal espécie de doação pode ser feita com o doador estabelecendo um capital e estipulando que o donatário não poderá tangenciá-lo, mas tão somente perceber seus rendimentos ${ }^{604}$, ou ainda autorizar o beneficiário a debitar gastos ou montante fixo em conta bancária ou cartão de crédito ${ }^{605}$.

No que toca à periodicidade com que se darão os estipêndios, é de livre disposição das partes, sendo comum a semanal, a mensal ou a anual ${ }^{606}$.

Deverá o doador se atentar para a possibilidade de a benesse levar ao desfalque da legítima, o que é vedado ${ }^{607}$, sendo que, na hipótese de as prestações terem por medida a vida do doador ou do donatário, o interesse do herdeiro somente surge no momento em que a parcela ultrapassar o limite imposto em lei ${ }^{608}$.

Como se verifica no citado dispositivo de lei, a doação em forma de subvenção periódica não poderá ultrapassar a vida do doador, podendo, porém, o contrato dispor

${ }^{600}$ Art. 545. “A doação em forma de subvenção periódica ao beneficiado extingue-se morrendo o doador, salvo se este outra coisa dispuser, mas não poderá ultrapassar a vida do donatário".

${ }^{601}$ CARLOS ROBERTO GONÇALVES, Direito (...), cit., p. 265; FLÁVIO TARTUCE, Direito (...), cit., p. 318 ; JONES FIGUEIRÊDO ALVES, Código (...), cit., p. 449; ORLANDO GOMES, Contratos, cit., p. 241.

${ }^{602}$ CARVAlHO SANTOS, Código (...), cit., p. 376; JONES FIGUEIRÊDO ALVES, Código (...), cit., p. 449; SYLVIO CAPANEMA DE SOUZA, Das Várias (...), cit., p. 166.

${ }^{603}$ AGOSTINHO ALVIM, Da Doação, cit., pp. 109-111; ORLANDO GOMES, Contratos, cit., p. 241; PAULO DE TARSO VIEIRA SANSEVERINO, Contratos (...), cit., p. 64; PAULO NADER, Curso (...), cit., p. 234; SILVIO LUÍS FERREIRA DA ROCHA, Curso (...), cit., p. 173. LUCIANO DE CAMARGO PENTEADO afirma que essa espécie de doação se aproxima do contrato de fornecimento, pois se trata de uma relação continuada cujas obrigações vão surgindo periodicamente [Doação (...), cit., p. 217]. Há quem entenda, de qualquer forma, que se trata de doações únicas, pelo que poderá haver rompimento do contrato pelo doador a qualquer tempo [nesse sentido: JO ̃̂̃O BAPTISTA VILLELA, Contrato (...), cit., pp. 277-278], mas há quem se oponha expressamente a tal consequência [assim: NELSON ROSENVALD, Contratos (...), cit., p. 588]. Sobre a possibilidade de se aplicar ao caso o instituto da onerosidade excessiva, confrontar: SíLVIO DE SALVO VENOSA, Direito (...), cit., p. 134; SYLVIO CAPANEMA DE SOUZA, Das Várias (...), cit., p. 167.

${ }^{604}$ PABLO STOLZE GAGLIANO, O Contrato (...), cit., pp. 128-129.

${ }^{605}$ MARIA HELENA DINIZ, Tratado (...), cit., p. 85; PAULO LÔBO, Direito (...), cit., p. 298.

${ }^{606}$ CARLOS ROBERTO GONÇALVES, Direito (...), cit., p. 265; LIMONGI FRANÇA, Manual (...), cit., p. 100; LUIZ GUILHERME LOUREIRO, Curso (...), cit., p. 511; PAUlO LÔBO, Direito (...), cit., p. 298.

${ }^{607}$ ARNALDO MARMITT, Doação, cit., p. 32; FRANCISCO GLAUBER PESSOA ALVES, Das Várias (...), cit., p. 899; LUIZ GUILHERME LOUREIRO, Curso (...), cit., p. 512.

${ }^{608}$ AGOSTINHO ALVIM, Da Doação, cit., pp. 111-112; ARNALDO RIZZARDO, Contratos, cit., p. 464. 
diferentemente dessa regra, desde que de modo expresso. No seu silêncio, caso os herdeiros continuem a arcar com o estipêndio, então há nova doação ${ }^{609}$. De qualquer modo, se houver disposição que determine a subvenção ultrapassar a vida do doador, então deve-se considerar que a obrigação dos herdeiros será limitada à força da herança recebida ${ }^{610}$.

Outrossim, o mencionado art. 545 do Código Civil de 2002 afirma expressamente que a doação por subvenção periódica não poderá ultrapassar a vida do donatário, pelo que se diz que se trata de ato personalíssimo ${ }^{611}$. Segundo lição de LUCIANO DE CAMARGO PENTEADO $^{612}$, tal limite visa coibir a utilização da doação para a perpetração de ato simulado.

Tal disposição veio a suprir a lacuna do art. $1.172^{613}$ do Código Civil de 1916, pois na sua vigência os autores anteviam a possibilidade, em que pese excepcional, de a doação em forma de subvenção periódica passar para as pessoas dos herdeiros do donatário, após a morte deste, desde que estipulado um termo final ${ }^{614}$, o que, para alguns, seria até o $2^{\circ}$ grau, em coerência à possibilidade de substituição fideicomissária ${ }^{615 / 616}$. CLÓVIS BEVILAQUA $^{617}$, por seu turno, acredita que seria desnecessário a lei fazer tal ressalva, pois somente se doa a alguém nomeado, não a uma conjectura, porém nada impede que o contrato preveja a existência de donatários que sucedam o primeiro beneficiário.

${ }^{609}$ ARNALDO MARMITT, Doação, cit., p. 33; CAIO MÁRIO DA SILVA PEREIRA, Instituições (...), cit., p. 219; JOÃO BAPTISTA VILLELA, Contrato (...), cit., p. 278; MARIA HELENA DINIZ, Tratado (...), cit., p. 85; NELSON ROSENVALD, Contratos (...), cit., p. 589.

No Direito Civil português a doação por subvenção periódica necessariamente durará até a morte do doador, por imposição do art. 943. ("Prestações periódicas") do diploma civil luso: "A doação que tiver por objecto prestações periódicas extingue-se por morte do doador". Assim, para que a liberalidade ultrapasse esse evento, é preciso que haja a concordância dos herdeiros, não tendo o doador originário poder de vinculá-los neste sentido (MANUEL BAPTISTA LOPES, Das Doações, cit., p. 29).

${ }^{610}$ CARLOS ROBERTO GONÇALVES, Direito (...), cit., p. 265; LUIZ GUILHERME LOUREIRO, Curso (...), cit., pp. 511-512; PAULO LÔBO, Direito (...), cit., p. 299.

${ }^{611}$ CHRISTIANO CASSETARI, Elementos (...), cit., p. 214; FLÁVIO TARTUCE, Direito (...), cit., p. 318; MARIA HELENA DINIZ, Curso (...), cit., p. 264; NELSON ROSENVALD, Contratos (...), cit., p. 589.

${ }^{612}$ Doação (...), cit., p. 217.

${ }^{613}$ Art. 1.172. "A doação em forma de subvenção periódica ao beneficiado extingue-se, morrendo o doador, salvo se este outra coisa dispuser".

${ }^{614}$ ARNALDO MARMITT, Doação, cit., p. 32.

${ }^{615}$ AGOSTINHO ALVIM, Da Doação, cit., p. 114.

${ }^{616}$ Aplaudindo a redação do art. 545 do Código Civil de 2002: PAULO DE TARSO VIEIRA SANSEVERINO, Contratos (...), cit., p. 112

617 Código (...), cit., p. 276. PAULO GERALDO DE OLIVEIRA MEDINA afirma expressamente que o entendimento ora esposado pelo mencionado doutrinador caiu por terra com a nova redação legal sobre o tema (A Doação, cit., p. 462). 
Na doação por subvenção periódica o donatário poderá ser pessoa jurídica, mas, mesmo assim, dever-se-á estabelecer um termo final, para não haver obrigação perpétua ${ }^{618}$. AGOSTINHO ALVIM ${ }^{619}$ adota o mesmo entendimento, mas se posiciona contra ao limite de 100 anos tirado do usufruto e prefere adotar como limite temporal a vida do doador, mais a segunda geração, em consonância com o regime das substituições fideicomissárias. Não obstante, difícil equiparar a sucessão das pessoas jurídicas e das pessoas naturais.

A presente espécie pode ser muito útil no planejamento de uma sucessão por meio de doação, haja vista que o doador pode querer garantir a subsistência de alguém, sabendo que o donatário não pode suprir sua sobrevivência, como no caso de criança, idoso ou enfermo.

De qualquer forma, deverá ocorrer a nomeação de um administrador da benesse, caso ela ultrapasse a vida do doador, a quem caberá dar cumprimento do desejo do disponente, pelo que, ao lançar mão desse meio, o doador deverá se preocupar com a remuneração desse serviço.

\subsection{1) Doação mista}

Doação mista é o negócio que se origina tanto de um ato de liberalidade como de um ato oneroso, e somente se o animus donandi mostrar-se prevalente é que será uma doação, podendo-se apontar, à guisa de exemplo, uma compra e venda cujo preço é bem abaixo do comum, o que pode se caracterizar como doação ${ }^{620}$. PABLO STOLZE GAGLIANO ${ }^{621}$ explica que a doação mista tem elementos de um negócio oneroso e consiste também numa liberalidade, e exemplifica sua lição com o que já foi dito acima, isto é, compra e venda com preço abaixo do mercado.

\footnotetext{
${ }^{618}$ ARNALDO MARMITT, Doação, cit., p. 32; SÍLVIO DE SALVO VENOSA, Direito (...), cit., p. 134.

${ }^{619}$ Da Doação, cit., p. 114. No mesmo sentido: NELSON ROSENVALD, Contratos (...), cit., p. 589; PAULO DE TARSO VIEIRA SANSEVERINO, Contratos (...), cit., p. 112.

${ }^{620}$ ARNALDO MARMITT, Doação, cit., pp. 30-31; CAIO MÂRIO DA SILVA PEREIRA, Instituições (...), cit., pp. 215-216; CARLOS ROBERTO GONÇALVES, Direito (...), cit., p. 264; EDUARDO ESPINOLA, Dos Contratos (...), cit. p. 195; FÁBIO ULHOA COELHO, Curso (...), cit., p. 244; MARIA HELENA DINIZ, Tratado (...), cit., p. 73; PAULO NADER, Curso (...), cit., p. 231; SAVIGNY, Sistema (...), cit., pp. 70-71 e 116-117 (o autor fala em prestação das duas partes do negócio, sendo que o sacrifício do donatário se afigura maior que o do doador, mas a intenção é de haver doação); VINCENZO TAVASSI, La Donazione, cit., pp. 82-83. NESTOR DIÓGENES também vê na doação com estipulação em favor de terceiro um tipo de negotium mixtum cum donatione [Doação (...), cit., p. 77]. CARLOS ALBERTO BITTAR, por seu turno, entende que a hipótese mista não representa doação [Contratos (...), cit., p. 45]. Sobre a dificuldade de se diferenciar os atos gratuitos e onerosos e o tipo do negotium mixtum cum donatione como meio de enquadramento dessa realidade: JEAN RAY, De La Notion (...), cit., pp. 157-159.

${ }^{621} O$ Contrato (...), cit., p. 127. No mesmo sentido: AMANDA ZOE MORRIS, Doação, cit., p. 282; ARNALDO RIZZARDO, Contratos, cit., p. 455; SÍlVIO DE SALVO VENOSA, Direito (...), cit., p. 126; SYLVIO CAPANEMA DE SOUZA, Das Várias (...), cit., p. 100.
} 
VICENTE SABINO JÚNIOR ${ }^{622}$, por sua vez, entende que a doação mista é um contrato de doação porque está marcada pela gratuidade, reconhecendo que muitos autores discordam de sua visão, mas reafirma que a causa do negócio é a liberalidade. Ademais, vêt nas doações "liberatórias" um tipo de doação mista, pois aquelas consistem na doação de um crédito ou direito próprio que o doador possuía em face do donatário, de modo que ambos os contratos, gratuito e oneroso, se fazem um só.

De todo modo, o ponto nodal está em que há uma diferença gratuitamente transferida embutida em um contrato oneroso e é aí que reside a doação mista ${ }^{624}$.

Para se enquadrar o negócio jurídico, nesta hipótese, em um contrato oneroso ou na doação, depende da análise do caso concreto, segundo alguns autores, devendo-se verificar a causa dominante para a realização do negócio ${ }^{625}$. LUCIANDO DE CAMARGO PENTEADO $^{626}$, por sua vez, pensa que a verificação do negotium mixtum cum donatione é questão de direito, não de fato.

Outrossim, VICENTE SABIONO JÚNIOR ${ }^{627}$ entende que na doação mista somente haverá doação se prevalece o elemento gratuidade, ao passo que LUCIANDO DE CAMARGO PENTEADO ${ }^{628}$ explica que não há ligação de dois negócios, mas sim um negócio que tenha o elemento de liberalidade presente, podendo ou não ser doação, de acordo com a forma adotada ${ }^{629}$, havendo ainda quem entenda ${ }^{630}$ que se deve analisar a intenção do doador, nos termos do art. $112^{631}$ do Código Civil de 2002.

\footnotetext{
${ }^{622}$ Contrato (...), cit., p. 32.

${ }^{623}$ Contrato (...), cit., p. 102.

${ }^{624}$ PONTES DE MIRANDA, Tratado (...), cit., p. 198. SAVIGNY admite, nesse sentido, a existência do negotium mixtum cum donatione na aposição de um pacto adjeto a um contrato oneroso, como a do vendedor que se compromete a responder pela evicção em qualquer hipótese, e na devolução a maior ou menor do objeto mutuado [Sistema (...), cit., pp. 120-122].

${ }^{625}$ AGOSTINHO ALVIM, Da Doação, cit., p. 13; NESTOR DIÓGENES, Doação (...), cit., p. 77; NELSON ROSENVALD, Contratos (...), cit., p. 584; PABLO STOLZE GAGLIANO, O Contrato (...), cit., p. 127. Para CARVALHO DE MENDONÇA, a presença de uma causa é o suficiente para afastar o caractere liberalidade, pelo que não há doação [Contratos (...), cit., p. 33]. A esse respeito, SAVIGNY ensina que se uma compra e venda é realizada por preço menor com a intenção de se beneficiar o comprador, há uma doação mista válida, mas se se der entre cônjuges, então somente a compra e venda tem validade, e, por fim, se esse for o único modo legal possível de as partes realizarem doação, então todo o ato é inválido, haja vista a existência de fraude [Sistema (...), cit., p. 117].

${ }^{626}$ Doação (...), cit., pp. 283-284.

${ }^{627}$ Doação, cit., p. 31

${ }^{628}$ LUCIANO DE CAMARGO PENTEADO, Doação (...), cit., pp. 284-285.

${ }^{629}$ ORLANDO GOMES esposa a mesma opinião, porém conclui que o negotium mixtum cum donatione nunca será doação [Contratos, cit., p. 240].

${ }^{630}$ CARLOS ROBERTO GONÇALVES, Direito (...), cit., p. 264.

${ }^{631}$ Art. 112. "Nas declarações de vontade se atenderá mais à intenção nelas consubstanciada do que ao sentido
} 
De qualquer modo, havendo doação mista, a parte pura será regulada pelo regime das liberalidades, ao passo que a outra terá o regramento dos contratos onerosos, mas se determinada situação limite não permitir tal cisão, então deve prevalecer alguma delas ${ }^{632}$. Há $^{633}$ quem entenda, porém, que não se deve proceder a tal divisão em hipótese alguma, devendo-se aplicar todo o arcabouço das normas dos atos liberais e onerosos, de acordo com cada negócio, ao passo que PONTES DE MIRANDA ${ }^{634}$ ensina que sempre se deve dispensar tratamento plural à hipótese, a fim de que não haja comunicação de nulidades.

O presente tipo é mencionado apenas para demonstrar sua problemática, não sendo recomendável para implementar estratégia sucessória.

\subsection{2) Doação indireta, simulada e disfarçada}

As doações indiretas são atos jurídicos que não atendem a forma de doação, mas que têm neles presente o animus donandi, como a renúncia de um herdeiro em favor do outro designado, remição de dívida ou a remissão do débito de um terceiro ${ }^{635}$. A diferença está em

literal da linguagem".

${ }^{632}$ AMANDA ZOE MORRIS, Doação, cit., p. 282; ARNALDO RIZZARDO, Contratos, cit., p. 455 (para o autor, prevalece de todo modo a doação e só excepcionalmente se aplicaria as regras pertinentes à onerosidade); MANUEL ALBADALEJO GARCÍA e SILVIA DIAZ ALABART, La Donación, cit., p. 484; SAVIGNY, Sistema (...), cit., pp. 124-125 (o autor defende, porém, que a impossibilidade de se separar o valor doado leva à conclusão de que todo o ato não é doação); SÍLVIO DE SALVO VENOSA, Direito (...), cit., pp. 126-127; SILVIO LUÍS FERREIRA DA ROCHA, Curso (...), cit., p. 179.

${ }^{633}$ CAIO MÁRIO DA SILVA PEREIRA, Instituições (...), cit., p. 216; EDUARDO ESPINOLA, Dos Contratos (...), cit. p. 195; VINCENZO TAVASSI, La Donazione, cit., p. 83 (o autor opina pela prevalência das normas da doação, haja vista os interesses nela tutelados que exigem maior proteção).

${ }^{634}$ Tratado (...), cit., p. 208.

${ }^{635}$ ARNOLDO WALD, Direito (...), cit., pp. 69-70; CAIO MÁRIO DA SILVA PEREIRA, Instituições (...), cit., p. 216; CARVALHO DE MENDONÇA, Contratos (...), cit., p. 82; EDUARDO ESPINOLA, Dos Contratos (...), cit. p. 195; FRANCISCO GLAUBER PESSOA ALVES, Das Várias (...), cit., p. 884-885 (o autor inclui também os motivos do agente na sua definição, ao lado do ânimo de doar); JEAN RAY, De La Notion (...), cit., pp. 78-81; MÉAU-LAUTOUR, La Donation (...), cit., pp. 405-408; ORLANDO GOMES, Contratos, cit., p. 241; PAUL DELNOY, Le Libéralités (...), cit., p. 34 (a previsão dessa modalidade na França se dá por construção pretoriana); RICHARD HYLAND, Gifts (...), cit., item 989 (o autor explica que os 'indirect gifts' é a utilização de instituto jurídico diverso e sem simulação para a prática de transferência gratuita); SILVIO LUÍS FERREIRA DA ROCHA, Curso (...), cit., p. 180; VICENTE SABINO JÚNIOR, Contrato (...), cit., pp. 84-85. Sobre a relação entre a solenidade da doação e a validade da doação, consultar: JEAN RAY, De La Notion (...), cit., pp. 25-29. Quanto à remissão da dívida por terceiro, há quem afirme somente ser doação quando o pagamento é feito em nome do doador, mas não o é quando o terceiro faz em nome próprio, pois nessa hipótese ainda remanesce seu direito de regresso [PAULO LÔBO, Das Várias (...), cit., p. 283], ao passo que outros pensam ser possível admitir doação na hipótese, desde que haja ciência do donatário ou posterior aceite [PLANIOL, Traité (...), cit., p. 642 (o autor fala em duas tradições: uma do donatário ao seu devedor a título de pagamento; e outra do doador ao donatário por liberalidade); PONTES DE MIRANDA, Tratado (...), cit., pp. 204 e 232; JOÃO BAPTISTA VILLELA, Contrato (...), cit., pp. 276-277]. A esse respeito, confrontar ainda: BIONDI, Le Donazioni, cit., pp. 405-409; GARDANI CONTURSI LISI, Le Donazioni, cit., pp. 91-93; SAVIGNY, Sistema (...), cit., pp. 162-166; TORRENTE, La Donazione, cit., pp. 210-212. Outrossim, há quem compreenda que a estipulação liberal em favor de terceiro não deixa de ser doação [nesse sentido: MÉAU-LAUTOUR, La Donation (...), cit., pp. 399-401; PLANIOL, Traité (...), cit., pp. 663-664], como no caso da nomeação de outrem como beneficiário de seguro de vida [SERPA LOPES, 
que a liberalidade é motivo do ato, mas não sua causa, de modo que as partes atingem seu fim utilizando-se de meio jurídico impróprio para tanto ${ }^{636}$, normalmente um contrato oneroso ${ }^{637}$.

Há, porém, quem afirme que a doação indireta não é, tecnicamente, uma doação, em que pese haver o enriquecimento unilateral, como no caso do simulacro de um contrato de compra e venda entre uma pessoa casada e seu amante ${ }^{638}$, mas o que se tem aí, segundo outros autores $^{639}$, seria uma doação disfarçada, que consiste na hipótese de se praticar um ato oneroso para ocultar a doação de herdeiros necessários ou do Fisco, ou ainda quando se doa um bem por interposta pessoa, sendo tal ato passível de revogação, a ser buscada pelos interessados.

Com efeito, a diferença entre a doação indireta e a disfarçada exige um acurado exame e, como balizas, CARVALHO DE MENDONÇA ${ }^{640}$, citando caso prático, afirma que a compra e venda por preço abaixo do mercado é doação indireta, ao passo que o mesmo contrato realizado a preço justo, mas sem que o vendedor o receba, é doação disfarçada, de maneira que é possível afirmar que no primeiro caso não há doação apenas aparentemente, ao passo que no segundo a doação se apresenta sob a aparência de outro ato jurídico.

Não obstante, ao lado dos que pensam que a doação disfarçada é a utilização de um contrato para a prática de simulação ou fraude à lei ${ }^{641}$, há os que separam da doação

Curso (...), cit., pp. 409-410; SYLVIO CAPANEMA DE SOUZA, Das Várias (...), cit., p. 101], mas há quem manifeste opinião contrária [nesse: sentido: JEAN RAY, De La Notion (...), cit., pp. 152-156 (o autor não chega a negar frontalmente a hipótese como doação, porém levanta sérias dúvidas a respeito e afirma ser difícil vislumbra-se no caso a gratuidade); PONTES DE MIRANDA, Tratado (...), cit., p. 230]. O direito norte-americano aceita o uso do contrato de seguro como modo de realização de doação [nesse sentido: ELIAS CLARK et al., Cases (...), cit., pp. 452-453; RICHARD HYLAND, Gifts (...), cit., itens 352 e 354].

636 SERPA LOPES, Curso (...), cit., p. 408 (o autor destaca o desiderato sincero do doador de realizar o benefício); VICENTE SABINO JÚNIOR, Contrato (...), cit., p. 87.

${ }^{637}$ PLANIOL, Traité (...), cit., p. 664 (o autor trata a espécie sob o nome de 'donation déguisée', isto é, disfarçada). No entanto, na p. 667 de sua obra, admite o doutrinador a prática de doação por meio de reconhecimento de dívida do doador em face do donatário.

${ }^{638}$ FÁBIO ULHOA COELHO, Curso (...), cit., pp. 243-244 (para o autor, a doação indireta é negócio unilateral não tipificado dentre os atos a título gratuitos); PABLO STOLZE GAGLIANO, O Contrato (...), cit., p. 127; SÍLVIO DE SALVO VENOSA, Direito (...), cit., p. 127 (segundo o autor, a doação indireta compõe o gênero liberalidade, mas não necessariamente a espécie).

639 ARNOLDO WALD, Direito (...), cit., p. 70; CARVALHO SANTOS, Código (...), cit., pp. $335-336$ (ao contrário dos demais, o autor admite a validade do negócio quando não se tratar de fraude, desde que obedecida a forma do contrato disfarce, mas reconhece que falta base legal para tanto); PAUL DELNOY, Le Libéralités (...), cit., p. 34; RICHARD HYLAND, Gifts (...), cit., item 985; VICENTE SABINO JÚNIOR, Contrato (...), cit., pp. 79-80.

${ }^{640}$ Contratos (...), cit., pp. 82-83. SERPA LOPES também classifica de indireta a doação realizada a preço menor [Curso (...), cit., pp. 408-409] e PAUL DELNOY chama de disfarçada a doação feita por meio de contrato de compra e venda sem pagamento do preço [Le Libéralités (...), cit., pp. 34-35]. PLANIOL, por seu turno, não faz qualquer diferença entre as hipóteses, e afirma que na compra e venda abaixo do preço há disfarce parcial [Traité (...), cit., pp. 664-665].

${ }^{641}$ PABLO STOLZE GAGLIANO, O Contrato (...), cit., p. 129. 
disfarçada a simulada, afirmando que há doação simulada quando falta ao ato duas características essenciais da doação: a gratuidade e a liberalidade ${ }^{642}$, podendo-se citar, à guisa de exemplo, a doação de um objeto para pagar uma dívida ${ }^{643}$.

Ademais, uma diferença prática entre a doação disfarçada e a simulada é que a segunda, por ser fraude a lei ou a direito de terceiros, é passível de anulação ${ }^{644}$, sendo que a simulação, no sistema da Lei 10.406/2002, é hipótese de nulidade absoluta, nos termos do art. 167 . $_{\text {aput }}{ }^{645}$, do mencionado diploma legal ${ }^{646}$.

Assim, se o ato importar em simulação ou fraude à lei ou a terceiros, é nulo, mas se não tiver tais efeitos, pode-se acolhê-los no sistema civil, em vista da necessidade de se atender a realidade prática dos atos ${ }^{647}$. De todo modo, as doações indiretas e disfarçadas podem ser revogadas pelos mesmos fundamentos de qualquer outra doação ${ }^{648}$.

Em vista de a simulação ser questão de ordem pública no sistema civil pátrio e por as doações indireta e disfarçada serem fronteiriças com ela, também não se deve utilizar delas para implantar-se sucessão por meio da doação, haja vista as dificuldades inerentes a esses tipos, o que fragilizaria juridicamente o ato.

\section{6) Promessa de doação}

A promessa de contrato, ou contrato preliminar, ou pré-contrato, é um negócio jurídico no qual as partes se obrigam a realizar um contrato principal, ocorrendo mais comumente na forma de promessa de compra e venda, que inclusive é causa do nascimento de um direito real ${ }^{649}$. Sua regulamentação está prevista na Seção VIII ("Do Contrato

${ }^{642}$ VICENTE SABINO JÚNIOR, Contrato (...), cit., p. 79. SERPA LOPES destaca as doações simuladas das indiretas [Curso (...), cit., p. 407].

${ }^{643}$ PONTES DE MIRANDA, Tratado (...), cit., pp. 248-249; VICENTE SABINO JÚNIOR, Contrato (...), cit., p. 58.

${ }^{644}$ CAIO MÁRIO DA SILVA PEREIRA, Instituições (...), cit., p. 216-217; CARVALHO DE MENDONÇA, Contratos (...), cit., p. 82; EDUARDO ESPINOLA, Dos Contratos (...), cit. p. 195; PONTES DE MIRANDA, Tratado (...), cit., pp. 248-249 (o autor chama as doações disfarçadas de dissimuladas e também entende que é hipótese de anulabilidade do contrato, pois nem doação há no caso, segundo seu entendimento); SILVIO LUÍS FERREIRA DA ROCHA, Curso (...), cit., p. 180; SYLVIO CAPANEMA DE SOUZA, Das Várias (...), cit., p. 100.

${ }^{645}$ Art. 167. "É nulo o negócio jurídico simulado, mas subsistirá o que se dissimulou, se válido for na substância e na forma".

${ }^{646}$ LUIZ GUILHERME LOUREIRO, Curso (...), cit., p. 515.

${ }^{647}$ Nesse sentido: MÉAU-LAUTOUR, La Donation (...), cit., pp. 409-410.

${ }^{648}$ CARVALHO SANTOS, Código (...), cit., p. 337. Também no direito norte-americano as doações disfarçadas são tratadas como doação, mas não como ato oneroso [RICHARD HYLAND, Gifts (...), cit., itens 986-988].

${ }^{649}$ PABLO STOLZE GAGLIANO, O Contrato (...), cit., p. 106. 
Preliminar”), do Capítulo I (“Disposições Gerais”), do Título V (“Dos Contratos em Geral”), da Parte Especial do Código Civil de 2002, a partir dos arts. 462 e seguintes.

Em princípio, é possível haver sua aplicação na doação, vez que a figura encontrase inserta na classe dos contratos ${ }^{650}$. Não obstante, a doutrina se divide em duas correntes a respeito desse tema: os que aceitam a promessa de doação e os que negam efeitos a ela ${ }^{651}$. A dificuldade de se admitir o contrato preliminar na doação reside no fato de ela ter como causa uma liberalidade, sendo que uma promessa de doação permitiria que o donatário pudesse exigir a execução específica da benesse ${ }^{652}$.

Dentre os que negam eficácia ao ato, explicam que prever a promessa de doação importaria na admissão de o donatário poder ingressar no Judiciário a fim de exigir o seu cumprimento ou pagamento de perdas e danos, em caso de inadimplemento, o que seria absurdo, pois o animus donandi deverá ser atual ${ }^{653}$.

Assim, se vier a ser formada promessa de contrato de doação e houver descumprimento contratual, não poderá o donatário ingressar em juízo e nem exigir eventual indenização por perdas e danos, pois a doação não se consumou com a transferência da coisa e, por ser uma liberalidade, é passível de retratação enquanto não se aperfeiçoa ${ }^{654}$. Não se

${ }^{650}$ Neste sentido: CAIO MÁRIO DA SILVA PEREIRA, Instituições (...), cit., p. 217; ROGÉRIO MARRONE DE CASTRO SAMPAIO, Direito (...), cit., p. 124.

${ }^{651}$ ARNALDO MARMITT, Doação, cit., pp. 97-98.

${ }^{652}$ MARIA HELENA DINIZ, Tratado (...), cit., p. 71; PABLO STOLZE GAGLIANO, O Contrato (...), cit., p. 107; SERPA LOPES, Curso (...), cit., pp. 388-391. SAVIGNY, por seu turno, explica que na verdade a simples promessa já é a doação, sendo a entrega do bem mero cumprimento de obrigação de dar contraída pelo pacto [Sistema (...), cit., pp. 141-142]. De fato, a discussão da celebração de contrato preliminar de doação só faz sentido quando ela é vista sob o prisma contratual, e ainda assim é passível de alta indagação.

${ }^{653}$ ARNALDO MARMITT, Doação, cit., pp. 98-99 (o autor apenas expõe o posicionamento, sem dele comungálo).

${ }^{654}$ JOÃO BAPTISTA VILLELA, Contrato (...), cit., pp. 266-270; PAUL DELNOY, Le Libéralités (...), cit., pp. 46-47 (o autor compreende que o art. 932 do Código Napoleônico obsta a executividade da promessa de doação); PAULO DE TARSO VIEIRA SANSEVERINO, Contratos (...), cit., p. 78; TORRENTE, La Donazione, cit., pp. 242-244.

O Superior Tribunal de Justiça já se manifestou no mesmo sentido, negando-se a reconhecer hipótese de doação coativa e a converter o descumprimento em perdas e danos: $4^{a}$ T., R. Esp. n. 730626/SP, rel. JORGE SCARTEZZINI, j. 17-10-2006. Da mesma maneira, há precedentes que até acolhem a argumentação de que a liberalidade que não observa a forma do art. 541 do Código Civil de 2002 seja tida por promessa de doação, entretanto lhe negam executividade: TJES, $3^{\mathrm{a}}$ Câm. Cív., Apel. n. 0800931-12.2010.8.08.0069, rel. ELIANA JUNQUEIRA MUNHOS FERREIRA, j. 03-04-2012; TJMG, 5a Câm. Cív., Apel. n. 003146748.2011.8.13.0042, rel. VERSIANI PENNA, j. 28-02-2013. Outro julgado considera ainda revogável a promessa de doação, mesmo tendo sido aceita: TJMG, $7^{\text {a }}$ Câm. Cív., Apel. n. 0038050-15.2005.8.13.0283, rel. ALVIM SOARES, j. 12-02-2008. Há ainda acórdão que afirma que a promessa de doação não serve para amparar alegação de posse com animus domini, por ser ato jurídico inexistente: TJRS, $18^{\mathrm{a}}$ Câm. Cív., Apel. n. 0078994-47.2014.8.21.7000, rel. NELSON JOSÉ GONZAGA, j. 08-05-2014.

Também no direito norte-americano a promessa de doação não pode ser executada, como regra geral, por lhe faltar consideration, elemento este contratual, como já explicado [ELIAS CLARK et al., Cases (...), cit., p. 
admite a promessa de doação nem sequer no âmbito da partilha realizada em separação ou divórcio ${ }^{655}$.

Nesse sentido, OZÉIAS J. SANTOS ${ }^{656}$ afirma explicitamente que não há margens para dúvidas quanto à possibilidade da promessa de doação, porém entende não ser possível a sua execução, com fundamento no art. $1.057^{657}$ do Código Civil de 1916, que no sistema atual encontra-se na forma do art. $392^{658}$ do Código Civil de 2002, porém tal entendimento não

443 (os autores apontam um julgado que permite a execução forçada de uma promessa de doação com caráter de caridade); RICHARD HYLAND, Gifts (...), cit., itens 679 e 693-709 (o autor reafirma a regra externada, porém explana o acirrado debate doutrinário que se formou no tema e as exceções que permitem a execução forçada da promessa de doação)].

${ }^{655}$ ARNALDO MARMITT, Doação, cit., pp. 103-104. DÉCIO ANTONIO ERPEN emite a opinião de que, se porventura, no acordo de partilha, um cônjuge ficar com um quinhão maior que o outro, não há doação, mas renúncia e transação. Se houver promessa de doação, será inexistente caso estivessem unidos sob o regime da comunhão universal de bens, mas se fosse o caso das demais disciplinas patrimoniais do casal, inclusive a separação obrigatória, então não há doação também, mas a qualificação jurídica correta do negócio também é a transação, que é passível de registro, mas não assim a promessa de doação, segundo seu parecer [Da Promessa de Doar nas Separações Judiciais, in GUSTAVO TEPEDINO e LUIZ EDSON FACHIN (Orgs.), Doutrinas Essenciais - Obrigações e Contratos, vol. V, São Paulo, Revista dos Tribunais, 2011, pp. 308310]. Pode contribuir com essa doutrina a distinção que CARLOS ALBERTO BITTAR faz entre doação e transação, pois, segundo ele, na segunda pode até haver gratuidade, justamente com o fito de dar fim à demanda, todavia não há animus donandi, mas sim um sacrifício patrimonial visando uma utilidade [Contratos (...), cit., pp. 43-44]. SILVIO RODRIGUES, por seu turno, afirma expressamente que a proibição de promessa de doação incide sobre as liberalidades puras, que são revogáveis até a ocorrência do aceite, mas, apesar de ressaltar que excluiu de sua lição as doações onerosas, não declina maiores desdobramentos doutrinários, ressaltando apenas que na promessa feita em separação ou divórcio há promessa de pagamento, mas não doação [Direito (...), cit., pp. 212-213].

Tais fundamentos jurídicos têm sido adotados pelo Superior Tribunal de Justiça, que iterativamente declarou a possibilidade de o Judiciário forçar o cumprimento da promessa de doação realizada no âmbito da partilha de separação ou divórcio, sob o fundamento de que não há liberalidade na hipótese. Nesse sentido: $2^{\mathrm{a}}$ Seção, Emb. de Div. no R. Esp. n. 125859/RJ, rel. RUY ROSADO DE AGUIAR, j. 26-06-2002; $3^{\mathrm{a}}$ T., R. Esp. 853133/SC, rel. HUMBERTO GOMES DE BARROS, j. 06-05-08; 3 ${ }^{\mathrm{a}}$ T., R. Esp. n. 742048/RS, rel. SIDNEI BENETI, j. 14-04-09; 4ª T., Ag. Reg. no R. Esp. n. 883232/MT, rel. RAUL ARAÚJO, j. 19-02-2013. Sobre esse tema, há ainda um precedente do Tribunal de Justiça do Espírito Santo se debruçando sobre instrumento particular consistente em termo firmado entre companheiros, no qual rompiam a relação e o varão reconhecia a paternidade sobre filho comum, prometendo ainda doar-lhe um imóvel em data futura, o mencionado Sodalício declarou que se trata de hipótese de doação pura, pelo que não passível de execução forçada, pela ausência de atualidade do animus donandi (3 ${ }^{\text {a }}$ Câm. Cív., Ap. 0000543-84.2009.8.08.0035, rel. ROBERTO DA FONSECA ARAÚJO, j. 04-06-2013). Outrossim, o Conselho Superior da Magistratura do Tribunal de Justiça de São Paulo proferiu acórdão no qual esposou-se a opinião de que o formal de partilha tirado da demanda é título suficiente para registrar a alienação em doação na matrícula do imóvel, desde que recolhido o tributo devido, sendo desnecessária a lavratura de escritura pública, considerando que o instrumento de transação em partilha emprega os verbos no futuro em vista da homologação judicial, mas uma vez que esse ato judicial ocorre, as partes já têm um título traslativo de domínio (Apel. n. 0005719-59.2012.8.26.0319, rel. ELLIOT AKEL, j. 03-06-2014).

VINCENZO TAVASSI explica que a jurisprudência italiana também rejeita a execução forçada da promessa de doação, porém no caso de promessa realizada em sede de partilha, qualifica o ato como um contrato atípico, para poder cominar o seu cumprimento (La Donazione, cit., pp. 39-40).

${ }^{656}$ Da Doação, cit., p. 21.

${ }^{657}$ Art. 1.057. "Nos contratos unilaterais, responde por simples culpa o contraente, a quem o contrato aproveite, e só por dolo, aquele a quem não favoreça. Nos contratos bilaterais, responde cada uma das partes por culpa".

${ }^{658}$ Art. 392. "Nos contratos benéficos, responde por simples culpa o contratante, a quem o contrato aproveite, e por dolo aquele a quem não favoreça. Nos contratos onerosos, responde cada uma das partes por culpa, salvo as exceções previstas em lei”. 
guarda compatibilidade com a teoria contratual, haja vista o princípio do pacta sunt servanda, e nem torna o cumprimento contratual direito potestativo do doador.

Em relação à corrente que aceita a possibilidade de efeitos da promessa de doação, há os que entendem por sua aplicabilidade em algumas hipóteses e os que pensam ser cabível indiscriminadamente ${ }^{659}$.

Na primeira fileira citada, entende-se ser possível a celebração de promessa de contrato de doação apenas em se tratando das doações retributivas ou modais, na primeira apenas enquanto o bem se refere à retribuição, e na segunda hipótese porque o modus daria caráter de contraprestação pelo donatário, mas sem haver execução específica da obrigação, de modo que, descumprida a promessa, o donatário não poderia perseguir a coisa, até porque não tinha direito real sobre ela, devendo então buscar perdas e danos ${ }^{660}$.

Assim, por exemplo, para PABLO STOLZE GAGLIANO ${ }^{661}$ a promessa de doação é perfeitamente cabível quando se trata de doação onerosa, mas que o mesmo não se dá na doação pura, pois como ela tem por causa um ato de liberalidade (com fins altruísticos ou não), sem nenhuma contraprestação da outra parte, torna-se incompatível admitir que o promitente-donatário possa proceder à execução específica do contrato contra o promitentedoador. Ou seja, para esse doutrinador, em caso de doação onerosa, o promitente donatário poderá requerer a execução específica da obrigação pactuada.

A reforçar essa constatação, o mesmo autor ${ }^{662}$ admite que exista a promessa de doação, mesmo quando pura, porém, em havendo o descumprimento da promessa, a solução será, ao invés da execução específica do quanto prometido, a conversão em indenização por perdas e danos que o promitente-donatário demonstre ter sofrido pela não celebração do contrato principal, podendo-se fundar tal pretensão, inclusive, na não observância dos deveres anexos à boa-fé objetiva.

Outrossim, na hipótese, porém, de se tratar de pacto de donando realizado no âmbito de partilha de bens em separação judicial, divórcio ou dissolução de união estável,

\footnotetext{
${ }^{659}$ ARNALDO MARMITT, Doação, cit., pp. 100-103.

${ }^{660}$ ARNALDO MARMITT, Doação, cit., pp. 100-101. Há quem concorde com esse posicionamento, sem, porém, descartar a possibilidade de execução específica da promessa feita [CAIO MÁRIO DA SILVA PEREIRA, Instituições (...), cit., pp. 217-218; CÉSAR FIUZA, Direito (...), cit., p. 508; DÉCIO ANTONIO ERPEN, Da Promessa (...), cit., pp. 303-304 e 312].

${ }^{661} \mathrm{O}$ Contrato (...), cit., pp. 107-108.

${ }^{662}$ O Contrato (...), cit., pp. 108-110.
} 
PABLO STOLZE GAGLIANO ${ }^{663}$ não só entende ser tal figura admissível, como também $v \hat{e}^{664}$ neste caso a exceção para se admitir o manejo da execução específica pelo promitentedonatário, mormente em se tratando de um dos cônjuges ou filhos do casal, pois na verdade, segundo o autor, a promessa feita é manifestação negocial de vontade e os princípios regentes do direito de família assim exige.

Por fim, há os que admitem a promessa de doação em qualquer hipótese, mesmo nas doações puras, isso porque nada impediria que as partes fizessem um contrato preliminar de doação, sendo que o animus donandi surge quando da celebração da promessa e o doador assume então uma obrigação de fazer, que pode ser especificamente executada pelo donatário $^{665}$, mormente no caso de doação realizada no bojo de partilha de bens em ação de separação ou divórcio ${ }^{666}$, que, além de tudo, é irretratável ${ }^{667}$.

Nesse sentido, ARNALDO MARMITT ${ }^{668}$ se posiciona de maneira favorável à execução da promessa de doação, pois não existiria qualquer barreira jurídica para tanto e em algumas situações concretas se mostra a medida de maior justiça, apontando, como exemplo, a promessa de doação feita no bojo da partilha de separação e divórcio, ou realizada por político em campanha ou de pessoa que promete doar casebre a senhora simples, em troca de um seu órgão e, após o sucesso da cirurgia de transplante, não só não cumpre a promessa, como ainda intenta ação possessória contra a promitente-donatária.

Como se verifica, o contrato preliminar de doação não tem base jurídica segura no Direito Civil brasileiro, o que o torna pouco atraente na preparação estratégica de sucessão.

${ }^{663}$ O Contrato (...), cit., p. 111.

${ }^{664}$ O Contrato (...), cit., p. 112-115. No mesmo sentido: AMANDA ZOE MORRIS, Doação, cit., p. 278; PAULO DE TARSO VIEIRA SANSEVERINO, Contratos (...), cit., pp. 78-79; SYLVIO CAPANEMA DE SOUZA, Das Várias (...), cit., pp. 101-112. Em sentido contrário: DÉCIO ANTONIO ERPEN, Da Promessa (...), cit., pp. 307-308.

665 ARNALDO MARMITT, Doação, cit., p. 101; ARNALDO RIZZARDO, Contratos, cit., pp. 450-453; EDUARDO ESPINOLA, Dos Contratos (...), cit. pp. 170-171; FLÁVIO AUGUSTO MONTEIRO DE BARROS, Manual (...), cit., p. 357; FLÁVIO TARTUCE, Direito (...), cit., pp. 328-329; FRANCISCO GLAUBER PESSOA ALVES, Das Várias (...), cit., pp. 878-879; NATAL NADER, Questões Relativas à Doação, cit., p. 458; PAULO LÔBO, Direito (...), cit., pp. 289-290; PAULO NADER, Curso (...), cit., p. 229; PLANIOL, Traité (...), cit., p. 642 (o autor admite expressamente que a doação se constitua por meio de uma promessa e aduz como exemplo o fato de o doador prometer entregar uma soma em dinheiro ao donatário, mas ressalta que o objeto do negócio é uma dação); PONTES DE MIRANDA, Tratado (...), cit., pp. 201-202 e 261-262; SÍLVIO DE SALVO VENOSA, Direito (...), cit., pp. 142-143; WASHINGTON DE BARROS MONTEIRO-DABUS MALUF, Curso (...), cit., pp. 165-166.

${ }^{666}$ ARNALDO MARMITT, Doação, cit., pp. 104-106; NATAL NADER, Questões Relativas à Doação, cit., pp. 458-459; PAULO LÔBO, Das Várias (...), cit., pp. 284-287; RODRIGO SENISE LISBOA, Manual (...), cit., p. 264.

667 ARNALDO MARMITT, Doação, cit., pp. 112-113.

${ }^{668}$ Doação, cit., pp. 107-109. 
Mesmo que o doador pretenda lançar mão de doação dita onerosa, ou da sólida doutrina a favor do negócio jurídico, terá ainda de elidir igualmente sólidas doutrina e jurisprudência.

Assim, não se voltará ao tema na presente pesquisa.

\section{7) Revogação da doação}

A doação pode se extinguir pelos meios naturais do contrato ou ser revogada ${ }^{669}$.

A doação, enquanto contrato, se extingue no momento em que o doador leva a efeito o cumprimento do quanto prometido e aceito pelo donatário, bem como quando é declarada sua invalidade por alguma nulidade ou anulabilidade, ou ainda ocorre sua resolução ${ }^{670}$.

O art. 1.181, caput e parágrafo único ${ }^{671}$, do Código Civil de 1916, consignava expressamente em sua redação as situações acima descritas, no que não foi seguido pelo art. $555^{672}$ do Código Civil de 2002, que somente prevê as hipóteses de revogação, sem falar na extinção comum ${ }^{673}$.

Com efeito, revogação não se aplica aos outros contratos, a não ser o de mandato, sendo que as demais espécies contratuais são passíveis de anulação, rescisão ou resolução. Desse modo, aplica-se à doação todo o regime contratual, mas há uma especialidade para sua revogação nas hipóteses de ingratidão ou descumprimento de encargo ${ }^{674}$.

${ }^{669}$ CARLOS ALBERTO BITTAR, Contratos (...), cit., p. 47; CARLOS ROBERTO GONÇALVES, Direito (...), cit., pp. 276-277; FRANCISCO GLAUBER PESSOA ALVES, Das Várias (...), cit., p. 918; LIMONGI FRANÇA, Manual (...), cit., p. 101; PABLO STOLZE GAGLIANO, O Contrato (...), cit., pp. 170-195; SILVIO LUÍS FERREIRA DA ROCHA, Curso (...), cit., p. 181.

${ }^{670}$ AMANDA ZOE MORRIS, Doação, cit., p. 282; ANTÔNIO CHAVES, Lições (...), cit., p. 254; CARVALHO SANTOS, Código (...), cit., p. 433; CLÓVIS BEVILAQUA, Código (...), cit., p. 285; EDUARDO ESPINOLA, Dos Contratos (...), cit. p. 201; PABLO STOLZE GAGLIANO, O Contrato (...), cit., p. 170; SÍlVIO DE SALVO VENOSA, Direito (...), cit., p. 137; SILVIO RODRIGUES, Direito (...), cit., p. 214; WASHINGTON DE BARROS MONTEIRO-DABUS MALUF, Curso (...), cit., pp. 1177-178. PAULO LÔBO, pelo contrário, ensina que as causas gerais de extinção contratuais não incidem na doação [Das Várias (...), cit., p. 354].

${ }^{671}$ Art. 1.181. "Além dos casos comuns a todos os contratos, a doação também se revoga por ingratidão do donatário. Parágrafo único. A doação onerosa poder-se-á revogar por inexecução do encargo, desde que o donatário incorrer em mora".

${ }^{672}$ Art. 555. "A doação pode ser revogada por ingratidão do donatário, ou por inexecução do encargo".

${ }^{673}$ Consultar a respeito: ARNALDO RIZZARDO, Contratos, cit., p. 470.

${ }^{674}$ AGOSTINHO ALVIM, Da Doação, cit., p. 259. Sobre a diferença da revogação no contrato de mandato: CARLOS ROBERTO GONÇALVES, Direito (...), cit., p. 277. Nesse tema, EDUARDO ESPINOLA explica que o uso do termo "revogação" é oriundo da doutrina francesa, dada a proximidade da doação com o testamento (esse sim revogável), no Código Napoleônico [Dos Contratos (...), cit. pp. 196-197]. 
Na doutrina de VICENTE SABINO JÚNIOR ${ }^{675}$, porém, as hipóteses de extinção do contrato de doação por presença de alguns dos vícios de vontade ou hipóteses de invalidade do ato jurídico é de revogação. Assim, para ele ${ }^{676}$, a tradição de objeto ilícito, ou a doação de coisa impossível de se realizar, ou a não observância da devida solenidade, ou ainda a falta de aceite, constituem exemplos de hipóteses de revogação da doação. Como se vê, há nessa opinião mero entendimento diferenciado do significado semântico do termo revogação ${ }^{677}$.

Neste capítulo, ficam distintas as hipóteses de dissolução contratuais gerais das de revogação, previstas no já transcrito art. 555 do Código Civil de 2002, interessando agora se debruçar sobre estas últimas ${ }^{678}$.

Os estudiosos do tema afirmam que a doação é, essencialmente, irrevogável ${ }^{679}$, seja pela sua natureza jurídica contratual ${ }^{680}$, seja porque a possibilidade de o doador poder revogar a doação feita anteriormente por ele traz situação excepcional aos direitos reais, haja

${ }^{675}$ Contrato (...), cit., pp. 137-138.

${ }^{676}$ Contrato (...), cit., p. 134.

${ }^{677}$ Sobre a diferença entre invalidade e revogação, consultar: ARNALDO RIZZARDO, Contratos, cit., p. 470471; ARNOLDO WALD, Direito (...), cit., pp. 72-74 (o autor diferencia também resolução e redução); FLÁVIO AUGUSTO MONTEIRO DE BARROS, Manual (...), cit., p. 358; FRANCISCO GLAUBER PESSOA ALVES, Das Várias (...), cit., pp. 918-920; NELSON ROSENVALD, Contratos (...), cit., p. 597. Sobre diversas hipóteses de extinção da doação, consultar: FÁBIO ULHOA COELHO, Curso (...), cit., pp. 249-251. Sobre as nulidades na doação: ANTÔNIO CHAVES, Lições (...), cit., pp. 255 e 258-261; ARNALDO RIZZARDO, Contratos, cit., pp. 468-470; CARVALHO SANTOS, Código (...), cit., p. 434; CÉSAR FIUZA, Direito (...), cit., pp. 510-511; CLÓVIS BEVILAQUA, Código (...), cit., p. 285; EDUARDO ESPINOLA, Dos Contratos (...), cit. p. 196; LIMONGI FRANÇA, Manual (...), cit., p. 101; MARIA HELENA DINIZ, Curso (...), cit., pp. 270-271; ORLANDO GOMES, Contratos, cit., pp. 241-242; PONTES DE MIRANDA, Tratado (...), cit., p. 265.

${ }^{678}$ Por entender que a doação modal é contrato bilateral, há quem afirme que o descumprimento de encargo leva à rescisão ou resolução, mas não à revogação, de modo que a lei teria se manifestado em termos incorretos [CARLOS ROBERTO GONÇALVES, Direito (...), cit., pp. 277; JONES FIGUEIRÊDO ALVES, Código (...), cit., p. 458; NELSON ROSENVALD, Contratos (...), cit., p. 596; ROBERTO WAGNER MARQUESI, $A$ Doação (...), cit., p. 494; SILVIO LUÍS FERREIRA DA ROCHA, Curso (...), cit., p. 186]. Na lição de PONTES DE MIRANDA há expressa menção de resolução contratual da doação por descumprimento de encargo, mesmo que o doutrinador esposa a tese de que o modus é anexo ao contrato unilateral. No entanto, o autor é avesso à ideia de que há bilateralidade na doação modal, mas ainda assim se antepõe ao instituto da revogação nessa hipótese, reafirmando que nesse caso a doação se resolve [Tratado (...), cit., pp. 211 e 266 268].

Quanto ao emprego do termo revogação pela lei, PONTES DE MIRANDA ressalta que é acertado, pois as causas de desconstituição do ato não são negociais e posteriores a ele [Tratado (...), cit., p. 270].

679 ARNALDO MARMITT, Doação, cit., p. 17; CARVALHO SANTOS, Código (...), cit., p. 432; LUIZ GUILHERME LOUREIRO, Curso (...), cit., p. 518; OZÉIAS J. SANTOS, Da Doação, cit., p. 15; PAUL DELNOY, Le Libéralités (...), cit., p. 52; PAULO NADER, Curso (...), cit., p. 237; PONTES DE MIRANDA, Tratado (...), cit., p. 269.

${ }^{680}$ ARNALDO MARMITT, Doação cit., p. 17; FLÁVIO AUGUSTO MONTEIRO DE BARROS, Manual (...), cit., p. 357; SILVIO LUÍS FERREIRA DA ROCHA, Curso (...), cit., p. 183. Nesse sentido, CARVALHO SANTOS ensina que as hipóteses legais não são exceções à irrevogabilidade da doação, mas sim descumprimento de condição resolutiva tácita [Código (...), cit., p. 432]. 
vista que pugna com o caráter perpétuo do direito de propriedade ${ }^{681}$. A acentuar a excepcionalidade da revogação, é de se considerar que para a doação ser revogada não basta declaração unilateral de vontade do doador, precisando ele recorrer ao Poder Judiciário para $\operatorname{tanto}^{682}$.

Não obstante, há quem entenda que o contrato de doação pode se desfazer por acordo entre as partes contratantes, desde que se observe a mesma forma da celebração do contrato $^{683}$. Nessa hipótese, porém, não há propriamente uma revogação, mas sim um novo ato de doação.

A revogação, enquanto tal, consiste em tolher de eficácia futura a doação realizada e tem por efeito a reversão do bem ao patrimônio do doador ${ }^{684}$. Trata-se de um direito potestativo do doador, pois a ele está reservado buscar o desfazimento da liberalidade, quando entende ter ocorrido as hipóteses previstas em lei ${ }^{685}$.

PONTES DE MIRANDA ${ }^{686}$ explica, ainda, que a opção legislativa não foi de reputar o ato desfeito por denúncia cheia contratual, mas sim dar ao doador a possibilidade de tirar "a voz" da transferência liberal. Ou seja, a revogação tolhe a eficácia do contrato ${ }^{687}$.

Como já foi dito, para ocorrer a revogação, faz-se necessária a propositura de uma ação judicial, não bastando mera declaração de vontade unilateral, sendo o direito de ação

${ }^{681}$ PABLO STOLZE GAGLIANO, O Contrato (...), cit., p. 171.

682 ARNALDO MARMITT, Doação, cit., p. 17; EDUARDO ESPINOLA, Dos Contratos (...), cit. p. 201; MANUEL BAPTISTA LOPES, Das Doações, cit., p. 149; OZÉIAS J. SANTOS, Da Doação, cit., p. 25; SILVIO RODRIGUES, Direito (...), cit., p. 217; WASHINGTON DE BARROS MONTEIRO-DABUS MALUF, Curso (...), cit., p. 181.

${ }^{683}$ CARVALHO SANTOS, Código (...), cit., p. 433; PONTES DE MIRANDA, Tratado (...), cit., p. 275 (o autor fala em negócio bilateral com eficácia de revogação); VICENTE SABINO JÚNIOR, Contrato (...), cit., p. 134.

PAUL DELNOY ensina que assim também o é no Direito Francês, por aplicação da segunda alínea do art. 1134 do diploma civil gálico: "1. Les conventions légalement formées tiennent lieu de loi à ceux qui les ont faites. 2. Elles ne peuvent être révoquées que de leur consentement mutuel, ou pour les causes que la loi autorise. 3. Elles doivent être exécutées de bonne foi." [Le Libéralités (...), cit., p. 52].

684 ARNALDO MARMITT, Doação, cit., p. 245; PAULO LÔBO, Das Várias (...), cit., p. 355 (o autor fala também em desfazer e invalidar o ato).

${ }^{685}$ FLÁVIO TARTUCE, Direito (...), cit., p. 329; PABLO STOLZE GAGLIANO, O Contrato (...), cit., p. 171. Mas apenas num sentido lato se pode falar em direito potestativo, porque não depende apenas do alvedrio do doador a fim de se conseguir a revogação, mas necessita também a configuração dos pressupostos legais e de sentença judicial (CELESTE IACOVINO, La Donazione, cit., p. 355).

${ }^{686}$ Tratado (...), cit., p. 271.

${ }^{687}$ CELESTE IACOVINO, La Donazione, cit., p. 356. 
personalíssimo, podendo os herdeiros atuarem somente quando a morte do doador vier a ocorrer após a citação na demanda ${ }^{688}$.

A legitimidade das partes da ação revogatória é disciplinada pelo art. $560^{689}$ do Código Civil de 2002, que prevê expressamente, quanto ao polo passivo, que os herdeiros do donatário somente responderão se ele foi citado antes de falecer ${ }^{690}$, pois do contrário ocorrerá a transmissão causa mortis da propriedade ${ }^{691}$.

O exercício desse direito pelo donatário, para alguns, terá efeito ex nunc ${ }^{692}$, ao passo que, para outros, a sentença que revoga uma doação terá efeito ex tunc e a benesse será tida por inexistente ${ }^{693}$. Há ${ }^{694}$, porém, quem entenda que na hipótese de revogação por

${ }^{688}$ ARNALDO RIZZARDO, Contratos, cit., p. 477; CAIO MÁRIO DA SILVA PEREIRA, Instituições (...), cit., p. 223; CARLOS AlBERTO BITTAR, Contratos (...), cit., p. 47; CARVAlHO SANTOS, Código (...), cit., p. 454; EDUARDO ESPINOLA, Dos Contratos (...), cit. pp. 199-200; FÁBIO UlHOA COELHO, Curso (...), cit., p. 254; FLÁVIO AUGUSTO MONTEIRO DE BARROS, Manual (...), cit., pp. 357-358; FRANCISCO GLAUBER PESSOA ALVES, Das Várias (...), cit., p. 936-937; MARIA HELENA DINIZ, Tratado (...), cit., p. 97; NELSON ROSENVALD, Contratos (...), cit., p. 600; ORLANDO GOMES, Contratos, cit., pp. 242-243; OZÉIAS J. SANTOS, Da Doação, cit., p. 25; PAULO LÔBO, Das Várias (...), cit., pp. 374-375; PONTES DE MIRANDA, Tratado (...), cit., p. 276; SÍlVIO DE SALVO VENOSA, Direito (...), cit., pp. 141-142.

${ }^{689}$ Art. 560. "O direito de revogar a doação não se transmite aos herdeiros do doador, nem prejudica os do donatário. Mas aqueles podem prosseguir na ação iniciada pelo doador, continuando-a contra os herdeiros do donatário, se este falecer depois de ajuizada a lide".

O regramento da legitimidade no Código Civil português é semelhante ao pátrio, como se verifica na redação do seu art. $976 .^{\circ}$ ("Prazo e legitimidade para a acção"): "1. A acção de revogação por ingratidão não pode ser proposta, nem depois da morte do donatário, nem pelos herdeiros do doador, salvo o caso previsto no n. ${ }^{\circ} 3$, e caduca ao cabo de um ano, contado desde o facto que lhe deu causa ou desde que o doador teve conhecimento desse facto. 2. Falecido o doador ou o donatário, a acção, quando pendente, é transmissível aos herdeiros de um ou de outro. 3. Se o donatário tiver cometido contra o doador o crime de homicídio, ou por qualquer causa o tiver impedido de revogar a doação, a acção pode ser proposta pelos herdeiros do doador dentro de um ano a contar da morte deste".

Já o Código Civil da Itália, no seu art. 802 ("Termini e legittimazione ad agire"), permite que os herdeiros promovam a ação de revogação ou então que a demanda seja proposta em face dos herdeiros do donatário ingrato, desde que observado o prazo : " 1 . La domanda di revocazione per causa d'ingratitudine deve essere proposta dal donante o dai suoi eredi, contro il donatario o i suoi eredi, entro l'anno dal giorno in cui il donante è venuto a conoscenza del fatto che consente la revocazione. 2. Se il donatario si è reso responsabile di omicidio volontario in persona del donante o gli ha dolosamente impedito di revocare la donazione, il termine per proporre l'azione è di un anno dal giorno in cui gli eredi hanno avuto notizia della causa di revocazione". Consultar a respeito: CELESTE IACOVINO, La Donazione, cit., pp. 369-371.

${ }^{690}$ ARNALDO RIZZARDO, Contratos, cit., p. 477; CARLOS ROBERTO GONÇALVES, Direito (...), cit., p. 281; EDUARDO ESPINOLA, Dos Contratos (...), cit. p. 200; FLÁVIO AUGUSTO MONTEIRO DE BARROS, Manual (...), cit., p. 361; FRANCISCO GLAUBER PESSOA ALVES, Das Várias (...), cit., p. 937; PAUlO NADER, Curso (...), cit., p. 238; SÍlVIO DE SALVO VENOSA, Direito (...), cit., p. 142; SILVIO LUÍS FERREIRA DA ROCHA, Curso (...), cit., p. 184.

${ }^{691}$ CÉSAR FIUZA, Direito (...), cit., p. 511; NELSON ROSENVALD, Contratos (...), cit., p. 600 (o autor explica que a lei homenageia a independência entre o autor da herança e seus herdeiros); PAULO LÔBO, Das Várias (...), cit., p. 375.

${ }^{692}$ CAIO MÁRIO DA SILVA PEREIRA, Instituições (...), cit., p. 225; CÉSAR FIUZA, Direito (...), cit., p. 512; LUIZ GUILHERME LOUREIRO, Curso (...), cit., p. 520; MARIA HELENA DINIZ, Tratado (...), cit., p. 96; NELSON ROSENVALD, Contratos (...), cit., p. 602; PABLO STOLZE GAGLIANO, O Contrato (...), cit., p. 171.

${ }^{693}$ PONTES DE MIRANDA, Tratado (...), cit., p. 265 (o autor ressalta, porém, que há efeitos especiais); 
ingratidão, a sentença terá efeito ex nunc, ao passo que na decisão que revoga a benesse por inexecução do encargo seu efeito será ex tunc, tendo por consequência prática, na primeira hipótese, que até a formação da litigiosidade, o donatário é legítimo possuidor, tendo direito a perceber os frutos da coisa, sendo que os atos de alienação são perfeitos, devendo converterse, então, em indenização ao doador.

O art. $563^{695}$ do Código Civil de 2002 é expresso na matéria. À luz do art. $1.186^{696}$ do Código Civil de 1916, cuja redação se manteve no citado art. 563, que apenas o adequou ao Código de Processo Civil, já que não há mais a litiscontestatio, AGOSTINHO ALVIM ${ }^{697}$ lecionava que a revogação por ingratidão do donatário terá efeitos ex nunc, o que importaria no fato de que atos de disposição feitos pelo donatário terão plena validade, de modo que entende que a ingratidão perpetrada não é uma condição resolutiva, sendo regida pelo art. $648^{698}$ do Código Civil de 1916, correspondente ao atual art. $1.360^{699 / 700}$.

Por empregar o termo "revogação", a norma deixa ao intérprete outros problemas dos efeitos perante terceiros após a sentença revogatória e, para solucionar tal problema, devese distinguir algumas situações basais.

VICENTE SABINO JÚNIOR, Contrato (...), cit., p. 135.

${ }^{694}$ ARNALDO MARMITT, Doação, cit., p. 281; CARVALHO SANTOS, Código (...), cit., p. 459; FLÁVIO AUGUSTO MONTEIRO DE BARROS, Manual (...), cit., p. 361; NATAL NADER, Questões Relativas à Doação (II), cit., pp. 472-473.

695 Art. 563. "A revogação por ingratidão não prejudica os direitos adquiridos por terceiros, nem obriga o donatário a restituir os frutos percebidos antes da citação válida; mas sujeita-o a pagar os posteriores, e, quando não possa restituir em espécie as coisas doadas, a indenizá-la pelo meio termo do seu valor".

${ }^{696}$ Art. 1.186. "A revogação por ingratidão não prejudica os direitos adquiridos por terceiro, nem obriga o donatário a restituir os frutos, que percebeu antes de contestada a lide; mas sujeita-o a pagar os posteriores, e, quando não possa restituir em espécie as coisas doadas, a indenizá-las pelo meio termo do seu valor".

${ }^{697}$ Da Doação, cit., p. 310. No mesmo sentido: ORLANDO GOMES, Contratos, cit., p. 243.

${ }^{698}$ Art. 648. "Se, porém, o domínio se resolver por outra causa superveniente, o possuidor, que o tiver adquirido por título anterior à resolução, será considerado proprietário perfeito, restando à pessoa em cujo benefício houve a resolução ação contra aquele cujo domínio se resolveu para haver a própria coisa, ou seu valor".

${ }^{699}$ Art. 1.360. "Se a propriedade se resolver por outra causa superveniente, o possuidor, que a tiver adquirido por título anterior à sua resolução, será considerado proprietário perfeito, restando à pessoa, em cujo benefício houve a resolução, ação contra aquele cuja propriedade se resolveu para haver a própria coisa ou o seu valor".

${ }^{700}$ Para AGOSINHO ALVIM (Da Doação, cit., pp. 311-312.), tal solução legal é a mais justa, pois o tratamento dado à propriedade resolúvel tem em vista o fato de que o terceiro adquirente tem ciência da condição resolutiva ou do encargo, ao passo que não se sabe se o donatário praticará ou não a ingratidão.

Também se conduziu no mesmo sentido o Código Civil da França, como se verifica no seu art. 958: “1. La révocation pour cause d'ingratitude ne préjudiciera ni aux aliénations faites par le donataire, ni aux hypothèques et autres charges réelles qu'il aura pu imposer sur l'objet de la donation, pourvu que le tout soit antérieur à la publication, au fichier immobilier, de la demande en révocation. 2. Dans le cas de révocation, le donataire sera condamné à restituer la valeur des objets aliénés, eu égard au temps de la demande, et les fruits, à compter du jour de cette demande". PAUL DELNOY explica ainda, a esse respeito, que somente entre as partes o efeito será ex tunc [Le Libéralités (...), cit., p. 57]. 
Em se tratando de bem imóvel, se registrada a citação na matrícula do bem, então a presunção iuris et de iure é de que o terceiro adquirente sabia do risco do negócio e está sujeito a perder o bem. Se tal providência não foi tomada, a simples existência da sentença revogatória não induz à perda de efeito da alienação perante o terceiro, mas poderá o autor provar a má-fé e anular a transferência. Além disso, poderá haver revogação se provada simulação ${ }^{701}$.

Se for bem móvel, porém, ao doador só resta provar eventual má-fé do terceiro adquirente ou realização de simulação, sendo inócuo qualquer registro ${ }^{702}$.

No tocante à responsabilidade pelos frutos, o dispositivo legal estabeleceu uma presunção iuris et de iure de boa-fé, cessando-se esta para o donatário após a citação ${ }^{703}$. Quanto à indenização prevista, o emprego de "meio-termo" indica que a mensuração será a média entre o maior e o menor preço atingido pelo bem doado no período entre a doação e a restituição da coisa $^{704}$.

Ademais, eventual cláusula proibitiva de revogação seria nula, pois o direito à revogação não é passível de renúncia ${ }^{705}$, o que se justificaria, segundo a doutrina ${ }^{706}$, por ser

${ }_{701}^{70}$ AGOSTINHO ALVIM, Da Doação, cit., pp. 312-315.

${ }^{702}$ AGOSTINHO ALVIM, Da Doação, cit., p. 315.

${ }^{703}$ AGOSTINHO ALVIM, Da Doação, cit., pp. 316-319; ARNALDO RIZZARDO, Contratos, cit., p. 476; CARLOS ROBERTO GONÇALVES, Direito (...), cit., p. 279; FLÁVIO AUGUSTO MONTEIRO DE BARROS, Manual (...), cit., p. 361; FLÁVIO TARTUCE, Direito (...), cit., p. 331; NELSON ROSENVALD, Contratos (...), cit., p. 602; PAULO LÔBO, Das Várias (...), cit., pp. 381-382; SILVIO RODRIGUES, Direito (...), cit., p. 218.

${ }^{704}$ AGOSTINHO ALVIM, Da Doação, cit., p. 320 (o autor ressalta, porém, que a base será o maior e o menor que a coisa teve nesse lapso temporal); CARVALHO SANTOS, Código (...), cit., pp. 461-462 (o autor ressalta que deverá também ser indenizado pelo donatário eventuais ônus reais que recaíram sobre o bem); CLÓVIS BEVILAQUA, Código (...), cit., p. 289; EDUARDO ESPINOLA, Dos Contratos (...), cit. p. 201; FÁBIO ULHOA COELHO, Curso (...), cit., p. 253; FRANCISCO GLAUBER PESSOA ALVES, Das Várias (...), cit., pp. 941-942 (o autor questiona, porém, a aplicação prática do dispositivo); JONES FIGUEIRÊDO ALVES, Código (...), cit., p. 464; NELSON ROSENVALD, Contratos (...), cit., p. 602. Há quem adote, como termo ad quem, a prática da ingratidão: FLÁVIO AUGUSTO MONTEIRO DE BARROS, Manual (...), cit., p. 361. PAULO LÔBO, por seu turno, ensina que prevalece a média do valor de mercado atual, se existente [Das Várias (...), cit., p. 382].

${ }^{705}$ ARNALDO RIZZARDO, Contratos, cit., p. 471; EDUARDO ESPINOLA, Dos Contratos (...), cit. p. 197; JONES FIGUEIRÊDO ALVES, Código (...), cit., p. 458; ORLANDO GOMES, Contratos, cit., p. 243; OZÉIAS J. SANTOS, Da Doação, cit., pp. 15 e 26; PONTES DE MIRANDA, Tratado (...), cit., p. 275; VICENTE SABINO JÚNIOR, Contrato de (...), cit., p. 142. Há quem ensine, porém, que é possível haver renúncia à revogação por descumprimento de encargo: CARVALHO SANTOS, Código (...), cit., pp. 438439; PAULO LÔBO, Das Várias (...), cit., p. 359.

Também o Código Civil português veda o doador de renunciar ao direito de revogação, como se vê no seu art. 977. ("Inadmissibilidade de renúncia antecipada"): "O doador não pode antecipadamente renunciar ao direito de revogar a doação por ingratidão do donatário". MANUEL BAPTISTA LOPES afirma que a norma protege os bons costumes, pois um pacto de renúncia à revogação tiraria do doador a faculdade de punir um ato imoral perpetrado pelo donatário, e ensina ainda que o diploma civil a teria por nula [Das Doações, cit., pp. 144-145].

706 ARNALDO MARMITT, Doação, cit., p. 272; CAIO MÁRIO DA SILVA PEREIRA, Instituições (...), cit., p. 
questão de ordem pública ${ }^{707}$. Não obstante, a nulidade da cláusula não inquina todo o negócio jurídico, que se mantém hígido ${ }^{708}$.

Com efeito, para AGOSTINHO ALVIM ${ }^{709}$ a regra do art. $1.182^{710}$ do Código Civil de 1916 veda a renúncia do direito de revogação por ingratidão pelo doador por ser de ordem pública $^{711}$, e tem seu fundamento nos fatos de as hipóteses de revogação serem dotadas de alta gravidade, de o doador poder mudar de ideia após a ocorrência de alguns dos fatos previstos para a revogação, de a renúncia prévia poder significar uma espécie de autorização ao donatário para a prática de alguns dos atos que induz à revogação e, por fim, de que o doador que renuncia ao direito de revogação antecipadamente está a demonstrar não estar no gozo pleno de sua razão, pelo que conclui que a norma tem natureza "tutelar",712. O dispositivo mencionado manteve-se no art. $556^{713}$ do Código Civil de $2002^{714}$.

No entanto, nada impede o perdão ou o não exercício do direito pelo doador ${ }^{715}$, bem como a renúncia quando da ocorrência de algumas das hipóteses legais ${ }^{716}$. Com efeito, nada obriga o doador a exercer o direito à revogação, o que ele não pode é abrir mão dessa

226; CARLOS ROBERTO GONÇALVES, Direito (...), cit., pp. 278-279; CLÓVIS BEVILAQUA, Código (...), cit., p. 286; FLÁVIO TARTUCE, Direito (...), cit., p. 329; FRANCISCO GLAUBER PESSOA ALVES, Das Várias (...), cit., p. 922; MARIA HELENA DINIZ, Tratado (...), cit., pp. 96-97; NELSON ROSENVALD, Contratos (...), cit., p. 597; PAULO LÔBO, Direito (...), cit., pp. 307-308; SILVIO RODRIGUES, Direito (...), cit., p. 215; WASHINGTON DE BARROS MONTEIRO-DABUS MALUF, Curso (...), cit., p. 183.

${ }^{707}$ SÍLVIO DE SALVO VENOSA ensina que a proibição é uma punição ao donatário ingrato e uma presunção da vontade do doador [Direito (...), cit., p. 138]. Escrevendo no âmbito do Código Napoleônico, PAUL DELNOY também leciona que a previsão legal de revogação da doação tem a função de proteger o doador e sancionar o donatário [Le Libéralités (...), cit., p. 55].

${ }^{708}$ CÉSAR FIUZA, Direito (...), cit., p. 512; FLÁVIO TARTUCE, Direito (...), cit., p. 329; FRANCISCO GLAUBER PESSOA ALVES, Das Várias (...), cit., p. 923.

${ }^{709}$ Da Doação, cit., pp. 270-271.

${ }^{710}$ Art. 1.182. "Não se pode renunciar antecipadamente o direito de revogar a liberalidade por ingratidão do donatário".

${ }^{711}$ No mesmo sentido: CARVALHO SANTOS, Código (...), cit., p. 442.

${ }^{712}$ Consultar também: FÁBIO ULHOA COELHO, Curso (...), cit., p. 253; MARIA HELENA DINIZ, Curso (...), cit., p. 274; PAULO NADER, Curso (...), cit., p. 237.

${ }^{713}$ Art. 556. "Não se pode renunciar antecipadamente o direito de revogar a liberalidade por ingratidão do donatário".

$714 \mathrm{O}$ art. 806 ("Inammissibilità della rinunzia preventiva") da lei civil italiana também proíbe o doador de renunciar à faculdade de revogar a liberalidade: "Non è valida la rinunzia preventiva alla revocazione della donazione per ingratitudine o per sopravvenienza di figli". Por se tratar de norma protetora de valores morais e familiares, é de ordem pública (CELESTE IACOVINO, La Donazione, cit., p. 361).

715 CAIO MÁRIO DA SILVA PEREIRA, Instituições (...), cit., p. 226; CARLOS ROBERTO GONÇALVES, Direito (...), cit., pp. 279; ORLANDO GOMES, Contratos, cit., p. 243; OZÉIAS J. SANTOS, Da Doação, cit., p. 15.

${ }^{716}$ ARNALDO RIZZARDO, Contratos, cit., p. 471; VICENTE SABINO JÚNIOR, Contrato de (...), cit., p. 142. 
faculdade antes de ocorrido o fato, mas se o fizer após o ocorrido, então se deduz que tenha perdoado o ofensor $^{717}$, sendo essa uma presunção juris tantum ${ }^{718}$.

Especificamente no caso de revogação por ingratidão, após a ocorrência de algumas das hipóteses autorizadoras, nada impede que o doador perdoe expressamente o donatário, por meio de uma missiva, por exemplo, ou tacitamente, seja quedando-se inerte, seja praticando atos contrários à vontade de revogar, como fazendo nova doação ao donatário ingrato $^{719}$. Se, porém, o donatário voltar a ser ingrato, abre-se nova possibilidade de revogação da benesse ${ }^{720}$.

Por derradeiro, vale se debruçar sobre o tema do prazo para o doador ingressar com a competente ação de revogação da liberalidade, pela ocorrência de algumas das hipóteses legais.

Quanto à ação para revogação de doação modal por encargo descumprido, a doutrina $^{721}$ entende que o doador tem o prazo decadencial de 10 anos, por aplicação do art. $205^{722}$ do Código Civil de $2002^{723}$. Quando há descumprimento de encargo, o prazo se conta

${ }_{718}^{717}$ ARNALDO MARMITT, Doação, cit., pp. 272-273; FLÁVIO TARTUCE, Direito (...), cit., p. 329.

718 WASHINGTON DE BARROS MONTEIRO-DABUS MALUF, Curso (...), cit., p. 183. CARVALHO SANTOS aduz sérias críticas à essa presunção [consultar: Código (...), cit., pp. 454-456].

${ }^{719}$ AGOSTINHO ALVIM, Da Doação, cit., p. 271; CARVALHO SANTOS, Código (...), cit., p. 453; CELESTE IACOVINO, La Donazione, cit., p. 361; FLÁVIO AUGUSTO MONTEIRO DE BARROS, Manual (...), cit., p. 359; FLÁVIO TARTUCE, Direito (...), cit., pp. 330-331 (no caso específico do homicídio, o autor admite a prova testemunhal do perdão, se o doador o fez no leito de morte); JONES FIGUEIRÊDO ALVES, Código (...), cit., p. 458; MARIA HELENA DINIZ, Tratado (...), cit., p. 97; PAULO LÔBO, Direito (...), cit., p. 308; PAULO NADER, Curso (...), cit., p. 237.

${ }^{720}$ AGOSTINHO ALVIM, Da Doação, cit., p. 271; ARNALDO RIZZARDO, Contratos, cit., p. 477; MARIA HELENA DINIZ, Curso (...), cit., p. 274.

${ }^{721}$ FLÁVIO AUGUSTO MONTEIRO DE BARROS, Manual (...), cit., p. 362; OZÉIAS J. SANTOS, Da Doação, cit., p. 25; PABLO STOLZE GAGLIANO, O Contrato (...), cit., p. 175; ROBERTO WAGNER MARQUESI, A Doação (...), cit., pp. 484-485. Há quem concorde com o tempo estabelecido, mas qualifica o prazo de prescricional: FRANCISCO GLAUBER PESSOA ALVES, Das Várias (...), cit., p. 939.

${ }^{722}$ Art. 205. "A prescrição ocorre em dez anos, quando a lei não lhe haja fixado prazo menor".

${ }^{723}$ Há quem ensine, porém, que somente se aplica o prazo do mencionado art. 205 quando o pedido for de resolução por descumprimento de cláusula contratual, que seria inclusive prescricional, mas não assim se o autor requerer a revogação, pois então incidiria o prazo decadencial de 1 ano [nesse sentido: PAULO LÔBO, Direito (...), cit., p. 307].

De outro modo, há a fileira dos que pensam que o prazo do art. 559 do Código Civil de 2002 se aplica também ao caso da revogação por descumprimento de encargo. Nesse sentido: ARNALDO RIZZARDO, Contratos, cit., p. 480; CAIO MÁRIO DA SILVA PEREIRA, Instituições (...), cit., p. 223; CHRISTIANO CASSETARI, Elementos (...), cit., p. 213; FLÁVIO TARTUCE, Direito (...), cit., pp. 331-333; NELSON ROSENVALD, Contratos (...), cit., p. 599].

A jurisprudência do Superior Tribunal de Justiça, porém, se formou no sentido de que a revogação da doação por falta de cumprimento de encargo prescreve dentro do prazo geral de prescrição, não se aplicando à hipótese a regra do art. 559 do Código Civil de 2002: $3^{\text {a }}$ T., R. Esp. n. 472733/DF, rel. ARI PARGENDLER, j. 06-02-2007; $2^{\mathrm{a}}$ T., R. Esp. n. 231945/SP, rel. JOÃOTÁVIO DE NORONHA, j. 03-08-2006. 
após o último dia de prazo ou interpelação pelo doador, pois o donatário deverá ter ciência da exigibilidade do cumprimento do encargo, que é questão de prova ${ }^{724}$.

Concernente à hipótese de ingratidão, VICENTE SABINO JÚNIOR ${ }^{725}$, que escreveu ainda na vigência do revogado Código Civil, entendia se tratar de prazo prescricional. Com efeito, o art. 178, $\S 6^{\circ}$, $\mathrm{I}^{726}$, do Código Civil de 1916, previa expressamente a hipótese, sendo que, por o prazo correr da ciência do fato, não do ato mesmo, por não haver nenhuma urgência que está a se esgotar e por expressa disposição de lei, seria o prazo prescricional, não de decadência ${ }^{727}$.

Outro, porém, é o regime no atual Código Civil. Para a revogação por ingratidão do donatário, cada fato, mesmo que ocorrido repetidas vezes, é autônomo para a contagem do prazo prescricional, que é de um ano, a contar da ciência do fato ensejador, o que engloba também a autoria ${ }^{728}$, sendo ônus do donatário a prova do termo a quo ${ }^{729}$. Tal prazo, no atual sistema civil, é prescricional, pois o contrário seria admitir que fluiria contra o incapaz, enquanto que o art. 559 do Código Civil de 2002 fala em "conhecimento", o que pressupõe capacidade $^{730}$.

No que toca às hipóteses concretas de revogação da doação, como já foi dito, de acordo com o art. 555 do Código Civil de 2002, são duas: a) inexecução do encargo, na doação modal; e, b) ingratidão do donatário. A revogação milita a favor do doador, mas, para

${ }_{722}^{724}$ AGOSTINHO ALVIM, Da Doação, cit., pp. 261-262.

${ }^{725}$ Neste sentido: VICENTE SABINO JÚNIOR, Contrato (...), cit., p. 135.

${ }^{726}$ Art. 178. "Prescreve: [...]§ $6^{\circ}$ Em 1 (um) ano: I - a ação do doador para revogar a doação; contado o prazo do dia em que souber do fato, que o autoriza a revogá-la (arts. 1.181 a 1.187) [...]".

${ }^{727}$ AGOSTINHO ALVIM, Da Doação, cit., pp. 262-263; CLÓVIS BEVILAQUA, Código (...), cit., p. 288. CARVALHO SANTOS entendia ainda que o mencionado prazo também se aplicava à revogação da doação por descumprimento de encargo e era decadencial [Código (...), cit., p. 451].

${ }^{728}$ CAIO MÁRIO DA SILVA PEREIRA, Instituições (...), cit., p. 223; CARLOS ROBERTO GONÇALVES, Direito (...), cit., p. 281 (o autor defende que deve concorrer mutuamente a ciência do ato e do autor para possibilitar a revogação); CARVALHO SANTOS, Código (...), cit., p. 451; CÉSAR FIUZA, Direito (...), cit., p. 512. No caso de atos continuados de ingratidão, o prazo começa a contar do último ato [CARVALHO SANTOS, Código (...), cit., pp. 452-453].

${ }^{729}$ ARNALDO MARMITT, Doação, cit., p. 248.

${ }^{730}$ AGOSTINHO ALVIM, Da Doação, cit., pp. 303-304; WASHINGTON DE BARROS MONTEIRO-DABUS MALUF, Curso (...), cit., p. 182. Entendo, porém, que se trata de prazo decadencial: AMANDA ZOE MORRIS, Doação, cit., p. 283; ARNALDO RIZZARDO, Contratos, cit., p. 476; CÉSAR FIUZA, Direito (...), cit., p. 512; CHRISTIANO CASSETARI, Elementos (...), cit., p. 215; FÁBIO ULHOA COELHO, Curso (...), cit., p. 254; FLÁVIO AUGUSTO MONTEIRO DE BARROS, Manual (...), cit., pp. 361; FRANCISCO GLAUBER PESSOA ALVES, Das Várias (...), cit., pp. 933-934; MARIA HELENA DINIZ, Tratado (...), cit., p. 97; NELSON ROSENVALD, Contratos (...), cit., p. 599; PAULO GERALDO DE OLIVEIRA MEDINA, A Doação, cit., pp. 474-475; PAULO LÔBO, Direito (...), cit., pp. 311; PAULO NADER, Curso (...), cit., p. 238; SÍLVIO DE SALVO VENOSA, Direito (...), cit., p. 141. 
proteção do donatário, o rol de hipóteses de aplicação é taxativo, a fim de ele não ser surpreendido $^{731}$, pelo que não pode o contrato criar novas hipóteses ${ }^{732 / 733}$.

Assim, o art. 555 do Código Civil de 2002 representa exceção à irrevogabilidade da doação, porém a previsão normativa tem rol numerus clausus e de interpretação restritiva $^{734}$. Por as situações previstas nesse dispositivo legal serem diferentes, convém analisá-las separadamente.

\section{1) Revogação por inexecução do encargo}

Poderá o doador revogar a doação se o donatário não cumprir o encargo ${ }^{735}$, cabendo ao beneficiário da liberalidade restituir o bem ao doador, cujo patrimônio voltará a integrar a coisa doada, mas, segundo VICENTE SABINO JÚNIOR ${ }^{736}$, não incorre o donatário no dever de indenizar por perdas e danos, e justifica sua afirmativa dizendo que o encargo é apenas acessório ${ }^{737}$.

Não obstante, como já se afirmou, há quem entenda que o encargo, uma vez previsto em contrato, compõe a doação, bem como que a revogação por descumprimento do encargo terá efeito ex tunc $^{738}$.

${ }^{731}$ ARNALDO MARMITT, Doação, cit., p. 246.

${ }^{732}$ ARNALDO MARMITT, Doação, cit., p. 267.

733 Para OZÉIAS J. SANTOS (Da Doação, cit., p. 25), a doação só pode ser revogada por ingratidão do donatário, de acordo com as hipóteses legais, concordando que o rol é taxativo, mas não encontra amparo legal a ideia de que só existe uma hipótese de revogação, nem sequer no Código Civil de 1916, que em seu art. 1.181 também previa a possibilidade de se revogar a doação por descumprimento de encargo, independentemente de cláusula de reversão.

Em relação ao Direito Civil de Portugal, outrora a doação podia ser revogada por ingratidão do donatário ou por superveniência de filhos ao doador (MANUEL BAPTISTA LOPES, Das Doações, cit., p. 133), mas o diploma civil luso foi alterado pelo Decreto Lei n. ${ }^{\circ} 496 / 77$, de modo que só há agora a primeira hipótese, ficando o seu art. 970. ("Revogação da doação") assim redigido: "As doações são revogáveis por ingratidão do donatário".

${ }^{734}$ PABLO STOLZE GAGLIANO, $O$ Contrato (...), cit., p. 171.

${ }^{735}$ LUIZ GUILHERME LOUREIRO, Curso (...), cit., p. 519; MARIA HELENA DINIZ, Curso (...), cit., p. 275; PABLO STOLZE GAGLIANO, $O$ Contrato (...), cit., p. 172.

${ }^{736}$ Contrato (...), cit., pp. 140-141.

${ }_{738}^{737}$ No mesmo sentido: CLÓVIS BEVILAQUA, Código (...), cit., p. 286.

${ }^{738}$ Há, porém, quem negue efeito retroativo à revogação da doação com encargo descumprido: LUIZ GUILHERME LOUREIRO, Curso (...), cit., pp. 519-520.

No Código Napoleônico também é possível haver revogação por descumprimento de encargo, como se verifica na redação do seu art. 954: "Dans le cas de la révocation pour cause d'inexécution des conditions, les biens rentreront dans les mains du donateur, libres de toutes charges et hypothèques du chef du donataire ; et le donateur aura, contre les tiers détenteurs des immeubles donnés, tous les droits qu'il aurait contre le donataire lui-même". Como se verifica na redação legal, a revogação terá efeito ex tunc, de modo que se desfazem todos os ônus que eventualmente o donatário fez recair sobre o bem doado [PAUL DELNOY, Le Libéralités (...), cit., p. 56]. 
Caso o contrato de doação celebrado não tiver estipulado prazo para o donatário cumprir o encargo, deverá então o disponente, nos termos do art. $562^{739}$ do Código Civil de 2002, proceder à notificação dele, a fim de constituí-lo em mora.

Para que haja mora autorizadora da revogação, deverá o prazo ser assinado pelo doador. A passagem de tempo suficiente para o donatário cumprir o encargo, por si só, não o induz em mora, devendo o prazo ser expressamente fixado pelo disponente, sendo que o critério de estabelecimento do tempo a ser concedido deve ser objetivo, adequado ao quanto necessário ao cumprimento da obrigação ${ }^{740}$.

CARVALHO SANTOS $^{741}$ leciona ainda, a esse respeito, que o donatário responde também por culpa, porque a condição resolutiva opera de pleno efeito, independentemente da vontade das partes.

Comentando a expressão "prazo razoável” utilizada pelo dispositivo legal, PABLO STOLZE GAGLIANO ${ }^{742}$ prefere não deduzir qualquer critério e afirma que depende do encargo que foi imposto. Ademais, se a notificação se der em termos genéricos, sem estipular um prazo ao donatário, entende o mesmo autor ${ }^{743}$ que poderá o juiz fixar um "termo de graça".

Outrossim, a possibilidade de revogar a doação por descumprimento do encargo não se limita apenas ao valor do quanto foi inadimplido, mas revoga todo o negócio ${ }^{744}$.

Para a promoção da ação de revogação de doação por descumprimento de encargo tem legitimidade apenas o doador, sendo personalíssimo o direito de promover a demanda ${ }^{745}$.

\footnotetext{
${ }^{739}$ Art. 562. "A doação onerosa pode ser revogada por inexecução do encargo, se o donatário incorrer em mora. Não havendo prazo para o cumprimento, o doador poderá notificar judicialmente o donatário, assinando-lhe prazo razoável para que cumpra a obrigação assumida".

${ }^{740}$ AGOSTINHO ALVIM, Da Doação, cit., pp. 260-261; CARLOS ROBERTO GONÇALVES, Direito (...), cit., p. 277; CÉSAR FIUZA, Direito (...), cit., p. 505; CLÓVIS BEVILAQUA, Código (...), cit., pp. 285-286; FLÁVIO AUGUSTO MONTEIRO DE BARROS, Manual (...), cit., p. 362; LUIZ GUILHERME LOUREIRO, Curso (...), cit., p. 519; MARIA HELENA DINIZ, Tratado (...), cit., p. 89; RODRIGO SENISE LISBOA, Manual (...), cit., p. 266.

${ }^{741}$ Código (...), cit., p. 435.

${ }^{742}$ O Contrato (...), cit., p. 174. No mesmo sentido: CHRISTIANO CASSETARI, Elementos (...), cit., p. 213; PAULO LÔBO, Direito (...), cit., p. 312.

${ }^{743} O$ Contrato (...), cit., p. 175.

744 AGOSTINHO ALVIM, Da Doação, cit., pp. 240-243; FLÁVIO AUGUSTO MONTEIRO DE BARROS, Manual (...), cit., pp. 358-359; SILVIO LUÍS FERREIRA DA ROCHA, Curso (...), cit., p. 177.

745 CARLOS ROBERTO GONÇALVES, Direito (...), cit., pp. 277-278; PABLO STOLZE GAGLIANO, $O$ Contrato (...), cit., p. 173.
} 
Com efeito, mesmo que a realização do encargo seja de interesse geral, se o doador estiver vivo quando o donatário incorrer em mora, a legitimidade para promover a competente ação judicial é dele, e somente quando o disponente já tiver falecido é que o Ministério Público surge como detentor da legitimidade para promoção de eventual execução $^{746}$, ou seus herdeiros e credores poderão obter a revogação da benesse ${ }^{747 / 748}$.

Havendo pluralidade de doadores, não necessariamente todos deverão manejar a ação de revogação por mora no cumprimento do encargo, mas o resultado somente aproveitará àqueles que assim o fizerem, na medida da quota que doou, presumindo-se idêntica a dos outros, se nada dispõe o contrato, sendo que, se indivisível o bem, tornar-se-á condômino do donatário ${ }^{749}$.

Quanto à hipótese de pluralidade de donatários, para ARNALDO MARMITT ${ }^{750}$, em se tratando de encargo indivisível, à luz dos arts. $891^{751}$ e $925^{752}$, primeira parte, do Código Civil de 1916, se um só deles deixar de cumpri-lo, então o inadimplemento é de todos, podendo levar à revogação total da liberalidade, sobrando aos donatários inocentes o direito de regresso em face do culpado.

Com efeito, se a obrigação for solidária e indivisível, como ocorre com as obrigações negativas, o não cumprimento do modus por um dos donatários leva à revogação de toda a benesse, ressalvado o direito de regresso pelos donatários não culpados, mas há a possibilidade de um dos não culpados purgar a mora e exigir o regresso dos outros ${ }^{753}$.

\footnotetext{
${ }^{746}$ FLÁVIO AUGUSTO MONTEIRO DE BARROS, Manual (...), cit., pp. 362; VICENTE SABINO JÚNIOR, Contrato (...), cit., p. 141.

${ }^{747}$ CARVALHO SANTOS, Código (...), cit., p. 438.

${ }^{748}$ Não obstante, há um julgado do Superior Tribunal de Justiça reputando como não personalíssimo o direito de ação para revogação de doação com encargo não cumprido: $3^{a}$ T., R. Esp. n. 95.309/SP, rel. EDUARDO RIBEIRO, j. 27-04-1998.

749 AGOSTINHO ALVIM, Da Doação, cit., pp. 265-266; ARNALDO MARMITT, Doação, cit., p. 260; CARLOS ROBERTO GONÇALVES, Direito (...), cit., p. 278.

${ }^{750}$ Doação, cit., p. 259. No mesmo sentido: CARLOS ROBERTO GONÇALVES, Direito (...), cit., p. 278.

${ }^{751}$ Art. 891. "Se, havendo dois ou mais devedores, a prestação não for divisível, cada um será obrigado pela dívida toda. (Redação dada pelo Decreto do Poder Legislativo no 3.725, de 15.1.1919)".

${ }^{752}$ Art. 925. "Sendo indivisível a obrigação, todos os devedores e seus herdeiros, caindo em falta um deles, incorrerão na pena; mas esta só se poderá demandar integralmente do culpado. Cada um dos outros só responde pela sua quota".

${ }^{753}$ AGOSTINHO ALVIM, Da Doação, cit., pp. 268-269.
} 
O quanto disposto nos mencionados artigos de lei se manteve nos arts. $259^{754} \mathrm{e}$ $414^{755}$ do Código Civil de 2002, pelo que remanesce no sistema atual os fundamentos invocados.

Não obstante, a regra é que o descumprimento do encargo por parte de um dos donatários não necessariamente induz à revogação de toda a benesse, pois os outros beneficiados podem ter dado cumprimento à sua parte na avença ou então pode o doador querer perdoar a alguns deles, mas não a outros, de modo que, na hipótese, somente se revoga a cota daquele que foi acionado e se a coisa doada for indivisível, então o doador se torna condômino dos restantes ${ }^{756}$.

De fato, se a obrigação assumida por meio de encargo for divisível e apenas um dos donatários não cumpri-la, ao passo que os restantes procedem ao adimplemento, então a revogação cabe apenas contra aqueles que não satisfizeram a obrigação ${ }^{757}$.

Como já se afirmou acima, AGOSTINHO ALVIM ${ }^{758}$ entende que poderá o donatário proceder à purgação da mora, por aplicação do art. $959^{759}$ do Código Civil de 1916, desde que não haja cláusula no contrato que a vede, ou o cumprimento da obrigação tenha se tornado inútil, ou ainda o encargo imposto tenha sido uma obrigação negativa, cuja não observância não induz à mora, mas caracteriza sim inadimplemento. Tal entendimento se coaduna com a redação dada ao art. $401^{760}$ do Código Civil de 2002.

A esse respeito, CARVALHO $\mathrm{SANTOS}^{761}$ ensina ainda que até mesmo os terceiros adquirentes dos bens do donatário poderão dar cumprimento ao encargo, a fim de

\footnotetext{
${ }^{754}$ Art. 259. "Se, havendo dois ou mais devedores, a prestação não for divisível, cada um será obrigado pela dívida toda".

755 Art. 414. "Sendo indivisível a obrigação, todos os devedores, caindo em falta um deles, incorrerão na pena; mas esta só se poderá demandar integralmente do culpado, respondendo cada um dos outros somente pela sua quota".

756 AGOSTINHO ALVIM, Da Doação, cit., pp. 267-268; CARLOS ROBERTO GONÇALVES, Direito (...), cit., p. 278.

${ }_{757}^{75}$ ARNALDO MARMITT, Doação, cit., p. 260.

${ }^{758}$ Da Doação, cit., p. 264.

${ }^{759}$ Art. 959. "Purga-se a mora: I - por parte do devedor, oferecendo este a prestação, mais a importância dos prejuízos decorrentes até o dia da oferta; II - por parte do credor, oferecendo-se este a receber o pagamento e sujeitando-se aos efeitos da mora até a mesma data; III - por parte de ambos, renunciando aquele que se julgar por ela prejudicado os direitos que da mesma lhe provierem".

760 Art. 401. "Purga-se a mora: I - por parte do devedor, oferecendo este a prestação mais a importância dos prejuízos decorrentes do dia da oferta; II - por parte do credor, oferecendo-se este a receber o pagamento e sujeitando-se aos efeitos da mora".

${ }^{761}$ Código (...), cit., p. 436.
} 
afastar a revocação do quanto adquirido, haja vista o efeito ex tunc da presente hipótese de revogabilidade.

\section{2) Revogação por ingratidão}

\section{A possibilidade de revogação da doação por ingratidão do donatário e as hipóteses} que a constituem é dada pelo art. 557 e incisos ${ }^{762}$, do Código Civil de 2002, cuja descrição é exauriente $^{763}$. O fundamento dessa norma estaria em que existe um dever moral e jurídico do

${ }^{762}$ Art. 557. "Podem ser revogadas por ingratidão as doações: I - se o donatário atentou contra a vida do doador ou cometeu crime de homicídio doloso contra ele; II - se cometeu contra ele ofensa física; III - se o injuriou gravemente ou o caluniou; IV - se, podendo ministrá-los, recusou ao doador os alimentos de que este necessitava".

${ }^{763}$ PABLO STOLZE GAGLIANO, O Contrato (...), cit., p. 176.

No Direito Civil luso, as causas de revogação da doação são pareadas com o direito sucessório, conforme se verifica na redação do art. 974. . (“Casos de ingratidão”) do seu diploma legal civil: "A doação pode ser revogada por ingratidão, quando o donatário se torne incapaz, por indignidade, de suceder ao doador, ou quando se verifique alguma das ocorrências que justificam a deserdação". Quanto às hipóteses que caracterizam a indignidade sucessória, são dadas pelo art. 2034. . (“Incapacidade por indignidade”) da mesma lei civil: "Carecem de capacidade sucessória, por motivo de indignidade: a) O condenado como autor ou cúmplice de homicídio doloso, ainda que não consumado, contra o autor da sucessão ou contra o seu cônjuge, descendente, ascendente, adoptante ou adoptado; b) $\mathrm{O}$ condenado por denúncia caluniosa ou falso testemunho contra as mesmas pessoas, relativamente a crime a que corresponda pena de prisão superior a dois anos, qualquer que seja a sua natureza; c) $\mathrm{O}$ que por meio de dolo ou coacção induziu o autor da sucessão a fazer, revogar ou modificar o testamento, ou disso o impediu; d) O que dolosamente subtraiu, ocultou, inutilizou, falsificou ou suprimiu o testamento, antes ou depois da morte do autor da sucessão, ou se aproveitou de algum desses factos", ao passo que as da deserdação encontram-se no art. 2166. ("Deserdação"): "1. O autor da sucessão pode em testamento, com expressa declaração da causa, deserdar o herdeiro legitimário, privando-o da legítima, quando se verifique alguma das seguintes ocorrências: a) Ter sido o sucessível condenado por algum crime doloso cometido contra a pessoa, bens ou honra do autor da sucessão, ou do seu cônjuge, ou de algum descendente, ascendente, adoptante ou adoptado, desde que ao crime corresponda pena superior a seis meses de prisão; b) Ter sido o sucessível condenado por denúncia caluniosa ou falso testemunho contra as mesmas pessoas; c) Ter o sucessível, sem justa causa, recusado ao autor da sucessão ou ao seu cônjuge os devidos alimentos. 2. O deserdado é equiparado ao indigno para todos os efeitos legais". Também no sistema civil português a descrição legal é taxativa, não podendo haver interpretação extensiva [MANUEL BAPTISTA LOPES, Das Doações, cit., p. 145].

No Código Civil da Itália, as hipóteses de doação estão descritas no art. 801 ("Revocazione per ingratitudine"), que assim dispõe: "La domanda di revocazione per ingratitudine non può essere proposta che quando il donatario ha commesso uno dei fatti previsti dai numeri 1, 2 e 3 dell'articolo 463, ovvero si è reso colpevole d'ingiuria grave verso il donante o ha dolosamente arrecato grave pregiudizio al patrimonio di lui o gli ha rifiutato indebitamente gli alimenti dovuti ai sensi degli articoli 433, 435 e 436". Quanto ao mencionado art. 463 ("Casi d'indegnità"), traz as hipóteses de indignidade sucessória, assim dispondo nos parágrafos mencionados: " $E$ ' escluso dalla successione come indegno: 1) chi ha volontariamente ucciso o tentato di uccidere la persona della cui successione si tratta, o il coniuge, o un discendente, o un ascendente della medesima, purché non ricorra alcuna delle cause che escludono la punibilità a norma della legge penale; 2) chi ha commesso, in danno di una di tali persone, un fatto al quale la legge dichiara applicabili le disposizioni sull'omicidio;3) chi ha denunziato una di tali persone per reato punibile con l'ergastolo o con la reclusione per un tempo non inferiore nel minimo a tre anni, se la denunzia è stata dichiarata calunniosa in giudizio penale; ovvero ha testimoniato contro le persone medesime imputate dei predetti reati, se la testimonianza è stata dichiarata, nei confronti di lui, falsa in giudizio penale; [...]”. Assim, verifica-se que, do mesmo modo que o Código Civil de Portugal, a lei civil italiana mantém alinhadas as causas de ingratidão para a doação e a indignidade para a sucessão [Consultar ainda: CELESTE IACOVINO, La Donazione, cit., pp. 362-365].

No Código Napoleônico também se optou, assim como a Lei 10.406/2002, criar-se um rol de hipóteses de ingratidão apenas para a doação, como se verifica no seu art. 955: "La donation entre vifs ne pourra être 
donatário de ser grato a quem lhe outorgou um benefício ${ }^{764}$, mas há posicionamento contrário, ensinando-se que inexiste o dito dever de gratidão, havendo antes exigência de sensibilidade moral do donatário para com o doador ${ }^{765}$.

VICENTE SABINO JÚNIOR ${ }^{766}$ afirma em um passo de sua obra que a lei não especifica os casos de ocorrência de revogação da doação por ingratidão do donatário, de modo que ela é muito ampla, a depender da apreciação que faça o doador, e explica, de modo genérico, que a manifestação principal de ingratidão é o descumprimento de um dever natural, como prestar assistência ao doador. Mas, em outro trecho ${ }^{767}$, cita o art. $1.183^{768}$ do Código Civil de 1916, que declina os casos em que a lei considera ter ocorrido ingratidão, de modo casuístico, no que foi seguido nas hipóteses do art. 557 do Código Civil de 2002.

Comentando o citado art. 1.183 do Código Civil de 1916, AGOSTINHO $\mathrm{ALVIM}^{769}$ externa a opinião de que o rol nele declinado é taxativo, pois a norma emprega o advérbio "só" logo no início de sua redação, o que tem como efeito prático o fato de não poder estendê-la a outras hipóteses ${ }^{770}$. Todavia, segundo o autor, nada impede que haja previsão contratual extensiva, ressalvando que se as partes avençarem que a doação se revogará caso não seja cumprido um ato positivo de gratidão, então se estará diante de um encargo, devendo, então, seguir disciplina própria.

O art. 557 do Código Civil de 2002 não manteve o advérbio "só", porém a redação que lhe foi emprestada leva a crer que o legislador quis declinar nos incisos os eventuais comportamentos do donatário que consistiriam em ingratidão, não se admitindo

révoquée pour cause d'ingratitude que dans les cas suivants : $1^{\circ}$ Si le donataire a attenté à la vie du donateur; $2^{\circ} S^{\prime} i l$ s'est rendu coupable envers lui de sévices, délits ou injures graves; $3^{\circ} S^{\prime} i l$ lui refuse des aliments". Também esse rol é fechado [PAUL DELNOY, Le Libéralités (...), cit., p. 56].

${ }^{764}$ ARNALDO RIZZARDO, Contratos, cit., p. 471; CARLOS ROBERTO GONÇALVES, Direito (...), cit., p. 278; FÁBIO ULHOA COELHO, Curso (...), cit., p. 252; FLÁVIO AUGUSTO MONTEIRO DE BARROS, Manual (...), cit., pp. 358-359; JONES FIGUEIRÊDO ALVES, Código (...), cit., p. 457; MARIA HELENA DINIZ, Tratado (...), cit., p. 94; WASHINGTON DE BARROS MONTEIRO-DABUS MALUF, Curso (...), cit., p. 178.

765 CAIO MÁRIO DA SILVA PEREIRA, Instituições (...), cit., p. 224.

${ }^{766}$ Contrato (...), cit., p. 142-143.

${ }^{767}$ p. 147.

768 Art. 1.183. "Só se podem revogar por ingratidão as doações: I - se o donatário atentou contra a vida do doador; II - se cometeu contra ele ofensa física; III - se o injuriou gravemente, ou o caluniou; IV - se, podendo ministrar-lhos, recusou ao doador os alimentos, de que este necessitava".

${ }^{769}$ Da Doação, cit., pp. 275-277.

${ }^{770}$ No mesmo sentido: ANTÔNIO CHAVES, Lições (...), cit., pp. 253 e 255. 
alargamento do conceito de "ingrato". Assim, as hipóteses previstas nesse dispositivo legal são taxativas ${ }^{771}$.

Insta salientar, como já dito, que o donatário não tem um dever de gratidão para com o doador, não precisando, assim, nutrir-lhe qualquer afeto ou reverência, podendo, por conta disso, até tratá-lo com frieza, desprezo ou desgosto ${ }^{772}$.

Em que pese a expressa fundamentação legal, é possível verificar na doutrina a existência de debate quanto ao fundamento da possibilidade de se revogar a doação por ingratidão do donatário.

Assim, para ARNALDO MARMITT ${ }^{773}$, a possibilidade de revogação pelo doador tem mero caráter compensatório, próprio do âmbito civil, e de modo algum representa uma pena ou um "castigo" ao ofensor.

No mesmo diapasão, AGOSTINHO ALVIM ${ }^{774}$ entende que a possibilidade de revogação da doação pelo doador por ingratidão do donatário não tem caráter punitivo, pois no âmbito civil não se visa a vingança, a utilidade ou a ressocialização, como ocorre na seara criminal. De outro lado, o autor também não vê na hipótese um ato de natureza ressarcitória, e conclui explicando que o fundamento último para a possibilidade de tal revogação é a teoria da imprevisão, pois o doador, ao realizar a benesse, visa proporcionar "felicidade" ao donatário, e se há a prática de algum ato de ingratidão, então houve imprevista alteração das

${ }^{771}$ ARNALDO RIZZARDO, Contratos, cit., p. 471; CAIO MÁRIO DA SILVA PEREIRA, Instituições (...), cit., p. 224; CARLOS ROBERTO GONÇALVES, Direito (...), cit., p. 278; CHRISTIANO CASSETARI, Elementos (...), cit., p. 215; FRANCISCO GLAUBER PESSOA ALVES, Das Várias (...), cit., p. 924; LUIZ GUILHERME LOUREIRO, Curso (...), cit., p. 518; NELSON ROSENVALD, Contratos (...), cit., p. 598; ORLANDO GOMES, Contratos, cit., p. 242; PAULO LÔBO, Das Várias (...), cit., p. 355; PAULO NADER, Curso (...), cit., p. 238; SÍLVIO DE SALVO VENOSA, Direito (...), cit., p. 138; SILVIO RODRIGUES, Direito (...), cit., pp. 216-217; WASHINGTON DE BARROS MONTEIRO-DABUS MALUF, Curso (...), cit., p. 179. Há quem entenda, porém, que se trata de mera exemplificação: FLÁVIO TARTUCE, Direito (...), cit., p. 330; JONES FIGUEIRÊDO ALVES, Código (...), cit., p. 459.

772 AGOSTINHO ALVIM, Da Doação, cit., pp. 275-276; FRANCISCO GLAUBER PESSOA ALVES, Das Várias (...), cit., p. 921 (o autor se opõe expressamente a uma suposta obrigação de não fazer do donatário); PABLO STOLZE GAGLIANO, $O$ Contrato (...), cit., p. 177.

Há um julgado do Superior Tribunal de Justiça no qual se confirmou decisão das instâncias inferiores de se afastar pretensão de revogação por ingratidão, declarando que não ficou provada a prática de quaisquer dos atos caracterizadores da ingratidão, ainda que a donatária, filha dos doadores, nunca mais tenha falado com os genitores após receber imóveis em doação, e nem sequer ter visitado seu pai no hospital quando este se viu acometido por câncer: $3^{\text {a }}$ T., R. Esp. n. 79154/SP, rel. HUMBERTO GOMES DE BARROS, j. 21-02-2006.

${ }^{773}$ Doação, cit., p. 274.

${ }^{774}$ Da Doação, cit., pp. 277-283. 
circunstâncias, pois doador e donatário sempre manterão algum liame, como, por exemplo, o dever de alimentos decorrente da disposição de bens ${ }^{775}$.

PABLO STOLZE GAGLIANO ${ }^{776}$, por seu turno, afirma que se encontra o fundamento da revogação ora comentada na boa-fé objetiva contratual, que justifica o reconhecimento dos deveres anexos de lealdade e confiança, mesmo na fase pós-contratual do negócio jurídico, e conclui que a faculdade de o doador poder revogar a doação por ingratidão reveste-se de caráter punitivo ${ }^{777}$.

É de se cogitar, também, a possibilidade de se revogar a doação pela ocorrência de alguns dos eventos previstos no art. 557 do Código Civil de 2002 anteriores à liberalidade. MANUEL BAPTISTA LOPES ${ }^{778}$ ensina que se o doador sabia do fato, a resposta é negativa, mas se veio a ter ciência dele somente após a prática da benemerência, então poderá revogála. À mesma solução se pode chegar com fundamento no erro enquanto vício do negócio jurídico $^{779}$.

Por fim, cumpre salientar que o direto à revogação da doação por ingratidão surge não apenas quando as hipóteses elencadas no art. 557 do Código Civil de 2002 se dão contra o próprio doador, mas também contra pessoas que lhe são próximas, de acordo com o quanto disposto no art. $558^{780}$ do mesmo diploma legal ${ }^{781}$.

Na esteira do entendimento hodierno do que seja proteção familiar, há ${ }^{782}$ quem inclua no rol do mencionado dispositivo também o companheiro na união estável. Outros

\footnotetext{
${ }^{775}$ No excerto mencionado, AGOSTINHO ALVIM explica que o fundamento imediato da revogação é a lei, porém a teoria da imprevisão é que informa a redação da norma.

776 O Contrato (...), cit.,, pp. 176 e 178-182.

777 Também defendendo o caráter punitivo da revogação por ingratidão: CAIO MÁRIO DA SILVA PEREIRA, Instituições (...), cit., p. 224; CARLOS ROBERTO GONÇALVES, Direito (...), cit., p. 278; CARVALHO SANTOS, Código (...), cit., p. 443; CHRISTIANO CASSETARI, Elementos (...), cit., p. 215; FRANCISCO GLAUBER PESSOA ALVES, Das Várias (...), cit., p. 920 (o autor destaca também que possibilita uma satisfação moral ao doador); SÍLVIO DE SALVO VENOSA, Direito (...), cit., p. 138 (o autor acrescenta também que a revogação repara o dano moral causado); SILVIO RODRIGUES, Direito (...), cit., p. 215.

${ }^{778}$ Das Doações, cit., p. 145.

${ }^{779}$ CELESTE IACOVINO, La Donazione, cit., p. 363.

${ }^{780}$ Art. 558. "Pode ocorrer também a revogação quando o ofendido, nos casos do artigo anterior, for o cônjuge, ascendente, descendente, ainda que adotivo, ou irmão do doador".

781 AGOSTINHO ALVIM (Da Doação, cit., pp. 272-275), diante do silêncio do Código Civil de 1916, ensinava que os fatos legalmente previstos que dão ensejo à revogação da doação só têm tal efeito se praticados contra a pessoa do doador, não contra terceiros, por mais ligados que a ele sejam, como filhos ou cônjuge. Sobre o art. 558 do Código Civil de 2002, consultar ainda: PAULO LÔBO, Direito (...), cit., pp. 310-311.

782 ARNALDO RIZZARDO, Contratos, cit., p. 471; NELSON ROSENVALD, Contratos (...), cit., p. 599; PABLO STOLZE GAGLIANO, O Contrato (...), cit., p. 193; PAULO LÔBO, Das Várias (...), cit., p. 370.
} 
autores $^{783}$, porém, ensinam que inexiste tal extensão, mesmo que haja a equiparação constitucional, pois nesse caso específico a lei quis proteger apenas o cônjuge, tanto que o citou expressamente, silenciando a condição de companheiro.

Outrossim, se houver mais de um donatário e o bem doado for divisível, apenas a parte do ingrato se revoga, mas se o bem for indivisível não há a possibilidade de revogar todo o ato ${ }^{784}$.

Feitas essas considerações, é o caso de se analisar cada um dos incisos do art. 557 da Lei 10.406/2002, a fim de se verificar todas as hipóteses de revogação da doação por ingratidão do donatário.

\subsection{1) se o donatário atentou contra a vida do doador ou cometeu crime de homicídio doloso contra ele}

A ação do donatário, seja na tentativa, ou na consumação, para abertura de possibilidade da revogação da benesse, deverá ser dolosa, e se for involuntária ou em legítima defesa, não incide a hipótese de revogabilidade ${ }^{785}$. Em havendo culpa ou ação preterdolosa, não há causa para revogação ${ }^{786}$, devendo ser resolvida no âmbito da responsabilidade civil ${ }^{787}$.

No que tange à legitimidade ativa para a propositura da ação de revogação sob o fundamento ora estudado, o Código Civil revogado trazia dificuldades, pois a princípio o direito de ação é personalíssimo, pelo que perecia junto com o doador.

Em vista da redação do art. $1.185^{788}$ do mencionado diploma legal, alguns autores $^{789}$ manifestavam sua indignação, buscando, de algum modo, interpretá-lo a contento,

${ }^{783}$ CARLOS ROBERTO GONÇALVES, Direito (...), cit., p. 278 (sem falar especificamente nessa hipótese, afirma o autor que o rol do mencionado art. 558 do Código Civil de 2002 é taxativo); FRANCISCO GLAUBER PESSOA ALVES, Das Várias (...), cit., p. 929.

${ }^{784}$ CAIO MÁRIO DA SILVA PEREIRA, Instituições (...), cit., p. 226; CÉSAR FIUZA, Direito (...), cit., p. 512.

785 CARLOS ROBERTO GONÇALVES, Direito (...), cit., p. 279; CLÓVIS BEVILAQUA, Código (...), cit., p. 287; EDUARDO ESPINOLA, Dos Contratos (...), cit. p. 198; FLÁVIO AUGUSTO MONTEIRO DE BARROS, Manual (...), cit., p. 359; MARIA HELENA DINIZ, Tratado (...), cit., p. 94; PAULO LÔBO, Das Várias (...), cit., pp. 362-363; VICENTE SABINO JÚNIOR, Contrato (...), cit., p. 147; WASHINGTON DE BARROS MONTEIRO-DABUS MALUF, Curso (...), cit., p. 179.

${ }^{786}$ CAIO MÁRIO DA SILVA PEREIRA, Instituições (...), cit., p. 224 (o autor fala apenas da culpa); FLÁVIO AUGUSTO MONTEIRO DE BARROS, Manual (...), cit., p. 359. Há quem entenda, porém, que a tentativa de homicídio culposa é causa para revogação, sendo que lei exigiria dolo apenas para o homicídio consumado: FRANCISCO GLAUBER PESSOA ALVES, Das Várias (...), cit., p. 926.

${ }^{787}$ AGOSTINHO ALVIM, Da Doação, cit., p. 286; ARNALDO RIZZARDO, Contratos, cit., p. 472.

${ }^{788}$ Art. 1.185. "O direito de que trata o artigo precedente não se transmite aos herdeiros do doador, nem prejudica os do donatário. Mas aqueles podem prosseguir na ação iniciada pelo doador, continuando-a contra os herdeiros do donatário, se este falecer depois de contestada a lide".

789 ARNALDO MARMITT, Doação, cit., pp. 269-270; NATAL NADER, Questões Relativas à Doação (II), cit., 
pois vedaria aos herdeiros que ingressassem com a ação revogatória caso o donatário praticasse homicídio consumado, o que seria injusto, pela gravidade da ação e pelo incentivo de se praticar o ilícito penal.

Assim, alguns doutrinadores ${ }^{790}$ que escreveram na vigência da antiga lei civil sugeriam que deverá ser combinada a norma mencionada com a regra do art. $1.184^{791}$ daquele mesmo diploma legal, de modo que se deve entender que aos herdeiros são transmitidos todos os direitos do falecido, inclusive o de ingressar em juízo para obter a revogação da benesse.

Não obstante, o art. $561^{792}$ do Código Civil de 2002 veio a satisfazer esse pleito já apresentado pela doutrina pátria, ressalvando-se que continua a ser direito potestativo do disponente se houver mera tentativa ${ }^{793}$.

A fim de esclarecer o escopo do artigo ora sob comento, na sua ressalva final, PABLO STOLZE GAGLIANO ${ }^{794}$ cogita, à guisa de exemplo, no caso de o doador perdoar o donatário nos seus estertores ${ }^{795}$. Tal perdão não tem solenidade prevista, podendo ser provado por qualquer meio admitido em direito ${ }^{796}$.

Por fim, como a previsão legal ora discutida também é crime, vale refletir sobre a relação entre os juízos cível e criminal.

p. 471.

790 ARNALDO MARMITT, Doação, cit., pp. 269-271; PONTES DE MIRANDA, Tratado (...), cit., p. 272.

${ }^{791}$ Art. 1.184. "A revogação por qualquer desses motivos pleitear-se-á dentro em 1 (um) ano, a contar de quando chegue ao conhecimento do doador o fato que a autorizar (art. 178, $\S 6^{\circ}, \mathrm{I}$ )".

792 Art. 561. "No caso de homicídio doloso do doador, a ação caberá aos seus herdeiros, exceto se aquele houver perdoado".

793 CARLOS ROBERTO GONÇALVES, Direito (...), cit., p. 281; FRANCISCO GLAUBER PESSOA ALVES, Das Várias (...), cit., p. 937; MARIA HELENA DINIZ, Tratado (...), cit., pp. 97-98; NELSON ROSENVALD, Contratos (...), cit., p. 601; PAULO GERALDO DE OLIVEIRA MEDINA, A Doação, cit. 475; PABlo STOLZE GAGLIANO, O Contrato (...), cit., p. 184; PAUlO LÔBO, Das Várias (...), cit., p. 363; SÍLVIO DE SALVO VENOSA, Direito (...), cit., p. 139.

${ }^{794}$ O Contrato (...), cit., p. 185. O autor entende que a redação dada ao art. 561 do Código Civil de 2002, in fine, é "infeliz", e se contrapõe frontalmente à possibilidade de haver perdão tácito ou presumido. Mas mesmo em relação ao perdão expresso, o mesmo autor (p. 186) faz diversas indagações a tal possibilidade, a fim de minar sua justeza, e afirma "nutrir profunda antipatia intelectual por essa forma esdrúxula de perdão", sem, no entanto, deixar de reconhecer sua aplicação por expressa disposição legal e que, portanto, importa o ato de vontade do doador. Também discordando da previsão de perdão pelo doador: ARNOLDO WALD, Direito (...), cit., p. 72. Tais posições contrárias ao perdão pelo doador não se justificam, pois é descabido desejar que o Estado vede o sujeito de direito de praticar atos moralmente heroicos, nivelando por baixo o padrão ético social.

795 Também cogitando essa possibilidade: ARNALDO RIZZARDO, Contratos, cit., p. 472; LUIZ GUILHERME LOUREIRO, Curso (...), cit., p. 519.

${ }^{796}$ CAIO MÁRIO DA SILVA PEREIRA, Instituições (...), cit., p. 225; PAULO LÔBO, Das Várias (...), cit., p. 377 (o autor ressalta que o ônus da prova é do donatário). 
Para AGOSTINHO ALVIM ${ }^{797}$, as esferas cível e criminal são independentes entre si, mas não se pode deixar de considerar a segunda parte da redação do art. $1.525^{798}$ do Código Civil de 1916, bem como do art. $65^{799}$ do Código de Processo Penal, de modo que a sentença criminal que verse sobre fato ou autoria, seja para condenar, seja para absolver, determina o cível, assim como a existência de algumas das excludentes de ilicitude ${ }^{800}$.

No entanto, continua a ponderar o mesmo autor ${ }^{801}$, pode ocorrer, afora as hipóteses acima, que a justiça civil chegue a conclusão diferente da penal, pois não leva em conta a sentença absolutória por falta de provas, o arrependimento eficaz ou a prática de crime impossível, ao passo que o ato praticado sob embriaguez será tido por culposo, a arredar a hipótese de revogação, ao passo que no âmbito penal será um ilícito. Sem prejuízo, pode o doador ingressar com ação civil na ausência de processo crime, podendo o juiz suspender o processo civil nesse caso, mas se a coisa julgada civil se formar antes da criminal, não poderá ser alterada, mesmo que seja contrária à decisão do processo criminal.

Outros autores ${ }^{802}$, porém, entendem que é cabível a revogação mesmo na pendência de processo criminal, mas, culminando este em sentença absolutória, afasta-se a hipótese de revogação, pelo que pode o juiz do cível suspender a demanda até o deslinde do feito penal.

Há ${ }^{803}$ ainda quem pense ser necessário haver condenação na justiça criminal para que o juiz do cível reconheça a alegação de homicídio tentado ou consumado, por conta do princípio da presunção de inocência, ao passo há ${ }^{804}$ quem ensine que apenas a sentença absolutória própria vincula o cível.

\footnotetext{
${ }^{797}$ Da Doação, cit., pp. 286-288.

${ }^{798}$ Art. 1.525. "A responsabilidade civil é independente da criminal; não se poderá, porém, questionar mais sobre a existência do fato, ou quem seja o seu autor, quando estas questões se acharem decididas no crime".

799 Art. 65. "Faz coisa julgada no cível a sentença penal que reconhecer ter sido o ato praticado em estado de necessidade, em legítima defesa, em estrito cumprimento de dever legal ou no exercício regular de direito".

800 No mesmo sentido: ARNALDO RIZZARDO, Contratos, cit., pp. 472-473; CAIO MÁRIO DA SILVA PEREIRA, Instituições (...), cit., p. 224; CARLOS ROBERTO GONÇALVES, Direito (...), cit., p. 279; FLÁVIO AUGUSTO MONTEIRO DE BARROS, Manual (...), cit., p. 346; SÍLVIO DE SALVO VENOSA, Direito (...), cit., p. 139. Há, porém, quem deixe de especificar a sentença absolutória, levando a crer que seu entendimento é de que qualquer absolvição vincula o juízo cível: CLÓVIS BEVILAQUA, Código (...), cit., p. 287; EDUARDO ESPINOLA, Dos Contratos (...), cit. p. 198; MARIA HELENA DINIZ, Tratado (...), cit., p. 94; SILVIO LUÍS FERREIRA DA ROCHA, Curso (...), cit., p. 185; WASHINGTON DE BARROS MONTEIRO-DABUS MALUF, Curso (...), cit., p. 180.

${ }^{801}$ Da Doação, cit., pp. 288-292.

${ }^{802}$ PABLO STOLZE GAGLIANO, O Contrato (...), cit., p. 186.

${ }^{803}$ PAULO LÔBO, Direito (...), cit., pp. 308-309.

${ }^{804}$ NELSON ROSENVALD, Contratos (...), cit., p. 598
} 
Outrossim, há ${ }^{805}$ quem entenda que na hipótese de ser decretada a revogação no juízo cível e no âmbito criminal exsurgir sentença absolutória, tudo se manterá caso o fundamento desta seja a falta de provas, não assim, porém, se tiver espeque no reconhecimento da inexistência de fatos ou da autoria, ou de alguma excludente de ilicitude, que terá o condão de anular a sentença revogativa da doação ${ }^{806}$.

\subsection{2) se cometeu contra ele ofensa física}

Ocorre quando o donatário agride o doador, de modo a lhe trazer dano físico, especialmente pela prática de lesão corporal ${ }^{807}$. A simples ameaça de ofensa ou xingamento não constitui a hipótese, devendo haver efetiva agressão, mesmo que não cause ferimento ${ }^{808}$.

A agressão deverá ser efetiva, mas não apenas física, podendo também ser somente psíquica ou um misto de ambas ${ }^{809}$, na forma dolosa, não podendo, porém, ser revide a uma agressão prévia da vítima, o que descaracteriza a hipótese de revogação da doação ${ }^{810}$. Igualmente, não se abre a possibilidade da revogação da doação quando a ofensa for culposa ou praticada em legítima defesa ${ }^{811}$.

ARNALDO MARMITT ${ }^{812}$ entende que o processo criminal não é prejudicial ao cível, mas que se houver sentença absolutória, então não há que se falar nas hipóteses de ilícito.

\subsection{3) se o injuriou gravemente ou o caluniou}

\footnotetext{
${ }^{805}$ ARNALDO MARMITT, Doação, cit., pp. 271-272; VICENTE SABINO JÚNIOR, Contrato (...), cit., p. 148.

${ }^{806}$ Há quem lecione que, nessa hipótese, o doador deverá manejar ação rescisória: AGOSTINHO ALVIM, Da Doação, cit., pp. 291-292; ARNALDO RIZZARDO, Contratos, cit., p. 473.

807 FRANCISCO GLAUBER PESSOA ALVES, Das Várias (...), cit., pp. 926-927; PABLO STOLZE GAGLIANO, O Contrato (...), cit., p. 187.

${ }^{808}$ AGOSTINHO ALVIM, Da Doação, cit., p. 294. O autor defende que o ato pode ser praticado até por alguém débil, mas há quem ensine que incide ao caso as excludentes de imputabilidade [CARLOS ROBERTO GONÇALVES, Direito (...), cit., p. 279; CARVALHO SANTOS, Código (...), cit., pp. 445-446]. Também entendendo que a simples ameaça não constitui o tipo legal: SÍLVIO DE SALVO VENOSA, Direito (...), cit., p. 140. Incluindo ainda possíveis injúrias como não caracterizadoras da hipótese: ARNALDO RIZZARDO, Contratos, cit., p. 473.

${ }^{809}$ ARNALDO MARMITT, Doação, cit., p. 272; PONTES DE MIRANDA, Tratado (...), cit., p. 272. PAULO LÔBO ensina que o ambiente social e cultural é determinante para se aferir a intenção de agressão por parte do donatário [ Direito (...), cit., p. 309].

${ }^{810}$ CLÓVIS BEVILAQUA, Código (...), cit., p. 287.

811 ANTÔNIO CHAVES, Lições (...), cit., p. 256; PABLO STOLZE GAGLIANO, O Contrato (...), cit., p. 187; VICENTE SABINO JÚNIOR, Contrato (...), cit., p. 148; WASHINGTON DE BARROS MONTEIRODABUS MALUF, Curso (...), cit., p. 180. Em sentindo contrário, admitindo a revogação por simples culpa: FRANCISCO GLAUBER PESSOA ALVES, Das Várias (...), cit., p. 926.

812 Doação, cit., p. 252. No mesmo sentido: ANTÔNIO CHAVES, Lições (...), cit., p. 256; FLÁVIO AUGUSTO MONTEIRO DE BARROS, Manual (...), cit., p. 360 (o autor não fala da sentença absolutória).
} 
Pela redação do inciso, o doador tem que ser vítima de injúria caracterizada pela gravidade da ofensa, de modo que determinadas ações do donatário que simplesmente insinuam uma ofensa, ironias ou que não tem repercussão, não são suficientes para embasar pretensão de desconstituição da doação ${ }^{813}$.

Há $^{814}$ quem pense que o legislador empregou desnecessariamente o advérbio "gravemente", pois o ato em si, por ser criminoso, já é grave, e, além disso, seria impossível o juiz aferir a gravidade da conduta. No entanto, é de se considerar a ponderação do fato de que a lei impõe gravidade a fim de não permitir que qualquer dissabor se torne motivo de revogação, cabendo ao magistrado avaliar a correta qualificação do ato praticado pelo donatário, e, além disso, pode ocorrer não apenas por meio de palavras, mas também de gestos $^{815}$.

Ademais, não tipifica a hipótese a injúria praticada em resposta a provocação do doador ou aquela cometida antes que o donatário tivesse ciência da doação que lhe é feita ${ }^{816}$. No âmbito do Código Civil de 1916, ARNALDO MARMITT ${ }^{817}$ sustentava que se o injuriado for um dos cônjuges doadores, apenas o cônjuge ofendido poderá manejar a ação de revogação e somente sua quota parte retornará a seu patrimônio. mas nada impede, porém, diante do art. 558 do Código Civil atual, que os dois doadores componham o polo ativo da demanda revogatória.

No tocante à calúnia, além de ser a ela aplicável o quanto dito em relação à injúria, é cabível a oposição de exceção da verdade pelo donatário, haja vista que a falsidade do quanto afirmado é constitutivo da sua configuração ${ }^{818}$. Não obstante, para VICENTE SABINO JÚNIOR ${ }^{819}$, a possibilidade de revogação nessa hipótese não necessita de prévia condenação penal.

\footnotetext{
${ }^{813}$ ARNALDO MARMITT, Doação, cit., p. 275.

${ }^{814}$ PABLO STOLZE GAGLIANO, O Contrato (...), cit., pp. 188-189.

815 AGOSTINHO ALVIM, Da Doação, cit., pp. 296-297; CARVAlHO SANTOS, Código (...), cit., p. 446; NELSON ROSENVALD, Contratos (...), cit., p. 598 (o autor também ressalta a repercussão social para mensuração da gravidade); PONTES DE MIRANDA, Tratado (...), cit., p. 273.

O Superior Tribunal de Justiça, nesse sentido, já afastou pretensão de revogação por injúria, confirmando decisão das instâncias inferiores, na qual ficou assentado que havia grande animosidade entre as partes e não ficou provado qualquer ato revestido de real gravidade ( $3^{\mathrm{a}}$ T., R. Esp. n. 1.350.46/SP, rel. SIDNEI BENETI, j. 05-02-2013).

${ }^{816}$ ARNALDO MARMITT, Doação, cit., p. 275; PONTES DE MIRANDA, Tratado (...), cit., p. 273.

${ }^{817}$ ARNALDO MARMITT, Doação, cit., p. 276.

${ }^{818}$ AGOSTINHO ALVIM, Da Doação, cit., p. 298; CARLOS ROBERTO GONÇALVES, Direito (...), cit., p. 280. Opinando em contrário: PAULO LÔBO, Das Várias (...), cit., p. 365.

${ }^{819}$ Contrato (...),cit., p. 148.
} 
Por derradeiro, para parte da doutrina ${ }^{820}$, deve-se aplicar ao caso interpretação extensiva, a fim de também entender-se cabível a ação revogatória na ocorrência de difamação, em que pese não constar da redação legal, pois essa também é uma espécie de crime contra a honra e, além disso, pode ter maior gravidade que a injúria, expressamente consignada no inciso sob comento. PONTES DE MIRANDA ${ }^{821}$ aduz, como critério interpretativo, que no direito privado a falsa difamação constitui calúnia, assim como a falta de provas da falsidade da imputação importa na prática de injúria.

Outros autores $^{822}$, porém, ensinam que não se considera o crime de difamação como fundamento para pretensão de revogação da liberalidade, pois o rol das hipóteses previstas é fechado.

\subsection{4) se, podendo ministrá-los, recusou ao doador os alimentos de que este necessitava}

Devem concorrer três requisitos para o donatário ter que prestar alimentos ao doador, sendo o primeiro o fato de o disponente se encontrar em estado econômico tal que não possa fazer frente às suas necessidades e às de sua família, o segundo a inexistência de pessoas com vínculos de parentesco, pois estes têm a obrigação primeira de lhe garantir o sustento, e, em terceiro lugar, a possibilidade do donatário de prestar alimentos até o valor do bem doado, o que torna injusta a recusa ${ }^{823}$.

Há ${ }^{824}$ quem entenda ser limitada a legitimidade do doador para o exercício do direito de revogação na hipótese sob comento, o mesmo valendo para a pessoa do donatário, que somente terá dever de prestar alimentos apenas se tiver vínculo familiar com o doador. No entanto, é possível interpretar a norma de modo complementar a esse posicionamento.

\footnotetext{
${ }^{820}$ ARNALDO RIZZARDO, Contratos, cit., p. 474; FLÁVIO AUGUSTO MONTEIRO DE BARROS, Manual (...), cit., p. 360; PABLO STOLZE GAGLIANO, O Contrato (...), cit., pp. 187-188; PAULO LÔBO, Direito (...), cit., p. 309.

${ }^{821}$ Tratado (...), cit., p. 273.

${ }^{822}$ AGOSTINHO ALVIM, Da Doação, cit., p. 296; ANTÔNIO CHAVES, Lições (...), cit., p. 256; ARNALDO MARMITT, Doação, cit., p. 276; CARLOS ROBERTO GONÇALVES, Direito (...), cit., p. 280; FRANCISCO GLAUBER PESSOA ALVES, Das Várias (...), cit., p. 929; JONES FIGUEIRÊDO ALVES, Código (...), cit., pp. 459-460 (o autor opina pela mudança da lei para se incluir a difamação); PAULO NADER, Curso (...), cit., p. 238; SÍLVIO DE SALVO VENOSA, Direito (...), cit., p. 140; SILVIO LUÍS FERREIRA DA ROCHA, Curso (...), cit., p. 185.

${ }^{823}$ ARNALDO MARMITT, Doação, cit., p. 277; ARNALDO RIZZARDO, Contratos, cit., p. 474; CAIO MÁRIO DA SILVA PEREIRA, Instituições (...), cit., p. 225; PABLO STOLZE GAGLIANO, O Contrato (...), cit., p. 191; SÍLVIO DE SALVO VENOSA, Direito (...), cit., p. 140. Consultar também: FLÁVIO AUGUSTO MONTEIRO DE BARROS, Manual (...), cit., p. 346; SILVIO LUÍS FERREIRA DA ROCHA, Curso (...), cit., pp. 185-186.

${ }^{824}$ PABLO STOLZE GAGLIANO, O Contrato (...), cit., p. 191.
} 
De fato, a função precípua de prestar alimentos é daqueles que possuem vínculos de parentesco entre $\mathrm{si}^{825}$, de modo que, se o doador estiver passando necessidades e o donatário puder satisfazê-las, mas a tal se recusa, então não é o caso de o disponente ingressar com ação de alimentos, mas apenas requerer a revogação da benesse ${ }^{826}$.

Outrossim, conforme a lição de MANUEL BAPTISTA LOPES ${ }^{827}$, o direito de revogação por falta de assistência alimentar continua a existir mesmo que a doação tenha se realizado com reserva de usufruto.

No entanto, poderá o donatário provar que há parentes para alimentar o doador, de modo que a recusa é justa ${ }^{828}$, pois sua responsabilidade é subsidiária em relação às pessoas que têm vínculo de parentesco com o doador ${ }^{829}$. Mas o recebedor da benesse não pode alegar em sua defesa enriquecimento superveniente do disponente, pois a ingratidão já foi perpetrada ${ }^{830}$.

Para a prova da recusa, pode o doador se utilizar de qualquer meio admissível, não precisando ela ser deduzida em juízo para amparar eventual pedido de revogação da doação ${ }^{831}$.

Por fim, PABLO STOLZE GAGLIANO ${ }^{832}$ entende que, por o direito a revogação da doação estar fundado na boa-fé objetiva pós-contratual, mesmo que seja inadimplida a obrigação de prestar alimentos e houver o manejo da sua execução forçada, com a respectiva ordem de pagamento, ou prisão civil, ou ainda o próprio pagamento da dívida, tal faculdade continua a perdurar em favor do doador.

\footnotetext{
${ }^{825}$ Tanto é assim que o donatário só tem de colaborar por força do quanto recebido, sendo justa a recusa do que for sobressalente ao valor do bem (nesse sentido: MANUEL BAPTISTA LOPES, Das Doações, cit., pp. 147148).

${ }^{826}$ AGOSTINHO ALVIM, Da Doação, cit., pp. 298-299. PONTES DE MIRANDA explica que o donatário não tem dever jurídico de prestar alimentos decorrente da doação, mas sim dever moral [Tratado (...), cit., p. 273].

${ }^{827}$ Das Doações, cit., pp. 146-147.

${ }^{828}$ AGOSTINHO ALVIM, Da Doação, cit., p. 299; PONTES DE MIRANDA, Tratado (...), cit., p. 274. Opinando, porém, que a recusa somente se dá em sede judicial: CARVALHO SANTOS, Código (...), cit., p. 447.

${ }^{829}$ FRANCISCO GLAUBER PESSOA ALVES, Das Várias (...), cit., p. 929. O parente indicado, porém, deverá ter condições econômicas de prestar alimentos [CARLOS ROBERTO GONÇALVES, Direito (...), cit., p. 280].

${ }^{830}$ AGOSTINHO ALVIM, Da Doação, cit., p. 299.

${ }^{831}$ MARIA HELENA DINIZ, Tratado (...), cit., p. 95; NELSON ROSENVALD, Contratos (...), cit., p. 598; PAULO LÔBO, Das Várias (...), cit., p. 366; WASHINGTON DE BARROS MONTEIRO-DABUS MALUF, Curso (...), cit., p. 181.

${ }^{832}$ O Contrato (...), cit., p. 191.
} 
Vistas as previsões legais de revogação da doação por ingratidão do donatário, cumpre, por derradeiro, debruçar-se sobre as hipóteses de vedação de revogação da benesse por ingratidão, elencadas nos incisos do art. $564^{833}$ do Código Civil de $2002^{834}$.

O motivo pelo qual a lei prevê essas exceções está em que são elas hipóteses de doações caracterizadas por certa carga de onerosidade ${ }^{835}$, ou então elas se afiguram prestação em favor do doador, de modo que não se vislumbra necessidade de exigir gratidão do donatário $^{836}$, sendo que a última hipótese de proteção de revogação tem o fito de premiar o aperfeiçoamento do matrimônio e protegê-lo ${ }^{837}$.

\subsection{5) as doações puramente remuneratórias}

Doações puramente remuneratórias são aquelas de pequeno valor, realizadas com o fito de premiar o donatário por um mérito ou em retribuição a um obséquio ${ }^{838}$. PABLO STOLZE GAGLIANO ${ }^{839}$ justifica tal proibição no fato de que se trata de uma recompensa ao donatário, que prestou determinado serviço ao doador, mas pensa que às vezes a regra pode dar azo a injustiças, como na hipótese de homicídio do disponente.

Por esse motivo, melhor compreensão da doação puramente remuneratória é aquela em que o bem doado equivale ao serviço prestado, de modo que a vedação fundamenta-se no fato de que ao proceder a uma doação remuneratória, o doador está a reconhecer uma obrigação natural, que, por sua natureza, uma vez satisfeita, o pagamento é irrepetível $^{840}$. Outrossim, dada a remuneração, não se pode falar em vínculo moral entre as partes $^{841}$.

${ }^{833}$ Art. 564. "Não se revogam por ingratidão: I - as doações puramente remuneratórias; II - as oneradas com encargo já cumprido; III - as que se fizerem em cumprimento de obrigação natural; IV - as feitas para determinado casamento"

${ }^{834}$ O Código Civil italiano também veda a revogação da doação em duas hipóteses, como se verifica do seu art. 805 ("Donazioni irrevocabili"): "Non possono revocarsi per causa d'ingratitudine, né per sopravvenienza di figli, le donazioni rimuneratorie e quelle fatte in riguardo di un determinato matrimonio". CELESTE IACOVINO justifica a previsão legal pela função particular que a doação remuneratória e a em vista de matrimônio exercem [La Donazione, cit., p. 356].

${ }^{835}$ PAULO LÔBO, Direito (...), cit., p. 307; SILVIO RODRIGUES, Direito (...), cit., p. 216.

Pelo mesmo fundamento, a jurisprudência se formou para afirmar que a doação realizada por conta de acordo realizado em sede de partilha em separação ou divórcio não é passível de revogação: STJ, $4^{\mathrm{a}}$ T., Agr. Reg. no R. Esp. n. 883.232/MT, rel. RAUL ARAÚJO, j. 19-02-2013.

${ }^{836}$ CARVALHO SANTOS, Código (...), cit., p. 463.

${ }^{837}$ CAIO MÁRIO DA SILVA PEREIRA, Instituições (...), cit., p. 226; FRANCISCO GLAUBER PESSOA ALVES, Das Várias (...), cit., pp. 943-944; SILVIO RODRIGUES, Direito (...), cit., p. 216.

${ }^{838}$ VICENTE SABINO JÚNIOR, Contrato (...), cit., p. 145.

${ }^{839}$ O Contrato (...), cit., p. 196.

${ }^{840}$ AGOSTINHO ALVIM, Da Doação, cit., pp. 322-323; FRANCISCO GLAUBER PESSOA ALVES, Das 
Se a doação ultrapassar o serviço prestado pelo donatário, então a parte sobressalente é doação pura, de modo que não goza da exceção sob comento ${ }^{842}$. PONTES DE MIRANDA $^{843}$ ressalta, porém, que é descabido falar em parte onerosa e parte gratuita na doação remuneratória, porque a remuneração almejada compõe o mundo fático, mas não o jurídico, de maneira que, ainda que remuneratória, a doação é toda pura. Assim, todas as doações remuneratórias são irrevogáveis por ingratidão ${ }^{844}$.

\subsection{6) as oneradas com encargo já cumprido}

Para alguns autores ${ }^{845}$, a justificativa de a lei prestar tal cobertura à doação onerosa reside no fato de que o donatário sofreu um decréscimo patrimonial no cumprimento do encargo visando ao aperfeiçoamento da transferência patrimonial, havendo ${ }^{846}$, porém, quem justifique que uma vez cumprida a avença extingue-se o dever de gratidão, que não pode ser eterno.

Não obstante, há ${ }^{847}$ quem explique que a irrevogabilidade prevista no dispositivo ora comentado abarca apenas a parte onerosa compreendida pelo encargo, sendo revogável a parte gratuita. Nesse sentido, AGOSTINHO ALVIM ${ }^{848}$ afirma ser aplicável ao caso o art. 1.167 do Código Civil de 1916, que tem correspondência com o art. 546 do Código Civil de 2002, de modo que, da mesma forma que ocorre na doação remuneratória, pode-se cindir a modal em uma parte pura e em outra onerosa, e explica que somente a parte gratuita é passível de revogação por ingratidão do donatário, ao passo que a parte onerosa não o é, pois, de algum modo, o doador foi recompensado ${ }^{849}$.

Várias (...), cit., p. 944; PAULO GERALDO DE OLIVEIRA MEDINA, A Doação, cit. 476; PAULO LÔBO, Das Várias (...), cit., p. 384.

${ }^{841}$ PAULO NADER, Curso (...), cit., p. 237. Há quem afirme também que deixa de haver liberalidade [FÁBIO ULHOA COELHO, Curso (...), cit., p. 252], o que reclama maiores esclarecimentos, a vista do art. 540 do Código de Processo Civil.

${ }^{842}$ ARNALDO MARMITT, Doação, cit., p. 254; CARVAlHO SANTOS, Código (...), cit., p. 464; CLÓVIS BEVILAQUA, Código (...), cit., p. 290; PAULO NADER, Curso (...), cit., p. 237; NELSON ROSENVALD, Contratos (...), cit., p. 602; PAULO GERALDO DE OLIVEIRA MEDINA, A Doação, cit. 476; SÍLVIO DE SALVO VENOSA, Direito (...), cit., p. 138.

${ }^{843}$ Tratado (...), cit., pp. 277-278.

${ }^{844}$ No mesmo sentido: CELESTE IACOVINO, La Donazione, cit., p. 357.

${ }^{845}$ ARNALDO RIZZARDO, Contratos, cit., p. 475 (o autor fala em quitação do donatário); FÁBIO ULHOA COELHO, Curso (...), cit., p. 252; PABLO STOLZE GAGLIANO, O Contrato (...), cit., p. 196.

${ }^{846}$ FRANCISCO GLAUBER PESSOA ALVES, Das Várias (...), cit., p. 944; MARIA HELENA DINIZ, Curso (...), cit., p. 273.

${ }^{847}$ ARNALDO MARMITT, Doação, cit., p. 254; CARVAlHO SANTOS, Código (...), cit., p. 464; PAUlO GERALDO DE OLIVEIRA MEDINA, A Doação, cit. 476.

${ }^{848}$ Da Doação, cit., p. 324.

${ }^{849}$ No mesmo sentido: ARNALDO RIZZARDO, Contratos, cit., p. 475. 
LUCIANO DE CAMARGO PENTEADO ${ }^{850}$ critica a previsão legal ora tratada, na medida em que regula, como se fossem iguais, o descumprimento do encargo e a ingratidão, ao arrepio do art. 555 do Código Civil de 2002, e deixa de esclarecer o intérprete em situação tão minudente, que exige enfrentar questões como a de prazos. De todo modo, infere daí que a doação modal se afasta da caracterização de contrato comutativo no atual Código Civil.

\subsection{7) as que se fizerem em cumprimento de obrigação natural}

A doutrina ${ }^{851}$ explica que a finalidade da norma é regulamentar a ocorrência de satisfação de obrigação não exigível, como a dívida oriunda de jogo ou aposta, ou aquela que se encontra prescrita, porque nestas hipóteses não há doação, dada e existência de onerosidade na relação jurídica, de modo que há, em verdade, adimplemento, por isso a vedação de se revogar o ato.

De todo modo, como já se disse a respeito da proibição de revogação de doação remuneratória, a entrega de bem em vista de uma obrigação natural é irrepetível ${ }^{852}$.

VICENTE SABINO JÚNIOR ${ }^{853}$ critica o emprego do termo "natural", por abranger apenas as obrigações havidas nos vínculos de parentesco, pelo que opina que deveria ter se empregado o vocábulo "moral", de modo a acobertar todas as obrigações que surgissem no âmbito social do indivíduo ${ }^{854}$.

Por seu turno, AGOSTINHO ALVIM ${ }^{855}$ discorre longamente sobre a distinção entre obrigação natural e obrigação moral, pois toda a tendência, ao menos quando escreveu, era de o segundo conceito absorver o primeiro e chega até a aceitar tal absorção. Mas como o Código Civil de 1916, tanto no inciso III do art. 1.187 , como no art. $970^{856}$, emprega obrigação natural, empreende a distinção e aponta como critério o fato de que a obrigação

\footnotetext{
${ }^{850}$ Doação (...), cit., p. 182.

${ }^{851}$ CARVAlHO SANTOS, Código (...), cit., p. 464; EDUARDO ESPINOLA, Dos Contratos (...), cit. p. 199; LUCIANO DE CAMARGO PENTEADO, Doação (...), cit., p. 122; PAULO GERALDO DE OLIVEIRA MEDINA, A Doação, cit. 476; PABLO STOLZE GAGLIANO, O Contrato (...), cit., pp. 196-197; PAULO LÔBO, Das Várias (...), cit., p. 385; PAULO NADER, Curso (...), cit., p. 238; SÍlVIO DE SALVO VENOSA, Direito (...), cit., pp. 138-139.

${ }^{852}$ FÁBIO UlHOA COELHO, Curso (...), cit., p. 252; NELSON ROSENVALD, Contratos (...), cit., p. 603.

${ }^{853}$ Contrato (...), cit., p. 146.

${ }^{854}$ No mesmo sentido: CARVAlHO SANTOS, Código (...), cit., p. 464; ClóviS BEVILAQUA, Código (...), cit., p. 290; ORLANDO GOMES, Contratos, cit., p. 243; PONTES DE MIRANDA, Tratado (...), cit., pp. 279-280 (o autor entende que a hipótese deve ser assim interpretada).

${ }^{855}$ Da Doação, cit., pp. 325-331.

${ }^{856}$ Art. 970 . "Não se pode repetir o que se pagou para solver dívida prescrita, ou cumprir obrigação natural".
} 
natural consiste em retribuir ou pagar por um ato ou serviço, como o pagamento de dívida prescrita ou oriunda de jogo, de maneira que se a doação for realizada em vista de se retribuir ou pagar por alguma coisa, então não é passível de revogação por ingratidão, por força do inciso III do art. 1.187, do Código Civil de 1916, cuja redação foi seguida pelo inciso ora comentado.

Outras explicações possíveis para a previsão legal é de que a irrevogabilidade destas doações decorrem do fato de não poderem ser exigidas em juízo ${ }^{857}$ ou por não ter existência jurídica, logo não podem ser revogadas ${ }^{858}$.

\subsection{8) as feitas para determinado casamento}

Tal previsão abrange todas as doações em torno do matrimônio, seja as antenupciais, seja para determinado casamento futuro, seja ainda aquelas feitas aos filhos quando se casarem $^{859}$.

A justificativa para tal proteção está no fato de que eventual revogação de doação por ingratidão do donatário poderá vir a atingir terceiros inocentes, como o outro cônjuge ou filhos e demais dependentes do casal, que não perpetraram a ingratidão ${ }^{860}$, além do que causaria discórdia familiar pela falta de um só membro ${ }^{861}$. Há ${ }^{862}$ quem acrescente também a necessidade econômica dos recém casados. Ou seja, o fundamento último é a proteção da família $^{863}$.

Vale lembrar que, se não se realizar o casamento, a doação se revogará de todo modo ${ }^{864}$, seja porque a não realização do matrimônio leva à caducidade da doação ${ }^{865}$, seja

\footnotetext{
857 ARNALDO MARMITT, Doação, cit., 1994, p. 255; ARNALDO RIZZARDO, Contratos, cit., p. 475; MARIA HELENA DINIZ, Tratado (...), cit., p. 96.

${ }^{858}$ FRANCISCO GLAUBER PESSOA ALVES, Das Várias (...), cit., p. 944.

859 AGOSTINHO ALVIM, Da Doação, cit., pp. 331-332; ARNALDO MARMITT, Doação, cit., p. 255; VICENTE SABINO JÚNIOR, Contrato (...), cit., p. 146.

${ }^{860}$ CARLOS ROBERTO GONÇALVES, Direito (...), cit., p. 282; CARVALHO SANTOS, Código (...), cit., pp. 464-465; PABLO STOLZE GAGLIANO, O Contrato (...), cit., p. 197; WASHINGTON DE BARROS MONTEIRO-DABUS MALUF, Curso (...), cit., pp. 183-184.

861 FRANCISCO GLAUBER PESSOA ALVES, Das Várias (...), cit., p. 944; PAULO GERALDO DE OLIVEIRA MEDINA, A Doação, cit. 476; PAULO NADER, Curso (...), cit., p. 238; SÍlVIO DE SALVO VENOSA, Direito (...), cit., p. 139.

${ }^{862}$ FÁBIO ULHOA COELHO, Curso (...), cit., p. 252.

863 AGOSTINHO ALVIM, Da Doação, cit., pp. 332-333; CELESTE IACOVINO, La Donazione, cit., p. 358; LUCIANO DE CAMARGO PENTEADO, Doação (...), cit., p. 182.

${ }^{864}$ AGOSTINHO ALVIM, Da Doação, cit., pp. 332-333.

${ }^{865}$ VICENTE SABINO JÚNIOR, Contrato (...), cit., p. 145.
} 
porque, segundo certo entendimento ${ }^{866}$, o casamento acarreta em manifestação de aceite, pelo que sua não ocorrência importa na frustração do fim do negócio.

Diante do que se expôs neste último tópico, no que interessa especificamente ao manejo da doação para implementação de planejamento sucessório, deve-se fazer algumas considerações.

Como se verificou, a doação é irrevogável, logo o doador deve refletir muito bem antes de realizá-la e o donatário, por sua vez, de aceitá-la. Com efeito, realizada a doação e cumpridos os requisitos legais, opera-se a transferência patrimonial por definitivo, nada podendo o doador fazer em contrário de modo unilateral, diferente do que se passa, por exemplo, com o testamento.

Mas tal característica pode ser vista como uma vantagem, porque muitas vezes o que se busca num planejamento sucessório é a estabilização das relações patrimoniais, e tal segurança pode ser contemplada ainda em vida pelo doador, o que outros meios jurídicos não são capazes de proporcionar.

Ademais, a lei assegura ao doador algumas garantias, que o protegem de eventuais situações excepcionais. Desse modo, se sofrer alguma grave investida do donatário, poderá reputá-lo por ingrato e buscar a revogação da doação e, da mesma forma, se passar a ter necessidade econômica, poderá alcançar do recebedor da benesse alimentos ou a devolução do bem.

Não obstante, como já se viu, a disciplina legal da ingratidão é casuística e abarca apenas comportamentos muito graves, de maneira que não deverá o disponente contar com a devolução do bem doado por simples dissabores nas relações com o donatário, pois não dão ensejo à revogação do ato, ao passo que o testamento é revogável sem nem mesmo ser necessária alguma justificativa.

${ }^{866}$ LUCIANO DE CAMARGO PENTEADO, Doação (...), cit., p. 180. 


\section{CAPÍtulo II - CASOS DE DOAÇÃo AFETAS À SUCESSÃo NO CÓDIGO CIVIL BRASILEIRO DE 2002}

Feita a análise dos elementos gerais da doação no sistema civil brasileiro atual, presentes estão os pressupostos necessários para se analisar o regime jurídico da doação como instrumento de implementação de um planejamento sucessório.

Para tanto, é mister analisar os casos de doações que podem estar presentes no âmbito sucessório, permitindo destarte articular todas as balizas legais que forem sendo localizadas num todo unitário, tornando possível a formulação de uma conclusão sobre o problema posto e seus desdobramentos práticos.

\section{1) Doação causa mortis}

Doação causa mortis é a aquela em que a transferência patrimonial gratuita se dá após a morte do doador, por meio de disposição contratual ${ }^{867}$. PONTES DE MIRANDA ${ }^{868}$ apresenta a espécie comentada como uma doação com condição, consistindo essa última na sobrevivência do donatário, esteja ou não ligada a um tempo ou evento determinado

Para alguns doutrinadores ${ }^{869}$, tal liberalidade não é possível de ser realizada no sistema civil brasileiro, porque a doação, por essência, deve representar alienação inter vivos, mas não mortis causa, que é próprio dos testamentos e legados.

Outros ensinam $^{870}$, ainda, que há dificuldades de admissibilidade dessa espécie no Código Civil pátrio, sob o argumento de que a doação causa mortis pretende exercer o papel do testamento, mas é intransponível a diferença entre essas figuras, já que o contrato de doação é irrevogável, ao contrário do testamento ${ }^{871}$.

${ }^{867}$ ELIAS CLARK et al., Cases (...), cit., p. 444; PABLO STOLZE GAGLIANO, O Contrato (...), cit., p. 52; PLANIOL, Traité (...), cit., p. 650.

${ }^{868}$ Tratado (...), cit., p. 212.

${ }^{869}$ ARNALDO RIZZARDO, Contratos, cit., p. 444; ARNOLDO WALD, Direito (...), cit., p. 64; CAIO MÁRIO DA SILVA PEREIRA, Instituições (...), cit., p. 216; LUIZ GUILHERME LOUREIRO, Curso (...), cit., p. 504; PAULO LÔBO, Direito (...), cit., p. 282; RODRIGO SENISE LISBOA, Manual (...), cit., p. 258; SYLVIO CAPANEMA DE SOUZA, Das Várias (...), cit., p. 85.

${ }^{870}$ PABLO STOLZE GAGLIANO, $O$ Contrato (...), cit., p. 52; WASHINGTON DE BARROS MONTEIRODABUS MALUF, Curso (...), cit., p. 165.

${ }^{871}$ Escrevendo no âmbito do Código Napoleônico, PLANIOL leciona que não há uma disposição de lei vedando a doação por morte no indigitado diploma, de tal modo que a doação por morte será aceitável desde que compatível com o regime legal. No entanto, continua o autor a explicar que é impossível sua aplicação, haja vista que ela milita contra a irrevogabilidade essencial à doação, ao mesmo tempo em que pode ser perfeitamente suprida pelo testamento [Traité (...), cit., pp. 650-651]. Deve-se levar em conta, porém, como já se disse acima, que o art. 893 do Código Civil da França tem o escopo de eliminar a doação causa mortis 
Afora isso, pode ainda a doação causa mortis caracterizar a estipulação de pacta corvina, vedada pelo art. 426 do Código Civil de $2002^{872}$.

Versando sobre a espécie ora estudada, OZÉIAS J. SANTOS ${ }^{873}$ explica que a doação mortis causa está fundada na liberalidade e sua principal característica seria a sua revogabilidade ${ }^{874}$, e externa a opinião de que tal forma de doação não foi admitida no Código Civil de 1916. Com efeito, muitos autores ${ }^{875}$ que escreveram sobre o tema no âmbito do Código Civil revogado também entendem que é característica da doação ser ato inter vivos, o que a distingue do testamento, sendo que o sistema civil então vigente inadmitiria a doação por morte ${ }^{876}$.

VICENTE SABINO JÚNIOR ${ }^{877}$, de outro lado, aponta que a doação mortis causa é diferente de legado, pois enquanto nesse último inexiste aceite do legatário e é passível de revogação unilateral pelo testador, na doação é essencial que o beneficiário aceite a liberalidade, que passa a ser irrevogável.

Ainda assim, o autor ${ }^{878}$ entende ser plenamente cabível a doação mortis causa, desde que não importe na negociação de herança de pessoa viva, pois assim esbarraria no art.

[JEAN RAY, De La Notion (...), cit., p. 47]. Além disso, no seu art. 946 ("En cas que le donateur se soit réservé la liberté de disposer d'un effet compris dans la donation ou d'une somme fixe sur les biens donnés, s'il meurt sans en avoir disposé, ledit effet ou ladite somme appartiendra aux héritiers du donateur, nonobstant toutes clauses et stipulations à ce contraires"), o Código Civil francês fulmina de nulidade a cláusula que permite ao doador dispor dos bens doados, de modo que a transmissão da propriedade deverá se dar ainda em vida do doador e de maneira definitiva [PAUL DELNOY, Le Libéralités (...), cit., p. 55].

872 EDUARDO ESPINOLA, Dos Contratos (...), cit., p. 168 (ao tratar da doação de bens futuros, o autor leciona que não pode ser objeto da liberalidade bem componente de sucessão não aberta); LUCIANO DE CAMARGO PENTEADO, Doação (...), cit., pp. 178-179; PAULO LÔBO, Direito (...), cit., p. 282.

${ }^{873}$ Da Doação, cit., p. 17.

${ }^{874}$ No mesmo sentido: PLANIOL, Traité (...), cit., p. 650.

Na commom law, pode-se elencar as seguintes características da espécie de doação ora comentada: se dá em vista de um perigo, mas não necessariamente no leito de morte; se passado o perigo e essa for a vontade do disponente, desfaz-se o ato; trata-se de doação revogável; é automática a caducidade do ato caso o donatário faleça antes do doador; o objeto doado poderá ser perseguido pelos credores do doador caso esse se reduza ao estado de insolvência; só pode ter por objeto, basicamente, bens móveis; e, a forma de transferência segue a da doação inter vivos [ELIAS CLARK et al., Cases (...), cit., pp. 444-445].

875 ARNALDO MARMITT, Doação, cit., p. 16; CARVALHO SANTOS, Código (...), cit., pp. 303-304; EDUARDO ESPINOLA, Dos Contratos (...), cit., p. 168; ORLANDO GOMES, Contratos, cit., pp. 235-236.

${ }^{876}$ ARNOLDO MEDEIROS DA FONSECA explica que o Código Civil de 1916 não aceita a doação em que a morte se configura em condição suspensiva, mas abre exceção quanto à doação feita em vista de casamento futuro (art. 314 do referido diploma), afora que admite ainda a doação com cláusula de reversão [Doação (...), cit., pp. 293-294]. Essa é também a lição de CLÓVIS BEVILAQUA, para quem a eliminação da doação causa mortis importou apenas no afastamento de instituto jurídico romano não mais em voga nas legislações modernas [Código (...), cit., p. 271].

${ }^{877}$ Contrato (...), cit., pp. 47-48.

${ }^{878}$ Contrato (...), cit., p. 15. 
$1.089^{879}$ do Código Civil de 1916. Desse modo, ensina que poderia o doador estipular, e o donatário aceitar, que a transferência do objeto da benesse se daria quando da morte do disponente (termo) ou se esse viesse a falecer na ocorrência de determinada eventualidade (condição).

No mesmo sentido, AGOSTINHO ALVIM ${ }^{880}$ também não vê nenhum óbice à admissão da doação mortis causa e entende que se trata de problema de nomenclatura, pois se a morte for vista como momento inicial para que a doação surta efeitos, desde que o donatário tenha dado seu aceite ainda enquanto o doador for vivo, nada obstaria sua validade. Ademais, continua o autor, o arrependimento do doador não seria causa suficiente para seu afastamento, pois o animus donandi se manifestou quando da liberalidade e, se for o caso, poderá o disponente proceder à revogação, se o caso ${ }^{881}$.

Da mesma maneira, LUCIANO DE CAMARGO PENTEADO ${ }^{882}$ também vê na doação mortis causa uma doação com condição, na hipótese de se admitir a validade do negócio se porventura o doador vier a falecer e o donatário sobreviver a ele ${ }^{883}$.

Como já se consignou, quando se versou sobre a doação em vista de casamento futuro, o mencionado art. 314 do Código Civil de 1916 trazia uma hipótese de doação causa mortis, pois previa que a liberalidade só vinha a se aperfeiçoar com a morte do doador, faltando-lhe ainda a irrevogabilidade, porque o doador podia desfazê-la até sua morte ${ }^{884}$. No entanto, não há mais tal previsão no sistema civil atual ${ }^{885}$.

Além do mais, há ${ }^{886}$ quem julgue ser inadmissível a doação mortis causa no sistema civil brasileiro, opinando porém pela sua admissão como se legado fosse. PABLO STOLZE GAGLIANO ${ }^{887}$, a esse respeito, apoiando-se no art. $170^{888}$ do Código Civil de

\footnotetext{
${ }^{879}$ Art. 1.089. "Não pode ser objeto de contrato a herança de pessoa viva".

${ }^{880}$ Da Doação, cit., pp. 132-134.

${ }^{881}$ Também se manifestando no mesmo sentido dos autores citados: PONTES DE MIRANDA, Tratado (...), cit., pp. 218-224.

${ }^{882}$ LUCIANO DE CAMARGO PENTEADO, Doação (...), cit., pp. 178-179.

${ }^{883}$ Nesse sentido, o direito norte-americano entende que é necessário haver uma real expectativa da morte do doador para haver doação causa mortis ("apprehension of death"), como, por exemplo, a realização de uma cirurgia, combinada com a condição de que se o doador sobreviver ao perigo o bem deverá retornar ao seu patrimônio [ELIAS CLARK et al., Cases (...), cit., pp. 449-450].

${ }^{884}$ ARNALDO MARMITT, Doação, cit., pp. 16-17.

${ }^{885}$ ARNOLDO WALD, Direito (...), cit., p. 75. Não obstante, há quem escreva no regime atual e ainda assim trate da possibilidade de haver doação causa mortis quando feita em vista de casamento futuro: CÉSAR FIUZA, Direito (...), cit., p. 507.

${ }^{886}$ ARNALDO MARMITT, Doação, cit., p. 16.

${ }^{887}$ O Contrato (...), cit., pp. 52-55.

${ }^{888}$ Art. 170. "Se, porém, o negócio jurídico nulo contiver os requisitos de outro, subsistirá este quando o fim a
} 
2002, entende que se pode admitir a doação mortis causa como se testamento fosse, desde que tivessem sido observados todos os requisitos formais desse instituto ${ }^{889}$.

Diante do que se expôs, é de se considerar que a doação causa mortis oferece pouca segurança ao doador para a implementação de um planejamento sucessório, haja vista que poderá ser fulminada de nulidade.

Assim, ao manejar a doação, o disponente deverá partir do pressuposto de que está a se despojar imediatamente da propriedade dos bens doados, ou ao menos ainda em sua vida, caso deseje apor alguma condição ao negócio jurídico. Não obstante, nada impede que realize a doação com reserva de usufruto vitalício ou com cláusula de resolução, a fim de assegurar os resultados almejados.

\section{2) Doação universal}

A doação universal é aquela em que o doador aliena todo o seu patrimônio, de modo que nada mais lhe resta para garantir sua subsistência, o que é vedado pelo art. $548^{890}$ do Código Civil de $2002^{891}$.

que visavam as partes permitir supor que o teriam querido, se houvessem previsto a nulidade".

${ }^{889}$ No Código Civil português há expressa vedação à doação mortis causa, porém se prevê exceções e a possibilidade de se aceitar o ato como testamento, como se verifica na redação do seu art. $946 .^{\circ}$ ("Doação por morte"): "1. É proibida a doação por morte, salvo nos casos especialmente previstos na lei. 2. Será, porém, havida como disposição testamenteira a doação que houver de produzir os seus efeitos por morte do doador, se tiverem sido observadas as formalidades dos testamentos". Ao comentar esse dispositivo, MANUEL BAPTISTA LOPES leciona que no direito civil luso a doação por morte, em regra, é nula, a não ser que seja possível sua conversão em testamento ou então se dê no âmbito da permissão legal. Quanto aos casos em que a lei permite a doação mortis causa, referem-se, basicamente, às doações feitas em vista de casamento futuro. No que toca à possibilidade de conversão, o autor se apoia em regra da parte geral do diploma civil português, que prevê a conversão na permissão específica da lei (Das Doações, cit., pp. 35-37). Ao contrário dessa solução, o Código Civil brasileiro é carente de disposição legal específica que autorize o intérprete a aproveitar a doação como se testamento fosse.

Já o Código Civil espanhol, por seu turno, no seu art. 620, cuja redação é "Las donaciones que hayan de producir sus efectos por muerte del donante participan de la naturaleza de las disposiciones de última voluntad, y se regirán por las reglas establecidas en el capítulo de la sucesión testamentaria", parece dar solução diversa ao problema, pois admite a doação causa mortis, mas lhe dispensa o tratamento de ato sucessório, com as regras típicas da transmissão por morte. MANUEL ALBADALEJO GARCÍA e SILVIA DIAZ ALABART lecionam, porém, que esse dispositivo veio a acabar com a doação causa mortis no direito civil ibérico, e sua finalidade é a de permitir que se aceite o ato de disposição como testamento, desde que cumpridos os requisitos legais das disposições de última vontade (La Donación, cit., pp. 601-616). Sem prejuízo, os mencionados doutrinadores admitem que o quanto posto no parágrafo segundo do art. 1.341 da lei civil espanhola ("I. Por razón de matrimonio los futuros esposos podrán donarse bienes presentes 2. Igualmente podrán donarse antes del matrimonio en capitulaciones bienes futuros, sólo para el caso de muerte, y en la medida marcada por las disposiciones referentes a la sucesión testada") tem o condão de prever uma hipótese na lei de doação causa mortis, mas explicam que tal dispositivo se justifica porque os bens futuros transmitidos somente serão cognoscíveis com a morte do doador [La Donación, cit., p. 616].

${ }^{890}$ Art. 548. "É nula a doação de todos os bens sem reserva de parte, ou renda suficiente para a subsistência do doador". 


\section{PABLO STOLZE GAGLIANO ${ }^{892}$ prefere interpretar o termo "subsistência",}

previsto na lei, como "mantença", e explica que assim o faz por comungar da tese de que o fundamento último da vedação da doação universal não reside na norma, mas sim no princípio da dignidade da pessoa humana, resguardado pela Constituição Federal ${ }^{893}$, sendo que a mera subsistência, para ele, não atende tal previsão constitucional, haja vista que a pessoa não necessita apenas de subsistir.

AGOSTINHO ALVIM ${ }^{894}$, por seu turno, leciona que a mens legis é a de que o doador deverá garantir sua subsistência, o que fará por meio da formação de uma renda ${ }^{895}$, por si ou por terceiros, ou na reserva de alguns bens ${ }^{896}$ (o que até mitiga a universalidade da

${ }^{891}$ O revogado Código Civil português de 1867 trazia disposição semelhante, conforme se verifica no seu art. $14600^{\circ}$, que dispunha: "É nula a doação, que abrange a totalidade dos bens do doador sem reserva de usufructo, ou que deixa o doador sem meios de subsistencia". Mas o citado dispositivo não foi reproduzido no diploma civil atual, que apenas faculta ao doador reservar para si o usufruto dos bens doados, de acordo com seu art. 958. ${ }^{\circ}$ ("Reserva de usufruto"): "1. O doador tem a faculdade de reservar para si, ou para terceiro, o usufruto dos bens doados. 2. Havendo reserva de usufruto em favor de várias pessoas, simultânea ou sucessivamente, são aplicáveis as disposições dos artigos 1441. ${ }^{\circ}$ e 1442. "” (MANUEL BAPTISTA LOPES, Das Doações, cit., pp. 94-95).

Da mesma forma, não há no Código Napoleônico a previsão de nulidade de doação por doação de todos os bens, exceto, claro, quando se tratar de proteção de herdeiros ou credores. Assim, vê-se na obra de PLANIOL que, afora a não observância da forma de celebração do ato ou da aposição de aceite, as doações proibidas pela lei são: de bens futuros; com condição potestativa; com encargo do donatário de pagar dívidas futuras do doador; e, com reserva do doador de dispor sobre bens já doados. Essas proibições estão elencadas no art. 943 a 946 do Código Civil da França [Traité (...), cit., pp. 682-683]. Também o Código Civil italiano não conhece a proibição de doação universal. Por fim, no regime jurídico civil espanhol também é possível haver doação universal, desde que se faça de maneira individualizada (MANUEL ALBADALEJO GARCÍA e SILVIA DIAZ ALABART, La Donación, cit., pp. 304-305).

892 O Contrato (...), cit., pp. 101-103.

${ }^{893}$ No mesmo sentido, quanto ao fundamento: MARIA HELENA DINIZ, Tratado (...), cit., p. 84; NELSON ROSENVALD, Contratos (...), cit., p. 591.

Há julgado do Superior Tribunal de Justiça que adota essa mesma base para declarar a nulidade presente em promessa de doação realizada em partilha de separação judicial, pois o varão teria realizado doação universal, sendo que ele próprio foi quem promoveu a demanda ( $3^{\mathrm{a}}$ T., R. Esp. n. 285421/SP, rel. VASCO DELLA GIUSTINA, j. 04-05-2010).

${ }^{894}$ Da Doação, cit., pp. 163-165.

${ }^{895}$ Há quem ensine que basta o estabelecimento de uma renda qualquer para atender a validade do ato: PAULO LÔBO, Direito (...), cit., p. 303.

${ }^{896}$ No mesmo sentido, quanto a renda ou usufruto: CAIO MÁRIO DA SILVA PEREIRA, Instituições (...), cit., p. 221; CARLOS ALBERTO BITTAR, Contratos (...), cit., pp. 45-46; CARLOS ROBERTO GONÇALVES, Direito (...), vol. III, cit., p. 274; FLÁVIO AUGUSTO MONTEIRO DE BARROS, Manual (...), cit., p. 352; FLÁVIO TARTUCE, Direito (...), cit., p. 326; SYLVIO CAPANEMA DE SOUZA, Das Várias (...), cit., p. 187; WASHINGTON DE BARROS MONTEIRO-DABUS MALUF, Curso (...), cit., p. 173. Na mesma linha, há precedente do Superior Tribunal de Justiça declarando válida doação feita de todos os bens em sede de divórcio (a virago, então casada no regime da comunhão universal, renunciou a toda sua meação na partilha), pois o varão-donatário comprometeu-se a pagar pensão alimentícia de 2 salários mínimos e a doar um imóvel em favor da doadora (4a T., R. Esp. n. 61225/SP, rel. BARROS MONTEIRO, j. 17-10-2000).

Há quem pontue, ainda, que basta a reserva de usufruto para afastar a proibição do art. 548 do Código Civil de 2002: CHRISTIANO CASSETARI, Elementos (...), cit., p. 214; FRANCISCO GLAUBER PESSOA ALVES, Das Várias (...), cit., p. 903; LUIZ GUILHERME LOUREIRO, Curso (...), cit., p. 515; MARIA HELENA DINIZ, Curso (...), cit., p. 263; SILVIO RODRIGUES, Direito (...), cit., p. 207; SYLVIO CAPANEMA DE SOUZA, Das Várias (...), cit., p. 188. PONTES DE MIRANDA, por seu turno, afirma que o usufruto, de per si, não basta para se afirmar que a subsistência do doador está garantida, mas ensina 
doação, segundo o doutrinador ${ }^{897}$ ), donde ele conclui que a garantia de subsistência: não pode consistir no salário do doador, mesmo que vultoso, pois perspectiva de ganho não é renda ${ }^{898}$; deve ser vitalícia, mas não necessariamente real, de modo que não há motivo para limitá-la apenas ao usufruto; e, deve manter o mesmo patamar financeiro do doador ${ }^{899}$, mas seu empobrecimento superveniente não revoga a doação ${ }^{900}$.

Ademais, não subsiste a doação mesmo que seja dada com encargo de o donatário prover o sustento do doador, continuando assim a esbarrar na proibição do citado art. 548 da Lei $10.406 / 2002^{901}$.

também que a doação de um único bem com reserva de usufruto não esbarra na nulidade da doação universal [Tratado (...), cit., pp. 246-247]. De outro lado, não pode o doador transmitir o usufruto de todos os seus bens e reservar para si apenas a nua propriedade [CARVALHO SANTOS, Código (...), cit., p. 396]. A esse respeito, o Superior Tribunal de Justiça firmou posição de que a reserva de usufruto, de per si, afasta a nulidade ora tratada: $3^{\mathrm{a}}$ T., R. Esp. n. 34271-9/SP, rel. CLAUDIO SANTOS, 22-06-1993. Por outro lado, em outro julgado dessa mesma Corte, manteve-se acórdão do Tribunal de Justiça do Paraná que declarava a nulidade por ocorrência de doação universal, ainda que houvesse reserva de usufruto do único imóvel de propriedade da doadora, e a essa conclusão se chegou porque a disponente tinha 88 anos de idade, era muito doente e analfabeta, pelo que ela precisava do bem para se manter ( $3^{\mathrm{a}}$ T., R. Esp. n. 656985/PR, rel. CARLOS ALBERTO MENEZES DIREITO, j. 07-10-2004).

${ }^{897}$ Opinando no mesmo sentido: CARVALHO SANTOS, Código (...), cit., p. 392.

${ }^{898}$ No mesmo sentido: PAUlO NADER, Curso (...), cit., p. 235; SYLVIO CAPANEMA DE SOUZA, Das Várias (...), cit., pp. 189-191. Na lição de outros autores, porém, o salário atende a renda exigida pela lei: JONES FIGUEIRÊDO ALVES, Código (...), cit., p. 451 (o autor fala em aposentadoria); MARIA HELENA DINIZ, Curso (...), cit., p. 262; NELSON ROSENVALD, Contratos (...), cit., p. 591; PAULO LÔBO, Direito (...), cit., p. 303. Sobre esse tema, CARVALHO SANTOS entende que somente se pode levar em conta essa possibilidade se o doador for funcionário público vitalício com garantia de aposentadoria [Código (...), cit., pp. 393-394].

${ }^{899}$ Tal elemento tem por escopo verificar se a subsistência do doador está garantida por meio da análise de suas circunstâncias pessoais [CARVALHO SANTOS, Código (...), cit., pp. 396-397; PAULO LÔBO, Direito (...), cit., p. 304]. SYLVIO CAPANEMA DE SOUZA externa opinião contrária, por entender que a questão não é saber-se se o disponente ficou mais empobrecido que dantes, mas sim se ele é capaz de se manter ou não [Das Várias (...), cit., p. 187].

900 Também chegando à mesma conclusão: PAULO NADER, Curso (...), cit., p. 235; SYLVIO CAPANEMA DE SOUZA, Das Várias (...), cit., p. 191. Nada impede, porém, que o doador pleiteie alimentos em face do donatário: CARVALHO SANTOS, Código (...), cit., pp. 399-403.

Sobre os elementos a serem analisados pelo juiz na qualificação da universalidade ou não da doação, confrontar: PONTES DE MIRANDA, Tratado (...), cit., pp. 245-246

Há um precedente do Tribunal de Justiça de Minas Gerais que muito interessa para a presente pesquisa. Consta do voto condutor do acórdão que um casal doou, em antecipação de herança, um bem imóvel às duas filhas com reserva de usufruto, mas posteriormente se separaram e ficou constando da partilha que o varão renunciaria ao usufruto vitalício. Somado com o fato de que em sede de execução de alimentos expediu-se mandado de prisão por inadimplemento da dívida, o mencionado Sodalício, apoiando-se na tese de que a renúncia posterior de usufruto vitalício transforma a liberalidade primeira em doação universal, tirando a subsistência do doador, fulminou de nulidade a doação, restaurando a meação do varão ( $10^{\mathrm{a}}$ Câm. Cív., Apel. n. 0004107-17.2006.8.13.0430, rel. ALBERTO ALUÍZIO PACHECO DE ANDRADE, j. 02-09-2008).

${ }^{901}$ FRANCISCO GLAUBER PESSOA ALVES, Das Várias (...), cit., p. 903; MARIA HELENA DINIZ, Tratado (...), cit., p. 84; PONTES DE MIRANDA, Tratado (...), cit., p. 246; RODRIGO SENISE LISBOA, Manual (...), cit., p. 258; VICENTE SABINO JÚNIOR, Contrato (...), cit., p. 57; WASHINGTON DE BARROS MONTEIRO-DABUS MALUF, Curso (...), cit., p. 173. Em sentido contrário, entendo possível a doação universal com encargo de o donatário ter de cuidar do doador: NELSON ROSENVALD, Contratos (...), cit., p. 591; SYLVIO CAPANEMA DE SOUZA, Das Várias (...), cit., pp. 188-189.

O Tribunal de Justiça de São Paulo também se manifestou considerando haver nulidade da doação por ser 
Há ${ }^{902}$ quem explique ainda que, mesmo havendo reserva de rendas em doação realizada, ainda assim continua a haver proteção dos credores do autor da benesse, os quais têm legitimidade para demandarem a anulação do ato ${ }^{903}$, exceto se o donatário assumir o pagamento das dívidas, constituindo autêntica novação ${ }^{904}$.

O desrespeito à proibição de doação universal é caso de nulidade absoluta ${ }^{905}$, passível de conhecimento ex officio e de ser arguida por qualquer interessado, como herdeiro ou credor, e até pelo Ministério Público ${ }^{906}$.

Não obstante, invocando o princípio da conservação dos negócios jurídicos, há ${ }^{907}$ quem admita ser possível, ao invés de inquinar todo o ato de nulidade, se proceder à redução da doação, de modo a garantir o mandamento legal, ao mesmo tempo em que se sustém a vontade do disponente.

AGOSTINHO ALVIM ${ }^{908}$, porém, escrevendo no âmbito do Código Civil de 1916, ensina que a doação universal é nula, mas não anulável, logo impassível de redução, por interpretação sistemática do art. $1.175^{909}$ do mencionado diploma legal, pois no artigo posterior $^{910}$ da lei impõe-se a nulidade apenas ao excesso, ao passo que neste se fala em

universal, ainda que o donatário assuma o encargo de sustentar o doador: $1^{\text {a }}$ Câm. de Dir. Priv., Apel. n. 0289739-88.2009.8.26.0000, rel. ALCIDES LEOPOLDO E SILVA JÚNIOR. j. 25-02-2014.

902 ARNALDO RIZZARDO, Contratos, cit., p. 468; CAIO MÁRIO DA SILVA PEREIRA, Instituições (...), cit., p. 221; CARVALHO SANTOS, Código (...), cit., p. 396; CLÓVIS BEVILAQUA, Código (...), cit., pp. 278279; PONTES DE MIRANDA, Tratado (...), cit., p. 247; SÍlVIO DE SALVO VENOSA, Direito (...), cit., p. 129; SILVIO LUÍS FERREIRA DA ROCHA, Curso (...), cit., p. 182; VICENTE SABINO JÚNIOR, Contrato (...), cit., p. 36.

${ }^{903}$ Se posicionando em sentido contrário, PAULO LÔBO ensina que a doação universal é nula, porém deve ser temperada, de maneira que não pode ser arguida por terceiro, pelo que ao credor restaria apenas a ação pauliana, fundada na fraude contra credores [Das Várias (...), cit., p. 330]. Confrontar: CARVALHO SANTOS, Código (...), cit., pp. 389-392 (o autor critica frontalmente essa opinião).

${ }^{904}$ CLÓVIS BEVILAQUA, Código (...), cit., p. 279; RODRIGO SENISE LISBOA, Manual (...), cit., p. 259; VICENTE SABINO JÚNIOR, Contrato (...), cit., p. 57; WASHINGTON DE BARROS MONTEIRODABUS MALUF, Curso (...), cit., p. 174.

${ }^{905}$ AGOSTINHO ALVIM, Da Doação, cit., p. 166; LIMONGI FRANÇA, Manual (...), cit., p. 101; ORLANDO GOMES, Contratos, cit., p. 243; OZÉIAS J. SANTOS, Da Doação, cit., p. 24; PABLO STOLZE GAGLIANO, $O$ Contrato (...), cit., pp. 101 e 104-105; SAMUEL LUIZ ARAÚJO, O Princípio (...), cit., p. 80; SÍLVIO DE SALVO VENOSA, Direito (...), cit., p. 129; SYLVIO CAPANEMA DE SOUZA, Das Várias (...), cit., p. 186.

906 AGOSTINHO ALVIM, Da Doação, cit., pp. 166-168; FLÁVIO TARTUCE, Direito (...), cit., p. 326; LUIZ GUILHERME LOUREIRO, Curso (...), cit., p. 515; PONTES DE MIRANDA, Tratado (...), cit., p. 247.

${ }^{907}$ FRANCISCO GLAUBER PESSOA ALVES, Das Várias (...), cit., p. 904; PABLO STOLZE GAGLIANO, $O$ Contrato (...), cit., p. 103.

${ }^{908}$ Da Doação, cit., p. 166.

${ }^{909}$ Art. 1.175. "É nula a doação de todos os bens, sem reserva de parte, ou renda suficiente para a subsistência do doador".

${ }^{910}$ Art. 1.176. "Nula é também a doação quanto à parte que exceder a de que o doador, no momento da liberalidade, poderia dispor em testamento". 
nulidade de todo o ato, de maneira que quis o legislador prever regimes diferentes para situações diferentes.

Tal observação guarda pertinência com o atual Código Civil, cuja ordem de artigos guarda plena igualdade em relação ao anterior, haja vista o que dispõem os arts. 548 e $549^{911}$ desse diploma legal ${ }^{912}$.

Por fim, vale observar que se houverem doações sucessivas, apenas a última que teve o condão de reduzir o doador à miséria será nula, mas se forem simultâneas, então todas serão fulminadas com a nulidade ${ }^{913}$.

Diante do que se expôs, verifica-se que a presente análise da doação universal tem suma importância no estudo do objeto da presente pesquisa, isto porque pode acontecer que o doador, no afã de partilhar todos os seus bens, pratique ato nulo.

Com efeito, ao realizar o planejamento da sua sucessão por meio de doação, o disponente deverá considerar que tem de reservar para sim algum meio patente de subsistência para que não realize alienação que futuramente será acoimada de nulidade. Além disso, deve ainda computar as obrigações que tem para com seus credores.

Pode acontecer também que um doador provecto deseje transferir todos os seus bens a um descendente, a fim de o donatário poder administrá-los e usá-los no sustento do doador, lançando mão da doação modal. No entanto, nessa hipótese, melhor será reservar-se o usufruto (seja de um ou de vários bens, se houverem) e outorgar mandato negocial ao descendente ${ }^{914}$.

Por fim, o doador deve ter em conta a barreira do art. 548 do Código Civil de 2002 mesmo que não tenha herdeiros necessários, pois a nulidade absoluta visa protegê-lo,

\footnotetext{
911 Art. 549. "Nula é também a doação quanto à parte que exceder à de que o doador, no momento da liberalidade, poderia dispor em testamento".

912 Também entendendo que todo o ato é nulo: CARVALHO SANTOS, Código (...), cit., pp. $394-396$ (não obstante, o doutrinador ensina que a nulidade pode vir a ser sanada por um novo negócio jurídico realizado entre doador e donatário); FÁBIO ULHOA COELHO, Curso (...), cit., p. 245; FLÁVIO AUGUSTO MONTEIRO DE BARROS, Manual (...), cit., p. 351; SILVIO RODRIGUES, Direito (...), cit., p. 207.

913 AGOSTINHO ALVIM, Da Doação, cit., p. 165.

${ }^{914}$ Há precedente do Tribunal de Justiça de São Paulo reconhecendo válida doação realizada por doadora idosa do único imóvel de sua propriedade aos seus cuidadores, realizada com reserva de usufruto, tendo ainda se considerado que ela tinha aposentadoria que garantia sua subsistência (4 Câm. de Dir. Priv., Apel. n. 0523894.2012.8.26.024, rel. ENIO ZULIANI, 13-02-2014).
} 
mas não terceiros. De outro lado, a realização de partilha em vida, de per si, não consiste em doação universal, a depender do quanto se dispôs entre as partes ${ }^{915}$.

\section{3) Doação entre cônjuges}

A doação realizada entre cônjuges tem grande importância na presente pesquisa, pois um elemento de grande importância no planejamento sucessório refere-se às relações familiares do doador, principalmente porque, na maior parte das vezes, se buscará contemplar seus parentes, herdeiros naturais, especialmente pelos vínculos de afeto. Mesmo que não seja esse o caso, eles gozam de proteção legal, que deve ser observada com cuidado, a fim de afastar eventuais nulidades.

O estudo do presente caso de doação se desdobrará em aferir sua possibilidade e o regramento jurídico que lhe é dispensado, a fim de aparar todas as arestas possíveis no tema.

Segundo PABLO STOLZE GAGLIANO ${ }^{916}$, se aplica à doação entre cônjuges a regra do art. $499^{917}$ do Código Civil de 2002, que regulamenta a compra e venda entre eles, de maneira que é possível haver doação entre os esposos, desde que a coisa doada não componha a comunhão de bens, o que é estabelecido pelo regime de bens do casal. Aduz ${ }^{918}$ também que, se os cônjuges podem fazer doação um ao outro por ocasião da partilha em separação ou divórcio, então nada impede a admissibilidade dessa modalidade, desde que não represente burla ao regime de bens e à lei ${ }^{919}$.

Deve-se considerar, além disso, que o art. $544^{920}$ do Código Civil de 2002 prevê expressamente a doação de um cônjuge a outro, impondo como efeito o adiantamento de

\footnotetext{
${ }^{915}$ Cf.: STJ, $3^{\text {a }}$ T., R. Esp. n. 1361983/SC, rel. NANCY ANDRIGHI, j. 18-03-2014.

${ }^{916}$ O Contrato (...), cit., p. 137.

${ }^{917}$ Art. 499. "É lícita a compra e venda entre cônjuges, com relação a bens excluídos da comunhão".

918 O Contrato (...), cit., pp. 139-140.

${ }^{919}$ Concordando com a possibilidade de haver doação entre cônjuges, apesar da divergência sobre o tema: ANTÔNIO CHAVES, Lições (...), cit., p. 235; EDUARDO ESPINOLA, Dos Contratos (...), cit., p. 160. Também opinando pela possibilidade de haver doação entre cônjuges, desde que sejam de bens que não componham a comunhão: ARNOLDO WALD, Direito (...), cit., p. 74; CHRISTIANO CASSETARI, Elementos (...), cit., p. 214; JONES FIGUEIRÊDO ALVES, Código (...), cit., p. 448; LUIZ GUILHERME LOUREIRO, Curso (...), cit., pp. 506 e 513; NELSON ROSENVALD, Contratos (...), cit., pp. 588-589. Há quem ensine ainda que só é possível haver essa modalidade quando é vigente o regime da comunhão universal: PAULO NADER, Curso (...), cit., p. 233.

${ }^{920}$ Art. 544. "A doação de ascendentes a descendentes, ou de um cônjuge a outro, importa adiantamento do que lhes cabe por herança".
} 
legítima $^{921}$, o que será melhor tratado a seguir, pois o que se disser sobre a doação de ascendente a descendente se aplicará ao caso, com as suas especificidades ${ }^{922}$.

Diante do que se verificou acima, a regulamentação jurídica da doação feita entre cônjuges dependerá do regime de bens em vigor no matrimônio.

Assim, se o regime de bens do casamento for o da comunhão universal de bens, que era o regime legal antes da Lei do Divórcio, para VICENTE SABINO JÚNIOR ${ }^{923}$ é

${ }^{921}$ FÁBIO ULHOA COELHO, Curso (...), cit., p. 246; FLÁVIO AUGUSTO MONTEIRO DE BARROS, Manual (...), cit., pp. 350-351; FRANCISCO GLAUBER PESSOA ALVES, Das Várias (...), cit., p. 897; PAULO LÔBO, Das Várias (...), cit., p. 311; RODRIGO SENISE LISBOA, Manual (...), cit., p. 263 (o autor acrescenta também o companheiro); SAMUEL LUIZ ARAÚJO, O Princípio (...), cit., p. 111; SYLVIO CAPANEMA DE SOUZA, Das Várias (...), cit., p. 90.

${ }^{922}$ A doação entre esposos, no Código Napoleônico, tem um capítulo próprio ("Chapitre IX: Des dispositions entre époux, soit par contrat de mariage, soit pendant le mariage"). O mencionado diploma previne os inconvenientes que a hipótese pode causar prevendo a revogabilidade para a doação de bens futuros e a irrevogabilidade para a doação de bens presentes, como se verifica no seu art. 1.096: "1. La donation de biens à venir faite entre époux pendant le mariage est toujours révocable. 2. La donation de biens présents qui prend effet au cours du mariage faite entre époux n'est révocable que dans les conditions prévues par les articles 953 à 958. 3. Les donations faites entre époux de biens présents ou de biens à venir ne sont pas révoquées par la survenance d'enfants" (PLANIOL, Traité (...), cit., pp. 903-909). Os perigos que se tenta prevenir estão em que, dada a condição matrimonial, pode haver abuso da relação afetiva, ou ainda que aqueles que são casados em segundas núpcias laborem contra os direitos dos filhos do primeiro casamento, daí a revogabilidade ad nutum (PAUL DELNOY, Le Libéralités (...), cit., p. 63).

Também o Código Civil português preferiu criar um regime próprio para as doações entre casados. Com efeito, no Capítulo X ("Doações para casamento e entre casados") há a Seção II ("Doações entre casados"), que é inaugurada pelo art. 1.761. ("Disposições aplicáveis"), que assim dispõe: "As doações entre casados regem-se pelas disposições desta secção e, subsidiariamente, pelas regras dos artigos 940.. a 979. .”. Como se verifica, as regras gerais de doação se aplicam apenas supletivamente à doação entre cônjuges no sistema civil luso e assim se dá porque se trata de espécie suscetível ao abuso e à má-fé, principalmente no que toca à burla do regime de bens, daí o legislador criar essa seção no Código (MANUEL BAPTISTA LOPES, Das Doações, cit., pp. 185-186). Quanto ao objeto doado, assim dispõe o art. 1.764..$^{\circ}$ ("Objecto e incomunicabilidade dos bens doados") do mesmo diploma legal: "1. Só podem ser doados bens próprios do doador. 2. Os bens doados não se comunicam, seja qual for o regime matrimonial" (consultar: MANUEL BAPTISTA LOPES, Das Doações, cit., pp. 190-191). Mas a grande diferença está em que a doação entre esposos no sistema civil português, assim como o francês, é revogável, conforme determina o art. $1.765 .^{\circ}$ ("Livre revogabilidade"): "1. As doações entre casados podem a todo o tempo ser revogadas pelo doador, sem que lhe seja lícito renunciar a este direito. 2. A faculdade de revogação não se transmite aos herdeiros do doador" (consultar: MANUEL BAPTISTA LOPES, Das Doações, cit., pp. 191-195).

Quanto ao Código Civil italiano, originalmente, em seu art. 781 ("Donazione tra coniugi"), vedava a liberalidade entre cônjuges: "I coniugi non possono, durante il matrimonio, farsi l'uno all'altro alcuna liberalità [c.c. 159, 162, 178, 219, 783, 1418], salve quelle conformi agli usi". GARDANI CONTURSI LISI, em sua pesquisa, demonstra que uma linha jurisprudencial se formou no sentido de aprofundar a proibição, dando-lhe aplicação extensiva a fim de atingir as doações indiretas, além de ressaltar seu caráter publicístico e de nulidade absoluta, ao passo que uma outra vertente tratou de distinguir algumas situações em que se afastava a proibição, por faltar animus donandi ao ato (Le Donazioni, cit., pp. 305-320). Não obstante, em decisão tomada em 27 de junho de 1973, n. 91, a Corte de Cassação da Itália declarou a inconstitucionalidade do dispositivo, e, fundada na tese de que a norma padeceria de anacronismo, declarou que ela implantava uma discriminação indevida entre os cônjuges, afrontando o princípio da livre iniciativa econômica [GIANFRANCO AMENTA, La Donazione (...), cit., pp. 152-153. O autor aduz ainda que a aplicação da Constituição nesse âmbito se deve apenas à omissão do legislador e demonstra que uma vez que o Judiciário interviu no assunto se tornou necessário que outros arestos sobreviessem para cobrir as lacunas que ensejou essa manifestação (pp. 153-155)].

${ }^{923}$ Contrato (...), cit., p. 74. 
válida a doação feita entre os esposos, porém o patrimônio de ambos é comum. No entanto, não deixa de lembrar que alguns bens não se comunicam, de modo que são passíveis de doação de um cônjuges a outro.

Com efeito, no Código Civil de 2002 há bens que não se comunicam mesmo no regime da comunhão universal, conforme o rol do art. $1.668^{924}$ desse diploma legal, de modo que, em tese, são passíveis de doação entre cônjuges unidos no regime da comunhão universal $^{925}$.

Outros autores $^{926}$, porém, entendem que a doação feita entre cônjuges casados no regime da comunhão universal representa burla à lei e ao regime de bens, pois a benesse seria absorvida pela comunhão, sendo que não poderia ser feita com cláusula de incomunicabilidade, pois contrariaria o regime de bens estabelecido ${ }^{927}$.

ARNALDO MARMITT ${ }^{928}$ explica ainda que no regime da comunhão de bens o direito de propriedade dos cônjuges é pro indiviso, o que significa que tantos os bens presentes como os futuros não são passíveis de cisão quanto à meação, de modo que a doação dos cônjuges entre si se absorveria na comunhão, ao passo que a aposição de cláusula de incomunicabilidade representaria fraude à imutabilidade do regime, segundo seu entender.

Não obstante, afirma o autor ${ }^{929}$ ainda que a impossibilidade jurídica da doação só vale enquanto vigente o regime da comunhão universal de bens, de modo que poderá haver doação entre as partes após a separação ou anulação do matrimônio, sendo que, se os

924 Art. 1.668. "São excluídos da comunhão: I - os bens doados ou herdados com a cláusula de incomunicabilidade e os sub-rogados em seu lugar; II - os bens gravados de fideicomisso e o direito do herdeiro fideicomissário, antes de realizada a condição suspensiva; III - as dívidas anteriores ao casamento, salvo se provierem de despesas com seus aprestos, ou reverterem em proveito comum; IV - as doações antenupciais feitas por um dos cônjuges ao outro com a cláusula de incomunicabilidade; V - Os bens referidos nos incisos V a VII do art. 1659".

${ }^{925}$ ARNOLDO WALD, Direito (...), cit., p. 74 (o autor admite que a princípio não é possível haver doação entre cônjuges casados no regime da comunhão universal); FLÁVIO TARTUCE, Direito (...), cit., p. 320; PAULO LÔBO, Das Várias (...), cit., p. 313 (o autor cogita sobre os bens recebidos com cláusula de incomunicabilidade ou gravado com fideicomisso sem que tenha ocorrido a condição suspensiva).

${ }^{926}$ ANTÔNIO CHAVES, Lições (...), cit., p. 235; ARNALDO RIZZARDO, Contratos, cit., p. 445; CARLOS ROBERTO GONÇALVES, Direito (...), vol. III, cit., p. 255; FLÁVIO AUGUSTO MONTEIRO DE BARROS, Manual (...), cit., p. 351; PAULO NADER, Curso (...), cit., p. 233; SAMUEL LUIZ ARAÚJO, O Princípio (...), cit., p. 81; SÍlVIO DE SALVO VENOSA, Direito (...), cit., p. 136.

A favor dessa opinião, já se manifestou o Superior Tribunal de Justiça: $2^{a}$ Seç., Ação Resc. n. 310/PI, rel. DIAS TRINDADE, j. 26-05-1993.

${ }^{927}$ ARNALDO MARMITT, Doação, cit., p. 120.

${ }^{928}$ Doação, cit., pp. 121-122.

${ }^{929}$ Doação, cit., p. 122. 
contratantes se reconciliarem, os bens doados voltarão a ser absorvidos pela comunhão, exceto as exceções previstas no art. $263^{930}$ do Código Civil de $1916^{931}$.

PABLO STOLZE GAGLIANO ${ }^{932}$ também entende que os que são casados na comunhão universal de bens não poderão fazer doações entre si, pois não haveria liberalidade, haja vista que o bem doado ingressaria no patrimônio do doador por conta da comunhão ${ }^{933}$.

No tocante à doação feita entre cônjuges unidos no regime da separação obrigatória de bens, também há divergência.

\section{VICENTE SABINO JÚNIOR ${ }^{934}$ afirma expressamente que a doação entre} cônjuges terá validade na união contraída sob o regime da separação obrigatória de bens. Com efeito, certa doutrina ${ }^{935}$ entende que não há desrespeito à lei nesse caso, pois o regime de bens é mutável e o patrimônio amealhado após o matrimônio se comunica, nos termos da súmula $377^{936}$ do Supremo Tribunal Federal, a demonstrar a relatividade do regime, de maneira que na separação total de bens apenas os adquiridos na constância do matrimônio não podem ser $\operatorname{doados}^{937}$.

${ }^{930}$ Art. 263. "São excluídos da comunhão (Redação dada pela Lei no 4.121, de 27.8.1962): I - as pensões, meiossoldos, montepios, tenças, e outras rendas semelhantes (Redação dada pela Lei $\mathrm{n}^{\circ} 4.121$, de 27.8.1962); II os bens doados ou legados com a cláusula de incomunicabilidade e os sub-rogados em seu lugar (Redação dada pela Lei $\mathrm{n}^{\circ}$ 4.121, de 27.8.1962); III - os bens gravados de fideicomisso e o direito do herdeiro fideicomissário, antes de realizar a condição suspensiva (Redação dada pela Lei no 4.121, de 27.8.1962); IV o dote prometido ou constituído a filhos de outro leito (Redação dada pela Lei no 4.121, de 27.8.1962); V - o dote prometido ou constituído expressamente por um só dos cônjuges a filho comum (Redação dada pela Lei $\mathrm{n}^{\mathrm{o}}$ 4.121, de 27.8.1962); VI - as obrigações provenientes de atos ilícitos (arts. 1.518 e 1.532) (Redação dada pela Lei $\mathrm{n}^{\circ}$ 4.121, de 27.8.1962); VII - as dívidas anteriores ao casamento, salvo se provierem de despesas com seus aprestos, ou reverterem em proveito comum (Redação dada pela Lei no 4.121 , de 27.8.1962); VIII as doações antenupciais feitas por um dos cônjuges ao outro com a cláusula de incomunicabilidade (art. 312) (Redação dada pela Lei $\mathrm{n}^{\circ}$ 4.121, de 27.8.1962); IX - as roupas de uso pessoal, as jóias esponsalícias dadas antes do casamento pelo esposo, os livros e instrumentos de profissão e os retratos da família (Redação dada pela Lei ${ }^{\circ}$ 4.121, de 27.8.1962); X - a fiança prestada pelo marido sem outorga da mulher (arts. 178, § 9, I, b, e 235, III) (Redação dada pela Lei no 4.121, de 27.8.1962); XI - os bens da herança necessária a que se impuser a cláusula de incomunicabilidade (art. 1.723) (Inciso acrescentado pelo Decreto do Poder Legislativo $\mathrm{n}^{\mathrm{o}}$ 3.725, de 15.1.1919 e alterado pela Lei $\mathrm{n}^{\circ}$ 4.121, de 27.8.1962); XII - os bens reservados (art. 246, parágrafo único) (Inciso acrescentado pela Lei $\mathrm{n}^{\circ} 4.121$, de 27.8.1962); XIII - os frutos civis do trabalho ou indústria de cada cônjuge ou de ambos (Inciso acrescentado pela Lei no 4.121, de 27.8.1962)".

931 Tal entendimento também é compartilhado por MANUEL BAPTISTA LOPES, com a ressalva de que, no sistema civil luso, o casal reconciliado se unirá sob a separação obrigatória de bens (Das Doações, cit., pp. 186-187).

${ }^{932}$ O Contrato (...), cit., pp. 138-139.

${ }^{933}$ No mesmo sentido: MARIA HELENA DINIZ, Curso (...), cit., p. 260.

${ }^{934}$ Contrato (...), cit., p. 74.

${ }^{935}$ FLÁVIO TARTUCE, Direito (...), cit., pp. 320-321.

936 Súmula 377: "No regime de separação legal de bens, comunicam-se os adquiridos na constância do casamento".

${ }^{937}$ PAULO LÔBO, Das Várias (...), cit., pp. 312-313; SAMUEL LUIZ ARAÚJO, O Princípio (...), cit., p. 82. O Superior Tribunal de Justiça também tem se posicionado no sentido de admitir a doação entre cônjuges 
ARNALDO MARMITT ${ }^{938}$, por seu turno, entende que a doação feita entre cônjuges casados no regime da separação obrigatória de bens também representa burla à lei, pois a norma impõe a não comunhão de bens justamente para proteger uma das partes, pelo que a disposição gratuita seria inválida ${ }^{939}$. Outros doutrinadores ${ }^{940}$ acrescentam, além disso, que o cônjuge casado na separação obrigatória de bens não concorre com os herdeiros do outro cônjuge, conforme determina o inciso I do art. $1829^{941}$ do Código Civil de 2002, daí também a proibição ${ }^{942}$.

De outro lado, sendo o regime de bens vigente o da separação consensual ou da separação parcial, pode haver doação dos bens particulares, por ausência de burla ao regime de bens vigente entre o casal ${ }^{943}$.

Desse modo, a doação feita de um cônjuge a outro, sendo ambos casados na separação obrigatória de bens, representa nulidade absoluta, passível de ser conhecida de ofício $^{944}$.

casados no regime da separação obrigatória de bens: $3^{\text {a }}$ T., Ag. Reg. no R. Esp. n. 194.325/MG, rel. VASCO DELLA GIUSTINA, j. 08-02-2011; $3^{\mathrm{a}}$ T., R. Esp. n. 471.958/RS, rel. NANCY ANDRIGHI, j. 18-12-2008.

${ }^{938}$ Doação, cit., p. 120.

${ }^{939}$ No mesmo sentido: ANTÔNIO CHAVES, Lições (...), cit., p. 235; ARNALDO RIZZARDO, Contratos, cit., p. 445; ARNOLDO WALD, Direito (...), cit., p. 74; CARLOS ALBERTO BITTAR, Contratos (...), cit., p. 46; LUIZ GUILHERME LOUREIRO, Curso (...), cit., p. 513; SÍLVIO DE SALVO VENOSA, Direito (...), cit., p. 136.

940 JONES FIGUEIRÊDO ALVES, Código (...), cit., p. 448; MARIA HELENA DINIZ, Curso (...), cit., p. 260.

${ }^{941}$ Art. 1829. "A sucessão legítima defere-se na ordem seguinte: I - aos descendentes, em concorrência com o cônjuge sobrevivente, salvo se casado este com o falecido no regime da comunhão universal, ou no da separação obrigatória de bens (art. 1.640, parágrafo único); ou se, no regime da comunhão parcial, o autor da herança não houver deixado bens particulares [...]".

${ }^{942}$ A Lei Civil portuguesa, no seu art. $1762 .^{\circ}$ ("Regime imperativo da separação de bens"), veda expressamente a doação entre casados no regime da separação obrigatória de bens: "É nula a doação entre casados, se vigorar imperativamente entre os cônjuges o regime da separação de bens". Também a referida norma tem o objetivo de preservar o regime de bens (MANUEL BAPTISTA LOPES, Das Doações, cit., p. 188).

943 ARNALDO MARMITT, Doação, cit., p. 125; ARNALDO RIZZARDO, Contratos, cit., p. 445; FLÁVIO TARTUCE, Direito (...), cit., p. 319 (o autor fala apenas da convencional); MARIA HELENA DINIZ, Curso (...), cit., p. 260; SAMUEL LUIZ ARAÚJO, O Princípio (...), cit., p. 82; SÍlVIO DE SALVO VENOSA, Direito (...), cit., p. 136.

${ }^{944}$ ARNALDO MARMITT, Doação, cit., p. 126. Nessa passagem o autor ensina também que é vedado inclusive aos nubentes burlarem a separação de bens imposta por lei, de modo que eles não podem fazer doação entre si se futuramente deverão casar-se no regime da separação. O Código Civil de Portugal, porém, no seu art. $1720 .^{\circ}$ ("Regime imperativo da separação de bens"), assim dispõe expressamente: " 1 - Consideram-se sempre contraídos sob o regime da separação de bens: a) $\mathrm{O}$ casamento celebrado sem precedência do processo preliminar de casamento; b) $\mathrm{O}$ casamento celebrado por quem tenha completado sessenta anos de idade. 2. $\mathrm{O}$ disposto no número anterior não obsta a que os nubentes façam entre si doações". De fato, a proibição só faz sentido quando a liberalidade se dá entre casados, mas não em vista de casamento (MANUEL BAPTISTA LOPES, Das Doações, cit., pp. 188-189), até porque falta base legal para se criar uma nova incapacidade de dispor. É nesse sentido, aliás, que já de posicionou o Superior Tribunal de Justiça: $3^{a}$ T., R. Esp. n. 1.254.252/SC, rel. NANCY ANDRIGHI, j. 22-04-2014. 
ARNALDO MARMITT ${ }^{945}$ explicita, porém, que apenas no regime da separação obrigatória de bens com causa bilateral de imposição da separação não pode haver doação entre os casados, mas que se a causa for unilateral, então o cônjuge não-infrator, como previsto no art. $226^{946}$ do Código Civil de 1916, poderá doar bens particulares seu ao outro, o que será plenamente válido, pois a vedação do dispositivo citado não pode ser interpretada ampliativamente.

Deste modo, com fundamento nos arts. 183 , XII ${ }^{947}$, e 258 , III, e parágrafo único $^{948}$, do Código Civil de 1916, o autor $^{949}$ enumera as pessoas que não podem realizar doação ao cônjuge: os menores de idade (16 anos para mulher e 18 anos para homem no sistema civil vigente à época); os que tenham idade acima do teto legal (à época, 50 anos para mulher e 60 anos para homem); e o menor que não tenha por representante legal algum de seus pais, mesmo casado.

No mesmo sentido, PABLO STOLZE GAGLIANO ${ }^{950}$ entende que na separação obrigatória de bens o patrimônio havido antes do enlace não pode ser doado, pois representaria burla ao regime de bens, ao passo que, se a coisa foi havida durante o casamento, incide a já mencionada súmula 377 do Supremo Tribunal Federal, pelo que se comunicam, de modo que também não poderiam ser doados.

LUCIANO DE CAMARGO PENTEADO ${ }^{951}$ sustenta ainda que se houver entre os cônjuges algumas das causas de impedimento previstas no art. $1.523^{952}$ do Código Civil de

945 Doação, cit., pp. 125-126.

${ }^{946}$ Art. 226. "No casamento com infração do art. 183, XI a XVI, é obrigatório o regime da separação de bens, não podendo o cônjuge infrator fazer doações ao outro".

${ }^{947}$ Art. 183. "Não podem casar (arts. 207 e 209): [...] XII - as mulheres menores de 16 (dezesseis) anos e os homens menores de 18 (dezoito)".

948 Art. 258. "Não havendo convenção, ou sendo nula, vigorará, quanto aos bens entre os cônjuges, o regime de comunhão parcial (Redação dada pela Lei $n^{\circ} 6.515$, de 26.12.1977). Parágrafo único. É, porém, obrigatório o da separação de bens do casamento: [...] III - do órfão de pai e mãe, ou do menor, nos termos dos arts. 394 e 395, embora case, no termos do art. 183, XI, com o consentimento do tutor (Redação dada pelo Decreto do Poder Legislativo no 3.725, de 15.1.1919)".

${ }^{949}$ Doação, cit., p. 126.

${ }^{950}$ O Contrato (...), cit., pp. 137-138

${ }^{951}$ Doação (...), cit., p. 156.

${ }^{952}$ Art. 1.523. "Não devem casar: I - o viúvo ou a viúva que tiver filho do cônjuge falecido, enquanto não fizer inventário dos bens do casal e der partilha aos herdeiros; II - a viúva, ou a mulher cujo casamento se desfez por ser nulo ou ter sido anulado, até dez meses depois do começo da viuvez, ou da dissolução da sociedade conjugal; III - o divorciado, enquanto não houver sido homologada ou decidida a partilha dos bens do casal; IV - o tutor ou o curador e os seus descendentes, ascendentes, irmãos, cunhados ou sobrinhos, com a pessoa tutelada ou curatelada, enquanto não cessar a tutela ou curatela, e não estiverem saldadas as respectivas contas. Parágrafo único. É permitido aos nubentes solicitar ao juiz que não lhes sejam aplicadas as causas suspensivas previstas nos incisos I, III e IV deste artigo, provando-se a inexistência de prejuízo, respectivamente, para o herdeiro, para o ex-cônjuge e para a pessoa tutelada ou curatelada; no caso do inciso 
2002, que induz ao regime da separação obrigatória de bens, nos termos do art. $1.641^{953}$ do mesmo diploma legal, então é possível afirmar que nessa situação há uma hipótese de nulidade caso eles façam doação entre si, como já preceituava o já mencionado art. 226 do Código Civil de 1916.

O fundamento para tal asserção é de que, assim como a lei tutela os cônjuges impondo-lhes núpcias no regime da separação, a fim de não se prejudicarem por conta da desproporcionalidade da idade e eventual afeto desarrazoado, também protege o doador que se vê enquadrado nesta situação, cobrando a mesma proteção legal. LUCIANO DE CAMARGO PENTEADO ${ }^{954}$ discorda também dos que não aplicam tal tese se escudando no princípio da dignidade humana, pois entende que os valores protegidos por essa nulidade são garantes da mesma dignidade e admitir o contrário seria empregar princípios gerais para descumprir a lei.

Quanto ao regime da comunhão parcial de bens, ARNALDO MARMITT ${ }^{955}$ entende que a doação de bens comuns importaria em burla ao regime de bens, que é imutável, pelo que não tem o condão de transformar a coisa dada em particular, de maneira que não pode ser realizada. Assim, não são passíveis de doação, na hipótese, os frutos percebidos ou pendentes, rendimentos advindos de vínculo empregatício ou de atividade empresarial e benfeitorias que se acresceram a algum bem particular.

Em se tratando, porém, de bens particulares, os cônjuges casados no regime da comunhão parcial de bens poderão doá-los entre si, pois não importaria em burla ao regime de bens $^{956}$.

Da mesma maneira, pode o cônjuge doar ao outro consorte bens particulares quando casados no regime da participação final dos aquestos ${ }^{957}$.

\footnotetext{
II, a nubente deverá provar nascimento de filho, ou inexistência de gravidez, na fluência do prazo".

${ }^{953}$ Art. 1.641. "É obrigatório o regime da separação de bens no casamento: I - das pessoas que o contraírem com inobservância das causas suspensivas da celebração do casamento; II - da pessoa maior de 70 (setenta) anos; (Redação dada pela Lei $n^{\circ} 12.344$, de 2010) III - de todos os que dependerem, para casar, de suprimento judicial".

956 ARNALDO MARMITT, Doação, cit., p. 123; FLÁVIO TARTUCE, Direito (...), cit., p. 320; MARIA HELENA DINIZ, Curso (...), cit., p. 260; PABLO STOLZE GAGLIANO, O Contrato (...), cit., p. 137; PAULO LÔBO, Das Várias (...), cit., p. 313; SAMUEL LUIZ ARAÚJO, O Princípio (...), cit., p. 81.

${ }^{957}$ MARIA HELENA DINIZ, Curso (...), cit., p. 260
} 
Por derradeiro, vale lembrar que, mesmo que a doação seja para terceiro, há a necessidade de anuência do outro cônjuge para a efetivação de liberalidade realizada pelo outro consorte ${ }^{958}$.

ARNALDO MARMITT ${ }^{959}$, escrevendo no âmbito do revogado Código Civil de 1916, explica que se faz necessária a autorização do outro cônjuge quando a coisa doada for bem ou rendimento comum, nos termos dos arts. $235, \mathrm{IV}^{960}$, e 242, $\mathrm{I}^{961}$, ou ainda imóvel.

No sistema atual, há hipóteses de doações, porém, que dispensam a outorga conjugal, sendo ela a remuneratória, a de pequeno valor, as feitas em vista de casamento de filho do casal e de bens particulares ${ }^{962}$, o que está acobertado pelo art. 1.647, IV e parágrafo único $^{963}$, do Código Civil de $2002^{964}$. Mas, como se verifica no caput e no citado inciso IV do dispositivo legal, em regra, carece a doação da outorga conjugal ${ }^{965}$. Em sendo bem imóvel, ainda que particular, deve haver a anuência do outro cônjuge, conforme o inciso $\mathrm{I}^{966}$ do art. 1.647 do Código Civil de $2002^{967}$.

ARNALDO MARMITT ${ }^{968}$ explica ainda que, dada a imutabilidade do regime de bens consagrada no art. $230^{969}$ do Código Civil de 1916, no regime da comunhão universal não pode um dos cônjuges beneficiar-se patrimonialmente em detrimento do outro, pelo que

958 Também prevendo o requisito: ARNALDO RIZZARDO, Contratos, cit., p. 445; FLÁVIO AUGUSTO MONTEIRO DE BARROS, Manual (...), cit., p. 350; RODRIGO SENISE LISBOA, Manual (...), cit., p. 262.

${ }^{959}$ Doação, cit., pp. 120-121.

${ }^{960}$ Art. 235. "O marido não pode, sem consentimento da mulher, qualquer que seja o regime de bens: [...]; IV fazer doação, não sendo remuneratória ou de pequeno valor, com os bens ou rendimentos comuns (art. 178, § 9o, I, b)".

${ }^{961}$ Art. 242. "A mulher não pode, sem autorização do marido (art. 251) (Redação dada pela Lei no 4.121, de 27.8.1962): I - praticar os atos que este não poderia sem o consentimento da mulher (art. 235) (Redação dada pela Lei $\mathrm{n}^{\circ} 4.121$, de 27.8.1962) [...]".

962 Também entendendo que a doação de bens particulares dispensa a outorga marital: RODRIGO SENISE LISBOA, Manual (...), cit., p. 265.

963 Art. 1.647. "Ressalvado o disposto no art. 1.648, nenhum dos cônjuges pode, sem autorização do outro, exceto no regime da separação absoluta: [...]; IV - fazer doação, não sendo remuneratória, de bens comuns, ou dos que possam integrar futura meação. Parágrafo único. São válidas as doações nupciais feitas aos filhos quando casarem ou estabelecerem economia separada".

${ }^{964}$ ARNOLDO WALD, Direito (...), cit., p. 65; FLÁVIO AUGUSTO MONTEIRO DE BARROS, Manual (...), cit., p. 350; LUIZ GUILHERME LOUREIRO, Curso (...), cit., p. 506; MARIA HELENA DINIZ, Curso (...), cit., pp. 259-260.

${ }^{965}$ FRANCISCO GLAUBER PESSOA ALVES, Das Várias (...), cit., p. 892.

966 "[...] I - alienar ou gravar de ônus real os bens imóveis; [...]".

${ }^{967}$ CARVALHO SANTOS, Código (...), cit., p. 319; CÉSAR FIUZA, Direito (...), cit., p. 502; MARIA HELENA DINIZ, Tratado (...), cit., p. 80; SILVIO LUÍS FERREIRA DA ROCHA, Curso (...), cit., p. 171. Há quem ensine, porém, que sendo o bem imóvel particular não é necessária a anuência do outro consorte: LUIZ GUILHERME LOUREIRO, Curso (...), cit., p. 506.

${ }^{968}$ Doação, cit., p. 119.

${ }^{969}$ Art. 230. "O regime dos bens entre cônjuges começa a vigorar desde a data do casamento, e é irrevogável". 
não se deve realizar transferência de um bem para a esfera particular de um deles sem que o respectivo consorte dê sua anuência para tal ato.

Assim, é vedada qualquer doação sem a anuência do outro cônjuge, e se tal não se der trata-se de uma anulabilidade, nos termos do art. $1.649^{970}$ do Código do Código Civil de 2002, pelo que passível de ser sanada pelas partes ${ }^{971}$. Cumpre observar também que a doação realizada por um dos cônjuges que desrespeite a meação do outro não é inválida, mas ineficaz, por falta de poderes para a prática do ato ${ }^{972}$.

Pela redação do art. $226^{973}$ da Constituição Federal de 1988, que deu especial proteção à união estável, ARNALDO MARMITT ${ }^{974}$ entende que a companheira deverá dar sua anuência para alienação de bens amealhados na constância da união, mormente os imóveis ${ }^{975}$, e se assim o faz, torna-se interveniente, pelo que eventual ação de nulidade deverá ter sua participação e tem ela legitimidade para promover ação anulatória de doação caso se trate de bem comum do casal.

Diante do que se expôs, conclui-se, em primeiro lugar, que, aquele que dispor de seus bens em termos de sucessão por meio de doação, em sendo casado, deverá fazê-lo com a autorização de seu respectivo cônjuge, independente do regime de bens que vigore na relação matrimonial, fazendo constá-la no instrumento de doação.

\footnotetext{
${ }^{970}$ Art. 1.649. “ A falta de autorização, não suprida pelo juiz, quando necessária (art. 1.647), tornará anulável o ato praticado, podendo o outro cônjuge pleitear-lhe a anulação, até dois anos depois de terminada a sociedade conjugal".

${ }^{971}$ Assim já o era no âmbito do Código Civil de 1916: STJ, $3^{\text {a }}$ T., R. Esp. n. 34329-3, rel. EDUARDO RIBEIRO, j. 28-06-1993.

972 LUCIANO DE CAMARGO PENTEADO, Doação (...), cit., p. 162; PONTES DE MIRANDA, Tratado (...), cit., p. 251.

${ }^{973}$ Art. 226. "A família, base da sociedade, tem especial proteção do Estado. $\S 1^{\circ}$ - O casamento é civil e gratuita a celebração. $\S 2^{\circ}$ - O casamento religioso tem efeito civil, nos termos da lei. $\S 3^{\circ}$ - Para efeito da proteção do Estado, é reconhecida a união estável entre o homem e a mulher como entidade familiar, devendo a lei facilitar sua conversão em casamento. § $4^{\circ}$ - Entende-se, também, como entidade familiar a comunidade formada por qualquer dos pais e seus descendentes. $\S 5^{\circ}$ - Os direitos e deveres referentes à sociedade conjugal são exercidos igualmente pelo homem e pela mulher. $\S 6^{\circ} \mathrm{O}$ casamento civil pode ser dissolvido pelo divórcio. (Redação dada Pela Emenda Constitucional n ${ }^{\circ} 66$, de 2010) $\S 7^{\circ}$ - Fundado nos princípios da dignidade da pessoa humana e da paternidade responsável, o planejamento familiar é livre decisão do casal, competindo ao Estado propiciar recursos educacionais e científicos para o exercício desse direito, vedada qualquer forma coercitiva por parte de instituições oficiais ou privadas. Regulamento $\S 8^{\circ}-\mathrm{O}$ Estado assegurará a assistência à família na pessoa de cada um dos que a integram, criando mecanismos para coibir a violência no âmbito de suas relações".

${ }^{974}$ Doação, cit., p. 130.

${ }^{975}$ No mesmo sentido: RODRIGO SENISE LISBOA, Manual (...), cit., p. 262.
} 
Outrossim, caso pretenda fazer doação ao consorte, o doador deverá levar em consideração o regime de bens do casal, a fim de não acometer um ato nulo, em que pese os precedentes judiciais favoráveis, os quais, ainda, não podem ser tidos por consolidados.

Assim, deve o disponente verificar se o bem que pretende transmitir gratuitamente é particular. Se não o for, talvez seja o caso de lançar mão de testamento para nomear o cônjuge herdeiro da parte disponível de seu patrimônio ou então instituir-lhe legados, pois nessa hipótese a doação se mostra insegura no sistema atual.

\section{4) Doação do cônjuge adúltero ao seu cúmplice}

Outra espécie de doação que importa ser verificada e que também guarda estreita relação com o direito de família é a doação feita pelo cônjuge traidor à pessoa com quem ele pratica o adultério, o que é vedado pelo art. $550^{976}$ do Código Civil de 2002, sendo que a mesma previsão havia no art. $1.177^{977}$ do Código Civil de $1916^{978}$.

O sistema civil veda a doação feita a quem adultera, a fim de resguardar o patrimônio familiar ${ }^{979}$ e os direitos sucessórios dos herdeiros legais ${ }^{980}$, bem como para proteger a família e sua moral, e impedir que o cônjuge adúltero possa se utilizar da doação como meio de manutenção da sua ilicitude ${ }^{981}$, resguardando, assim, a estabilidade matrimonial $^{982}$.

${ }^{976}$ Art. 550. “A doação do cônjuge adúltero ao seu cúmplice pode ser anulada pelo outro cônjuge, ou por seus herdeiros necessários, até dois anos depois de dissolvida a sociedade conjugal".

977 Art. 1.177 "A doação do cônjuge adúltero ao seu cúmplice pode ser anulada pelo outro cônjuge, ou por seus herdeiros necessários, até 2 (dois) anos depois de dissolvida a sociedade conjugal (arts. $178, \S 7^{\circ}$, VI, e 248 , IV)".

978 O Código Civil de Portugal de 1867, no seu art. 1.480, assim dispunha: "São nullas as doações feitas por homem casado à sua concubina. Esta nullidade, porém, só póde ser declarada a requerimento da mulher do doador ou dos herdeiros legimários della, não podendo todavia a respectiva acção ser intentada senão dentro de dous annos depois de dissolvido o matrimonio". Segundo a lição de CUNHA GONÇALVES, trata-se de hipótese de nulidade, aplicável também a doações realizadas pela mulher, de interesse privado, que prescrevia no prazo de 2 anos a contar da dissolução matrimonial, sem prejuízo de a nulidade poder ser buscada ainda na vigência do casamento [Tratado (...), cit., p. 212]. Esse dispositivo não foi reproduzido no Código Civil luso em vigência.

No sistema francês, o Código Napoleônico também acabou por suprimir a vedação de doação a pessoa concubina, porém a jurisprudência mostrou-se ciosa em manter a proibição reconhecendo algumas hipóteses de anulabilidade para o caso, vindo a seguir um novo entendimento que, na tentativa de afastar esse primeiro, qualifica a doação como indenização ao concubino que se enredou em relação ilícita por causa do doador ou ainda como alienação em cumprimento de dever moral [PLANIOL, Traité (...), cit., pp. 805-807].

979 ARNALDO RIZZARDO, Contratos, cit., p. 447; JONES FIGUEIRÊDO ALVES, Código (...), cit., p. 454; MARIA HELENA DINIZ, Tratado (...), cit., p. 80.

${ }^{980}$ PABLO STOLZE GAGLIANO, O Contrato (...), cit., pp. 153-156.

${ }^{981}$ CARLOS ROBERTO GONÇALVES, Direito (...), vol. III, cit., p. 274; FRANCISCO GLAUBER PESSOA ALVES, Das Várias (...), cit., p. 906; LUCIANO DE CAMARGO PENTEADO, Doação (...), cit., p. 152; PAULO GERALDO DE OLIVEIRA MEDINA, A Doação, cit., p. 470; SILVIO RODRIGUES, Direito (...), 
Interessante arrazoado é feito por LUCIANO DE CAMARGO PENTEADO ${ }^{983}$ ao tratar da hipótese do art. 550 do Código Civil de 2002, pois aduz, como fundamento para a norma, a ponderação de que a fim de resguardar o princípio da dignidade da pessoa humana é que o legislador civil prevê uma série de situações fáticas que são tidas por proibidas, invalidando assim a liberalidade, pois versa sobre casos diversos, desde a proteção do dever de fidelidade conjugal, como na hipótese sob comento, passando por uma relação creditícia, até um valor moral, quando não o bem do próprio doador ${ }^{984}$.

Para que se verifique a proibição legal, não é necessária a ocorrência de repetidas traições, sendo que um adultério apenas é o suficiente para atrair a vedação ${ }^{985}$. ARNALDO MARMITT $^{986}$ leciona que adultério é diferente de concubinato, apesar de a lei, nos arts. 178, $\S 7^{\circ}, \mathrm{VI}^{987}, 248, \mathrm{IV}^{988}$, e 1.177 do Código Civil de 1916, parecer tratar como realidades iguais. De qualquer maneira, pondera que para a configuração da anulabilidade basta uma relação sexual apenas, não se fazendo necessário provar uma relação extraconjugal estável, segundo o mencionado doutrinador ${ }^{989}$.

AGOSTINHO ALVIM ${ }^{990}$ ensina, porém, não ter utilidade buscar-se a diferença entre concubina ou relação passageira, pois, pela redação da lei, um só adultério já configura a hipótese do art. 1.177 do Código Civil de 1916.

Outrossim, a ação adúltera do doador deverá ser típica, de modo que se o beneficiário for pessoa com quem teve relação antes do matrimônio, a liberalidade é válida ${ }^{991}$,

cit., p. 211.

982 ARNALDO MARMITT, Doação, cit., p. 142.

983 Doação (...), cit., pp. 152-153.

${ }^{984}$ Confrontar também: SÍLVIO DE SALVO VENOSA, Direito (...), cit., p. 136.

985 CARLOS ROBERTO GONÇALVES, Direito (...), vol. III, cit., p. 275; PAULO GERALDO DE OLIVEIRA MEDINA, A Doação, cit., p. 470; SILVIO RODRIGUES, Direito (...), cit., p. 211; VICENTE SABINO JÚNIOR, Contrato (...), cit., p. 35.

${ }^{986}$ Doação, cit., pp. 144-145.

987 Art. 178. "Prescreve: [...]§ 7o Em 2 (dois) anos: (Parágrafo alterado pela Lei no 13, de 29.1.1935 e restabelecido pelo Decreto-lei $\mathrm{n}^{\circ}$ 5.059, de 8.12.1942) [...]VI - a ação do cônjuge ou seus herdeiros necessários para anular a doação feita pelo cônjuge adúltero ao seu cúmplice; contado o prazo da dissolução da sociedade conjugal (art. 1.177); (Redação dada pelo Decreto do Poder Legislativo $\mathrm{n}^{\circ}$ 3.725, de 15.1.1919)".

988 Art. 248. "A mulher casada pode livremente: (Redação dada pela Lei $\mathrm{n}^{\circ}$ 4.121, de 27.8.1962): [...]; IV Reivindicar os bens comuns, móveis ou imóveis, doados ou transferidos pelo marido à concubina (art. 1177). (Redação dada pela Lei $\mathrm{n}^{\circ}$ 4.121, de 27.8.1962)".

989 Nesse sentido, FLÁVIO AUGUSTO MONTEIRO DE BARROS ensina que o cúmplice tem relações esporádicas, ao passo que o concubinato é estável, de modo que a parte concubina pratica adultério, ao passo que o cúmplice não necessariamente é concubino [Manual (...), cit., p. 355]. CARVALHO SANTOS afirma que é proposital os termos empregados pela lei, porque almejou estender a proibição para além do concubinato, a fim de atingir o adultério esporádico [Código (...), cit., p. 415]. Confrontar ainda: ARNALDO RIZZARDO, Contratos, cit., pp. 446-447; NELSON ROSENVALD, Contratos (...), cit., p. 593.

${ }^{990}$ Da Doação, cit., p. 193. 
assim como se a relação veio a existir somente após a doação ${ }^{992}$. No mesmo sentido, AGOSTINHO ALVIM ${ }^{993}$ leciona que se a benesse for feita a pessoa que vivia amasiada com o doador antes de ele ter contraído núpcias, então não se aplica a anulabilidade. Também não se aplica se não houve efetiva conjunção carnal, segundo o mencionado doutrinador.

Havia quem ensinava ${ }^{994}$ que o adultério poderá ser provado em processo-crime, que determinará o juízo cível, ou no próprio bojo da ação civil. Com efeito, AGOSTINHO ALVIM $^{995}$ esposa a opinião de que não é necessária condenação criminal de adultério para configurar a hipótese ${ }^{996}$, mas se houver é admissível sua utilização para fundamentar a anulação, nos termos do art. 1.525do Código Civil de 1916, que entende não ser aplicável apenas aos casos de responsabilidade civil. Tal questão, porém, perdeu seu objeto, com o advento da Lei 11.106/2005, que revogou o art. 240 do Código Penal, que tipificava o adultério como conduta delituosa.

Em se tratando de doação por subvenção periódica, se o donatário vier a se tornar cúmplice de adultério com o doador, até então o negócio jurídico é válido, mormente o principal, mas afetará as futuras liberalidades, eivando-as de invalidade, sendo tal hipótese excepcional na teoria geral das validades, pois se trata de anulabilidade que decorre de fato posterior $^{997}$.

PABLO STOLZE GAGLIANO ${ }^{998}$ afirma que nada impede que se faça doação à companheira, não se aplicando à hipótese a previsão do art. 550 do Código Civil de $2002^{999}$. Com efeito, o $\S 1^{\circ}$ do art. $1.723^{1000}$ do Código Civil de 2002 afirma que não há união estável quando ocorre as causas de impedimentos matrimoniais do art. 1.521 do mesmo diploma legal, estando entre elas o fato de a pessoa já ser casada (inciso VI) ${ }^{1001}$. Logo, se o doador tem

\footnotetext{
${ }^{991}$ ARNALDO MARMITT, Doação, cit., p. 140; CARLOS ROBERTO GONÇALVES, Direito (...), vol. III, cit., p. 276.

992 PAULO LÔBO, Direito (...), cit., p. 306.

${ }^{993}$ Da Doação, cit., pp. 193-194.

${ }^{994}$ VICENTE SABINO JÚNIOR, Contrato (...), cit., pp. 35-36.

995 Da Doação, cit., pp. 194-195.

${ }^{996}$ Da mesma forma: PAULO GERALDO DE OLIVEIRA MEDINA, A Doação, cit., p. 470.

${ }^{997}$ LUCIANO DE CAMARGO PENTEADO, Doação (...), cit., p. 155.

${ }^{998}$ O Contrato (...), cit., pp. 153-156.

999 No mesmo sentido: AMANDA ZOE MORRIS, Doação, cit., p. 280; FLÁVIO AUGUSTO MONTEIRO DE BARROS, Manual (...), cit., p. 356; FLÁVIO TARTUCE, Direito (...), cit., pp. 326-327; SAMUEL LUIZ ARAÚJO, $O$ Princípio (...), cit., p. 83.

${ }^{1000}$ Art. 1.723. "É reconhecida como entidade familiar a união estável entre o homem e a mulher, configurada na convivência pública, contínua e duradoura e estabelecida com o objetivo de constituição de família. § 10 A união estável não se constituirá se ocorrerem os impedimentos do art. 1.521; não se aplicando a incidência do inciso VI no caso de a pessoa casada se achar separada de fato ou judicialmente [...]”.

${ }^{1001}$ Art. 1.521. "Não podem casar: [...]; VI - as pessoas casadas; [...]".
} 
uma companheira, não está casado, pelo que não há adultério, de modo que, com efeito, não faz sentido se falar na aplicação da regra citada. Caso contrário, trata-se de adultério, atraindo a aplicação do dispositivo mencionado ${ }^{1002}$.

CLOVIS BEVILAQUA ${ }^{1003}$ ensina que foi proposital o emprego do termo “cônjuge" pelo art. 1.777 do Código Civil de 1916, a fim de igualar homem e mulher na proibição ${ }^{1004}$. Outrossim, afirma o autor que a faculdade de buscar o desfazimento da doação pelo inocente independe do regime de bens matrimonial vigente ${ }^{1005}$.

Há discussão, além disso, se a invalidade do art. 550 do Código Civil de 2002 é nula ou anulável.

Para OZÉIAS J. SANTOS ${ }^{1006}$, a doação feita por cônjuge adúltero ao cúmplice é anulável, até porque teria uma causa ilícita ${ }^{1007}$. Com efeito, ARNALDO MARMITT ${ }^{1008}$ afirma que é hipótese de anulabilidade, fundada na fraude, com base no art. 147, $\mathrm{II}^{1009}$, do Código Civil de 1916, aduzindo ainda que por força da própria lei é que se deve considerar caso de anulabilidade, de acordo com os já citados arts. 248, IV, e 1.177 do Código Civil de 1916. Outros autores ${ }^{1010}$, além de invocarem a expressa disposição legal, acrescentam que o prazo de dois anos para intentar a ação seria exíguo para uma nulidade, sendo mais próprio para casos de anulabilidade ${ }^{1011}$.

${ }^{1002}$ Diferenciando a companheira da concubina, há um precedente do Superior Tribunal de Justiça afirmando que na primeira hipótese não se aplica a proibição de doação à cúmplice de adultério, porque se trata de entidade familiar: $4^{\text {a }}$ T., R. Esp. n. 3560-0/RS, rel. FONTES DE ALENCAR, j. 13-12-1993.

${ }^{1003}$ Código (...), vol. IV, cit., p. 281.

1004 Essa igualdade se manteve na Lei 10.406/2002, até como princípio das relações conjugais [ARNALDO RIZZARDO, Contratos, cit., p. 446; PAULO NADER, Curso (...), cit., p. 235; SILVIO RODRIGUES, Direito (...), cit., p. 211].

${ }^{1005}$ No mesmo sentido: CARVALHO SANTOS, Código (...), cit., p. 415.

${ }^{1006}$ Da Doação, cit., p. 23.

1007 No mesmo sentido: ORLANDO GOMES, Contratos, cit., p. 242.

1008 Doação, cit., p. 141.

1009 Art. 147. "É anulável o ato jurídico: [...]; II - por vício resultante de erro, dolo, coação, simulação, ou fraude (arts. 86 a 113)".

1010 PABLO STOLZE GAGLIANO, O Contrato (...), cit., p. 156; PONTES DE MIRANDA, Tratado (...), cit., p. 256 (explica o doutrinador que a lei fala em "anulada", mas não "nula").

1011 Também opinando que se trata de caso de anulabilidade: ANTÔNIO CHAVES, Lições (...), cit., p. 258; ARNOLDO WALD, Direito (...), cit., p. 66; CAIO MÁRIO DA SILVA PEREIRA, Instituições (...), cit., p. 222; CARLOS ROBERTO GONÇALVES, Direito (...), vol. III, cit., p. 275; CÉSAR FIUZA, Direito (...), cit., p. 503; CHRISTIANO CASSETARI, Elementos (...), cit., pp. 214-215; FÁBIO ULHOA COELHO, Curso (...), cit., p. 247; FRANCISCO GLAUBER PESSOA ALVES, Das Várias (...), cit., p. 906; JONES FIGUEIRÊDO ALVES, Código (...), cit., p. 454; LIMONGI FRANÇA, Manual (...), cit., p. 101; LUIZ GUILHERME LOUREIRO, Curso (...), cit., p. 517; MARIA HELENA DINIZ, Tratado (...), cit., p. 80; NATAL NADER, Questões Relativas à Doação (II), cit., p. 469; NELSON ROSENVALD, Contratos (...), cit., p. 593; PAULO NADER, Curso (...), cit., p. 235; RODRIGO SENISE LISBOA, Manual (...), cit., p. 259; SAMUEL LUIZ ARAÚJO, O Princípio (...), cit., p. 83; SILVIO LUÍS FERREIRA DA ROCHA, Curso 
AGOSTINHO ALVIM ${ }^{1012}$, por seu turno, afirma que é passível de discussão saber se a doação feita pelo cônjuge adúltero ao cúmplice é eivada de nulidade absoluta ou apenas anulável. Em favor da primeira hipótese, invoca o art. $82^{1013}$ do Código Civil de 1916, que impõe a licitude do objeto do ato jurídico, sob pena de nulidade, nos termos do inciso II do art. $145^{1014}$ do mesmo diploma, sendo que o adultério contaminaria todo o ato, tornando-o ilícito.

Já a favor da anulabilidade, argumenta que a interpretação sistemática do Código Civil de 1916 leva a tal ilação, haja vista que os artigos 1.175 e 1.176 daquele diploma afirmam, já no intróito, que se trata de caso de nulidade, ao passo que a lei civil, no art. 1.177, emprega o vocábulo "pode"1015. Outrossim, se fosse nulidade absoluta, até o juiz ex officio poderia dela conhecê-la, mas a lei restringe apenas ao cônjuge inocente e aos herdeiros necessários legitimidade para alegá-la em juízo.

Assim, diante destes argumentos e do fato de que o prazo prescricional é exíguo, bem como considerando que o rol do art. 147 do Código Civil de 1916 não é fechado, havendo outras hipóteses de anulabilidade no sistema civil, termina por concluir o autor que se trata de anulabilidade. Todas estas considerações guardam plena compatibilidade com o sistema civil atual.

LUCIANO DE CAMARGO PENTEADO ${ }^{1016}$, por sua vez, também ensina que a doação feita pelo cônjuge adúltero ao cúmplice é anulável, pois assim afirma a redação legal e é o quanto se deduz do prazo de 2 anos para seu desfazimento. Na mesma linha de raciocínio, pondera que o adultério é um ato ilícito, pelo que a doação feita pelo cônjuge adúltero ao seu cúmplice poderia ser tida por nula por esse simples fato, à luz do quanto dispõe o art. 145, II, do Código Civil de 1916, mas a lei especial é que prevalece, pelo que incide no caso o art. 550 do Código Civil de $2002^{1017}$.

\footnotetext{
(...), cit., p. 183.

1012 Da Doação, cit., pp. 200-202.

${ }^{1013}$ Art. 82. "A validade do ato jurídico requer agente capaz (art. 145, I), objeto lícito e forma prescrita ou não defesa em lei (arts. 129, 130 e 145)".

${ }^{1014}$ Art. 145. "É nulo o ato jurídico: [...]; II - quando for ilícito, ou impossível, o seu objeto [...]".

1015 PABLO STOLZE GAGLIANO faz a mesma interpretação sistemática no âmbito do Código Civil de 2002 ( $O$ Contrato (...), cit., p. 156)

${ }^{1016}$ Doação (...), cit., p. 154.

1017 Há ainda quem lecione ser o dolo a causa da anulabilidade: FRANCISCO GLAUBER PESSOA ALVES, Das Várias (...), cit., p. 906.
} 
Não obstante, sugere o autor que o melhor seria tratar a hipótese como nulidade absoluta, e assim o faz com base no fato de que o art. $1.474^{1018}$ do Código Civil de 1916 (o autor assume não ter sido tal dispositivo transplantado para o Código Civil de 2002, como se depreende da redação do art. $793^{1019}$ desse diploma, mas é da opinião de que os princípios informadores da norma vão além da sua positivação, pelo que aproveitável) proibia a nomeação como beneficiário de seguro quem não pudesse receber doação, sendo que o endereçado dessa disposição seria justamente o cúmplice do cônjuge adúltero ou a concubina, fulminando de nulidade se tal ato ocorresse, de maneira que, proporcionalmente, o mesmo deveria ocorrer com a doação ensejadora da proibição normativa.

Por outro lado, acrescenta ainda o mencionado doutrinador ${ }^{1020}$ que diante da possibilidade de manejo da ação reivindicatória, deve-se constatar que não há transferência da propriedade, pelo que é melhor concluir que se trata de caso de nulidade, haja vista que não cessa sua ineficácia. Com efeito, à luz do art. 1.642, $\mathrm{V}^{1021}$, do Código Civil de 2002, pode-se concluir que não há transmissão de propriedade na doação feita pelo cônjuge adúltero ao cúmplice, haja vista que o consorte inocente poderá reivindicar a coisa doada, sendo que as hipóteses de anulabilidade implicam em eficácia do ato, mas tal dispositivo não permite configurar-se tal situação.

Por fim, aduz o pesquisador ${ }^{1022}$ que a situação de adultério é de gravidade considerável, haja vista que a proibição legal visa proteger o cônjuge traído de ser enganado também patrimonialmente, pelo que rende homenagens ao princípio da dignidade da pessoa humana, a recomendar ser tratada sob as hipóteses de nulidade de pleno direito ${ }^{1023}$.

PABLO STOLZE GAGLIANO ${ }^{1024}$ ressalta ainda que se houver doação disfarçada em contrato de compra e venda ou doação simulada feita por interposta pessoa, em favor da

\footnotetext{
1018 Art. 1.474. "Não se pode instituir beneficiário pessoa que for legalmente inibida de receber a doação do segurado".

${ }^{1019}$ Art. 793. "É válida a instituição do companheiro como beneficiário, se ao tempo do contrato o segurado era separado judicialmente, ou já se encontrava separado de fato".

${ }^{1020}$ Doação (...), cit., pp. 154-155.

${ }^{1021}$ Art. 1.642. "Qualquer que seja o regime de bens, tanto o marido quanto a mulher podem livremente: [...] V reivindicar os bens comuns, móveis ou imóveis, doados ou transferidos pelo outro cônjuge ao concubino, desde que provado que os bens não foram adquiridos pelo esforço comum destes, se o casal estiver separado de fato por mais de cinco anos; [...]".

1022 Doação (...), cit., p. 155.

1023 De outro lado, há autores que questionam a constitucionalidade do art. 550 do Código Civil vigente ou postulam subsidiariamente sua interpretação restritiva [NELSON ROSENVALD, Contratos (...), cit., p. 593; PAULO LÔBO, Direito (...), cit., p. 306]. FLÁVIO TARTUCE, por seu turno, pretende ver uma tendência de desuso da norma [Direito (...), cit., p. 327].

${ }^{1024}$ O Contrato (...), cit., p. 157.
} 
concubina, então incidirão aos casos os arts. $167^{1025}, 168^{1026}$ e $169^{1027}$ do Código Civil de 2002, de modo que o negócio não será mais anulável, mas sim nulo, passível de conhecimento de ofício, imprescritível e insuscetível de convalidação.

Conforme consta do art. 550 do Código Civil de 2002, e constava no art. 1.177 do Código Civil revogado, o prazo para se intentar a ação de anulação é de 2 anos. Para alguns autores $^{1028}$, esse prazo é decadencial.

ARNALDO MARMITT ${ }^{1029}$ afirma que a maior parte da doutrina trata o mencionado prazo como decadencial, de modo que não se suspende, não se interrompe e corre contra todos os sujeitos de direito, mas, sem formular expressamente sua contrariedade a esse entendimento, somente fala em prazo prescricional, donde se depreende que para o autor é caso de prescrição.

Já AGOSTINHO ALVIM ${ }^{1030}$, de maneira assertiva, afirma que se trata de prazo prescricional $^{1031}$, pois a decadência é exceção e somente se aplica se houver uma justificativa especial, ausente no caso.

A contagem do biênio se inicia da dissolução da sociedade conjugal, que ocorre quando da morte de um dos cônjuges, da separação deles ou do seu divórcio ${ }^{1032}$. AGOSTINHO ALVIM ${ }^{1033}$, no mesmo sentido, leciona que o prazo prescricional começa a fluir da dissolução conjugal, da morte do cônjuge adúltero ou do trânsito em julgado da sentença de separação ${ }^{1034}$. Em caso de nulidade matrimonial, segundo o autor, estando o

${ }^{1025}$ Art. 167. "É nulo o negócio jurídico simulado, mas subsistirá o que se dissimulou, se válido for na substância e na forma".

1026 Art. 168. “As nulidades dos artigos antecedentes podem ser alegadas por qualquer interessado, ou pelo Ministério Público, quando lhe couber intervir".

${ }^{1027}$ Art. 169. "O negócio jurídico nulo não é suscetível de confirmação, nem convalesce pelo decurso do tempo".

${ }^{1028}$ CARLOS ROBERTO GONÇALVES, Direito (...), vol. III, cit., p. 276; FÁBIO ULHOA COELHO, Curso (...), cit., p. 247; LIMONGI FRANÇA, Manual (...), cit., p. 101; LUCIANO DE CAMARGO PENTEADO, Doação (...), cit., p.154; LUIZ GUILHERME LOUREIRO, Curso (...), cit., p. 517; MARIA HELENA DINIZ, Curso (...), cit., p. 264; NELSON ROSENVALD, Contratos (...), cit., p. 593; PABLO STOLZE GAGLIANO, O Contrato (...), cit., p. 156; PAULO LÔBO, Direito (...), cit., p. 306.

${ }^{1029}$ Doação, cit., pp. 150-152.

${ }^{1030}$ Da Doação, cit., p. 207.

${ }^{1031}$ Também entendendo que se trata de prazo prescricional: PAULO GERALDO DE OLIVEIRA MEDINA, $A$ Doação, cit., p. 470.

Há julgado do Superior Tribunal de Justiça que qualifica o prazo como prescricional: $3^{\mathrm{a}}$ T., R. Esp. n. 72997/SP, rel. HUMBERTO GOMES DE BARROS, j. 18-05-2004.

1032 LUIZ GUILHERME LOUREIRO, Curso (...), cit., p. 517; PABLO STOLZE GAGLIANO, O Contrato (...), cit., p. 156; PAULO GERALDO DE OLIVEIRA MEDINA, A Doação, cit., p. 470; PAULO LÔBO, Direito (...), cit., p. 306.

1033 Da Doação, cit., pp. 207-208.

1034 Assim, há quem entenda que a proibição de doar ao cúmplice de adultério não se aplica ainda que haja 
cônjuge inocente de boa-fé, então é o caso de casamento putativo, podendo a outra parte traída promover a competente demanda.

Nada impede, porém, que a ação anulatória seja intentada ainda na existência da sociedade conjugal, mas será de legitimidade exclusiva do outro cônjuge, pois os herdeiros não podem se intrometer na intimidade do casal ${ }^{1035}$. AGOSTINHO ALVIM ${ }^{1036}$ explica que a lei, ao colocar a dissolução como prazo inicial, apenas quis resguardar ao cônjuge inocente a possibilidade de manter o relacionamento longe da contenda, mas que nada impede a renúncia de tal proteção, de modo que pode o cônjuge promover a ação anulatória ainda na constância da sociedade conjugal.

ARNALDO MARMITT ${ }^{1037}$, por sua vez, também entendeque nada impede que a ação anulatória seja intentada ainda na vigência do matrimônio. De todo modo, falecido o cônjuge adúltero, ipso facto começa a fluir o prazo prescricional, como já dito ${ }^{1038}$.

Quanto à legitimidade ativa da ação, ela só pode ser proposta pelo cônjuge inocente, e somente na sua morte é que se transfere aos herdeiros necessários, e isso porque ele é o maior ofendido com a conduta e pode ter interesse em não dar publicidade ao evento $^{1039}$. No entanto, vindo este a falecer, como a lei fala em herdeiros necessários, então a

separação de fato: CARVALHO SANTOS, Código (...), cit., p. 417; NATAL NADER, Questões Relativas à Doação (II), cit., p. 469; SILVIO RODRIGUES, Direito (...), cit., p. 212 (o autor assume, porém, que essa posição poderá levar a injustiças). Essa opinião, porém, conta com oposição: CHRISTIANO CASSETARI, Elementos (...), cit., p. 215; FLÁVIO TARTUCE, Direito (...), cit., p. 327; FRANCISCO GLAUBER PESSOA ALVES, Das Várias (...), cit., p. 906; JONES FIGUEIRÊDO ALVES, Código (...), cit., pp. 454455; NELSON ROSENVALD, Contratos (...), cit., p. 593. Escrevendo em regime legal anterior, alguns autores ensinavam que não se aplicava a norma do art. 1.177 do revogado Código Civil quando o doador já estava desquitado [CARVALHO SANTOS, Código (...), cit., p. 417; PONTES DE MIRANDA, Tratado (...), cit., p. 257].

O Superior Tribunal de Justiça posicionou-se com o entendimento de que a doação de bens adquiridos após a separação de fato é válida: $3^{\mathrm{a}}$ T., R. Esp. n. 408.296/RJ, rel. ARI PARGENDLER, j. 18-06-2009; $4^{\mathrm{a}}$ T., R. Esp. n. 36206-7/RS, rel. BARROS MONTEIRO, j. 18-04-1995.

1035 CARVALHO SANTOS, Código (...), cit., p. 422 (o autor não menciona explicitamente a legitimidade exclusiva do cônjuge, porém não cogita nos herdeiros ingressando com ação anulatória, nesse caso); JONES FIGUEIRÊDO ALVES, Código (...), cit., p. 454; PABLO STOLZE GAGLIANO, O Contrato (...), cit., pp. 156-157.

${ }^{1036}$ Da Doação, cit., pp. 206-207.

1037 Doação, cit., p. 152.

${ }^{1038}$ No mesmo sentido: CARLOS ROBERTO GONÇALVES, Direito (...), vol. III, cit., pp. 275-276.

1039 ARNALDO MARMITT, Doação, cit., p. 139; CARLOS ROBERTO GONÇALVES, Direito (...), vol. III, cit., p. 275; FLÁVIO AUGUSTO MONTEIRO DE BARROS, Manual (...), cit., p. 356; NATAL NADER, Questões Relativas à Doação (II), cit., p. 469; PAULO LÔBO, Direito (...), cit., p. 306; PONTES DE MIRANDA, Tratado (...), cit., p. 256; SILVIO LUÍS FERREIRA DA ROCHA, Curso (...), cit., p. 183; SILVIO RODRIGUES, Direito (...), cit., p. 212. 
legitimidade passa primeiramente aos descendentes, e somente na falta destes aos ascendentes, que só herdam quando inexiste aquela classe de herdeiros ${ }^{1040}$.

Essa é a posição de AGOSTINHO ALVIM ${ }^{1041}$, que afirma ser exclusiva do cônjuge inocente a legitimidade para propositura da ação, enquanto ainda vivo, pois pode acontecer de ele ter interesse em não trazer à baila situação tão desonrosa. Vindo a falecer, aí poderão os herdeiros necessários intentarem a demanda buscando a anulação do ato, sendo que os descendentes excluem os ascendentes por somente os primeiros serem herdeiros atuais, pelo que têm maior interesse moral e econômico do que os segundos.

Assim, o herdeiro só tem legitimidade para propor a ação após a morte do cônjuge inocente, e, sobrevindo tal fato, recebe o prazo do art. 550 do Código Civil de 2002 no estado em que se encontrar e se já decorrido o biênio prescricional, então não poderá mais buscar a anulação da liberalidade ${ }^{1042}$. Mas, se o cônjuge traído já tiver intentado a ação competente, ela se transmitirá a todos aqueles que, a qualquer título, sejam herdeiros do autor da demanda, pelo que poderá ser continuada até mesmo pelo legatário ${ }^{1043}$.

Se há vários herdeiros e se a demanda for intentada por apenas um deles, ainda assim deverá ser reivindicado todo o bem doado, ainda que divisível, pois se trata de uma regra moral, mas as custas e despesas processuais serão suportadas pelo herdeiro litigante, porém apenas ele usufruirá do resultado da demanda, pois admitir o contrário seria acolher o enriquecimento sem causa dos outros herdeiros inertes. No entanto, poderão os demais herdeiros ingressarem no processo como assistentes, o que os obrigaria a reembolsar eventuais custas, mas os faria participar do resultado da ação ${ }^{1044}$.

AGOSTINHO ALVIM ${ }^{1045}$ entende que se o legitimado para intentar a ação estiver interditado ou ausente, não poderá fazê-lo, nem mesmo por curador, até pela natureza da anulação, que envolve, mais do que um direito real, o valor familiar. Por esse mesmo motivo, afirma que o direito de ação não é passível de cessão. Além disso, pode o titular

\footnotetext{
1040 ARNALDO MARMITT, Doação, cit., p. 140.

${ }^{1041}$ Da Doação, cit., pp. 202-204.

1042 ARNALDO MARMITT, Doação, cit., p. 152; CARLOS ROBERTO GONÇALVES, Direito (...), vol. III, cit., p. 275; CARVALHO SANTOS, Código (...), cit., p. 421; FLÁVIO AUGUSTO MONTEIRO DE BARROS, Manual (...), cit., p. 356. Em outro sentido, WASHINGTON DE BARROS MONTEIRO-DABUS MALUF ensinam que a dissolução da sociedade conjugal já faz surgir a legitimidade para os herdeiros [Curso (...), cit., p. 176].

1043 ARNALDO MARMITT, Doação, cit., p. 152.

${ }^{1044}$ AGOSTINHO ALVIM, Da Doação, cit., pp. 204-206.

${ }^{1045}$ Da Doação, cit., pp. 205-206.
} 
renunciar a ele após a prática do adultério, o que impede as outras classes de legitimados de exercê-lo. Não obstante, o perdão expresso ou tácito do adultério não induz à impossibilidade de se intentar a ação de anulação da liberalidade feita ao cúmplice.

Com efeito, VICENTE SABINO JÚNIOR ${ }^{1046}$ afirma que justamente por a vedação de doação à concubina ou adúltera ter por fundamento a dignidade do matrimônio é que a anulabilidade continua a existir mesmo que haja perdão da parte traída ou o seu consentimento. ARNALDO MARMITT ${ }^{1047}$, por sua parte, leciona que mesmo que haja perdão expresso do cônjuge inocente ou então ele volte a morar com a parte adúltera, pode manejar a ação anulatória, porque a lei visa proteger a diminuição patrimonial injustamente realizada.

No entanto, ainda assim o direito de anular a doação feita pelo cônjuge adúltero ao cúmplice é passível de renúncia, de modo que se ele anuir, demovido por qualquer motivo, com a benesse, sabendo que as partes contratantes mantém entre si relação adúltera, não poderá posteriormente manejar a ação anulatória. Do mesmo modo, nem mesmo os outros herdeiros poderão pleitear a anulabilidade se o cônjuge traído anuiu com tal situação ${ }^{1048}$.

Quanto ao sujeito passivo, será o cúmplice do adultério ou seus herdeiros, até a força da quota hereditária recebida ${ }^{1049}$, havendo quem ${ }^{1050}$ afirme ainda que o polo passivo deverá ser integrado pelo doador. Se a coisa ainda estiver na posse do cúmplice, poderá ser reivindicada, mas se tiver sido alienada para terceiros, sua reivindicação só se faz possível se houver conluio ou falta de título aparente de propriedade ${ }^{1051}$.

Vale ressaltar que a anulabilidade incide apenas sobre o bem doado, de modo que se o cônjuge adúltero doar ao cúmplice soma em dinheiro e com o numerário adquiri imóvel, não será possível reivindicar o bem de raiz e nem anular a aquisição, mas apenas a busca da mesma quantia em dinheiro, tendo a mesma consequência para bens móveis já alienados pelo

\footnotetext{
1046 Contrato (...), cit., p. 36.

1047 Doação, cit., p. 140.

${ }^{1048}$ ARNALDO MARMITT, Doação, cit., pp. 146-147; CARVALHO SANTOS, Código (...), cit., p. 421. Não é essa, porém, a opinião de VICENTE SABINO JÚNIOR, para quem a única mitigação possível à regra do art. 1.177 do Código Civil de 1916 é a hipótese de os herdeiros necessários ou o cônjuge enganado não exercerem o direito à anulação, pois nada lhes obriga a assim procederem [Contrato (...), cit., p. 35].

1049 AGOSTINHO ALVIM, Da Doação, cit., p. 208; CARLOS ROBERTO GONÇALVES, Direito (...), vol. III, cit., p. 275.

${ }^{1050}$ CARVALHO SANTOS, Código (...), cit., p. 422; PAULO NADER, Curso (...), cit., pp. 235-236.

1051 AGOSTINHO ALVIM, Da Doação, cit., pp. 208-209.
} 
donatário $^{1052}$. VICENTE SABINO JÚNIOR ${ }^{1053}$, porém, destaca que o cônjuge inocente poderá buscar a anulação de doação realizada pelo cúmplice à família.

Ademais, como se verifica da redação do art. 1.642, $\mathrm{V}^{1054}$, do Código Civil de 2002, o cônjuge traído, além de anular o negócio jurídico, pode ainda reivindicar o bem doado. Ao se debruçar sobre esse dispositivo, LUCIANO DE CAMARGO PENTEADO ${ }^{1055}$ chama atenção para o fato de que o negócio jurídico é invalido pela ilicitude de ato antecedente.

Tal faculdade também tinha previsão no art. 248, IV, do Código Civil de 1916, e, a esse respeito, ARNALDO MARMITT ${ }^{1056}$ ensina que há confusão interpretativa entre os termos anular e reivindicar feita pelos estudiosos em vista do que dispõem os arts. 178, VI, $\S$ $7^{\circ}$ e 248, IV, do Código Civil de 1916, e afirma ser duas coisas diferentes, pois o inocente deverá antes anular a doação e só após reivindicá-la, podendo cumular os pedidos em uma só ação, e isto porque não é possível reivindicar sem antes ter o título da propriedade ${ }^{1057}$. No entanto, segundo o autor, só poderá promover a demanda se a coisa dada for do patrimônio comum do casal.

No mesmo sentido, LUCIANO DE CAMARGO PENTEADO ${ }^{1058}$ entende que para haver a reivindicação do bem é preciso que haja o manejo de ação constitutiva.

AGOSTINHO ALVIM ${ }^{1059}$ trata da polêmica que havia no âmbito do Código Civil de 1916, pois o art. 1.177 fazia expressa remição ao inciso VI do $\S 7^{\circ}$ do art. 178, bem como ao inciso IV do art. 248, todos daquele diploma, sendo que esse último dizia que a esposa inocente poderia reivindicar os bens doados à "concubina". Para o autor, deve-se

\footnotetext{
1052 ARNALDO MARMITT, Doação, cit., pp. 149-151; FLÁVIO AUGUSTO MONTEIRO DE BARROS, Manual (...), cit., p. 356; MARIA HELENA DINIZ, Tratado (...), cit., p. 86; PONTES DE MIRANDA, Tratado (...), cit., p. 257; WASHINGTON DE BARROS MONTEIRO-DABUS MALUF, Curso (...), cit., p. 176.

1053 Contrato (...), cit., p. 35.

${ }^{1054}$ Art. 1.642. "Qualquer que seja o regime de bens, tanto o marido quanto a mulher podem livremente: [...] V reivindicar os bens comuns, móveis ou imóveis, doados ou transferidos pelo outro cônjuge ao concubino, desde que provado que os bens não foram adquiridos pelo esforço comum destes, se o casal estiver separado de fato por mais de cinco anos; $[\ldots]$ ".

1055 Doação (...), cit., p. 152.

${ }^{1056}$ Doação, cit., pp. 142-143.

1057 Como se depreende do já citado art. 248, IV, do Código Civil de 1916, apenas a esposa poderia manejar a ação reivindicatória, o que CLÓVIS BEVILAQUA justifica pelo fato de que no revogado sistema era o marido que ficava na administração do patrimônio comum [Código (...), vol. IV, cit., p. 281].

${ }^{1058}$ Doação (...), cit., p. 154.

${ }^{1059}$ Da Doação, cit., pp. 195-197.
} 
compreender nesta expressão também o adultério, pois, à exceção do art. 1.719 , III ${ }^{1060}$, do Código revogado (cuja limitação ao concubinato é compreensível por questão de prova e delicadeza, haja vista que o concubinato é notório, de modo que é fácil provar mesmo com a morte do testador, sem necessidade de revolver sua intimidade, mormente porque ele não poderá se defender), a lei civil punia severamente o adultério, haja vista que era causa de impedimento e desquite (arts. 183, VII, e 137, VI) ${ }^{1061}$. Além disso, tanto os arts. $178, \S 7^{\circ}$, VI, como o art. 1.171, falam em adultério, de modo que o art. 248, IV seria um "deslize ou descuido do legislador"1062.

Pode-se dizer, de certo modo, que tal crítica foi acolhida pela lei civil atual, pois o legislador da Lei 10.406/2002 simplesmente retirou as remissões diretas, dando a entender que não há conexão entre os arts. 550 e 1.642, V, do Código Civil de 2002, pelo que apenas a doação feita à concubina é que permite a reivindicação do objeto da liberalidade, mas não assim quando o donatário tiver mantido relação casual com o doador, havendo apenas, nesse caso, a possibilidade da anulabilidade do art. 550 do mesmo diploma legal ${ }^{1063}$.

VICENTE SABINO JÚNIOR ${ }^{1064}$ afirma que se o casal for unido sob o regime da comunhão universal de bens, a parte inocente pode ingressar com ação reivindicatória, que poderá levar à recomposição do patrimônio do casal com o objeto da liberalidade, ao passo que os demais regimes não permitem essa via processual ${ }^{1065}$.

AGOSTINHO ALVIM ${ }^{1066}$, por sua vez, afirma que a faculdade de reivindicar o bem doado ao cúmplice de adultério é aplicável independentemente do regime de bens, pois seu fundamento seria a possibilidade de o cônjuge inocente honrar a imoralidade matrimonial perpetrada, assim como independentemente da espécie, se móvel ou imóvel. Como se verifica da redação do caput do art. 1.642 do Código Civil de 2002, essa última opinião é que foi acolhida pelo legislador.

\footnotetext{
${ }^{1060}$ Art. 1.719. "Não podem também ser nomeados herdeiros, nem legatários: [...] III - a concubina do testador casado; [...]".

${ }^{1061}$ No mesmo sentido: CARVALHO SANTOS, Código (...), cit., p. 415.

1062 Por conta disso, havia quem ensinasse que o art. 1177 do Código Civil de 1916 complementava a norma do art. 248, V, de modo que o cônjuge impossibilitado de promover a reivindicação do bem doado poderia alcançar a anulação do ato [NATAL NADER, Questões Relativas à Doação (II), cit., p. 469].

${ }^{1063}$ FLÁVIO TARTUCE emite a opinião de que haveria conflito entre as duas normas e entende que a aplicação de um dispositivo somente é possível com a exclusão do outro [Direito (...), cit., p. 327].

${ }^{1064}$ Contrato (...), cit., pp. 35 e 53-54.

1065 No mesmo sentido: CARVALHO SANTOS, Código (...), cit., pp. 415-416; CLÓVIS BEVILAQUA, vol. IV, Código (...),vol. cit., p. 281; NATAL NADER, Questões Relativas à Doação (II), cit., p. 469.

${ }^{1066}$ Da Doação, cit., p. 197.
} 
Outra peculiaridade que havia no Código Civil de 1916 é que o bem reivindicado pelo cônjuge inocente ficava à sua livre disposição, nos termos do quanto dispunha o inciso $\mathrm{V}$ do art. $248^{1067}$ daquele diploma legal. AGOSTINHO ALVIM ${ }^{1068}$ opina pela não aplicação desse dispositivo se for bem particular do cônjuge traidor, mas se for da comunhão, o marido adúltero perde sua parte. Já ARNALDO MARMITT ${ }^{1069}$ afirma que, uma vez julgada procedente a anulação da doação, o bem doado volta ao patrimônio comum do casal, e antepõe-se ao entendimento de que a coisa doada passa a ser do patrimônio particular da esposa traída, em punição ao marido adúltero, pois a Constituição Federal consagrou a igualdade entre homem e mulher.

De todo modo, tal dispositivo não consta do Código Civil de 2002 e demonstra o cuidado que o legislador civil teve ao fazer constar expressamente no inciso V do art. 1642 que a reivindicação só é possível de ser feita sobre os bens comuns ${ }^{1070}$.

Por derradeiro, vale ressaltar que o art. 248, IV, trazia um parágrafo único ${ }^{1071}$, que, segundo AGOSTINHO ALVIM ${ }^{1072}$, não precisava ter dito que a doação disfarçada não tem o condão de afastar o direito à reivindicação pela mulher inocente, pois a simulação é sempre passível de arguição, donde conclui que se trata de hipótese de simulação presumida pela lei, sendo ela juris tantum, sem prejuízo de a donatária, sendo capaz de provar que a compra e venda foi real, poder requerer a devolução do preço pago.

Como tal dispositivo não está mais presente no atual Código Civil, dita presunção não existe no sistema civil atual. No entanto, a simulação é hipótese de nulidade absoluta, de modo que poderá ser arguida a qualquer tempo, nos termos do art. 167 da Lei 10.406/2002.

Diante do que se expôs, verifica-se que não é dado ao proprietário contemplar pessoa com quem tenha relacionamento extraconjugal por meio de uma doação, sendo ela uma alienação frágil e ensejaria grande celeuma.

\footnotetext{
${ }^{1067}$ Art. 248. “A mulher casada pode livremente: (Redação dada pela Lei no 4.121, de 27.8.1962): [...] V - Dispor dos bens adquiridos na conformidade do número anterior e de quaisquer outros que possua, livres da administração do marido, não sendo imóveis (Redação dada pela Lei no 4.121, de 27.8.1962) [...]”.

${ }^{1068}$ Da Doação, cit., pp. 197-198.

1069 Doação, cit., pp. 147-149. AGOSTINHO ALVIM já antevia a necessidade de se igualar os direitos, pois lecionava, a esse respeito, que na omissão da lei e por se tratar de situação semelhante, era possível beneficiar o marido com a previsão do art. 248, V, do Código Civil de 1916, por aplicação analógica da norma (Da Doação, cit., pp. 199-200).

${ }^{1070}$ Consultar a esse respeito: JONES FIGUEIRÊDO ALVES, Código (...), cit., p. 454.

1071 Parágrafo único. "Este direito prevalece, esteja ou não a mulher em companhia do marido, e ainda que a doação se dissimule em venda ou outro contrato (Redação dada pela Lei no 4.121, de 27.8.1962)".

${ }^{1072}$ Da Doação, cit., pp. 198-199.
} 
Além do mais, a norma ora examinada do art. 550 do Código Civil de 2002 tem como principais endereçados os herdeiros necessários do doador, afinal de contas claramente visa proteger a higidez de sua sucessão, podendo, dentro das hipóteses legais, a cônjuge e seus filhos buscarem a anulação da doação. E com isso deve contar o doador, caso queira alienar gratuitamente seus bens com segurança.

\section{5) Doação de ascendente para descendente}

O art. $544^{1073}$ do Código Civil de 2002 permite que haja doação de um ascendente ao seu descendente, mas impõe como efeito da benesse o adiantamento da parte que o donatário receberá por transmissão mortis causa ${ }^{1074}$. O Código Civil de 1916 também trazia previsão semelhante, que versava apenas de doação de pai para filho, em seu art. $1.171^{1075}$.

A esse respeito, ARNALDO MARMITT ${ }^{1076}$ faz notar a incoerência que havia no art. 1.171 do Código Civil de 1916 ao falar apenas em "pais" e "filhos", pois os artigos $1.176^{1077}$, que versava sobre a doação inoficiosa, e $1722^{1078}$, que regulava a legítima, ambos do mesmo diploma, se aplicavam aos ascendentes e descendentes, haja vista que os filhos não são os únicos herdeiros necessários, como se depreenderia do art. $1.721^{1079}$ daquele Código, pelo que entende que a norma do art. 1.171 se aplicava a todos os descendentes. Com a redação do art. 544 do atual Código Civil tal questão foi resolvida pela lei ${ }^{1080}$.

A possibilidade de doação de ascendente para descendente remanesce mesmo que o donatário tenha sofrido a pena de deserdação. Se coincidir as causas de deserdação com as

${ }^{1073}$ Art. 544. "A doação de ascendentes a descendentes, ou de um cônjuge a outro, importa adiantamento do que lhes cabe por herança".

${ }^{1074}$ No entanto, o Superior Tribunal de Justiça, debruçando-se sobre caso em que o varão doou imóvel a filhos seu, em cumprimento de transação celebrada para resolução de partilha em separação judicial e alimentos objetos de execução, declarou que não há adiantamento de legítima na hipótese, porque a qualificação jurídica do ato é dação em pagamento, mas não doação ${ }^{1074}$ (4 $4^{\mathrm{a}}$ T., R. Esp. n. 629117/DF, rel. HONILDO AMARAL DE MELLO CASTRO, j. 10-11-2009).

1075 Art. 1.171. "A doação dos pais aos filhos importa adiantamento da legítima".

${ }^{1076}$ Doação, cit., p. 66.

1077 Art. 1.176. "Nula é também a doação quanto à parte que exceder a de que o doador, no momento da liberalidade, poderia dispor em testamento".

1078 Art. 1.722. "Calcula-se a metade disponível (art. 1.721) sobre o total dos bens existentes ao falecer o testador, abatidas as dívidas e as despesas do funeral. Parágrafo único. Calculam-se as legítimas sobre a soma que resultar, adicionando-se à metade dos bens que então possuía o testador a importância das doações por ele feitas aos seus descendentes (art. 1.785)".

${ }^{1079}$ Art. 1.721. "O testador que tiver descendente ou ascendente sucessível não poderá dispor de mais da metade de seus bens; a outra pertencerá de pleno direito ao descendente e, em sua falta, ao ascendente, dos quais constitui a legítima, segundo o disposto neste Código (arts. 1603 a 1619 e 1723)".

1080 Confrontar: SYLVIO CAPANEMA DE SOUZA, Das Várias (...), cit., p. 152. 
de revogação da doação por ingratidão, fica ao alvedrio do doador buscar ou não o desfazimento da liberalidade ${ }^{1081}$.

VICENTE SABINO JÚNIOR ${ }^{1082}$ afirma que o fundamento da regra do art. 1.171 do Código Civil de 1916 está em que a lei quer evitar que haja tratamento desigual entre os herdeiros, daí a obrigação de o beneficiado levar a liberalidade à colação, a fim de todos receberem quinhões hereditários iguais ${ }^{1083}$. Comentando o mesmo dispositivo, AGOSTINHO ALVIM $^{1084}$ também explicita o fundamento da norma, que seria a proteção da legítima dos herdeiros necessários.

Desse modo, a escritura de doação de ascendente para descendente, em si, não é nula, mas tem por efeito o adiantamento da legítima, sendo que ao donatário resta a obrigação de levar o bem recebido à colação ${ }^{1085}$. Com efeito, a conferência da higidez da liberalidade deverá se realizar no inventário dos bens do doador, que tem a faculdade de dispensar o donatário de tal formalidade, desde que faça constar expressamente do instrumento de doação que a coisa doada compõe a parte disponível do seu patrimônio, mas se nada tratar a respeito no contrato, então o bem doado comporá a legítima ${ }^{1086}$.

No mesmo sentido, AGOSTINHO ALVIM ${ }^{1087}$ aduz que o bem doado de pai para filho será, após, descontado do quinhão que caberia ao donatário por herança, a não ser que o

\footnotetext{
${ }^{1081}$ VICENTE SABINO JÚNIOR, Contrato (...), cit., p. 68.

1082 Contrato (...), cit., p. 43.

${ }^{1083}$ No mesmo sentido: SAMUEL LUIZ ARAÚJO, O Princípio (...), cit., p. 80.

${ }^{1084}$ Da Doação, cit., p. 104.

1085 PAULO LÔBO explica, assim, que o legislador apenas "inibe" a espécie, mas não a invalida ou a proíbe [Direito (...), cit., p. 296].

O Superior Tribunal de Justiça já declarou que a colação é um dever do donatário descendente do autor da herança: $3^{\text {a }}$ T., R. Esp. n. 9081/SP, rel. CLAUDIO SANTOS, j. 24-02-1992. Ademais, não se pode confundir essa obrigação com o de prestar contas. Com efeito, em hipótese em que o falecido, ainda em vida, abriu conta poupança em cotitularidade com descendentes seu, mas depois se retirou da aplicação, o Superior Tribunal de Justiça declarou que o correto é exigir a colação do numerário, mas não prestação de contas, pelo que determinou o não conhecimento de ação de prestação de contas manejada incidentalmente ao inventário (3 $3^{a}$ T., R. Esp. n. 658244/CE, rel. NANCY ANDRIGHI, j. 07-03-2006).

1086 ARNALDO MARMITT, Doação, cit., p. 65; LUIZ GUILHERME LOUREIRO, Curso (...), cit., p. 513; PAULO NADER, Curso (...), cit., p. 233; SILVIO LUÍS FERREIRA DA ROCHA, Curso (...), cit., p. 180; SAMUEL LUIZ ARAÚJO, O Princípio (...), cit., p. 80; SILVIO RODRIGUES, Direito (...), cit., p. 206; SYLVIO CAPANEMA DE SOUZA, Das Várias (...), cit., p. 159; WASHINGTON DE BARROS MONTEIRO-DABUS MALUF, Curso (...), cit., p. 172.

Há um julgado do Superior Tribunal de Justiça admitindo formulação ampla (o adjetivo é dado pelo próprio relator) para se entender dispensado o donatário de levar bem a colação. Com efeito, o mencionado Sodalício entendeu que, por constar em cláusula testamentária que o herdeiro estava dispensado de colacionar "liberalidades" havidas em vida por doação, não precisaria trazer ao inventário usufruto recebido de cotas acionárias ( $3^{\text {a }}$ T., R. Esp. n. 16/SP, rel. EDUARDO RIBEIRO, j. 05-09-1989).

${ }^{1087}$ Da Doação, cit., pp. 104-105.
} 
doador faça constar no instrumento da liberalidade, ou em documento autônomo ${ }^{1088}$, podendo ser inclusive testamento, que a coisa doada deverá ser computada da parte disponível, mas ainda nesse caso o filho terá de levar a benesse recebida à colação.

Afirma ${ }^{1089}$, ainda, que de acordo com o art. $1.789^{1090}$ do Código Civil de 1916, não se presume que a coisa deva ser descontada da parte disponível, pois para atingir esse efeito deverá constar de documento escrito ${ }^{1091}$. Tal dispositivo encontra-se reproduzido na norma do art. 2.006 ${ }^{1092}$ do Código Civil de 2002.

Outrossim, dada a existência de momento futuro para conferência da benesse, na doação de ascendente para descendente não se faz necessária o consentimento dos demais herdeiros ${ }^{1093}$. Com efeito, não é necessário a anuência dos outros filhos para a realização da liberalidade, ao contrário do que ocorre na compra e venda de pai para filho, porque os outros herdeiros terão oportunidade de conferir a benesse na colação do bem doado ao inventário, o que não ocorre na compra e venda ${ }^{1094}$.

${ }^{1088}$ Há quem defenda que a dispensa somente poderá se dar no próprio instrumento de doação ou por testamento: SYLVIO CAPANEMA DE SOUZA, Das Várias (...), cit., p. 160.

Há, porém, aresto do Superior Tribunal de Justiça admitindo a dispensa da colação por instrumento inter vivos posterior à liberalidade: $3^{\mathrm{a}}$ T., R. Esp. n. 440128/AM, rel. CARLOS ALBERTO MENEZES DIREITO, j. 03-06-2003.

A legislação civil portuguesa, no seu art. 2.113. ("Dispensa da colação"), autoriza expressamente a dispensa por documento apartado: "1. A colação pode ser dispensada pelo doador no acto da doação ou posteriormente. 2. Se a doação tiver sido acompanhada de alguma formalidade externa, só pela mesma forma, ou por testamento, pode ser dispensada a colação. 3. A colação presume-se sempre dispensada nas doações manuais e nas doações remuneratórias". No entanto, a dispensa deve ser inequívoca, gozando de presunção iuris et de iure nos casos do parágrafo 3 (MANUEL BAPTISTA LOPES, Das Doações, cit., pp. 206-208).

${ }^{1089}$ Da Doação, cit., p. 106.

${ }^{1090}$ Art. 1.789. "A dispensa de colação pode ser outorgada pelo doador, ou dotador, em testamento, ou no próprio título da liberalidade".

${ }^{1091}$ Há precedente adotando essa posição: STJ, $4^{a}$ T., Agr. em R. Esp. n. 148.835/SP, rel. LUIS FELIPE SALOMÃO, j. 04-10-2012.

${ }^{1092}$ Art. 2.006. "A dispensa da colação pode ser outorgada pelo doador em testamento, ou no próprio título de liberalidade".

${ }^{1093}$ ARNALDO MARMITT, Doação, cit., p. 67; ARNALDO RIZZARDO, Contratos, cit., p. 444; CARLOS ROBERTO GONÇALVES, Direito (...), vol. III, cit., p. 268; CARVALHO SANTOS, Código (...), cit., p. 368; EDUARDO ESPINOLA, Dos Contratos (...), cit., p. 160; JESUALDO EDUARDO DE ALMEIDA JÚNIOR, Os contratos de compra e venda, de doação e de permuta entre ascendentes e descendentes, in AJURIS 89(2003), p. 133; LUIZ GUILHERME LOUREIRO, Curso (...), cit., p. 513; NELSON ROSENVALD, Contratos (...), cit., p. 589; PAULO NADER, Curso (...), cit., p. 233; SILVIO LUÍS FERREIRA DA ROCHA, Curso (...), cit., p. 180.

${ }^{1094}$ AGOSTINHO ALVIM, Da Doação, cit., p. 104; FLÁVIO AUGUSTO MONTEIRO DE BARROS, Manual (...), cit., p. 354; SYLVIO CAPANEMA DE SOUZA, Das Várias (...), cit., pp. 155-156.

Em hipótese na qual a mãe doou bens a todos os filhos, menos um, o descendente excluído insurgiu-se contra o ato alegando sua nulidade por falta de autorização dele, por aplicação analógica da regra do contrato de compra e venda, vindo o caso a ser apreciado pelo Superior Tribunal de Justiça, que não deu guarida à tese apresentada, sob os fundamentos de que não há razão para se aplicar interpretação extensiva a norma restritiva de direito e de que ao filho excluído será oportunizada a conferência da higidez da liberalidade em 
Se a doação for dirigida para filho menor, seria medida de prudência nomear-se um curador especial para o donatário ${ }^{1095}$.

Outrossim, ARNALDO MARMITT ${ }^{1096}$ entende que, mesmo em se tratando de doação para filho, deverá haver a outorga do outro cônjuge, independentemente do regime de bens que vigore entre o casal. Em se tratando de bens ou rendimentos comuns ao casal, afirma ser necessária a anuência do outro cônjuge, exceto se a disposição liberal for de bens de pequeno valor ou remuneratória. Em se tratando de doação antenupcial, porém, desnecessária a sobredita anuência, o que está de acordo com o art. 1.647, IV ${ }^{1097}$, do Código Civil de 2002.

De acordo com o art. $2.002^{1098}$ da Lei 10.406/2002, o donatário que recebe doação de um seu ascendente deverá levar a coisa doada à colação no bojo do inventário dos bens do doador, como já foi dito acima, a fim de, conforme afirma a lei, igualar a legítima ${ }^{1099}$.

Assim, trata-se a colação de ato jurídico em que o donatário faz constar no inventário dos bens de um seu ascendente que lhe fez doação a respectiva coisa doada, a fim de possibilitar a justa mensuração da legítima ${ }^{1100}$. É ato obrigatório, sem poder o donatário apresentar escusas, e, caso o bem doado não mais subsista, deverá então apresentar o valor

sede de colação nos autos do inventário (4 ${ }^{\mathrm{a}}$ T., R. Esp. n. 124220/MG, rel. CESAR ASFOR ROCHA, 25-111997). Também adotando a mesma solução jurídica: STJ, $3^{\text {a }}$ T., R. Esp. n. 17555/MG, rel. DIAS TRINDADE, j. 09-03-1992.

1095 ARNALDO MARMITT, Doação, cit., p. 65; WASHINGTON DE BARROS MONTEIRO-DABUS MALUF, Curso (...), cit., p. 168.

${ }^{1096}$ Doação, cit., pp. 65-66.

1097 Art. 1.647. "Ressalvado o disposto no art. 1.648, nenhum dos cônjuges pode, sem autorização do outro, exceto no regime da separação absoluta: [...] IV - fazer doação, não sendo remuneratória, de bens comuns, ou dos que possam integrar futura meação. [...]".

1098 Art. 2.002. "Os descendentes que concorrerem à sucessão do ascendente comum são obrigados, para igualar as legítimas, a conferir o valor das doações que dele em vida receberam, sob pena de sonegação".

${ }^{1099}$ Esse é também o regime do Código Civil português, que assim dispõe no seu art. 2.104. ("Noção"): "1. Os descendentes que pretendam entrar na sucessão do ascendente devem restituir à massa da herança, para igualação da partilha, os bens ou valores que lhes foram doados por este: esta restituição tem o nome de colação. 2. São havidas como doação, para efeitos de colação, as despesas referidas no artigo $2110 .^{\circ}$ ". Da mesma forma que no sistema pátrio, o escopo da norma é proteger a legítima dos herdeiros necessários, a fim de garantir tratamento igualitário a eles, de maneira que se houver doação de ascendente para descendente, como no sistema brasileiro, há que se falar em colação (MANUEL BAPTISTA LOPES, Das Doações, cit., pp. 199-201).

1100 FLÁVIO AUGUSTO MONTEIRO DE BARROS, Manual (...), cit., p. 354; LIMONGI FRANÇA, Manual (...), cit., p. 101; NATAL NADER, Questões Relativas à Doação (II), cit., p. 467; PABLO STOLZE GAGLIANO, O Contrato (...), cit., p. 78. 
correspondente em espécie, pois do contrário perderá o direito ao bem ${ }^{1101}$, o que é regulamentado pelo art. 2.003 e parágrafo único ${ }^{1102}$ do Código Civil de 2002.

Os netos, no entanto, não estão obrigados a levarem à colação os bens que receberam em doação, por não serem herdeiros necessários ${ }^{1103}$, porém deverão fazê-lo caso venham a suceder por representação ${ }^{1104}$, nos termos do art. $2.009^{1105}$ do Código Civil de 2002.

O fundamento da necessidade de se levar à colação os bens recebidos em doação por um dos herdeiros está no objetivo da lei, que visa evitar que o doador dê tratamento desigual aos seus filhos, sem estar fundado em um critério objetivo, o que até explica o fato de a doação remuneratória estar dispensada de ser trazida à colação, como se verifica na redação do art. $2.011^{1106}$ do Código Civil de $2002^{1107}$.

Por o escopo da colação ser a proteção apenas da legítima, os bens nela apresentados não compõem a parte disponível ${ }^{1108}$. Pode-se dizer também que a colação

1101 JESUALDO EDUARDO DE ALMEIDA JÚNIOR, Os contratos (...), cit.., p. 134; LUIZ GUILHERME LOUREIRO, Curso (...), cit., p. 513; PABLO STOLZE GAGLIANO, O Contrato (...), cit., p. 78; SYLVIO CAPANEMA DE SOUZA, Das Várias (...), cit., p. 158.

${ }^{1102}$ Art. 2.003. "A colação tem por fim igualar, na proporção estabelecida neste Código, as legítimas dos descendentes e do cônjuge sobrevivente, obrigando também os donatários que, ao tempo do falecimento do doador, já não possuírem os bens doados. Parágrafo único. Se, computados os valores das doações feitas em adiantamento de legítima, não houver no acervo bens suficientes para igualar as legítimas dos descendentes e do cônjuge, os bens assim doados serão conferidos em espécie, ou, quando deles já não disponha o donatário, pelo seu valor ao tempo da liberalidade".

${ }^{1103}$ ARNALDO MARMITT, Doação, cit., p. 213; NELSON ROSENVALD, Contratos (...), cit., p. 588.

${ }^{1104}$ CARLOS ROBERTO GONÇALVES, Direito (...), vol. III, cit., p. 268; MARIA HELENA DINIZ, Curso (...), cit., p. 261; PAULO LÔBO, Direito (...), cit., pp. 296-297; PONTES DE MIRANDA, Tratado (...), cit., p. 264.

${ }^{1105}$ Art. 2.009. "Quando os netos, representando os seus pais, sucederem aos avós, serão obrigados a trazer à colação, ainda que não o hajam herdado, o que os pais teriam de conferir".

No sistema civil lusitano outra solução é dada, porque, por expressa disposição legal, será a data da doação que determinará se o donatário é herdeiro presumido ou não do doador, o que afeta o dever de trazer o bem doado à colação. Essa é a redação do art. 2.105. ("Descendentes sujeitos à colação") do diploma civil daquele país: "Só estão sujeitos à colação os descendentes que eram à data da doação presuntivos herdeiros legitimários do doador". Desse modo, se o donatário é neto do doador e vem a tomar parte da sua sucessão por direito de representação, ainda assim não precisa colacionar o que recebeu por liberalidade, mas não assim se ao tempo da doação seu descendente direto já tiver falecido (MANUEL BAPTISTA LOPES, Das Doações, cit., pp. 201-202).

${ }^{1106}$ Art. 2.011. "As doações remuneratórias de serviços feitos ao ascendente também não estão sujeitas a colação".

${ }^{1107}$ CARVALHO SANTOS, Código (...), cit., p. 366; LUCIANO DE CAMARGO PENTEADO, Doação (...), cit., p. 164; PAULO GERALDO DE OLIVEIRA MEDINA, A Doação, cit., p. 468; SILVIO RODRIGUES, Direito (...), cit., p. 206; SYLVIO CAPANEMA DE SOUZA, Das Várias (...), cit., pp. 153-155.

Por a colação ter por objetivo a proteção dos herdeiros, falece legitimidade ao testamenteiro de exigir a prática do ato por descendente que tenha recebido doação do autor da herança (STJ, 3a T., R. Esp. n. 167421/SP, rel. PAULO DE TARSO SANSEVERINO, j. 07-12-2010), assim como ao herdeiro testamentário, que não se beneficia com eventual ordem de redução da doação (STJ, $3^{\mathrm{a}}$ T., R. Esp. n. 400948/SE, rel. VASCO DELLA GIUSTINA, j. 23-03-2010).

${ }^{1108}$ PABLO STOLZE GAGLIANO, O Contrato (...), cit., p. 79. 
protege não apenas os descendentes, mas também o cônjuge supérstite, que é herdeiro necessário, nos termos do art. $1.845^{1109}$ do Código Civil de $2002^{1110}$. Por esse mesmo motivo, o marido ou a mulher sobrevivente também têm o dever de colacionar os bens havidos por doação, em que pese o silêncio da lei a este respeito ${ }^{1111}$.

Como já se afirmou, um bem doado de um ascendente ao seu descendente não se presume que saia da parte disponível, mas que seja sim adiantamento de legítima, a não ser que haja disposição contrária no instrumento do contrato de doação, conforme dispõe expressamente o art. $2.005^{1112}$ do Código Civil de 2002, o qual, porém, em seu parágrafo único $^{1113}$, criou uma hipótese legal de presunção, pela qual se ocorrer de o doador realizar uma benesse em favor de alguém que, no momento da liberalidade, não sabia que era seu filho, mas, posteriormente toma ciência deste fato, de modo que passa o donatário a ser herdeiro necessário do autor da benesse, mesmo assim presume-se que a coisa doada compunha a parte disponível ${ }^{1114}$.

Quanto ao dever do donatário herdeiro de levar o bem doado à colação, não se trata de uma limitação ao direito de propriedade, porque o negócio é válido, tendo como condição de eficácia a morte do disponente, pelo que se trata de uma restrição ao direito do proprietário $^{1115}$.

Outrossim, em relação à previsão do art. $2.008^{1116}$ do Código Civil de 2002, que impõe ao renunciante da herança e ao herdeiro excluído por indignidade o dever de proceder à colação dos bens que recebeu em doação, PABLO STOLZE GAGLIANO ${ }^{1117}$ entende que deveria ser incluído neste rol também o deserdado, mesmo que assim não esteja previsto em lei ${ }^{1118}$.

\footnotetext{
${ }^{1109}$ Art. 1.845. "São herdeiros necessários os descendentes, os ascendentes e o cônjuge".

${ }^{1110}$ FLÁVIO TARTUCE, Direito (...), cit., p. 319; PABLO STOLZE GAGLIANO, O Contrato (...), cit., p. 79.

${ }^{1111}$ FLÁVIO AUGUSTO MONTEIRO DE BARROS, Manual (...), cit., p. 355; PABLO STOLZE GAGLIANO, $O$ Contrato (...), cit., p. 82.

1112 Art. 2.005. "São dispensadas da colação as doações que o doador determinar saiam da parte disponível, contanto que não a excedam, computado o seu valor ao tempo da doação".

${ }^{1113}$ Parágrafo único. "Presume-se imputada na parte disponível a liberalidade feita a descendente que, ao tempo do ato, não seria chamado à sucessão na qualidade de herdeiro necessário".

1114 PABLO STOLZE GAGLIANO, O Contrato (...), cit., pp. 86-87. SYLVIO CAPANEMA DE SOUZA defende que a presunção também se aplica para o caso de o donatário ser neto do doador, e o pai do primeiro e filho do segundo vem a falecer [Das Várias (...), cit., p. 159].

1115 LUCIANO DE CAMARGO PENTEADO, Doação (...), cit., pp. 163-164.

1116 Art. 2.008. "Aquele que renunciou a herança ou dela foi excluído, deve, não obstante, conferir as doações recebidas, para o fim de repor o que exceder o disponível".

${ }^{1117}$ O Contrato (...), cit., p. 92.

${ }^{1118}$ Esse é também o entendimento de MANUEL BAPTISTA LOPES, haja vista que no Código Civil de
} 
Para calcular se a legítima foi devidamente resguarda, deverá se levar em conta, quanto à coisa ofertada, o valor constante do instrumento e na ausência desse dado deverá se proceder à estimativa do montante, conforme dispõe o art. 2.004 , caput e $\S 1^{\mathrm{o} 1119}$, do Código Civil de $2002^{1120}$. Ademais, poderá ser cabível uma medida cautelar à época da liberalidade para averiguação do valor da coisa doada ad perpetuam rei memoriae ${ }^{1121}$.

O caput do art. 2.004 do Código Civil de 2002 prevê a situação da doação feita sem constar o valor do bem doado ou mera estimativa dele, mas reforça, de todo modo, o critério temporal, que será a data da realização da benesse, podendo inclusive, para fins de prova, o juiz ordenar a realização de laudo pericial e proceder, dessa forma, à estimativa e atualização do real valor da coisa doada ${ }^{1122}$.

Para AGOSTINHO ALVIM ${ }^{1123}$, caso o valor que foi estimado da coisa doada seja menor, a princípio deverá ser mantido, em homenagem à vontade do autor da herança e pela falta de precisão da estimativa. Admite, porém, que o valor atribuído ao bem poderá estar muito díspar da realidade e entende possível a sua revisão, mas não no inventário, pela sua complexidade, pelo que o herdeiro deverá intentar ação autônoma.

Eventuais acessões ou benfeitorias que tenham se acrescentado à coisa doada antes da colação deverão ser indenizadas ao herdeiro donatário, caso volte a integrar o espólio por eventual inoficiosidade, pois até então sua posse era de boa-fé subjetiva, ou seja, o

Portugal, no segundo parágrafo do art. $2.166^{\circ}$ (Deserdação), há expressa equiparação entre o instituto e a declaração de indignidade, como se verifica: " 2 . O deserdado é equiparado ao indigno para todos os efeitos legais" (Das Doações, cit., p. 205).

1119 Art. 2.004. "O valor de colação dos bens doados será aquele, certo ou estimativo, que lhes atribuir o ato de liberalidade. § 1o Se do ato de doação não constar valor certo, nem houver estimação feita naquela época, os bens serão conferidos na partilha pelo que então se calcular valessem ao tempo da liberalidade. [...]".

${ }^{1120}$ Debruçando-se sobre liberalidade realizada ainda na vigência do antigo Código Civil, o Superior Tribunal de Justiça declarou que o art. 1.792 do mencionado diploma legal (Art. 1.792. "Os bens doados, ou dotados, imóveis, ou móveis, serão conferidos pelo valor certo, ou pela estimação que deles houver sido feita na data da doação") teria sido revogado pelo parágrafo único do art. 1.014 do Código de Processo Civil (Art. 1.014. "No prazo estabelecido no art. 1.000, o herdeiro obrigado à colação conferirá por termo nos autos os bens que recebeu ou, se já os não possuir, trar-lhes-á o valor. Parágrafo único. Os bens que devem ser conferidos na partilha, assim como as acessões e benfeitorias que o donatário fez, calcular-se-ão pelo valor que tiverem ao tempo da abertura da sucessão"), de modo que a data-base para avaliação dos bens doados seria a da abertura da sucessão ( $3^{\mathrm{a}}$ T., R. Esp. n. 595742/SC, rel. NANCY ANDRIGHI, j. 06-11-2003). Com a assunção do atual Código Civil, prevalece, agora, o disposto no art. 2.004 e parágrafos., seja pelo critério temporal, seja pela especialidade, pois se trata de matéria de direito material, mas não de processo (confrontar: CAIO MÁRIO DA SILVA PEREIRA, Instituições (...), cit., p. 222; FÁBIO ULHOA COELHO, Curso (...), cit., p. 246; PAULO NADER, Curso (...), cit., p. 235).

${ }^{1121}$ ARNALDO MARMITT, Doação, cit., pp. 216-217; SYLVIO CAPANEMA DE SOUZA, Das Várias (...), cit., p. 158.

${ }^{1122}$ PABLO STOLZE GAGLIANO, O Contrato (...), cit., pp. 85-86.

${ }^{1123}$ Da Doação, cit., pp. 105-106. 
recebedor da benesse ignorava a nulidade, sendo detentor de um justo título ${ }^{1124}$. Tal afirmação tem respaldo no $\S 2^{\mathrm{o}^{1125}}$, do art. 2.004 do Código Civil de $2002^{1126}$. Ademais, no caso de a coisa doada ser levada à colação e se constatar excesso, pelo que ela retorna à herança, não responderá o donatário pelos frutos que percebeu até então ${ }^{1127}$.

Outrossim, por o donatário estar na posse do bem e por ter justo título, corre ao seu favor prazo de prescrição aquisitiva, podendo inclusive ser alegada em sede de exceção, quando da colação ${ }^{1128}$.

PABLO STOLZE GAGLIANO ${ }^{1129}$ entende haver contradição entre o art. 2.002 e o $\S 2^{\circ}$ do art. $2.007^{1130}$, ambos do Código Civil de 2002, pois o primeiro dispõe que preferencialmente leva-se à colação numerário correspondente ao valor da benesse à época do ato, ao passo que no segundo dispositivo legal impõe-se que a colação seja feita preferencialmente com os bens doados que levaram à inoficiosidade, e só excepcionalmente em espécie. Afirma ${ }^{1131}$, assim, que deve prevalecer, como regra, a possibilidade de primeiro o donatário reparar a inoficiosidade por meio de dinheiro e só se não houver meios é que se retorna o bem para o acervo hereditário, até em vista da função social da propriedade, pois foi dada à coisa alguma destinação econômica.

Ademais, se o bem trazido à colação tiver sido objeto de doação com encargo e se o donatário tiver dado cumprimento ao modo, então o espólio deverá indenizá-lo por isso, tendo o donatário, inclusive, direito de retenção. Caso a doação seja um negotium mixtum, como parte do bem doado foi dado em pagamento justo e a outra parte em liberalidade, a

\footnotetext{
${ }^{1124}$ PABLO STOLZE GAGLIANO, O Contrato (...), cit., pp. 82-83.

$1125 \S 2^{\circ}$ "A redução da liberalidade far-se-á pela restituição ao monte do excesso assim apurado; a restituição será em espécie, ou, se não mais existir o bem em poder do donatário, em dinheiro, segundo o seu valor ao tempo da abertura da sucessão, observadas, no que forem aplicáveis, as regras deste Código sobre a redução das disposições testamentárias".

${ }^{1126}$ PABLO STOLZE GAGLIANO, O Contrato (...), cit., p. 85.

1127 AGOSTINHO ALVIM, Da Doação, cit., pp. 174-179; FLÁVIO AUGUSTO MONTEIRO DE BARROS, Manual (...), cit., p. 355.

${ }^{1128}$ LUCIANO DE CAMARGO PENTEADO, Doação (...), cit., p. 164.

${ }^{1129}$ O Contrato (...), cit., p. 88.

1130 Art. 2.007. "São sujeitas à redução as doações em que se apurar excesso quanto ao que o doador poderia dispor, no momento da liberalidade. [...] $\S 2^{\circ}$ A redução da liberalidade far-se-á pela restituição ao monte do excesso assim apurado; a restituição será em espécie, ou, se não mais existir o bem em poder do donatário, em dinheiro, segundo o seu valor ao tempo da abertura da sucessão, observadas, no que forem aplicáveis, as regras deste Código sobre a redução das disposições testamentárias. [...]”.

${ }^{1131}$ O Contrato (...), cit., p. 89.
} 
colação não se poderá realizar pela devolução da coisa, mas sim em numerário, somente na parte em que for doação, a fim de garantir a igualdade entre os herdeiros ${ }^{1132}$.

Como se verifica, é plenamente possível no direito brasileiro os ascendentes fazerem doação aos descendentes, desde que observadas algumas regras legais.

Assim, deverá o doador saber de antemão que está a antecipar a herança que o donatário iria receber. Caso queira afastar esse efeito, deverá fazer constar expressamente do instrumento que está a alienar gratuitamente a sua cota disponível ou dispensar o donatário de trazer o bem doado à colação, o que tem o mesmo efeito. Se porventura assim não se conduziu o disponente no momento da liberalidade, nada impede que o faça posteriormente, desde que sejam observados os mesmo requisitos formais da doação.

Na hipótese de o doador não querer adiantar a legítima de algum herdeiro seu, ainda assim poderá doar aos outros descendentes à revelia do não contemplado, seja qual for o motivo, porque a lei não exige a anuência de todos os descendentes e garante a esse último a oportunidade da colação, o que permite, inclusive, a possibilidade de estipular aceitação da doação em momento posterior à liberalidade.

Cabe ao doador, ainda, observar duas medidas importantes, se o caso: cuidar para que os donatários absolutamente incapazes estejam devidamente representados e os relativamente incapazes assistidos; e, se casado, contar com a anuência do cônjuge.

Tendo em vista a exigência da colação, importa ao doador curar para que a liberalidade não avance sobre a legítima dos herdeiros necessários, sendo o donatário um descendente ou não, mas no caso de se tratar de neto seu cujo genitor descendente ainda esteja vivo, é dispensá-lo da colação, se assim o quiser, pois pode ocorrer de se tornarem herdeiros por representação.

De todo modo, é importante observar com rigor as proporções, a fim de evitar maiores transtornos posteriores. É certo que, para fins fiscais, necessariamente terá de fazer constar no instrumento os valores dos bens ${ }^{1133}$, mas é importante que haja um consenso nesse

\footnotetext{
${ }^{1132}$ LUCIANO DE CAMARGO PENTEADO, Doação (...), cit., pp. 300-302.

${ }^{1133} \mathrm{Na}$ realização do planejamento, deve-se ter em conta que o Superior Tribunal de Justiça já decidiu que a doação de imóvel não é fato gerador de imposto de renda, não incidindo ao caso o art. 43 do Código Tributário Nacional (Art. 43. "O imposto, de competência da União, sobre a renda e proventos de qualquer natureza tem como fato gerador a aquisição da disponibilidade econômica ou jurídica: I - de renda, assim entendido o produto do capital, do trabalho ou da combinação de ambos; II - de proventos de qualquer natureza, assim entendidos os acréscimos patrimoniais não compreendidos no inciso anterior. § $1^{\circ} \mathrm{A}$
} 
sentido e que se utilize um critério avaliativo objetivo e cláusula expressa em que doador e donatários concordam com os valores imputados aos bens, a fim de evitar discussão futura.

\section{6) Doação inoficiosa}

Como se verifica na redação do art. $549^{1134}$ do Código Civil de 2002, o doador recebe da lei uma limitação equiparada à do testador, que, segundo o art. $1.789^{1135}$ do mesmo diploma legal, só pode destinar aos legatários apenas metade de seu patrimônio, de maneira que se a doação ultrapassar essa barreira se torna o que a dogmática jurídica classifica por inoficiosa. Assim, a doação inoficiosa consiste no doador privar os seus herdeiros necessários de seus respectivos direitos sucessórios sem a devida base legal para tanto ${ }^{1136}$, ou seja, quem tem herdeiros necessários não pode doar metade de seus bens ${ }^{1137}$.

Segundo VICENTE SABINO JÚNIOR ${ }^{1138}$, certa doutrina cogita na possibilidade de se fundamentar o regime da inoficiosidade das doações no enriquecimento ilícito, mas o autor nega a aplicabilidade de tal tese no sistema civil brasileiro, pois a inoficiosidade não decorre de suposto pagamento indevido, tendo outro fundamento.

A inoficiosidade deve ser entendida junto com a disciplina do testamento, pois também nesse instituto é vedado ao testador que tenha herdeiros necessários dispor de mais da metade de sua herança, em proteção à legítima dos herdeiros ${ }^{1139}$. Assim, o sistema cria uma rede protetiva da legítima que não pode ser de nenhum modo ultrapassada ${ }^{1140}$.

incidência do imposto independe da denominação da receita ou do rendimento, da localização, condição jurídica ou nacionalidade da fonte, da origem e da forma de percepção (Incluído pela LCP $\mathrm{n}^{\circ}$ 104, de 10.1.2001); $\S 2^{\circ} \mathrm{Na}$ hipótese de receita ou de rendimento oriundos do exterior, a lei estabelecerá as condições e o momento em que se dará sua disponibilidade, para fins de incidência do imposto referido neste artigo (Incluído pela LCP $\mathrm{n}^{\mathrm{o}}$ 104, de 10.1.2001”), porque há, em verdade, redução patrimonial (2a T., R. Esp. n. 675271/RS, rel. ELIANA CALMON, j. 13-09-2005), de maneira que não precisa se preocupar o doador com esse passivo.

1134 Art. 549. "Nula é também a doação quanto à parte que exceder à de que o doador, no momento da liberalidade, poderia dispor em testamento".

${ }_{1135}$ Art. 1.789. "Havendo herdeiros necessários, o testador só poderá dispor da metade da herança".

${ }^{1136}$ AMANDA ZOE MORRIS, Doação, cit., p. 280; FLÁVIO AUGUSTO MONTEIRO DE BARROS, Manual (...), cit., p. 352; VICENTE SABINO JÚNIOR, Contrato (...), cit., p. 37.

${ }^{1137}$ MARIA HELENA DINIZ, Tratado (...), cit., p. 85; VICENTE SABINO JÚNIOR, Contrato (...), cit., p. 80. Em defesa desse princípio protetivo dos herdeiros, o Superior Tribunal de Justiça reputou por inoficiosa a alienação de toda a propriedade do varão à virago, com reserva de usufruto vitalício ao disponente, em virtude de acordo celebrado em sede de separação, afirmando a Corte que nesse caso o ato de transferência se reputa gratuito, pois que desfalcou a legítima de herdeiro necessário, no caso filho do primeiro casamento do marido separando (3 ${ }^{\mathrm{a}}$ T., R. Esp. n. 1.217.154/DF, rel. NANCY ANDRIGHI, j. 15-05-2014).

1138 Contrato (...), cit., p. 122.

1139 ARNALDO MARMITT, Doação, cit., pp. 197; ARNALDO RIZZARDO, Contratos, cit., p. 460; CARLOS ROBERTO GONÇALVES, Direito (...), vol. III, cit., p. 269; NATAL NADER, Questões Relativas à Doação, cit., p. 459; PAULO GERALDO DE OLIVEIRA MEDINA, A Doação, cit., p. 470; PAULO LÔBO, Das 
Vale ressaltar que a inoficiosidade não é caracterizada apenas pelo excesso. AGOSTINHO ALVIM ${ }^{141}$ explica que há outros tipos de excessos na doação igualmente proibidos pela lei, como a de mais da metade dos bens de um nubente a outro, conforme o art. $312^{1142}$ do Código Civil de 1916, ou a universal, todavia, explica o autor, o adjetivo inoficiosa somente se aplica à espécie ora comentada porque importa na quebra do dever de ofício do pai em preservar a legítima de seus filhos.

Assim, ligado ao conceito de inoficiosidade, está o conceito de legítima, parte da herança reservada por lei aos herdeiros necessários ${ }^{1143}$. De acordo com o art. $1.845^{1144}$ do Código Civil de 2002, os herdeiros necessários são os descendentes, os ascendentes e o cônjuge do autor da herança, os quais têm direito à legítima, que, segundo o art. $1.846^{1145}$ do mesmo diploma, consiste na metade dos bens do falecido ${ }^{1146}$.

PABLO STOLZE GAGLIANO ${ }^{1147}$, no entanto, pensa que a proteção legal reservada aos herdeiros necessários se dá por questões meramente de estabilidade financeira, e externa opinião de que acha duvidosa a eficácia social e a justiça dessa proteção, pois seria causa de intermináveis contendas entre parentes; injustificado e arcaico cerceamento à liberdade de testar; e, contrário à liberdade constitucional de dispor inerente ao direito de propriedade, sendo que entende como único limite justo se os descendentes forem menores ou dotados de alguma incapacidade.

Com efeito, LUCIANO DE CAMARGO ${ }^{1148}$ também opina no sentido de que a proibição à doação inoficiosa é uma hipótese de limitação ao direito de propriedade, mas vê

Várias (...), cit., p. 333; PONTES DE MIRANDA, Tratado (...), cit., p. 254; SILVIO RODRIGUES, Direito (...), cit., p. 207; SYLVIO CAPANEMA DE SOUZA, Das Várias (...), cit., p. 192.

${ }^{1140}$ FÁBIO ULHOA COELHO, Curso (...), cit., pp. 245-246; JOÃO LUIZ ALVES, Código (...), vol. II, cit., p. 250; NATAL NADER, Questões Relativas à Doação, cit., p. 460; NELSON ROSENVALD, Contratos (...), cit., p. 592; SÍLVIO DE SALVO VENOSA, Direito (...), cit., p. 130; SILVIO RODRIGUES, Direito (...), cit., p. 208; WASHINGTON DE BARROS MONTEIRO-DABUS MALUF, Curso (...), cit., p. 174.

${ }^{1141}$ Da Doação, cit., p. 170-171.

${ }^{1142}$ Art. 312. "Salvo o caso de separação obrigatória de bens (art. 258, parágrafo único), é livre aos contraentes estipular, na escritura antenupcial, doações recíprocas, ou de um ao outro, contanto que não excedam à metade dos bens do doador (arts. 263, VIII, e 232, II)".

${ }^{1143}$ CARVAlHO SANTOS, Código (...), cit., p. 404; JONES FIGUEIRÊDO ALVES, Código (...), cit., p. 452; PABLO STOLZE GAGLIANO, O Contrato (...), cit., p. 56.

${ }^{1144}$ Art. 1.845. "São herdeiros necessários os descendentes, os ascendentes e o cônjuge".

1145 Art. 1.846. "Pertence aos herdeiros necessários, de pleno direito, a metade dos bens da herança, constituindo a legítima".

${ }^{1146}$ No mesmo sentido: FÁBIO ULHOA COELHO, Curso (...), cit., p. 245; JONES FIGUEIRÊDO ALVES, Código (...), cit., p. 452; LUIZ GUILHERME LOUREIRO, Curso (...), cit., p. 516; PAULO LÔBO, Das Várias (...), cit., p. 333; SYLVIO CAPANEMA DE SOUZA, Das Várias (...), cit., p. 192.

1147 O Contrato (...), cit., pp. 58-60.

${ }^{1148} \operatorname{Doação~(...),~cit.,~p.~} 160$. 
nessa especificidade não um limitante vetusto à liberdade individual, mas sim um elemento que ressalta a socialização desse direito. Desse modo, à evocada "liberdade constitucional de dispor inerente ao direito de propriedade" antepõe-se o igualmente princípio constitucional da função social da propriedade.

Voltando-se ao tema principal deste item, tem-se que a inoficiosidade se verifica quando o doador, tendo herdeiros necessários, faz liberalidade desrespeitando a legítima que lhes reserva a norma civil ${ }^{1149}$. Desse modo, se o doador não tiver herdeiros necessários, então não há que se preocupar com a inoficiosidade, mas caso os tenha, então a metade excedente será nula ${ }^{1150}$.

Outrossim, deve-se considerar que se o doador for casado no regime da comunhão universal de bens, terá de respeitar a meação do outro cônjuge, pelo que somente poderá doar um quarto de todo o patrimônio, de modo que para aferição da legítima deve-se subtrair a meação ${ }^{1151}$.

A inoficiosidade poderá se observar também nos atos simulados, de modo que se houver uma doação disfarçada em contrato de compra e venda, e essa exceder a legítima dos herdeiros, então deverá ser reduzida, mantendo-se a liberalidade na parte disponível ${ }^{1152}$.

Pode haver também inoficiosidade na hipótese de doações sucessivas, seja a um mesmo donatário, seja a pessoas diferentes, mas a redução recairá apenas na última doação que se tornou inoficiosa ${ }^{1153}$. Deve-se ter por parâmetro a situação econômica do doador no

${ }^{1149}$ AGOSTINHO ALVIM, Da Doação, cit., p. 170; CÉSAR FIUZA, Direito (...), cit., p. 510; CHRISTIANO CASSETARI, Elementos (...), cit., p. 214; NATAL NADER, Questões Relativas à Doação, cit., p. 459.

${ }^{1150}$ FLÁVIO AUGUSTO MONTEIRO DE BARROS, Manual (...), cit., p. 352; LUCIANO DE CAMARGO PENTEADO, Doação (...), cit., p. 161; LUIZ GUILHERME LOUREIRO, Curso (...), cit., p. 516; PAULO LÔBO, Direito (...), cit., p. 304; PONTES DE MIRANDA, Tratado (...), cit., p. 250; SILVIO RODRIGUES, Direito (...), cit., p. 208.

Nesse sentido, há ainda um julgado do Superior Tribunal de Justiça em que se debruçou sobre doação realizada a dois filhos, tendo sido preterido um terceiro, à época nascituro de cuja existência o doador tinha plena ciência, tendo sido considerado no voto condutor do acórdão que até poderia haver inoficiosidade, mas no caso concreto ficou demonstrado que não houve avanço de legítima, pelo cômputo do acervo patrimonial do disponente ( $3^{\text {a }}$ T., R. Esp. n. 1.198.168/RJ, rel. NANCY ANDRIGH, j. 22-08-2013). Conferir ainda, do mesmo órgão judicante: $4^{\mathrm{a}}$ T., R. Esp. n. 112.254/SP, rel. FERNANDO GONÇALVES, j. 16-11-2004.

${ }^{1151}$ VICENTE SABINO JÚNIOR, Contrato (...), cit., pp. 52-53.

1152 ARNALDO MARMITT, Doação, cit., pp. 207-208; NATAL NADER, Questões Relativas à Doação, cit., pp. 463-464.

${ }^{1153}$ ARNALDO MARMITT, Doação, cit., pp. 210-211; CARLOS ROBERTO GONÇALVES, Direito (...), vol. III, cit., p. 270; CARVALHO SANTOS, Código (...), cit., pp. 411-412; NATAL NADER, Questões Relativas à Doação, cit., p. 460; NELSON ROSENVALD, Contratos (...), cit., p. 592; PONTES DE MIRANDA, Tratado (...), cit., pp. 254-255; SYLVIO CAPANEMA DE SOUZA, Das Várias (...), cit., p. 193. 
momento da realização da primeira benesse ${ }^{1154}$, para se evitar que o doador sempre vá doando metade dos seus bens, até esgotá-los, em evidente fraude à lei ${ }^{1155}$. Havendo inoficiosidade, a redução deverá se iniciar pela última liberalidade realizada, até ser reposta a legítima ${ }^{1156}$. Em sendo doações simultâneas, a redução atingirá cada uma das liberalidades na sua proporção $^{1157}$.

Outrossim, poderá haver inoficiosidade em doações realizadas no bojo da partilha em sede de ação de separação ou divórcio, bem como nas doações antenupciais ${ }^{1158}$.

No tocante aos filhos, deverão receber tratamento diferenciado em relação aos estranhos quanto à inoficiosidade, pois o doador poderá doar aos seus filhos a sua parte disponível e a parte que lhes competir por legítima ${ }^{1159}$.

A esse respeito, AGOSTINHO ALVIM ${ }^{1160}$ leciona que na doação de pai para filho poderá ocorrer de o doador dispor da parte disponível mais a legítima correspondente ao descendente, sem com isso incorrer em inoficiosidade, pois o se conceito decorre do art. $1.790^{1161}$ do mesmo diploma, que faz a separação entre a parte disponível e a legítima e dá abertura para sua somatória. Essa interpretação é aplicável à atual redação do art. 2.008 do Código Civil de 2002.

${ }^{1154}$ FLÁVIO AUGUSTO MONTEIRO DE BARROS, Manual (...), cit., pp. 352-353; PAULO LÔBO, Direito (...), cit., p. 304; PAULO NADER, Curso (...), cit., p. 235.

${ }^{1155}$ AGOSTINHO ALVIM, Da Doação, cit., p. 191; CARLOS ROBERTO GONÇALVES, Direito (...), vol. III, cit., p. 270. Ressalte-se, porém, que, enquanto o doador não tiver herdeiros necessários, poderá doar livremente, de modo que leva-se em conta apenas as doações realizadas em momento posterior ao surgimento de herdeiros [NELSON ROSENVALD, Contratos (...), cit., p. 592; PONTES DE MIRANDA, Tratado (...), cit., pp. 250-251].

${ }^{1156}$ AGOSTINHO ALVIM, Da Doação, cit., p. 191.

${ }^{1157}$ ARNALDO MARMITT, Doação, cit., pp. 210-211; CARVALHO SANTOS, Código (...), cit., p. 412; LUIZ GUILHERME LOUREIRO, Curso (...), cit., p. 517; NATAL NADER, Questões Relativas à Doação, cit., p. 460.

${ }^{1158}$ PABLO STOLZE GAGLIANO, O Contrato (...), cit., p. 57; PONTES DE MIRANDA, Tratado (...), cit., p. 251.

Nesse sentido, já se posicionou o Superior Tribunal de Justiça no âmbito da separação: $3^{a}$ T., R. Esp. n. 154.948/RJ, rel. WALDEMAR ZVEITER, j. 19-02-2001. A mesma Corte também já declarou inoficiosa doação antenupcial: $3^{a}$ T., R. Esp. n. 5.325/SP, rel. WALDEMAR ZVEITER, j. 20-11-1990.

1159 ARNALDO MARMITT, Doação, cit., pp. 149-151; FLÁVIO AUGUSTO MONTEIRO DE BARROS, Manual (...), cit., p. 352

Não obstante, não poderá o doador, nesse caso, dispensar de se levar à colação toda a liberalidade, senão incorrerá em inoficiosidade, pois ficará adulterado o cálculo da legítima dos herdeiros, como já decidiu o Superior Tribunal de Justiça: $4^{a}$ T., R. Esp. n. 86.518/MS, rel. SÁLVIO DE FIGUEIREDO TEIXEIRA, j. 01 09-1998.

${ }^{1160}$ Da Doação, cit., pp. 172-173

${ }^{1161}$ Art. 1.790. "O que renunciou à herança, ou foi dela excluído, deve, não obstante, conferir as doações recebidas, para o fim de repor a parte inoficiosa. Parágrafo único. Considera-se inoficiosa a parte da doação, ou do dote, que exceder a legítima e mais a metade disponível". 
Cabe também perquirir se a inoficiosidade da doação é hipótese de nulidade ou de anulabilidade.

Para alguns autores ${ }^{1162}$ a doação inoficiosa é nula.

Neste sentido, PABLO STOLZE GAGLIANO ${ }^{1163}$ afirma que a proteção legal da legítima é de interesse público. Ademais, pondera que, como se verifica na redação dos arts. $496^{1164}, 533$, II ${ }^{165}$, 550, caput, $1.558^{1166}$ e $2.027^{1167}$, todos do Código Civil de 2002, o legislador civil afirma explicitamente quando é hipótese de ato jurídico anulável, ao passo que inaugura a redação do art. 549 com a locução "é nulo", sendo que no dispositivo seguinte, o 550, a redação legal afirma ser caso de anulabilidade, de modo que há elementos suficientes para se concluir que a doação inoficiosa representa hipótese de nulidade absoluta.

Contra a conclusão de se tratar de nulidade, o mesmo autor ${ }^{168}$ levanta a objeção de que ela representaria constante insegurança, pois como o já transcrito art. 169 do Código Civil de 2002 impõe a imprescritibilidade dos atos nulos, então o donatário poderia ver revogada a benesse a qualquer tempo ${ }^{1169}$, mas responde que o manto da imprescritibilidade ou ausência de decadência só vale para o ato em si, não para seus efeitos patrimoniais, de modo que incide o prazo geral do art. $205^{1170}$ do Código Civil sobre eventual pretensão de perdas e danos ou ação reivindicatória.

Por fim, avocando o autor ${ }^{1171}$ de novo o interesse público no resguardo da legítima e a redação do art. 549 do Código Civil de 2002, acaba por concluir que a doação inoficiosa é nula de pleno direito, até porque admitir o contrário representaria uma injustiça,

1162 CARLOS ALBERTO BITTAR, Contratos (...), cit., pp. 45-46; LIMONGI FRANÇA, Manual (...), cit., p. 101; ORLANDO GOMES, Contratos, cit., p. 242; OZÉIAS J. SANTOS, Da Doação, cit., p. 24; SAMUEL LUIZ ARAÚJO, O Princípio (...), cit., p. 84; VICENTE SABINO JÚNIOR, Contrato (...), cit., p. 52.

${ }^{1163}$ O Contrato (...), cit., pp. 67-68.

1164 Art. 496. "É anulável a venda de ascendente a descendente, salvo se os outros descendentes e o cônjuge do alienante expressamente houverem consentido".

1165 Art. 533. "Aplicam-se à troca as disposições referentes à compra e venda, com as seguintes modificações: [...]; II - é anulável a troca de valores desiguais entre ascendentes e descendentes, sem consentimento dos outros descendentes e do cônjuge do alienante".

${ }^{1166}$ Art. 1.558. "É anulável o casamento em virtude de coação, quando o consentimento de um ou de ambos os cônjuges houver sido captado mediante fundado temor de mal considerável e iminente para a vida, a saúde e a honra, sua ou de seus familiares".

${ }^{1167}$ Art. 2.027. "A partilha, uma vez feita e julgada, só é anulável pelos vícios e defeitos que invalidam, em geral, os negócios jurídicos".

1168 O Contrato (...), cit., p. 69.

1169 Assim, entendo que seja hipótese de anulabilidade, justamente por haver prescrição: JONES FIGUEIRÊDO ALVES, Código (...), cit., p. 453.

${ }^{1170}$ Art. 205. "A prescrição ocorre em dez anos, quando a lei não lhe haja fixado prazo menor".

${ }^{1171}$ O Contrato (...), cit., pp. 70-71. 
vez que o biênio do art. $179^{1172}$ do Código Civil de 2002 é muito exíguo em se tratando de conflitos familiares.

Também para VICENTE SABINO JÚNIOR ${ }^{1173}$ o respeito à legítima é questão de ordem pública ${ }^{1174}$, devendo a lei sobrepujar a vontade do doador.

AGOSTINHO ALVIM ${ }^{1175}$, por seu turno, pondera que a favor do entendimento dos que acham que a doação inoficiosa seja hipótese de nulidade relativa pode-se argumentar que a legítima é passível de renúncia, o que não costuma ocorrer nas questões de ordem pública. Ademais, pode ocorrer que o filho lesado, por questões afetivas, prefira não contrariar uma liberalidade feita pelos seus pais, ou pode ser que estes tenham doado em excesso a filho menos favorecido economicamente, sendo delicado o magistrado interferir ex officio em questões de tal jaez, o que torna recomendável considerar o ato apenas como anulável.

Não obstante, engrossa o autor ${ }^{1176}$ as fileiras dos que, como o legislador civil de 1916, entendem que a doação inoficiosa é hipótese de nulidade absoluta. Um argumento que levanta em favor da tese é que, sendo nulo o negócio, então a sentença que o declara terá efeito ex tunc, o que se afigura mais justo, pois, em geral, o filho lesado só vem a descobrir a inoficiosidade muito depois, pois não é necessária sua anuência no nascedouro da liberalidade feita inoficiosamente.

Quanto à questão da intervenção ex officio do juiz na matéria, pondera ${ }^{1177}$ que, na prática, não se verifica, pois ele somente assim o faz se a nulidade absoluta estiver provada cabalmente, sendo difícil de se verificar um instrumento de doação no qual conste todo o patrimônio do doador e o rol dos seus herdeiros necessários, até porque se isso acontecesse o tabelião dificilmente lavraria escritura em que a inoficiosidade é tão patente, de modo que esse argumento não colhe razão.

De qualquer forma, a nulidade recai apenas sobre a parte excedente ${ }^{1178}$, daí a consequencia de haver redução da liberalidade ${ }^{1179}$, que pode se extinguir ou não, a depender

\footnotetext{
1172 Art. 179. "Quando a lei dispuser que determinado ato é anulável, sem estabelecer prazo para pleitear-se a anulação, será este de dois anos, a contar da data da conclusão do ato".

1173 Contrato (...), cit., p. 81.

${ }^{1174}$ No mesmo sentido: FLÁVIO TARTUCE, Direito (...), cit., p. 324.

${ }^{1175}$ Da Doação, cit., pp. 183-184.

${ }^{1176}$ Da Doação, cit., pp. 182-183.

${ }^{1177}$ Da Doação, cit., pp. 185-186.

${ }^{1178}$ ANTÔNIO CHAVES, Lições (...), cit., p. 240; FÁBIO ULHOA COELHO, Curso (...), cit., p. 246; FLÁVIO
} 
do quanto for necessário para repor a legítima dos herdeiros. Ou seja, enquanto a lei proíbe a doação universal, apenas limita a inoficiosa ${ }^{1180}$.

Há na doutrina intenso debate sobre o momento do cômputo ou da ocorrência da inoficiosidade da doação. Como se verifica na redação do art. 549 do Código Civil de 2002, o excesso ocorre no momento da liberalidade, e o mesmo dispunha o art. 1.176 do Código Civil de 1916. Como o legislador quer proteger a legítima, logo é válida a doação que não ultrapassar a metade do patrimônio do doador, sendo que a data-base para se efetuar o cálculo da inoficiosidade será o da doação ${ }^{1181}$.

CLOVIS BEVILAQUA ${ }^{1182}$ afirma que dois foram os problemas que se tentaram sanar com a previsão legal de se calcular a oficiosidade no momento da liberalidade: em primeiro lugar, explica o autor a necessidade de dar segurança jurídica ao ato e estabilidade no direito dominial, pois uma vez recebida a benesse o donatário tem direito de dispor sobre o bem; outrossim, o doutrinador considera injusto o sistema de aferição na abertura da sucessão, porque poderia levar ao empobrecimento do donatário em função dos outros herdeiros ${ }^{1183}$.

No sistema civil atual, para se calcular a inoficiosidade, deve-se, no momento da benesse, somarem-se todas as liberalidades feitas pelo doador até então, acrescer o valor do bem que será doado e computar os débitos, para, só então, verificar se houve dano ou não à $\operatorname{legítima~}^{1184}$.

AUGUSTO MONTEIRO DE BARROS, Manual (...), cit., p. 352; FLÁVIO TARTUCE, Direito (...), cit., p. 324; JONES FIGUEIRÊDO ALVES, Código (...), cit., p. 451; MARIA HELENA DINIZ, Tratado (...), cit., p. 85; PAULO GERALDO DE OLIVEIRA MEDINA, A Doação, cit., p. 470; PAULO LÔBO, Das Várias (...), cit., p. 333; SILVIO LUÍS FERREIRA DA ROCHA, Curso (...), cit., p. 182; SILVIO RODRIGUES, Direito (...), cit., p. 210; SYLVIO CAPANEMA DE SOUZA, Das Várias (...), cit., p. 193.

${ }^{1179}$ CAIO MÁRIO DA SILVA PEREIRA, Instituições (...), cit., p. 221; CÉSAR FIUZA, Direito (...), cit., p. 510; LUIZ GUILHERME LOUREIRO, Curso (...), cit., p. 516; MARIA HELENA DINIZ, Curso (...), cit., p. 263; NATAL NADER, Questões Relativas à Doação, cit., p. 459; ORLANDO GOMES, Contratos, cit., p. 238; PAULO NADER, Curso (...), cit., p. 235; WASHINGTON DE BARROS MONTEIRO-DABUS MALUF, Curso (...), cit., p. 174.

${ }^{1180}$ PONTES DE MIRANDA, Tratado (...), cit., p. 244.

${ }^{1181}$ PABLO STOLZE GAGLIANO, O Contrato (...), cit., p. 60; SÍlVIO DE SALVO VENOSA, Direito (...), cit., p. 130.

${ }^{1182}$ Código (...), cit., pp. 279-280.

1183 Confrontar: EDUARDO ESPINOLA, Dos Contratos (...), cit., pp. 166-167; PONTES DE MIRANDA, Tratado (...), cit., pp. 252-253.

${ }^{1184}$ ARNALDO MARMITT, Doação, cit., pp. 202-205; CARVALHO SANTOS, Código (...), cit., pp. 405-410 (o autor defende que as dívidas deverão ser levadas em conta primeiro e calcular-se a inoficiosidade do que houver de débito); JOÃO LUIZ ALVES, Código (...), vol. II, cit., p. 250. 
PABLO STOLZE GAGLIANO ${ }^{1185}$ concorda com tal opção legislativa, porque o contrário traria insegurança, no seu entender ${ }^{1186}$, e defende também que a previsão legal respeita expressa regulamentação do Código, conforme se verifica na redação do art. $2.004^{1187}$ do Código Civil de $2002^{1188}$.

Já para VICENTE SABINO JÚNIOR ${ }^{1189}$, o excesso se afere no momento da morte do doador, sendo que eventuais bens doados em inoficiosidade voltarão a compor a herança e serão partilhados entre os herdeiros, sem que os credores possam formular reclamação. Assim, prefere ${ }^{1190}$ explicar o fato de o cálculo da inoficiosidade ser a data da doação afirmando que, para a lei, é como se o doador tivesse falecido no momento da liberalidade, e aduz que tal critério dá ensejo a outras injustiças, pelo que é da opinião de que sempre poderá haver motivos para quaisquer dos herdeiros promoverem a ação de anulação, o que seria, por coerência, admissível.

AGOSTINHO ALVIM ${ }^{1191}$ também critica o fato de o excesso ser apurável no momento da liberalidade, pois se houver várias doações, então terá de se verificar eventual inoficiosidade em todas ocasiões, o que seria pouco prático. Ademais, a aferição do excesso no momento da liberalidade põe a descoberto os demais herdeiros se houver empobrecimento do genitor, o que contraria o conceito de "comunhão familial", sendo mais razoável exigir-se do donatário que abra mão de seu patrimônio pelos seus outros irmãos, até porque ele já goza de razoável proteção legal.

Dentro da mesma linha crítica, o autor ${ }^{1192}$ aventa a hipótese de um pai que doa toda a sua parte disponível para um dos filhos e depois dissipa a outra metade e vem a falecer. Se aplicada a costumeira interpretação do art. 1.176 do Código Civil de 1916, a doação terá

\footnotetext{
1185 O Contrato (...), cit., p. 61.

${ }^{1186}$ Esse também é o ensinamento de SILVIO RODRIGUES [Direito (...), cit., p. 208].

1187 Art. 2.004. "O valor de colação dos bens doados será aquele, certo ou estimativo, que lhes atribuir o ato de liberalidade".

1188 Também concordando com a lei: CHRISTIANO CASSETARI, Elementos (...), cit., p. 214; MARIA HELENA DINIZ, Tratado (...), cit., p. 85; PAULO LÔBO, Das Várias (...), cit., p. 333; PAULO NADER, Curso (...), cit., p. 235; SAMUEL LUIZ ARAÚJO, O Princípio (...), cit., p. 85; WASHINGTON DE BARROS MONTEIRO-DABUS MALUF, Curso (...), cit., p. 175.

O Superior Tribunal de Justiça firmou posição nesse mesmo sentido: 2a Seção, Aç. Resc. n. 3.493/PE, rel. MASSAMI UYEDA, j. 12-12-2012; 3 ${ }^{\mathrm{a}}$ T., R. Esp. n. 111.426/ES, rel. EDUARDO RIBEIRO, j. 19-11-1998 (o julgado destaca que o termo inicial não é o registro na matrícula do imóvel, mas sim a lavratura da escritura de doação).

1189 Contrato (...), cit., p. 37.

${ }^{1190}$ Contrato (...), cit., p. 81.

${ }^{1191}$ Da Doação, cit., pp. 173-174.

${ }^{1192}$ Da Doação, cit., p. 173.
} 
sido válida e os demais herdeiros nada terão a reclamar, pois à época da liberalidade a benesse foi legal. Entende, porém, que a correta aplicação do artigo está em compreender que ele serve apenas para que os herdeiros possam fulminar de nulidade eventuais munificências que o patriarca possa fazer em flagrante prejuízo à sua legítima, sem ter que esperarem pelo seu decesso. Ir além disso é admitir a iniquidade e afirma que o dispositivo arrebata a proteção da legítima, o que não se pode cogitar, haja vista que a lei e a doutrina colocam-na num invólucro inquebrantável.

\section{Aliás, por esse mesmo motivo, LUCIANO DE CAMARGO PENTEADO ${ }^{1193}$} entende que a doação feita a descendente vai para a colação a fim de igualar a legítima, pois pode ser que por causa superveniente ela se tornou inoficiosa, mas ressalva que o valor base será o data da liberalidade ${ }^{1194}$.

No entanto, a maior parte da doutrina ${ }^{1195}$ entende que mesmo na hipótese de empobrecimento superveniente do doador persiste a doação, se à época da liberalidade foi observado o regramento do art. 549 do Código Civil de 2002.

Para que se discuta em juízo a ocorrência de eventual inoficiosidade da doação, deve-se manejar o que a doutrina comumente chama de ação de redução ou ação de nulidade, haja vista que a doação inoficiosa induz à nulidade do ato, na parte excedente. Há extenso debate sobre o momento em que nasce para o autor a pretensão de exercer o direito de propor tal demanda ${ }^{1196}$.

VICENTE SABINO JÚNIOR ${ }^{1197}$ explica que alguns autores entendem que o início da pretensão para se promover a sobredita demanda se dá quando da doação, ao passo que para outros ela nasceria somente da abertura da sucessão e se filia a essa segunda corrente, pois para ele deve-se verificar nessa ocasião o excesso, já que a aferição do valor do

\footnotetext{
${ }^{1193}$ Doação (...), cit., p. 161.

${ }^{1194}$ Em sentindo contrário, entendendo que a inoficiosidade se mede no momento da liberalidade, independente de enriquecimento posterior do doador: LUIZ GUILHERME LOUREIRO, Curso (...), cit., p. 516; NELSON ROSENVALD, Contratos (...), cit., p. 592; PAUlO LÔBO, Direito (...), cit., p. 305; PONTES DE MIRANDA, Tratado (...), cit., p. 254.

1195 Afora os que foram acima citados, manifestam-se nesse sentido: AMANDA ZOE MORRIS, Doação, cit., p. 280; FÁBIO ULHOA COELHO, Curso (...), cit., p. 246; FLÁVIO AUGUSTO MONTEIRO DE BARROS, Manual (...), cit., p. 352; LUIZ GUILHERME LOUREIRO, Curso (...), cit., p. 516; NATAL NADER, Questões Relativas à Doação, cit., p. 462; NELSON ROSENVALD, Contratos (...), cit., p. 592; PAULO LÔBO, Direito (...), cit., p. 305; SYLVIO CAPANEMA DE SOUZA, Das Várias (...), cit., pp. 194-195.

1196 JONES FIGUEIRÊDO ALVES, Código (...), cit., p. 452; MARIA HELENA DINIZ, Tratado (...), cit., p. 85; NATAL NADER, Questões Relativas à Doação, cit., p. 460; SILVIO RODRIGUES, Direito (...), cit., pp. 209-210; WASHINGTON DE BARROS MONTEIRO-DABUS MALUF, Curso (...), cit., p. 175.

${ }^{1197}$ Contrato (...), cit., pp. 81-82.
} 
bem quando realizada a liberalidade só faz sentido enquanto se presume que o doador teria falecido naquele momento, de modo que, se tiver havido a diminuição do patrimônio do donatário, então fica justificado os herdeiros pleitearem a nulidade do ato.

Na mesma linha, ARNALDO MARMITT ${ }^{1198}$ leciona que por eventual excesso da doação somente ser aferível com a morte do doador, a ação de nulidade somente seria cabível após este evento, pois até então seria "prematura", sendo que os demais descendentes teriam mera expectativa de direito ${ }^{1199}$, de modo que se promovessem a demanda estariam a litigar sobre herança de pessoa viva, o que é vedado pelo art. 1.089 do Código Civil de 1916.

No entanto, entende o doutrinador ${ }^{1200}$ que é possível, ainda em vida do doador, intentar-se ação declaratória do quantum da doação, a fim de acautelar futuro direito dos donatários, e no polo passivo deverão figurar doador e donatário. Todavia, afirma que eventualmente poderá ter efeito anulatório o pleito, de modo que a parte excessiva retornará ao patrimônio do doador, se estiver vivo, ou comporá a quota parte do herdeiro na herança.

Para AGOSTINHO ALVIM ${ }^{1201}$, porém, a ação de nulidade pode ser intentada ainda em vida do doador. Argumenta ${ }^{1202}$ que a existência de doação não exclui a possibilidade de se discutir ainda em vida do doador a benesse realizada e isso até evita a possibilidade de o donatário dissipar a coisa recebida. Além disso, sendo nulidade absoluta, não há justificativa de impor ao herdeiro lesado um tempo de espera ${ }^{1203}$. Por fim, não se trata de discussão de herança de pessoa viva, pois quando o disponente ainda é vivo, então o pedido da ação não será que o bem seja reivindicado ao autor, mas sim que retorne ao patrimônio do próprio doador.

A maior parte da doutrina ${ }^{1204}$ se agrupa junto a esta última tese, inclusive aqueles que dissertaram especificamente sobre o tema ${ }^{1205}$.

\footnotetext{
${ }^{1198}$ Doação, cit., pp. 66-67.

${ }^{1199}$ No mesmo sentido: JOÃ̃ LUIZ ALVES, Código (...), vol. II, cit., p. 250.

${ }^{1200}$ ARNALDO MARMITT, Doação, cit., pp. 200-202.

${ }^{1201}$ Da Doação, cit., p. 172.

1202 Da Doação, cit., pp. 187-188.

1203 Também entendo que por a inoficiosidade ser caso de nulidade absoluta é passível de imediata discussão judicial: NATAL NADER, Questões Relativas à Doação, cit., p. 460.

${ }^{1204}$ ARNALDO RIZZARDO, Contratos, cit., p. 461; FLÁVIO AUGUSTO MONTEIRO DE BARROS, Manual (...), cit., pp. 353-354; FLÁVIO TARTUCE, Direito (...), cit., p. 324; MARIA HELENA DINIZ, Curso (...), cit., p. 263; NELSON ROSENVALD, Contratos (...), cit., p. 592; PAULO LÔBO, Direito (...), cit., p. 305; PONTES DE MIRANDA, Tratado (...), cit., p. 251; SÍLVIO DE SALVO VENOSA, Direito (...), cit., pp. 130-131; SILVIO RODRIGUES, Direito (...), cit., p. 210; WASHINGTON DE BARROS MONTEIRODABUS MALUF, Curso (...), cit., p. 174.
} 
Com efeito, PABLO STOLZE GAGLIANO ${ }^{1206}$ afirma que a pretensão de obter em juízo a nulidade da doação por inoficiosidade surge da disposição liberal, não do falecimento do doador, pois a nulidade nasce da própria benesse. Além disso, pondera o autor que o donatário usaria e gozaria do bem por todo esse tempo sem fazer jus a esse direito, além do que estaria dando ensejo à contagem de prescrição aquisitiva para a usucapião.

LUCIANO DE CAMARGO PENTEADO ${ }^{1207}$ também conclui que a ação de nulidade nasce quando da prática da liberalidade. Pondera que a legítima só pode ser calculada na morte do de cujus, mas, em vista do art. 549 do Código Civil de 2002, é no momento da liberalidade que se verifica o desrespeito à legítima, de modo que ainda em vida do doador poderão os herdeiros necessários buscar a nulidade do ato em face do donatário. Caso o doador tenha se enriquecido posteriormente à doação e estava de boa-fé, ainda assim é cabível a ação, podendo haver ratificação posterior do disponente.

Ademais, mesmo que morto o doador, poderá o filho prejudicado intentar a ação de nulidade, sem prejuízo do inventário, pois a estreita via da colação não lhe permite discutir pretensões de maior envergadura, como a reivindicação do bem, os frutos percebidos desde o ato da benesse ou a persecução até terceiros adquirentes ${ }^{1208}$. Por conta disso, ARNALDO RIZZARDO $^{1209}$ explica que o ingresso da ação de redução pelo herdeiro ainda em vida do doador é uma faculdade dele, pelo que o prazo prescricional passa a fluir apenas com a morte do doador.

Para AGOSTINHO ALVIM ${ }^{1210}$, se por ocasião da colação verificar-se que a liberalidade foi nula quando da realização do ato, mas houve enriquecimento do autor da herança, de modo que então deixou de exceder a legítima, é possível, por analogia ao art. $622^{1211}$ do Código Civil de 1916, considerá-lo convalidado por força de lei, até porque não há interesse jurídico dos outros herdeiros a ser protegido, pois não houve prejuízo ${ }^{1212}$. Por outro

\footnotetext{
${ }^{1205}$ O Superior Tribunal de Justiça também já se manifestou de forma favorável a essa opinião: $3^{\text {a }}$ T., R. Esp. n. 7.879/SP, rel. COSTA LEITE, j. 24-02-1994.

${ }^{1206}$ O Contrato (...), cit., p. 73.

1207 Doação (...), cit., pp. 161-162.

${ }^{1208}$ AGOSTINHO ALVIM, Da Doação, cit., p. 189.

${ }^{1209}$ Contratos, cit., pp. 461-462.

${ }^{1210}$ Da Doação, cit., p. 190.

1211 Art. 622. "Feita por quem não seja proprietário, a tradição não aliena a propriedade. Mas, se o adquirente estiver de boa-fé, e o alienante adquirir depois o domínio, considera-se revalidada a transferência e operado o efeito da tradição, desde o momento do seu ato".

${ }^{1212}$ Como já foi visto, há quem contrarie essa tese: ARNALDO RIZZARDO, Contratos, cit., p. 461.
} 
lado, estando o doador vivo e mesmo que se enriqueça, entende que podem os outros filhos intentarem a demanda competente, pois o disponente corre o risco de vir a empobrecer.

Quanto ao prazo para ingressar com a ação de nulidade, ARNALDO MARMITT $^{1213}$ afirma ser prescricional e vintenária, por se tratar de vínculo pessoal. Explica o doutrinador que o mesmo prazo se aplica na doação disfarçada, pois a simulação é anulável e tem prazo de quatro anos, de acordo com o art. 178, § 9, V, 'b', do Código Civil de 1916, o que seria paradoxal permitir no caso de inoficiosidade, que é nula de pleno direito, ao passo que quando há fraude não o seria ${ }^{1214}$. Ademais, esse é o regime da compra e venda sem anuência dos demais herdeiros, de acordo com a súmula 494 do Supremo Tribunal Federal.

Assim, aplica-se ao caso o prazo geral de prescrição do art. 205 do mesmo diploma legal, pelo que ocorre em dez anos ${ }^{1215}$.

Todavia, segundo PABLO STOLZE GAGLIANO ${ }^{1216}$, por a doação inoficiosa ser ato jurídico nulo, é imprescritível a pretensão de obter-se declaração da nulidade do ato em si ${ }^{1217}$, mas afirma que é de 10 anos o prazo prescricional para se pleitear a reivindicação do bem ou a condenação no pagamento do donatário em perdas e danos ${ }^{1218}$.

Com efeito, PONTES DE MIRANDA ${ }^{1219}$ explica, a esse respeito, que a ação fundada na inoficiosidade não é de declaração de nulidade, porque senão seria imprescritível, mas sim tem natureza subsidiária, daí que a prescrição é da pretensão de reaver o bem que se deveria herdar e que estaria na esfera patrimonial de terceiros.

A legitimidade ativa da ação é dos herdeiros necessários ${ }^{1220}$, sendo que, à luz do art. 1.845 do Código Civil de 2002, não poderá ser proposta pelo companheiro, em que pese o

1213 Doação, cit., pp. 214-215.

${ }^{1214}$ Cf., nesse sentido, os seguintes precedentes do Superior Tribunal de Justiça: $4^{\mathrm{a}}$ T., R. Esp. n. 591.401/SP, rel. CESAR ASFOR ROCHA, j. 23-03-2004; $3^{\text {a }}$ T., R. Esp. n. 115.768, rel. HUMBERTO GOMES DE BARROS, j. 19-02-2004.

1215 ARNALDO RIZZARDO, Contratos, cit., p. 462; SYLVIO CAPANEMA DE SOUZA, Das Várias (...), cit., p. 196.

Essa é, ademais, a conclusão da jurisprudência do Superior Tribunal de Justiça, para quem o prazo começa a fluir do ato reputado por nulo: $3^{\mathrm{a}}$ T., R. Esp. n. 1.321.998/RS, rel. NANCY ANDRIGHI, j. 07-08-2014; $3^{\mathrm{a}}$ T., R. Esp. n. 1.049.078/SP, rel. RICARDO VILLAS BÔAS CUEVA, j. 27-11-2012.

${ }^{1216}$ O Contrato (...), cit., pp. 70-71.

${ }^{1217}$ No mesmo sentido: NELSON ROSENVALD, Contratos (...), cit., p. 592; PAULO LÔBO, Direito (...), cit., p. 305.

${ }_{1218}$ Confrontar: FLÁVIO TARTUCE, Direito (...), cit., pp. 324-325.

${ }^{1219}$ Tratado (...), cit., p. 250.

${ }^{1220}$ FLÁVIO AUGUSTO MONTEIRO DE BARROS, Manual (...), cit., p. 353; FLÁVIO TARTUCE, Direito (...), cit., p. 325; JOÃO LUIZ ALVES, Código (...), vol. II, cit., p. 250; NATAL NADER, Questões Relativas à Doação, cit., p. 461; PAULO LÔBO, Direito (...), cit., p. 305; PONTES DE MIRANDA, Tratado (...), cit., 
tratamento constitucional dispensado à união estável ${ }^{1221}$. Também não tem legitimidade ativa o legatário ou qualquer outro sujeito que não tenha direito à legítima do doador, pelo que se conclui se tratar de direito personalíssimo ${ }^{1222}$.

Para ARNALDO MARMITT ${ }^{1223}$, a ação de nulidade poderá ser proposta não apenas pelos herdeiros necessários, mas também pelo próprio doador, exclusivamente. No entanto, para ele, os herdeiros necessários somente poderão intentar a ação de anulação após a morte do doador, pois não pode haver litígio sobre herança de pessoa viva, o mesmo valendo para ação declaratória, pois não haveria interesse de agir. Como já visto, tal posição é minoritária.

Outrossim, para o mesmo autor ${ }^{1224}$, em não havendo descendentes, poderão os ascendentes buscar a anulação da munificência. Já para AGOSTINHO ALVIM ${ }^{1225}$, o ascendente teria interesse em promover a ação de nulidade, tanto na ausência de descendentes, pois nesse caso seria herdeiro necessário, como na existência dessa classe, pois o art. $121^{1226}$ do Código Civil de 1916 dá guarida à expectativa de direito do titular de direito eventual. Além disso, acrescenta o autor que se trata de hipótese de nulidade absoluta, conhecível ex officio $^{1227}$.

p. 251; VICENTE SABINO JÚNIOR, Contrato (...), cit., p. 53.

${ }^{1221}$ CARLOS ROBERTO GONÇALVES, Direito (...), vol. III, cit., p. 269 (o autor entende, porém, que o legislador deve alterar essa realidade); PABLO STOLZE GAGLIANO, $O$ Contrato (...), cit., pp. 71-72. Em sentido contrário: LUIZ GUILHERME LOUREIRO, Curso (...), cit., p. 516; PAULO LÔBO, Das Várias (...), cit., p. 333 .

${ }^{1222}$ VICENTE SABINO JÚNIOR, Contrato (...), cit., p. 81. Em sentido contrário, PONTES DE MIRANDA entende que também o credor do espólio pode se insurgir contra eventual inoficiosidade se o acervo hereditário não for suficiente para fazer frente às dívidas [Tratado (...), cit., p. 251]. CARVALHO SANTOS, porém, insurge-se expressamente contra a hipótese de o credor manejar a ação de redução [Código (...), cit., p. 404].

Também entendendo que se trata de ação personalíssima, há precedente do Superior Tribunal de Justiça declarando ter legitimidade ativa para ação de redução herdeira necessária que tenha cedido a terceiro seus direitos hereditários (3 ${ }^{\mathrm{a}}$ T., R. Esp. n. 1.361.983/SC, rel. NANCY ANDRIGHI, j. 18-03-2014). Por outro lado, a mesma Corte já decidiu também que um herdeiro pode pleitear a redução da liberalidade até a recomposição de toda a legítima, ainda que haja outros herdeiros que não componham o polo ativo da demanda (4 T., Emb. de Decl. no R. Esp. n. 656.990/RJ, rel. RAUL ARAÚJO, j. 17-12-2013).

${ }^{1223}$ Doação, cit., pp. 198-200.

${ }^{1224}$ Doação, cit., p. 200.

${ }^{1225}$ Da Doação, cit., pp. 186-187.

${ }^{1226}$ Art. 121. "Ao titular do direito eventual, no caso de condição suspensiva, é permitido exercer os atos destinados a conservá-lo".

${ }^{1227}$ Acompanhando essa posição: NATAL NADER, Questões Relativas à Doação, cit., p. 462. 
CLÓVIS BEVILAQUA ${ }^{1228}$ leciona, a esse respeito, que é despiciendo aguardar-se pela abertura da sucessão a fim de se saber quem são os herdeiros do doador, de modo que os herdeiros potenciais, ainda em vida do disponente, poderão promover a demanda.

Quanto ao pólo passivo, a ação poderá ser promovida em face do doador e do donatário, mas caso o primeiro tenha falecido, então a demanda se voltará apenas contra o recebedor da benesse ${ }^{1229}$.

Uma vez que julgada procedente a ação, a doação deverá ser reduzida até à recomposição da herança, de maneira que a inoficiosidade jamais levará à anulação do ato em si, mas sim à redução da benemerência até o montante passível de disposição ${ }^{1230}$. Se o doador estiver vivo, o bem voltará a compor seu patrimônio, mas se estiver morto, então se somará à herança, para partilha entre os herdeiros necessários ${ }^{1231}$.

Nessa hipótese, sendo os bens doados passíveis de divisão, então eles retornarão ao quinhão até que a legítima seja reposta. Se indivisíveis, deverá o donatário indenizar o doador ou seu espólio ${ }^{1232}$, ou poderá adjudicar a coisa recebida, ou então ela voltará a compor o acervo hereditário, mas deverá o recebedor da benesse ser reembolsado no valor excedente à composição da legítima, sendo que ele não responderá pelos frutos e rendimentos havidos até então $^{1233}$. Desse modo, a reposição do acervo hereditário pode se dar tanto em valores como em bens, de acordo com a data da benesse ${ }^{1234}$, como já dito.

Quanto ao efeito da sentença que decretar a nulidade da liberalidade, por ser de natureza declaratória e por se tratar de reconhecimento de nulidade, ainda que parcial, terá efeito $e x$ tunc $^{1235}$. Por esse motivo, ARNALDO MARMITT ${ }^{1236}$ conclui que o bem deverá retornar para o patrimônio do donatário, ainda que tiverem sido alienados para terceiros, pois

\footnotetext{
${ }^{1228}$ Código (...), vol. IV, cit., p. 280.

${ }^{1229}$ CARVALHO SANTOS, Código (...), cit., p. 405; NATAL NADER, Questões Relativas à Doação, cit., p. 462; PABlo STOLZE GAGLIANO, O Contrato (...), cit., p. 73; PONTES DE MIRANDA, Tratado (...), cit., p. 251.

${ }^{1230}$ ARNALDO MARMITT, Doação, cit., pp. 197-198.

1231 CARVAlHO SANTOS, Código (...), cit., p. 404; CLÓviS BEVILAQUA, Código (...), vol. IV, cit., p. 280; VICENTE SABINO JÚNIOR, Contrato (...), cit., p. 53.

1232 LUIZ GUILHERME LOUREIRO, Curso (...), cit., p. 517. Em sentido contrário, entendendo que deverá haver a decretação da nulidade de toda a liberalidade: PAULO LÔBO, Das Várias (...), cit., p. 333.

${ }^{1233}$ VICENTE SABINO JÚNIOR, Contrato (...), cit., p. 82.

${ }^{1234}$ LUCIANO DE CAMARGO PENTEADO, Doação (...), cit., p. 164; NATAL NADER, Questões Relativas à Doação, cit., p. 462; WASHINGTON DE BARROS MONTEIRO-DABUS MALUF, Curso (...), cit., p. 175.

${ }^{1235}$ PABLO STOLZE GAGLIANO, O Contrato (...), cit., p. 71; PONTES DE MIRANDA, Tratado (...), cit., pp. 253-254.

${ }^{1236}$ Doação, cit., pp. 205-206.
} 
se é ineficaz e inválido, houve transferência por quem não tinha poderes para tanto, não se aplicando o art. $648^{1237}$ do Código Civil de 1916 ao caso, haja vista que a nulidade havia desde o nascedouro do negócio, não sendo superveniente ${ }^{1238}$.

AGOSTINHO ALVIM ${ }^{1239}$, porém, é da opinião de que por aplicação do art. $1.787^{1240}$ do Código Civil de 1916, se o donatário vier a alienar a terceiros bens que recebeu em inoficiosidade, os adquirentes não serão atingidos pela nulidade ${ }^{1241}$, e justifica ${ }^{1242}$ tal efeito dizendo que são causados pela dilapidação do patrimônio por parte do filho donatário, mas não pela lei, e por se tratar de posse de boa-fé ${ }^{1243}$.

Assim, não sendo possível a restituição, converte-se em perdas e danos ${ }^{1244}$. Sendo insolvente o donatário, ainda assim responderá pela restauração da legítima, pois não se pode presumir a solidariedade dos outros herdeiros ${ }^{1245}$.

Outrossim, aberta a sucessão e constatado que os bens do espólio não fazem frente a todos os legados e liberalidades feitas pelo autor da herança em vida, deve-se reduzir as disposições testamentárias, em seguida os legados e, por fim, as doações ${ }^{1246}$.

Diante de tudo o que se expôs, é evidente a importância de se levar em conta a barreira do art. 549 do Código Civil de 2002 no uso da doação como instrumento de planejamento sucessório.

Assim, o doador deve ter em conta que se tiver descendentes, ascendentes ou cônjuge não pode doar metade de seus bens, e se o fizer estará a realizar negócio instável, passível de ser reduzido por quem tiver interesse a tanto. Caso não os tenha, porém, a

\footnotetext{
${ }^{1237}$ Art. 648. "Se, porém, o domínio se resolver por outra causa superveniente, o possuidor, que o tiver adquirido por título anterior à resolução, será considerado proprietário perfeito, restando à pessoa em cujo benefício houve a resolução ação contra aquele cujo domínio se resolveu para haver a própria coisa, ou seu valor". O artigo correspondente no Código Civil de 2002 é o de número 1360.

${ }^{1238}$ No mesmo sentido: NATAL NADER, Questões Relativas à Doação, cit., p. 463.

${ }^{1239}$ Da Doação, cit., p. 174.

1240 Art. 1.787. "No caso do artigo antecedente, se ao tempo do falecimento do doador, os donatários já não possuírem os bens doados, trarão à colação o seu valor. (Redação dada pelo Decreto do Poder Legislativo $\mathrm{n}^{\circ}$ 3.725, de 15.1.1919)". Tal dispositivo foi mantido no Código Civil de 2002 por meio do parágrafo único do art. 2003 do mencionado diploma.

${ }^{1241}$ No mesmo sentido: PAULO LÔBO, Das Várias (...), cit., p. 335.

${ }^{1242}$ Da Doação, cit., p. 179.

${ }^{1243}$ Entendendo que a doação, ainda que inoficiosa, gera efeitos: ANTÔNIO CHAVES, Lições (...), cit., p. 259.

1244 ARNALDO MARMITT, Doação, cit., pp. 205-206; MARIA HELENA DINIZ, Curso (...), cit., p. 263; PAULO LÔBO, Direito (...), cit., p. 305.

1245 ARNALDO MARMITT, Doação, cit., pp. 211-212; CARVALHO SANTOS, Código (...), cit., p. 414.

${ }^{1246}$ VICENTE SABINO JÚNIOR, Contrato (...), cit., p. 82.
} 
liberalidade não será afetada pela barreira legal, devendo-se observar apenas a proibição da doação universal.

Por outro lado, uma vez decidido a manejar a doação, o autor da liberalidade deverá efetuar o cálculo correto de todo o seu patrimônio, separando-se antes a meação de seu cônjuge, se houver, e distinguir a legítima da parte disponível. É de bom alvitre, além disso, arquivar-se, de algum modo, as certidões de avaliações dos bens, pois em hipótese de questionamento futuro facilitará a prova do monte-mór, especialmente na hipótese de posteriormente serem realizadas novas doações em caso de novo enriquecimento do doador.

Feito isso, compete verificar a figura do donatário. Sendo terceiro não herdeiro, o doador poderá dispor a seu favor apenas a metade de seus bens, ao passo que se for herdeiro necessário, poderá alienar gratuitamente em favor dele a parte disponível, fazendo constar a dispensa de colação no instrumento, mais a parte legítima, donde se verifica que o disponente pode até dirigir o bem que comporá a legítima do herdeiro, de modo que a lei dá ao doador a mesma área de atuação do testador, nos termos do art. $2.014^{1247}$ do Código Civil de 2002.

\section{7) Partilha em vida}

Como se verifica na redação do art. $2.018^{1248}$ do Código Civil de 2002, o sistema civil atual admite a realização de partilha em vida por ato entre vivos, assim como já o permitia o art. $1.776^{1249}$ do Código Civil de $1916^{1250}$.

1247 Art. 2.014. "Pode o testador indicar os bens e valores que devem compor os quinhões hereditários, deliberando ele próprio a partilha, que prevalecerá, salvo se o valor dos bens não corresponder às quotas estabelecidas". Consultar a respeito: ARNALDO RIZZARDO, Direito das Sucessões, $8^{\mathrm{a}}$ ed., Rio de Janeiro, Forense, 2014, p. 698.

1248 Art. 2.018. "É válida a partilha feita por ascendente, por ato entre vivos ou de última vontade, contanto que não prejudique a legítima dos herdeiros necessários".

${ }^{1249}$ Art. 1.776. "É válida a partilha feita pelo pai, por ato entre vivos ou de última vontade, contanto que não prejudique a legítima dos herdeiros necessários".

${ }^{1250}$ Há quem critique a previsão legal, pela suposta insegurança que acarretaria uma partilha em vida: CLÓVIS BEVILAQUA, Código Civil dos Estados Unidos do Brasil, vol. VI, 10 a ed., Rio de Janeiro, Ed. Paulo de Azevedo, 1955, p. 210; JOÃO LUIZ ALVES, Código Civil da República dos Estados Unidos do Brasil, vol. III, $2^{a}$ ed., São Paulo, Saraiva, 1936, pp. 180-181. PONTES DE MIRANDA, porém, ao mesmo tempo em que ressalta, como ponto negativo da partilha em vida, seu suposto caráter de patriarcalismo romano posto a serviço das famílias burguesas dos sécs. XVIII e XIX (p. 252), salienta que tal ferramenta implica na economia com a simplificação do inventário e no afastamento de eventuais contendas (Tratado de Direito Privado - Partes Especial, Tomo LX, $2^{\text {a }}$ ed., Rio de Janeiro, Borsoi, 1969, p. 254). No mesmo sentido, ITABAIANA DE OLIVEIRA pontua que a doação-partilha previne discórdias, permite o direcionamento dos bens de acordo com a individualidade dos herdeiros, evita a dilapidação do patrimônio (o autor sublinha os de caráter agrícola) e oportuniza aos pais se desembaraçarem da administração patrimonial de acordo com seu julgamento (Tratado de Direito das Sucessões, vol. III, 4ª ed., São Paulo, Max Limonad, 1952, p. 898). Também compartilhando dessa opinião: CARLOS MAXIMILIANO, Direito das Sucessões, vol. III, $5^{\mathrm{a}}$ ed., Rio de Janeiro - São Paulo, Freitas Bastos, 1964, p. 313; ESTEVAM DE ALMEIDA, Partilha em vida pelos 
Em vista do quanto preconizado no dispositivo legal, PABLO STOLZE GAGLIANO $^{1251}$ opina pela possibilidade de se utilizar o contrato de doação como meio de se realizar partilha em vida, em anteposição ao testamento, que permite a realização de partilha causa mortis $^{1252}$. O mesmo fazia AGOSTINHO ALVIM ${ }^{1253}$ no âmbito da lei civil revogada, ensinando que a doação-partilha é prevista no art. 1.776 do Código Civil de 1916, e apesar da lei empregar apenas o termo "pai", afirma que o ato pode ser realizado pela mãe apenas, ou até pelos pais em conjunto ${ }^{1254}$.

\footnotetext{
paes, in RF 46(1926), p. 17.

${ }^{1251}$ O Contrato (...), cit., pp. 74-75.

${ }^{1252}$ Concordando que a partilha em vida por ato inter vivos se caracteriza como doação-partilha: CARLOS ALBERTO BITTAR, Direito das sucessões, Rio de Janeiro, Forense Universitária, 1992, p. 152; CARLOS MAXIMILIANO, Direito (...), cit., p. 313; CARLOS ROBERTO GONÇALVES, Direito Civil Brasileiro, vol. VII, $3^{\text {a }}$ ed. rev. e atual., São Paulo, Saraiva, 2009, p. 534 (o autor explica que a regra excepciona a vedação de pacta corvina); FRANCISCO JOSÉ CAHALI, A Partilha no Inventário, in FRANCISCO JOSÉ CAHALI e GISELDA MARIA FERNANDES NOVAES HIRONAKA, Direito das Sucessões, $3^{\mathrm{a}}$ ed. rev., atual. e ampl., São Paulo, Revista dos Tribunais, 2007, pp. 410-412; ITABAIANA DE OLIVEIRA, Tratado (...), cit., p. 900; MAURO ANTONINI, Contratos (em espécie) - Arts. 1.784 a 2.027, in CEZAR PELUSO (Coord.), Código Civil Comentado, $4^{\mathrm{a}}$ ed., Barueri, Manole, 2010, p. 2.229; NEY DE MELLO ALMADA, Sucessões, São Paulo, 2006, Malheiros, p. 369; SILVIA MARIA BENEDETTI TEIXEIRA, Planejamento Sucessório: uma Questão de Reflexão, in IBDFAM 31(2005), p. 10; SILVIO DE SALVO VENOSA, Direito Civil, vol. VII, $5^{\text {a }}$ ed., São Paulo, Atlas, 2005, p. 401; WASHINGTON DE BARROS MONTEIRO e ANA CRISTINA DE BARROS MONTEIRO FRANÇA PINTO, Curso de Direito Civil, vol. VI, $38^{\mathrm{a}}$ ed., São Paulo, Saraiva, 2011, p. 354.
}

ARNALDO RIZZARDO, por seu turno, é da opinião de que, apesar da aproximação com a doação, a partilha em vida não tem alguns de seus efeitos, como a não transmissão do direito de propriedade (pelo que defende que o ascendente pode até alienar bens), e a indispensabilidade da abertura de inventário [Direito (...), cit., p. 699]. Confrontar ainda a opinião do autor com a de JOÃO ALBERTO LEIVA JOBS, para quem a partilha, diferentemente do contrato, parte de uma situação de transmissibilidade pré-estabelecida pelo princípio da saisine (Da Nulidade da Partilha, $2^{\mathrm{a}}$ ed., São Paulo, Saraiva, 1986, pp. 107-121). Ver ainda: ESTEVAM DE ALMEIDA, Partilha (...), cit., p. 18; PONTES DE MIRANDA, Tratado (...), Tomo LX, cit., p. 257. Ademais, esse último autor, em outro passo de sua obra, nega qualquer aproximação entre a doação e a partilha em vida, pelo que afirma inexistir no ato transmissão de propriedade [Tratado (...), Tomo LX, cit., 1969, p. 251]. Também entendendo que a partilha em vida por ato inter vivos não é uma doação: ARNOLDO WALD, O Regime Jurídico da Partilha em Vida in RT 622(1987), pp. 8-10. Engrossando tais fileiras, há ainda a doutrina de ASTOLPHO DE REZENDE, para quem a partilha em vida não é uma liberalidade, mas sim uma renúncia traslativa do ascendente em favor de seus herdeiros (Do Inventário (...), cit., pp. 298-301). Acolhendo esses últimos posicionamentos doutrinários, há precedentes do Superior Tribunal de Justiça afirmando que a partilha em vida não é doação. Assim, um aresto manteve acórdão de Tribunal estadual que entendeu, no caso sub judice, haver partilha em vida, pois o disponente teria realizado cinco escrituras públicas de doação no mesmo cartório, data e horário, com a presença de todos os herdeiros e anuência de todos eles no atos dos demais irmãos, e, por conta disto, afirmou a Corte que não há doação no caso, pelo que inexiste por consequência o dever de doação ( $3^{a}$ T., R. Esp. n. 6.528/RJ, rel. NILSON NAVES, j. 11/06/1991). Por outro lado, mas seguindo a mesma senda, há um julgado em que, pela falta de requisitos do art. 1.776 do Código Civil de 1916, qualificou-se a liberalidade trazida pelas partes a Juízo como contrato de doação e julgou-se de acordo com os regramentos dela, exigindo-se assim que os bens fossem colacionados, já que no instrumento não houve expressa dispensa pelo doador ( $3^{a}$ T., R. Esp. n. 730.483/MG, rel. NANCY ANDRIGHI, j. 03-05-2005).

${ }^{1253}$ Da Doação, $3^{\text {a }}$ ed., cit., p. 106.

${ }^{1254}$ Também entendendo que a partilha em vida realizada por ato inter vivos pode ser tida por doação: CLÓVIS BEVILAQUA, Código (...), vol. VI, cit., p. 210. ANTÔNIO JOSÉ DE SOUZA LEVENHAGEN, porém, ensinava que nesse caso celebrava-se "escritura pública de partilha em vida" (Sucessão legítima, inventário e partilha, São Paulo, Atlas, 1978, p. 103. No que se refere à interpretação extensiva do termo "pai" a todos os 
Há autores ${ }^{1255}$, ainda, que acrescentam que a partilha em vida é um ato sui generis, pois o regime jurídico da doação é contratual, ao passo que o da partilha é de direito sucessório.

Conforme a advertência constante do art. 2.018 do Código Civil de 2002, o doador deve ter o cuidado de não transgredir a legítima dos herdeiros necessários, pois se tal ocorresse inquinaria o ato de nulidade ${ }^{1256}$. Além disso, como a partilha em vida por ato inter vivos equivale à doação, à mesma conclusão se chegaria por aplicação do art. 549 do mencionado diploma legal, sendo esse também o fundamento que permite afirmar-se não poder haver partilha de toda a universalidade patrimonial, por aplicação do art. 548 da Lei $10.406 / 2002^{1257}$. A partilha em vida também não poderá envolver, ainda, bens futuros ${ }^{1258}$, mas se dispor sobre eles será ineficaz nessa parte ${ }^{1259}$.

Os efeitos da hipótese ora tratada são os mesmos da partilha realizada quando da morte do autor da herança e se viabiliza de acordo com sua vontade, sendo que não necessariamente igualará as quotas partes de cada herdeiro, desde que respeitada a legítima $^{1260}$. Se houver inoficiosidade, o ato continua sendo válido, estando inquinada de nulidade apenas a parte excedente, que deverá sofrer redução ${ }^{1261}$.

ascendentes, há a concordância de ASTOLPHO DE REZENDE [Do Inventário (...), cit., pp. 306-307] e PONTES DE MIRANDA [Tratado (...), Tomo LX, cit., p. 250].

${ }^{1255}$ ARNALDO MARMITT, Doação, cit., p. 302; JOÃO ALBERTO LEIVA JOBS, Da Nulidade (...), cit., pp. 733-734; MAURO ANTONINI, Contratos (...), cit., p. 2.299; SILVIA MARIA BENEDETTI TEIXEIRA, Planejamento (...), cit., pp. 11-12.

${ }^{1256}$ ANTÔNIO JOSÉ DE SOUZA LEVENHAGEN, Sucessão (...), cit., p. 103; CARLOS ALBERTO BITTAR, Direito (...), cit. p. 152; PABLO STOLZE GAGLIANO, O Contrato (...), cit., p. 75; PONTES DE MIRANDA, Tratado (...), Tomo LX, cit., pp. 251-252; SALOMÃO DE ARAUJO CATEB, Direito das Sucessões, $5^{\text {a }}$ ed., São Paulo, Atlas, 2008, p. 281.

${ }^{1257}$ ASTOLPHO DE REZENDE, Do Inventário (...), cit., pp. 309-310 (o autor emite essa opinião mesmo rejeitando que se trate de doação); CARLOS MAXIMILIANO, Direito (...), cit., p. 315; CARLOS ROBERTO GONÇALVES, Direito (...), vol. VII, cit., pp. 535-536; CLÓVIS BEVILAQUA, Código (...), vol. VI, cit., p. 210; ITABAIANA DE OLIVEIRA, Tratado (...), cit., p. 903; JOÃO ALBERTO LEIVA JOBS, $D a$ Nulidade (...), cit., p. 733; JOÃO LUIZ ALVES, Código (...), vol. III, cit., p. 181; MAURO ANTONINI, Contratos (...), cit., p. 2.299; NEY DE MELlO ALMADA, Sucessões, cit., p. 369; SALOMÃO DE ARAUJO CATEB, Direito (...), cit., p. 282; SILVIO DE SALVO VENOSA, Direito (...), vol. VII, cit., p. 403; WASHINGTON DE BARROS MONTEIRO-FRANÇA PINTO, Curso (...), cit., p. 354.

${ }^{1258}$ ASTOLPHO DE REZENDE, Do Inventário (...), cit., p. 311; CARLOS MAXIMILIANO, Direito (...), cit., p. 315; SILVIO DE SALVO VENOSA, Direito (...), vol. VII, cit., p. 401.

${ }^{1259}$ CARLOS MAXIMILIANO, Direito (...), cit., p. 315; ITABAIANA DE OLIVEIRA, Tratado (...), cit., p. 902.

1260 ARNALDO MARMITT, Doação, cit., p. 303; ARNOLDO WALD, O Regime (...), cit., pp. 10 e 12-13; ESTEVAM DE ALMEIDA, Partilha (...), cit., p. 16; SILVIA MARIA BENEDETTI TEIXEIRA, Planejamento (...), cit., pp. 10 e 12; ZENO VELOSO, Arts. 1.784 a 2.027, in REGINA BEATRIZ TAVARES DA SILVA, Código Civil Comentado, $7^{\mathrm{a}}$ ed. rev. e atual., São Paulo, Saraiva, 2010, p. 2015.

${ }^{1261}$ ARNALDO MARMITT, Doação, cit., p. 304; CARLOS MAXIMILIANO, Direito (...), cit., pp. 315-316; CARLOS ROBERTO GONÇALVES, Direito (...), vol. VII, cit., p. 535; JOÃO ALBERTO LEIVA JOBS, Da Nulidade (...), cit., p. 733; MAURO ANTONINI, Contratos (...), cit., p. 2.299. Em sentido contrário, 
Além disso, é importante, como lembra AGOSTINHO ALVIM ${ }^{1262}$, observar-se o regime de bens do cônjuge do doador, sendo que ele não terá limites para doar se for viúvo ou desquitado. No regime da separação de bens, também é possível haver doação, mas se imóvel deverá ter o consentimento do outro cônjuge, espontâneo ou judicialmente suprido. Mas se o doador for casado no regime da comunhão universal, deverá obter o consentimento do outro cônjuge, pois não tem o direito de impor-lhe um plano de partilha feito segundo seu alvitre. Não há restrição, porém, se ambos os cônjuges forem doadores ${ }^{1263}$.

Como o critério de averiguação de eventual inoficiosidade se dá na data da liberalidade $^{1264}$, para PABLO STOLZE GAGLIANO ${ }^{1265}$ pode ocorrer uma situação de insegurança ao donatário, haja vista que ele não terá meios de se cientificar se o negócio jurídico é passível de anulação pelos herdeiros, o que se constata apenas no momento da colação dos bens do doador no inventário de seu patrimônio. Por isso, sugere que o doador faça constar do instrumento que o bem doado refere-se à sua parte disponível, que terá o condão de afastá-lo da composição dos bens transmissíveis.

É certo que a benesse deverá envolver todos os herdeiros necessários e todos os bens do acervo ${ }^{1266}$, pelo que não é cabível depois inventário dos bens do doador ${ }^{1267}$, sendo que

opinando que a nulidade é da partilha: ITABAIANA DE OLIVEIRA, Tratado (...), cit., p. 904; NEY DE MELLO ALMADA, Sucessões, cit., p. 369.

${ }^{1262}$ Da Doação, cit., pp. 106-107.

${ }^{1263}$ ASTOLPHO DE REZENDE, Do Inventário (...), cit., p. 308; ITABAIANA DE OLIVEIRA, Tratado (...), cit., p. 901; SILVIA MARIA BENEDETTI TEIXEIRA, Planejamento (...), cit., p. 13.

${ }^{1264}$ No caso, a verificação se dará no momento de realização da partilha: ARNALDO RIZZARDO, Direito (...), cit., p. 699; PONTES DE MIRANDA, Tratado (...), Tomo LX, cit., p. 256; SILVIA MARIA BENEDETTI TEIXEIRA, Planejamento (...), cit., p. 13.

1265 O Contrato (...), cit., p. 75.

${ }^{1266}$ Há quem ensine, porém, que só pode haver alienação da parte disponível: JOÃO ALBERTO LEIVA JOBS, Da Nulidade (...), cit., p. 732. PONTES DE MIRANDA emite opinião contrária a essa tese, e afirma ser possível o ascendente partilhar em vida a legítima, desde que direcionada a herdeiro necessário [Tratado (...), Tomo LX, cit., p. 256]. Também concordando que a doação-partilha envolva todos os bens do doador, desde que não seja universal: CARLOS ALBERTO BITTAR, Direito (...), cit. p. 152. CARLOS MAXIMILIANO, por seu turno, leciona que a partilha em vida poderá abranger apenas parcela do patrimônio do doador [Direito (...), cit., p. 315].

1267 Somente justificaria a abertura de inventário a existência de bens não partilhados [CARLOS MAXIMILIANO, Direito (...), cit., p. 318; MAURO ANTONINI, Contratos (...), cit., p. 2.299] ou a superveniência de outros bens à partilha [FRANCISCO JOSÉ CAHALI, A Partilha (...), cit., p. 412; NEY DE MELLO ALMADA, Sucessões, cit., p. 370]. Há autores, porém, que esposam a opinião de que sempre se faz necessária a abertura do inventário [PONTES DE MIRANDA, Tratado (...), Tomo LX, cit., p. 251; SILVIO DE SALVO VENOSA, Direito (...), vol. VII, cit., p. 402], ficando dispensada apenas a partilha judicial, seguindo-se o rito da amigável para alguns estudiosos [ANTÔNIO JOSÉ DE SOUZA LEVENHAGEN, Sucessão (...), cit., p. 103], ao passo que outros opinam ter a partilha em vida rito próprio, que por sua vez é diferente da amigável [PONTES DE MIRANDA, Tratado (...), Tomo LX, cit., p. 252], havendo, por fim, quem entenda ser a partilha em vida uma subespécie da partilha amigável, pelo que careceria sempre de homologação judicial [SEBASTIÃO LUIZ AMORIM e EUCLIDES BENEDITO DE OLIVEIRA, Inventários e Partilhas, $19^{\mathrm{a}}$ ed. rev. e atual., São Paulo, LEUD, 2005, p. 435]. A respeito dessa 
se uma parte entender que um seu direito foi desfalcado, deverá buscar o reconhecimento do fato por ação própria ${ }^{1268}$. Mas ainda assim nada impede de se adotar a precaução acima recomendada.

Outrossim, a partilha em vida, por ser doação, tem natureza jurídica contratual e seus efeitos, por ser ato inter vivos, serão imediatos, de modo a constituir partilha definitiva $^{1269}$.

Além disso, os donatários todos deverão apor seu aceite à munificência ${ }^{1270}$, mas não necessariamente no mesmo ato, podendo ocorrer posteriormente, inclusive em instrumento apartado ${ }^{1271}$, ou ainda na forma presumida, na hipótese do art. 543 do Código Civil de $2002^{1272}$. ESTEVAM DE ALMEIDA ${ }^{1273}$ ensina, a esse respeito, que se um herdeiro se recusar a aceitar a liberalidade, isso, por si só, não anula o ato e deverá o objeto doado ficar à sua disposição, devendo ele buscar em juízo o desfazimento da partilha em vida, caso entenda haver alguma injustiça.

Deve-se observar, ainda, que não pode haver a exclusão de nenhum dos filhos, mesmo os póstumos, ou então dos netos herdeiros por representação ${ }^{1274}$, valendo a regra inclusive para o caso de o doador desconhecer um seu herdeiro ${ }^{1275}$. Por conta disso, os bens

última posição, ao mesmo tempo em que acolhe a partilha em vida como doação, FRANCISCO CAHALI emite a opinião de que o art. 2.018 do Código Civil de 2002 está mal posicionado, levando à confusão com a partilha amigável, mas repudia expressamente esse entendimento [A Partilha (...), cit., pp. 411-412].

1268 ARNALDO MARMITT, Doação, cit., p. 303; ARNOLDO WALD, O Regime (...), cit., p. 15; ASTOLPHO DE REZENDE, Do Inventário (...), cit., p. 317; CARLOS MAXIMILIANO, Direito (...), cit., p. 318; MARIA BERENICE DIAS, Manual das Sucessões, São Paulo, Revista dos Tribunais, 2008, p. 368; MAURO ANTONINI, Contratos (...), cit., p. 2.299; SILVIA MARIA BENEDETTI TEIXEIRA, Planejamento (...), cit., p. 10.

1269 ARNALDO MARMITT, Doação, cit., p. 303; ARNALDO RIZZARDO, Direito (...), cit., pp. 698-699; ITABAIANA DE OLIVEIRA, Tratado (...), cit., p. 904; NEY DE MELLO ALMADA, Sucessões, cit., p. 370; PABLO STOLZE GAGLIANO, O Contrato (...), cit., p. 75; SILVIO DE SALVO VENOSA, Direito (...), vol. VII, cit., p. 402; ZENO VELOSO, Código (...), cit., p. 2015. Concordando com a conclusão mas por fundamento diferente: ASTOLPHO DE REZENDE, Do Inventário (...), cit., p. 302.

1270 NEY DE MELLO ALMADA, Sucessões, cit., p. 370; SILVIA MARIA BENEDETTI TEIXEIRA, Planejamento (...), cit., p. 11.

1271 ARNALDO MARMITT, Doação, cit., p. 303; CARLOS MAXIMILIANO, Direito (...), cit., p. 315.

1272 MAURO ANTONINI, Contratos (...), cit., p. 2.299. CARLOS MAXIMILIANO, porém, leciona que o aceite terá de ser necessariamente expresso [Direito (...), cit., p. 315].

${ }^{1273}$ Partilha (...), cit., p. 18.

1274 CARLOS MAXIMILIANO, Direito (...), cit., pp. 313-314; CLÓVIS BEVILAQUA, Código (...), vol. VI, cit., p. 210; NEY DE MELLO ALMADA, Sucessões, cit., pp. 369 e 370; SILVIO DE SALVO VENOSA, Direito (...), vol. VII, cit., p. 402.

1275 SALOMÃO DE ARAUJO CATEB, Direito (...), cit., p. 282. 
doados não precisam ser levados à colação ${ }^{1276}$, o que se justifica até pela inexistência de inventário na maior parte das vezes ${ }^{1277}$.

Caso, porém, algum herdeiro seja omitido, então não se anula o negócio, mas sim se procede a abertura do inventário e os donatários deverão levar o quanto recebido à colação, a permitir assim a reposição da legítima do herdeiro preterido ou daquele que surgiu depois da partilha, se o caso ${ }^{1278}$. Com efeito, ITABAIANA DE OLIVEIRA ${ }^{1279}$ explica que apenas a desigualdade da legítima é que justifica o ato de colação, pois nem a anuência do donatário é capaz de afastar a exigência de respeito à legitima estampada no artigo da lei.

No que se refere à pessoa do donatário, há ${ }^{1280}$ quem entenda não ser cabível a realização de partilha em vida em favor dos absolutamente incapazes, porque, por imposição do $20.16^{1281}$ do Código Civil de 2002, somente se pode realizar, nesse caso, por meio judicial $^{1282}$.

Outros doutrinadores $^{1283}$, porém, ensinam que pode haver partilha em vida a favor dos incapazes. Se o filho for absolutamente incapaz, deverá lhe ser dado curador especial, e se for interditado, o curador deverá intervir no ato ${ }^{1284}$, assim como o Ministério Público ${ }^{1285}$, de

1276 CARLOS ROBERTO GONÇALVES, Direito (...), vol. VII, cit., p. 535; NEY DE MELLO ALMADA, Sucessões, cit., p. 370; SEBASTIÃO AMORIM-EUCLIDES DE OLIVEIRA, Inventários (...), cit., p. 434; SILVIA MARIA BENEDETTI TEIXEIRA, Planejamento (...), cit., p. 12.

1277 ARNOLDO WALD, O Regime (...), cit., p. 13; CARLOS MAXIMILIANO, Direito (...), cit., p. 318; MAURO ANTONINI, Contratos (...), cit., p. 2.299.

1278 MAURO ANTONINI, Contratos (...), cit., pp. 2.299-2.300. Outros autores, por outro lado, opinam pela nulidade do ato e o refazimento da partilha [ASTOLPHO DE REZENDE, Do Inventário (...), cit., p. 302; ITABAIANA DE OLIVEIRA, Tratado (...), cit., p. 899; SILVIO DE SALVO VENOSA, Direito (...), vol. VII, cit., p. 402], ao passo que PONTES DE MIRANDA afirma ser nula a partilha quando não contempla herdeiro existente, ao passo que é ineficaz se ele é superveniente [Tratado (...), Tomo LX, cit., p. 251]. ESTEVAM DE ALMEIDA, por seu turno, é da opinião de que se houver herdeiro preterido ou posterior, anula-se a partilha, mas, no primeiro caso, admite três exceções: morte do herdeiro preterido antes do doador; renúncia ao direito por parte do herdeiro não contemplado; ou, ainda, declaração de sua indignidade [Partilha (...), cit., pp. 15-16]. Também CARLOS MAXIMILIANO opina pela manutenção do ato caso o doador sobreviva ao herdeiro não beneficiado, na hipótese de o falecido filho não ter deixado herdeiros necessários [Direito (...), cit., pp. 314-315].

${ }^{1279}$ Tratado (...), cit., p. 904.

1280 JOÃO LUIZ ALVES, Código (...), vol. III, cit., p. 180; PONTES DE MIRANDA, Tratado (...), Tomo LX, cit., p. 256.

1281 Art. 2.016. "Será sempre judicial a partilha, se os herdeiros divergirem, assim como se algum deles for incapaz".

${ }^{1282}$ Assim, PONTES DE MIRANDA ensina que deve haver sentença judicial homologatória, no caso, mas que não tornaria o ato judicial [Tratado (...), Tomo LX, cit., pp. 254-255].

1283 ARNALDO MARMITT, Da Doação, cit., p. 108. CARLOS MAXIMILIANO, Direito (...), cit., p. 316. Confrontar ainda, a esse respeito, a doutrina de ESTEVAM DE ALMEIDA, que defende a autonomia do regime jurídico da partilha em vida das disposições legais precedentes, referentes à partilha realizada quando já aberta a sucessão [Partilha (...), cit., pp. 16-17].

${ }^{1284}$ CARLOS MAXIMILIANO, Direito (...), cit., p. 316; ITABAIANA DE OLIVEIRA, Tratado (...), cit., p. 902.

1285 Nesse sentido, CLÓVIS BEVILAQUA ensina que deve haver a intervenção da autoridade pública que 
modo a evitar futura alegação de nulidade. Sendo o donatário nascituro, também deverá haver a nomeação de curador, mas a liberalidade ficará condicionada ao nascimento com vida do recebedor da benesse ${ }^{1286}$.

Ademais, não pode haver partilha em vida em favor de herdeiros eventuais, mas somente dos necessários, pois do contrário estar-se-á a fazer pacto sobre herança de pessoa viva $^{1287}$

Poderá ainda o doador apor cláusula de reversão à benesse, mas se assim não o fizer e o descendente vier a falecer, os bens recebidos serão transmitidos aos seus herdeiros, que poderá inclusive ser o próprio doador, caso o donatário não tenha descendentes ${ }^{1288}$.

Se houver dívidas do doador anteriores à benesse, então os herdeiros respondem por ela na medida do que receberam, por aplicação do art. $1.997^{1289}$ do Código Civil de $2002^{1290}$. CLÓVIS BEVILAQUA ${ }^{1291}$ explica que essa conclusão decorre do fato de se tratar de uma doação, pelo que a fraude contra credores é reprimida ${ }^{1292}$, ressalvando, porém, que os donatários só passam a ser herdeiros com a morte do doador ${ }^{1293}$.

Vale mencionar, por fim, que por se tratar de doação, a partilha em vida é passível de revogação por ingratidão ${ }^{1294}$, mas se a ingratidão foi perpetrada em data anterior ao ato de liberalidade, houve perdão, sendo válido o negócio jurídico ${ }^{1295}$.

protege os menores [Código (...), vol. VI, cit., p. 210].

${ }^{1286}$ ITABAIANA DE OLIVEIRA, Tratado (...), cit., p. 902. ESTEVAM DE ALMEIDA, por seu turno, entende que é dispensável a nomeação de curador especial caso o menor possa ser representado por seus pais [Partilha (...), cit., pp. 17-18], sendo essa também a lição de CARLOS MAXIMILIANO [Direito (...), cit., p. 316].

${ }^{1287}$ CARLOS MAXIMILIANO, Direito (...), cit., p. 314; FRANCISCO CAHALI, A Partilha (...), cit., p. 410; SILVIO DE SALVO VENOSA, Direito (...), vol. VII, cit., p. 401.

1288 ITABAIANA DE OLIVEIRA, Tratado (...), cit., p. 903.

1289 Art. 1.997. "A herança responde pelo pagamento das dívidas do falecido; mas, feita a partilha, só respondem os herdeiros, cada qual em proporção da parte que na herança lhe coube".

${ }^{1290}$ ARNALDO MARMITT, Doação, cit., p. 304; ASTOLPHO DE REZENDE, Do Inventário (...), cit., pp. $303-$ 305.

${ }^{1291}$ Código (...), vol. VI, cit., p. 210.

1292 Também entendendo que se trata de transmissão liberal, logo passível de anulação pelos credores: ITABAIANA DE OLIVEIRA, Tratado (...), cit., pp. 902-903; JOÃO ALBERTO LEIVA JOBS, Da Nulidade (...), cit., p. 732; NEY DE MELLO ALMADA, Sucessões, cit., p. 370; SILVIO DE SALVO VENOSA, Direito (...), vol. VII, cit., pp. 402-403. O mesmo vale para o empresário falido: CARLOS MAXIMILIANO, Direito (...), cit., p. 317.

1293 Externando a mesma opinião: CARLOS MAXIMILIANO, Direito (...), cit., p. 317; ITABAIANA DE OLIVEIRA, Tratado (...), cit., p. 904; JOÃO ALBERTO LEIVA JOBS, Da Nulidade (...), cit., p. 732; SILVIO DE SALVO VENOSA, Direito (...), vol. VII, cit., p. 402.

1294 CARLOS MAXIMILIANO, Direito (...), cit., p. 317; CLÓVIS BEVILAQUA, Código (...), vol. VI, cit., p. 210; ITABAIANA DE OLIVEIRA, Tratado (...), cit., p. 902; SILVIO DE SALVO VENOSA, Direito (...), vol. VII, cit., p. 402. Se posicionando de forma contrária: ASTOLPHO DE REZENDE, Do Inventário (...), 
Como se verifica por tudo o que foi exposto neste item, é bastante delicada a aplicação do contrato de doação como método de implantação de partilha ainda em vida do doador no âmbito do direito civil brasileiro, pois há opiniões doutrinárias substanciais contra tal ato jurídico, bem como precedentes do Superior Tribunal de Justiça, que preferem tratar cada uma dessas figuras como se fossem realidades estanques.

É certo que tal celeuma ainda deverá ser amadurecida no debate acadêmico e na lide forense, pois é preciso terminar de se entender o papel da doação, que, mais uma vez, se mostra insuficiente para abarcar toda a realidade quando vista apenas sob o prisma contratual.

Com efeito, o art. 2.018 do Código Civil de 2002 afirma expressamente que a partilha em vida se realiza por ato inter vivos ou mortis causa. Ora, sendo a causa do ato, por favor da lei, a vontade do disponente, o que é a transmissão gratuita de bem senão uma doação no primeiro caso e, na outra hipótese, um testamento? É difícil vislumbrar qualquer fundamento útil que justifique a adoção de um nome especial para o negócio jurídico e a criação de um instituto próprio em direito civil, sendo antes mais razoável entender-se a partilha em vida como uma modalidade de doação ou de testamento, que por sua vez compõem o campo das liberalidades.

Pode-se argumentar que a partilha em vida, ao contrário da doação, tem por efeito a dispensa da colação. O problema de tal ilação é que desrespeita o sistema do Código e dá azo à prática de injustiça. Com efeito, bastaria o disponente fazer uma escritura chamando-a de "partilha em vida", ao invés de doação, e, com isso, estaria acobertada qualquer inoficiosidade.

Mas a esse argumento, pode-se objetar que o herdeiro prejudicado poderá promover demanda autônoma. Ora, se é assim, não é melhor admitir-se o processamento do inventário e a colação dos bens, cujo rito foi pensado justamente para essa finalidade, até porque terá de ocorrer a oitiva da Fazenda Pública e eventual reavaliação dos bens do acervo hereditário?

Todavia, mesmo que assim não fosse, o argumento inicial cai por terra, porque apesar de na partilha em vida, supostamente, não haver necessidade de colação, ainda assim admite-se discussão do ato por meio de ação autônoma, logo esse fundamento não parece ser 
suficiente para justificar a criação de um instituto próprio, divorciado da doação, figura já estabelecida na tradição jurídica pátria como método de transmissão gratuita da propriedade por atos entre vivos, haja vista que o efeito almejado de dispensa do Poder Judiciário não serve como característica distintiva ${ }^{1296}$.

De qualquer maneira, afora o debate sobre a natureza jurídica da partilha em vida, verificou-se nestas linhas que é imprescindível manejá-la tendo em vista toda a disciplina jurídica da doação, como já foi exposta até aqui, pois do contrário corre-se sério risco de se praticar ato nulo.

A via inversa também é verdadeira, pois ficou nítido também que se pode perfeitamente usar a doação como método de realização de partilha em vida, desde que respeitadas algumas normas específicas do caso, a fim de afastar eventuais invalidades. Isso demonstra, inclusive, que uma melhor aproximação científica do assunto exige que se atenda a um regime jurídico geral, aplicado a um caso específico, tendo-se o objetivo de se realizar uma partilha como causa imediata ${ }^{1297}$.

Desse modo, como já impõe o art. 549 do Código Civil de 2002, o doador deve curar para que não haja o desrespeito à legítima dos herdeiros necessários, isto é, cônjuge, herdeiros e ascendentes. Mas nada impede, porém, que direcione os bens que comporá a legítima de cada qual.

Além disso, não deve dispor também, nesse caso, sobre os bens futuros, evitandose ainda condições ou termos, para fique timbrada a definitividade da transferência.

Quanto à parte disponível, melhor fazer constar do instrumento que está dispensada sua colação, como foi mencionado acima. Desse modo, qualquer que seja a qualificação jurídica emprestada ao ato, tal efeito será alcançado e se conservará, ao menos por proximidade, a vontade do doador, reduzindo-se apenas, se o caso, estritamente a legítima. Ademais, poderá distribuir a cota mencionada de maneira desigual, de acordo com os fundamentos estratégicos adotados para a implementação do planejamento sucessório.

\footnotetext{
${ }^{1296}$ De outro lado, deve-se levar em conta que a dispensa de colação goza de forte fundamento quando se diz que tal se dá por já ter havido a concordância de todos os outros herdeiros, como ocorre no contrato de compra e venda.

${ }^{1297}$ Nesse sentido, a doação-partilha assemelha-se à doação remuneratória. Com efeito, ainda que o legislador tivesse criado um artigo na teoria geral das obrigações do Código Civil normatizando a transmissão gratuita de bens com o fito de remunerar o beneficiário por parte do disponente, tal negócio jurídico continuaria a ser doação.
} 
No que se refere à pessoa do doador, se casado, deve buscar a anuência do outro cônjuge e, se possível, realizar em conjunto com este o planejamento sucessório, funcionando ambos como doadores, afastando-se assim qualquer sombra de desrespeito à legítima ou à meação.

Quanto aos donatários, devem estar presentes ao ato todos os herdeiros necessários efetivos do doador e, se possível, deve haver a aposição de aceite de todos eles, ainda que de modo tácito, sendo preferível o aceite expresso. Outrossim, havendo beneficiário absolutamente incapaz, deve se diligenciar pela sua devida representação. Não se deve olvidar, ainda a esse respeito, que a liberalidade só vem a lhe beneficiar, mas, de todo modo, por estar em jogo a sua legítima, importa alcançar-se a chancela da autoridade, para evitar-se futura celeuma.

Caso o doador queira ainda contemplar terceiro não herdeiro, melhor fazê-lo em ato apartado.

Outrossim, afigura-se importante carrear-se à escritura de doação certidões negativas de débito que a praxe impõe, para proteção dos próprios donatários. De qualquer maneira, a fim de garantir a igualdade entre os herdeiros, é importante apor-se na escritura cláusula em que o doador se compromete a responder pelos juros, vícios redibitórios e evicção, como já se afirmou.

Por fim, havendo a prática de ingratidão por um dos donatários, e não estando o doador disposto a perdoá-lo, ao invés de se buscar a revogação da liberalidade, é o caso de se pleitear, se possível, a declaração de deserdação ou indignidade, pois do contrário o objeto doado voltará ao filho ingrato, por força de sucessão causa mortis. 


\section{CONCLUSÃO}

Diante do que foi exposto ao longo da pesquisa, pode-se afirmar que a doação, no sistema civil pátrio, é uma ferramenta jurídica segura para a implementação de um planejamento sucessório, desde que se saiba manejá-la em adequação aos balizamentos legais, doutrinários e jurisprudenciais.

Assim, importa ter em conta, em primeiro lugar, que a doação é um contrato no Código Civil de 2002, o que significa dizer que surge de um acordo de vontades, o qual, em via de regra, consistirá na assunção de uma obrigação do doador de entregar o bem doado ao donatário. Ou seja, é preciso que haja entendimento entre as partes envolvidas e que o pacto final venha a ser cristalizado por outros expedientes posteriores à celebração do contrato.

A forma jurídica a ser dada a esse acordo de vontades, para fins de planejamento sucessório, será a escritura pública, pois assim se evita nulidade nesse quesito e se permite a descrição detalhada do pacto celebrado e dos seus objetos, com a chancela do tabelião no que toca à livre manifestação da vontade das partes. Outrossim, importa consignar-se expressamente que o ato é praticado por uma vontade liberal do doador de transferir gratuitamente bens seu ao donatário.

Tendo a tal se procedido, devem as partes cuidar para que se proceda à entrega dos bens móveis doados e aos devidos registros quando for o caso, como a escrituração de ações ou registro na matrícula dos imóveis, para que assim haja efetiva transferência patrimonial. Além disso, é preciso verificar se toda a operação é aritmeticamente benéfica ao donatário, para que não haja dúvidas quanto à transferência gratuita.

Outrossim, por a doação ser um contrato tipificado em lei, para fins de planejamento sucessório, convém não se pensá-la de maneira não prevista no regramento legal ou por vias transversas, como atos mistos, disfarçados, indiretos ou simulados, isso porque tais medidas, ainda que muitas vezes jurídicas, abandonam seu executor na incerteza da falta de previsão legal. Cria-se uma estratégia sucessória justamente para minorar as incertezas que trazem o decesso do doador, daí a importância de se conhecer a fundo as normas do Código Civil e observá-las na medida das necessidades práticas.

Outra consequência da contratualidade da doação é o cuidado que se deve ter quanto à manifestação de vontade dos herdeiros e demais pessoas afetadas. Assim, deverá se priorizar o aceite expresso ainda na lavratura do ato, mas, como se viu, se o caso concreto 
exigir, a lei coloca à disposição do doador outras maneiras, como o aceite tácito ou aquele em que se consigna prazo ao donatário, desde que respeitada as regras pertinentes a cada modalidade de doação. Além disso, deve se primar também pela correta representação dos incapazes, a fim de se afastar quaisquer dúvidas. Importa salientar também que se mostra prudente, caso o doador esteja acometido de alguma enfermidade relevante, se buscar o amparo de um laudo médico quanto à sua capacidade de discernimento.

Como o aceite pelos donatários deflagram efeitos especiais em relação à mora, aos vícios redibitórios e à evicção, o doador poderá dispensar o benefício que a lei lhe dá, a fim de garantir a igualdade entre eventuais beneficiários que sejam ao mesmo tempo herdeiros necessários.

Em relação às diversas modalidades que a doação pode se apresentar, o doador deve adotar uma série de cuidados, a fim de não praticar ato juridicamente inválido. Assim, se fizer doação pura, poderá contar com aceite presumido, mas não assim se for onerosa. Se quiser apor condição ou termo, não poderá ser potestativo puro e deverá ser possível dos pontos de vista físico e jurídico, e, em relação aos bens futuros e alheios, melhor não dispor deles em vida.

Além disso, caso o doador queira impor algum encargo, deverá observar a necessidade de que ele consista numa obrigação juridicamente possível e lícita, assim como importa que seja passível de medição econômica e em valor menor que a liberalidade, com a expressa concordância pelo donatário de que responderá pela hipótese de o modus vir a se tornar maior por causas supervenientes à munificência. Deverá ainda o doador contar com o pressuposto de que, se o donatário for o beneficiado pelo encargo, não será possível exigir-lhe sua execução específica, mas apenas a revogação da benesse.

Caso o doador esteja doando em vista dos merecimentos do donatário, importa fazer constar seus motivos na escritura, a fim de possibilitar eventual alegação de erro de pessoa, mas deve cuidar para que haja aceite expresso, vez que paira dúvidas na doutrina sobre sua onerosidade. Se a doação for remuneratória, é importante também consignar-se o que se está a remunerar, cuidando para que não haja excessos e, se o houver, expressar-se a anuência dos atores do negócio jurídico. Isso ainda permitirá ao doador provar a relação jurídica para o caso de erro de pessoa ou cobrança do que se remunerou, além de ensejar ao donatário herdeiro provar a desnecessidade de colação do bem. 
Na hipótese de o planejamento realizado englobar donatários noivos, o doador deverá verificar se convém incluir dentre os beneficiários a prole futura do casal e, em caso afirmativo, apor ainda que se estão incluídos os filhos que vierem a ser reconhecidos ou adotados. Se houver a inclusão dos futuros filhos, é importante o doador regular também a administração do patrimônio, quanto à pessoa do administrador e o tempo de duração da administração.

Se ainda o doador almejar que os bens doados voltem ao seu patrimônio caso o donatário venha a falecer antes dele, deverá fazer constar expressamente a cláusula de reversão no instrumento contratual, até para que terceiros de boa-fé tenham ciência do gravame. Tal disposição poderá estar contida, inclusive, quando o beneficiário é herdeiro do doador, sem prejuízo do direito de representação dos netos, cuja participação no quinhão correspondente da herança do avô está garantida pela lei.

Poderá ainda o doador utilizar-se de doação por subvenção periódica na implantação de seu planejamento sucessório, sem se olvidar de regrar a administração do benefício por terceiro caso o próprio doador não possa fazê-lo ou venha a falecer.

Há ainda casos de doação que não se recomenda utilizar em vista de planejamento sucessório, dada sua vulnerabilidade a questionamentos futuros, sendo elas a doação em comum, a mista, a indireta, a disfarçada e a simulada. De igual modo, pelos motivos já vistos, para quem almeja aplainar em vida sua sucessão, não é recomendável se lançar mão da promessa de doação, a não ser no âmbito da partilha em separação ou divórcio, porque nesse caso surge um ato oneroso. Por fim, deve-se evitar a doação a causa de morte, que goza de pouca segurança no sistema civil brasileiro.

Outro elemento da doação que o planejador deverá levar em consideração, assim como seus beneficiários, é que a doação é um ato irrevogável e opera efeitos imediatos, ao contrário do testamento, que é mortis causa e passível de revogação unilateral sem necessidade de justificação. Assim, a doação é para os que almejam a transferência gratuita de bens em caráter definitivo, sem prejuízo de o disponente se reservar no usufruto de todos ou alguns bens. Por outro lado, a própria norma civil prevê a revogação da benesse, seja quando há descumprimento de encargo, seja quando o donatário incorre nas hipóteses legais de ingratidão. 
Após computados todos esses elementos gerais, deverá aquele que almeja usar a doação para execução de planejamento sucessório cuidar para não esbarrar em algumas disposições legais, sob pena de praticar ato nulo ou anulável.

Desse modo, o doador tem de ter em mente que não poderá despojar-se de todos os seus bens e sem nada ficar. Assim, deve reservar para si algum rendimento ou o usufruto de alguma propriedade, computando-se ainda todas as suas dívidas, para que estas não venham a consumir aquilo que lhe sobrou. Outrossim, não pode o doador reservar-se apenas os seus proventos ou aposentadoria, pois assim incorrerá na nulidade da lei.

Também deverá o doador se atentar se for casado. Em primeiro lugar, porque sempre deverá contar com a autorização do consorte e respeitar-lhe o direito de meação. Além disso, se o donatário for a pessoa do cônjuge, então só poderá doar-lhe os bens particulares, o que é ditado pelo regime de bens do matrimônio. Por fim, não poderá doar a pessoa com quem pratica adultério, pois se trata de ato anulável.

Se o donatário for seu descendente, o doador deve saber que ao fazer a liberalidade está a adiantar a legítima do recebedor, podendo afastar esse efeito com a aposição de cláusula de que o objeto doado deve sair da parte disponível ou então dispensar o beneficiário de levá-lo à colação quando da abertura do inventário do ascendente. Não se faz necessário, também, obter-se a anuência dos demais herdeiros, mas nada impede que esses compareçam ao ato na qualidade de anuentes, se assim convir.

Além disso, pode o doador transmitir ao donatário-descendente toda a sua parte disponível, apondo cláusula expressa nesse sentido, mais a legítima do herdeiro, se assim se entender melhor no planejamento sucessório realizado.

De qualquer forma, deve se atentar o doador que tenha herdeiros necessários a não praticar ato inoficioso, pelo que deverá levar em conta, em seu planejamento, que não pode doar, sucessiva ou simultaneamente, metade de seu patrimônio para terceiros não herdeiros, sob pena de a liberalidade ser reduzida, até que se garanta mais uma vez a legítima hereditária. Ao realizar a sua primeira doação, o doador deve contar que a partir desse momento sua parte disponível já está comprometida e sempre deverá se referir a essa doação para cálculo de todas as outras liberalidades que eventualmente sobrevierem. 
Até por conta do cálculo da oficiosidade, é importante o doador cuidar para que haja um critério objetivo de avaliação dos bens doados e que o donatário e demais anuentes concordem com os valores expressamente, a fim de se evitar futuros questionamentos quanto a esse tema e se permita a prova da legítima.

Por fim, cumpre dizer que é possível utilizar-se da doação para realização de partilha em vida, desde que alguns cuidados sejam observados. Assim, deverá haver escrupuloso respeito à legítima dos herdeiros, que é compatível com a faculdade de se realizar partilha desigual, no que toca à parte disponível. Outrossim, não deve a doação-partilha dispor sobre bens futuros e nem conter condições ou termos, para segurança do ato.

Ademais, convém o doador se precaver quanto a eventual inoficiosidade, de modo que deve dispensar os donatários da colação, ainda que estejam a receber quinhões iguais. Outrossim, sendo ele casado, é importante contar com a anuência de seu cônjuge, mas melhor ainda é se realizar a partilha em vida com ambos figurando como disponentes.

Faz-se necessário que a partilha em vida contemple apenas herdeiros necessários, devendo-se doar a terceiros em instrumento apartado. É importante também que todos eles aceitem a benesse de maneira expressa e no ato mesmo da doação, pelo que se deve cuidar para que os menores estejam devidamente representados.

Outro elemento importante é a demonstração, pelo doador, de que não está a lesar credores, carreando as certidões negativas competentes para tanto. Afora isso, nesse caso específico pode ser importante que o doador renuncie ao benefício quanto aos vícios redibitórios e evicção, para resguardar a isonomia entre os herdeiros.

Por fim, deve o doador estudar a possibilidade de querer ou não revogar a benesse no caso de haver ingratidão pelo herdeiro ou então averiguar se estará disposto inclusive a buscar a declaração de sua indignidade, pois, do contrário, a simples revogação por ingratidão não trará nenhuma consequência patrimonial ao donatário ingrato, que ingressará na posse e propriedade dos bens reavidos quando morto o doador, pois os demais herdeiros já receberam sua parte.

Diante de tudo isso, fica claro que para o uso da doação como ferramenta de aplicação de planejamento sucessório deve se estar a par de todos os elementos colhidos na lei, doutrina e jurisprudência a respeito dessa figura jurídica, a fim de se praticar um ato 
prudente e se alcançar um resultado definitivo, na medida do que for possível ao Direito de possibilitar a paz social. 


\section{BIBLIOGRAFIA}

\section{FONTES}

AASP, Jurisprudência On-line. Disponível em http://www.aasp.org.br/aasp/login/login.asp?URL_GO=http://juris.aasp.org.br/jurisprudencia 2/loginservice chave $={ }^{\wedge} \mathrm{CHAVE}^{\wedge}$.

BRASIL, Código Civil, Lei n. 3.071, de $1^{\circ}$-1-1916 (posteriormente revogada pela Lei 10.406/2002). Disponível em: http://www2.senado.leg.br/bdsf/bitstream/handle/id/70309/704509.pdf?sequence=2.

BRASIL, Código Civil, Lei n. 10.406, de 10-1-2002. Disponível em: http://www.planalto.gov.br/ccivil_03/leis/2002/110406.htm.

ESPANHA, Código Civil, Real Decreto de 24-7-1889. Disponível em: http://www.boe.es/buscar/pdf/1889/BOE-A-1889-4763-consolidado.pdf.

ESTADOS UNIDOS DA AMÉRICA, Family Business Institute. Disponível em: http://www.familybusinessinstitute.com/.

FRANÇA, Code civil, versão consolidada em 1-1-2014. Disponível em: http://www.legifrance.gouv.fr/affichCode.do;jsessionid=40A5674D5A0DCECDABA6642C5 9D905E1.tpdjo03v_2?cidTexte=LEGITEXT000006070721\&dateTexte=20140201.

ITÁLIA, Codice Civile del Regno D'Italia, decreto do Rei Vitorio Emanuelle II por autorização da lei de 2-4-1865. Disponível em: http://www.notaio-busani.it/itit/codice_civile_1865.aspx.

ITÁLIA, Codice Civile - aggiornato al 28-2-2013. Disponível em: http://www.cameracivilebergamo.it/wordpress/wp-content/uploads/2013/03/Codice-Civileaggiornato-al-28-febbraio-2013.pdf.

KUJAWSKI, Gilberto de Mello, Idéia do Brasil: a arquitetura imperfeita, Série Livre Pensar 9, São Paulo, Senac, 2001.

MARCHI, Eduardo C. Silveira. Guia de Metodologia Jurídica - Teses, Monografias e Artigos, $2^{\text {a }}$ ed., São Paulo, Saraiva, 2009, pp. 2-301. 
PORTUGAL, Código Civil Portuguez, aprovado por Carta de Lei de 1-7-1867. Disponível em: http://www.fd.unl.pt/Anexos/Investigacao/1664.pdf.

PORTUGAL, Código Civil, Decreto-Lei n. 47344, de 25-1-1966. Disponível em: http://www.pgdlisboa.pt/leis/lei_print_articulado.php?tabela=leis\&artigo_id=\&nid=775\&nver $\mathrm{sao}=\&$ tabela $=$ leis.

REAL ACADEMIA ESPAÑOLA, Diccionario de la Lengua Española, 22a ed., Madrid, Edição Kindle, 2001.

OXFORD UNIVERSITY PRESS, Oxford Dictionary of English, editado por Catherine Soanes e Angus Stevenson, $2^{\circ}$ ed., Oxford, Edição Kindle, 2010.

SAAVEDRA, Miguel de Cervantes, El ingenioso hidalgo don Quijote de la Mancha, trad. port. de Sérgio Molina, O Engenhoso Fidalgo D. Quixote De La mancha, Livro Primeiro, $6^{\mathrm{a}}$ ed., São Paulo, 2011.

SUPERIOR TRIBUNAL DE JUSTIÇA, Jurisprudência do Superior Tribunal de Justiça. Disponível em: http://www.stj.jus.br/SCON/.

SYNAPSE DÉVELOPPEMENT, Dictionnaire français de définitions, Toulouse, Edição Kindle, 2011.

TRIBUNAL DE JUSTIÇA DO ESTADO DO DISTRITO FEDERAL, Jurisprudência. Disponível em: http://www.tjdft.jus.br/institucional/jurisprudencia.

TRIBUNAL DE JUSTIÇA DO ESTADO DO ESPÍRITO SANTO, Jurisprudência/TJES. Disponível em: http://aplicativos.tjes.jus.br/sistemaspublicos/consulta_jurisprudencia/cons_jurisp.cfm.

TRIBUNAL DE JUSTIÇA DO ESTADO DE MINAS GERAIS, Consulta de Jurisprudência. Disponível em: http://www.tjmg.jus.br/portal/jurisprudencia/consulta-de-jurisprudencia/.

TRIBUNAL DE JUSTIÇA DO ESTADO DO RIO DE JANEIRO, Consulta de Jurisprudência. Disponível em: http://www.tjrj.jus.br/scripts/weblink.mgw?MGWLPN=CONSULTA\&LAB=XJRPxWEB\&P $\mathrm{GM}=\mathrm{WEBJRP} 101 \& \mathrm{PORTAL}=1$. 
TRIBUNAL DE JUSTIÇA DO ESTADO DO RIO GRANDE DO SUL, Jurisprudência. Disponível em: http://www.tjrs.jus.br/site/jurisprudencia/.

TRIBUNAL DE JUSTIÇA DO ESTADO DE SÃO PAULO, Consultas de Jurisprudências. Disponível em: https://esaj.tjsp.jus.br/cjsg/consultaCompleta.do?f=1.

VVAA, Novo Testamento, trad. port. Mateus Hoepers, $8^{\mathrm{a}}$ ed., Editora Vozes, Petrópolis, Rio de Janeiro, 1973.

ZINGARELLI, Nicola, Vocabolario della Lingua Italiana, 12ª ed., Bolonha, Edição Kindle, 2011. 


\section{BIBLIOGRAFIA}

D’ABRAnCHES FERRÃO, Antonio, Das Doações - Segundo o Código Civil Português, Tomo I, Coimbra, F. França Amado, 1911, pp. 2-485.

ALBADALEJO GARCÍA, Manuel, e DIAZ ALABART, Silvia, La Donación, Madrid, Colegio de Registradores de la Propiedad y Mercantiles de España, 2006, pp. 21-936.

ALMADA, Ney de Mello, Sucessões, São Paulo, 2006, Malheiros, pp. 23-387.

ALMEIDA, Estevam, Partilha em vida pelos paes, in RF 46(1926), pp. 15-18.

ALMEIDA JÚNIOR, JESUALDO EDUARDO DE, Os contratos de compra e venda, de doação e de permuta entre ascendentes e descendentes, in AJURIS 89(2003), pp. 129-154.

ALPA, Guido, Manuale di Diritto Privato, 6 ${ }^{\mathrm{a}}$ ed., Pádova, Casa Edicitre Dottore Antonio Milani, 2009, pp. 1-1294.

ALVES, Francisco Glauber Pessoa, Das Várias Espécies de Contrato - Arts. 533 a 578, in ARRUDA ALVIM e THEREZA ALVIM (Coords.), Comentário ao Código Civil Brasileiro - Do Direito das Obrigações, vol. V, Rio de Janeiro, Forense, 2007, pp. 3-989.

ALVES, João Luiz, Código Civil da República dos Estados Unidos do Brasil, vol. II, 2ª ed., São Paulo, Saraiva, 1935, pp. 1-605.

João Luiz, Código Civil da República dos Estados Unidos do Brasil, vol. III, 2a ed.,

São Paulo, Saraiva, 1936, pp. 1-212.

ALVES, Jones Figuêiredo, Arts. 421 a 729, in REGINA BEATRIZ TAVARES DA SILVA, Código Civil Comentado, $7^{\mathrm{a}}$ ed. rev. e atual., São Paulo, Saraiva, 2010, pp. LXIV-2046.

ALVIM, Agostinho, Da Doação, $3^{\text {a }}$ ed., São Paulo, Saraiva, 1980, pp. 3-333.

AMENDOLARA, Leslie, A Sucessão na Empresa Familiar, $2^{\text {a }}$ ed., São Paulo, Lazuli Editora, 2005, pp. 13-46. 
AMENTA, Gianfranco, La Donazione e la Sua Struttura Contrattuale, Torino, G. Giappichelli, 2002, pp. 1-160.

AMORIM, Sebastião Luiz, e OLIVEIRA, Euclides Benedito de, Inventários e Partilhas: direito das sucessões - teoria e prática, $19^{\mathrm{a}}$ ed. rev. e atual., São Paulo, Livraria e Editora Universitária de Direito, 2005, pp. 29-504.

ANTONINI, Mauro, Contratos (em espécie) - Arts. 1.784 a 2.027, in CEZAR PELUSO (Coord.), Código Civil Comentado - Doutrina e Jurisprudência, $4^{\mathrm{a}}$ ed. rev. e atual., Barueri, Manole, 2010, pp. 15-2.334.

ARAÚJO, Samuel Luiz, O Princípio da Igualdade e sua Projeção no Contrato de Doação, Porto Alegre, Núria Fabris, 2009, pp. 15-113.

ASCOLI, Alfredo, Trattato delle Donazioni, $2^{\mathrm{a}}$ ed. rev., Milano, Società Editrice Libraria, 1935, pp. IX-494.

BALBI, Giovanni, Saggio Sulla Donazione, in R. UNIVERSITÀ DI TORINO, Memorie Dell'Istituto Giuridico, Série II, Memoria L, Torino, L'Istituto Giuridico della R. Università, 1942, pp. 5-178.

BARROS, Flávio Augusto Monteiro de, Manual de Direito Civil - Direito das obrigações e contratos, vol. II, São Paulo, Método, 2005, pp. 27-392.

BERNHOEFT, Renato, Como criar, manter e sair de uma sociedade familiar (sem brigar), $4^{\mathrm{a}}$ ed., São Paulo, Editora Senac, 2005, pp. 15-124.

BEVILAQUA, Clóvis, Código Civil dos Estados Unidos do Brasil, atualizada por Achilles Bevilaqua e Isaias Bevilaqua, vol. IV, 10ª ed., Rio de Janeiro, Ed. Paulo de Azevedo, 1955, pp. 5-370.

Clóvis, Código Civil dos Estados Unidos do Brasil, atualizada por Achilles Bevilaqua e Isaias Bevilaqua, vol. VI, 10ª ed., Rio de Janeiro, Ed. Paulo de Azevedo, 1955, pp. 5-247.

BIONDI, Biondo, Le Donazioni, in FILIPPO VASSALI (Dir.), Trattato di Diritto Civile Italiano, vol. XII, tomo IV, Torino, Unione Tipografico-Editrice Torinense, 1961, pp. XV1075 . 
BITTAR, Carlos Alberto, Contratos Civis, 2a ed., Rio de Janeiro, Forense Universitária, 1991, pp. 1-259.

BITTAR, Carlos Alberto, Direito das Sucessões, Rio de Janeiro, Forense Universitária, 1992, pp. 1-158.

CAHALI, Francisco José, e HIRONAKA, Giselda Maria Fernandes Novaes, Direito das Sucessões, $3^{\text {a }}$ ed. rev., atual. e ampl., São Paulo, Revista dos Tribunais, 2007, pp. 19-432.

CARVALHO DE MENDONÇA, Manuel Inácio, Contratos no Direito Civil Brasileiro, Tomo I, $4^{\mathrm{a}}$ ed. atual. por José de Aguiar Dias, Rio de Janeiro, Forense, 1957, pp. 7-397.

CASSETARI, Cristiano, Elementos de Direito Civil, São Paulo, Saraiva, 2011, pp. 27-606.

CATEB, Salomão de Araujo, Direito das Sucessões, 5a ed., São Paulo, Atlas, 2008, pp. XXIV-309.

CHAVES, Antônio, Lições de Direito Civil - Obrigações III, São Paulo, Revista dos Tribunais, 1976, pp. VI-263.

CLARK, Elias, et al., Cases and Materials on Gratuitous Transfers - Wills, Intestate Succession, Trusts, Gifts, Future Interests and Estate and Gift Taxation, $5^{\mathrm{a}}$ ed., Saint Paul, Thomson West, pp. 1-926.

COELHO, Fábio Ulhôa, Curso de Direito Civil - Contratos, vol. III, 6 ${ }^{\text {a }}$ ed., São Paulo, Saraiva, 2013, pp. 17-495.

COELHO DA ROCHA, Manuel Antonio, Instituições de Direito Civil, Tomo II, in ALCIDES TOMASETTI JR. (Coord.), Clássicos do Direito Brasileiro, São Paulo, Saraiva, 1984, pp. 426-427.

CUNHA GONÇALVES, Luiz da, Tratado de Direito Civil - Em Comentário ao Código Civil Português, com adaptação ao direito brasileiro de Orozimbo Nonato, Costa Manso e Laudo de Camargo e anotação de José Geraldo Rodrigues de Alckmin, vol. VIII, Tomo I, $2^{\text {a }}$ ed. atual. e aum. e $1^{a}$ ed. brasileira, São Paulo, Max Limonad, 1956, pp. 11-468.

DAVID, René, Le Droit Anglais, 1987, trad. port. de Eduardo Brandão, O Direito Inglês, $2^{\mathrm{a}}$ ed., São Paulo, Martins Fontes, 2006, pp. 1-118. 
DELNOY, Paul, Les Libéralités et Les Successions, Liège, Ed. Collection Scientifique de la Faculté de Droit de Liège, 1991, pp. 21-297.

DIAS, Maria Berenice, Manual das Sucessões, São Paulo, Revista dos Tribunais, 2008, pp. 23-612.

DINIZ, Maria Helena, Curso de Direito Civil Brasileiro - Teoria das obrigações contratuais e extracontratuais, vol. III, 29ª ed., São Paulo, Saraiva, 2013, pp. 1-896.

, Tratado Teórico e prático dos contratos, v. II, $7^{\mathrm{a}}$ ed., São Paulo, Saraiva, 2013, pp. 21-758.

DIÓGENES, Nestor, Doação Não É Contrato, Recife, 1947, pp.5-142.

ESPINOLA, Eduardo, Dos Contratos Nominados no Direito Civil Brasileiro, $2^{\mathrm{a}}$ ed., Conquista, Rio de Janeiro, 1956, pp. 7-523.

FIUZA, César, Direito Civil - Curso Completo, $11^{\mathrm{a}}$ ed. rev. e atual., Belo Horizonte, Del Rey, 2008, pp. 1-1056.

FOWLER, Robert Ludlow, The Law Of Charitable Uses - Trusts And Donations In New York, 1896, ed. fac-sim., New Delhi, Isha Books, 2013, pp. 1-154.

GAGLIANO, Pablo Stolze, O contrato de doação: análise crítica do atual sistema jurídico e os seus efeitos no direito de família e das sucessões, $3^{\text {a }}$ ed., São Paulo, Saraiva, 2010, pp. 21207.

GOMES, Orlando, Contratos, 12ª ed., Rio de Janeiro, Forense, 1993, pp. 3-541.

GONÇALVES, Carlos Roberto, Direito Civil Brasileiro - contratos e atos unilaterais, vol. III, 4 ed. rev. e atual., São Paulo, Saraiva, 2007, pp. 1-684.

GONÇALVES, Carlos Roberto, Direito Civil Brasileiro - direito das sucessões, vol. VII, 3 ed. rev. e atual., São Paulo, Saraiva, 2009, pp. XVII-548.

HYLANDS, Richard, Gifts: a study in comparative Law, New York, Oxford University Press, Edição Kindle, 2009.

HOLMES JUNIOR, Oliver Wendell, The Common Law, Boston, Little Brown and Company, 1951, pp. 1-409. 
ITABAIANA DE OLIVEIRA, Arthur Vasco de, Tratado de Direito das Sucessões, vol. III, $4^{\mathrm{a}}$ ed. rev. e atual. pelo autor com a colaboração de Aires Itabaiana de Oliveira, São Paulo, Max Limonad, 1952, pp. 775-1047.

JOBS, João Alberto Leivas, Da Nulidade da Partilha: uma aplicação dos métodos histórico e fenomenológico ao estudo do direito, $2^{\text {a }}$ ed., São Paulo, Saraiva, 1986, pp. XXVIII-819.

IACOVINO, Celeste, TAVASSI, Vincenzo, e CASSANDRO, Tania, in Antonio Cataudella (Coord.), La Donazione, Milano, Dott. A. Giuffrè, 1996, pp. 3-444.

LEVENHAGEN, Antônio José De Souza, Sucessão legítima, inventário e partilha, São Paulo, Atlas, 1978 (reimp.), pp. 11-119.

LISBOA, Rodrigo Senise, Manual de Direito Civil - Contratos, vol. III, $7^{a}$ ed., São Paulo, Saraiva, 2013, pp. 1-505.

LIMONGI FRANÇA, Rubens, Manual de Direito Civil, vol. IV, t. II, São Paulo, Revista dos Tribunais, pp. 1-308.

LÔBO, Paulo, Das Várias Espécies de Contratos - Da Compra e Venda - Da Troca ou Permuta - Do Contrato Estimatório - Da Doação - Arts. 481 a 564, in ANTÔNIO JUNQUEIRA DE AZEVEDO (Coord.), Comentários ao Código Civil, vol. VI, São Paulo, Saraiva, 2003, pp. 1-385.

, Direito Civil - Contratos, São Paulo, Saraiva, 2011, pp. 15-451.

LISI, Lycia Gardani Contursi, Le Donazioni, in WALTER BIGIAVI, Giurisprudenza Sistematica Civile e Commerciale, Torino, Unione Tipografico-Editrice Torinense, 1967, pp. 3-367.

LOPES, Manuel Baptista, Das Doações, Coimbra, Almedina, 1970, pp. 8-269.

LOUREIRO, Luiz Guilherme, Curso Completo de Direito Civil, $2^{\mathrm{a}}$ ed., São Paulo, Método, 2009, pp. 39-1295.

MACEDO, José Ferreira de, Sucessão na Empresa Familiar - Teoria e Prática, São Paulo, Nobel, 2009, pp. 16-163.

MARMITT, Arnaldo, Doação, Rio de Janeiro, Aide Editora, 1994, pp. 7-308. 
MAXIMILIANO, Carlos, Direito das Sucessões, vol. III, $5^{\text {a }}$ ed., Rio de Janeiro - São Paulo, Freitas Bastos, 1964, pp. 17-460.

MÉAU-LAUTOUR, Huguette, La Donation Déguisée en Droit Civil Français, Paris, Librairie Générale de Droit et de Jurisprudence, 1985, pp. 20-484.

MEDINA, Paulo Geraldo de Oliveira, A Doação, in DOMINGOS FRANCIULLI NETTO (Coord.), GILMAR FERREIRA MENDES (Coord.) e IVES GANDRA DA SILVA MARTINS FILHO (Coord.), O Novo Código Civil - Estudos em homenagem ao Professor Miguel Reale, São Paulo, LTR, 2003, pp. 25-1423.

MONTEIRO, Washington de Barros, DABUS MALUF, Carlos Alberto, e TAVARES DA SILVA, Regina Beatriz, Curso de Direito Civil - direito das obrigações $2^{a}$ parte, vol. V, $38^{\mathrm{a}}$ ed., São Paulo, Saraiva, 2011, pp. 17-646.

MONTEIRO, Washington de Barros, PINTO, Ana Cristina de Barros Monteiro França, Curso de Direito Civil - direito das sucessões, vol. VI, $38^{\mathrm{a}}$ ed., São Paulo, Saraiva, 2011, pp. 11371.

MORRIS, Amanda Zoe, Doação, in GISELDA M. F. NOVAES HIRONAKA (Orient.), AMANDA ZOE MORRIS (Coord.), e LUCAS ABREU BARROSO (Coord.), Direito Civil Direito Dos Contratos, vol. III, São Paulo, Revista dos Tribunais, 2008, pp. 1-461.

NADER, Paulo, Curso de Direito Civil - Contratos, vol. III, $4^{\text {a }}$ ed. rev. e atual., Rio de Janeiro, 2009, pp. 3-549.

OZÉIAS, J. Santos, Da Doação: Teoria, Jurisprudência, Legislação e Prática, Campinas, Agá Juris, 1998, pp. 8-271.

PENTEADO, Luciano de Camargo, Doação com Encargo e Causa Contratual, Campinas, Millennium, 2004, pp. XXXV-372.

PEREIRA, Caio Mário da Silva, Instituições de Direito Civil - Contratos, vol. III, $13^{\mathrm{a}}$ ed. rev. e atual. por Regis Fichtner, Rio de Janeiro, Forense, 2009, pp. 5-523.

PLANIOL, Marcel, Traité Élémentaire de Droit Civil-Conforme Au Programme Officiel des Facultés de Droit, com colaboração de Georges Ripert, Tomo III, 10ª ed., Paris, Librairie Générale de Droit \& de Jurisprudence, 1927, pp. 3-976. 
PONTES DE MIRANDA, Francisco Cavalcanti, Tratado de Direito Privado - Partes Especial, Tomo XLVI, $3^{\text {a }}$ ed. reimp., Rio de Janeiro, Borsoi, 1972, pp. 3-412.

PONTES DE MIRANDA, Francisco Cavalcanti, Tratado de Direito Privado - Partes Especial, Tomo LX, 2a ed. , Rio de Janeiro, Borsoi, 1969, pp. 3-372.

PRADO, Roberta Nioac, COSTALUNGA, Karime e KIRSCHBAUM, Deborah, Sucessão e Planejamento Societário II, in ROBERTA NIOAC PRADO, DANIEL MONTEIRO PEIXOTO e EURICO MARCOS DINIZ DE SANTI (Coords.), Estratégias Societárias, Planejamento Tributário e Sucessório, 2a ed., Série GVLaw, São Paulo, Saraiva, 2011, pp. 25-497.

RAY, Jean, De La Notion de Donation - En Droit Civil Français, Paris, Recueil Sirey, 1912, pp. 7-205.

REZENDE, Astolpho de, Do Direito das Sucessões - Do Inventário e Partilha - Arts. 1.7701.805, in PAULO DE LACERDA, Manual do Código Civil Brasileiro, vol. XX, Rio de Janeiro, Jacintho Ribeiro dos Santos Editor, 1930, pp. 3-505.

RICCA, Domingos, Sucessão na Empresa Familiar - conflitos e soluções, São Paulo, Editora CLA, 2007, pp. 11-150.

RIZZARDO, Arnaldo, Contratos - Lei 10.406 de 10.01.2002, $10^{\mathrm{a}}$ ed., Rio de Janeiro, Forense, 2010, pp. 1-1436.

RIZZARDO, Arnaldo, Direito das Sucessões, $8^{\mathrm{a}}$ ed., Rio de Janeiro, Forense, 2014, pp. XXX768.

ROCHA, Silvio Luís Ferreira da Rocha, Curso Avançado de Direito Civil - Contratos, in EVERALDO AUGUSTO CAMBLER (Coord.), São Paulo, Revista dos Tribunais, 2002, pp. 27-505.

RODRIGUES, Silvio, Direito Civil - Dos Contratos e das Declarações Unilaterais da Vontade, vol. III, 30ª ed. atual., São Paulo, Saraiva, 2004, pp. 3-426.

ROSENVALD, Nelson, Contratos (em espécie) - Arts. 481 a 652, in CEZAR PELUSO (Coord.), Código Civil Comentado - Doutrina e Jurisprudência, $4^{\mathrm{a}}$ ed. rev. e atual., Barueri, Manole, 2010, pp. 15-2334. 
SABINO JÚNIOR, Vicente, Contrato de Doação: Doutrina - Prática - Legislação Jurisprudência, São Paulo, Brasilivros, 1979, pp. 9-174.

SAMPAIO, Rogério Marrone de Castro, Direito Civil - Contratos, $5^{\mathrm{a}}$ ed., São Paulo, Atlas, 2004, pp. 17-165.

SANSEVERINO, Paulo de Tarso Vieira, Contratos Nominados II, in MIGUEL REALE (Coord.) e JUDITH MARTINS-COSTA (Coord.), Biblioteca de Direito Civil - Estudos em homenagem ao Professor Miguel Reale, vol. IV, São Paulo, Revista dos Tribunais, 2005, pp. 23-345.

SAVIGNY, Friederich Karl Von, System des heutigen römischen Rechts, trad. it. de Vittorio Scialoja, Sistema del Diritto Romano Attuale, vol. IV, Torino, Unione Tipografico-Editrice Torinense, 1889, pp. 1-638.

SERPA LOPES, Miguel Maria, Curso de Direito Civil - Fontes das Obrigações: Contratos, vol. III, $6^{\text {a }}$ ed. rev. e atual., Rio de Janeiro, Freitas Bastos, 1996, pp. 23-430.

SÉROUSSI, Roland, Introdution aux droits anglais et américain, 1999, trad. port. de Renata Maria Parreira Cordeiro, Introdução ao Direito Inglês e Norte-Americano, São Paulo, Landy Editora, 2006, pp. 13-203.

SOUZA, Sylvio Capanema de, Das Várias Espécies de Contratos - Da Troca ou Permuta Do Contrato Estimatório - Da Doação - Da Locação de Coisas, in SÁLVIO DE FIGUEIREDO TEIXEIRA (Coord.), Comentários ao Novo Código Civil, vol. VIII, Forense, Rio de Janeiro, 2008, pp. 1-563.

TAMBÁ, Vassanta Porobo, Doação Verbal de Móveis - a Tradição - Reflexões críticas sobre a tese do Prof. Antunes Varela e Jurisprudência Diversa, Coimbra, Almedina, 1970, pp. 15-114.

TARTUCE, Flávio, Direito Civil - teoria geral dos contratos e contratos em espécie, vol. III, $3^{\text {a }}$ ed. rev. e atual., São Paulo, Método, 2008, pp. 1-611.

TEIXEIRA DE FREITAS, Augusto, Consolidação das leis civis, ed. fac-sim., vol. I, Brasília, Senado Federal, 2003, pp. CCXXI-522.

TEIXEIRA, Silvia Maria Benedetti, Planejamento Sucessório: uma Questão de Reflexão, in IBDFAM 31(2005), pp. 5-18. 
TEPEDINO, Gustavo (Org.), e FACHIN, Luiz Edson (Org.), Doutrinas Essenciais Obrigações e Contratos, vol. V, São Paulo, Revista dos Tribunais, 2011, p. 25-1199.

TORRENTE, Andrea, La Donazione, in ANTONIO CICU (Dir.) e FRANCESCO MESSINEO (Dir.), Trattato di Diritto Civile e Commerciale, vol. XXII, Milano, Dott. A. Giuffrè, 1956, pp. XII-589.

TROPLONG, Raymond-Théodore, Des Donations Entre-Vifs et Des Testaments, in Commentaire du Titre II du Livre III du Code Napoleón, Tomo I, $3^{\mathrm{a}}$ ed., Paris, Henri Plon, 1872, pp. CXXIV-558.

VELOSO, Zeno, Arts. 1.784 a 2.027, in REGINA BEATRIZ TAVARES DA SILVA, Código Civil Comentado, $7^{\mathrm{a}}$ ed. rev. e atual., São Paulo, Saraiva, 2010, pp. LXIV-2046.

VENOSA, Sílvio de Salvo, Direito Civil - Contratos em Espécie, vol. III, $5^{\mathrm{a}}$ ed., São Paulo, Atlas, 2005, pp. 21-662.

VENOSA, Sílvio de Salvo, Direito Civil - Direito das Sucessões, vol. VII, $5^{\mathrm{a}}$ ed., São Paulo, Atlas, 2005, pp. 15-422.

VILLELA, João Baptista, Contrato de Doação: Pouca Luz e Muita Sombra, in ANTONIO JORGE PEREIRA JÚNIOR (Coord.) e GILBERTO HADDAD JABUR (Coord.), Direito dos Contratos, São Paulo, Quartier Latin, 2006, pp. 21-495.

WALD, Arnoldo, Direito Civil - contratos em espécie, vol. III, $18^{\mathrm{a}}$ ed. reform., São Paulo, Saraiva, 2009, pp. 1-433.

O Regime Jurídico da Partilha em Vida, in RT 622(1987), pp. 8-15. 